.H56 1902 FISH

\title{
JOHAN HJORT
}

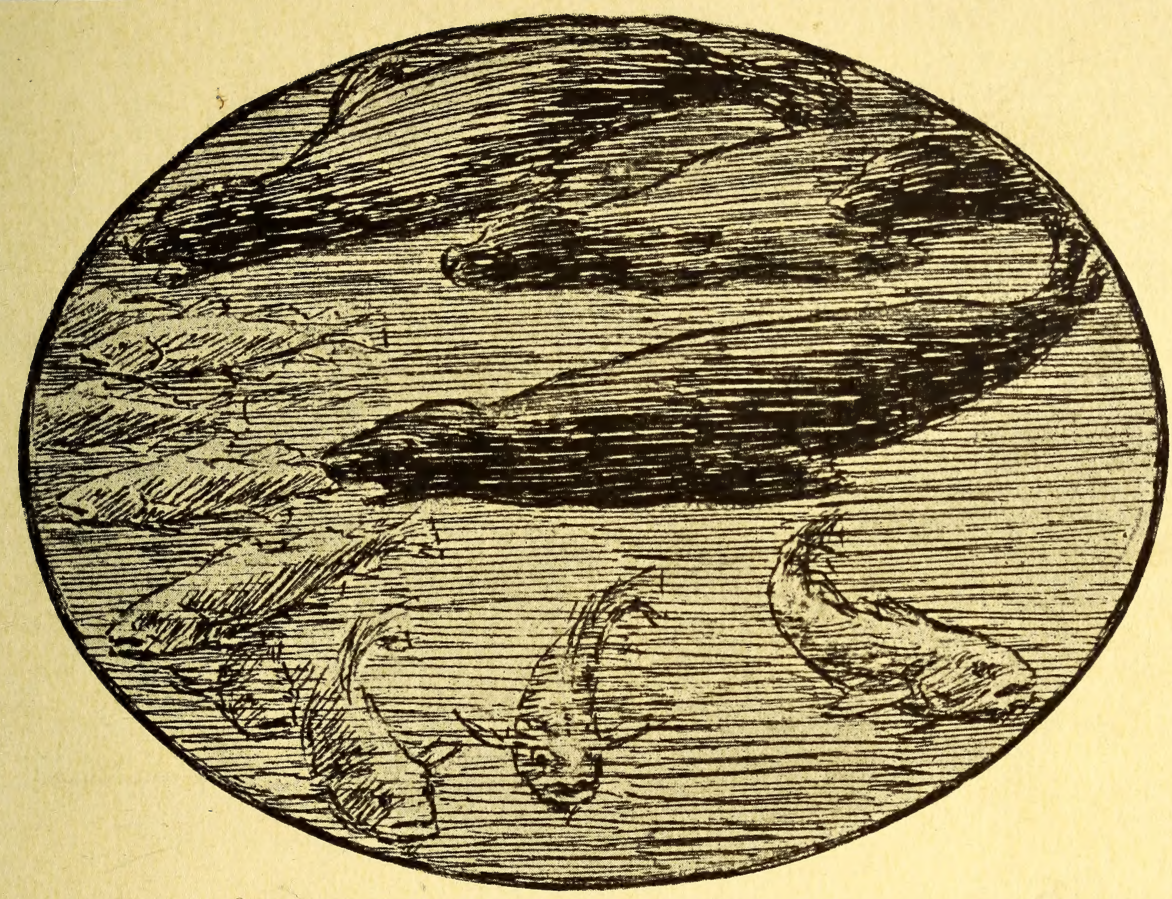

\section{FISKERI OG HVAL FANGST I DET : : : NORDLIGE NORGE}

\author{
BERGEN
}

JOHN GRIEGS FORLAG

1902 




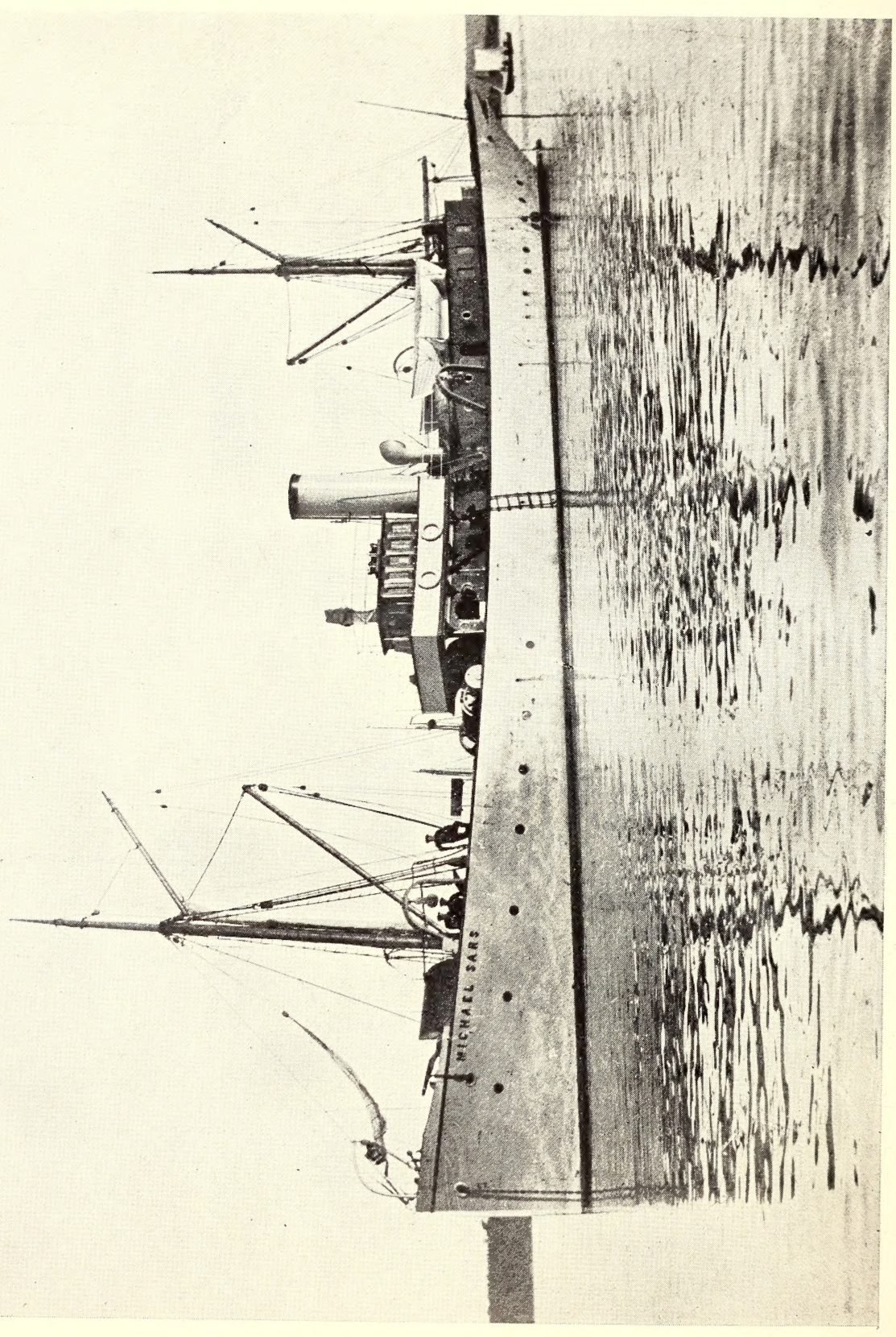




\section{JOHAN HJORT}

\section{FISKERI OG HVALFANGST}

\section{DET NORDLIGE NORGE}

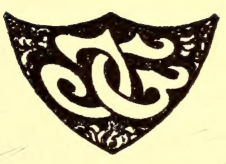

BERGEN

JOHN GRIEGS FORLAG

1902 


\section{Indhold.}

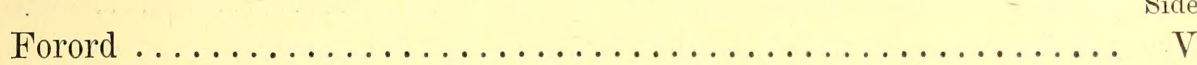

Første kapitel: Finmarkshavet $0 g$ dets dyreverden ........... 1

Havet ....................................... 1

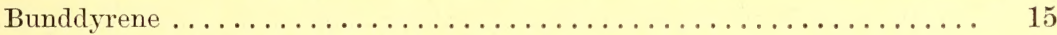

De drivende organismer (Planktonet) ..................... 24

Fuglelivet................................... 35

Andet kapitel: Fiskenes liv $0 g$ vandringer ............. 39

Torsken ....................................... 39

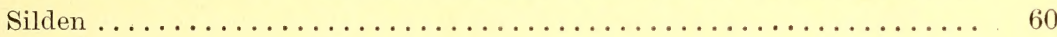

Lodden ......................................... 63

Haakjærringen .................................. 66

Kobben........................................ 68

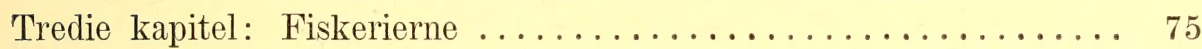

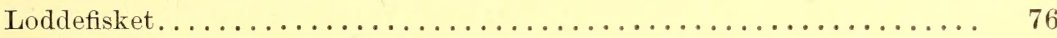

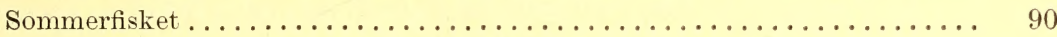

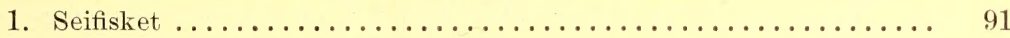

2. Torskefisket, bankfisket $\ldots \ldots \ldots \ldots \ldots \ldots \ldots \ldots \ldots \ldots \ldots \ldots, 93$

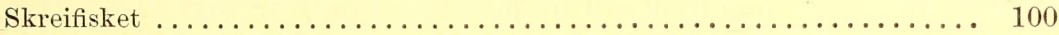

"Alken"s forsøg fra Andenæs til Røst................... 103

„Havellen"s forsøg fra Sørøen til Malangen ................ 105

Fjerde kapitel: Hvalerne ...................... 113

Systematisk oversigt:

Tandhvalerne .................................... 115

Bardehvalerne ..................................... 123

Hvalernes liv og vandringer:

De arktiske hvaler............................... 127

De nordatlantiske hvaler:

Planktonhvalerne ................................... 132

De blæksprutjagende hvaler....................... 141

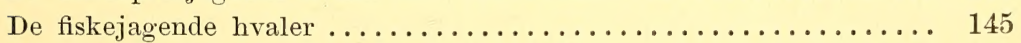

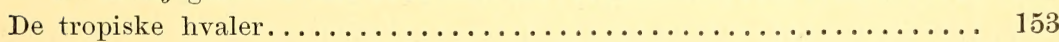

Femte kapitel: Hvalfangsten ...................... 155

1. Fangsten af grønlandshval og nordkaper ................. 159

2. Kaskelotfangsten............................ 167 


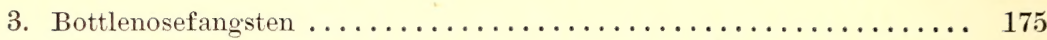

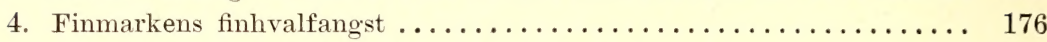

Sjette kapitel: Striden mellem fiskeri $0 g$ hvalfangst ......... 196

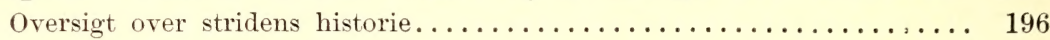

Nu gjældende bestemmelser........................ 202

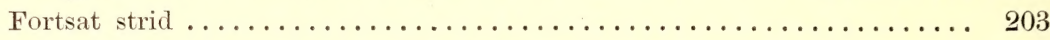

De udførte undersøgelsers forudsætninger ................. 203

Diskussion af stridsspørgsmaalene................... 204

Finhvalens betydning for fiskerierne ................. 206

De opstillede krav om fredningsbestemmelser............... 211

Følgerne af $\mathrm{og}$ betingelserne for gjennemførelsen af totalt forbud.... 213

Den juridiske side. Hr. statsadrokat Urbyes udtalelse . . . . . . . . 214

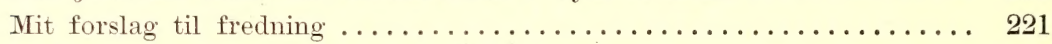

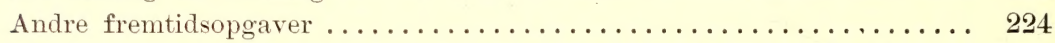

Syvende kapitel: Hvilke maal bør arbeidet for det nordlige Norges

fiskerier stille $\operatorname{sig}$ ? . . . . . . . . . . . . . . . . 226

Dybere aarsager til antihvalfangstbevægelsen............... 226

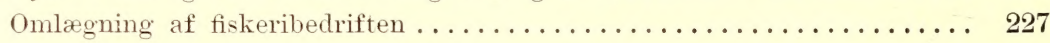

Forestillinger om lykkeligere svundne tider................ 230

Arbeidet for tekniske fremskridt. . . . . . . . . . . . . . . . . 231

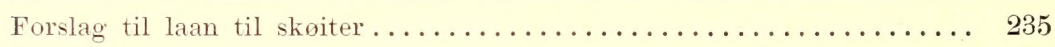

Kan kobbeindrandringerne bekjæmpes? ................ 237

Eksport og omsætningsforholdene .................. 239

Organisation af fiskeriinteresserne......................... 241

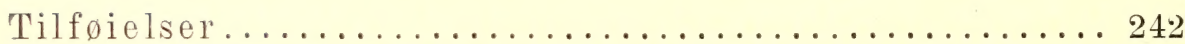

1. Blæksprutter fra Bottlenosemaver.................. 242

2. Fangsten paa Malangsgrunden $\mathrm{i}$ aar $\ldots \ldots \ldots \ldots \ldots \ldots \ldots \ldots \ldots 242$

3. Rettelse ...................................... 242

Tabeller over hvalfangst i Finmarken efter hvalfangernes fangstjournaler.............................. 243 


\section{Forord.}

Denne bog har til hensigt at meddele resultaterne af de togter, som i aarene 1900-1901 er udført med fiskeriundersøgelsernes dampskib „Michael Sars". Som maal var der stillet disse togter den opgave at tilveiebringe et paa selvstændige iagttagelser og erfaringer bygget materiale til belysning af de store spørgsmaal, som har beskjæftiget befolkningen i det nordlige Norge, og som særlig er bleven almenheden bekjendt gjennem den gamle strid mellem fiskeri og hvalfangst.

Denne opgave har ikke kunnet lade sig forene med de fordringer, som under arbeidets udførelse fra forskjelligt hold har været fremsat, nemlig, at undersøgelserne samtidig ogsaa skulde optage spørgsmaal i andre dele af landet. Noget valg af arbeidsfelt har der, om den stillede opgave skulde fremmes, overhovedet ikke været anledning til at træffe; men et valg vilde under alle omstændigherer maatte have ført til en begrænsning af arbeidet til en bestemt del af den lange kyst.

Med den stillede opgave var ogsaa arbeidets art given; det maatte blive rettet mod forstaaelsen af de store naturforhold i den nordligste del af Nordhavet og de eiendommelige forhold, under hvilke det nordlige Norges fiskerier og fangst finder sted. Kun i anden række kunde arbeidet stille sig bestemte maal af umiddelbar økonomisk betydning for et bestemt mindre distrikt; dette fulgte umiddelbart deraf, at de spørgsmaal, hvis løsning stod som opgavens maal, og som var stillet $\mathrm{og}$ formet af befolkningen selv, fordrede langt mere theoretiske end økonomiske undersøgelser.

Det vil forhaabentlig vise sig, at det udførte arbeide har kunnet bidrage sit til løsningen af spørgsmaalet, men adskilligt mangler endnu til hel forstaaelse af alle de forhold, som stadig fremkalder ønsket om større klarhed. Det var mig fra første øieblik indlysende, at ingen undersøgelse i den tid, som det kunde antages, at forholdene vilde indrømme den til i ro 
at beskjæftige sig med opgaven, vilde kunne løse dens mange vanskeligheder $\mathrm{og}$ gaader. Allerede paa forhaand udtalte jeg derfor, at de første aars arbeide maatte rettes mod det, at give den første oversigt over forholdene $\mathrm{og}$ mod at udarbeide plan for fremtidens bestræbelser mod fremskridt i viden $0 \mathrm{~g}$ i økonomisk udbytte. Under arbeidet blev det mig for hver dag mere klart, at det bedste, som nogen undersøgelse kunde gjøre i øieblikket, vilde være det at give en fremstilling - bygget paa de vundne erfaringer - af, hvor nødvendigt det er, at det nordlige Norges fiskerbefolkning samler al sin interesse om direkte økonomiske maal. Det staar for mig som, at man ellers løber faren for en dag at befinde sig i stillestaaende uvirksomhed eller tilbagegang istedetfor i fremgang.

For at bidrage mit til, at en saadan beslutning tages, har jeg ikke villet undlade at udtale min mening om de reiste spørgsmaal, selv om jeg under udarbeidelsen af begrundelsen af min mening gjentagende gange har følt onskeligheden af at kunne have fortsat arbeidet. Det har dog stadig været mig magtpaaliggende at lade fremstillingen selv vise, hvad der efter min mening mangler til en fuld forstaaelse, og derved tor denne bog ogsaa indholde nogen veiledning for dem, der senere maatte beskjæftige sig med de opgaver, som behandles. Af stor betydning for mine overveielser har selvfølgelig ogsaa de af de tidligere undersøgelser fastslaade kjendsgjerninger været. Særlig har de af professorerne G. O. Sars og G. A. Guldberg udførte arbeider samt samarbeidet med lederne af den russiske undersøgelsesekspedition, de herrer dr. KNipowitsch og dr. Breiteuss, været mig til stor hjælp.

I følelsen af nødvendigheden af, at vor fiskerbedrift stiller sig direkte økonomiske maal har jeg, saalangt de andre opgaver tillod det, arbeidet med at planlægge $o g$ udføre de nødvendige forarbeider for saadanne. Af de udførte forsøg og af de forsøg, som vil blive udført i tilknytning til de her meddelte resultater, faar det afgjøres, hvorvidt denne side af ekspeditionens arbeide har naaet sit maal.

Fremstillingen har havt den vanskelighed at overvinde, at den dels tilsigter at meddele arbeidets resultater til dem, der ikke har fagmæssig uddannelse i de anvendte arbeidsmaader, dels ogsaa har villet give - især yngre fagmænd - en oversigt over naturforholdene i havet $0 \mathrm{~g}$ arbeidsvilkaarene i den nordlige landsdels vigtigste bedrift. Det er mit haab, 
at den læser, for hvem arbeidet og dets maal har betydning, vil kunne se bort fra, at bogen saaledes for ikke-fagmanden indeholder enkelte oplysninger, som er ham utilgjængelige, og at fremstillingen for fagmanden - det være den erfarne fisker eller studerende - paa enkelte steder har faaet en unødig bredde. Fremstillingen afviger fra de fleste - vrige videnskabelige ekspeditioners beretninger derved, at den har begrændset sig til omtalen af de vundne resultater og de for disses forstaaelse nødvendige oplysninger, medens skildringen af togterne selv har været udeladt for at gjøre bogen kortere og derved forhaabentlig lettere tilgjængelig.

De resultater, som ekspeditionen har naaet, skyldes udelukkende den varme interesse for arbeidet og dets opgaver, som ekspeditionens deltagere har havt. Alene vilde neppe nogen kunnet udføre den store masse iagttagelser, undersøgelser og specialarbeider, paa hvilke resultaterne er bygget. Slutningerne $o g$ overveielserne bærer jeg dog udelukkende ansvaret for. I mere videnskabelig form vil de udførte arbeider fremkomme $\mathrm{i}$ andet bind af "Report on norwegian fishery and marine investigations". Det store hydrografiske materiale, der har givet værdifulde kundskaber om Nordhavets strømforhold vil her findes bearbeidet af hr. professor Nansen og hr. Helland-Hansen, de drivende organismer af hr. H. H. Gran, bundorganismerne af hr. professor Coliett og dr. AppelLøF, fiskeriundersøgelserne af undertegnede. Hr. bestyrer Knut DahL har i lang tid ydet mig stor hjælp ved at overtage mit arbeide ombord, naar mit fravær var nødvendigt. Hr. kand. Wоццевжк har ydet mig den bedste hjælp med tegningernes udførelse; disse skyldes delvis fotografier tagne af ham selv, af hr. Gran og hr. Dahl. Af stor betydning for figurerne til kapitlet over hvalerne har det været, at konservatorerne GRIEG og AppelløF med stor beredvillighed har tilladt, at fotografier er taget i Bergens museums samlinger. Frk. Gullaksen har ordnet og gjennemgaaet de store samlinger af egprøver og fiskeunger; hr. fiskeriinspektør Sørensen har opstillet de talrige statistiske data. Til slutning ud taler jeg det ønske, at de herrer, som i flere aar har deltaget i fiskeriundersøgelserne og som har deltaget i større eller mindre tidsrum i „Michael Sars"s ekspedition, nemlig de herrer professor Nansen, docent Gran, bestyrer Knut Dahl, assistent Helland-Hansen og zoolog Wolleb жек, fartøiets fører i aarene 1900-1901, hr. inspektør G. Sørensen 
og dets nuværende fører, kaptein Iversen, ved gjennemlæsning af denne bog vil finde, at ekspeditionens maal og resultater har været værd den interesse, opofrelse og energi, de har viet den, og den værdifulde støtte, de har ydet mig. Langs hele kysten har jeg ogsaa fra fiskeriinteresserede i raad og daad faaet mangen en værdifuld hjælp. Jeg ber enhver især modtage herfor min hjertelige tak, særlig de, som har givet det værdifuldeste af alt, anledningen til aaben og fordomsfri udveksling af tanker $o g$ erfaringer.

„Michael Sars“. Mai 1902.

Johan Hjort. 


\section{Første kapitel.}

\section{Finmarkshavet og dets dyreverden.}

\section{Havet.}

Havbunden. Den bratte eg, som skiller det indtil 2000 favne dybe Nordhav fra de 1-200 favne dybe norske kystbanker, forløber helt fra Romsdalen til Senjen i en noget bugtet linie parallel med den norske kyst $0 \mathrm{~g}$ i en afstand af fra ca. 15 til 25 geografiske mile. Nordenfor Senjen viger eggen og kysten ud fra hinanden, idet eggen fortsætter i næsten lige linie nordover mod Spitsbergen, mens kysten bøier østover. Herved breder bankerne sig ud til at danne det store hav, der i syd begrænses af Finmarken og Murmankysten, i øst af Novaja Zemblja, i nord af Spitsberg-Bjørnøplateauet $\mathrm{g} g$ af isen $\mathrm{og}$ ishavets vandmasser. Dette hav, Østhavet, som de norske fangstmænd kalder det, Barents Sea, som det kaldes paa de engelske søkarter, har i alt væsentligt samme karakter, som de norske kystbanker. Fra eggen gaar der, som sees af fig. 1, en fordybning $\mathrm{i}$ havbunden østover, saaledes at denne midt mellem Bjørnøen og Norge har et dyb af ca. 250 favne. Fra dette med ganske blødt mudder bedækkede dyb skraaner havbunden opover mod grundere flader baade $\mathrm{i}$ øst, nord og syd. Østover $-\bmod d e 150-100$ favne dybe banker nordenom Murmankysten, nordover mod den grunde op til 15 favne dybe Spitsbergen-Bjørnøbanke og sydover mod den mellem 100 og 150 favne dybe landbakke, som $\mathrm{i}$ en bredde af $2-4 \mathrm{mil}$ omgiver Finmarkens kyst.

Ganske regelmæssige er dog ikke disse skraaninger. Saaledes gaar ved Bjørnøen 200-favne-dybet saa nær Bjørnøplateauet, at der dannes en slags skarp eg, hvor havbunden fra 70-90 favne i meget kort distance gaar ned til ca. 250 favne. Dette Bjørnø-Spitsbergenplateau er derfor vel begrænset som en egen banke, det viser en variation i dyb- 
derne og bundens beskaffenhed, snart sten, snart sand, snart mudder, som fremkalder meget interessante og varierede livsbetingelser. Grundest
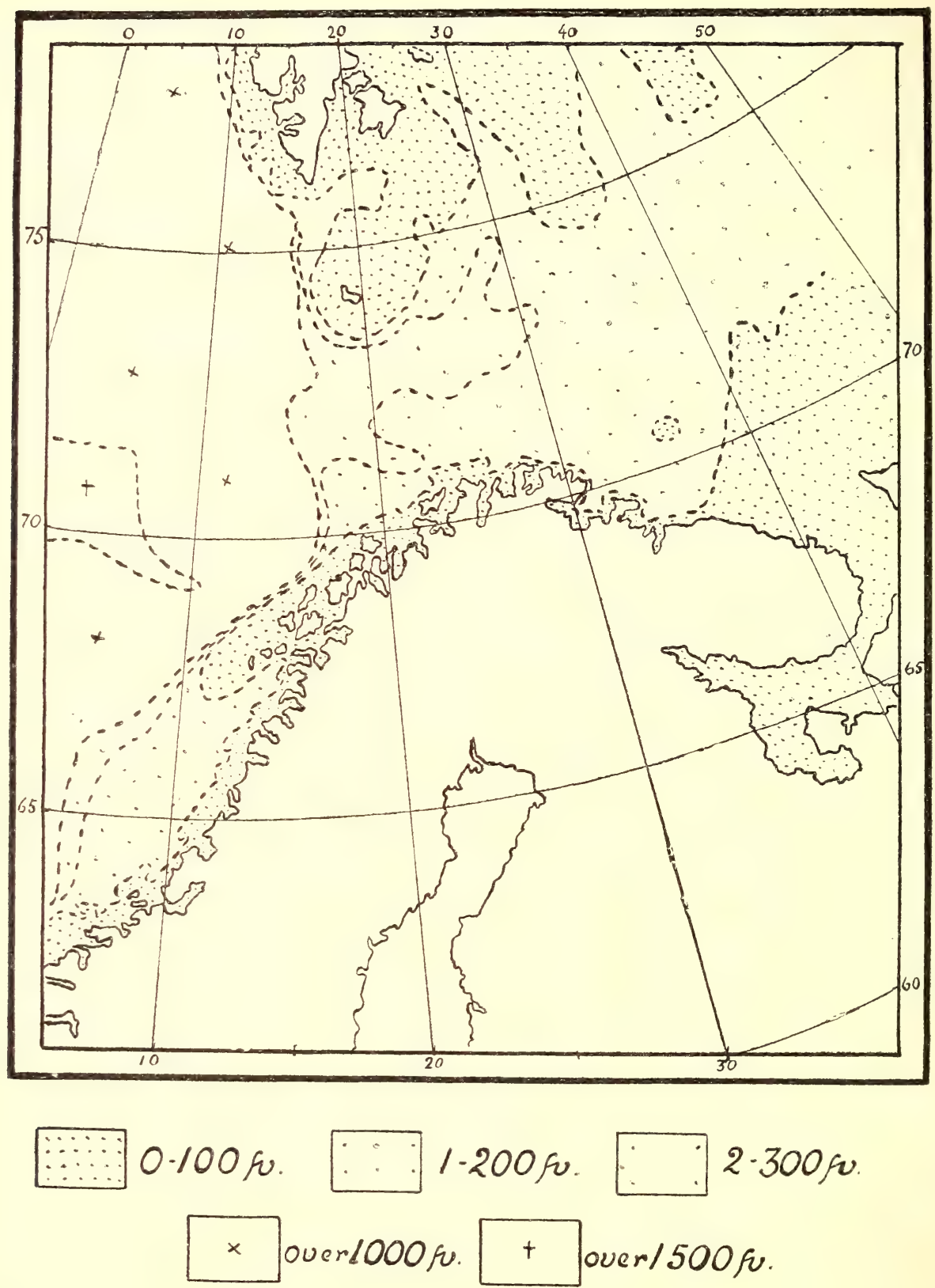

Fig. 1. Dybdekart over havet udfor Norges nordligste kyst.

er banken mellem de to øer Bjørnøen og Spitsbergen; her viser det engelske kart, som næunt, dybder som 15, 20, 25, 40 favne. Rundt 
Bjørnøen især sønden- og østenom denne findes jevn bund med ca. 70 favne.

Langt øst viser Østhavets bund ogsaa mindre dybder med sandige bundafleiringer, saaledes henimod Novaja Zemblja og nord om Hvidehavets munding, hvor der findes et stort flak ca. 40 mil i kvadrat af ca. 40 favnes dyb.

Havet nærmest Finmarkskysten udmerker sig, som nævnt, ved landbakken, en i bredde noksaa meget varierende kystbanke, der i regelen har et merkbart afheld ned mod havdybet udenfor, saa at der her ogsaa tales om en eg. Bunden er paa landbakken mest stenet og ujevn, mens havbunden udenfor er bedækket af blødere dog noget sandblandet mudder. Denne havbund nærmest udenfor landbakken gaar i regelen jevnt nedad mod det ovenfor nævnte store 200-favnedyb, men enkelte steder danner den dog grundere partier, saaledes ea. 8 mil øst af Vardø den saakaldte Østbanke af optil 60 farnes dyb, og en omkring 100 farne dyb banke nordenom Nordkap, hvor bunden ogsaa er haardere end ellers.

Nærmest land danner landbakken enkelte steder ganske grunde partier, de saakaldte "skaller", der især i Finmarkens vestligste del og i Tromsø amt blir udprægede. Saaledes er bekjendte Tubaaen udfor Sørøens nordspids, Gjesbaaen i Loppehavet vestenom Sørøen. Og her antager desuden landbakken mere karakteren af flade banker, saaledes har den rundt Sørøen, Loppen, Silden etc. sandige partier af ca. 20-30-40 favnes dyb, der ogsaa, hvad bundforhold angaar, minder meget om de bekjendte fiskebanker udenfor Senjen i Tromsø amt.

Finmarkens fjorde frembyder mange eiendommeligheder fremfor andre fjorde i landet. Ligesom landet er langt mindre sønderrevet i øer, skjær og baaer, saaledes er fjordene mere at betragte som store aabne havarme.

Deres dybde er i regelen af omtrent samme dyb som landbakken, ca. 100 favne, (f. eks. Laksefjord, Porsangerfjord, Varangerfjord), og de naar saaledes ikke de store dybder som fjordene længer syd. De udmerker sig ved en jevn mudderbedækket bund, som intet fæste byder for nogen redskaber.- Bunden skraaner jevnt op mod stranden, og udfor denne findes mange steder store arealer med fin, hvid sand og ringe dybder (5-10 favne); ligesaa har fjordene i regelen ud mod havet endel aabne, tragtformige smaafjorde som biarme, og disse udmerker sig ogsaa ved ganske jevn, grund sandbund.

Som havbunden faar sin eiendommelighed fra den geologiske beskaffenhed af det faste land, saa paavirkes havets fysikalske og biologiske forhold i mange henseender af landets naturbeskaffenhed, og vi vil 
derfor, før vi skildrer havet, med nogle ord omtale de klimatiske forhold i Finmarken. ${ }^{1}$ )

Indlandsklimaet i Finmarken udmerker sig fremfor alt ved de store vekslinger fra sommer til vinter. I Karasjok, 430 fod høit, og langt inde i landet har man om sommeren aflæst en temperatur af op til $31^{0}$ celsius; om vinteren har derimod gjennemsnitstemperaturen for aarets 3 koldeste maaneder været beregnet til $\div 15^{0} .5$, saaledes at det hele aars gjennemsnitstemperatur fandtes at være $\div 3^{0}$. Ude ved havkysten derimod naar temperaturen om sommeren aldrig saa høit; $9^{0}$ er i Vardø den varmeste maaneds (augusts) gjennemsnitstemperatur. Om vinteren synker temperaturen paa den anden side ikke saa lavt; $\div 6^{0}$ er den koldeste maaneds gjennemsnitstemperatur, men da sommeren er saa kort, ja først kan siges at indtræde $\mathrm{i}$ sidste halvdel af juni, og er forbi med august, er aarets gjennemsnitstemperatur i Vardø alligevel saa lav som $0^{0} .5$.

Endnu langt mindre er de vekslinger, havet frembyder, og langt høiere er dets aarlige gjennemsnitstemperatur. Vi har en temmelig fuldstændig række temperaturobservationer fra havet udenfor Vardø for aaret 1901 (dels tagne af „Michael Sars“, dels af redningsskøiten „Kristiania“s fører kaptein Paulsen). Denne viser:

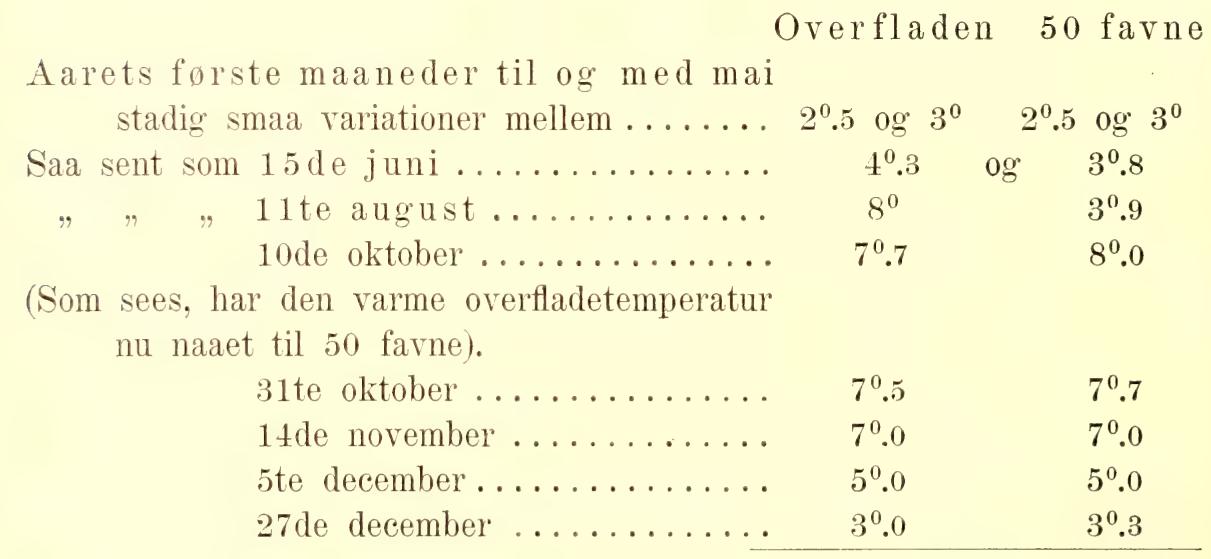

Som man af denne tabel ser, var temperaturvariationerne i de øverste 50 favne udenfor Vardø i aaret 1901 begrænsede til omraadet $2^{0} .5-8^{0}$. Dette gjælder vistnok ikke for alle aar, især er der ved de af fiskeriinspektør Søkensen foranledigede temperaturobservationer vist, at der om vinteren især efter østlige storme kan indtræde lavere temperatur, saaledes enkelte aar ned til ${ }^{1 / 2} 2^{0}$, men bortseet fra disse variationer

1) Se Axel Steen: Climate. Norway. Official publication 1900. 
fra aar til aar, giver dog tabellen et godt indtryk af den "aarlige periode" i temperaturvariationerne i havet udenfor kysten paa et sted som Vardø, og havoverfladens aarlige middeltemperatur vil formentlig kunne fastslaaes til mellem $4^{0} \mathrm{og} 5^{0}$, nærmest $5^{0} .0$. Denne temperatur er, som man ser, langt høiere end landets. Ovenfor nævntes jo, at Vardøs middeltemperatur kun var $+0^{0} .5$. Dette store overskud i havets varme, sammenlignet med landets, tilføres det søndenifra med sydlige havstrømme, $\mathrm{og}$ af overskuddets størrelse kan man forstaa, hvilken overordentlig indflydelse paa havet og dets beboere disse havstrømme maa have. En aarlig middeltemperatur af $5^{0}$ naaes nemlig paa land langs den norske kyst først, naar man kommer saa langt syd som mundingen af Trondhjemsfjorden, 180 geogr. mil længer syd og vest end Vardø.

Det er Golfstrømmen eller Atlanterharsstrømmen, som fører dette varme vand op til Norges nordligste kyst. Man har beviser for denne strøms tilstedeværelse og oprindelse under langt sydligere bredder foruden i den nævnte høie temperatur ogsaa i strømflasker, der er udkastede langt syd og gjenfundne langs Norges nordlige kyst, endvidere i de bekjendte flydende, sydamerikanske store frø, mest bekjendt Entada gigalobium, som af $\mathrm{og}$ til findes langs kysten, i drivtømmer af sydlige trær, der findes bevoksede med sydatlantiske organismer helt oppe ved Nordkap. Jeg var selv heroppe vidne til, at hvalfangeren Montex IngEBRIGTSEN fra Tromsø indbugserede en mægtig firskaaren tømmerstok af pitch pine overgroet med tusinder af store $(10-15 \mathrm{~cm}$. store) langhalse („fugleunger", Lepas anatifera).

Atlanterhavsstrømmen kommer, som bekjendt, ind i det norske hav mellem Shetland $\mathrm{og}$. Island, den bøier straks østover og følger den norske kyst $i$ en bredde af 40-60 geografiske mil og en dybde af et par hundrede favne. Mod vest grænser strømmen mod den østgrønlandske polarstrøm med en grænse, der efter aarstiderne flyttes adskillig øst og vest.

Om sommeren er vandet i Nordhavet indtil $10-11^{0}$ varmt; denne varme er dels ført med fra sydligere bredder, dels skyldes den direkte solen. Om vinteren derimod blir det varme vand sterkt afkjølet; da strømmer der til kold luft fra de omgivende store kolde omraader og berøver vandet i overfladen dets varme. Men naar temperaturen aftar, blir dette overfladevand efterhaanden tungere end det vand, som ligger under, og derfor synker det, mens det varmere stiger op. Herved kan alt vandet i de øverste 100-150 meter paa hvert sted bli blandet sammen, saa det faar omtrent samme saltmængde og samme lave temperatur; $\mathrm{og}$ temperaturen blir lavest ved grænsen mod polarvandet med dets ismasser. Som det sees paa de 2 overfladekart er temperaturen fra sommer 1900 til marts 1901 aftat med $4-5$ grader, mens derimod det salte vand i overfladen har faaet en større udbredelse; thi paa grund af vertikalstrøm- 
ningerne kommer meget af alt det salte vand, som fandtes i 50-100 meters dybde, op til overfladen. Til andre aar kan sikkert de salte partier i overfladen være adskillig mindre end i 1901.
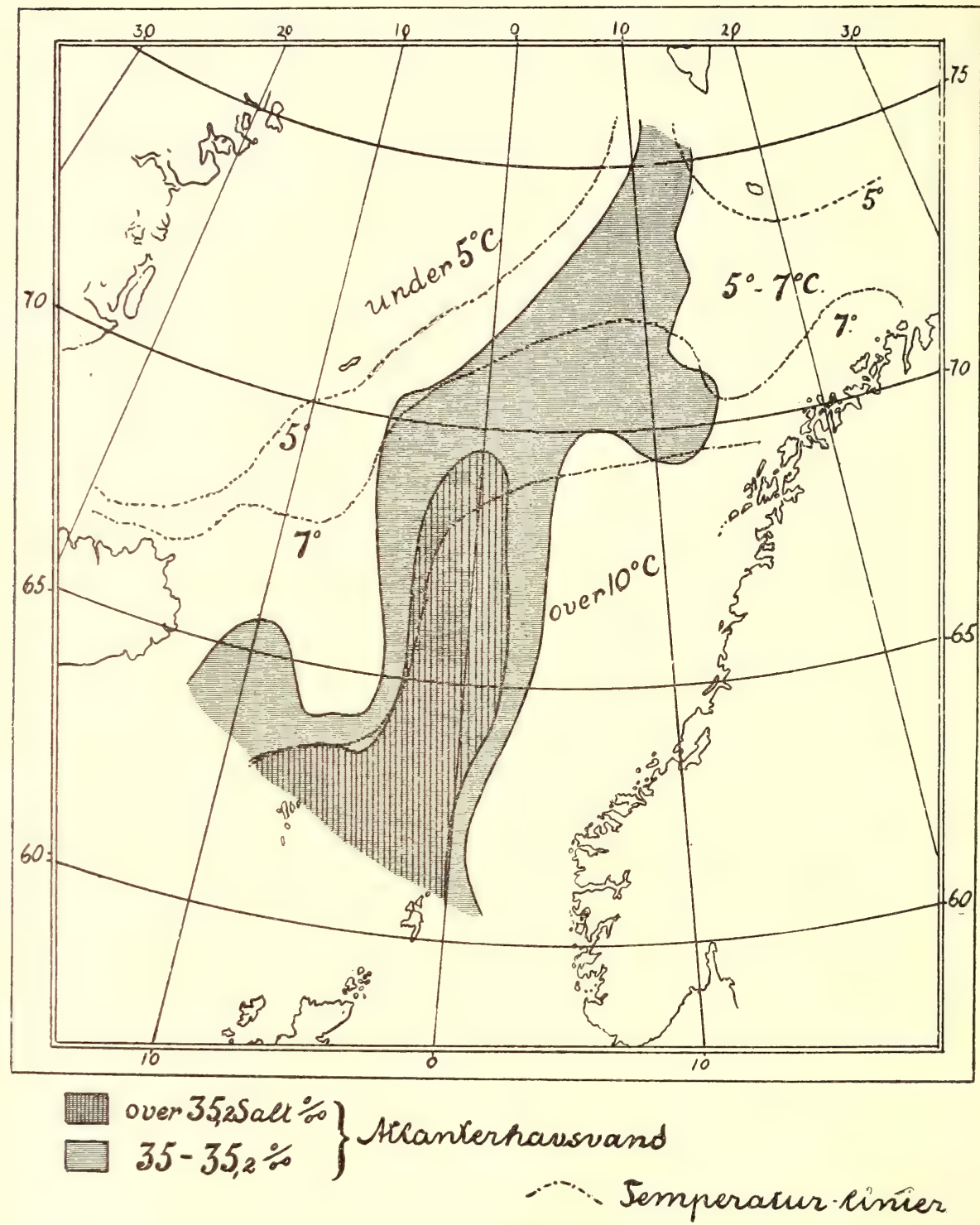

Fig. 2. Havoverfladens saltgehalt og temperatur sommeren 1900 efter professor Nansens undersøgelser under „Michael Sars" togter.

Øst, mod Norge beskyller strømmens vandlag de norske kystbanker, den overdækkes i større eller mindre bredde af kystvandet fra Norges elve og fjorde. Naar den kommer nord til Vestfinmarkens kyster, deler 
den sig i to grene, hvoraf den ene følger eggen nordover mod Spitsbergen, den anden Norges kyst ind i Østhavet. Her indtager den hele den centrale del af farvandet.

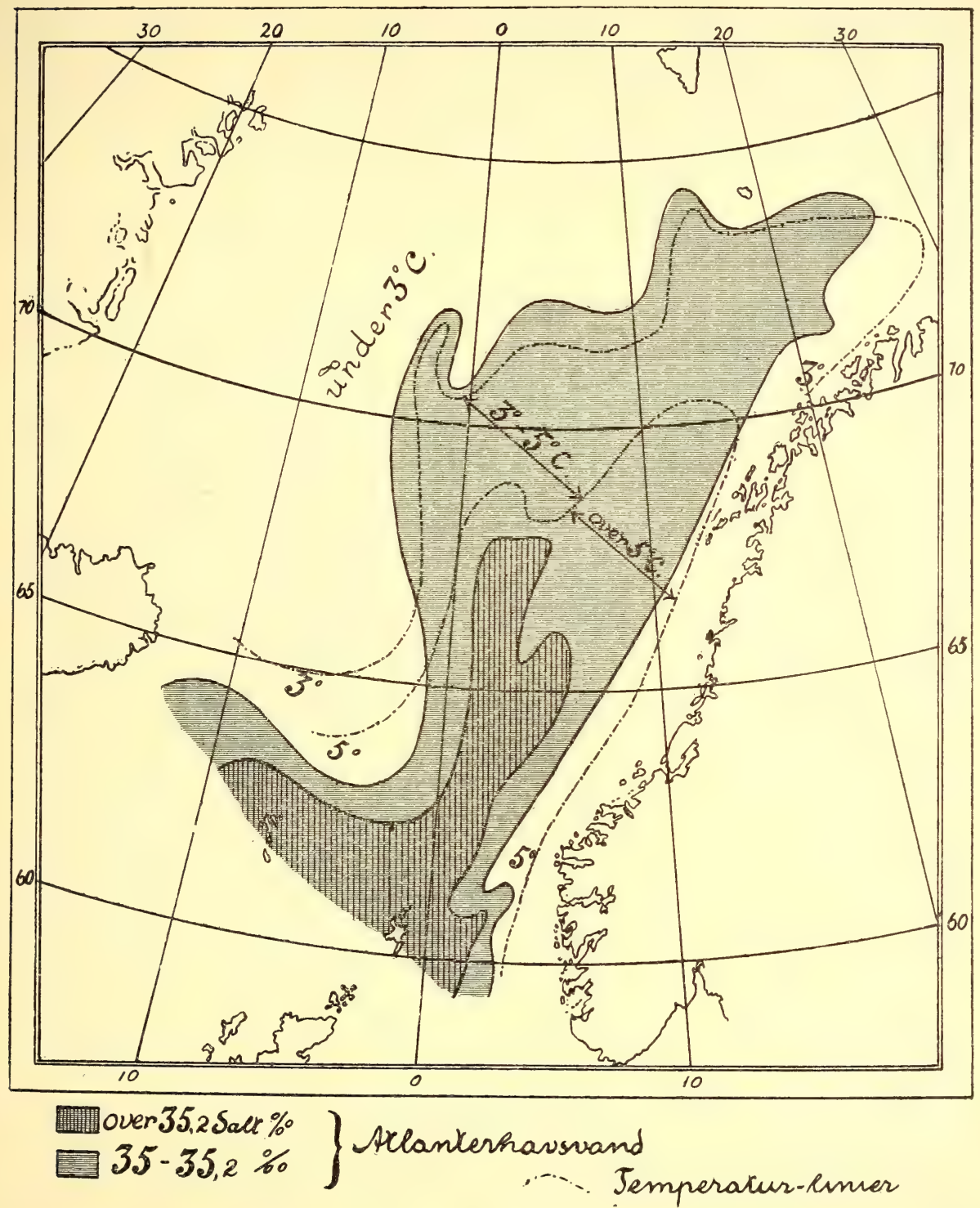

Fig. 3. Havoverfladens saltgehalt og temperatur februar-april 1901 efter HELLANDHansens undersøgelser under "Michael Sars" togter.

Som man ser af fig 4, der fremstiller et tversnit af havet mellem Norge og Bjørnøen ved sommertid, bestaar hele den midtre del af havet af altlanterhavsvand; i overfladen naar temperaturen optil $7^{0} \mathrm{og}$ henimod 
bunden (200-250 favne) til ca. $3^{0}$. Mod Bjørnøen begrænses dette varme vand af et iskoldt vandlag, hvis temperatur gaar helt ned til :$1^{0}, 6$; det er ishavsvandet som her skyder sig ned fra polarhavet og dæmmer op det varme vand. Mod Norge begrænses atlanterhavsvandet af kystvand, der spædes op med ferskvand fra land og derfor har noget lavere saltgehalt. Om vinteren ser man (se fig. 5) fremdeles atlanterhavsvandet gjøre sig sterkt gjældende. Dets temperaturer er nu adskillig lavere, dog gjælder dette væsentlig temperaturerne i de øverste 100 favne, dybets temperaturer har holdt sig omtrent uforandret.

Af dette kan vi slutte, ati atlanterhavsstrømmen fortsættes aaret

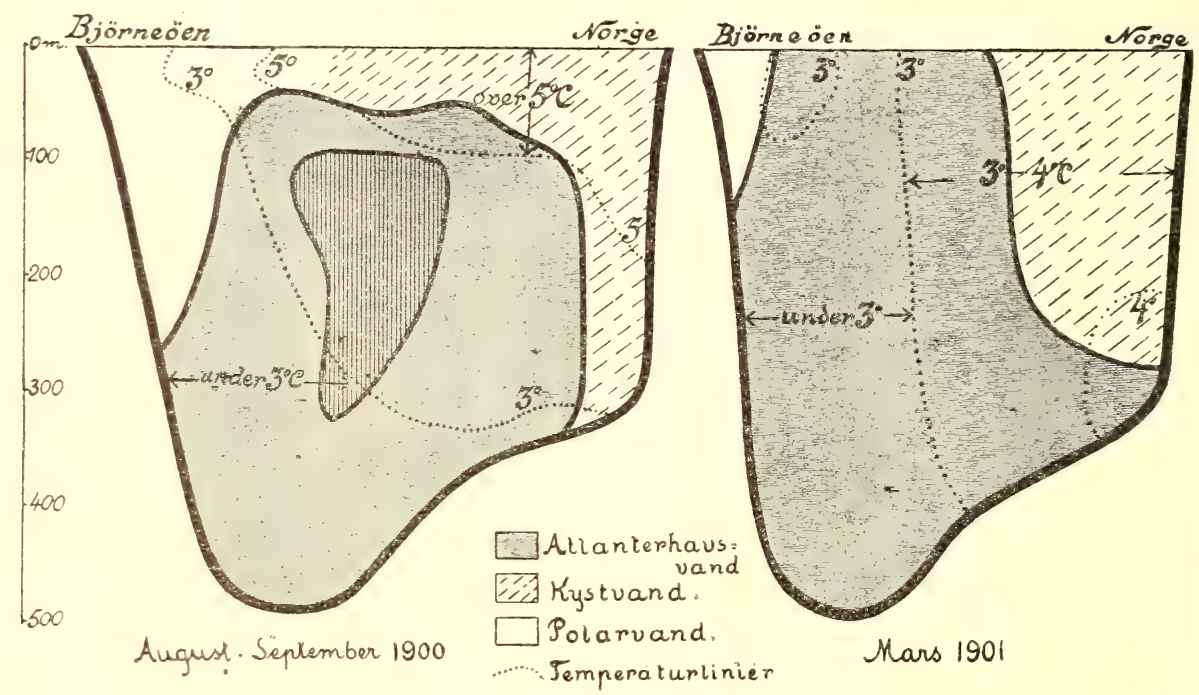

Fig 4. Snit af havet mellem Bjørnøen og Norge august 1900 efter professor Nansens undersøgelse af "Michael Sars" materiale.

Fig. 5. Snit af havet mellem Bjørnøen og Norge marts 1901 efter Helland-Hansens undersøgelser.

rundt og ikke stanser til nogen aarstid. Det samme fremgaar ogsaa af de drivende gjenstande $\mathrm{i}$ havet, specielt af de drivende organismer. Det lykkedes os med "Michael Sars" i aaret 1901] at udføre endel togter over atlanterhavsstrømmen, udfor. Tromsø, mellem Norge og Bjørnøen o. s. v. ved vintertid (februar-marts), $0 \mathrm{~g}$ i denne tid fandtes drivende organismer, der af hr. H. H. GRAN er blevet; bestemt som sydatlantiske former, der har sit hjem langt borte fra Finmarkens hav. Disse former hører specielt til de laveste, de saakaldte encellede former. (Han har meddelt mig følgende liste paa de mest karakteristiske af disse drivende sydlige vintergjæster: Podolampas palmipes, Dinophysis homunculus, Euodia cuneiformis, Dactyliosolen antarcticus samt en hel række arter 
sydlige Radiolarier). Ved disse fund bevises atlanterharsstrømmens k onstante retning aaret rundt, hvilket er et resultat vundet ved vore togter og af stor betydning for forstaaelsen af dyrelivet.

Atlanterhavsstrømmen er saaledes aar om andet konstant $\mathrm{i}$ sin retning, derimod ikke i styrke eller i evne til at trænge frem. Den afbalanceres nemlig af kolde havstromme. Disse faar sin oprindelse fra to kilder, polarhavet $\mathrm{og}$ kystvandet.

Polarstrømmene omgiver atlanterhavsvandet paa alle kanter undtagen, hvor den berører den norske kyst. Mod vest trænger den atlan-

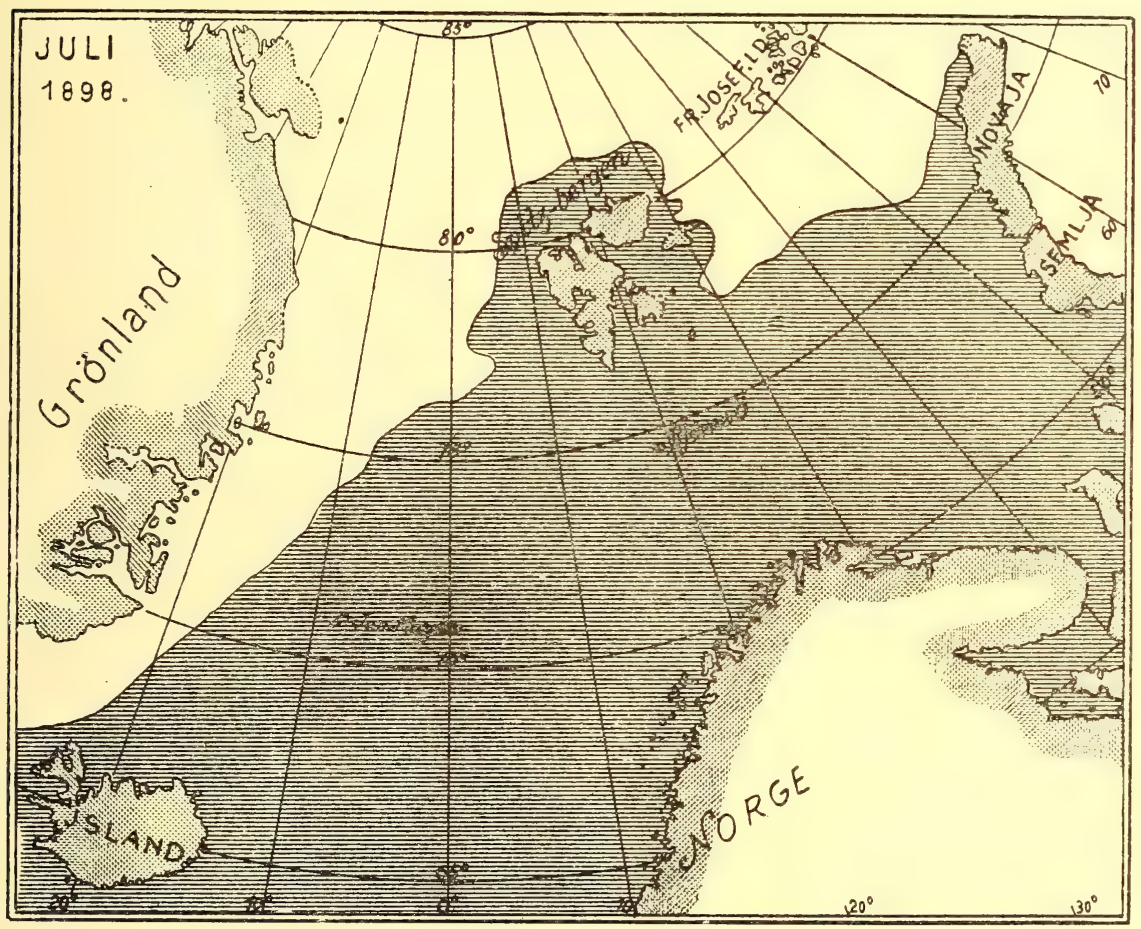

Fig. 6. Isgrænsen juli 1898. Efter det danske meteorologiske instituts beretninger.

terhavsvandet sammen, og berøver det megen varme. Mens vi saaledes under vort augusttogt i 1900 fandt vand af over $5^{0}$ helt til en $70-80$ mil udfor Senjen eller Tromsø og polarvandets ismasser da havde en afstand fra Norge af mindst 120 mil, har hvalfanger Ingebrigtsen, som paa sine bottlenosjagter tidlig paa vaaren og sommeren streifede over denne havstrækning og der stadig gjorde temperaturobservationer, meddelt mig, at han $\mathrm{i}$ april maaned (da isen $\mathrm{i}$ almindelighed naar længst hen mod Norge) har kunnet finde vand af over $4^{0}$ kun i et belte af $35-40$ mil nv. af Røst; i denne afstand mødte han et koldt belte af kun $0^{0}-2^{0}$, og 15 mil længer mod nv. stødte han paa isen. Den 18de-19de mai 
1881 var isen og med den polarvandet kun 50 mil nv. af Malangen. Af bottlenosfangeren „Jasai"s journaler, der ogsaa indeholder meget interessante temperaturobservationer i maanederne april-juni vest for Tromsø, og som velvillig er mig overladt, sees, at det kolde vand af ca. $1^{0} \mathrm{i}$ april maaned $\mathrm{i}$ aarene $1893-94 \mathrm{var}$ ca. $60 \mathrm{mil} \mathrm{nv}$. af Malangen. Atlanterhavsstrømmen klemmes altsaa sammen til en langt smalere bredde om vinteren vest for det nordlige Norge.

Nord for Norge er utvivlsomt ogsaa det samme tilfældet, skjønt man her har langt færre sikre observationer at slutte dette af. Saale-

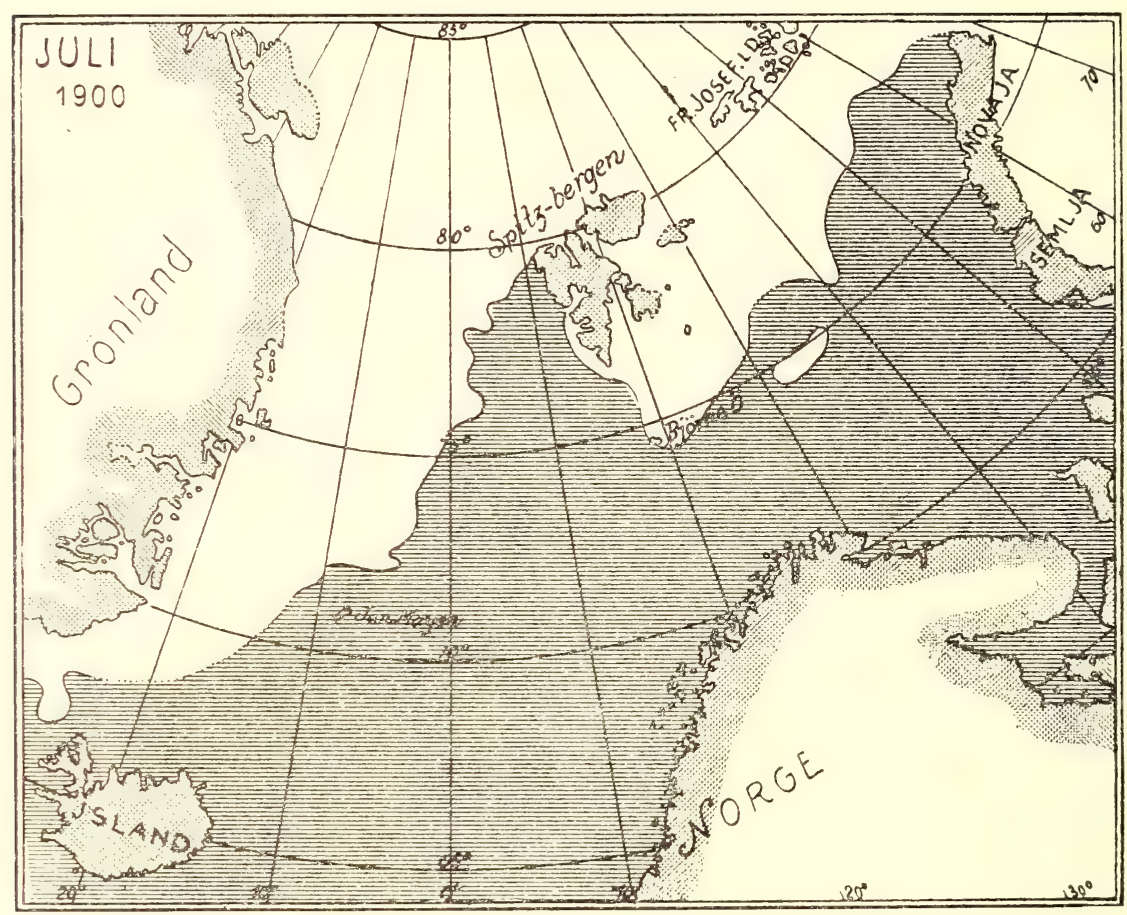

Fig. 7. Isgrænsen juli 1900. Efter det danske meteorologiske instituts beretninger.

des vil man af vort vintertogt, marts 1901, faa det indtryk, at atlanterhavsstrømmen var lige bred den vinter som foregaaende sommer. Der maa imidlertid være store variationer i dette, og disse variationer maa have stor betydning for klimatet i Finmarken og for fiskerierne. Saaledes fortalte INGEBRIGTSEN mig, at isen i den samme vinter 1881, da den kun var 50 mil nv. af Malangen, kun laa 20 mil retvisende nord af nordre Fugleø (Loppehavet), hvilket mindst er ca. 40 mil, ja kanske endnu mere, nærmere end hvad den i regelen er om sommeren.

Isgrænserne giver $\mathrm{i}$ det hele udmerkede billeder af polarstrøm- 
menes variationer, og de indeholder det eneste materiale, som haves om disse ting.

De viser (se fig. 6-9), hvorledes isen om sommeren i regelen træffes vest ved Jan Mayen, nord ved Bjørnøen eller nordligere, at der findes et stort aabent hav indover i østhavet, saa vore fangstfolk om sommeren, som bekjendt, kan naa henimod Frantz Josefsland og Novaja Zemblja. De viser, at isen om vinteren trækker nærmere Norge i en stor bue, at det aabne vand op mod Spitsbergen lukker sig, for forst om sommeren at splittes op igjen som en lang spalte, at østhavets farbare del ind-

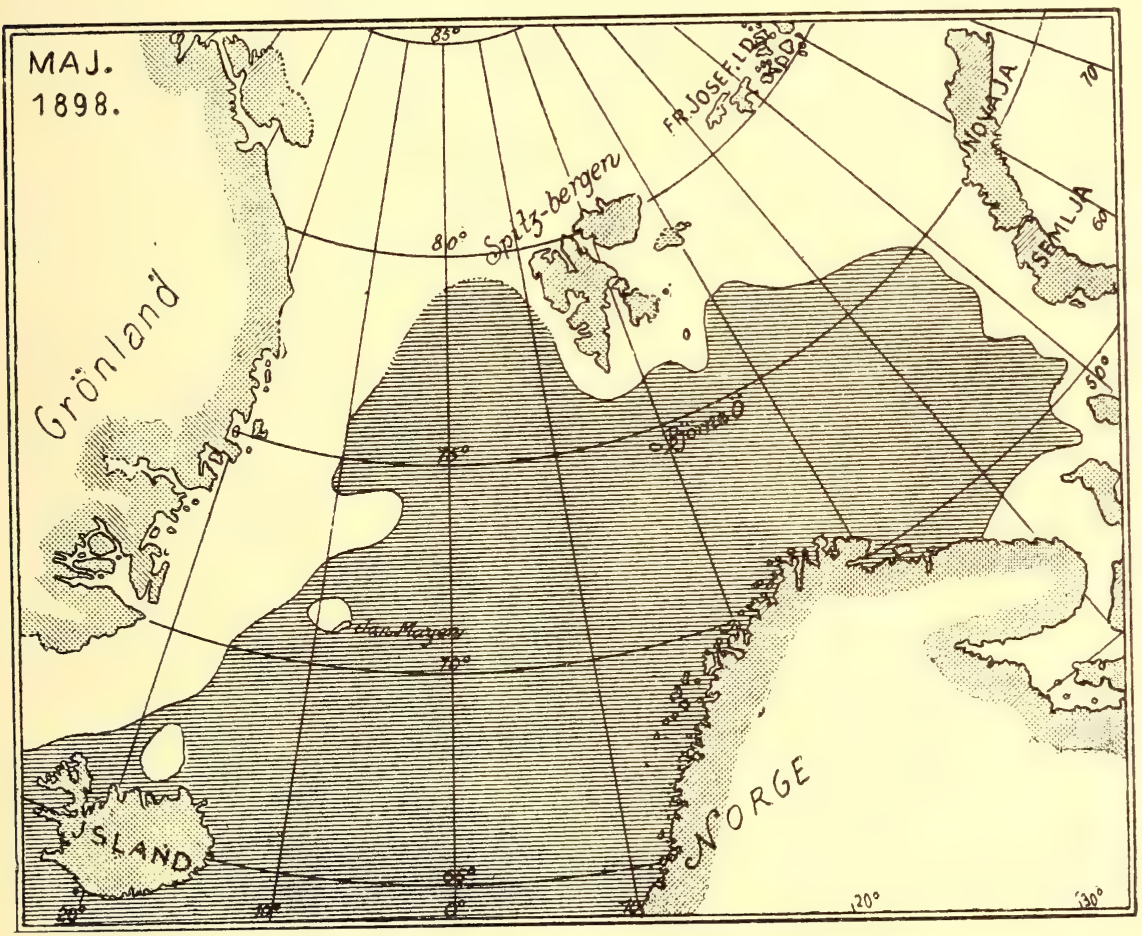

Fig. 8. Isgrænsen i mai 1898. Efter det danske meteorologiske instituts beretninger.

skrænkes til en ca. 40 mil bred rende, der parallelt følgør Norges kyst og Murmankysten, og at derved det store hav mellem Bjørnøen og Spitsbergen i vest og Frantz Josefs land og Novaja Zemblja i øst er dækket af en eneste sammenhængende ismasse. De journaler, jeg har faaet af vore ishavsfarere (sælfangere), viser, at dette varer langt ud i juni.

Kandidat WoLLевжк, der i aaret 1900 medfulgte chefsfartøjet „Heimdal" paa dets tur til „Østisen“, tog her endel temperaturobservationer, der viser forholdene $\mathrm{i}$ de vandmasser, som isen svømmer i. 
24 de mai (paa $68^{\circ} .20^{\prime}$ nord, $40^{\circ} .35^{\prime} 0$ )

overfladen :- $1^{0} .65$

10 favne $\div 1^{0} .65$

$35-\div 1^{0} .65$

31 te mai (paa $71^{0} .48^{\prime}$ nord, $\left.49^{0} .38^{\prime} 0\right)$

overfladen $\div 1^{0} .32$

10 favne $\div 1^{0} .50$

$50-\div 1^{0} .65$

$60-\div 1^{0} .80$.

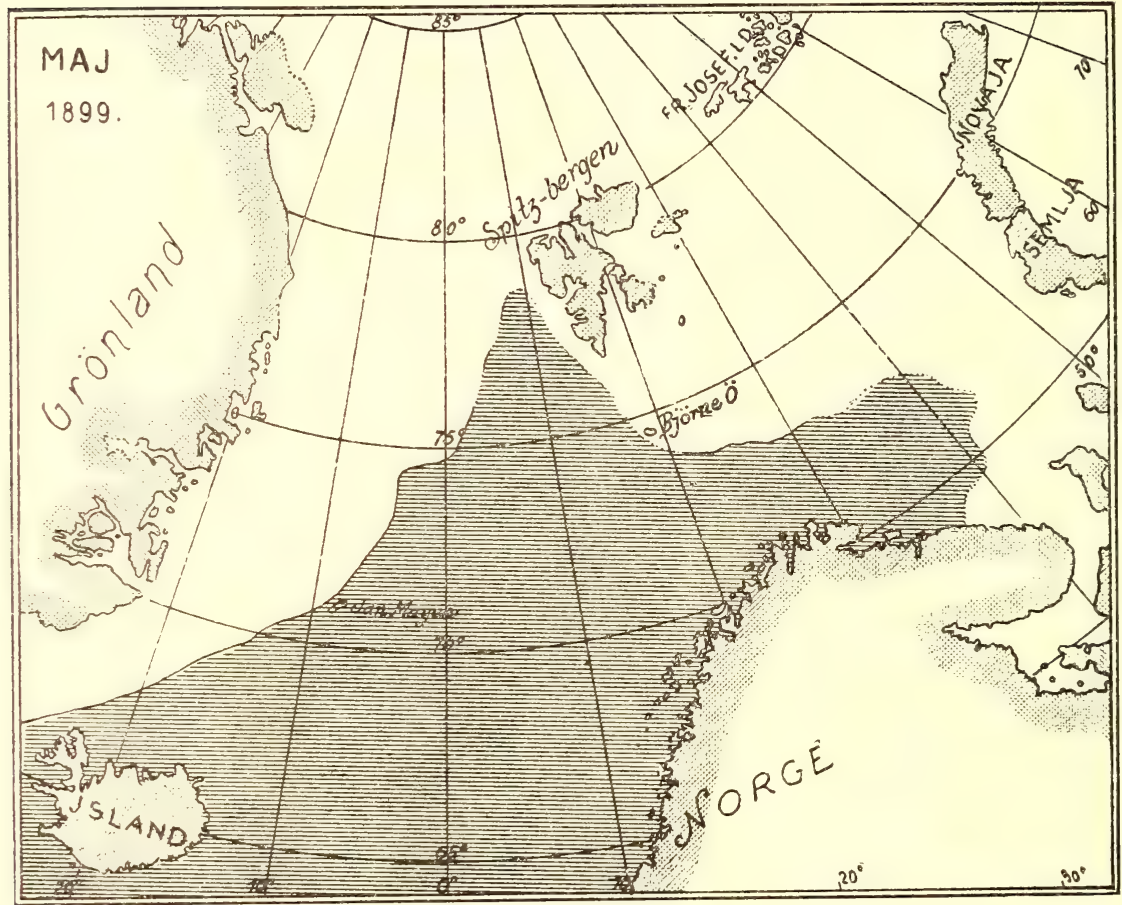

Fig. 9. Isgrænsen mai 1899. Efter det danske meteorologiske instituts beretninger.

Isgrænsen fandtes paa „Heimdal"s togt i en bue udenfor Hvidehavets munding op vestenfor Novaja Zemblja i en afstand af flere mil af denne.

Den russiske ekspedition under ledelse af professor KNipowitsch har gjort denne del af Østhavet til gjenstand for en særdeles grundig undersøgelse. Af denne $^{1}$ ) fremgaar det, at den største del af havet østenfor den 40de længdegrad aaret rundt har meget lave temperaturer. Især er havbunden bedækket af vand af temperaturer af ca. $0^{0}$ ofte $\div 1^{0} \_-10^{0}$. Kun om sommeren $0 \mathrm{~g}$ noget udover høsten bliver de $\emptyset$ verste

1) N. Knipowitsch: Arbeiten der Expedition etc. der Murmanküste von Mai bis November 1900. 
5 favne noget opvarmede til $2^{0}-3^{0}$, og da kan ogsaa en varmebølge i dybet vestenfra trænge fremover noget længer øst især en 3-4 mil nord af Kap Kanin, Hvidehavets munding, hvor dette sidstes kolde vandmasser ikke længer kan spores. Ligeledes har den russiske ekspedition til forskjellige aarstider udført en række strabatiøse togter i en linie fra Kolafjorden ret nord til isgræensen (ca. $75^{\circ}$ nord) langs den 33te længdegrad, $\mathrm{og}$ ved disse undersøgelser har det vist sig, at der fra vaaren udover sommer og høst gaar en stor bølge af varmt vand østover langs Murmankysten. Bundtemperaturen stiger saaledes betydelig selv i 100 favnes dyb i kysthavet der fra juni til høsten ved tilstrømning af varmere vand vestenfra.

Ovenfor nævntes, at atlanterhavsvandet overalt grænser mod polarvandet undtagen langs Norges kyst, hvor det støder mod kystvandet. Dette er, fordi det er opblandet med ferskvand, lettere end atlanterhavsvandet og flyder derfor ovenpaa, eller det kan trænges ind mod det faste land. Som kysten den største del af aaret er koldere end havet der nord, og det ferskvand, der tilføres havet, kommer fra landets elve og smeltende snemasser, er kysthavet i det hele om vinteren og vaaren koldere end det aabne hav; derimod er det om sommeren ofte varmere. Mest udpræget finder man forskjellen paa kystvandet og havet ved at sammenligne temperaturforholdene om sommeren inde $\mathrm{i}$ en af de dybere fjordes inderste bassiner med forholdene i havet udenfor kysten. Medens saaledes havets overflade udenfor Nordkap og i det ydre af Porsangerfjorden i august 1900 havde en temperatur af ca. $7^{0}$ og i 100 favnes dyb ca. $4^{0}$, var temperaturen inderst i Porsangerfjorden i overfladen $7^{0} \mathrm{og}$ ved bunden $\div 1^{0}$. Herinde stod vinterens kolde vand i dybet, kun i overfladen havde sommervarmen formaaet at gjøre sig gjældende.

Forholdene i kysthavet om vaaren kan illustreres saaledes:

\section{I mai 1901.}

Udenfor kysten. Ytre Porsanger Indre Porsanger. Tamsø

$\begin{array}{rrrr}\text { Overfladen } \ldots \ldots & 2^{0} .9 & 3^{0} .5 & 3^{0} .5 \\ 25 \text { favne } \ldots \ldots & 2^{0} .7 & 2^{0} .2 & 1^{0} .2 \\ 50-\ldots \ldots & 2^{0} .9 & 2^{0} .2 & 1^{0} .2 \\ 100-\ldots \ldots & 3^{0} .4 & & \end{array}$

I april 1901.

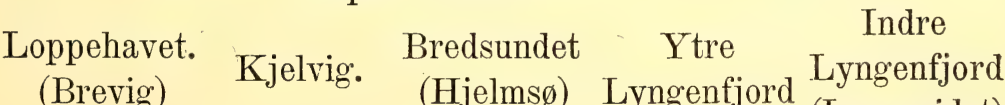

$\begin{array}{rccccc}\text { Overfladen. } & 3^{0} .1 & 2^{0} .8 & 1^{0} .7 & 2^{0} .5 & \text { (Lyngseidet) } \\ 25 \text { favne . } & 3^{0} .7 & 2^{0} .8 & 1^{0} .6 & 2^{0} .6 & 0^{0} .8 \\ 50-. & 4^{0} .1 & 2^{0} .8 & & 3^{0} .3 & \\ 100-. & 4^{0} .1 & & & & \end{array}$


Der er, som man ser, en tydelig paaviselig forskjel mellem havet udenfor kysten paa den ene side og skjærgaarden og fjordene paa den anden side, og jo længer ind man kommer, desto større blir forskjellen.

Dette kolde kystvand, som fylder skjærgaard og fjorde, staar nu ved kystvandet udenfor Murmankysten i forbindelse med polarvandet. Ligesom isgrænsen langt øst i Østhavet bøier mod syd og der møder kystens især Hvidehavets ismasser, saaledes forener det kolde polarvand sig med Hvidehavets vandmasser, der især efter isløsningen flyder vestover langs Murmankysten til Finmarkskysten, og herved opstaar formentlig om vaaren en vestgaaende kyststrøm, der fører koldt vand østenfra vestover. Nogle eksempler herpaa fra mine togter langs Finmarken og Murmankysten viser dette:

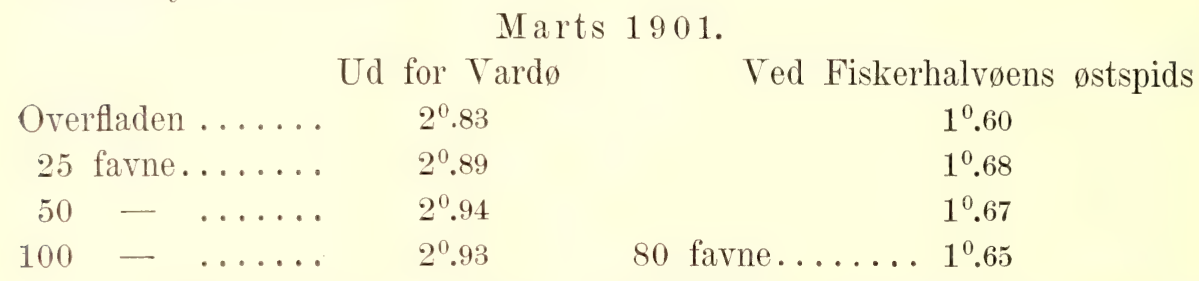

I overensstemmelse hermed er den erfaring, der findes i Finmarken, at koldt veir og lav temperatur i vandet indtræder med østlige storme.

Hvallovkomiteen af 1890 meddeler saaledes i sin indstilling, at den 1ste mai 1888 fandt dr. SJøstrand udenfor Karabelna (paa østsiden af Fiskerøen) $\div 0^{0} .75$ i overfladen, og russiske hvalfangere i marts og april mellem Murman og Tana $\div 0^{0} .75$ til $\div 1^{0} .5$.

$\mathrm{Vi}$ ser her øst i virkeligheden kystvandet staa i direkte forbindelse med polarvandet ud for Novaja Zembljas kyster. Overgangen dannes af Hvidehavet, der i hydrografisk henseende dels har karakteren af en stor fjord dels af en arm af polarhavet. Ligesom Porsangerfjordens inderste del har ogsaa "Hvidehavet" aaret rundt med undtagelse af de aller øverste overfladelag særdeles lave temperaturer. I den inderste del af Hvidehavet fandt Kмгрошітsсн saaledes i august maaned følgende interessante forhold. I de øverste 10 favne en synkende temperatur fra + $13^{0}$ i overfladen til $+5^{0}$, allerede i 20 favne var temperaturen $0^{0}$, i 25 farne $\div 0^{0} .5$, i 50 favne $\div 1^{0} .5$, i 75 favne $\div 1^{0} .6$.

I forbindelse hermed kan nævnes, at isen som bekjendt ligger særdeles længe i Hvidehavet, der alene betragtes farbart i maanederne juni -oktober. Naar det om vaaren eller forsommeren bryder op, ismasserne smelter, og desuden de vældige snemasser fra landet og elvene føres ud i havet, sender det store vandmasser ud langs Murmankysten, og især ved østlige storme kan da disses indflydelse paa kysthavet spores langt restover, saaledes ogsaa ved den norske Finmarkskyst. 


\section{Bunddyrene.}

De første naturforskere, som anstillede grundige undersøgelser af dyrelivet $\mathrm{i}$ det hav, der beskyller det nordlige Norges kyster, var Michaes SaRs og G. O. Sars. ${ }^{1}$ ) Ifra femti- til syttiaarene undersøgte de strækningen fra Lofoten til Finmarken, og her søgte de overalt fra stranden til blaaleren paa flere hundrede favnes dyb med smaa bundskraber at samle de forskjellige dyreformer, der kunde give et billede af livets art og beskaffenhed i de forskjellige havdybder. Det hovedindtryk, disse mænd fik af dyrelivet, var det, at det bestod af en blanding af meget forskjelligartede bestanddele, dels dyreformer, de saakaldte arktiske, som findes i størst mængde og trives bedst i de rent polare eller arktiske farvand, og dels sydligere former, som i store mængder findes i langt varmere have, men som her forekommer som enkelte spredte individer. G. O. SARS, der bygger sin tænkning over dyrelivet nordpaa, paa kundskaben om det tidsrum i jordklodens historie, der kaldes istiden, da vort land var dækket og vore fjorde udfyldt af vældige bræer, som man nu finder dem ved Spitsbergen, siger om faunaen, dyrelivet nordpaa, ${ }^{2}$ ) at denne „paa de fleste punkter er af en meget blandet charakter, idet det oprindelige arktiske element er tilblandet talrige dyreformer af aabenbart sydligere oprindelse. At her har skeet en indvandring sydfra, og at denne indvandring fremdeles gaar for sig, synes at være utvivlsomt $\mathrm{og}$ kan tildels ogsaa ganske direkte paavises." Han paaviser endvidere, hvorledes denne indvandring begunstiges eller stanses alt efter de i vor tid herskende naturforhold, saaledes at der f. eks. inderst i de dybe fjorde, hvor al vinterens kolde vand frembringer en lav temperatur findes igjen en mængde „efterliggere" fra den arktiske istid, mens der ude ved havkysten, hvor den varme havstrøm raader, lever langt sydligere dyreformer, et forhold, der blir noksaa klart, efter hvad ovenfor er meddelt nemlig, at vi inderst i en fjord som Porsangerfjordens Østbotten kunde finde temperaturer helt ned til $\div 0.65$ midtsommers. Endvidere viser SARS, hvorledes man, jo længer nord og øst man kommer, møder mere og mere arktiske dyreformer. Ved Lofoten, ja selv saa langt nord som ved Hasvig paa sydvestsiden af Sørøen fandt SARs taunaen meget opblandet med sydlige former. "Navnlig viste dybhavsfaunaen sig her kun lidet for-

1) Se f. eks. Michael Sars: „Bidrag til en skildring af den arktiske molluskfauna ved Norges nordlige kyst."

G. O. SARS: Mollusca regionis arcticae norvegice. Universitetsprogram. 1878.

2) Nogle bemærkninger om den marine faunas charakter ved Norges nordlige kyster. Tromsø museums aarshefter II. Tromsø 1879. 
skjellig fra samme i Vestfjorden." „Først østenom Nordkap bliver det arktiske element i faunaen dominerende ogsaa ud mod havkysten og paa de større dyb. Her taber nemlig Atlanterhavsstrømmens indvirkning sig mere og mere, alt eftersom kysten bøier af i sydostlig retning, og Varangerfjorden, skjønt i sin charakter fuldstændig lig Vestfjorden og ligesom denne snarere at betragte som en havarm end som en fjord, viser lige fra stranden af og ned til de største dybder en fuldkommen ren og ublandet arktisk fauna."

Et klart billede af denne dyreverdenens successive forandring fra syd mod nord kan man naturligvis kun faa ved kjendskabet til de enkelte former, saa meget mere som disse i sin levevis indbyrdes er meget forskjellige, idet nogle lever paa grundt vand, andre i større dyb, atter

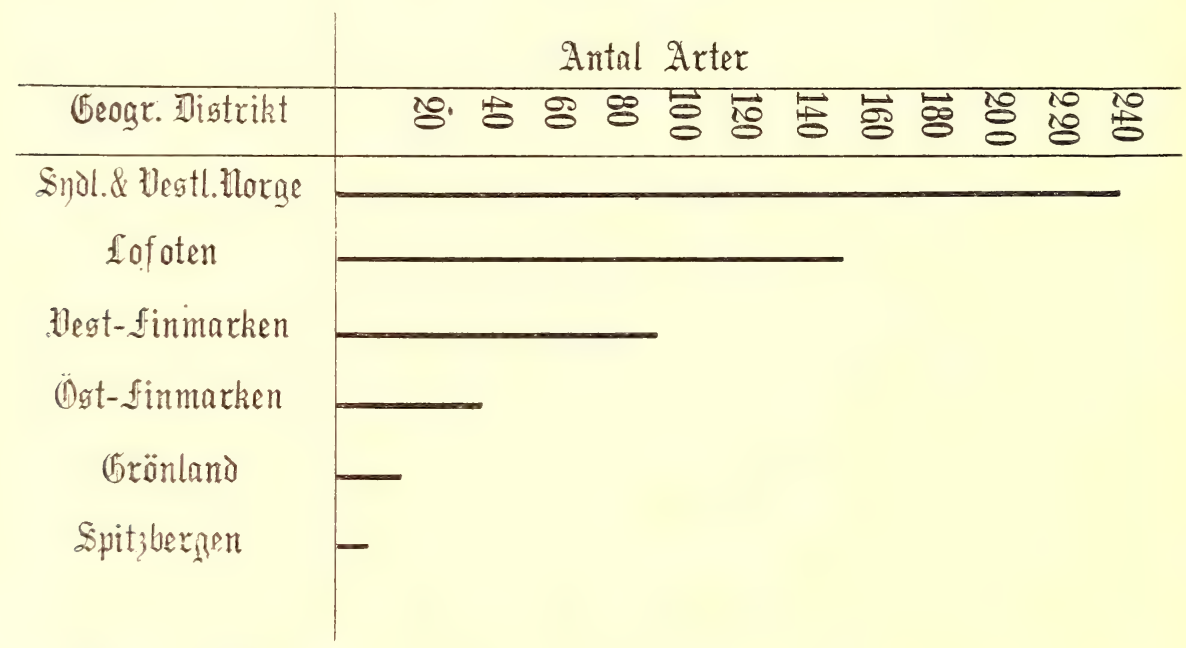

Fig. 10. Grafi-k fremstilling af Middelladvets molluskers udbredelse mod nord efter G. O. SARS arktiske mollusker (Norges arktiske fauna).

andre er ikke født, hvor de lever, men som fritsvømmende larver ført did af havstrømmene 0.s.v.

I mangel af det mere omfattende indblik i havets livsforhold, som alene specialforskeren kan erhverve sig, vil man allerede af forholdsvis enkle sammenstillinger af hovedresultaterne af disse mænds arbeider kunne se lovmæssigheden i organismernes udbredelse. Med saadant maal for øie har jeg af G. O. SARs verk om de arktiske molluskers (skjæl og snegler) udbredelse søgt at udarbeide en grafisk fremstilling paa den ene side af de arktiske (Polarøernes) og paa den anden side af de sydlige (Middelharets) formers udbredelse udentor de farvand, hvor de forekommer i størst mængde, øiensynlig trives bedst og derfor i almindelighed siges „at have sit hjem". 
Som man af fig. 10 vil se, aftager artsantallet af Middelhavets mollusker mod nord, størst er forskiellen fra Vest- til Østfinmarken, kun nogle ganske faa findes endnu oppe ved Spitsbergen. Omvendt aftager de arktiske mollusker sydover, kun nogle ganske faa gaar ind i Midde]havet. Denne successive forandring i bundfaunaen svarer saaledes til lignende forandringer i havet selv.

Efter med disse faa ord at have skildret bundfaunaens biologiske karakter saaledes som studiet af en enkelt karakteristisk dyregruppe. molluskerne, har kunnet forklare den, skal vi i det følgende betragte lidt nærmere dens sammmensætning.

I august 1900 udførte vi endel trawltræk dels med engelsk trawl, dels med rægetrawl helt fra det inderste af Porsangerfjorden op til Bjørnøen, og sommeren 1901 undersøgte vi farvandet endnu nordligere op mod Spitsbergen $\mathrm{og}$ i dette lands fjorde. Jeg har saaledes til disposition en stor række undersøgelsesstationer, der giver et godt overblik over forholdene i Finmarkshavet. For at denne væsentlig paa ikke fagmæssig uddannede læsere beregnede fremstilling ogsaa skal kunne læses med udbytte af fagfolk vil jeg i det følgende ogsaa nævne endel latinske navne paa de forekommende dyr, og herunder skildre dyrelivet paa nogle faa blandt de mange udsøgte og karakteristiske stationer.

1. 24de august 1900 . Inderst i Porsangerfjorden (den saakaldte Østpol) gav et træk med rægetrawl af ca. 15 fods vidde i 1 time i $30-50$ favne dyb følgende ting:

Løsreven tang fra det grunde vand af arterne Fucus serratus, Desmarestia aculeata, Lucernarier, Ascidier i stor mængde.

En mængde skjæl og snegler væsentlig arktiske

Cardium islandicum (døde skaller.)

Arca glacialis

Yoldia limatula (store og smaa.)

Leda pernula.

Pecten gronlandicus 25 stykker.

Nicania banksiï.

Astarte crenata (crebricostata).

Mytilus edulis (døde skaller).

Macoma calcaria.

Nucula tenuis.

Lunatia gronlandica.

Buccinum undulatum. - gronlandicum.

Dendronotus arborescens.

- robustus.

Coryphella sp. 
Endel pighuder (søstjerner, slangestjerner).

Asterias.

Ctenodiscus crispatus i masser.

Ophiacantha bidentata i mængde.

Talrige store og mindre krabber og rægearter nemlig

ca. 150 Sclerocrangon boreas.

145 Sabinea septemcarinata.

Endel smaa Pandalus borealis.

- $" \quad$ - annulicornis.

Mange Hippolyte polaris.

5 - spinus.

1 - turgida.

Flere roksne Hyas araneus.

Endel yngre - coarctatus.

Af fisk erholdtes følgende:

ca. 50 „gabeflyndre" Drepanopsetta plattesoides.

2 Lycodes.

44 Agonus decagonus.

2 Artediellus uncinatus.

3 Liparis liparis (forma lineatus Lep.).

De 4 sidste er typiske, arktiske, smaa fiske uden praktisk betydning, gabeflyndre kjendes af fiskerne langs hele vor kyst, den forekommer helt til Spitsbergen, har ingen madværdi. Interessant er denne rigdom paa dyr dybt inde i fjorden, hror som tidligere nævnt bundtemperaturen var $\div 1^{0} .2$.

2. Trods de herfra forskjelligartede naturforhold, var dyrelivet længer ude i fjorden noget lignende. Saaledes gjordes den 25 de august 1900 et træk med rægetrawl 1 time i 100 favnes dyb i Porsangerfjorden lidt nord for Kistrand.

Trawlen kom her op med en mængde lysebrunt mudder med orme (annelider) og mængder af søstjerner (ctenodiscus crispatus) og store slangestjerner (Ophiura Sarsii).

De rigtigste former var:

Koraldyr. Actinostula callosa.

Skjæl. Arca glacialis talrig med spongier.

Pecten gronlandicus.

Admete viridula.

Cardium islandicum store levende eksemplarer.

Astarte crenata (crebricostata).

Snegler. Neptunea despecta.

Ukko turtoni. 
Bela nobitis.

Siphonodentalium vitreum.

Søstjerner. Asterias.

Ctenodiscus crispatus.

Slangestjerner. Ophiopholis aculeata.

Ophiura Sarsii.

Mosdyr. Alcyonidium gelatinosum.

Krebsdyr. Flere Ampelisca Eschrichtii.

Haploops tubicola.

Lepideceum umbo.

ca. 1 liter Pandalus borealis.

Hippolyte polaris. $\{$ ræger.

Smaa Hyas coarctatus.

Pagurus pubescens.

Nymphon gracilipes.

- hirtipes.

Af fisk kun nogle smaa gabeflyndrer, Drepanopsetta og 1 Lumpenus lampetriformis.

Den væsentlige forskjel i faunaen her længer ude, hvor bundtemperaturen var $3^{0} .55$, er, at individantallet af rægerne, især Pandalus, „Drammens"- eller „Brevigsrægen“, er langt større. Fisk kan man ikke vente mange af i rægetrawlen, der ikke fanger saa mange af disse, desuden synes trækket ikke ganske vellykket, da der var mudder i posen, hvilket ikke er tilfældet ved et rigtig godt træk.

3. Det næste træk er station 58, beliggende midt mellem Norge og Bjørnøfeltet, her er dybden 300 meter, ca. 160 favne, og bundtemperaturen $3^{0} .13$. Et træk med engelsk trawl gir her:

Mindst en ton store kaalhovedlignende svampe,

Geodia Baretti.

Store snegler. Sipho islandicus.

Volutopsis norvegicus.

Ukko turtoni.

Neptunea despecta.

Søstjerner. Astrogonium phrygianum.

Slangestjerner. Ophiura Sarsii.

$\mathrm{R}$ ger. Pandalus borealis.

Andre krebs. Collossendeis proboscidea.

Hyas coarctatus.

Af fisk dels nogle dybhavsfisk Cottunculus microps.

3 Lycodes.

11 gabeflyndrer, Drepanopsetta.

12 uer Sebastes marinus. 
1 torsk $44 \mathrm{~cm}$. lang.

1 sei $65 \mathrm{~cm}$. lang.

Dette træk er meget karakteristisk og viser, hror vanskelig undersøgelsen af bunden er; thi massen af store svampe gjør trækkene yderst besværlige, ligesom redskaberne ødelægges som paa stenbund.

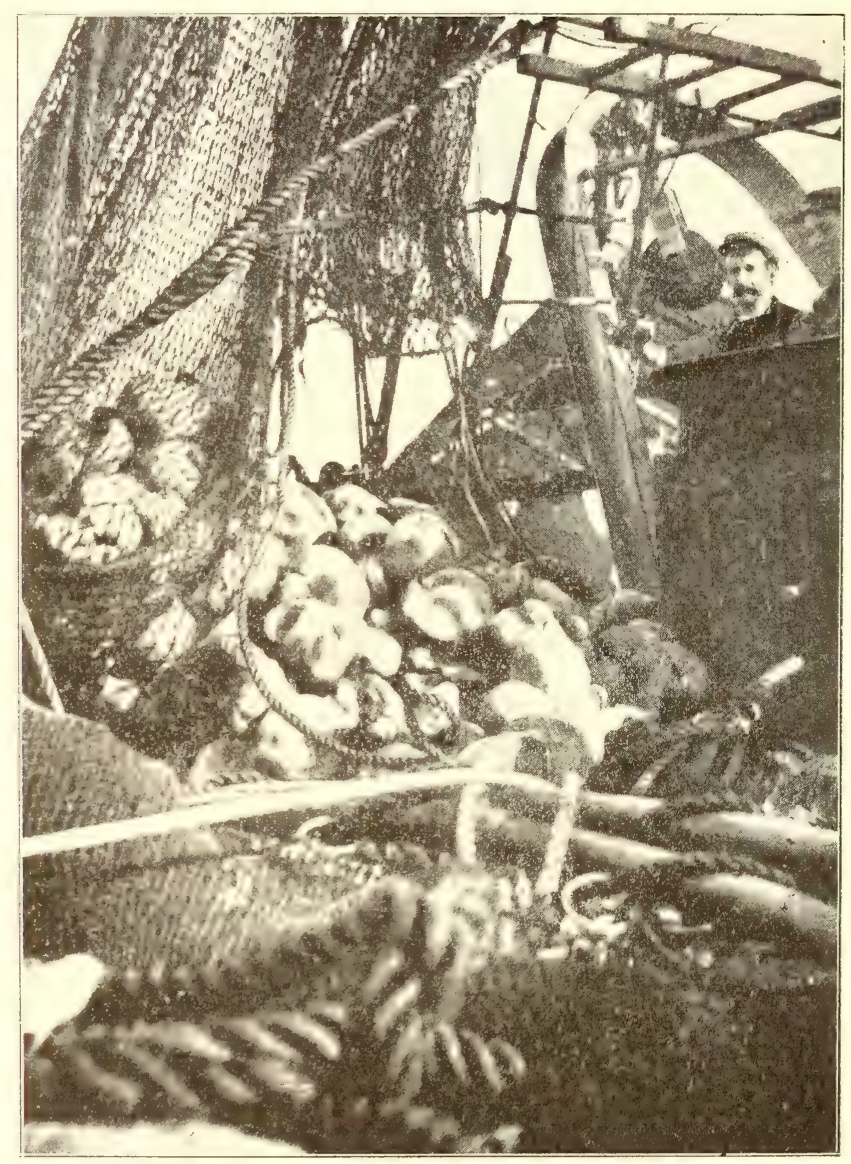

Fig. 11. Indholdet af et træk mel enge!sk trawl fra 200 favne nord for Nordkap visende de store runde kiselsvampe.

Stor frygt for trawling behøver man derfor nok ikke have; thi hror ikke klipper og sten er iveien, synes de store svampe at ødelægge mulighederne.

4. Den næste station, vi nævner, er Spitsbergen, Green Harbour en arm af Vestkystens største fjord, Isefjorden. Et træk her midtfjords, 75 favne, rægetrawl gav 1 tønde dyr nemlig: 
Søpindsvin. Echinus droebachiensis.

Søstjerner. Solaster papposus.

Slangestjerner. Ophiacantha bidentata.

Ophiocten sericeum.

Ophiura Sarsii.

Liliestjerner. Antedon Eschrichtii.

Skjæl. Tellina calcarea.

Cardium islandicum.

Snegler. Sipho.

Buccinum.

Ræger. Sclerocrangon boreas i masser.

Sabinea septemcarinata.

Pandalus borealis faa.

Hippolyter.

Hyas.

Pagurer.

Fisk. 53 gabeflyndre Drepanopsetta 1 størrelser fra $5-17 \mathrm{~cm}$.

96 Lumpenus (69 L. maculatus).

(21 L. lampetriformis).

(6 L. medius.)

25 Liparis liparis (lineatus og fabricii).

30 Lycodes.

5 Agonus decagonus.

44 Artediellus uncinatus.

12 Phobetor ventralis.

2 Triglops pingelii.

70 Gadus saida.

1 torsk (Gadus callarias) $13.2 \mathrm{~cm}$.

338

Dette træk maa siges at være udmerket, saavel med hensyn til den tekniske side, som med hensyn til den interesse, fangsten frembyder. Det viser 0 s en særdeles rig fauna af karakteristiske arktiske dyreformer, specielt mængder af søpindsvin, liliestjerner (Antedon Eschrichtii), arktiske ræger (Sclerocrangon boreas) og typiske arktiske fisk at arter, hvis individer er meget smaa selv i voksen alder; talrigst repræsenteret er ulkernes gruppe (de smaa Centridermichthys, Agonus, Phobetor, Triglops), karakteristisk er ogsaa „polartorsken“, Gadus saida, der staar torsken meget nær, men dog let kjendes ved sin langt smalere hale. Alene en eneste fisk hører ikke egentlig hjemme blandt disse, det er den lille $13.2 \mathrm{~cm}$. (5 tommer) lange torsk. Dens forekomst her oppe skal senere blive omtalt. 
Som man ved betragtning af de 4 nærnte stationer selv uden zoologiske kundskaber kan se, er det i de store hovedtræk de samme dyreformer, som forekommer paa dem alle, mest ligner stationen i det inderste af Porsangerfjorden og i Spitsbergensfjorden hinanden, de har bl. a. masseforekomster af den store ark tiske ræge (Sclerocrangon boreas) og de arktiske ulker fælles. I modsætning hertil har den ydre del af Porsangerfjorden og havet Norge-Bjørnøen det tilfælles, at her overveier den langs hele vor kyst saa talrig forekommende "Drammens" eller "Brevigsræge“ (Pandalus borealis), ligesaa træder her de arktiske, smaa fiskearter i mængde ganske tilbage for de større fiskearter, der kræver varmere vand, eller ogsaa for de større arktiske fisk. Disse erholder man ikke i den lille rægetrawl. For at fiske dem maa man prøve med liner. Dette har vi gjort baade i Spitsbergens fjorde og i de inderste arktiske dele af norske fjorde uden fangst. Paa bankerne rarierer fiskefaunaen meget $\mathrm{i}$ de forskjellige dybder. Jeg skal her nævne de fiske, som forekommer i mængder og synes at danne den mest karakteristiske del af fiskefaunaen. Vi vil da dele denne i vandrefiskene og de mere lokalbundne, som foretager smaa vandringer, og for de flestes redkommende ogsaa lægger sine eg paa bunden, hvorved heller ikke deres larver blir ført langt fra det sted, hvor de voksne lever, et forhold, som i særlig grad er karakteristisk for de ovenfor nævnte arktiske fiske.

Vandrefiskene omfatter især de fiske, som er gjenstand for de store fiskerier, de skal derfor særlig blive omtalt i et eget kapitel. Her skal kun nævnes, at deres forekomst paa bankerne veksler meget, at de $i$ de store træk iallefald er knyttet til den varme del af Østhavet, og at derfor deres udbredelse betinges af, hvor langt de varmere vandlag trænger frem mod nord $0 \mathrm{~g}$ øst sommer $0 \mathrm{~g}$ høst, mens vinterens kulde $\mathrm{og}$ det fremtrængte polarvand trænger dem tilbage. De vigtigste skal blot her opregnes, de er:

\section{Torsken.}

Hysen.

Seien.

Silden.

Lodden.

Haakjærringen.

De mere lokalbundne arter, der i størst mængde forekommer paa bankerne, er følgende:

Brosme (brosmius brosme.)

Langstjert (ogsaa kaldet havmus eller isfisk) Macrurus Fabricii, meget talrig især i 200 favne dybet. 
Kveite (Hippoglossus vulgaris) forekommer især paa bakker med haard bund som f. eks. ved Bjørnøen, landbakken, Østbanken (Vardø). (Se kap. II.)

Svartkveite (Platysomatichthys hippoglossoides) forekommer paa dybt vand helst 200 favne paa bankerne. (Se kap. II.)

Gabeflyndre (Drepanopsetta platessoides) almindelig overalt paa mudderbund, saavel i de mest arktiske som i varmere vandlag.

Uer (Sebastes marinus) almindelig i alle størrelser paa bankerne. (Se kap. II.)

- Havkat l(Anarrhicas, latifrons, minor, lupus) almindelige fra Norge til Spitsbergen.

Rokker fremfor alt Raja radiata, der kan faaes i hundreder paa linerne paa bankernes mudderbund.

Til en nærmere omtale af fiskefaunaen, dens forekomst mod dybet paa eggen vest om bankerne, dens mængdevise forekomst paa forskjellige steder etc. skal vi senere komme tilbage. Her rære det tilstrækkeligt at have nævnt dens almindeligste og mest karakteristiske repræsentanter og disses almindeligste biologiske forhold.

Foruden „Michael Sars"ekspeditionen har ogsaa flere andre ekspeditioner undersøgt disse nordlige have. De vigtigste af disse ekspeditioner er den norske Nordhavsekspedition ${ }^{1}$, den tyske ekspedition til det nordlige Ishav i aaret 1898 under ledelse af Dr. Fritz Röner og Dr. Fritz Schaudinn $^{2}$ ), den russiske Murmanekspedition under ledelse af professor KNIPOWITSCH ${ }^{3}$.

Disse tre ekspeditioners undersøgelser støtter og udvider de ovenfor udviklede erfaringer. Saaledes meddeler Knıpowitsch, at de ovenfor omtalte, til de varmere vandlag bundne dyreformer, findes langt østover i Østhavet. I hele havet udenfor Murmankysten og ind i dennes fjorde finder han de samme dyreformer, vi har skildret som karakteristiske for havet mellem Norge og Bjørnøen, saaledes f. eks. mængder af den store ræge, Pandalus borealis. Af denne har han ved indgangen af Motowskyfjorden engang $\mathrm{i}$ et træk med rægetrawl af en halv times varighed kunnet fiske 16 liter; ligesaa forekommer den talrig saa langt øst som Kap Kanin. Hele havet, siger han, mellem Murmankysten og den 75de breddegrad i et dyb af 200-300 meter (100-160 favne) vrimler af krebsdyr især Pandalus. Torsken nærer sig der af disse krebsdyr, Knıpowitsch har kunnet finde 80-100 stykker i en enkelt torskemave. Denne fauna strækker sig langt øst, saaledes har han fundet havkat

1) Se G. O. SARS: Indberetning til indredepartementet for 1878 .

2) Reisebericht. Fauna arctica. Jena 1900.

3) Knipowitsch: Arbeiten der Expedition an der Murman Küste Mai bis Sept. 1899. 
(Anarrhicas lupus) helt henimod Novaja Zemblja. I isvandet nordenom $75^{0}$ finder han den samme fauna af smaa arktiske fisk etc., som jeg særlig har omtalt for Spitsbergens vedkommende; om sommeren, naar de varme strømme trænger frem, gaar ofte den "varmere" og "kolde" fauna over i hinanden, saaledes har han da undtagelsesvis fundet torsken under lave temperaturer sammen med de arktiske fiske.

Römer og Schaudinn udførte i det særdeles gunstige isfrie aar 1898 en omseiling af Spitsbergen med en tysk fiskedamper „Heỉgoland“, og de fik derved en enestaaende anledning til at undersøge havet mellem de talrige øer paa Spitsbergens østside. De fandt her en udpræget arktisk fauna, endnu mere blottet for "varmere" former end paa Spitsbergens vestside, saaledes istedetfor Pandalus borealis kun de ganske arktiske ræger Sclerocrangon boreas og Sabinea septemearinata. De fandt endvidere her ost ingen andre fisk end de smaa arktiske. Torsk fandt de kun paa den „flade, rige Spitsbergen Bank, der ligger nordost om Bjørnøen." Hvad det arktiske dyreliv angaar, viste dette karakteristiske forskjelle mellem Vest- og Ost-Spitsbergen, saaledes vest, som jeg ovenfor har skildret det, masser af pighuder (søstjerner, slangestjerner etc.) og krebsdyr, øst derimod mængder af fastroksende former fremfor alt svamper med kalk og kiselskeletter, søpunge (ascidier), søroser (aktinier), mosdyr (bryozoer) og søpolyper (hydroider). Alle disse dyr dannede et overtræk over den mest stenede bund som græs paa land, og imellem dette græs vrimlede der af krybende orme, snegler og lavtstaaende krebsdyr (amfipoder, isopoder).

Saaledes ser vi, at bunddyrenes udbredelse ogsaa, ligesom studiet af havstrømmene, viser os, at disse nordlige have maa deles i to store regioner, den varmere area $\mathrm{og}$ den kolde, hver for sig med sit særegne dyreliv, den ene fortrængende den anden, alt eftersom aarstidernes vekslinger bringer de flydende grænser til at flytte sig nordover eller sydover.

\section{De drivende organismer (Planktonet).}

De fastsiddende eller kun lidet bevægelige bunddyrs udbredelse afhænger af alle de forhold, som gjør sig gjældende i farvandet a aret rundt, saaledes f. eks. af temperaturens vekslinger fra den ene aarstid til den anden; nogle kan nemlig ikke overleve altfor lave vintertemperaturer, andre igjen ikke altfor høie sommertemperaturer o.s.v. Lever de i mængde paa en lokalitet, kan man derfor slutte sig til, at lokalitetens aarlige "klimat", om man tør kalde det saa, passer for dem. Helt ander- 
ledes er forholdet med de drivende organismer. Deres forekomst paa et sted til et bestemt tidspunkt tillader kun den slutning, at de i $\emptyset$ ieblikket kan leve der. Forandringer i naturforholdene betyder enten deres død, eller at de føres bort af havstrømmene, eller at de gaar over i andre former, der er mere modstandsdygtige, de saakaldte sporer, eg eller lignende. I denne form overlever de da de ugunstige livsforhold for saa igjen at „blomstre op" eller „sværme“, naar de gunstige forhold paany indtræder.

Ved at studere de forskjellige formers opblomstring, bortdøen eller sporedannelse kan man derfor faa en udmerket forstaaelse af deres afhængighed af de ydre forholds indflydelse i havet. Dette studium, som hertillands nu i ca. 9 aar i særdeles stor udstrækning specielt har været drevet af hr. H. H. GRAn, har bragt en række yderst værdifulde resultater, der nu muliggjør en uventet klar forstaaelse af de forskjellige formers livshistorie. Før jeg skildrer denne, vil jeg med nogle ord omtale, hvilke former der udgjor hovedbestanddelen af disse organismer.

Planktonet omfatter baade de drivende planter $0 g$ dyr. Planterne er ganske smaa, i regelen mikroskopiske, meget lavtstaaende former, de hører ræsentlig til de saakaldte kiselalger (diatomeer), de kan, naar de optræder i store masser sees $\mathrm{i}$ vandet, $0 \mathrm{~g}$ de g.jør dette ugjennemsigtigt. Siler man vandet med en hov af fineste silke, samles de paa denne som en brunlig, slimagtig masse, der bestaar af millioner af individer. Disse former er i regelen kystformer, der danner sporer, forsynede med et sterkt kiselskelet. Sporerne synker tilbunds, ligger da paa det fine mudder, til forholdene blir gunstige for en opblomstring.

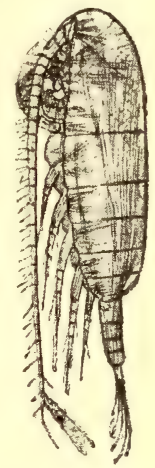

Fig. 12. Rødaaten (Calanus finmarchicus) efter G.O. SARS

En anden gruppe lavtstaaende organismer er de saakaldte p e ri dinier, der er dækkede af et tyndt celluloseskal. De er ikke kystformer, men lever hele sit liv svævende i havet; naar forholdene der blir dem ugunstige, dør de fleste bort, kun nogle enkelte faa blir tilbage, og de formerer sig da igjen under gunstige omstændigheder saa sterkt, at en opblomstring kan siges at finde sted. Dyrene hører for den allerstørste dels vedkommende til krebsdyrenes store gruppe. Blandt disse forekommer der endnu mange forskjellige former, af hvilke enkelte udvalgte repræsentanter nærmere skal omtales paa grund af den enorme betydning, de har for hele havets økonomi. Det dyr, som vel overhovedet forekommer i det største antal individer i det norske Nordhav, er en liden meget primitivt bygget krebs, den saakaldte Calanus finmarchicus, der ogsaa er vore fiskere bekjendt som indhold af sildemaver; den kaldes da „rødaat ${ }^{\text {“ }}$ 
(Se fig. 12). Den er kun nogle faa millimeter lang, hører til den laveststaaende af alle krebsdyrgrupperne $0 \mathrm{~g}$ findes i slige masser over hele Nordhavet, at man ti! visse aarstider i faa minutter med en ganske liden hov kan samle hundredetusinder. Foruden den forekommer ogsaa en hel række nærstaaende former, der dog staar tilbage i individantal og derfor ogsaa i betydning, jeg skal alene omtale, at medens Calanus finmarchicus er karakteristisk for hele Nordhavet, er en meget nærstaaende form Calanus hyperboreus særegen for polarvandet.

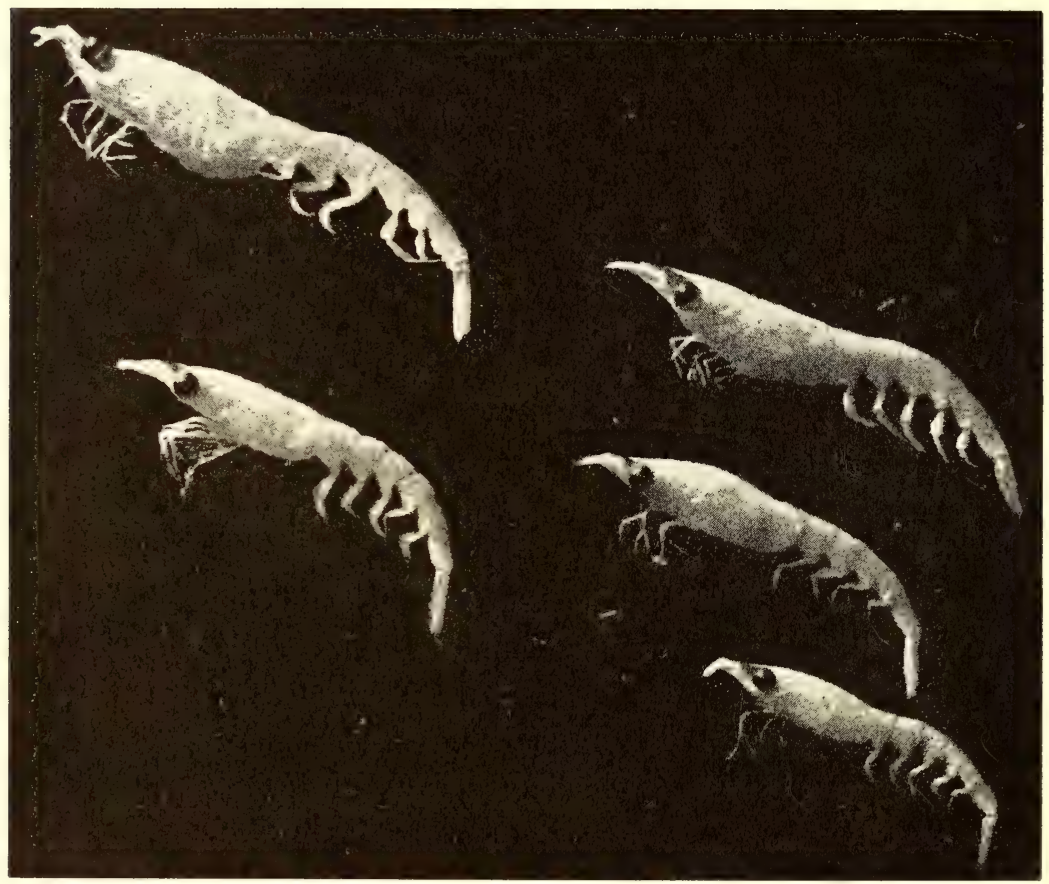

Fig. 13. Kril (omtrent 2 gange forstørret) efter fotografi.

Foruden disse ganske smaa former findes desuden en gruppe krebsdyr, noget større og høiere udviklet, nemlig de saakaldte ephausider og amfipoder, hvortil hører væsentlig følgende arter:

Nyctiphanes norvegicus, en ca. 1 tomme lang krebs, Boreophausia inermis, Thysanoëssa neglecta og longicaudata. Parathemisto oblivia, Euthemisto libellula, de sidste fem former ca. $1 / 2$ tomme lange. Alle disse fire former sammenfattes vistnok af fiskerne under fællesnavnet „kril“ og har stor betydning for os her som en væsentlig bestanddel af hvalernes næring. (Se fig. 13 og 14).

Størst af alle planktonkrebs er endelig de egentlige ræger, af hrilke der forekommer to former nemlig Hymenodora glacialis (se fig. 15), 
og Pasifaë tarda. Disse dyr tilhører ganske andre arter end det idligere som bunddyr omtalte ræger, de er fundne frit svømmende i Nordhavets midtre vandlag og spiller utvivlsomt stor rolle som næring for mange af de store arktiske dyr, som f. eks. grønlandssælen (mere herom senere).

Foruden disse krebsdyr forekommer der en hel række dyreformer af andre dyregrupper af stor betydning som næring for fisk, fugl, sæl og hvaler i de arktiske egne. Saadanne er vingesneglene, af hvilke særlig to arter ogsaa er fiskerne bekjendt.

Clio borealis er den største form, den er i levende tilstand pragtfuldt rødfarvet og ligner da sommerfugle i vandet, jeg har hørt fiskere sammenligne dem med disse. Fiskerne kalder dem ofte "hvalaat" (se fig. 16). Sammen med denne lever Limacina helicina, ogsaa vel bekjendt af vore ishavsfarere, den kaldes af disse "flueaat" og har baade ved størrelse $0 \mathrm{~g}$ bevægelser meget lighed med en stor flue. (Se fig. 17).

Ved siden af disse spiller en hel række, af fiskerne mindre bekjendte, former ogsaa rolle som bestanddel af planktonet, saaledes vandklare meduser, orme etc., hvis nærmere beskrivelse her vilde føre for vidt, men som leilighedsvis vil blive nævnt, hvor fremstillingen derved for fagmanden maa antages at faa videre indhold.

Hvad der nu gir planktonstudiet sin betydning og nødvendighed for en - forstaaelse af Finmarkshavet og dets dyreliv, er væsentlig de to sider af planktonformernes eiendommelige livshistorie,

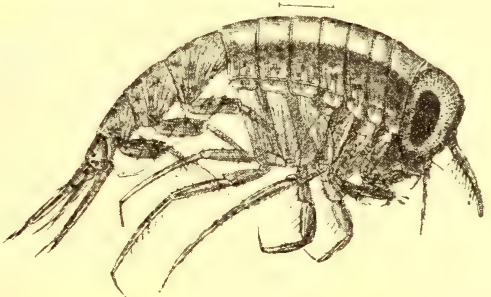

Fig. 14. Smaakrehs fra planktonet (Parathemisto oblivia) efter G. O. SArs.

1) deres hurtige opblomstring og bortdøen og lovene for disse forhold, 2) deres store afhængighed af de ydre forhold - af havet selv.

\section{Opblomstringen.}

Enhver, som har undersøgt det svævende liv i havet til de forskjellige aarstider, vil være slaaet af den store forskjel i mængden (kvantiteten), som kan finde sted. Enhver fisker ved, at havet er klart og gjennemsigtigt om vinteren, at der om vaaren og sommeren vokser op en mængde smaat kryb, som gjør havet ganske ugjennemsigtigt, ja forandrer dets farve. For forstaaelsen af Nordhavet var det for os vigtigt at slaa fast, om dette alene gjaldt kysten eller ogsaa det hele hav. Vore vintertogter, som udstraktes til en fsærdeles stor del af Nordhavet, viste overalt en særdeles sparsomi forekomst af levende organismer ved vintertid. Saaledes maatte vi i marts maaned paa hele strækningen Norge--Bjørnøen 
lige op til isen og 60 mil vest af Tromsø slæbe vore fine hove $1 / 2-1$ time, før man overhovedet kunde se noget med blotte øie paa hovens silkedug. Og denne fattigdom gjaldt ikke alene overfladen, men havet ned til dyb af ca. 100 farne. Nogle faa eksempler illustrerer dette. I februar 1901 gjordes i Vestfjorden et træk med en stor hov af 8 fods diameter, et træk fra 200 meters dyb til overfladen med en fangst af

$\begin{array}{rlc}380 & \text { smaa Calanus finmarchicus "rodaat" } \\ 6 & - \text { Calanus hyperboreus } & \text { do. } \\ 9 & - \text { Mysider } & \text { "kril" } \\ 2 & \text { - Parathemisto } & \text { do. } \\ 11 & - \text { Sagitter } & \text { smaa orme } \\ 2 & - \text { Asteridelarver } & \end{array}$

Hoven har paa dette træk gjennemsilet en vandmasse af 1000 tons vand, $0 \mathrm{~g}$ hrert enkelt individ af rødaaten har havt en vandmasse af noget over $2^{1 / 2}$ tons vand at bevæge sig $\mathrm{i}$, forudsat, at de har været

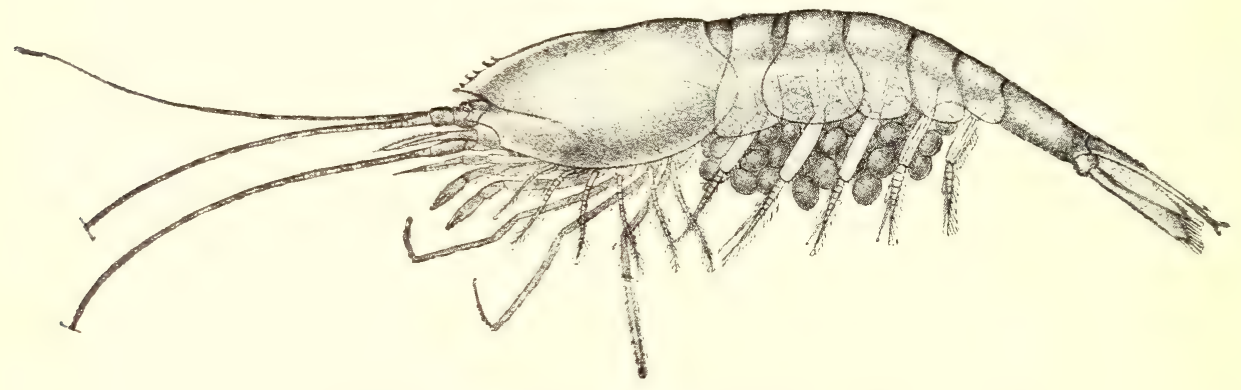

Fig. 15. Pelagisk rage (Hymenodora glacialis) efter G. O. SARs.

jernt fordelt gjennen vandmassen, hvad man omtrent kan antage. Naar man tænker sig, at disse smaa dyr" selv kun har en vægt af høist $1 / 2$ milligram, vil man forstaa, hvor uhyre spredt i vandmassen de har forekommet. Talrige træk viser overalt det samme; saaledes 19 de marts 1901 Vardø $1^{1} / 2$ mil af land, samme hov $0-200$ meter. Nogle faa hundrede Calanus.

Allerede i april maaned begynder imidlertid opblomstringen, og denne antager allerede paa dette tidspunkt noget forskjellig karakter paa de forskjellige steder. Væsentlig forskjellige forhold viser nu nemlig kystformerne og de oceaniske former.

Kystformerne opstaar som nævnt af de smaa hvilesporer, der ligger paa havbunden, især de grunde flade strækninger, dækkede af sand eller mudder. Saadanne strækninger forekommer især i skjærgaardens bugter og i grunde fjorde. Man kan saaledes i april maaned i Troms $\emptyset$ sundet se dette vrimlende af kiselalger $0 \mathrm{~g}$ af larver af bundens dyreliv. Disse kiselalger har heroppe alle en ren arktisk karakter, sydgrænsen 
for deres forekomst overhovedet er ifølge GRAN Stat, og deres bedste udviklingstid er april-mai langs den norske kyst, medens de oppe i Ishavet nær isen trives hele sommeren igjennem, og der ligesom ved Norges kyst gir rig næring til udviklingen af planktondyrene. (De vigtigste former er ifølge Gran:

Fragilaria oceanica, cylindrus, Navicula Vanhoffeni, Bacteriosira fragilis, Thalasiossira hyalina, Chatoceras furcellatum, Melosira hyperborea. Ikke saa udpræget arktiske er følgende former, der ogsaa blomstrer i Tromsøsundet i april: Thalassiosira Nordenskjöldii, gravida, Chetoceras diadema, sociale, teres, Biddulphia aurita, Coscinosira polychorda). Foruden disse arktiske kystformer forekommer i Finmarkshavet ogsaa en hel del sydligere kystformer, men disse blomstrer først i sommer-eller høstmaanederne nordpaa, medens de sydpaa blomstrer langt tidligere paa aaret. (Ifølge Gran er de vigtigste følgende: Evadne Nordanni, Podon polyphemoides, Leuckarti, Chatoceras laciniosum, Willei, contortum, didymum, Rhizosolenic setigera, Eucampia Zoodiacus, Stephanopyxis turris, Thalassiosira gelatinosa.

Denne kystformernes opblomstring har, som vi siden skal se, det yderst interessante tilfælles med fiskeeggene, at de lige efter opblomstringen er meget begrænsede til bestemte omraader i sin forekomst. Ligesom eggene kun findes svævende over kystbankerne saa at sige lige over det sted, hvor de gydende fisk staar, saaledes kiselalgerne lige over det sted, hvor sporerne laa paa bunden i

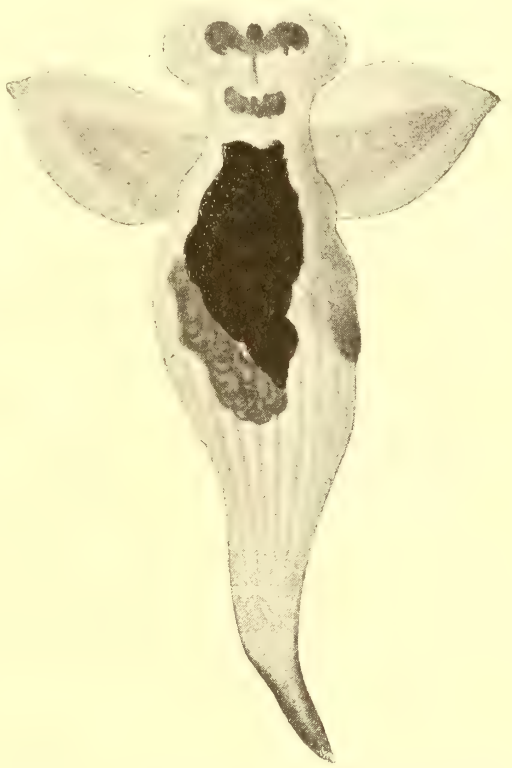

Fig. 16. "Hvalaaten" (Clio borealis) efter VANHøFFEN. hviletilstanden.

De blandes derfor ikke saa meget med de oceaniske former, som blomstrer op for sig.

Som eksempel paa disses raske formering skal vi tage den før omtalte Calanus finmarchicus, hvis sparsomme forekomst vi tidligere omtalte. Mens vi i marts maaned kun fandt 380 individer i et træk fra 200 meter til overfladen, finder vi 10de april paa Svendsgrunden i et træk med samme hov fra 100 meter til overfladen 2356 individer, et andet træk samme dag 16420, hvilket er henimod 100 gange saa mange som i marts, beregnet paa samme vandmasse, atter et andet træk gav en stor masse, henimod 1 liter. Og dette forhold vedbliver stadig udover 
sommeren, saaledes at man den 1 ste juni 1901 i Altenfjorden ved 5 minutter at trække en hov af 3 fods diameter i overfladen kunde samle $1 / 2$ liter udelukkende fuld af Calanus. Vægten af et andet træk med samme hov i 10 minutter var, efterat vandet var presset af, 0.8 kilo, hvortil vilde svare mindst 2000000 individer Calanus. Saadanne træk viser os, at denne lille uanselige form nu begynder at optræde i slige masser, at man kan forstaa, at den ved sin mængde maa kunne afgive næring selv til havets største kolosser, hvalerne. Hvad er nemlig ikke en stor blaahvals gab mod den lille hov af 3 fods diameter, hvor hurtig maa den ikke kunne samle mangfoldige kilo af dette sit næringsmiddel. Og dette næringsmiddel findes over hele Nordhavets overflade. Under et togt over den nordlige del af Nordhavet i juli maaned 1901 gjordes saaledes en række træk med den ovenomtalte hov af 8 fods diameter fra $200 \mathrm{~m}$. til overfladen, hvorved i regelen samledes mellem 200 og $250 \mathrm{ccm}$. overveiende

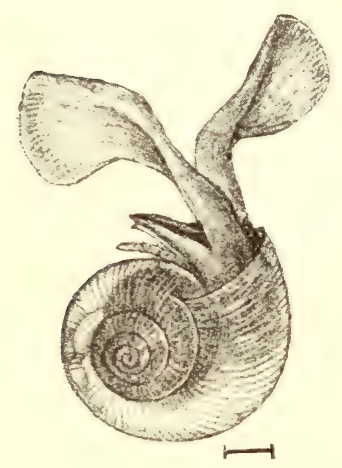

Fig. 17. "Flueraten" ( $\mathrm{Li}$ macina helicina) efter G. O. SARS. bestaaende af Calanus finmarchicus med nogen tilblanding af de dyr, der ovenfor er betegnet som kril (Thysanoëssa, Parathemisto, Euthemisto).

Disse sidste former har en lignende udvikling. I april maaned fandtes de saaledes kun som eg blandt planktonet, de voksne var antagelig i dybet. Blandt de flydende fiskeeg kunde ogsaa ephausideeggene findes paa fiskebankerne(Svendsgrunden, Malangsgrunden) i tusinder, senere udover sommeren var de da at finde i større eller mindre mængder over Nordhavet op mod Bjørnøen. Deres mængdevise forekomst havde dog altid noget vist gaadefuldt ved sig, og det i større grad end tilfældet var med $\mathrm{Ca}$ lanus, skjønt denne ogsaa kunde forekomme høist ujevnt; sammenlign f. eks. de ovenfor nævnte aprilprøver. Men de dyr, som her sammenfattes under begrebet "kril“, fandtes, ofte kun enkeltvis og ganske spredt, ofte i mængder. Især fandtes de at være samlede ude paa de saakaldte "skaller", de grunde partier ude paa bankerne $6-8$ mil af land, hvor seien leger om sommeren. Her fandtes seimaverne propfulde af disse dyr og af de smaa drivende torskeunger, $0 \mathrm{~g}$ af seiens forekomst i knuder kan man ogsaa slutte sig til, at dens „aat" ikke var saa jevnt fordelt, men forekom i sværme eller knudeformige sammenstuvninger.

Ogsaa det arktiske plankton blomstrer op mod sommeren. Hele sommeren kan man finde ganske smaa unger af de arktiske dyr, som sandsynligris har en meget kort levetid, saaledes fandt jeg ganske smaa unger af vingesneglen Clio saa sent som 10de august. Da disse arktiske former er meget haardføre overfor temperaturen, er det vistnok neppe temperatur- 
forskjellene, der bringer dem til at formere sig saa raskt. Lys et spiller her vistnok den væsentligste rolle, idet solstraalerne muliggjør plantelivets (kiselalgernes) opblomstring, hvorved næringen til planktondyrene skabes.

Mørketiden varer som bekjendt

ved Tromsø fra 26 de november til 17 de januar

ved Nordkap fra 18de november til 25de januar

ved Spitsbergen fra 26de oktober til 17 de februar

medens midnatssolen sees

ved Tromsø fra 21de mai til 23de juli

ved Nordkap fra 14de mai til 30te juli

ved Spitsbergen fra 20de april til 23de august.

Jo længer nord man kommer, desto mere intens blir forskjellen mellem lys og mørke. Saaledes ved Spitsbergen, hvor det arktiske plankton er saa udpræget. Her er der kun to maaneder fra den fire maaneder lange mørketids sidste dag, til midnatssolen i fire maaneder er paa himmelen uden at gaa ned; i disse to maaneder forberedes udriklingen af det arktiske plankton for med et slag at udfolde sig i den tid, solen er oppe dag og nat.

\section{Planktonets afhængighed af naturforholdene $\mathrm{i}$ havet (havstrømmene).}

De smaa drivende organismer i havet er dels ubevægelige (de fleste diatomeer), dels har de forskjellige slags svømmeapparater, ved hjælp af hvilke de kan bevæge sig mellem hverandre (peridineer og dyreformerne). Men selv om disse bevægelser kan være noksaa raske $\mathrm{i}$ forhold til dyrenes størrelse, er de alligevel smaa i forhold til havets egne bevægelser, og organismerne kommer praktisk talt til at følge med havstrømmene, eftersom de bevæger sig fremover. Paa den maade kan kystformer, som udvikler sig paa grundt vand om vaaren, i løbet af sommeren drive langt ud over havet; arter fra det varme Atlanterhav kan findes udenfor kysten af det nordlige Norge, og ishavsformer kan paatræffes ved Færøerne, ja lige ned i Nordsøen og Skagerak.

Eftersom strømmene bevæger sig fremover, vil dog vandmasserne langsomt forandre karakter; den gren af Golfstrømmen, som stadig bevæger sig gjennem aabningen mellem Shetland og Færøerne og derfra videre til Finmarken og Spitsbergen, afkjøles paa reien; størstedelen af organismerne fra det varme Atlanterhav dør ud og erstattes af andre, som er mere haardføre $\mathrm{g} g$ derfor seirer i konkurrancen. Men enkelte af de sydlige former kan alligevel holde sig længe, og merkelig nok kan man finde flest af dem senhøstes og om vinteren, naar søen ellers er 
meget fattig paa plankton, og alle arter vokser langsomt og forbruger meget mindre næring end om sommeren.

Som eksempler kan nævnes en vakker rødbrun kolonidannende manæt Physophora hydrostatica, endvidere Arachnactis albida, og af mikroskopiske organismer en hel række sirlige radiolarier, peridineer som Podolampas palmipes, Dinophysis homunculus, Goniodoma acuminatum, diatomeer som Dactyliosolen antarcticus, Euodia cuneiformis, Asteromphalus heptactis, Corethron hystrix.

Paa samme maade findes der f. eks. i den østislandske polarstrøm en række organismer, som har sit rette hjem i Ishavet (Clio boreatis,

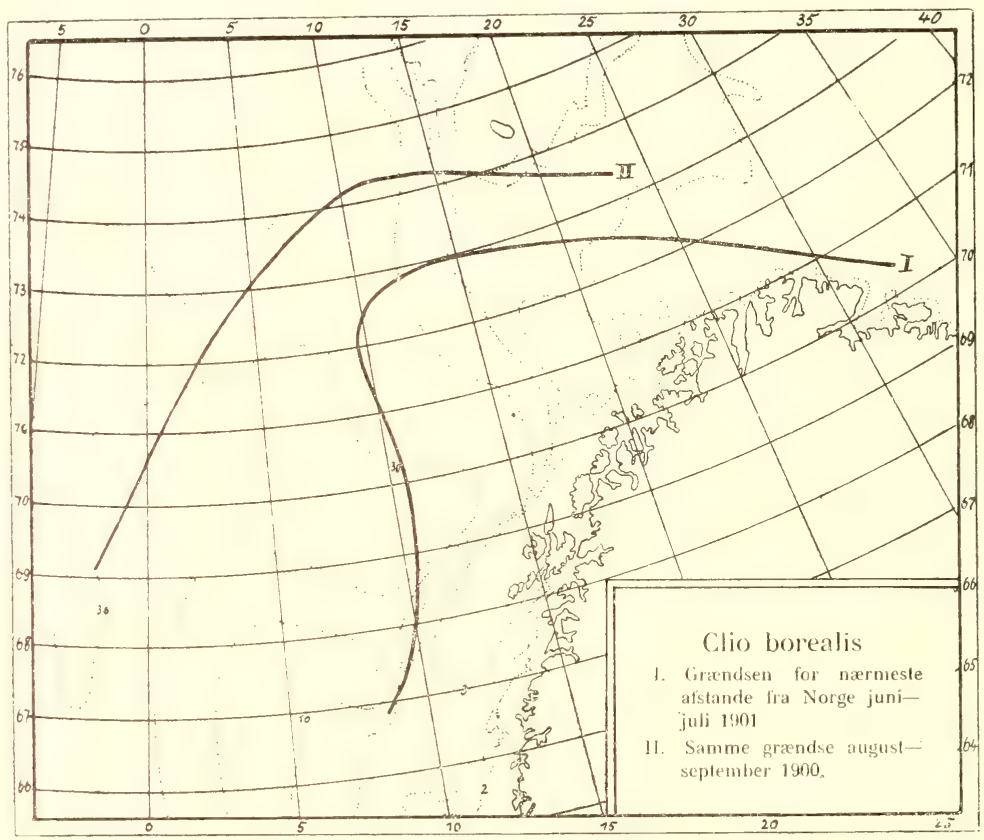

Fig. 18. Udbredelsen af ,hvalaaten" til forskjellige tider efter vore togters resultater.

Limacina arctica, Calanus hyperboreus, Metridia longa, Ceratium arcticum, Rhizosslenia hebetata). Enkelte af disse findes regelmæssig ogsaa udenfor Ishavet, men da kun paa dybt vand, hvor temperaturen er jevn hele aaret igjennem. Naar polarstrømmens vandmasser bevæger sig sydover, følger organismerne med, og naar den f. eks. nordenfor Færøerne støder mod Golfstrømmen, kan endel af dens vandmasser rives med og blande sig med Golfstrømmens, organismerne kan fremdeles følge med, og paa denne maade kan dyr fra Ishavet som Clio borealis (hvalaaten), ja selv mikroskopiske planter (Ceratium arcticum) finde sin vei lige til Norges sydlige $0 g$ restlige kyst. Naar de findes, er det altid et sikkert merke paa 
en tilblanding af ishavsvand; men denne tilblanding kan rære ganske ubetydelig, saa at disse organismer er det eneste sikre hjælpemiddel, vi har til at bevise det. Hvis vi derfor konstruerer karter orer disse dyrs udbredelse, kan vi faa et indtryk af, hvor langt polarstrømmens indflydelse strækkker sig. Erfaringen viser ogsaa, at deres udbredelse varierer med aarstiderne; de arktiske dyr findes om vinteren og vaaren nærmere ind til Norges kyst end om høsten. Kartet, fig. 18, viser saaledes udbredelsen af hvalaaten (Clio borealis) i mai-juni 1901 og i august-september 1900. Den kan betragtes som en af de mest karakteristiske repræsentanter for Ishavets fritsvømmende dyreliv.

Et tydeligt indtryk af, hvorledes planktonorganismerne bevæger sig med havstrømmene, faar vi ogsaa, naar vi følger ".Hichael Sars"s sommertogt i 1900 .

I fjordene og paa kystbankerne finder vi et meget rigt plankton af sydlige oceaniske former, blandet med talrige kystformer, saasom forskjellige smaa meduser, larver af muslinger og søstjerner, og nogle smaa krebsdyr, Evadne Nordmanni og to arter af slegten Podon, som overvintrer paa bunden $\mathrm{i}$ form af tykskallede vintereg.

Udenfor Storeggen er vi midt i hjertet af Golfstrømmen. De oceaniske former er de samme som paa bankerne, kun endnu talrigere; mellem dem findes saa udpræget sydlige former som Oithona plumifera, Corethron hystrix, Dinophysis homunculus. Men vi finder ogsaa ganske enkelte individer af ishavsformer, nemlig den lille mikroskopiske Ceratium arcticum. Netop her nordenfor Færøerne gaar den østislandske polarstrøm meget langt mod syd $\mathrm{og}$ øst, og vi kan altsaa merke en srag tilblanding af ishavsvand lige ind til Storeggen.

Videre vestover tiltager ishavsformerne i mængde, og de sydlige oceaniske arter aftager; her findes Ceratium arcticum i betydeligt antal. Endnu længer vest er arktiske former overveiende i dybet, men langs med overfladen findes der et tyndt vandlag, hvori der lever store mængder af kystformer og det saadanne arter, at de maa have drevet udover fra Island (Asterionella japonica, Rhizosolenia delicatula, Chcetoceras cinctum, foruden Evadne Nordmanni, Podon Leuckarti og lysbrune slimklumper af Phooocystis Pouchetii, en lavtstaaende alge).

Dette kystplankton holder sig væsentlig uforandret, til vi kommer til Islands kyst, og paa nordsiden af Island finder vi ikke spor af atlantiske former længere.

Paa ruten nordover mod Jan Mayen forsvinder ogsaa kystformerne, og vi beholder igjen kun ishavsformer, tildels blandede med saadanne arter, som hører hjemme over hele Nordhavet (Ceratium longipes, Calanus finmarchicus).

Ved selve Jan Mayen er planktonet ublandet arktisk og rent 
oceanisk, paa ganske sparsomme undtagelser nær, som kan have drevet ud fra Jan Mayens egen kyst (Dinobryon pellucidum).

Paa reisen østover træffes sydlige arter igjen, men endnu meget sparsomt. De findes fremdeles, men ganske underordnet, videre østover; først midtveis mod Norge optræder de i store mængder, og samtidig fandt vi for første gang igjen forskjellige kystformer, saasom meduser, løsrevne tangdusker og fiskeyngel, som maa være gydt samme vaar et eller andet sted red de norske kystbanker (sammenlign følgende kapitel). Tidere indover mod land blev planktonet mere $\mathrm{og}$ mere rigt paa forskjellige kystformer, men beholdt forøvigt sin karakter uforandret.

Paa den nordlige rute samme sommer, fra Finmarken til Bjørnøen og tilbage til Testeraalen, er modsætningerne mindre udprægede. Hele veien med undtagelse af stationerne 61 ved Bjørnøen og 64 længst mod nordvest, findes i større eller mindre mængder sydlige former, baade oceaniske og kystformer (Ceratium tripos, Globigerina bulloides, Evadne Nord= manni, fiskeyngel). Men paa hele strækningen findes ogsaa arktiske former (Ceratium arcticum), og paa station 64 fandtes en torskeunge med en stor Clio i gabet. Vi har med andre ord her mod nord en meget mere gjennemgaaende blanding af de kolde og varme vandmasser.

I det store $0 \mathrm{~g}$ hele kan vi se, at om sommeren kystformerne $\mathrm{og}$ de sydlige oceaniske former findes udbredt omtrent over den samme strækning; Golfstrommen stryger saa nær ind under Norges kyst, langs med eggen er strommen sterkest, at den blander sig med kystrandet, som flyder udorer langs overfladen paa grund af sin lethed (lavere saltgehalt og høiere temperatur), og dyrene følger med. Ydergrænserne for disse organismer falder sammen med grænsen for de drivende fiskeunger, der jo ogsaa maa komme fra kysten (se følgende kapitel).

Hidtil har vi kun talt om planktonet i de øverste vandmasser, hvori der om sommeren udvikler sig et myldrende liv ved lysets og varmens indrirkning. Men dette lag er ikke dybt; tidlig paa sommeren er det kun ned til 10-20 farnes dybde, at vi finder nogen større rigdom, udorer eftersommeren blir fordelingen jevnere, $\mathrm{og}$ man finder et rigt dyreliv lige ned til 50 farne under overfladen. Men nedenfor er det temmelig fattigt; vi finder faa arter og heller ikke mange individer, saadanne almindelige arter som Calanus finmarchicus og Euchceta norvegica. Det er paafaldende, at de fleste individer fra dybet er fuldvoksne, medens ungerne af de samme arter svømmer i tætte sværme; oppe blandt alle algerne nær overfladen.

Saalænge vi endnu befinder os i Golfstrømmens vandmasser, er dyrelivet meget ensformigt; men kommer vi endnu dybere ned, til det iskolde rand. som hele reien dækker Nordhavets bund under 3-400 favnes dybde, og som staar i direkte forbindelse med Ishavets vandmasser, da finder vi igjen 
et karakteristisk samfund af store planktonorganismer; individrigdommen er kanske ikke væsentlig større end i Golfstrømmens vandmasser ovenfor, men artantallet er betydelig større. Store ræger, Hymenodora glacialis, eiendommelige meduser som Atolla verillii, forskjellige krebs: Euthemisto libellula, Cyclocaris Guilhelmi, Conchoecia maxima, Calanus hyperboreus, Euchoeta barbata $0 \mathrm{~g}$ forskjellige sjeldne mindre arter, tildels saadanne som SARs for første gang har beskreret fra Nansenekspeditionen. og desuden talrige glasklare, over tommelange pilorm (Spadella).

Alle disse arter findes hos os kun i det kolde vand under Golfstrømmen, men i Ishavet kan de findes lige op imod overfladen.

De danner næringen for de fiske, som det under ekspeditionen lykkedes os at paavise i de midtre lag („bathypelagiske“) som uer, torsk, hyse mellem havets overflade og bunden (se herom næste kapitel).

\section{Fuglelivet.}

I sin vakre skildring "Fugleliv i det arktiske Norge" siger CoLLetT: „Det er et velkjendt faktum som ogsaa paatrænger sig enhver naturforsker under hans færd nordover langs Norges kyster, at antallet af de forskjellige fuglearter aftager $i$ en paafaldende grad mod norden, mens til gjengjæld individantallet tiltager saa betydeligt, at vi neppe nogetsteds $i$ vor verdensdel synes at se fuglelivet udfolde sig rigere, end netop, naar vi staar paa Nord-Europas yderpunkter mod Ishavet. Det er nærmest i de store kolonier „Fuglebjergene", hvor dette intense fugleliv aabenbarer sig. Saadanne fuglebjerge optræder sporadisk lang hele den norske kyst fra Stavanger af $0 g$ op til Varangerfjorden $0 g$ den russiske grænse."

Det er fra de mange arktiske ekspeditioner almindelig bekiendt, at dette fugleliv om sommeren paa polarøernes klipper naar endnu større dimensioner. Ogsaa langs iskanten paa de yderste smaa isflak findes der om sommeren en masse fugl, saaledes at hele Østhavets grænser om sommeren myldrer af bevingede beboere. Disses levevis er i mange henseender meget forskjellig alt efter de forskjellige arter.

Der findes former som den almindelige brednebbede alke (Alca torda), som ikke ruger nordenfor Norge, andre som den spidsnebbede Spitsbergalke (Uria brünnichii), havhesten (Fulmarus glacialis), Spitsberg-erfuglen en teisteart (Uria mandti), de hvidvingede magger (Larus glaucus, L. leucopterus og L. eburneus), som aldrig ruger i Norge, men kun ved Østhavets nordligste grænser. 
Enhrer, som har besøgt polarøerne (Jan Mayen, Bjørnøen, Spitsbergen, Kong Karls land o.s.v.), vil altid erindre de tusinder af alker, arktiske maager og harhest, som bedækker klipperne om sommeren. Nathorst siger om Mount Misery paa Bjørnøen, at de spidsnebbede alker „her bygger i hundredetusinder eller millioner, og hver afsats paa klippen è besat med fugle. Naar man skyder et skud, sværmer de ud

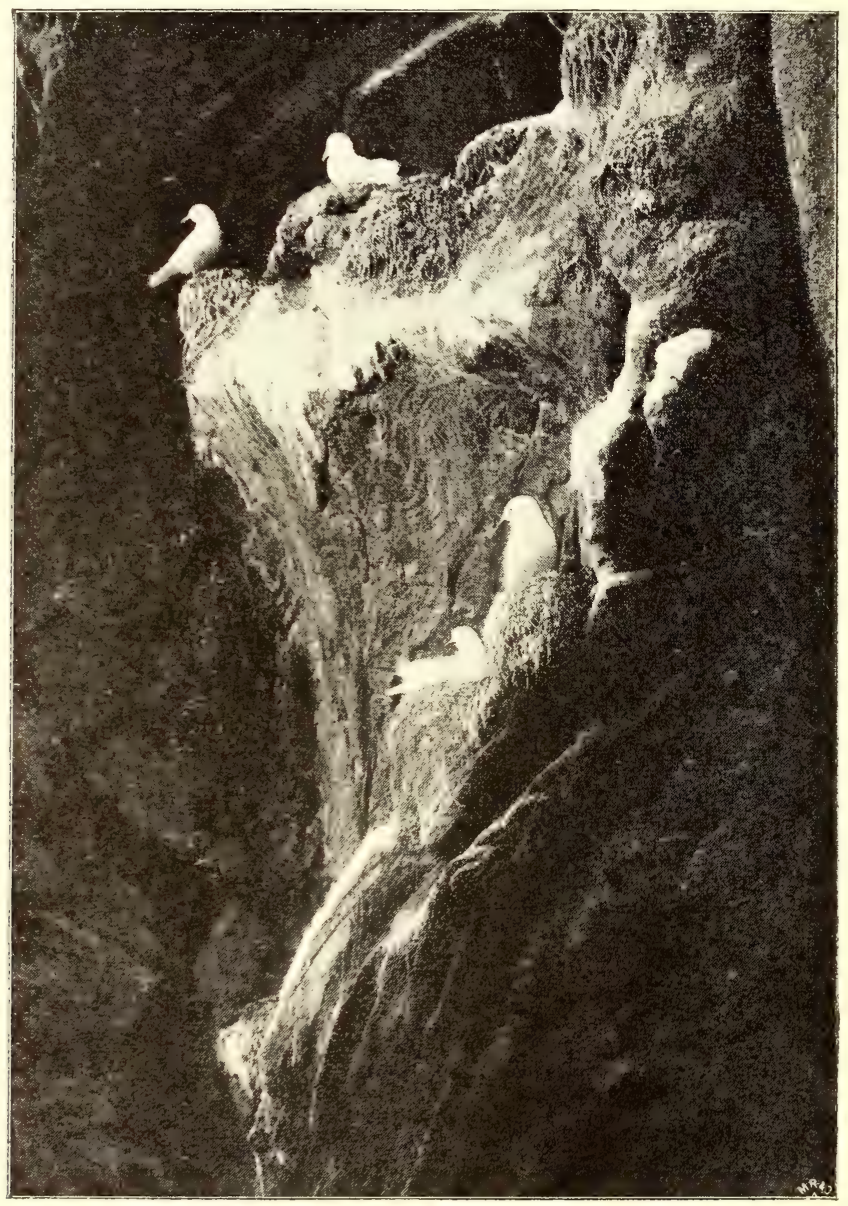

Fig. 19. Reder af krykkje (Rissa tridactyla) (Stappen, Nordkap) efter CoLletr.

som sneflokker i luften, og man ser ingen aftagen i de tilbageværendes antal." Ogsaa langs iskanten, hvor sælfangsten foregaar, sees de i masser. De lever overveiende af planktonet, biæksprutter og lodde. Om sommeren i rugetiden er jo det arktiske plankton i sin høieste blomstring. Kril, hralaat og andre krebsdyr vrimler i havoverfladen langs hele iskanten og skaffer baade de roksne og ungerne rigelig føde og et tykt spæklag 


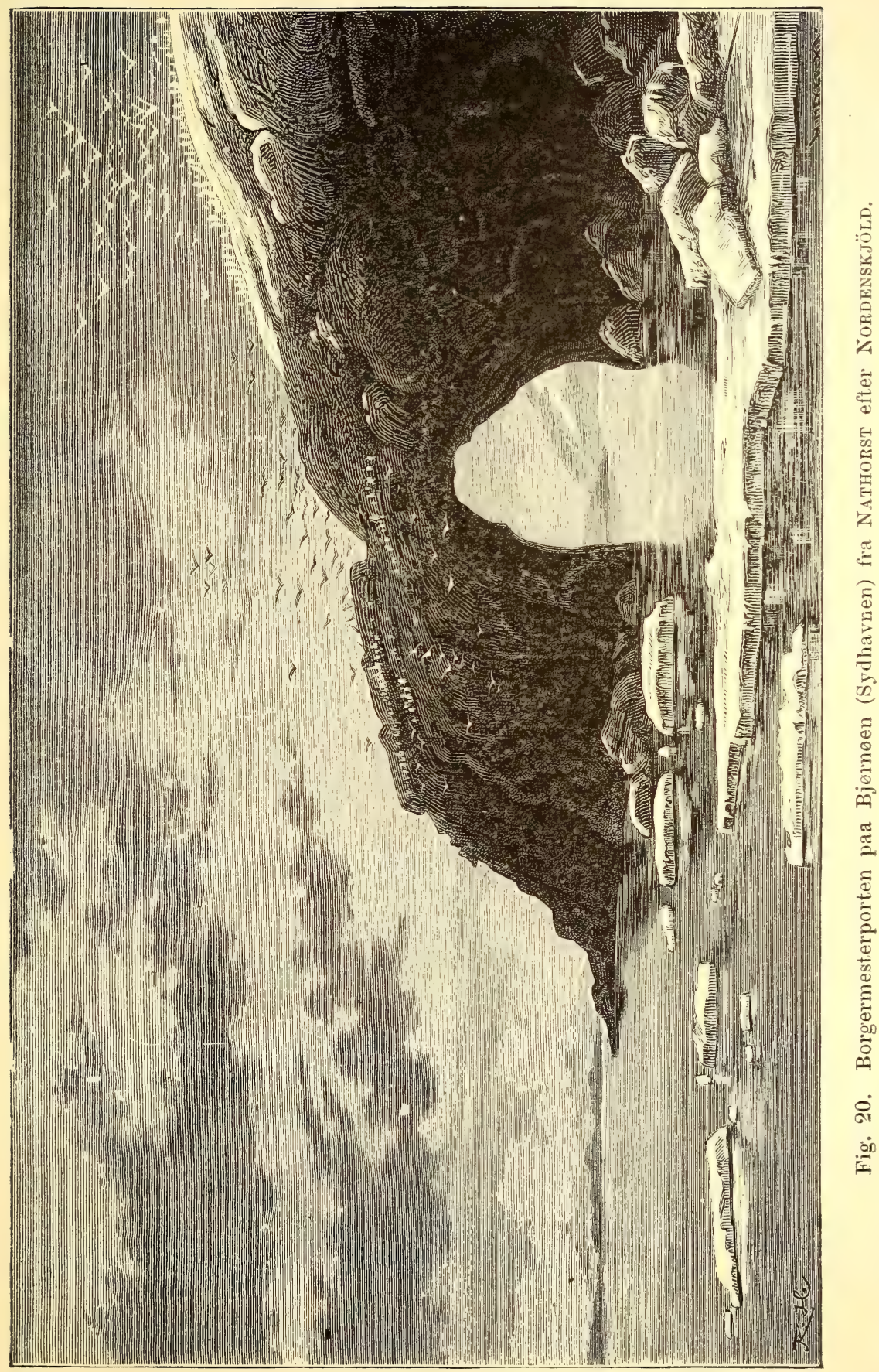


til den lange mørke vinter, da planktonet dør bort, og kosten derfor blir langt ringere.

Naar isen lægger sig i fjorde, sund og belter mellem polarøerne, og samtidig kulden $0 \mathrm{~g}$ mørketiden indtræeler, er livsbetingelserne ikke længer tilstede heroppe, $0 \mathrm{~g}$ fuglene maa da forsvinde. Nogle af dem som havhesten spredes da ud over hele Nordhavets overflade. Seiler man over dette om vinteren, ser man overalt ensomme, spredte havheste uden hvile svæve - lig store lydløse flaggermus - over havfladen ustanselig skuende ned i havet efter det sparsomme bytte, som havet nu kan byde.

De arktiske fugle, som besidder større evne til at dykke og dermed har evnen til at forfølge i dybet de fiskemasser, fremfor alt lodden, som ofte hærer sig op fra bunden og stimer gjennem hele vandmassen, de samler sig udover høsten $0 \mathrm{~g}$ vinteren om fiskestimerne $0 \mathrm{~g}$ f flger disse paa trækket mod Norge. Under loddeindsigene ser man da et vældigt „brug" af disse fugle (spidsnebbede alker, Spitsberg-erfugl, hvidvingede maager) folge lodden.

En stor del af de arktiske fugle vandrer ogsaa i vinterens løb langs hele Norges kyst. Det er saaledes bekjendt, at Vestlandets og Østlandets fjorde (Kristianiafjorden| helt ind til Kristiania) $0 g$ skjærgaard besøges i masser af spidsnebbede alker, som om sommeren aldeles mangler $\mathrm{i}$ disse. Disse alker $\mathrm{er}^{\circ} \mathrm{dog}$ - saavidt man ved - hovedsagelig den sydligere art eller varietet (uriı troile), der ruger i Norge, mens der om rinteren i Finmarken findes i de største masser af polarøernes varietet (uria brïnnichii), som aldrig ruger i Norge, men om sommeren lever sammen med de øvrige høiarktiske arter.

Disse yderst interessante fuglevandringer vil vistnok give anledning til interessante studier for de zoologer, som i fremtiden faar anledning til at studere dem. Her har det kun været hensigten med nogle ord at omtale deres sammenhæng med de store fænomener inden havets dyreverden, og saadan sammenhæng vil det vistnok ogsaa lykkes fremtiden at rise for den store fuglevandring sydover langs. Norges kyst om høsten. 


\section{Andet kapitel. \\ Fiskenes liv og vandringer.}

Grundlaget for forstaaelsen af et farvands fiskerier er kjendskabet til fiskenes livshistorie og fremfor alt da kundskaben om, hvor de opholder sig, og under hvilke ydre livsforhold de befinder sig paa de forskjellige alderstrin. Under mine togter har jeg anvendt særdeles meget arbeide paa at søge dette bragt paa det rene for de vigtigste fiskes vedkommende, $0 \mathrm{~g}$ i det ílgende skal jeg som indledning til betragtningen af fiskerierne meddele nogle af mine vigtigste resultater og da begrænse mig til de fiskearter, der har størst betydning for Finmarken.

Den fisk, som spiller den aldeles overveiende rolle for fiskerierne, er som bekjendt

\section{Torsken.}

Torsken begynder sin eksistens som et lidet kuglerundt, glasklart $\mathrm{eg}$, af en diameter af ca. $1.3 \mathrm{~mm}$. Eggene flyder i havets overflade, saa nær denne, at de kan samles i masse af en liden hov, som slæbes i overfladen. G. O. SARs, som forst opdagede, at torskens eg flød i havet, fandt dem paa denne maade i Vestfjorden under Lofotfisket, og han studerede deres udvikling nærmere. Senere har Hensen og Apstein gjort et stort anlagt forsøg paa ved tællinger at finde mængden af de drivende eg i forskjellige farvand, og Hensen har udkastet den tanke, at man ad den vei maaske kunde beregne antallet af gydende fisk $\mathrm{i}$ et farvand.

Saa interessante og værdifulde disse forsøg ${ }^{1}$ ) er ved den mængde

1) Hensen, V. Ueber das Vorkommen u. die Menge der Eier einiger Ostseefische. Jahresber. der Kom. z. Unters. der deutsch. Meere 1882. Hensen und Apstein. Die Nordsee-Expedition 1895. Wiss. Meeresunt. Bd. II 1897. 
nye forestillinger, hrormed de udvider vor kundskab om fiskenes liv, saa maa disse forskeres maal endnu langt fra siges at være naaet. Dels har der vist sig store praktiske ranskeligheder; saaledes har Hesccke ${ }^{1}$ ) paarist, at torskens eg er saa lige hysens, at de i virkelighed ikke kan skilles fra hinanden uden ved at opdrættes til larver, hvilket selvfølgelig er yderst besrærligt tilsøs. Endmere synes mig eggenes eiendommelige fordeling i haret, saaledes som jeg har fundet det, og som nedenfor skal beskrives, at tale mod muligheden af ad den vei at faa et indblik i, hror mange fiske et farvand gjemmer. Det viser sig nemlig, at de flydende eg straks red gydningen forekommer uregelmæssig, og ikke saadan jevnt fordelt i haret, som de tyske forskere antog, saaledes at det enkelte træk ikke svarer til forholdet over større strækninger, endvidere viser det sig, at eggene snart kommer i berægelse, de føres afsted med strømmen, den ene lokalitets eg blandes med den andens. Derimod viser det sig ved de talrige undersøgelser, vi har udført, at det ved at fiske eggene paa mange steder orer et stort farrand er muligt at finde ud, hvor gydningen har foregaaet. man kan med andre ord benytte den omstændighed, at eggene er saa meget lettere at fiske, end de voksne fisk er det, til at kartlæg ge torskestammens gydning, og dette er efter min mening det første og iallefald for øieblikket vigtigste resultat, saadanne undersøgelser kan give.

Til opnaaelsen af dette maal anvendte jeg en noget anden maade at samle eggene paa end de tyske forskere. Mens de trak en hov helt fra bunden op til orerfladen $0 \mathrm{~g}$ saaledes gjennemfiskede en vandsøile af horens diameter og talte de eg, der forekom i denne vandsøile, fandt jeg altid eggene allerøverst i vandskorpen $0 \mathrm{~g}$ foretrak derfor at slæbe hoven i orerfladen saaledes, at halvparten var over vandet. Jeg fik derved skummet havorerfladen $\mathrm{i}$ en bredde som hovens diameter, 1 meter, i en længde, srarende til 5 minutters gang med ca. 1-2 mils fart, altsaa ca. 200 meters længde. Herved opnaaedes den fordel, at hvor eggene forekom meget spredt og sparsomt, der forøgedes i overordentlig høi grad udsigten til at faa prøver af dem, der fandtes.

Paa den anden side viste selve den maade, eggene forekom paa, at man ad denne vei fik den bedste forestilling. Til kontrol af denne methode gjordes træk med lukkehov vertikalt saaledes, at hoven lukkedes under orerfladen, uden fangst af eg, hvorved konstateredes, at man ved saaledes at slæbe $\mathrm{i}$ overfladen ikke udsatte sig for at gaa glip af nogen $i$ dybet, hvilket ogsaa paa grund af den høie saltgehalt i disse nordlige farvand paa forhaand maatte antages sandsynligt.

1) Heincke u. Ehrenbatm. Eier u. Larven von Fischen der deutschen Bucht. Wiss. Meeresunt. N. F. III. 1900. 
For enkelte af de indsamlede prøvers vedkommende bestemtes antallet af eg. Ved disse tal er at bemerke, at da den længde, hvori hoven slæbtes, naturligris ikke kan forudsættes at have været akkurat den samme i alle tilfælde, $\mathrm{og}$ mindst har varieret mellem $150 \mathrm{og} 300$ meter, saa er det ikke med nøiagtighed muligt at sammenligne disse prøver indbyrdes. Derimod viser selve prøverne ved den overordentlige forskjel, de indbyrdes viser, at den opnaaede nøiagtighed er fuldstændig stor nok, iallefald at den fuldt ud tilfredsstiller den fordring, som alene bor stilleved saadanne 'sammenligninger, nemlig at methoden ikke medfører storre feil, end andre uundgaaelige forhold medfører.

Med denne methode, der af og til kontrolleredes red rertikaltræk, har jeg da i maanederne marts, april og mai 1901, saavidt veirforholdene tillod det, søgt at danne mig et overblik over udbredelsen af de flydende eg og dermed over gydepladsene lang's det nordlige Norge, i det nordlige Nordhav og Østhavet. Saaledes undersøgtes havet i marts under et togt Nordkap-Bjørnøen, derfra vest og tilbage Sørøen, i marts (13de-31te marts) havet udenfor Finmarken (Hammerfest-Murmankysten), i april (1ste-23de) bankerne udenfor Vesteraalen, Senjen-Sørøen, Lofoten, i tiden 24de april-6te juni havet Hammerfest-Murmankysten. I mai maaned udførte hr. Heluand-Hansen ombord i „Heimdal" undersøgelser mellem Aalesund-Bottlenosefeltet og dette - Lofoten.

Resultaterne af alle disse undersøgelser kan sammenfattes i følgende:

1. Torskens gydning finder kun sted inde paa kystbankerne. I tiden 1ste til 23de april fandtes de flydende eg saavel indenfor Lofoten i Vestfjorden, som udenfor paa Vesteraalsbankerne, Senjenbankerne o.s.v., men ikke et eneste eg udenfor den bratteeg, der i ca. 15 mils afstand her følger kysten.

2. Heller ikke andre fiskes flydende eg fandtes udenfor eggen med undtagelse af endel eg, som hr. Helland-Hansen i mai maaned fandt indtil 60 mil $(240$ kvartmil) udenfor Nordlands kyst. (Disse eg havde følgende størrelser: 1.32, 1.19, $1.14 \mathrm{~mm}$.). De kan desværre ikke bestemmes.

3. Paa selve bankerne var eggene yderst ujevnt fordelt, de fandtes i masser paa de banker, hvor der drives stort fiske, og hror vi kunde konstatere tilstedeværelse af fisk, nemlig paa de saakaldte "fiskebanker" især de flade $30-40$ favne dybe sandstrækninger, mens vi i de saakaldte "render" af 1-200 favnes dyb mellem disse, hror tisken ikke findes, kun fandt meget faa eg. Nogle tal vil illustrere dette. (Se fig. 21).

Paa banken ved Brevik (Sørøen) ................ 4845 eg.

Paa Svendsgrunden....................... 3636 "

I renderne mellem Andenæs og Svendsgrunden......... 170, 


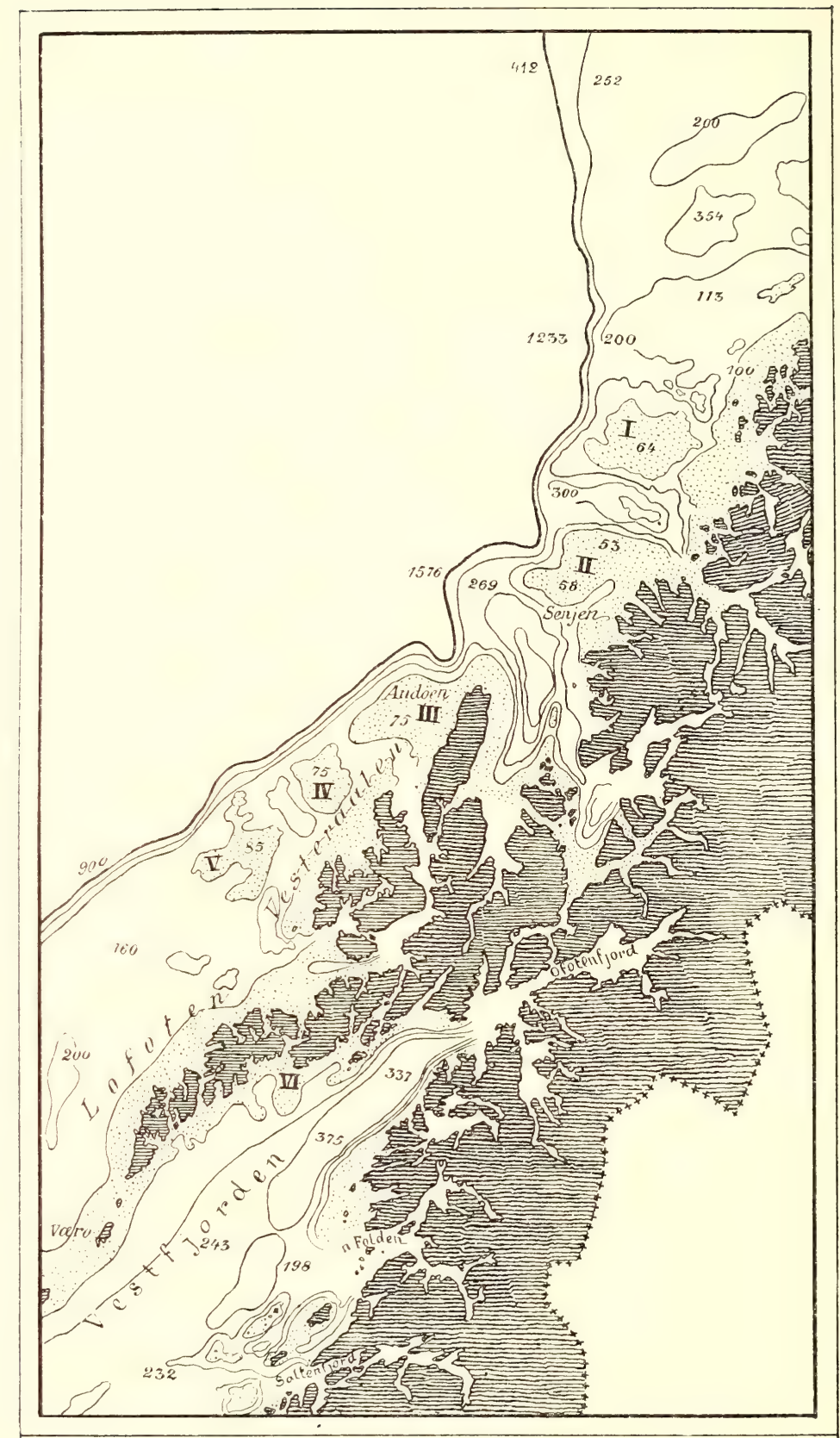

Fig. 21. Dybdekart over kystbankerne fra Røst til Loppehavet efter dybdekartet til "Norge i det 19de aarhundrede".

De punkterede strækninger betegner dybder mindre end 100 meter $=$ ca. 50 favne. Tallene angiver dyben i meter. $\mathrm{I}=$ Malangsgrunden. II $=$ Svendsgrunden. III, IV, $\mathrm{V}=$ Vesteraalsbankerne. $\mathrm{VI}=$ Lofotenbankerne. 
Paa banken udfor Andenæs ................. 957 eg

Dybrenden ved Hekkingen. . ................. 10 ,

Paa Malangsgrunden ................ 8470 og 3565 ,

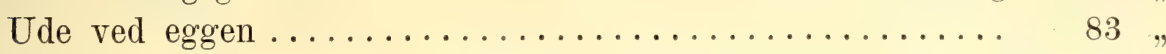

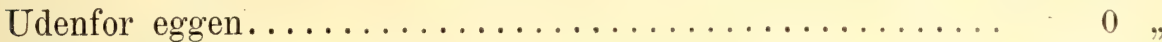

Paa Lofotbanken...................... 2333 ,

Inde i Lyngenfjorden ..................... 16 ,

Ved at sammenholde disse træk med fig. 21, som viser dybderne, vil man faa et indtryk af den karakteristiske mængdefordeling af eggene i dette farvand første halvdel af april maaned 1901.

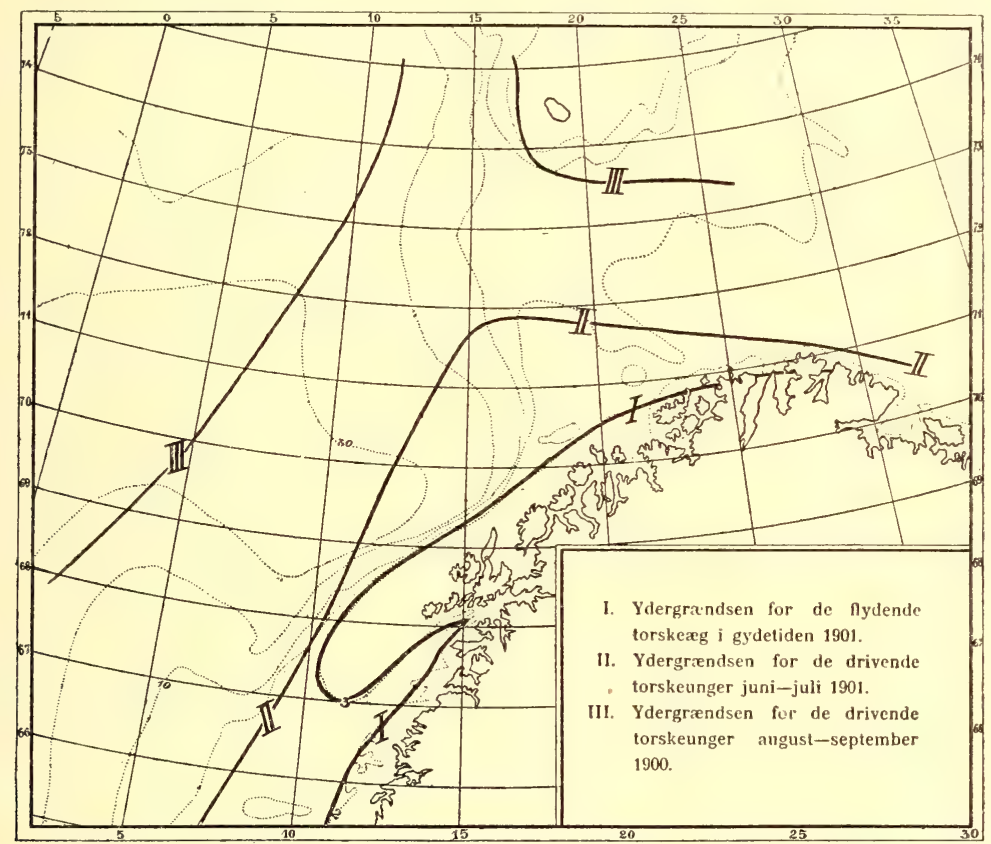

Fig. 22. Udbredelsen af de flydende eg og torskeyngel til forskjellige aarstider.

(Naar man paa den ene side betragter den uregelmæssige form, som havbunden fremviser, (dybdekartet) og paa den anden side disse tal, vil man forstaa umuligheden her at vove noget forsøg paa at beregne det hele farvands egmængde.)

4. De ovennævnte tal gjælder eg af bestemte størrelser, nemlig de størrelser, inden hvilke torske- og hyseeggene kan variere, og de kan med sikkerhed bestemmes som henhørende enten til arten torsk eller hyse. For mange prøvers vedkommende, nemlig de, i hvilke eggene befinder sig paa tidlige udviklingsstadier, kan ikke afgjøres, hvormange 
er torsk, hvormange hyse. I andre prøver er eggene saa langt komne, at dette kan afgjøres, og her kan man se, at begge arter er repræsenterede, men at torsken $\operatorname{dog}$ er i langt overveiende antal, hvilket ogsaa stemmer med fiskernes erfaringer fra bankerne paa denne tid.

5. Foruden disse eg af to arter, torsk og hyse, findes der i prøverne ogsaa eg af mange andre arter fisk, foruden eg af krebsdyr (som ephausiderne), saaledes af rødspætten, kveiten, gabeflyndre (Drepanopsetta) og brosme. Det vilde imidlertid her føre for vidt at omtale disse nærmere, $0 g$ deres forekomst skal derfor først nærmere omhandles $\mathrm{i}$ en mere videnskabelig fremstilling af disse ting.

6. Saadanne masseforekomster af eg som de ovenfor nævnte fandtes kun søndenfor Sørøen, den nordligste lokalitet var Brevikbanken. Hverken i havet mellem Finmarken $0 \mathrm{~g}$ Bjørnøen eller i Finmarkens kysthav og fjorde kunde nogen lignende mængde af eg konstateres, skjønt der udførtes en særdeles stor mængde hovtræk, og det baade vertikalt - fra bunden til overfladen med store hove af 8 fods diameter - og horizontalt i overfladen. Jeg har derfor paa fig. 22 ved kurve I skematisk antydet begrænsningen af denne masseforekomst. Til fuldstændiggjørelse af dette skal jeg her oplyse, at der ogsaa enkeltvis, dog i langt mindre mængde fandtes flydende torskeeg i kysthavet helt øst mod Murmankysten, denne forekomst var dog saa sparsom, at den kun kan sammenlignes med de træk, der søndenfor er gjort i fjordene ikke paa bankerne, hror den egentlige massegydning af skreien finder sted. Jeg skal derfor anføre nogle eksempler paa, hvad saadanne træk gav.

\section{2 den mai 1901.}

5-6 kvartmil nv. for Maasø, overfladehov. Hoven 5' slæbning. 2 eg af størrelse som torsk ${ }^{1}$ ).

$16 \mathrm{eg}$ af kveite.

4de mai 1901.

Indløbet til Kjøllefjord overfladehov 5'.

6 eg af rødspætte.

$10 \mathrm{eg}$ af kveite.

$4 \mathrm{eg}$ af torsk.

$$
8 \mathrm{de} \text { ', mai } 1901 .
$$

Mellem Nordkyn og Mehavn overfladehov $5^{\prime}$

4 eg af rødspætte

$58 \mathrm{eg}$ af torsk

$6 \mathrm{eg}$ af kveite.

1) I det følgende kaldes gaduseg af størrelsen ca. $1.3 \mathrm{~mm}$ torskeeg. 
8de mai 1901.

3 kvartmil n. af Nordkyn overfladehov $5^{\prime}$

$89 \mathrm{eg}$ af kveite.

$13 \mathrm{de}$ mai 1901.

Langs Porsangerfjord overfladehov $5^{\prime}$

6 eg af rødspætte

$12 \mathrm{eg}$ af torsk

9 eg af kveite.

21 de mai 1901.

$1 \mathrm{eg}$ af torsk

$7 \mathrm{eg}$ af kveite

(237 larver af lodde

1 larve af uer).

22 de mai 1901.

Varangerfjord ved Vadsø overfladehov 5'

$4 \mathrm{eg}$ af kveite

$151 \mathrm{eg}$ af torsk

55 eg af flyndre (Pleuronectes limanda).

Disse eksempler maa være tilstrækkelig til sammenligning med trækkene fra skreibankerne. De viser, at gydningen østenom Hammerfest kun sker i meget ringe udstrækning, noget, som ogsaa i fuldeste maal, som vi senere skal se, bekræftes af studiet af de drivende larvers og yngels udbredelse. Nævnes bør kun, at der ogsaa i marts og april gjordes træk med samme resultat, men antages de første dage af mai at svare nærmest til den tid, da gydningen var rigest længer syd. Naar de tyske forskere Schaudinn og Rømer i sin Fauna arctica meddeler i juni maaned at have fundet flydende torskerogn og -larver nordenfor Bjørnøen, synes dette at staa i strid hermed. Jeg maa imidlertid bemerke, at det kan formodes, at disse larver skrev sig fra polartorsken, Gadus saida, hvis forplantning dog ikke er bekjendt. At her ikke foregaar nogen større gydning af torsken anser jeg sikkert bevist ved mine mange hovtræk og studier af torskeyngelens udbredelse i sommerens løb, hvorom mere nedenfor.

7. Af denne eggenes karakteristiske udbredelse kan der ikke alene sluttes, hvor torsken begynder sin eksistents, men ogsaa, hvor den som vokser vandrer hen for at gyde, med andre ord, hvor skreimasserne er at finde under gydningen. Naar man nærmere betragter kartet, fig. 21, og dermed sammenholder de nævnte tal for mængden af 
eg paa de forskjellige banker inden dette kart, synes det mig endog, som om der maatte være en praktisk veiledning at søge i disse tal, saaledes at man ved dem formelig kan lede efter de gydende fiskemasser. Vi prøvede ogsaa under vort togt paa disse banker at fiske, hvor der fandtes flest $\mathrm{eg}$ og fandt her mere fisk end andetsteds, hvilket de fiskeforsøg, som nedenfor skal omtales, maa siges at have bekræftet i fuldt maal (se følgende kapitel).

Vore vigtigste slutninger er derfor disse: De store skreimasser gyder søndenom Sørøen. Østenom denne finder kun sammenlignelsesvis langt mindre gydning sted svarendetil, hvad ogsaa er tilfrldet i de fleste norske fjorde.

De flade kystbanker af ca. 30-50 favnes dyb yderst' i og udenfor skjærgarden er torskens eneste gydepladse.

Her findes torskens flydende eg samlede i store masser, og her gjennemgar de sin første udvikling. Udover sommeren udvikler disse eg sig til smaa unger af en til nogle tommers længde. Paa kartet fig. 22 er disses udbredelse ved sommertid (juni-juli 1901) fremstillet ved kurve II. Det har stor interesse nærmere at studere de resultater, paa grundlag af hvilke denne kurve er tegnet.

I juni maaned udførtes et togt i den sydligste del af det omraade, som kartet fremstiller. Fra Svendsgrunden udenfor Senjen sattes kursen udfor eggen direkte ud til yderste station beliggende paa $70^{\circ} 11^{\prime} \mathrm{n} .0 g^{\prime} 8^{\circ} 15^{\prime}$ ost (altsaa lidt vestenfor det tal 30 som angiver dybdekurven for 3000 meter). Fra dette punkt gik togtet tilbage mod Skomvær fyr (det vestligste punkt i Lofotrækken). Overalt - ialt paa 17 forskjellige stationer slæbtes en stor hov af 8 fods diameter i overfladen i regelen 15-30 minutters tid. Inde paa bankerne og saa langt ud. som kurve II viser, fandtes da de drivende smaa larver af en størrelse af $0.9-3$ centimeter $(1 / 3-1$ tomme lange) De svømmede livlig i overfladen, dog havde deres bevægelse mere den hensigt at holde dem srærende, nogen srømning i bestemte retninger har de endnu ikke begyndt. Sammen med dem fandtes mængder af andre organismer nemlig foruden de tidligere omtalte planktonformer larver af dyr, som fødes ved kysten, saaledes særlig smaa manæter af nogle centimeters diameter, larver af søstjerner etc., samt en hel del drivende ting fra land som tangbusker $0 \mathrm{~g}$ lignende. Foruden de smaa torskeunger $0 g^{\prime}$ hyseunger fandtes ogsaa mængder af ganske smaa larver af en anden fisk nemlig: ueren (rødfisken, sebastes marinus). Denne fisk føder, som bekjendt, smaa "levende unger" af en størrelse af ca. 0.8 centimeter, og de fiskedes i samme hovtræk som torskens, saaledes toges, for at nævne et eksempel, i et træk over eggen udenfor Svendsgrunden 8 yngel af uer (i 
størrelse fra 0.7 til $1.0 \mathrm{ctm}$.$) og 14$ yngel af torsk (i størrelse fra 0.9 2.8 ctm., flest ca. 1.5 ctm.)

Af kurve II ser man, at disse smaa yngel har væsentlig anden udbredelse end den, der tidligere er omtalt for eggenes vedkommende. Disse var, som ovenfor udviklet, begrænset til bankerne, ja til de $30-$ 40 favne dybe flak, medens de smaa torskeunger er langt udenfor eggen, der ogsaa sees antydet paa kartet ved de punkterede dybdekurver. Trækkene $\mathrm{i}$ havet udenfor kurve II viser nu den interessante ting, at ikke alene her torskelarverne ophører, men ogsaa larverne af de øvrige kystformer, hvilket slaaende beviser, at der er en skarp grænse i udbredelsen for alle de kystformer, som driver, og at disse, ligesom de vandlag, hvori de driver, nu om sommeren er i bevægelse udover Nordhavets overflade. Anderledes forholder det sig imidlertid med larverne af u eren, disse findes, hvor langt vi gaar ud, og langt ude i særlige masser, saaledes gav en halvtimes træk ikke mindre end 628 saadanne smaa uerunger af en gjennemsnitlig størrelse af 0.8 ctm. Forklaringen hertil er den, at disse smaa, nyfødte unger fødes herude udenfor bankerne, og det kan forstaaes ved det fund, jeg paa vort første togt i aaret 1900 gjorde, nemlig at de voksne uer vandrer ude over Nordhavet $\mathrm{i}$ de midtre vandlag 100 favne fra overfladen og 15-1600 favne fra bunden. Foruden uerens unger finder vi her udenfor kystformernes vandlag flere arktiske former, der synes at skyves ud af det fremstrømmende kystvand. Især er det karakteristisk, at den vigtige vingesnegl (Clio boreatis) hvalaaten har omtrent samme grænse indad mod kysten, som torskyngelen har udad mod havet. De udelukker med andre ord hinanden, om jeg end paa grænsen en enkelt gang har fundet dem sammen.

$\mathrm{Vi}$ nævnte, at den sydligste del af farvandet undersøgtes $\mathrm{i}$ juni, den nordligste og østligste del af kurven fremgaar af undersøgelser udførte i juli og tildels august maaned. Saaledes gjorde jeg i juli maaned et togt fra Andenæs (Vesteraalen) op mod $72^{\circ}$ n. $10^{\circ}$ ost (den nordvestlige del af kurven) derfra i lige linie paa Fruholmens fyr, senere ijuliaugust (25de juli til 11te august) undersøgtes farvandet HammerfestBjørnøen $0 \mathrm{~g}$ havet nord for Vardø $0 \mathrm{~g}$ Murmankysten. I det første julitogt (det op til $72^{0}$ n. $10^{0}$ ost) fandt vi, som man ser af kurven, torskeungerne længer ud til havs end under junitogtet, hvilket forklares derved, at de har havt en maaned længer at drive i. I den østlige del af farvandet var torskeungerne dog kun at finde meget nær land, og i ringe mængde, trods at jeg her undersøgte havet helt op mod Spitsbergen $0 \mathrm{~g}$ nord af Murmankysten og Vardø ved en mængde træk $0 \mathrm{~g}$ det saa sent som midten af august. Fælles for alle togter var dog den karakteristiske skarpe grænse melllem torskeungerne $o g$ kystformerne paa den ene side og de arktiske former (især vingesneglen Clio se fig. 18) paa den anden 
side. Ligesom torskeungerne kun fandtes nær land ud for Vardø, saaledes gik Clio og de andre arktiske former her ogsaa nær land, ja i august fandtes den endog med larver saa langt ind som i Varangerfjorden. Torskeungerne er nu vokset adskillig i størrelse. Den 13de juli havde de en størrelse af $3.5-4$ ctm., 21 de august 7 ctm. Uerungerne harde ogsaa $\mathrm{i}$ disse nordlige farvand en udbredelse uafhængig af den nærnte grænse mellem kystformer og arktiske havformer, det forklares derved, at de roksne forekommer over hele farvandet. Baade over de store Nordharsdybder og i havet mellem Norge og Bjørnøen, ja endog i Spitsbergens fjorde fandt vi de smaa unger i betydelig mængde.

I aaret 1900 udførte vi endel togter over Nordhavet til en endnu senere aarstid, saaledes fra Jan Mayen til Norge omkring midten af august, fra Nordkap til Bjørnøen og havet vestenom denne i de første dage af september. Torskeungerne fandtes ogsaa da i mængde i havets overflade, de harde til den tid en størrelse af indtil 9.5 centimeter (ca. 4 tommer), og deres udbredelse $\mathrm{i}$ havets overflade strakte sig, som man ser af kartets kurve III, endnu langt længer (mindst 30 mil) tilhars. Dette kan efter min mening ikke alene forklares derved, at togtet udførtes senere paa aaret, skjønt dette vistnok maa have bidraget noget dertil, men det maa $\operatorname{dog}$ for en væsentlig del forklares i forskjelligheder mellem kystvandets forhold $i$ de to aar. [ aaret 1901 undersøgte jeg nemlig havet udenfor Finmarken saa sent som midten af august, hrilket kun er ca. 14 dage tidligere end septembertogtet 1900, og i august 1901 var hele den drivende arktiske fauna saa nær Norge som kurve II's østlige del antyder, medens den samme fauna i 1900 forst var at finde nordenom kurve III, samtidig med at man da mellem de steder, som antydes af denne kurve, og Norge overalt kunde fiske torskeungerne.

Saaledes girer studiet af disse drivende organismer os et dybere indblik i harets berægelser og forholdene i havet i de forskjellige aar, end det maaske vil rære muligt at naa til paa anden maade, og dette studium viser os de forskjellige aarstiders $o g$ de forskjellige aars vekslinger i havet og i dettes livsbetingelser.

Ti saa tidligere, at torskeungerne tidlig paa sommeren alene kunde holde sig srærende i havets overflade, jo længer det lider ud over sommeren, desto mere udriklet blir deres svømmeevne. I juli maaned viser dette sig derved, at de kan begynde at samle sig i knuder eller smaa stim. Bedst ser man dette ude paa de saakaldte "skaller", grundere partier ude paa bankerne, hvor seien gaar og fraadser i torskeunger $0 \mathrm{~g}$ kril. Her kan man en stille dag pludselig se havets overflade kruset af de spidse seifinner, som kan samle sig til en eneste stor klump eller masse, saa søen bobler lang vei. Her ude ligger fiskere med kastenøter og 
passer paa disse øieblikke for da at samle i noten hundreder eller tusinder i et enkelt træk. Vi saa saadanne seifiskere i juli maaned udenfor Vesteraalen, paa Svendsgrunden, paa Gjesbaaen, i Loppehavet 0 . s. v. I et kast fangedes 700 sej. Ud af noten gjennem maskerne saa jeg store stimer af smaa torskeunger komme, og i sejmaverne fandtes masser af torskeunger, sammen med kril. Her faar man et indtryk af, hvor mange torskeunger der findes, og hvor mange der i naturen selv gaar tilgrunde. Intet steds er de vel saa talrige som netop her ude, baade længer tilhavs og særlig ind i fjordene blir de sparsommere, og det jo længer ind man kommer i fjorden. Mens et træk i juni mellem Landegode og Svolvær ude i Vestfjorden saaledes gav 52 torskeunger, fiskedes i Ofotenfjorden i 4 træk tilsammen 2, ligesaa i Trondhjemsfjorden, i Kristianiafjorden o. s. v., hvilket bekræfter hr. K. DAHLS og mine tidligere resultater ${ }^{1}$ ), at yngelen driver ud af vore fjorde og ud i det aabne hav for at vokse op sin første levetid derude.

Ud over høsten sker der imidlertid store forandringer i havet. Som omtalt i kap. I dør da efterhaanden det rige plankton bort, og hermed forsvinder torskeungernes næring. De maa nu af alle kræfter søge at benytte den svømmeevne, de har erhvervet sig, til at søge andetsteds efter næring, de maa med andre ord søge mod havbunden. Heri understøttes de efter alt, hvad man kan skjønne, mægtigt af havstrømmene, der til denne aarstid sætter paa land, og saaledes kan torskeungerne da efterhaanden dels dreven af vandlagenes bevægelser dels svømmende i smaa stimer søge ind mod landet $o g$ ind i fjordene. Saaledes saa jeg paa Østlandet i de fjorde, hvor hele sommeren ingen fiskeunger fandtes, om høsten (i oktober) pludselig hundreder i mine vadtræk, samtidig med, at strandbredden i skjærgaarden var fuld af tusinder af døde manæter, der var ført paa land. Ogsaa disse manæter var engang født nær land som smaa unger, de havde drevet mangfoldige mil om i havet og førtes nu til landet igjen. Paa samme maaade fører havstrømmene de smaa fiskeunger tidlig paa sommeren ud til havs for at lade dem vokse op blandt sommerens rige næring (planktonet), og naar dette igjen forsvinder, føres de tilbage mod kysthavets bunddyr. Deres videre skjæbne afhænger da meget af, hvor de føres hen i kysthavet, nogle kommer ind til den grunde kyst og lever blandt de vældige taremasser i skjærgaarden, andre kommer kun over bankernes store dybder 1-200 favne, men ud over vinteren, naar de nærmer sig afslutningen af det første leveaar, da formaar de endog at slaa sig ned paa havbunden her nord i

1) Johan HJort og Knut Dahl: Fiskeforsøg i norske Fjorde. Kristiania 1899. 
disse store havdybder ${ }^{1}$ ). Saaledes finder man om vaaren over hele Finmarkshavet paa 100-200 favne vand smaa torskeunger, som fødtes vaaren forud paa skreibankerne i Nordland, ligesom man finder torskeunger af samme alder blandt tangmasserne nær land og i bugterne langs land. For oversigtens skyld skal vi i det følgende kalde de smaa drivende torskeunger i deres første leveaar, altsaa fra marts - april det ene til marts -april det næste aar for 0-gruppen, den næste aargang, som altsaa tilhører bunddyrene for 1-gruppen, den følgende for 2-gruppen 0. s. v. Betragter vi nu denne 1-gruppe, saa forekommer den altsaa over hele Bjørnø-Finmarksbanken ja helt op mod Spitsbergen og nord om Murmankysten. Under kysten gaar den, som nævnt, op paa grundt vand, og i fjordene som Porsangerfjorden kan man tage dem i stranden med finmasket kastenot (grundvad). De nærer sig altsaa af bunddyrene, man finder smaa bundkrebsdyr af mange slags, orme 0.s.v. o.s.v. i deres maver, de er antagelig temmelig jevnt spredt ud over dybets bløde lerebund.

Hvad der synes mig mest interessant ved denne forekomst af Igruppen over saa store dele af Østhavet, er den omstændighed, at gruppens udbredelse er saa ganske anderledes end de flydende egs udbredelse. Man erindrer nemlig, at her i Østhavet fandtes kun ganske faa flydende eg langs land. Ved at sammenligne alt, hvad der er sagt herom og om de drivende fiskeunger med disse meddelelser om de første bundstadier, vil man forstaa, at disse ikke er født i $\emptyset$ sthavet, det er Skrejbankernes yngel, s.om e'r drevet derhen. Nu er hermed ikke sagt, at det er al skreibankernes yngel; thi en hel del af denne strander ogsaa langs Nordlands, Tromsøs kyster, men en stor del af den føres altsaa helt op i Østhavet, og dette viser, hvor langt fra det sted, hvor de fodtes. de kan drive hen.

Hrad denne 1-gruppens størrelse angaar, saa var den i mai 1901 , da den altsaa var 12-13 maaneder gammel, af $10-23 \mathrm{~cm}$. (4-11 tommers) længde. Nogle maal af torskeunger fra 100 favne $\mathrm{i}$ Varangerfjorden viser dette: $10,11,12,13,17,18,18,17,17,17,15$, $20,19,20,18 \mathrm{~cm}$.

Senere udover sommeren, naar de er $5 / 4$ aar gamle, er de lidt større. Nogle maal fra et træk paa 130 favnes dyb langt nord for Murmankysten viser dette: $19.5,20.5,21.5,22.5,20,24.5,24,28.5,25.5,29.5 \mathrm{~cm}$., som man ser mellem $20 \mathrm{og} 30 \mathrm{~cm}$. (8-12 tommer.)

\footnotetext{
1) Om nogen blir tilbage ude i det flere tusinde favne dybe Nordhav og der om høsten sænker sig ned til deti de midtre vandlag svævende plankton, der findes ca. 100- 500 favne fra overfladen selv om vinteren, naar de øverste 100 favnes plankton er bortdød, har jeg ikke kunnet konstatere. De 1 aar gamle torskeunger er allerede vanskelige at fange, naar de gaar pelagisk (ikke langs bunden).
} 
Intetsteds langs hele den norske kyst har jeg kunnet finde saadanne masser af denne størrelse af torsken som i Finmarken. Paa ankerpladsene som f. eks. Honningsvaag, Troldfjorden (Rolfsø) ete. var det en almindelig fornøielse ombord at jukse smaatorsk af ca. $30 \mathrm{~cm}$. længde (12 tommer), og i løbet af ganske kort tid havde man adskillige snes paa dæk.

$\mathrm{Og}$ merkelig er denne smaatorskens udbredelse fra ankerpladsenes 8-10 favne til det dybe flak af ca. 200 favnes dyb over hele Østhavet.

Før vi gaar over til at skildre de ældre aarganges liv og vandringer, skal vi give endel meddelelser om torskens videre vekst.

Vi saa ovenfor, at de et aar gamle torsk, I-gruppen, om vaaren havde en størrelse af ea. $20 \mathrm{~cm}$., den følgende sommer, da de altsaa er halvandet aar gamle, finder man dem af ea. $30 \mathrm{~cm}$. størrelse. Fra nu af blir det meget vanskeligt at studere veksten, de forskjellige individer har øiensynlig en meget forskjellig vekst, alt efter de forhold, de lever under. Dr. C. G. Joh. Petersen, lederen af den danske fiskeriundersøgelse, udtrykker dette træffende saaledes:

„Man tænke sig en mand tage en sæk med ganske ensartet sædekorn af hvede, rug eller ligegyldigt hvilken slags korn, og udsaa dette paa forskjellige steder, noget i god jord, noget i daarlig jord. Skjønt afkommet her er brødre og søstre, altsaa af samme race, bliver kornet meget forskjelligt paa de forskjellige steder, men man kan ikke med rette kalde det tynde korte korn paa de daarlige jorder for en anden race end det kraftige paa de gode jorder; thi det er jo kun de ydre betingelser, der have frembragt gruppevis fordelte, individuelle variationer."

Da nu disse individer af I-gruppen lever under saa forskjellige omstændigheder, er, som sagt, deres vekst forskjellig. Stiller man imidlertid maal af alle de størrelser af torsk, vi om vaaren fangede i Finmarken, og som altsaa væsentlig bestaar af den saakaldte "finmarkstorsk" eller "loddetorsk", sammen til en grafisk oversigt, viser den konstruerede kurve (fig. 23) en tydelig gruppe, I-gruppen, og saa en stor gruppe, som vistnok omfatter maal af noksaa forskjellig størrelse, men som dog tydelig samler sig om maalene ca. $50 \mathrm{~cm}$. Denne gruppe vil vi kalde IIgruppen. Ifølge de undersøgelser, som i Skotland er udført af dr. Fulton ${ }^{1}$ ), i Danmark af dr. Petersen ${ }^{2}$ ), maa man antage, at denne IIgruppe svarer til anden aarsklasse og altsaa gjengiver maal af 2

1) W. T. Fulton: On the rate of growth of the cod etc. 19 Report. 1900.

2) C. G. Joh. Petersen: Torskens biologi i de danske farvande. Beretn. fra dansk biol. station no. XI 1902. 


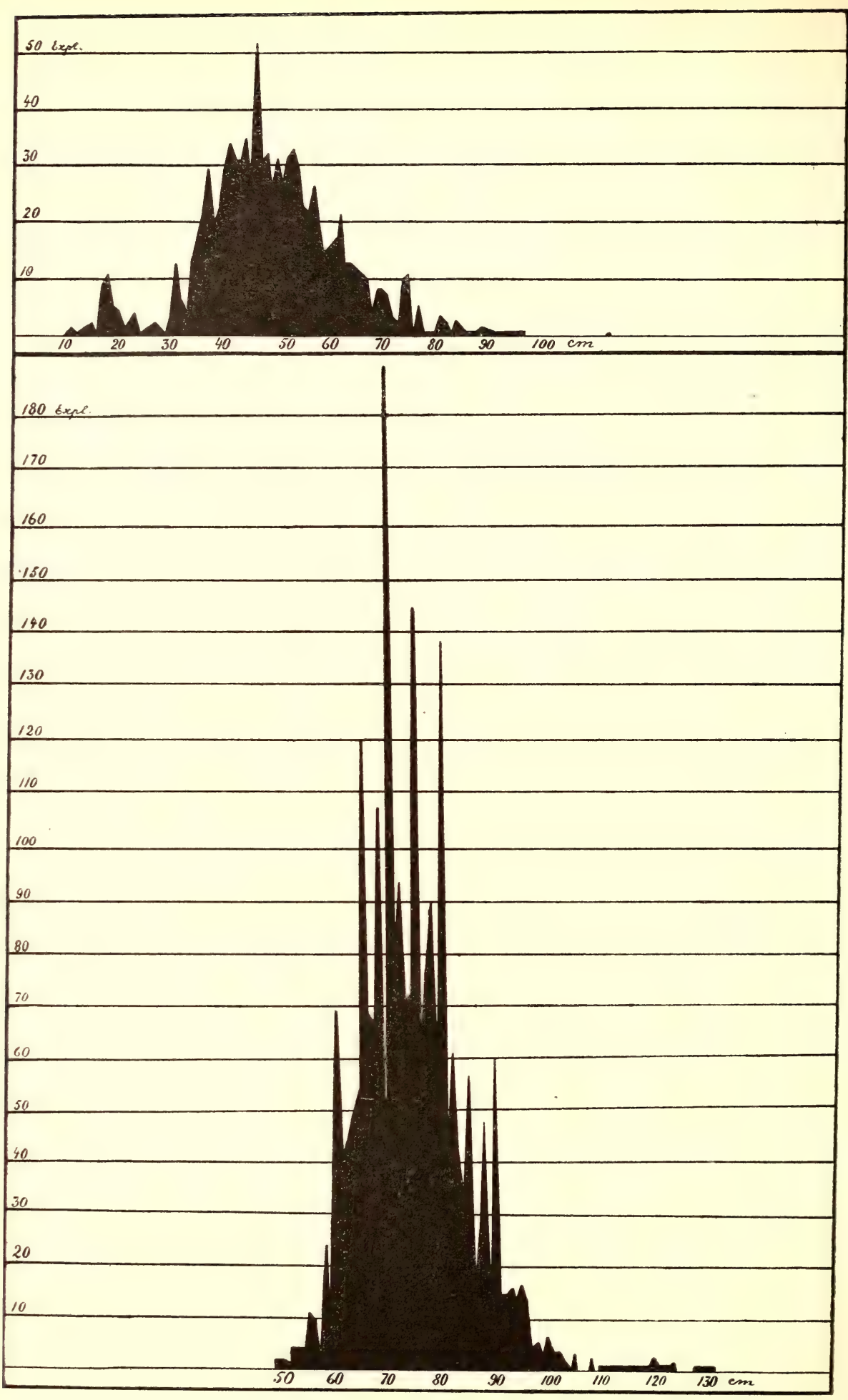

Fig. 23. Grafisk fremstilling af torskens størrelser. Øverste del i april 1901 under Finmarksfisket. - Nederste del af fisken paa Malangsgrunden 1902. 
aar gamle dyr. Forudsætningen for denne antagelse er da den, at de tildels noksaa store forskjelle i størrelse mellem enkelte af gruppens individer kan tilskrives forskjellige opholdssteder og livsbetingelser. Foruden I-gruppen og II-gruppen ser ri blandt kurvens maal endel større maal, der dog er meget faatallig repræsenteret. Som en egen stor kurve, der synes særdeles skarpt afgrænset, ser vi derimod disse maal, der samler sig om størrelserne af ca. $70 \mathrm{~cm}$., som altsaa giver maalene for III-gruppen eller de antagelig 3 aar gamle dyr. Disse er ikke fangede om vaaren i Finmarken, men i marts 1902 paa Malangsgrunden og repræsenterer den gydende torsk "skreien“. Enkelte større torsk ser vi ogsaa angivet paa kurven, de er dog saa faatallige, at der intet haab er om at kunne ordne dem til grupper.

Vi har altsaa følgende aarsklasser:

Yngelen eller 0-gruppen født om vaaren samme aar.

Smatorsken eller I-gruppen, om vaaren 1 aar, da ca. $20 \mathrm{~cm}$. lang.

„Finmarkstorsken“, „loddetorsken“ eller 2-gruppen, om vaaren 2 aar, da ca. $50 \mathrm{~cm}$. lang.

„Skreien“ eller III-gruppen, omfattende de største torsk, af hvilke den mindste aargang er 3 aar gammel om vaaren, og da ca. 70 em. lang.

Efter denne oversigt over torskens vekst skal vi fortsætte vor fremstilling af dens vandringer og opholdssteder paa forskjellige alderstrin.

Vi nævnte, at den som et til halvandet aar gammel fandtes helt fra stranden til 200 favnes dyb $0 \mathrm{~g}$ saaledes var spredt over særdeles store arealer. Den lever da af bunddyrene, mest krebsdyr. De, som lever langs land dels i fjordene, som jo i Finmarken ligner havarme, udvikler sig under sin vekst til de saakaldte taretorsk og fjordtorsk, som skjelnes af fiskerne fra havtorsken. Intetsteds langs hele kysten finder man saa mange torsk langs kysten som ved Finmarken. Ude paa skallerne eller baaerne som Gjesbaaen, Tubaaen kan man til næsten alle aarets tider fiske rødbrune "taretorsk" i betydelig mængde $o g$ i næsten alle størrelser. Hvorvidt disse lever paa disse baaer hele sit liv eller kun større eller mindre tid tager station her, naar de paa sine vandringer tilfældigvis kommer til en slig plads, kan man intet positivt sige om for tiden. Efterat det er lykkedes den danske dr. Petersen at bevise, at torsken i løbet af faa timer skifter farve og udseende efter sit opholdssteds art, saa er det i allefald sikkert, at det ikke er nogen egen race torsk, som lever her, og sandsynligt, at individerne heller ikke er bundne til disse steder hele livet. I enkelte af Finmarkens fjorde sker der dog særdeles regelmæssige opsig af gydende torsk i gydetiden (april) f. eks. i Kjøllefjord og paa mange andre steder, hvilket tyder paa, at ikke smaa 
mængder lever under kysten. Herom vidner ogsaa de betydelige sommerfiskerier.

Men det er dog den langt overveiende del, som tilhører det aabne hav, og fra det øieblik, da smaatorsken ude i havet — i dens andet leveaar - faar svømmedygtighed nok, begynder den at foretage særdeles store vandringier.

Specielt kjendt i Finmarken er da den store vandring, som den foretager mod kysten om vaaren, naar lodden søger op i bugter og sund for at lægge sin rogn lpaa sandbunden der. Da finder det saakaldte loddefiske sted, under hvilket store masser "loddetorsk" fanges. Som ovenfor nævnt er denne overveiende af en størrelse af ca. $50 \mathrm{~cm}$. (IIgruppen) og derfor meget mindre end skreien (III-gruppen og de følgende aargange), af hvilke der dog findes en del ogsaa. Et indtryk af mængdeforholdet mellem de forskjellige størrelser under Finmarksfisket faar man af følgende tal:

Den 10de mai 1901 udfor Omgangsklubben paa ca. 20 fv. vand fangedes ca. 250 torsk paa juks. Af 200 som undersøgtes var nogle $0 g$ tyve i størrelserne fra $65-80 \mathrm{~cm}$., og deres kjønsorganer viste, at de enten var udgydte eller under gydning. De øvrige ca. 180 var af størrelserne 40-60 cm. og havde ganske uudviklede kjønsorganer.

Denne loddetorsk bestaar altsaa af II-gruppen, det er de smaatorsk, som aaret forud færdedes ude i Osthavet og levede af bunddyrene der, og som nu har samlet sig og under jagt paa lodden nærmet sig kysten.

Ved denne blir de da i maanederne april, mai $o g$ juni, saa forsvinder iallefald den store hovedmasse af dem, og de fører nu en meget omflakkende tilværelse. Af deres senere opholdssteder kjender man kun godt de steder, hvor de i det følgende aar som skrei gyder, særlig er Lofotenbankerne jo fra de xldste tider kjendte og berømte.

I den store del af deres liv, som ligger udenfor opholdet under Finmarken i loddetiden $0 \mathrm{~g}$ under Nordlandsbankerne i skreitiden, er derimod deres liv meget lidet kjendt, og alle iagttagelser herom har derfor meget stor interesse.

Af de iagttagelser, man nu kan bygge sin kundskab paa, fremgaal det, at deres vandringer er meget vekslende fra det ene aar til det andet.

I slutten af 70-aarene $0 g$ tildels i 80 -aarene fandtes alle størrelser af de ældre aargange af torsken om sommeren i masser under Spitsbergen. I sin beretning fra Nordhavsekspeditionen fortæller G. O. SARs følgende: "Ved vor ankomst senere (15de august)“, 1878, „til Norskøerne ved nordvestpynten af Spitsbergen nær den 80de breddegrad dreves her netop af en del norske fiskefartøier et torskefiskeri, som i storartethed søger sin lige. Fiskemethoden var yderlig primitiv, idet alene haandsnøre benyttedes, hverken liner eller garn. Men selv paa 
denne maade kunde samtlige fartøier i forholdsvis utrolig kort tid fuldstændig lastes med fisk. Det gjaldt her kun om hænder til at hale op fisken med; thi fisk var der overalt i mængde, hvor man lod sit snøre gaa ned. Fiskerbaadene behøvede i regelen kun at ro nogle faa aaredrag ud fra ankerpladsen, for at alle mand straks kunde komme i fuldt arbeide med fiskeriet, som saaledes gik for sig under de gunstigste omstændigheder, nemlig baade $\mathrm{i}$ ganske smult hav og paa forholdsvis grundt rand $(16-18$ favne). For at give et begreb om dette fiskes storartethed, hidsættes følgende opgift, hvis paalidelighed kunde kontrolleres af os, medens vi opholdt os paa selve stedet. Fra et af fartøierne („Isbjørnen") sendtes kl. 10 om aftenen den 16de august 3 baade ud paa fiskeri hver med 2 mand. Kl. $4^{1 / 2}$ om morgenen vendte disse baade tilbage fuldlastede med tilsammen 1153 stor torsk. Efter at have flekket torsken og hvilet sig lidt, tog de samme mænd ud igjen kl. 8 og vendte tilbage kl. $1 \frac{1}{2} 2$ om eftermiddagen med tilsammen 1100 torsk. I løbet af 12 timer har saaledes disse 6 mænd alene med simpelt haandsnøre opfisket det anseelige antal af 2253 torsk, hvilket giver hver mand ca. 375 fisk eller mere end 1 fisk hvertandet minut. At her maa have været ganske enorme torskebjerge opunder kysten, er klart, og et med mere tidsmæssige fiskeredskaber drevet fiskeri maatte utvirlsomt her have kunnet give et aldeles storartet udbytte.

Fisken, som jeg her havde rigelig anledning til at undersøge i frisk tilstand, skilte sig i ingen henseende fra den ved vore kyster forekommende banktorsk. Skjønt den var temmelig jevnt stor, enkelte individer endog usædvanlig store og neppe staaende tilbage for den største Lofotskrei, fandtes dog hverken rogn eller issel i nogen af dem. Derimod var mavesækken paa dem alle fuldproppet af forskjellige sødyr, hvoriblandt ogsaa den ovenfor omtalte flueate af $o g$ til kunde gjenkjendes. Efter fiskernes udsagn var det tidligere saagodtsom udelukkende denne aate, torsken havde i sig, og da havde fisken fersk afkogt havt en eiendommelig mindre behagelig lugt og smag, der tildels endnu kunde spores hos enkelte individer." - - Om denne aate siger SARS, at den er "som andre pelagiske dyr særdeles flygtig i sin forekomst, saa at det ofte kan hænde, at den ligesaa pludselig igjen forsvinder, efter at den en tid har fyldt alle bugter og sunde."

Da al torsk under Spitsbergen i disse aar kun var store fisk, og der ingen smaatorsk fandtes, sluttede SARS, at den ikke tilhørte Spitsbergen, men var kommen søndenfra og tilhørte den stamme, som gjød ved Lofoten. Ved Spitsbergen er jo alt isdækket om vinteren og i torskens gydetid, saa her var det jo sandsynligt, at ingen torsk fandtes til den tid. SARS udtaler ogsaa, at al torsk var saa stor heroppe, at der 
kun fandtes ældre - ingen unge individer, hvoraf han slutter, at Spisbergen kun var dens opholdssted i en mindre del af dens liv.

I 80-aarene holdt dette Spitsbergen-fiske op. Under det togt, som „Michael Sars" i 1901 foretog til Spitsbergen, søgte vi baade med trawl og liner baade i fjordene (Isefjord, Green-Harbour, Bellsund) og udenfor paa kystbanken efter torsk uden at fange mere end et eksemplar af I-gruppen, som vel af havstrømmen er ført derop. Alle ishavsfarere bekræfter det samme, at der i de senere aar ikke har været torsk at merke under Spitsbergen.

Ved Bjørnøen synes torsken endnu mere vekslende i sin forekomst; thi mens den ved Spitsbergen har forekommet i perioder (rækker af aar), er forholdet ved Bjørnøen ganske variabelt. I aaret 1900 forsøgte "Michael Sars" med liner efter torsk paa Bjørnøbanken uden nogen fangst hverken oppe paa plateauet eller i eggen. I sidste halvdel af juli 1901 var forholdet derimod meget anderledes. Forsøg oppe paa banken gav da heller ingen fangst, derimod fandtes der masser af torsk den saakaldte eg ned mod det dyb, som i syd og vest omgiver banken. I sætninger paa 128 farne af 400 kroge erholdtes saaledes flere gange mellem $70 \quad 0 \mathrm{~g} 80$ torsk af størrelserne $70-120 \mathrm{~cm}$. , desuden havkat, hyse, kveite og haakjærring. Torsken havde bundkrebsdyr (hyas), ræger (pandalus) og lodde i maven. Paa kartet (fig. 24) er med $x$ afsat de steder, hror disse fangster gjordes, og maa man antage, at der her var meget fisk tilstede.

Vekslingerne fra det ene aar til det andet hænger her paa det nærmeste sammen med forskjellighederne i havet i de to aar. Af iskartet juli 1900 (fig. 7) ser man, at Bjørnøbanken var dækket af is og isvand. I aaret 1901 var der derimod isfrit og langt varmere $\mathrm{i}$ havet rundt Bjørnøen. I overensstemmelse hermed vil torskens forekomster antagelig altid variere paa dette hjørnepunkt midt mellem ishavsstrøm og atlanterhavsstrøm. Det ene aar vil den ene strøm have overvægten, det andet aar den anden, men vil man i thermometret have et let middel til at orientere sig i dette spørgsmaal. Saaledes var vandets temperatur paa banken i $1900 \div 1^{0} .5$, mens det i 1901 var + mellem $1^{0}$ og $2^{0}$.

Hvad torskens forekomst midtsommers forøvig angaar, da synes det, som om den skyr den ca. 200 favne dybe rende, som vestenifra gaar ind over Østhavet, og hvis bund er dækket af det bløde mudder. Her har jeg iallefald ved sommertid aldrig truffet den i mængde. Derimod synes den at trække længer øst og nord ind i Østhavet, hvor bunden langsomt skraaner op mod mindre dybder med haardere bund. Paa kartet fig. 24 er afmerket endel steder med tidsangivelse, hvor ishavsfangstmænd har opgivet mig, at de har seet torsk midtsommers i havet østenom Bjørnøen. 


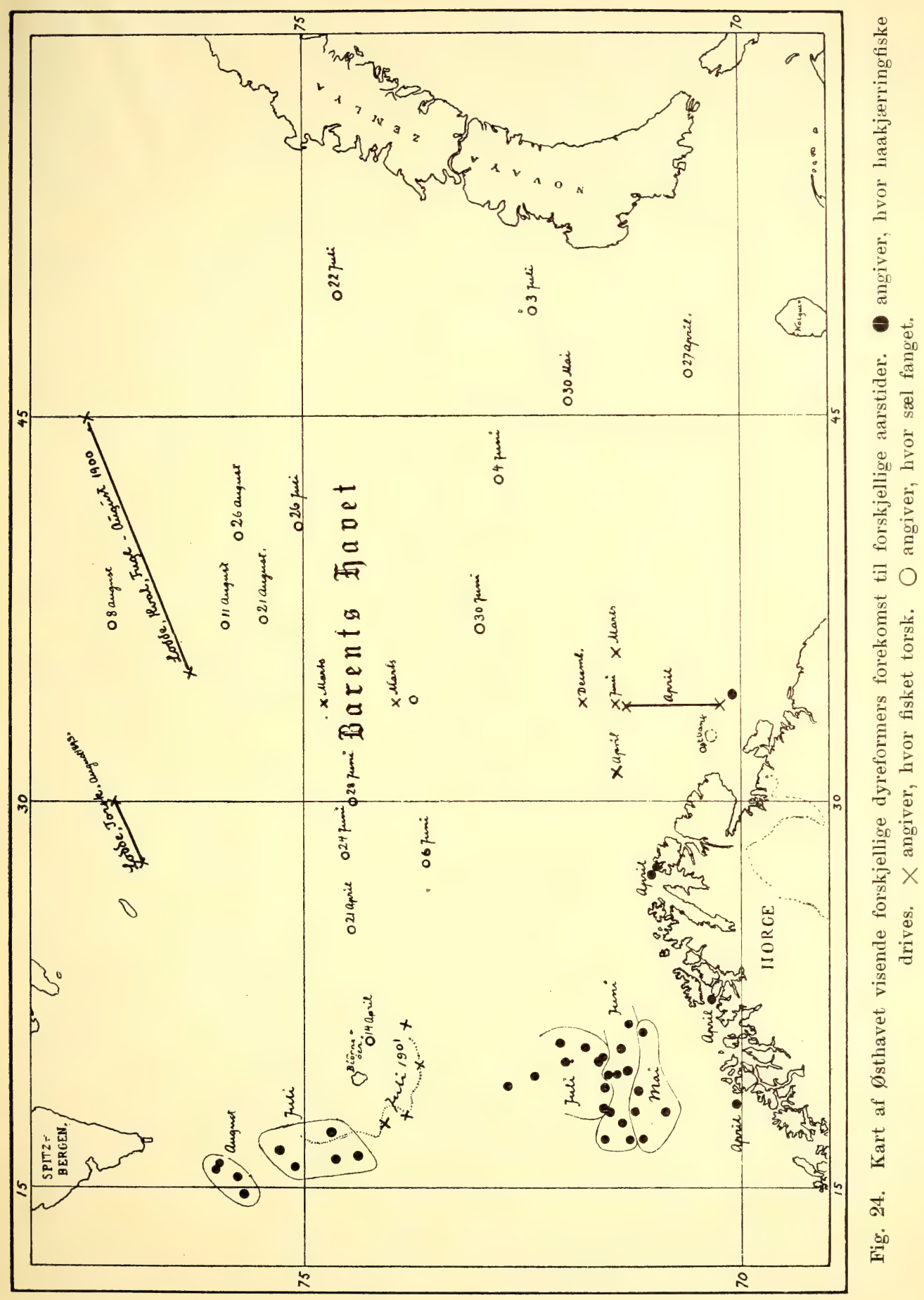


Der foreligger endvidere endel værdifulde erfaringer over torskens forekomst i denne østlige del af Østhavet, dels ved de af fiskeriinspektør Sørensen udførte fiskeforsøg paa den saakaldte Østbanke (se kartet fig. 24) øst om Vardø, hvor der midtsommers ogsaa af "Michael Sars" fandtes adskillig stor torsk, dels i det bekjendte Murmanfiske, som af russerne om sommeren drives paa Murmankysten, $\mathrm{og}$ dels $\mathrm{i}$ endel af den russiske undersøgelsesekspedition under ledelse af N. Клгpowitsch drevne undersøgelser.

Disse sidste har med engelsk trawl gjort en hel del fiskeforsøg væsentlig i linie ret nordover langs Kolafjordens længdegrad (ca. $33^{\circ} .30^{\circ}$ ) til forskjellige aarstider og desuden foretaget endel togter saavel østover som mod Bjørnøen. Af disse togters resultater har hr. KNipowitsch meddelt, at der allerede i slutten af marts (saaledes i aaret 1901) kan tindes mængder af torsk langt fra land i havet nord om Murmankysten. I en halv time toges saaledes med en liden engelsk trawl paa $71^{0} .29^{\prime} \mathrm{n}$. og $35^{\circ} .42^{\prime}$ o. 483 torsk og i et nyt træk sammesteds paa 1 time 406 torsk. Under samme togt fandtes da helt op til $74^{\circ} .47^{\prime}$ (Kolafjordens længde) i 40 minutter 50 torsk, saaledes at hr. KNipowitsch slutter, at der ved denne tid ,indenfor den varme Atlanterhavstrøms udbredelse var meget store mængder fisk" paa dette felt. (Se kartet fig. 24, hvor disse fangsters lokalitet er betegnede med $\times$ og tidsangivelse).

I april 1900 fandtes ligeledes store masser af torsk ret nord af Kolafjorden paa strækningen fra $70^{\circ} .15^{\prime}$ n. til $71^{\circ} .26^{\prime}$ n. altsaa n.o. om Vardø. (Se kartet fig. 24).

"I sidste halvdel af juni," siger Knipowitsch videre, „var der forholdsvis faa fisk langs den samme længdegrad." „Nu nærmede fisken sig kysten, og det almindelige Murmanfiske begyndte. Senere til slutten af sommeren var der lidet fisk i det aabne hav, dog fandtes stadig flere nordenom $71^{\circ} .30^{\prime}$ eller deromkring."

„Saaledes kommer fisken aabenbart til os vestenifra, og den holder sig til en begyndelse i den varme strøm, saaledes at man kan finde den i stor mængde $\mathrm{i}$ den varme strøm eller i nærheden af den, mens der i nærheden af kysten ingen fisk findes, og Murmanfisket endnu ikke har begyndt. I mai 1900 sendte jeg skonnerten „Pomor" for at fiske mellem $71^{0}$ og $71^{0} .30^{\prime}$ n., og den fandt virkelig fisk nok til, at der blev fangst, medens der under land endnu intet fiskedes. Aldeles ligedan fandt vi i mai 1898 ved $71^{\circ} .47^{\prime}$ nordenfor fiskeværet Waida Guba en kolossal mængde fisk, især kveiter, medens der endnu ikke fangedes noget under land."

"Mod slutten af sommeren har der vist sig store mængder af fisk ikke alene under Murmankystens østlige del, men de trænger ogsaa langt frem mod øst. Saaledes fandt "Pomor" i de sidste dage af sep- 
tember en stor masse fisk ved Nokujevøen. Baade i 1899 og i 1900 fandtes fisk, især hyse, ved Kap Kanin-Noss. . . . I oktober voksede mængden af fisken i det aabne hav i antal - øiensynlig fordi den trak sig tilbage fra kysten. I ringe antal kunde man til begyndelsen af december finde fisk nord om Murmankysten, sidste gang ved $72^{\circ}$. n."

Af disse meddelelser vil man se, at der om vaaren sker et stort indsig af torsk østover i Østhavet, at dette indsig følger den varme strøm og om sommeren nærmer sig Murmankysten og Østhavets fladere partier for senhøstes at trække sig tilbage igjen.

Disse vandringer er imidlertid øiensynlig underkastet meget store vekslinger. Intet viser dette mere end det ovenfor omtalte Spitsbergenfiske $0 \mathrm{~g}$ de vekslinger i fiskerierne, som vi i næste kapitel ganske kort skal omtale.

Her vil vi kun henpege paa den eiendommelige parallel mellem disse vandringer - østover om vaaren og vestover senhøstes - og det evige isbeltes bevægelser -- tilbagetræden om sommeren $0 g$ fremtrængen mod vinteren.

Hvad der i det foranstaaende er meddelt over torskens liv $0 \mathrm{~g}$ vandringer, vil vi saaledes søge at sammenfatte $\mathrm{i}$ følgende ord:

Det nordligste Norges torskemasser fødes paa Nordlands $0 \mathrm{~g}$ 'Tromsøs 30-40 favne dybe kystbanker som smaa flydende eg, der i sommerens løb vokser op til nogle tommer stor „yngel“, der af fralandsstrømme føres udover Nordhavets overflade $0 \mathrm{~g}$ der findes i mængder, for i næste vinters løb under paalandsstrømme og under vandringer at føres mod kysten eller kystbankerne eller Østhavets store indtil 200 favne dybe flader, hvor de ernærer sig af bunddyrene (krebsdyr). Næste aar, da de er 1 aar gamle, er de da ca. 20-25 cm. (10 tommer) lange. Af disse blir de, som lever ved land, taretorsk, og de søger mest den haarde bund ved landet, de andre ud paa flaket vokser i løbet af det følgende aar til "loddetorsk" af $50 \mathrm{~cm}$. (20 tommers) længde, og disse siger i masser i april-mai\} under land langs Finmarken og Murmankysten forfølgende lodden. Om sommeren vandrer de enkelte aar østover - andre nordover mod isen, i regelen forfølgende lodden, for saa, naar næste vinter igjen kommer, at vandre vestover mod de banker, hvor de selv fødtes. De er da 3 aar gamle og ca. $70 \mathrm{~cm}$. (30 tommer) lange, de har moden rogn og melke og kaldes af fiskerne "skrei“. Efter gydningen vandrer de igjen østover, nogle blander sig med de yngre aarsklasser og foretager sammen med disse de store vandringer i Østhavet. Andre forlader imidhertid helt kystbankernes omraade og færdes ude i Nordhavet. I april 1901 fandt jeg saaledes udenfor eggen over 1000 favnes dyb i ca. 100 favne fra overfladen enkelte store udgydte skrei saaledes 14 de april paa 
$68^{0} .44^{\prime}$ n. og $13^{\circ} .39^{\prime}$ o. en skrei $114 \mathrm{~cm}$. lang, 19de april paa $69^{\circ} .49^{\prime} \mathrm{n}$. og $16^{0} .12^{\prime}$ en skrei $70 \mathrm{~cm}$., første gang ogsaa 3 hyser $75,75,68 \mathrm{~cm}$.

Disse fisk fangedes paa en line paa 500 kroge, som blev hængt ret op og ned fra en stor boje. Da der saaledes kun var faa kroge i det dyb, hvor fisken stod, kunde man ikke vente sig større fangst.

Til andre aarstider har vi ogsaa paavist enkelte slige vandrende fisk ude over de store Nordhavsdyb, baade i februar og juli (paa $71^{0} .20^{\circ}$ og $13^{0} .58^{\prime}$ o.) fandtes hyser ude i Nordhavet. Desuden paavistes i aaret 1900 endel torsk, hyse, sei især i den sydligere del af Nordhavet, noget som er vore bottlenosefangere bekjendt.

Hvilken størrelse og betydning dette fænomen har, har jeg endnu kun havt liden anledning til at studere. Vandrer større mængder af skreien derud, eller er det kun enkelte forvildede individer? Disse særdeles interessante spørgsmaal hænger utvivlsomt sammen med spørgsmaalene om sildens og blæksprutternes vandringer og livshistorie i Nordhavet. Herom ved man imidlertid endnu næsten intet. Man ved kun, at bottlenosen paa feltet er fuld af store blæksprutter, at der om høsten sker store indsig til kysten af akkeren (Ommatostrephes todarus), men dennes vandringer udenfor kysten er ganske ukjendt, ligesom dens forplantning og naturhistorie i det hele.

At fisk kan vandre derude over de svære dyb i Nordhavet, har vi iallefald seet, $\mathrm{og}$ fremtiden faar belære os videre om disse ting. Den fisk, som forekommer i størst mængder i de midtre vandlag, synes i den nordlige del af Nordhavet at være ueren, som vi i august 1900 (over 1500 farnes dyb) 100 favne fra overfladen tog $\mathrm{i}$ et antal af 65 paa 600 kroge. I 1901 fandt vi den ogsaa spredt ved forskjellige forsøg langt udenfor bankerne. Om dens drivende yngel har vi ovenfor talt.

\section{Silden.}

Studiet af sildens liv og vandringer frembyder langt større vanskeligheder end tilfældet er for torskens vedkommende. Sildens eg lægges paa bunden og kan ikke saa let findes som torskens. Den voksne sild har meget raske bevægelser og undgaar derfor næsten alle redskaber undtagen drivgarn 0.1 , der kræver særdeles lang tid og desuden kun kan anvendes i begrænsede dybder.

Fra forskjellige hold og paa forskjellig maade har det i de sidste aar lykkedes mig at indvinde endel nye erfaringer om sildens vandringer. 
I aaret 1900 prøvede "Michael Sars" at sætte efter sild paa

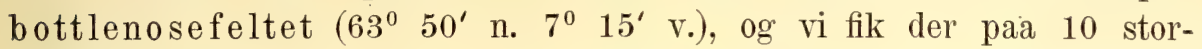
maskede garn 1 tønde sild; alt tydede dog paa, at den ringe fangst skyldtes de store masker. Samme aar fik hr. H. W. Fries fra Aalesund adskillig sild nærmere eggen mod Færøerne og over eggen fra Shetland mod den norske rende.

I aaret 1901 medfulgte hr. Helland-Hansen chefsfartøiet „Heimdal" paa dets vanlige ishavstogt for at tage hydrografiske observationer $\mathrm{og}$ indsamle meddelelser om bottlenosefangernes erfaringer. Talrige fangstmænd havde da imødekommet den til dem tidligere rettede anmodning om at undersøge bottlenosens maveindhold, og det viste sig, at dette især paa $2^{0}$ v. $0 \mathrm{~g} 63^{0} \mathrm{n}$. meget ofte havde været sild, ligesom sild her ofte var iagttaget. Oftest var dog maveindholdet af bottlenosen blæksprutter.

Af de mange meddelelser, hr. Heldand-Hansen erholdt, skal her kun meddeles nogle faa:

6 te mai praiedes "Stella" af A alesund, havde 7 bottlenose. Den første mai var sild fundet i bottlenosemaven paa $62^{0} 50^{\prime}$ n. og $2^{0}$ v. Har tidligere der ofte fundet sild i bottlenosen, ialmindelighed dog blæksprut. Paa nævnte sted saaes meget sild, ogsaa adskillig sildehval. Havde tidligere aar derude pilket sei og torsk.

Samme dag praiedes "Onyx" af Tønsberg, havde seet sild i massevis paa omtrent $62^{3} / 4^{0} \mathrm{n}$. og $2^{0}$ v. Ogsaa seet sildehval.

Samme dag praiedes "Copernicus" af Tønsberg. Meddelte, at sild fandtes ved $62^{1 / 2} 2^{0}-63^{0}$ n. og $2^{0}-3^{0}$ v. Fundet meget, men smaa sild i bottlenosemaven. Har faaet sei $0 \mathrm{~g}$ torsk paa pilk i $5-50$ favnes dyb senere paa aaret i juni. „Endnu for tidligt.“

Samme dag praiedes „Heim“ af Aalesund, været paa feltet siden 16de april og faaet 19 bottlenose. Har ikke seet sild, men meget fugl og aate.

Samme dag praiedes „Flid" af Tønsberg. I slutningen af april fundet stor fedsild i bottlenosemaverne paa omtrent $63^{\circ} \mathrm{n}$. Paa dette sted ofte sildesyner. Paa $6^{0}$ v. $0 \mathrm{~g} 63^{\circ}$ n. ofte tidligere fundet torsk og sei, ogsaa seet sild almindelig der.

Samme dag praiet "Heimdal" af Sandefjord. Ikke seet sild i maven paa bottlenose, men stor sild i vandet paa $63^{\circ} 47^{\prime}$ n. og $3^{0} 25^{\prime}$ v., "hvor der er sterkt strømras".

7 de mai praiedes „Fram" af Tønsberg, havde 22 bottlenose. I et par fundet fedsild paa $63^{0}$ n. og $2^{1 / 2^{0}}$ v. Paa det sted, hvor "Fram“ praiedes $63^{1} /^{0}$ n. og $3^{0}-4^{0}$ v., var der seet store stimer af mindre sild dagen forud om eftermiddagen. Anser det for tidlig paa aaret for torsk og sei.

Disse eksempler blandt flere lignende faar her være tilstrækkelig. 
Af kartet (figur 56) vil man se, at der ogsaa i den nordlige del af Nordharet fanges bottlenose, og her skal der ifølge Tromsø- og Hammerfestfangstmændenes udtalelser ogsaa være seet sild. IvGEBRigtsex har saaledes meddelt, at han i mai 1888 paa $71^{\circ}$ n. og $10^{\circ}$ o. (ca. 45 mil fra Vesteraalen) skjød bottlenose med sild i maven. Sælfanger Fr. OLsex, fører af "Kristiane" af Hammerfest har berettet, at han i slutten af august maaned 1900 seilede gjennem sild hele veien fra Jan Mayen til 7-8 mil af Nordfuglø. Han har 8 aar været paa „Vesthavet", men kun denne ene gang seet saadan sildeforekomst. (Derimod ofte seet rødfisk og haakjærring i overfladen $73^{0} \mathrm{n}$. og antagelig $4^{0}-5^{0}$ v.).

Sælfanger Joнам Nielsex, fører af „Freya“, Hammerfest, passerede 12 te august 1900 Jan Mayen med kurs for Grønland, saa sild ca. 25 mil vest for Jan Mayen i overfladen (det samme gjorde ovennærnte Fr. Otsex). Har været i Vesthavet 10-12 aar, men kun seet sild det aar, derimod ofte fundet sild i klapmydsen under Spitsbergen.

Sælfanger Ole Hansen, fører af "Alken“, Hammerfest, saa sidst i juni 1897 helt fra $74^{0}$ n. $3^{0}$ o. til Spitsbergens Foreland, 20 mil af, masser af sild i stille veir. Skjød her klapmydsen i klarvandet. Alle disse sælfangere har ofte seet klapmydsen i „klarvandet“ (hvor ingen is) paa bottlenosefeltet (det nordligste).

I haabet om nærmere at udrede disse forekomster søgte jeg igangsat et fiskefors $ø$ med drivgarn efter sild i den nordlige del af Nordhavet, og med relvillig assistance af d'hrr. Eldingsen, Vesteraalen, og konsul Robertson, Hammerfest, lykkedes det at faa udsendt kutteren "Mira“, som under ledelse af „Michael Sars“, nuværende fører hr. Iversen krydsede over det nordligste bottlenosefelt op imod $72^{0}$ n. og $10^{0}$ o. Her sattes gjennem et langt tidsrum mai-juli, saa ofte veiret tillod det, drivgarn, men fangsten var særdeles liden. Der viste sig at staa spredt enkeltvis sild, saaledes at der paa 20 sildegarn kunde fanges $3-4-7-9$ sild paa en sætning.

Den samme eiendommelig spredte forekomst viste ogsaa endel fiskeforsøg, som blev gjort nærmere kysten, Lop pehavet, og er det en almindelig erfaring, som den, der har gjort mange drivgarnsforsøg, vil have.

Videre erfaringer om sildeforekomster har jeg faaet giennem hvalfangerne i Finmarken. Det viste sig, at mange af de finhval, der skydes om sommeren i havet mellem Bjørnøen og Norge, havde sild i maven, dog mest mellemstørrelser (stor og liden Kristianiasild). Særlig synes der en 10-20 mil nord af Finmarkskysten at være et strøg, hvor disse sildeforekomster synes almindelige. Her færdes ogsaa store mængder „springere".

Smaasilden saa vi midtsommer i utrolige masser i maverne paa den sei, som fangedes ude paa "skallerne" f. eks. Gjesbaaen. 
Saaledes ser vi alt ialt, at der foreligger erfaringer om, at silden er spredt over enorme strækninger af Nordhavet, om den enkelte steder end kun kan paavises i meget spredte forekomster og i ringe individantal. Vi har herved leveret endel kjendsgjerninger, som bekræfter SARS' bekjendte hypothese angaaende sildens vandringer. Da Nordhavet for størstedelen jo er 1000-2000 favne dybt, er ingen af disse sild født der ude, de maa være vandrede did og maa igjen vandre tillands, naar de selv skal gyde sin rogn paa de grunde sandflak.

Vanskeligheden ved at udrede disse vandringer ligger, som sagt, der, at det er saa vanskeligt at bringe paa det rene, hvad en dyb vandmasse overhovedet indeholder af sild, og de drivgarnsforsøg, som har været prøvet, har det utilfredsstillende ved sig, at de kun undersøger de øverste faa favne af havet. De kan derfor aldrig give nogen sikker følelse af, at spørgsmaalet om sildens forekomst er udredet. Fra Aalesund foreligger desuden den erfaring, at der under langefisket paa 150 favnes dyb om sommeren ofte paatræffes fersk sild i langens mave. Saadanne erfaringer gjør undersøgelserne over disse dyr end mere usikre og vanskelige.

Under land har sildens optræden i det nordligste Norge som bekjendt været meget vekslende. I 60-aarene $0 \mathrm{~g}$ begyndelsen af 70 -aarene til 1873 var der som bekjendt et meget stort sildefiske, som igjen forsvandt, men som i de aar, det varede, med stor regelmæssighed aar for aar gjentog sig paa de samme steder af kysten.

I selve Finmarken har der i de senere aar kun været lidet sild; derimod fortælles der, at nordlændinger, som i 40-aarene reiste til Finmarken, havde med storsildgarn og fiskede til agn.

Af amtmandens beretning for 1868 fremgaar det, at der om høsten stødte sild langs kysten i hele Vestfinmarken, hvoraf der dog blev fisket meget lidet, da man ikke var beredt paa det slags fiske. Senere synes der efter amtmandsberetningerne kun at være fisket mindre partier fedsild iallefald østenom Hammerfest.

\section{Lodden.}

Lodden er en egte arktisk fisk. Den findes udbredt fra Labrador og Newfoundland, Grønland, Island til Østhavet. Hos os er loddens optræden begrænset til en bestemt del af aaret (vaaren) og til Finmarkens kyst. Undtagelsesvis og $\mathrm{i}$ enkelte individer er lodden observeret helt til Kristianiafjorden. 
Om lodden siger G. O. SaRs: „Den er ifølge sin hele bygning en egte pelagisk fisk $0 \mathrm{~g}$ viser saavel i det ydre som i den indre organisation stor overensstemmelse med silden, om den end efter visse zoologiske merker navnlig den saakaldte fedtfinne bag paa ryggen, ialmindelighed regnes til en anden familie, nemlig laksefiskene. En eiendommelighed red lodden er den særdeles skarpt udprægede forskjel i det ydre mellem begge kjøn. noget der har givet anledning til særskilte benævnelser for begge. Hunfisken kaldes heroppe ialmindelighed sildlodde eller rognlodde. hanfisken fakselodde. Begge indfinder sig ialmindelighed samtidigt, dog saaledes, at snart sildlodden, snart fakselodden er den overveiende $\mathrm{i}$ antal. Aabner man bugen paa de i begyndelsen af fisketiden indfangede eksemplarer, vil man hos dem alle uden undtagelse finde generationsorcanerne fuldt udviklede. Hos sildlodden er størsteparten af bughulen fyldt med den temmelig grovkornede, rødgule rogn, der ved nøiere eftersyn viser sig indesluttet i en enkelt tyndhudet sæk, beliggende til venstre side af tarmkanalen. Den høire rognsæk er derimod, imod hvad tilfældet er hos andre fiske, aldrig udviklet. Hos fakselodden er vistnok begge: de baandformige melkesække tilstede; men ogsaa her findes en konstant assymetri; idet den høire melkesæk altid er betydelig mindre (neppe halvt saa stor) end den venstre. Ved et sagte tryk paa bugen lader i almindelighed rogn som melke sig let udpresse og kan da nøiere undersøges. Rognen synker, straks den er gydt, tilbunds og fæster sig ved hjælp af et eiendommeligt, i vand koagulerende slim saa fast til de paa bunden rærende gjenstande, at den kun med vold kan fjernes fra disse. Undertiden lægger den sig sammen i større klumper eller kager, idet det ene lognkorn fæster sig til det andet. Melken synker ogsaa tilbunds $0 \mathrm{~g}$ absorberes af rognen, som herved befrugtes." „Den tid, som medgaar til fosterets fulde udvikling, har jeg endnu ikke havt anledning til at faa konstateret. Dog er det rimeligt, at denne er forskjellig efter vandets temperatur."

SARs observerede nyudklækket loddeyngel af 8-10 mm. længde første gang den 17 de juni $0 g$ senere stadig i Varangerfjorden. Senere ud paa sommeren fandt han, at den udgjorde ,den væsentligste aate for seien $o g$ forefandtes $\mathrm{i}$ enorme masser sammen med kril og andre pelagiske dyr ved seigrundene. De indfangede sei havde saggodtsom alle maven fuldproppet af en geleagtig masse, som ved nærmere eftersyn befandtes. saagodtsom udelukkende at bestaa af loddeyngel. De største ved hjælp af de fine net indfangede eksemplarer havde da naaet en længde af 23 mm., og alle finner var fuldt udviklede, saa de med fuld sikkerhed kunde erkjendes som virkelige loddeunger.

En undersøgelse af mavens og tarmens indhold hos den indfangne roksne lodde gav det resultat, at den udelukkende nærer sig af pelagiske 
dyr (plankton). SARs nævner forskjellige saadanne dyr, hvilke alle "samtidigt var observeret i fjorden“.

Under høisommeren lever lodden $\mathrm{i}$ den rent arktiske del af Østhavet, delvis sammen med torsken, skjønt den vistnok ofte trænger ind i koldere vandlag end denne.

Paa kartet fig. 24 har jeg afsat endel steder, hvor lodden er observeret i Østhavet om sommeren. Selv fandt vi den i mængde i den torsk, vi fiskede i eggen af Bjørnøbanken juli 1901 (paa kartet er stederne merket med kryds). De paa kartet afsatte meddelelser øst om Hopen stammer fra sælfangere. Saaledes meddelte JAsper Aı.exandersen fører af "Avance" af Hammerfest, at han den 12te august 1898 saa lodde, hval og fugl uden is paa $77^{\circ}$ n. $0 g 56^{\circ}$ o. (ca. 15 mil n.o. af Novaja Zemblja). I august 1900 seilede han til 7 mil af Frantz Josefs land, derfra sydover til $77^{0} \mathrm{n} \cdot 0 \mathrm{~g}^{\circ} 45^{\circ} \mathrm{o}$. Her begyndte lodden langs iskanten (se kartet fig. 24) og under den videre seilads vestover lang's denne saa han stadig lodde og hval indtil $76^{\circ} \mathrm{n} .0 \mathrm{~g} 35^{\circ} \mathrm{o}$., hror store masser lodde $0 g^{\circ}$ hval saavel ved iskanten som inde blandt isen. „4 mil syd af Hopen saaes masser af sæl, derfor antagelig lodde." Ligesaa saaes i 1893 masser af lodde ved Hopen og død torsk i mængde.

Johan Altman og Johan Alexandersen, som tidiggere var ishavsskippere, nu fløtmænd i Hammerfest, har seet disse ting aarevis tidligere, især masser af lodde mellem "Kalkof" (Kolgujew) og Novaja Zemblja.

Hvalfanger Ingebrigtsen har midt paa sommeren hvert aar fra 10-12 mil vest af Bjørnøen og derfra østover seet lodde. I september 1899 observeredes masser af lodde og torsk 10 mil n.o. af Bjørnøen paa grundt vand.

Saadanne meddelelser har jeg erholdt i mængde ved samtaler med ishavsfarere, deraf fremgaar, at lodden holder sig paa grænselagene mod isen om sommeren. Dens geografiske udbredelse vil da veksle med isgrænserne, $o g$ naar isbæltet om vinteren trækker sig sammen mod Finmarken, vil ogsaa lodden nærme sig dennes kyster. I aarets første maaneder finder man den $\mathrm{i}$ havet mellem isen og land, de samler sig da til vældige stimer, som, idet de passerer havet, ligesom samler op alt, hvad der findes af større bevægelige dyr og fører dem alle mod kysten. Fra isgrænserne tager de med sig det rige fugleliv, spidsnebbede alker, krykjer, maager og havhest, Spitsbergærfugl $0 g$ alle de andre arktiske fugle, fra Østhavets banker tager de med sig loddetorsken, hysen og haakjærringen, $o g$ de stimer, som ikke følger bunden, men af og til nærmer sig overfladen, tager helt fra isgrænsen $o g$ til land de store finhval og springerne med sig, saaledes at man kan møde et helt tog af dyr alt styrende paa land mod de flade sandige kyster, hvor lodden skal gyde. 
I det følgende kapitel, i hvilket fiskerierne skildres, er ogsaa beskrevet nogle saadanne loddeindsig, som i 1901 fandt sted i martsapril maaned. Man vil der se, at vi først fandt lodden i fisken paa bankerne langt fra land, før fisket under land begyndte, og at vi senere saa det store "brug“" med fugl og hval nærme sig kysten. I begyndelsen af mai fiskedes nær land paa forskjellige steder torsk og hyse med maverne fuldproppede af fin skjælsand $0 \mathrm{~g}$ lodderogn. Mange havde $0 \mathrm{~g}$ saa lodde $\mathrm{i}$ maven, $\mathrm{og}$ vi havde mange anledninger til at se lodden blive fisket paa de sandige flak nær land (f. eks. ved Honningsvaag). Senere udover sommeren fandt vi som Sars loddeyngel i planktonhove $\mathrm{i}$ havet helt fra Murmankysten til vestover i Finmarken.

Desuden havde vi leilighedsvis anledning til at bekræfte CoLLetws beskrivelse af loddens rekst. Han fandt i juli 1878 ved Tamsøen i Porsangerfjorden sei $0 \mathrm{~g}$ torsk fuld af loddeyngel fra $3.8-6 \mathrm{~cm}$. lange. Desuden fandt han yngel af $10 \mathrm{~cm}$. længde, som han antager er loddens I-gruppe, altsaa de 1-aar gamle dyr, hvilke jeg ogsaa leilighedsvis fandt. Disse, antager Colletr, om høsten søger ud til de store dyb i ishavet, $\mathrm{og}$ at de det folgende aar som forplantningsdygtige 2-aarige individer vender mod land for at gyde.

Naar lodden har gydt, render den tilbage mod Ishavet, igjen.

Under denne randring, der i regelen finder sted i mai, ledsages den af de samme masser af alker og maager, som nogle maaneder fulgte den mod Norge. Denne randring observeres hyppig af hvalfangerne, som pløier haret mellem Norge og Bjørnøen. Hr. Ingebrigtsen har saaledes meddelt ofte at have seet den og iagttaget, hvorledes i begyndelsen af mai sværmer af alker $0 \mathrm{~g}$ havhest kommer til Bjørnøen for i sommerens lob at hække deroppe.

\section{Haakjærringen.}

Ogsaa om denne de arktiske haves store haitisk foreligger der endel oplysninger, som giver os bidrag til forestillingen om de store vandringer, det arktiske dyreliv foretager, og som vi derfor skal nævne uden at gjore fordring paa at give en skildring af haakjærringens naturhistorie i det hele. Denne er ogsaa særdeles ufuldkomment kjendt.

Haakjærringen forekommer i de arktiske have i enorme masser. Ted den norske kyst aftager den sydover, men fanges om vinteren fra isen enkeltris helt ind i Bundefjorden ved Kristiania. Paa Nordlands kystbanker findes den i masser om vaaren samtidig med skreiens opsig, 
og man har den bestemte erfaring, at en saadan banke først kan drives, naar haakjærringen er skræmt bort af linebruget. Det tar derfor en vis tid at oparbeide en. slig banke, mener man. I dybet har jeg fundet haakjærring ud for eggen paa liner sat i ca. 550 favnes dyb, og den hører utvivlsomt til de fisk, som kan forekomme fra grundt vand til særdeles store dybder.

Der drives en ganske betydelig fangst efter haakjærringen af dækkede fartøier, som fortrinsvis udrustes fra Hammerfest og Vardø. Ifølge den officielle statistik for 1900 var der da fra Finmarkens amt 6 baade og 21 fartøier, som drev haakjærringfangst, de havde en besætning af henholdsvis $24 \mathrm{og} 96$ mand tilsammen. Udbyttet var ea. 4000 hl. lever til en værdi ea. kr. 40000. I 1898 var udbyttet ca. kr. 72000. Fartøiet ligger under fangsten for varp (400 favne 5-toms kabel og dræg). Der fiskes med en stor kraftig jernkrog med en smekker jernkjætting som fortom og et stort jernlod som søkke. Som agn bruges kobbespæk, og fisken hives op med et lidet spil. Saaledes kan der fiskes op til 60 haakjærring paa en dag.

For os har det her kun betydning at gjøre opmerksom paa, at man af de erfaringer, som disse fangstmænd har, tydelig kan slutte, at haakjærringen foretager store vandringer.

Paa kartet (se fig. 24) er der med runde merker afsat de steder, hvor der til forskjellige maaneder af aaret af Hammerfestfangerne drives haakjærringfiske. Man ser da, at ifølge disse fangstmænds journaler drives fangsten i april paakystbankerne og landbakken, $\mathrm{i}$ mai allerede langt fra land, og fra nu af trækker fangsten sig efterhaanden længer og længer fra land. Hvert fangstfartøi gjør i regelen 2 ture, en i april-juni til kystbankerne og Østhavets store flak, og en i juli, august ja tildels i september til flaket mellem Bjørnøen og Spitsbergen. Lignende ture gjøres af Vardøfiskere i nordøstlig retning fra Vardø.

Som man af kartet ser, flytter de saaledes gradvis fra april til august fra kystbankerne helt henimod Spitsbergen, og det er fordi haakjærringen i denne tid efterhaanden vandrer denne strækning. Som bevis herpaa meddelte flere fangstmænd, at de under Spitsbergen og Bjørnøen stadig fandt støre eller mindre dele af liner og garn i maverne paa haakjærringen. Da der heroppe aldrig sættes liner og garn, maa haakjærringen selv have været under Norges kyst og hentet disse.

Desuden fortæller de, at der i haakjærringens maver findes alslags fisk, saaledes stor og aldeles fersk laks taget i den s.v. om Bjørnøen paa 100-150 favne vand. Mest var der torsk i maverne. Saaledes 
maa man antage, at haakjærringen følger torskemasserne paa deres vandring til og fra Norges kyst.

Dette haakjærringfiske er et overordentlig slidsomt liv. I disse nordlige farvand er der jo mest storm hele aaret rundt, og da at ligge forankret „paa svai" med de smaa skuder i kulde og svær rulling og hive paa de tunge haakjærringer er selvfølgelig meget surt. Desuden er lotten liden, i regelen for hver mand for hele tiden (april-september) $250-300$ kroner.

En ishavsfarer, som i 30 aar havde faret paa haakjærringfangst om sommeren, fortalte mig, at han i disse aar antagelig havde fisket op 7000 hl. haakjærringlever.

Leveren er som bekjendt det eneste af dyret, som bruges, resten kastes ud igjen.

\section{Kobben.}

(Grønlandssælen, Phoca groenlandica).

Ostharets sæler kan deles i kystsæler og vandresæler.

Kystsælerne er væsentlig repræsenterede ved stenkobben (Phoca ritulina), den almindelige kystsæl eller spættede sæl. Denne er ovenpaa graahrid eller gulgraa med mere eller mindre tæot siddende graasorte flekker, som hos yngre kan smelte sammen.

Den er udbredt fra Ostersøen langs kysten til Finmarken, hvor den ofte forfolger laksen langt op i elvene. Kaster sine unger i mai-juni.

Ringsælen (Phoca foetida) er graasort eller mørkebrun „med storre eller mindre ofte sammenflydende hvidagtige eller gulhvidagtige ringer".

LilljeborG ${ }^{1}$ ) siger om denne sæl, at den fortrinsvis tilhører den ostlige del af den skandinaviske halvø. Forekommer fra Botniske bugt mod Oresund, dog talrigst længst inde. Sparsom i Bohuslæn. Forekommer i Hridehavet og derfra undertiden maaske mod Østfinmarken. Findes af og til i Østisen (Røuer og Schaudinn).

Vandresælerne. Grønlandssælen, „kobben" (Phoca groenlandica). „Den nyfødte unge er beklædt med myg, gulhvid uld, og denne dragt aflægges, inden 3 uger eller høist en maaned er omme." Fældningen varer 7-10 dage; efter denne er sælen overalt graa paa rygsiden, paa undersiden

1) W. Lilljeborg, Sveriges och Norges Ryg radsdjur I, fra hvilken endel af beskrivelserne er hentede. 
hvidagtig, og over hele kroppen er der strøet sorte flekker. Mellem denne og den voksne sæls dragt er der forskjellige overgange; under disse forsvinder den graa farve, de sorte flekker blir sparsommere, og nu indtræder forskjel paa kjønnene. Den voksne hun er oventil straagul med gulbrun skygge paa ryggen, paa undersiden lys. Den gamle han er i følge Quennerstedt: „Hvid, næsen, panden $0 \mathrm{~g}$ hovedets sider sorte; paa hver side af kroppen en sort, halvmaaneformig og uregelmassig begrænset flek, som bagom strækker sig helt til haleroden og fortil løber sammen over ryggen. Halen med en aflang sort flek." Derfor kaldes den ofte „svartsiden“. Lever fornemmelig paa drivis, i Vestisen, Østisen og Hvidehavet. Kaster i marts.

Er i Hvidehavet og Østisen gjenstand for fangst. I Hvidehavet udgjør den saagodtsom den udelukkende gjenstand for fangsten, i Ostisen fanges den sammen med storkobben. Om dens vandringer se nedenfor. Storkobben (Phoca barlata) veksler ogsaa meget farve med

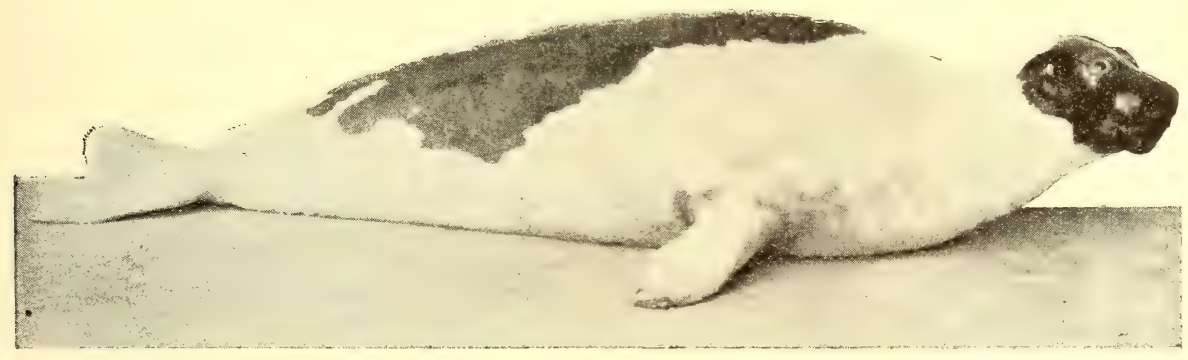

Fig. 25. Kobben, Gronlandssælen efter fotografi af eksemplar i Bergens Museum.

alderen, idet de blir mere $0 g^{\circ}$ mere blaa. De allerældste mister haarbedækningen, og den sorte hud er da nøgen. Er den største af farvandets sæler, op til 10 fod. Holder sig mest ved iskanten og sees sjelden udenfor. Meget almindelig overalt i Østisen fra Spitsbergen mod NovajaZemblja og udgjør en væsentlig del af sælfangernes fangst. Hvalper i slutningen af mai.

Klappmytsen (Cystophora cristata) forekommer i Østisen kun vekselvis $0 \mathrm{~g}$ sjelden $\mathrm{og}$ spiller derfor ikke den rolle som i Vestisen.

Af disse sæler er det de to „kobben" $o g$ "storkobben", som i aldeles overveiende grad er gjenstand for de norske ishavsfareres fangst, som seiler i Østhavet, og af disse to igjen er det „kobben" (grønlandssælen), som af $\mathrm{g}$ til optræder i slige masser under den norske kyst, at 
den antages at spille den største rolle for de store Finmarksfiskeriers gang; af denne grund skal vi her nærmere søge at skildre, hvad der er bekjendt om dens vandringer.

Kobben søger ifølge den russiske forfatter Alexander Schultz ${ }^{1}$ ) i oktober ind i Østhavets østligste bugter og altsaa ogsaa ind i Det hvide hav. „I Dwinabugten viser de sig i begyndelsen af februar. Kystens beboere gjør straks jagt paa dem, skyder dem i vandet eller isflakene.

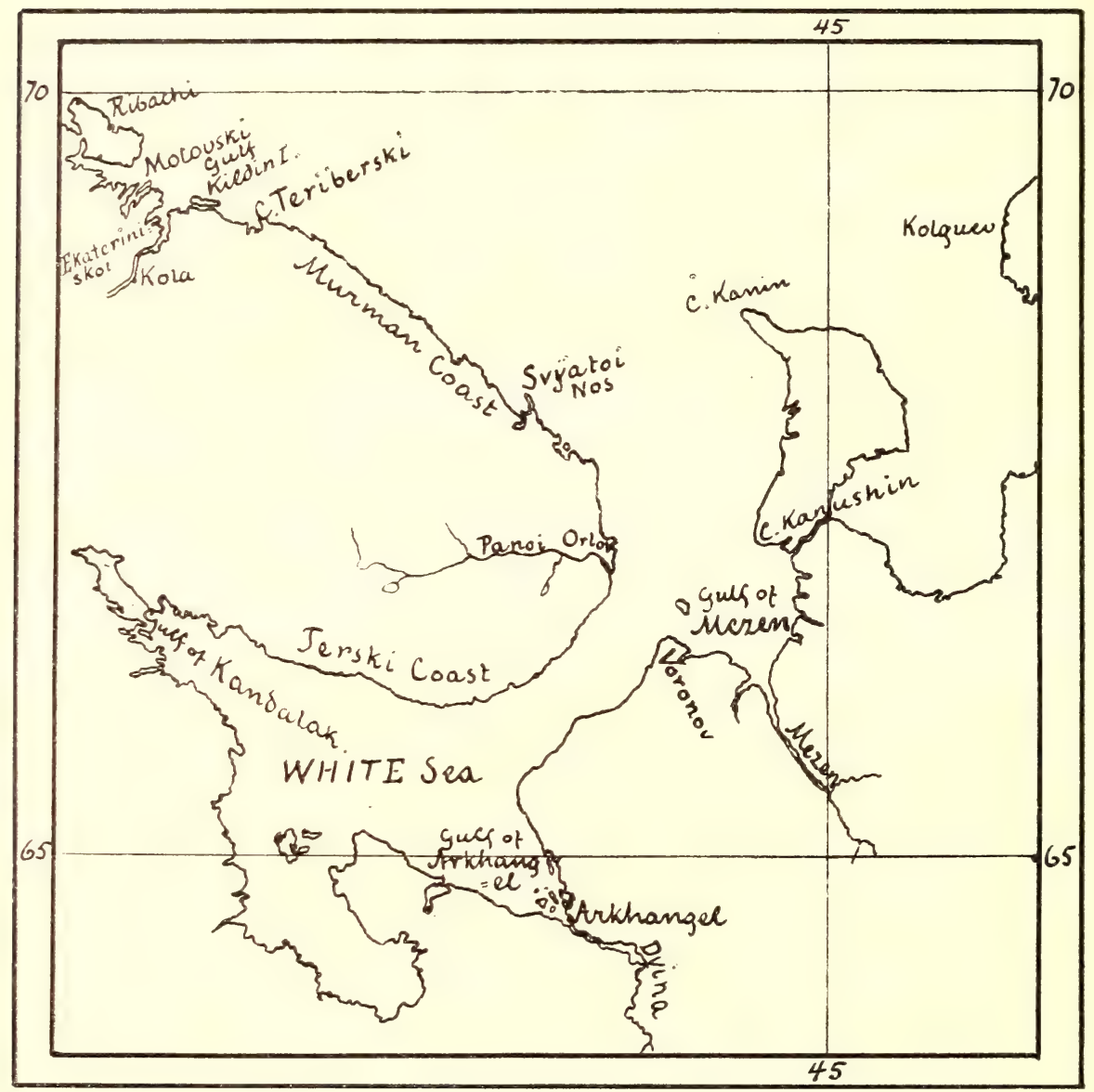

Fig. 26. Kart over Hvidehavet og Murmankysten.

Straks efter (antagelig i marts) begynder den anden jagt, som fortrinsvis rettes mod de unge kobber. Disse dræbes først for sit vakre, hvide skinds skyld, men senere for det tykke spæk; thi en 5 uger gammel kob gir allerede $1-1^{1 / 2}$ pud $(16-25$ kilo) spæk." Til denne jagt samles

1) Alexander Schultz: Fischerei u. Robbenjagd im weissen Meere u. nördlichen ocean. Dresden 1872. 
kystboerne i kredsene Archangel, Mesen og Pinega. Jagten angives at vare til 23de marts og drives af ca. 3000 jægere. I nærheden af Kap Woronoff er der opført 19 hytter, af hvilke nogle rummer 5, andre 1020 mand; og disse hytter beboes kun i jagttiden.

I april trækker kobben ud fra hele det store Hvidehav, og da begynder en ny jagt (den 3die) i Mesenbugten (red indløbet til Hvidehavet, se kartet). Kobben samler sig da skarevis, og ca. 800 mand driver da jagten.

Den 4de jagt finder sted ved Kap Kanuschin, den begynder midt i marts og varer til 9de mai. Ungerne er da saa store, at de klarer sig alene. Der fanges i denne tid mest unger, dog ogsaa endel voksne.

Jægerne bor i hytter, de iagttager kobben fra kysten og gaar i smaa partier paa jagt paa isen. Herunder slæber de en baad paa meier. 7 mand i hvert parti; de er i regelen forklædt i skind.

Paa vestkysten af Hvidehavet, Terskykysten varer jagten fra 1ste til 25de marts og drives af ca. 500 jægere.

Ifølge dr. O. Grimm blev der i 1882 drevet fangst af 4164 folk med et udbytte af 70-80000 pud (12-1300 tons) spæk.

Af den foregaaende fremstilling ser man, at ungerne allerede $\mathrm{i}$ begyndelsen af april er noksaa store, og at de da nærmer sig' den ydre del af Hvidehavet (Mesenbugten). I slutten af april $0 g$ i løbet af mai, alt efter de forskjellige aar, blir da isen mere $0 \mathrm{~g}$ mere løs i Hvidehavet, $0 g^{\circ}$ kobben begynder at trække tilhavs. Isen ligger da, som man vil se af iskarterne, $\mathrm{i}$ en stor bue, og i regelen trækker de da langs denne bue vestover mod Bjørnøen. Paa kartet (fig. 24) er med runde ringe angivet, hvor kutteren „Susan“, fører Jasper Alexandensen af Hammerfest, i aaret 1901 drev sælfangst til forskjellige maaneder, $\mathrm{og}^{*}$ heraf vil man formentlig nogenlunde se sælens opholdssteder. Dog maa man erindre, at sælfangerne ogsaa jager storkobben. „Susan“ seilede fra Hammerfest først mod Bjørnøen, hvor den indtraf 14de april. Man fik her en større isbugt, antagelig 8-10 mil dyb, seilede tvers over bugten og traf isodde igjen 21 de april (se kartet). Seilede herfra direkte østover mod Østisen, der naaedes 27 de april. Herfra gik isen i sydvestlig retning mod Kaninnose. (Se kartet fig. 26.) Straks derefter fik man storm af no., der drev ismasserne vestover, og 14de mai laa isen vest af Svyatoinos. Den 15de mai toges 288 kob 20 kvartmil vest af Kaninnose. De fleste norske sælfangere var da her i nærheden, hvor der gjordes fangst til slutningen_af mai maaned, da man seilede nordover uden at følge iskanten, der bøiede ind mellem Kolguew (norsk Kalkof) og Novaja Zemblja. Isen traf man igjen 30te mai (se kartet fig. 24), og herfra gik den i nordvestlig og vestlig retning. 4de juni var man længer nordvest. Her fangedes_endel sæl, ligesom der var masser af aate. Hval saaes derimod ikke. Isen 
gik videre i nordvestlig retning. Man fandt der 6te juni en bugt, som gik op mod Hopen indtil 40 kvadratmil af denne, derfra bøiede isen igjen mod Bjørnøen, hvorfra den igjen stod nordover mod Spitsbergen. Paa denne isodde ned mod Bjørnøen fangedes i juni flere hundrede sæl, ligesom en flerhed af norske sælfangere holdt sig der. Den 24de juni var man igjen under iskant, ligesaa 30te juni (se kartet fig. 24). Herfra seilede man mod østsiden af Novaja Zemblja, hvor man kom 3die juli ca. 20-30 kvartmil af $\mathrm{og}$ senere fulgtes igjen iskanten nordover til 22de juli. Herfra var der en stor bugt med enkelte strimler helt til Frantz Josefs land. Man seilede over denne bugt $\mathrm{og}$ traf isodden 26de juli, hvor isen gik nv. til Kong Karls land, men syd for Hopen og Spits-

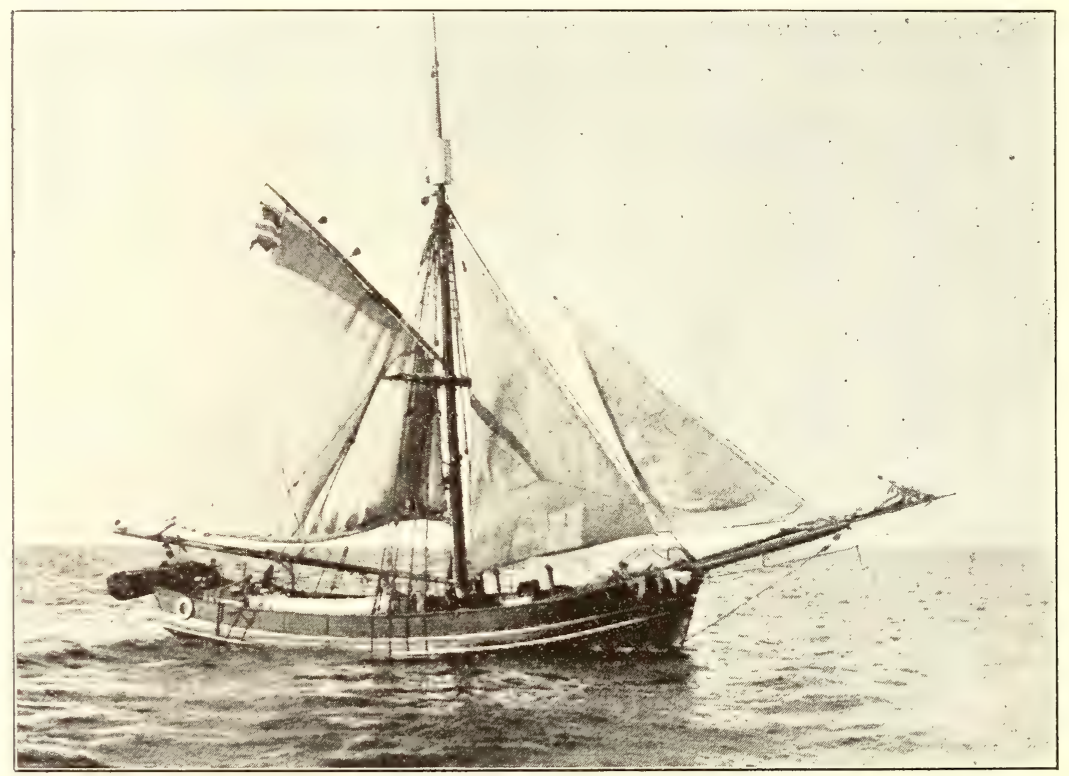

Fig. 27. Norsk sælfanger i Østhavet. Efter fotografi under „Heimdal"s togt af hr. WOLLEBæK.

bergen var der ikke mere is. I begyndelsen af august færdedes man da langt nord $77^{0} .37^{\prime}$ og $32^{0} .59^{\prime}$ til $35^{0} .13^{\prime}$ Ost. Her saaes masser af hval og fugl, der saaes at tage lodde. Hvor kartet viser 8de august, fandt man isen, som gik i sydvestlig retning og senere sydostlig. Her 29de august omkring blev man i hele august og fangede nogle hundrede sæl. Den forlod man isen $0 \mathrm{~g}$ seilede hjem med en fangst af $1900 \mathrm{sæl}$, 1 hvalros og 1 bjørn. 
Denne fremstilling af en ishavsfarers togter i Østisen under sælfangst om sommeren synes mig at give et indblik i, hvorledes isforholdene efterhaanden forandrer sig i Østhavet, og hvorledes dermed kobbens opholdssteder skifter. Man ser, at fangsten begynder udenfor mundingen af Hvidehavet, efterhaanden trækker nordover parallelt med Novaja Zembljas kyst, derfra $\mathrm{i}$ en bue mod Bjørnøen. Senere seiler da fangstfartøierne paa kryds og tvers i Østhavet og nærmer sig herunder, alt eftersom isen

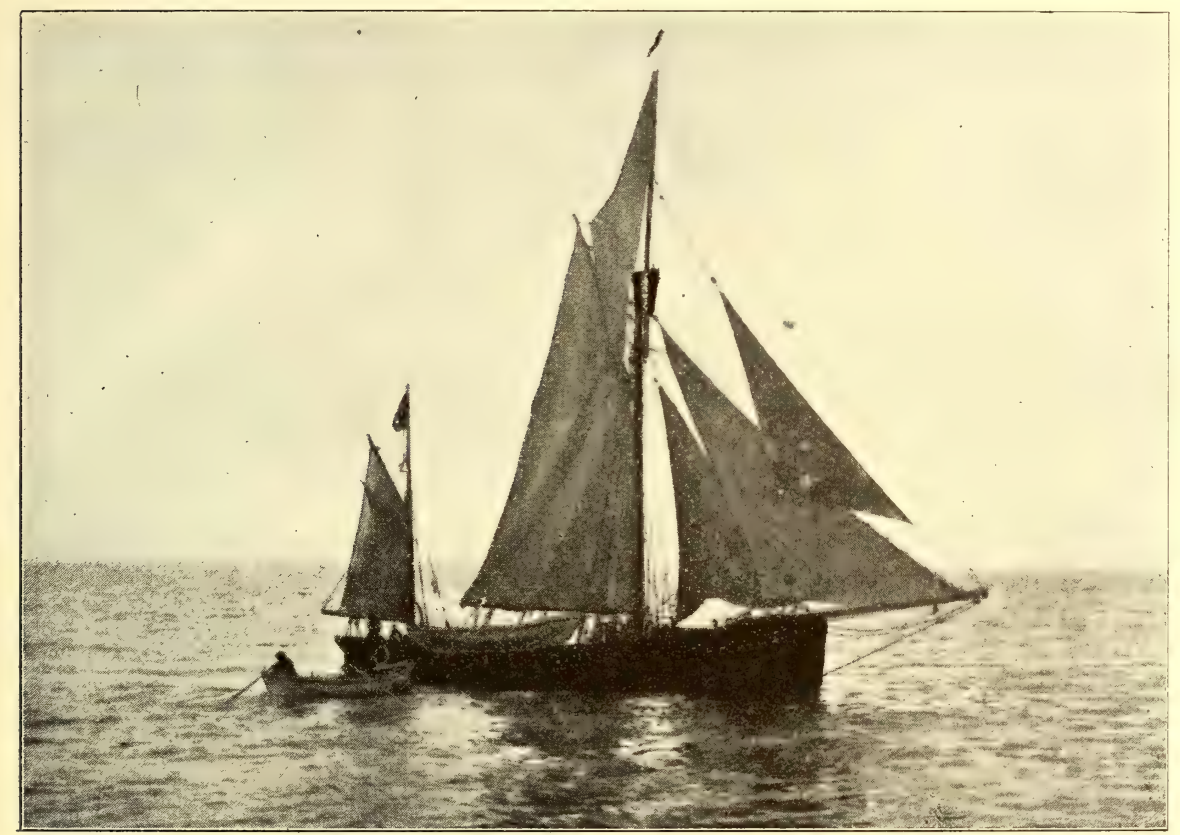

Fig. 28. Norsk sælfanger i Østhavet. Efter fotografi under "Heimdal"s togt af hr. WOLLEBæk.

løsner, mere og mere op mod Franz Josefs land. Mod slutten af august indtræder da høststormene, og fangsten afsluttes.

Under kobbens vandring fra Hvidehavets munding mod isen hænder det ofte, og efter hvad der paastaaes særlig i de senere aar, at den tager veien om Østfinmarken og herunder optræder i enorme masser i Norges østligste fjorde særlig Varangerfjorden.

I aaret 1901 indfandt kobben sig over hele Østfinmarken i den sidste uge af mai. Der var gjort udmerkede fangster af torsk rundt Vardø, og der stod i den tid en stor fisketyngde under land. Den 18de 
mai gjordes saaledes et trawltræk i Varangerfjorden, som i ca. 1 times. tid gav 337 torsk, 162 hyse, 12 uer og endel andre fisk (en liden 60 fods trawl). Fiskerne havde ogsaa usedvanlig rige fangster i disse dage.

Den 19de og 20de var der saa storm af ost, som gik over til nord og senere helt over til vest.

Den 21de gik „Michael Sars“ ud fra Vardø havn. Kob observere* des da allerede udenfor havnemoloen, i Bussesundet mod Kibergnesset.

Den 22de saaes loddeknuder med hval og kob hele dagen paa sundet. Om aftenen var der et umaadeligt brug over hele den strækning af havet mellem Kibergodden og Vardøen, der kunde overskues fra ankerpladsen under den gamle hvalfangerstation. „Et solstreif,“ skriver hr. Kxut Dahl i journalen, „der en stund faldt over landskabet, bragte fugleskarerne, der svævede over havet, til at se ud som en lysende taage. Saalangt oiet kunde naa, $0 \mathrm{~g}$ saalangt vi kunde se i kikkerten, stod fuglestærmerne tætte, og kobbestimerne jagede mellem mængder af hval. Disse rar raagehral og en enkelt spækhugger. Langs landet paa det grunde rand saaes ikke en eneste fiskerbaad, og vore forsøg paa med juks i lobet af dagen at konstatere fisk gav alle negativt resultat. Alle fiskerne havde sat sine liner en $3 / 4$ mil af land paa $70-100$ favne vand, og efterhaanden som de fik bruget igjen, krydsede de sig under land i vestenstormen, som varede hele natten."

Den 23de undersøgtes en del kob. Maverne indeholdt baade torsk og lodde. Hos en var maven fuld udelukkende af torskeknogler i saadan mængde, at der mindst maatte ha været et snes torsk i dens mave. Hos en anden var maven fuldpakket med lodde.

Disse store stimer af vandrende kobber staar dog sjelden længe under land, efter kortere eller længere tid forsvinder de og trækker sig oporer mod isen. Orenfor har vi omtalt deres vandringer langs iskanten og de togter, som de fangstmænd maa gjøre, som forfølger dem. Senere skal vi nærmere omtale, hvilken indflydelse disse kobbestimer har for fiskerierne, og drøfte spørgsmaalet, om der kan tænkes midler til at øve indflydelse paa stimernes vandringer. 


\section{Treciie kapitel.}

\section{Fískerierne.}

Finmarkens befolkning har kun en eneste leverei: fiskerierne. Af disse afhænger de gode $o g$ de daarlige tider, som andre steder i verden er resultatet af saa mangeartede og komplicerede forhold. Der fiskes i Finmarken det hele aar, $0 \mathrm{~g}$ desuden drives der fangst i Østhavet; men fiskeriet er høist forskjelligt til forskjellige tider af aaret saaledes, at de forskjellige aarstiders bedrift adskilles som vidt forskjellige fiskerier med forskjellige navne og med meget forskjellig driftsmaade. Disse fiskerier er:

1. Vinter- og vaarfisket eller som det i Finmarken kaldes „loddefisket" og i det øvrige land „Finmarksfisket". Som dette sidste navn antyder, spiller det den langt overveiende rolle. Det foregaar i regelen i maanederne marts, april og mai $0 \mathrm{~g}$ har fangst af loddetorsken til maal.

2. Sommer- $0 \mathrm{~g}$ høstfisket svarer mere til bankfisket længer syd og har ligesom dette ikke alene en eneste fiskeart som gjenstand for fiskeriet. Der fanges baade torsk, hyse, kveite, flyndre, uer, sei etc. sildfiske.

3. Sildefisket, dels omfattende fedsild, dels vaarsild, dels smaa-

4. Haakjærringfisket, der. som man vil have seet af foregaaende kapitel, foregaar over hele Østhavet.

5. Ishavsfangsten efter hvalros, kobbe ete.

6. Hralfangsten er den i femte kapitel skildrede „finhvalfangst".

Af disse fiskerier skal vi her begrænse os til de to første, som er de egentlige fiskerier, af de øvrige er haakjærringfisket og ishavsfangsten omtalt i forrige kapitel og skal desuden leilighedsvis omtales i det følgende. Hvalfangsten omtales i sit eget kapitel. Før vi gaar over til skildringen af de store fiskerier, skal vi med nogle ord omtale de forskjellige fiskeriers indbyrdes værdi og betydning, og da indskrænke os 
til at anføre, hvad statistiken meddeler for et vilkaarligt valgt aar, der kan tjene som eksempel, nemlig aaret 1899 . Ifølge amtmandens beretning for dette aar gav:

Loddefisket

Sommer-og hostfisket

Sild e fisket

Haakjæringfisket

Ishavsfangsten

Hvalfangsten et udbytte af .................. 2700000

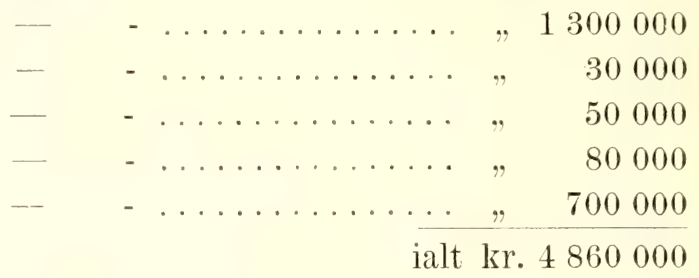

Som vi senere skal se, veksler disse beløb meget fra aar til aar, men vil man dog af det nævnte eksempel faa et indtryk af, hvorledes forholdet mellem de forskjellige bedrifter i store træk stiller sig, og vi skal derefter mere indgaaende betragte enkelte af dem.

\section{Loddefisket.}

Af den fremstilling, som vi i det foregaaende kapitel har givet af fiskenes liv og vandringer, vil man have seet, at lodden under sin vandring mod den norske kyst i maanederne marts-april samler op en stor mængde af alle de større dyr, som findes mellem isgrænsen og kysten og fører dem alle mod land. De mængder af hval og fugl, som saaledes sees, kaldes ofte „loddebrug“. Da de ældste aarsklasser af torsken skreien - paa den tid for største delen er vestpaa for at gyde, er det væsentlig de yngre aarsklassers (de to aar gamle og ca. $50 \mathrm{~cm}$. lange) dyr, som saaledes i enorme masser samles til fiskebjerge, der følger efter de forudilende loddemasser og stuves mere eller mindre ind mod kysten. Det saakaldte loddefiske bestaar da deri, at lodden fiskes til agn for fiskernes kroge og derigjennem loddetorsken, som ved siden af en mindre del hyse, kveite etc. udgjør det overveiende udbytte af fisket.

Som ved alle de fiskerier, der er af hængige af vandrefiskenes indsig til kysterne, bestaar fiskernes liv under et saadant loddefiskeri i en ventetid, før indsiget kommer, en tid, i hvilken han lidet andet kan gjøre end at afvente fiskemassernes komme og red første budskab søge at komme paa pladsen, i en strærsom fisketid, med al den afveksling som fiskestimernes lunefuldhed, veirets store omvekslinger etc. medfører, og da tilslut i en lang seilads til sit hjemsted. Først skal vi i al korthed skildre det loddefiske, som "Michael Sars" havde anledning til at overvære, og senere 
skal vi da nærmere betragte, hvad statistiken og litteraturen meddeler om andre aars fiskerier.

„Michael Sars" ankom til Finmarken i de sidste dage af februar 1901, og første del af marts anvendtes da til at undersøge havet udenfor kysten for at se efter de loddebrug, som ventedes. Under land var nemlig intet iagttaget endnu. I tiden 3die til 6te marts gjordes et togt op til drivisen nogle mil af Bjørnøen og tilbage med undersøgelser af havstrømme $0 \mathrm{~g}$ drivende organismer. Paa denne tur saaes ikke en eneste hval. En enkelt ensom havhest var det eneste tegn til liv over havfladen. Langs kysten var alt ligesaa dødt. Ikke en fiskerbaad var at se langs kysten

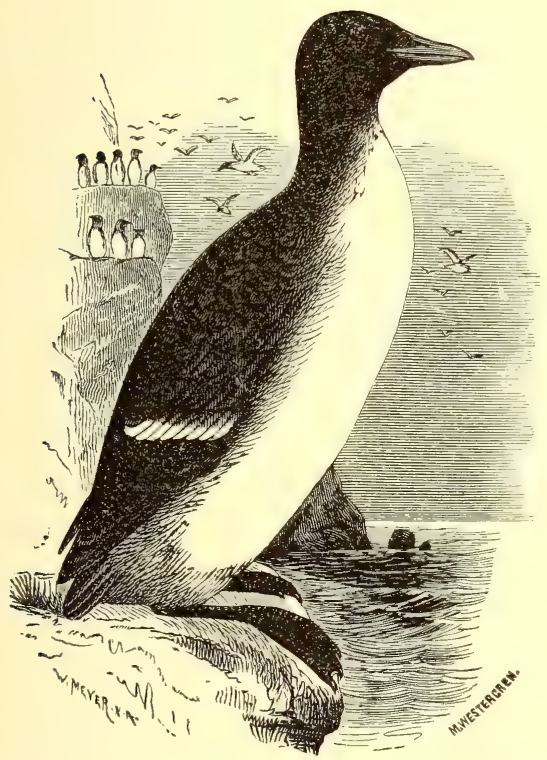

Fig. 29. Spidsnæbbet alke (Spitsbergalke Uria brïnniehii). Fra NATHORst efter NordensKJöLd.

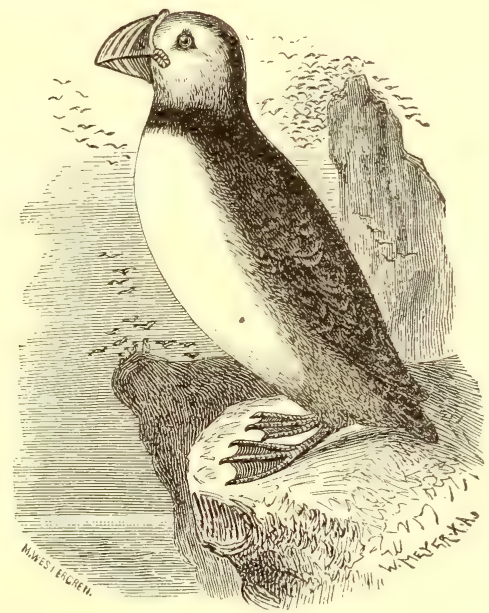

Fig. 30. Lundefugl (Mormon arcticus). Fra Nathorst efter NoRdenskJöLd.

udenfor fjordene. Indi disse som f. eks. Kjøllefjord foregik der lidt fiske, og hvalfangerne skjød knølhval med tomme maver paa vandring vestover. Først mellem Nordkap og Vardø begyndte der at vise sig endel alker, ærfugl, endel maager, havhest $0 \mathrm{~g}$ springere, og ved ankomsten til Vardø erfor vi, at der havde vist sig brug under Murmankysten. Vi fulgte derfor vore russiske kollegers venlige indbydelse til Alexandrowsk og dampede østover. Udenfor Fiskerhalvøen saaes adskillig fugl især ved dennes østlige pynt og paa tilbageturen adskillige springere (Delphinus acutus). Paa Østbanken, 7-8 mil øst af Vardø, fik vi 15de marts paa liner adskillig hyse $o g$ lidt torsk, i disse var der af og til lodde baade hunlodde og fakselodde. Ligesaa den 16de paa 100 favnes dyb 
1 mil af Vardø. Her var hysen ganske fuldproppet af lodde, og her saa vi ogsaa adskillig fugl $o g$ endel finhval. Den $17 \mathrm{de}$ og 18 de var der storm af nordost med snebyger, og da vi den 19de igjen stak tilhavs for at se efter brug, mødte vi dette i ca. 3 mils afstand fra land.

I dagene til og med 21de marts observeredes her ude millioner af alker, havhest, krykjer og den store, spidsvingede borgmestermaage. Alkerne laa saa tæt paa vandet, at der mindst maa have været flere paa hver kvadratmeter, saa langt man kunde se, og naar dampbaaden gik frem gjennem disse masser, hørtes der en hel støi af alkerne, som slog vandet med vingerne, idet de dukkede, saasnart skibssiden kom nær dem. Vi skjød en hel del alker, som alle var ganske fulde af lodde, og ved at trække en stor hov af 21 fods diameter i 20 favnes dyb fik vi endel lodde i hoven. Men stormen afbrød igjen vore undersøgelser, fra 22 de til 27 de marts maatte vi ligge i Baadsfjord i storm og snebyger. Her traf vi hralfangerne, som fortalte, at nu havde ogsaa knølhvalen lodde i maven.

Den 27 de marts saa vi, hvorledes det store brug strak sig helt til Tanafjordens østside, mens vi vestenfor ikke saa noget. Her saa vi først bruget den 29de, da der blev fisket lodde udenfor nordre Honningsvaag (nær Nordkap). Med undtagelse af et stæng ved Vadsø var dette det første fiske. Her saa vi talrige baade fiske lodde med smaa finmaskede synkenøter ude paa det grunde sandflak nær land, og en agndamper laa parat til at ile med lasten til Lofotfisket, da der endnu ingen fisk var formerket under land.

Skjønt der saaledes var masser af lodde udenfor kysten og enkelte „straaler" af $0 \mathrm{~g}$ til stak under land, begyndte dog torskefisket først i begyndelsen af april. Først ved midten af maaneden kom der fart i fisket, der fiskedes da i Vestfinmarken til Tanafjorden, $0 \mathrm{~g}$ i slutten af maaneden trak det østover til Syltefjord og Havningberg.

Den 27 de april var der 1623 baade i arbeide, hvoraf 30 i Kjøllefjord, 576 østenfor og 1017 vestenfor denne fjord, der var da opfisket 1806000 kilogram torsk. Nu kunde man se de smaa otringer ligge udenfor kysten og drive juksefiske, og der viste sig desuden flere brug udenfor kysten. Hvalfangerne kom ind med finhval, som der randt lodde ud af. Hr. Ingebrigtsen skjød saaledes 4-5 paa en uge. Desuden var der masser af fugl, alker, (Uria Brünnichii), krykjer, ærfugl og masser af Spitsbergærfuglen (pragtærfuglen), (Somateria spectabilis). Store stim af springere saaes i overfladen, og fuglen drog lodde af sjøen.

Den første mai saaes saaledes 3 à 4 kvartmil af Hjelmsø 100 baade, som drev med juks, og fra „Michael Sars“ juksedes paa 30-70 favne vand i kort tid 100 torsk, endel brosme og stenbit. Den 2den mai fik man ved Nordkap paa juks torsk med maverne fulde af lodderogn og fin 
skjælsand, andre torsk havde lodde i maren. I mai maaned foregik nu den hovedsagelige del af fisket, allerede fra de første dage af fiskedes over hele Finmarken fra vest til og med Varangerfjorden (hvor ogsaa flere loddestæng, som ved Vardø og grænse - Jakobselv).

I de to uger 27 de april til 12te mai fiskedes 2.6 millioner kg. torsk, i tiden 12te mai til 26de mai fiskedes 7.5 millioner kg. torsk. I det sidste tidsrum fiskedes godt baade øst og vest. Særlig ved Vardø gjordes adskillige gode fangster, skjønt man ofte var hindret af storm og agnmangel.

Den 26de mai var der saaledes i det hele opfisket noget over 11740000 kilogram. Der fandtes da 3410 baade, 20 i Kjøllefjord, 1823 østenfor, 1567 vestenfor.

I mai maaned kunde man udenfor kysten baade iagttage fiskerne $0 \mathrm{~g}$ selv konstatere mængder af fisk.

Den 10de mai juksedes om natten vestenfor Omgangsklubben i 20-40 favnes dyb 247 torsk fulde af lodderogn, sand og lodde.
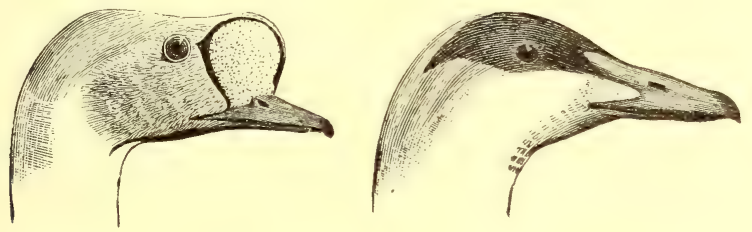

Fig. 31. Hoved af almindelig ærfugl (Somateria mollissima) tillhøire og af Spitsbergærfugl, praktærfugl (Somateria spectabilis) tilvenstre. Fra Nathonst efter NoRdenskJöLd.

Den 13de mai juksedes inde i Porsangerfjorden nær Langøen torsk i $20-60$ favne.

Den 14de mai toges i et kort træk i en liden engelsk trawl ca. 200 torsk nord af Nordkyn i 180 favnes dyb. Den 18de mai 85 torsk, 4 hyser, 8 stenbit paa 50 favne i et kort træk engelsk trawl udenfor Kiberg ved Vardø. Samme dag i 100 favnes dyb lidt længer ud i Varangerfjorden i $1^{1 / 2}$ times træk 337 torsk, 162 hyser og 12 uer 0 . s. v.

Af disse eksempler vil man se, at torsken i dette tidsrum stod næsten i alle dyb fra henimod 200 favne op til 20 favne.

Som vi af foregaaende kapitel har seet indtraadte der den 19de20de mai en sterk ostlig og nordostlig storm, og fra den 21de af antager fisket en anden karakter.

Et vældigt brug af alker, Spitsbergærfugl, lodde, hval (vaagehval, spækhugger) og kob havde nærmet sig land og fandtes over hele farvandet rundt Vardø, særlig Bussesund. I slutten af mai merkedes kobben over hele Østfinmarken $0 \mathrm{~g}$ i begyndelsen af juni helt til Hjelmesø. Allerede den 21 de mai mislykkedes alle forsøg paa med pilk at 
faa fisk nær land, $o g$ i slutten af mai $o g$ begyndelsen af juni var fisken som strøgen bort fra Tarangerfjorden $0 g$ farvandet rundt denne. Fiskerne fra Vardø fik i de første dage af juni omtrent ingen fangst. 2 dampbaade, som satte 15000 kroge paa Ostbanken østenom Vardø, fik 1 torsk, 1 hyse $0 g 2$ smaa kveiter. Et trawltræk i Varangerfjorden 100 favne den 6te mai gar foruden en del lokale smaafiske (gabeflyndre, arktiske ulker ete.) 2 torsk (15 og $18 \mathrm{~cm}$.) 2 hyser (18 og $22 \mathrm{~cm}$.) og 9 uer $(12-25 \mathrm{~cm}$.$) altsaa nogle faa smaafisk. Ft andet træk sammesteds.$ endel flere smaafisk $0 g$ nogle faa store torsk, som man ser en stor forandring fra trækkene sammesteds den 18 de mai.

Fisket var nu flyttet længer vest. Allerede ud for Makkur (Baadsfjord) saa ri fiskere, som fik $4-500 \mathrm{~kg}$. torsk paa 3600 kroge 2 mil af land, længer ud fik en "sneseiler" paa sine 2 doryer $1200 \mathrm{~kg}$. Her fik vi selr ogsaa paa ca. 1000 kroge 165 hyser, 80 torsk, 13 uer, stenbit etc. I fisken var der endnu enkeltvis lodde. Forsøg paa trawling mislykikedes, da trawlen kom op med flere ton svampe.

Endnu længer vest i Mehavn berettede fiskerne, at der var rigt med fisis. men at der havde varet særdeles stormfuldt. En mand fortalte saaledes, at han i 6 uger kun havde havt 4 sjøveir, men paa disse havde folkene hart vel 200 kroners lot (for baaden ialt $1400 \mathrm{kr}$.). En lofotræring harde for pintse paa 3 sjøveir havt $250 \mathrm{kr}$. lot, de erklærede derfor, at saafremt reiret havde været godt, vilde der været et storartet fiske.

Paa grund af ciet darlige veir og agnmangel kom der dog i første halvdel af juni ikke saa meget fisk paa land. Den 15de juni var der ialt opfisket $15904000 \mathrm{~kg}$. Tilstede var da 2274 baade.

Ogsaa næste uge var fisket smaat tildels paa grund af stormfuldt veir og agnmangel, $0 \mathrm{~g}$ den 22 de juni kunde loddefisket siges afsluttet med $17716000 \mathrm{~kg}$.

Dog ril dette, at fisket nu afsluttedes, kun sige, at fisket forandrede karakter. Dels reiste de fleste fremmede fiskere hjem, dels begyndte de øvrige hjemmefolk ogsaa at lægge sig efter fangst af anden fisk, særlig da hyse, uer, kreite o. s. v. Med andre ord sommerfisket var begyndt.

Denne kortfattede skildring af loddefisket i aaret 1901 kan nu kun tildels gjælde som eksempel paa fisket i sin almindelighed; thi med undtagelse af sildefiskerierne er der vel neppe noget fiske, der frembyder saa mange vekslinger som loddefisket. Disse vekslinger gjælder dels det samlede udbytte fra aar til aar, dels fiskets gang inden selve Finmarkens distrikt. Det ene aar er nemlig fisket koncentreret mere i Østfinmarken, det andet mere i Vestfinmarken. Over de aarlige variationer foreligger der, som bekjendt, kun en fuldstændig og paalidelig statistik fra og med 


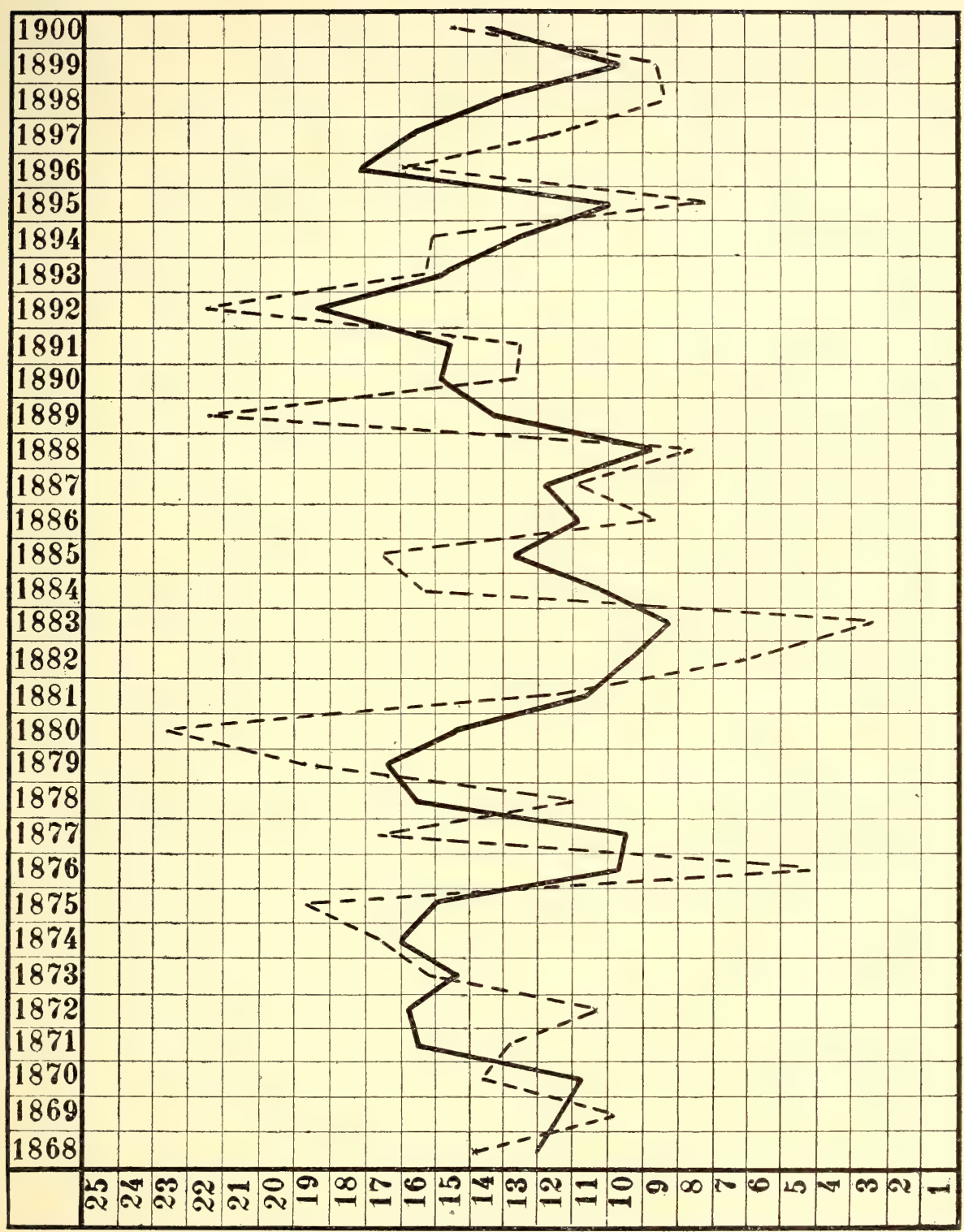

Fig. 32. Loddefisket i Finmarken i aarene 1868-1900.

- angiver antallet af fiskere $\mathrm{i}$ tusinder.

- - - angiver antallet af torsk i millioner. 
aaret 1868. Paa figur 32 er der givet en grafisk fremstilling af, hvad denne statistik lærer os med hensyn til spørgsmaalet om, hvor stort krantum (antal torsk i millioner) der er opfisket i aarene 1868-1900 samt hvor mange fiskere, der i disse aar har deltaget i fisket.

Som man ser er disse to ting yderst vekslende. Antallet af de opfiskede millioner torsk har varieret fra mellem 3 og 4 i aaret 1883, mellem 23 og 24 i aaret 1850 .

Og disse rekslinger viser heller ingen bestemt retning, hverken aftagende eller tiltagende; 2 efter hinanden følgende aar viser de allerstørste forskjelle og det baade i tiltagende og aftagende retning.

Antallet af fiskere folger i det store og hele taget kvantumet, saaledes at dette iallefald i nogen grad synes afhængigt af, hvor mange som driver fisket, skjønt der dog findes undtagelser fra regelen saa store, at vekslingen i fiskets udbytte maa have andre aarsager. Under alle omstændigheder kan det fastslaaes, at heller ikke antallet af fiskere har vist sig at have nogen bestemt stigende eller aftagende tendents.

Med hensyn til tiden før vor officielle statistiks begyndelse - aaret 1868, kan det nærnes, at der foreligger mange kilder, der med fuld paalidelighed og i udstrakt grad bekræfter dette den senere statistiks resultat, at fiskerierne stadig har vist sig yderst lunefulde $\mathrm{og}$ vekslende. En udførlig fremstilling af, hvad der er bekjendt om dette, foreligger i indstillingen fra hralfangstkommissionen af 1890. Af denne fremgaar det, at der allerede fia tiden omkring 1620 foreligger meddelelser om tider, da fisket har været daarligt, medens der til andre tider indimellem har været udmerkede fiskerier. Da dette spørgsmaal saa ofte og udførligt tidligere er behandlet, finder jeg det her tilstrækkeligt at fremhæve, at alt det foreliggende materiale udenfor al tvivl beviser, at fiskets gang. i tidligere tider ligesom nu har udmerket sig ved store og pludselige vekslinger fra det ene aar til det andet.

De samme rekslinger viser sig ogsaa i forholdet mellem fisket i Østfinmarken og Vestfinmarken. Saaledes meddeler hvalfangstkommissionen følgende: 


\begin{tabular}{c|r|r|r}
\hline \multirow{2}{*}{ Aar } & \multicolumn{2}{|c}{ Opfisket millioner stykker } \\
\cline { 2 - 4 } & Vestfinmark. & Østfinmarken & Ialt \\
\hline \hline & & & \\
$1867 \ldots \ldots$ & & 13.7 & 16.3 \\
$1868 \ldots \ldots \ldots$ & 0.8 & 14.1 & 14.9 \\
$1869 \ldots \ldots$ & 2.4 & 8.9 & 11.3 \\
$1870 \ldots \ldots$ & 3.7 & 10.9 & 14.6 \\
$1871 \ldots \ldots$ & 8.9 & 7.7 & 16.6 \\
$1872 \ldots \ldots$ & 4.1 & 7.3 & 11.4 \\
$1877 \ldots \ldots$ & 8.8 & 8.8 & 17.6 \\
$1881 \ldots \ldots$ & 1.0 & 11.8 & 12.8 \\
$1889 \ldots \ldots$ & 11.8 & 10.6 & 22.2 \\
\hline
\end{tabular}

Disse eksempler viser dette slaaende nok, især de tre sidstnævnte aar, hvoraf det ene (1877) viser lige stor fangst i Vest- og Østfinmarken, mens det andet (1881) viser næsten intet $\mathrm{i}$ vest $\mathrm{og}$ udmerket i Østfinmarken og det tredie (1889) et større fiske i Vestfinmarken end længer øst.

Ifølge ishavsfareres mening skal disse vekslinger hænge meget sammen med loddeforekomsterne i ishavet. Naar der viser sig masser lodde ved Bjørnøen, skal der efterpaa blive bedre fiske vest, og naar lodden om sommeren er samlet i største mængder i Østisen, skal der være størst sandsynlighed for Østfinmarksfiske. Herom kan jeg ingen selvstændig mening have.

Af de her meddelte statistiske data faar man det indtryk, at der ingen paaviselige forandringer $\mathrm{i}$ fiskeribedriften har foregaaet. For at kunne drøfte sandheden af dette, maa vi først nærmere betragte selve bedriften, saaledes som den er i øieblikket og har været i den tid, for hvilken der foreligger paalidelige oplysninger. Heldigvis har vi her amtmandsberetningerne at holde os til. Disse savner vistnok oplysninger om mange ting, som vi for vort øiemed her kunde ønske at vide, men findeholder dog bedre oplysninger, end man kan finde mange steder ellers.

Betragter vi nu efter disse beretninger bedriften, som den har været $\mathrm{i}$ et af de senere aar f. eks. 1899, vil man se, at der da ialt under fisket var 16683 fiskere med 4473 baade. I en tælling, som blev holdt den 13de mai, var der 10749 fiskere, af disse var 4696 fra Finmarken, 6053 fremmede. Disse fremmede var helt fra de trondhjemske 
landdistrikter: og Helgeland paa den ene side og Finland og Rusland paa den anden side. De fleste fremmede var fra Nordland og Tromsø, $0 \mathrm{~g}$ af nordlændingerne var de fleste fra Lofoten og Vesteraalens distrikter.

Af samtlige i 1891 tilstedeværende 16683 fiskere benyttedes ifølge beretningen

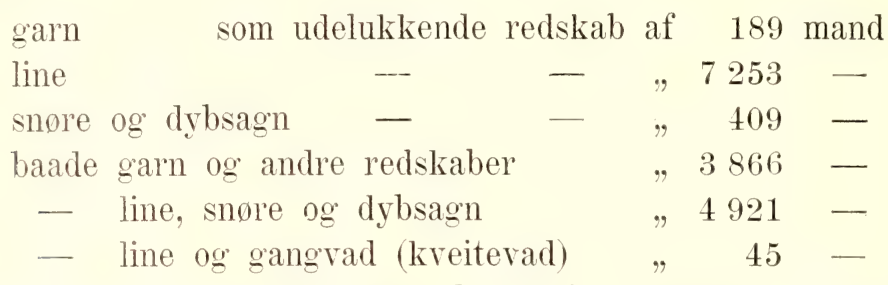

Som man ser har $1217 t$ mand brugt liner, altsaa de allerfleste, og af disse har igjen de fleste brugt liner som hovedredskab. I overensstemmelse hermed er det da, at af det opfiskede kvantum torsk angives

$7361+50$ torsk at rære fisket med liner

$$
\begin{array}{rrrrr}
548700 & - & - & - & \text { garn } \\
9946 \pm 0 & - & - & - & \text { dybsagn } \\
\text { og } 7 \pm 6600 \text { af forskjellige } & \text { redskaber. }
\end{array}
$$

Fisket er, som man vil se, i overveiende grad et linefiske.

Udbrttet for hrer mand sees at have varieret fra den. høieste lot $500 \mathrm{kr}$. ned til 40 , og gjennemsnitslotten for hele fisket sættes i de følgende aar til folgende beløb

$$
\begin{aligned}
& 189+\text { til } 159.41 \mathrm{pr} \text {. mand } \\
& 1895 \text { - } 110.59 \text { - } \\
& 1896 \text { - } 207.22- \\
& 1897 \text { - } 99.32- \\
& 1898 \text { - } 90.57 \text { - } \\
& 1899-160.88
\end{aligned}
$$

Disse gjennemsnitsbeløb er fremkomne ved at dividere udbyttet af hele fangsudbyttet med antallet af de tilstedeværende fiskere. Da nu imidlertid mange af disse vistnok kun i kort tid har deltaget i fisket, bør antagelig den gjennemsnitlige lot for dem, som i hele fisket var tilstede, sættes betydelig høiere. Føier man herfor $50 \%$ til, vil mandslotten i 1899 altsaa have være ca. 240 kroner, hvilket nogenlunde svarer til de lotter, som jeg ved samtaler med mange fiskere har hørt udtale som jerne lotter. Det er dog selvsagt, at beløbet varierer fra aar til aar og fra mand til mand overordentlig, hvilket da ogsaa statistiken til overflod viser. Men et vist indtryk af en almindelig fiskers udbytte faar man iallefald af disse tal.

Ved nu at studere amtmandsberetningerne tilbage i tiden faar man et helt andet begreb om tidligere tiders loddefiskerier. Der viser sig nemlig, at der efterhaanden er indtraadt stor forskjel i driftsmaaden. 
Om denne indeholder amtmandsberetningerne fra 1870-1877 adskillige interessante bemerkninger, og fra 1878 til nu angives der, hvormeget der er opfisket med de forskjellige slags redskaber. For a aret 1870 skriver saaledes amtmanden: „Ogsaa iaar forsøgte enkelte i begyndelsen af fisket ved Vardø at bruge garn, men uden held, da redskabet beskadigedes af haakjærring. Linebruget, som - er det, der giver mest anledning til tvist og eiendomsindgreb paa sjøen, synes at tiltage. Fiskeri fra dæksfartøier dreves, saavidt oplyst, kun af 27 mand. De tilsvarende tal var i 1867 338, i 1868 116, i 1869 som iaar, nogle og tyve. Det tør heraf vel sluttes, at erfaring ikke har godtgjort hensigtsmæssigheden af denne fangstmaade under loddefisket."

For 1871 læser vi: "Garn brugtes ved Vardø i lidt større udstrækning end for og viste $\mathrm{i}$ begyndelsen af fisket sin overlegenhed over haandsnøret. Forholdet mellem linen og dybsagnet har forandret sig lidt til skade for det sidstnærnte redskab, hrilket i 1870 benyttedes af noget over, men iaar af noget under en trediedel af samtlige fiskere. I 1867 stod begge redskaber ikke langt fra lige."

For 1872: "Antallet af dem, som drer fiske alene med dybsagn, hvilket ifjor var gaaet ned til langt under en trediedel af samtlige fiskere, er iaar sunket til omkring en femtedel. Det vilde gaaet yderligere ned, dersom de havde rigere tilgang paa lodde til agn for linebruget."

Paa hosstaaende tabel ser man en fortegnelse over, hvormeget der er opfisket med de forskjellige slags redskaber i aarene 1878-1901. (Herved maa dog tages i betragtning tallene i rubrikken "forskjellige redskaber", hvilke tal formodentlig angiver det kvantum, om hvilket man ikke ved, hvorledes det er fanget). Men af tabellen fremgaar det iallefald, at i slutten af 70-aarene var dybsagnfisket væsentlig støre end, linefisket, saaledes fiskedes

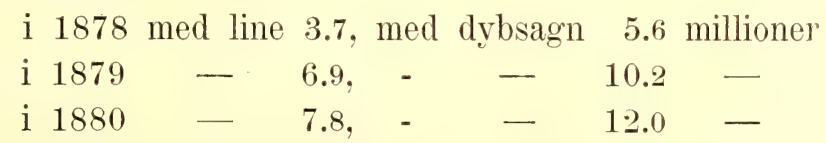

I 80-aarene forandredes dette jevnt; kun i enkelte aar er dybsagnfisket overlegent som i 1885 , i $1887 \mathrm{og}$ i 1889.

I de sidste aar har imidlertid linefisket været langt overveiende saaledes fiskedes f. eks.

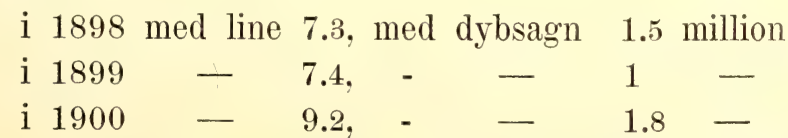

For at give et begreb om, hvilken forandring i fiskemaaden dette betegner, skal jeg nævne, at der alene fra Vardø i et af de sidste aar, nemlig 1887 , da der var godt dybsagnfiske, fiskedes med dybsagn 2765000 torsk, medens der i slutten af 90-aarene fiskedes langt mindre paa dybs- 


\begin{tabular}{|c|c|c|c|c|c|}
\hline \multirow{2}{*}{ Aar } & \multicolumn{5}{|c|}{ Opfisket } \\
\hline & med garn & med liner & med snøre & $\begin{array}{c}\text { med forskjel. } \\
\text { redskaber }\end{array}$ & Ialt \\
\hline $1878 \ldots \ldots$ & 891000 & 3781000 & 5568000 & - & 12065000 \\
\hline $1879 \ldots \ldots$ & 1555500 & 6925000 & 10239400 & - & 19333400 \\
\hline $1880 \ldots \ldots \ldots$ & 862000 & 7808000 & 11969000 & - & 23626000 \\
\hline $1881 \ldots \ldots \ldots$ & 196000 & 6555300 & 4711700 & 1386000 & 12849000 \\
\hline $1882 \ldots \ldots \ldots$ & 238000 & 4725300 & 1526700 & 610400 & 7100000 \\
\hline $1883 \ldots \ldots \ldots$ & 87000 & 1951000 & 627300 & 889700 & 3555100 \\
\hline $188 t \ldots \ldots \ldots$ & 628500 & 7613000 & $6184 t 00$ & 1716000 & 16142400 \\
\hline $1885 \ldots \ldots \ldots$ & 381000 & 7297000 & 9192800 & 716500 & 17587800 \\
\hline $1886 \ldots \ldots \ldots$ & 482000 & 4929500 & 3676200 & 679000 & 9766700 \\
\hline $1887 \ldots \ldots \ldots$ & 316000 & 3487600 & 7693500 & 404000 & 11901100 \\
\hline $1888 \ldots \ldots \ldots$ & 460000 & 4107000 & 2236000 & 1883000 & 8686000 \\
\hline $1889 \ldots \ldots$ & 532000 & 727300 & 13341400 & 1181000 & 22327400 \\
\hline $1890 \ldots \ldots$ & 781800 & 3261300 & 6628200 & 3026100 & 13697400 \\
\hline $1891 \ldots \ldots \ldots$ & 790500 & 5440700 & 6809500 & 545000 & 13585700 \\
\hline $1892 \ldots$ & 637300 & 10660200 & 10589900 & 473000 & 22360400 \\
\hline $1893 \ldots \ldots \ldots$ & 808000 & 10281000 & 4968000 & 240000 & 16297000 \\
\hline $1894 \ldots \ldots \ldots$ & - & 一 & - & 一 & - \\
\hline $1895 \ldots \ldots$ & 228000 & 9128400 & 233000 & 1) & 9659400 \\
\hline $1896 \ldots \ldots \ldots$ & 396000 & 14501700 & 2084500 & 一 & 16982200 \\
\hline $1897 \ldots$ & 949100 & 10519450 & 1405800 & - & 12874350 \\
\hline $1898 \ldots \ldots \ldots$ & 674000 & 7251980 & 1452700 & - & 9378680 \\
\hline $1899 \ldots$ & 548700 & 7361450 & 994640 & 746600 & 9551390 \\
\hline $1900 \ldots \ldots$. & 1410300 & 9156380 & 1807300 & 3110800 & 15484780 \\
\hline $1901 \ldots \ldots \ldots$ & 1008000 & 5591585 & 737200 & 1901110 & 9237895 \\
\hline
\end{tabular}

1) Med not fisket 70000 . 
agn over hele Finmarken, og det trods det samlede kvantum, taget paa alle redskaber i disse aar, var omtrent de samme.

Statistikken fortæller altsaa om en sterk tilbagegang i dybsagnfisket eller om en omlægning af bedriften fra haandsnøre, dybsagn eller juks, som det kaldes, dette billige redskab, til de langt kostbarere liner. Og dette fremholdes ogsaa i de mest kraftige udtryk af fiskerbefolkningen selv. Paa de møder, jeg i 1901 holdt med fiskerne i Finmarken, udtalte mange ældre folk, som i mange aar havde drevet fiske, det som sin erfaring, at fisken for 20 aar siden var langt nærmere land under loddefisket end i de senere aar,og at det var dette, som dengang muliggjorde juksefisket.

Enhver bedrifts forandring fra en driftsmaade til en anden medfører for dem, som staar i bedriften, store følger i mangfoldige livsforhold. Naar den nye driftsmaade, som her, er kostbarere, medfører den ikke alene forskudsudlæg til dyrere redskaber, men ogsaa stadig udgifter, her f. eks. til $\mathrm{ag} n$. Disse sidste kan beløbe sig til særdeles store summer, hvorom mere senere.

Hvad nu alle disse udgifter angaar, saa kan man forstaa deres betydning for befolkningen af den korte bemerkning, som findes i en gammel amtmandsberetning (for 1868), og som end mere viser forholdene, naar man husker, at der dengang vasentlig var tale om dybsagnsfiske.

Der siges nemlig, at der i 1868 var tilbagegang i antallet af fiskere, og ,denne tilbagegang i et forhold, som i lange tider aarlig har vokset, lader sig formentlig kun forklare af den nød, som ifjor herskede inden Nordlands og Tromsø amter og gjorde for mange udrustningen til Finmarksfiske til en umulighed."

Men en forandring i redskaber trækker ogsaa mange andre forandringer med sig, fremfor alt i fartøier. Medens juksefisket foregik nær land, og det derfor baade af hensyn til seiladsen og redskabets anvendelse var det mest praktiske at bruge de fra aarhundreder tilbage tilvante otringer, forlangte linefisket lang seilads tilhavs, og det viste sig da for de nordlige landsdeles befolkning mest praktisk at anvende noget større, enten dækkede eller halvdækkede "sneseilsbaade" (af skøitefaçon) med tilhørende fladbundede fiskebaade af det amerikanske „dory"-system. Overalt langs hele vor kyst fra Vestlandet $0 g$ nordover, har dette system fundet indpas. For Finmarkens vedkommende udtaler amtmanden i beretningen for aaret 1900: „Med hensyn til driftsmaaden og baadenes udstyr merkes der nu en betydelig forandring, idet man i den sidste tid omtrent kun har begyndt at benytte større, tildels dækkède sneseilsbaade, forsynede med 1-2-4 slæbebaade, hvoraf igjen et par stykker doryer. Ligeledes er en forbedret linehaler, „andøver" kaldet, bleven almen bekjendt" etc. 


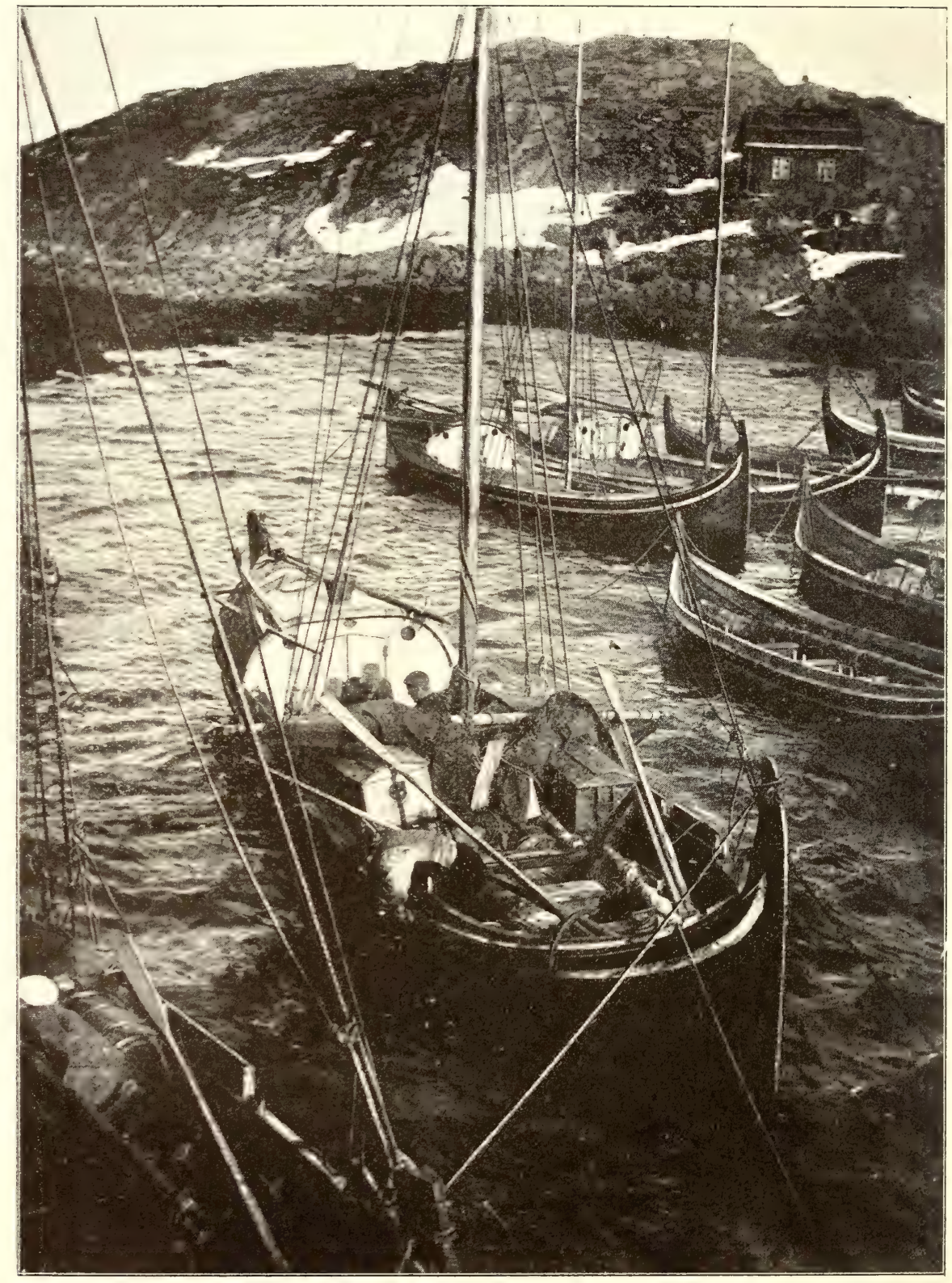

Fig. 33. Otringer med „agterskot" paa fiskevær i Finmarken. 
Med baade eller „farkoster" af ny type følger imidlertid igjen for fiskeren helt nye livsforhold. Anskaffelsen af et saadant fartøi betegner for ham nødvendigheden af en stor kapital, som han i regelen ikke eier, og som han kun med de største ranskeligheder kan opdrive. Naar den større farkost er anskaffet, opstaar spørgsmaalet om at kunne beskjæftige den, forrente $o g$ betale afdrag af kapitalen $o g$ derfor holde baaden i virksomhed aaret rundt. Der indtræder en række nye forhold mellem dem, som eier farkosten $o g$ de andre ombord. Medens de alle før var mere eller mindre lige, blir der nu større forskjel paa dem, et

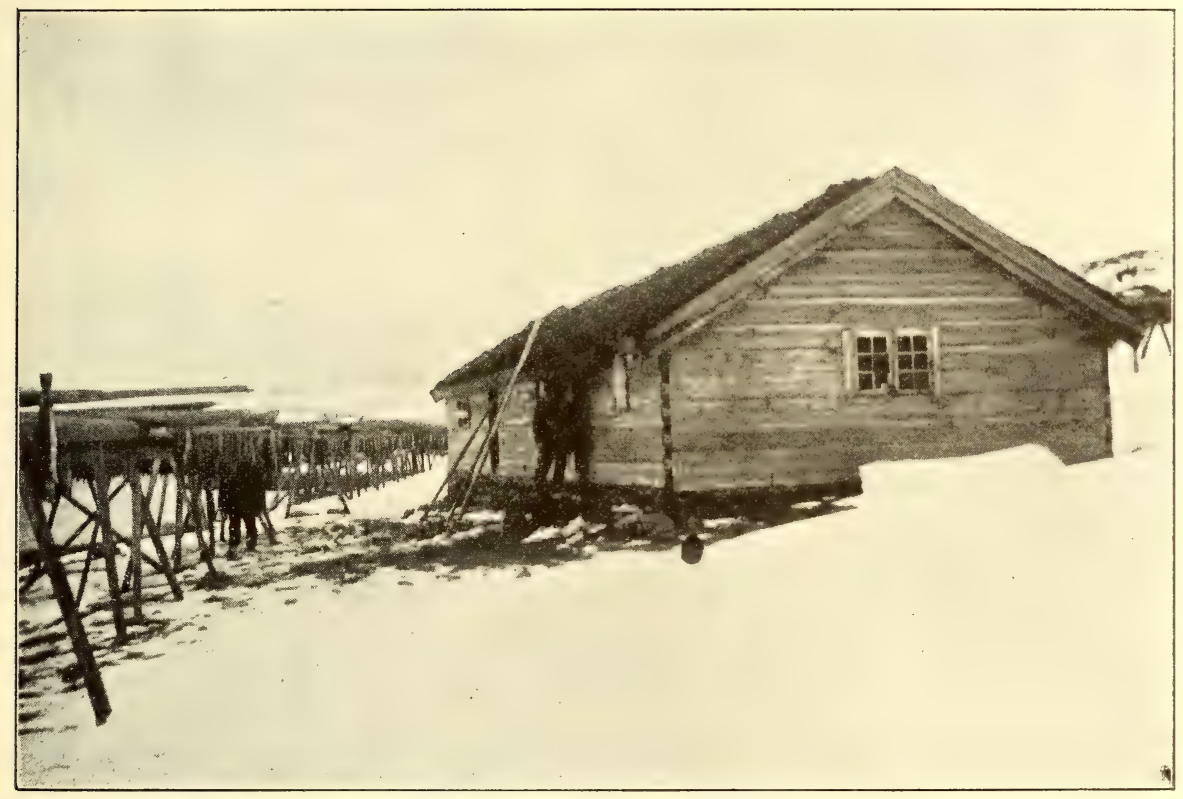

Fig. 34. Rorbod med gjælder for fisken udenfor paa Fiszevær i Finmarken.

forhold, som de, der maa underordne sig, er lidet vant til og ikke straks finder sig i. Ogsaa i hans levevis er der store forandringer. Al den tid, han ikke er beskjæftiget med fisket selv eller seilads, er han i sin otring henvist til det lille „agterskot" (se fig. 33), hvor 4 mand tilbringer de lange vinternætter og de mange "landliggedage". Kommer han i havn, hvor der er anledning til det, har han ofte de smaa rorboder paa land at ty til, men mest er det nok agterskotten, de maa holde sig til. Den, som imidlertid faar bedre fartøi, han faar ogsaa i regelen bedre rum at være i, og han har det i mange henseender bedre. Saaledes opstaar der stadig flere og flere forskjelligheder mellem folk. Størst blir jo disse for deres vedkommende, som faar sig dampbaade at føre eller til eie. Her er jo driftsmaaden end mere kompliceret, end mere kostbar og end mere 
afvigende fra alle de mere oprindelige forhold, under hvilke vore fiskeriers livsrilkaar for forholdsvis faa aar tilbage var stillet.

Hvad er aarsagen til disse forandringer i driftsmaaden? Paa den ene side fremholdes der, at fiskens indsig i de senere aar har vist en hel anden karakter end tidligere. Medens den tidligere kom saa nær land, at juksefiske i otringer baade kunde drives og var dẹt mest lønnende, fordi omkostningerne var mindst, staar fisken nu ude i eggen, og dermed har de større baade og linefisket vist sig nødvendigt. Som hovedsageligste aarsag til denne fiskens forandrede indsig fremhæves af særdeles mange fiskere den sterke aftagen af hvalbestanden, som man mener at kunne konstatere, og som man med bestemthed paastaar er hvalfangstens skyld. Fra andet hold har der været fremholdt, at det er linefisket, som holder fisken ude fra land, fordi fiskerne allerede møder de under indsig værende fiskemasser med sine liner og holder dem derude. Atter andre har ment, at det er naturforholdene i havet, som betinger fiskens forskjellige sig i de forskjellige aar.

Til. nærmere orerveielse over disse spørgsmaal skal vi komme tilbage i sjette kapitel, efterat vi først i det følgende har givet en oversigt over de ovrige fiskerier, over hvalernes liv og vandringer samt over hvalfangsten $\mathrm{og}$ dens historie.

\section{Sommerfisket.}

I den nordligste del af landet og særlig i Finmarken er sommerfisket i mange henseender anderledes end andre steder. Mit indtryk af forholdene er iallefald det, at intetsteds langs kysten er der ved sommertid saa meget fisk under land som der nord. Mens der nemlig langs sydkysten i dens fjorde og skjærgaard kun kan fiskes særdeles lidet, foregaar der langs Finmarkens kyst, ja selv i fjordene ikke smaa fiskerier.

Amtmandens aarsberetning for 1899 viser, at fiskeriet i det aar gav følgende udbytte:

„a. Torsk, sei, kveite, flyndre, hyse, uer m. v. solgt i raa eller saltet tilstand til russerne for 29492 matter mel (matten veier ca. $144 \mathrm{~kg}$.), som efter dets pris til almuen er ansat til ...... kr. 501582.00

b. $209550 \mathrm{~kg}$. rotskjær, som angives til ........ " 96251.25

c. 279680 " sei af alle størrelser ........... " 48793.50

d. Forskjellige fiskevarer, saasom, torsk, hyse, sei solgt i raa tilstand til norske handelsmænd eller til rus-

Transport kr. $\quad 646626.75$ 
Transport kr. 646626.75

serne mod andre varer end mel, rundfisk og titling fra høstfisket, uer, laks fanget ved kysten m. v. udbragt til en pengeværdi af ..............., 484379.70

e. $18382^{1 / 2}$ hl. lever udbragt til............. " 180511.75

tilsammen kr.1311518.20"

Dette fiske sees at strække sig fra Alten til Varangerfjorden, det drives dog ikke i lige udstrækning overalt. Længst ude ved havkysten som ved Maasø, Kjelvik, Vardø fiskes der mest. Paa disse 3 steder stiller forholdene sig saaledes:

Mas $\emptyset$ fisket for kr. 303150 af 2500 mand med en gjennemsnitslot af

$184 \mathrm{kr}$. (høieste lot $500 \mathrm{kr}$.).

Kjelvik fisket for $169000 \mathrm{kr}$. af 1150 mand med en gjennemsnitslot af

$147 \mathrm{kr}$. (høieste lot $600 \mathrm{kr}$.).

Vardø fisket for $166223 \mathrm{kr}$. af 800 mand med gjennemsnitslot af 347

for hjemmefolket, $167 \mathrm{kr}$. for fremmede, høieste lot $500 \mathrm{kr}$.

Alt ialt skal der i 1899 have været 10742 mand tilstede, hvoraf 5103 fremmede. Dette forklares saadan, at sommerfisket er en direkte fortsættelse af loddefisket, og at mange blir igjen flere maaneder, efterat lodden har forladt kysten. Da de fremmede dog ikke blir hele sommeren $0 \mathrm{~g}$ høsten, men reiser i de første maaneder efter loddefiskets ophør, er deres lot mindre. Saaledes sættes den gjennemsnitlige lot under sommerfisket 1899 for hjemmefolket til kr. 130.15, for fremmede kr. 84.88.

Betragter man sommerfiske-bedriften nærmere, viser det sig, at den i grunden bestaar af en hel del meget forskjellige fiskerier, hvilket man ogsaa allerede kan slutte sig til af den under gjengivelsen af statistiken meddelte opregning af de mange forskjellige fiskearter, som er gjenstand for fiskeriet. Man kan saaledes sige, at man har et kystfiske, der igjen omfatter to meget forskjellige bedrifter, nemlig seifisket og torskefisket med juks og liner. Begge disse fiskerier gaar imidlertid over i bankfiske, idet fiskerne ofte ogsaa søger seien og torsken paa dybere vand og længer fra land og derunder ogsaa fisker hyse, kveite, svartkveite, uer 0.s.v.

\section{Seifisket.}

Finmarkens seifiske skildrer LüTzow-HoLm i „Norge i det nittende aarhundrede" i følgende malende ord: „Det er midnat. Den fugtige 
østenvind fra Ishavet har jaget bølgerne fra morgenstunden af. Men naar kvelden kommer, lægger de sig bølge efter bølge, og ved midnatstide er havets uro stilnet. Graahvidt, stivnet som i døden hviler det sig ud efter dagens jag.

Men ikke længe varer dets hvile. Uventet, som rørt af en tryllestav, bliver der med ét liv $0 \mathrm{~g}$ bevægelse derude. Den store, øde ensomhed afløses af et bevæget liv, - - nattens underlige stilhed afbrydes af en brusende lyd som fra mægtige fossefald. Havet, det blanke, graahvide, vaagner. Det er, som om der i dets hemmelighedsfulde dyb tændes en rældig ild. Havfladen blinker, bobler, syder i kog.

„Seien gaar!" - I millionvis er seien steget op fra dybet; thi den har seet sin deiligste drom opfyldt: havet yrende fuld af delikat aate (kril). Nu leker den sin frydefulde lek i den solglinsende flade. Men just under leken ringer dødsklokkerne, just under leken skal den gjøres til bytte. Udover mod „seiflakene" stevner nu baad efter baad.

Paa alle de smaa næs, hror en stue kan bygges, og i alle de smaa indhug i fjeldvæggen, hror havn for nogle baade kan erobres, har de finmarkske fiskere reist sine gammer, sine stuer eller sine rorboder. Du opdagede dem ikke, da du sad oppe paa vidden og saa udover. Smaa og vel gjemte ligger de i fjeldkløfterne opunder fjeldsiden. Herude paa næsset $\mathrm{og}$ i kløften har finmarkingen gjennemkjæmpet saa mange tunge og morke trængselens vinterdage. Men naar det i februar og marts gaar fra mund til mund: "Loddén er kommen!" eller i juni og juli rabet lyder: „Seien gaar!" - da er savn og trængsel glemt.

„Seien gaar!“ for finmarkske fiskere et trylle-ord.

Staar han midt $i$ arbeidet med at sanke ind de faa høstraaene til vinterføde for koen, han kaster ljaaen og riven. Sidder han i fjæren og agner linen til natsæt for at fange torsk, han la'r liner, angler og makkekoppen blive, hror de er. Til seien skal han have not, garn; dem griber han da. En god "sei-nat" opveier mangfoldige lange slitsomme dages, ja ugers torskefiske. Notlagets fire baade slaar sig sammen, fire mand i hver baad, og saa bærer det udover, lappen med korte, ujevne tag, nordmanden med jevne, sterke, kvænen med lange, seige. Du kjender dem paa aaretagene.

Snart yrer det af hujende, skrigende fiskere af alle disse nationer ude ved „seiflakene" (de steder, hvor seien i store, brede stimer boltrer sig i havfladen). Aa, for et liv! Mad til de tomme fade, mel til den lange vinter, lys til middagsmørke dage, klæder mod kulden og den stormjagede snekave, betaling af skatter, gjæld og afgifter; det er alt dette, som for Finmarkens fiskere ligger indesluttet i trylleordet „Seien gaar!“ Det er midnattens sommerhaab for den kommende vinterdags øde."

Slig drives dette seifiske ude ved de saakaldte skaller yderst ude 
i havkanten og i de store aabne fjorde, som ligner mere havarme. Saaledes f. eks. i Porsangerfjorden, langt ind f. eks. ved Kistrand. I Troms $\emptyset$ og Nordlands amter er det derimod mest ude ved havkanten eller ude paa kystbankerne, hvor disse danner grunde partier (baaer eller skaller). Saadanne er Gjesbaaerne ud for Loppehavet eller Vesteraalsskallerne ud for Hadselfjorden eller ude paa de 30-40 favne dybe, Svendsgrunden og Malangsgrunden, vestenfor Senjen og Tromsø.

Paa nordre og søndre „Skallen“ udfor Hadselfjorden saaes saaledes flere kuttere for anker i juli maaned. De fiskede sei med synkenøter fra doryer. Det samme saaes senere i juli paa Gjesbaaen (Loppehavet). Jeg var der ombord hos et notlag, som den 13de juli havde fisket 3000 sei. Senere, 16de august, saa jeg ogsaa seifiske drevet herude. Man kunde nu ikke drive med synkenot, da seien, for saa vildt, ,fordi dens aate (smaasilden) var saa stort." Derimod fiskede man den paa trøe (stang med pilk). Dæksbaaden laa for varp, dens to doryer roede omkring, en mand roede, en stod agterud med to trøer og vippede seien ind, som stadig bed paa pilken. Saaledes havde disse 4 mand paa et døgn fisket halv tredie tusind sei, et slaaende bevis for den enorme masse, der fandtes.

Den 17 de august praiedes en hel del skøiter, som laa for anker paa Svendsgrundens vest-eg (vest for Senjen). De fiskede sei paa juks. Nogle havde 500, andre 1000 , atter andre 2500 i nogle døgns fiske. De fiskede kun om natten. Seien havde mest smaasild til aate.

Disse eksempler viser os, at seifisket drives som bankfiske.

\section{Torskefisket og bankfisket.}

Sommerens torskefiske er, som tidligere nævnt, en fortsættelse af loddefisket. Dels blir nemlig en stor del af loddetorsken staaende under land, dels siger endel af skreien vestenifra østover. Man begaar saaledes en stor feil ved at tro, at der om sommeren er saa fattigt for fisk i Finmarken, som andetsteds langs kysten. Fisket drives baade med juks $0 \mathrm{~g}^{2}$ med line. Paa skallerne staar der betydelige mængder torsk om sommeren, saaledes paa Gjesbaaen, Tubaaen (Sørøens nordside), „Sleppen“, hvor der drives et juksefiske, som kan give lastede baade.

Desuden sættes liner paa landbakken udenfor kysten. Østenfor „Østvaagen" ved Vardø i bakken paa 70-80 favne vand saaes fiskerne om sommeren sætte jevnlig ca. $1000 \mathrm{krog}$ hver baad. Nogle saadanne. baades fangst var i august: 
En fik 150 kilo hyse, 150 kilo torsk

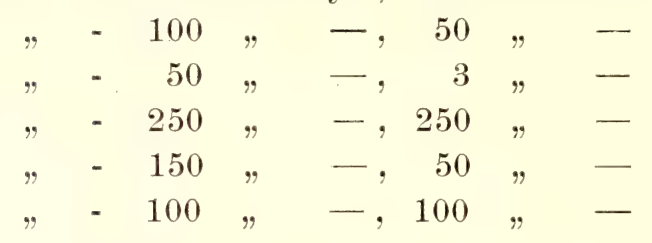

Som man ser, er her fangsten ligesaa meget hyse som torsk. Længer ud paa bakken blir nu fangsten ogsaa andre fisk, som uer. Og kommer vi nedenfor landbakken med vore liner til den 200 favne dybe mudderbund, findes der mængder af svartkveite (Hippoglossus hippoglossoides), der ofte kaldes den "grønlandske kveite“, den findes paa stort dyb i mængde langs hele vore bankers eg helt ned til Aalesundskanten. Ca. 2-3 mil ret ud for Vardø findes et dyb paa 2-300 favne, hvor den fiskes. Den sælges til russerne for $10-15$ øre kiloet.

Om dette fiske siger fiskeriinspektør Sørensen i sin aarsberetning for 1899: „Enkelte af de baade, der iaar drev dette fiske, gjorde særdeles gode forretninger, saa det er at antage, at endnu flere baade vil drive dette fiske til kommende sommer, hvis der skulde blive lidet fisk under land."

Kommer man længere udover fra land, grundes dette 200-300 farne dyb op, saa at man $6-8$ mil fra land har 100-140 favne, den saakaldte $\varnothing$ stbanke. Her har hr. Sørensen efter foranstaltning af Tardø fiskeriforening med dampskibet „Finmark" udført endel meget vellykkede fiskeforsøg i tiden juli-september. I nævnte aarsberetning skildrer han disse fiskeforsøg saaledes:

„Dampskibet var leiet af handelsmand Skanche i Mehavn, der af fiskeriforeningen skulde have $\mathrm{kr}$. $500.00 \mathrm{pr}$. maaned i leie samt halvparten af fangstudbyttet imod at holde halvpart i brug og agn, den anden halvpart i dette holdtes af fiskerne, der skulde have den anden halvpart af udbyttet samt kr. 30.00 pr. maaned af fiskeriforeningen. Meningen var, at man skulde faa fiskere med, der var hjemmehørende i Vardø, men da fiskerne her havde liden tro paa, at fisket saa langt fra land vilde være lønnende, fik man kun 3 fiskere med fra Vardø, resten maatte tages fra andre steder, ialt var der 8 fiskere ombord.

Da fiskeriforsøgene væsentlig skulde gaa ud paa at søge efter kveite, skulde den i Finmarken almindelig benyttede kveiteline (gangvad) benyttes, og meningen var da, at vi skulde bruge 4 doryer med 300 angler gangvad fra hver, men det viste sig imidlertid allerede under de første forsøg, at det var temmelig risikabelt at slippe doryernel saa langt fra sig, som de maatte være for at sætte og trække liner, naar alle doryer maatte være ude samtidig. Skodden kom nemlig paa pludselig og 
tæt, og omendskjønt alle doryer var forsynede med kompas og lur, var det $\operatorname{dog}$ vanskelig at finde dem igjen, da strømmen satte dem ud af kurs. $\mathrm{Vi}$ besluttede derfor at forsøge at sætte $0 \mathrm{~g}$ trække linen fra dampskibet, $\mathrm{og}$ da dette viste sig at gaa meget godt selv i sterk strøm, kuling og sjøgang, benyttede vi senere ikke doryerne. Hele gangradet, ea. 1100 angler, udsattes $\mathrm{i}$ en længde, og da der var 6 favne $0 \mathrm{~g}$ tildels mere mellem hver angel, overfor man saaledes for hver sætning 5 à 6 kvartmil. De kagger - almindelige aalesundskagger — som benyttedes til ilerne, viste sig ikke at være hensigtsmæssige, da de i den ofte sterke strøm blev sat under og tildels sprængtes, hvorfor vi maatte benytte doryerne at lægge for ilerne.

I den tid vi drev fisket, fra 13de juli til 4de september, sattes gangvadet ialt 16 gange paa forskjellige steder over en strækning øst $0 \mathrm{~g}$ vest af ca. $10 \mathrm{mil} 0 \mathrm{~g} \mathrm{i}$ en afstand af 5 til $10 \mathrm{mil}$ fra land. Dybderne var forskjellige, fra 70 til 180 favne, $o \mathrm{~g}$ bundens beskaffenhed ligeledes forskjellig, fra fin sand til lere $\mathrm{og}$ dynd. Overalt traf vi dog fisk, om dog i forskjellig mængde; saaledes fik vi for hver sætning fra 400 til $1200 \mathrm{~kg}$. kveite foruden endel stor torsk og brosme, men paa grund af det brug, der benyttedes - gangvad med angler no. 0 - kunde kun større fiske faaes, vi fik saaledes sjelden en kveite under $20 \mathrm{~kg}$., almindeligst fra 40 til $60 \mathrm{~kg}$., men enkelte gange ogsaa op til $150 \mathrm{~kg}$. samt torsk, der i sløiet stand veiede $12-16 \mathrm{~kg}$.

Den samlede fangst af kveite beløb sig til $9300 \mathrm{~kg}$., der sammen med den øvrige fisk, vi fik, hvoriblandt haakjærring, saa vi fik $14 \mathrm{hl}$. lever, udbragtes til kr. 3100 . Fiskernes lot blev i disse to maaneder kr. 170.00, saa de med sine maanedspenge havde en nogenlunde god fortjeneste.

Efter den erfaring, jeg høstede af fiskeforsøgene iaar, er jeg bleven bestyrket $\mathrm{i}$ den tro, at havfisket længere fra land maa kunne drives med held udfor Finmarkskysten om sommeren med mindre dampskibe, passende brug og en besætning af 5 à 6 fiskere."

Omı denne fiskebanke søgte vi ogsaa med „Michael Sars“ at faa selvstændige erfaringer, og disse gik ganske i samme retning som $\mathrm{Hr}$. Sørensenss. Den 7de august 1901 slæbte vi saaledes 2 fiskekuttere 6-7 mil ost til syd af Vardø.

Kutterne satte „gangvad“ (kveiteliner) og torskeline (ca. 2000 kroge) 128 favne.

Den ene fik 13 kveiter fra 2.6 til 1.12 meters længde

20 torsk $-1.3-0.6 \quad$ do.

Dette indbragte kr. 206,78.

Den anden fik 13 kveiter og ca. 100 store torske samt 3 hl. haakjærringlever. Hans udbytte var vel kr. 300. 
Lignende fangster gjordes af „Michael Sars“ ogsaa længer øst (ret nord af Kolafjorden) $33^{0} 46^{\prime}$ paa ca. $71^{0}$ nordlig bredde hvor ca. 120 favnes dyb.

Idetheletaget findes utvivlsomt paa det grundere parti af Østhavet om sommeren store mængder fisk (store torsk, kveite, haakjærring), hrilket ogsaa de i forrige kapitel omtalte russiske undersøgelser har vist.

I august 1901 var der desuden storartet juksefiske paa MurmanKysten østenom øen Kildin, ja helt ind i Hvidehavet, ogsaa paa landbakken udenfor Finmarkskysten dreves godt linefiske.

I de grundere partier af Osthavet, saasom Østbanken og bankerne nordenom Murmankysten, samt i n.o. retning af Vardø, endvidere nordenom Nordkap samt Bjørnøbanken har man derfor utvivlsomt felter, der har rist sig verd at prøve videre. I slutten af mai iaar (1902) vil et saaclant prøvefiske med statsbidrag blive igangsat for at prøve, hvad der med en moderne udrustet fiskedamper kan findes af felter østenom Nordkap, hror sommerbankfiske kan foregaa, og denne damper vil da begynde paa de orenfor nærnte banker.

Længer vest i Testfinmarken og Tromsø amt har havbankerne en ganske anden karakter. Her gaar Osthavets store flade over i den almindelige kystbanke med dens bratte eg ned mod Nordhavets tusinde farnes stordyb. Her vest drives derfor bankfisket mere paa samme maade som langs hele den norske vestkyst.

Intet sted gaar eggen kysten saa nær som ved Andenæs (se fig. 21). Her kan derfor egfisket drives med smaa otringer saaledes, som det for en menneskealder siden blev drevet fra Aalesund paa Storeggen. Baadene fisker i regelen sin agn (sei, hyse) med juks nær land og sætter saa sine liner $\mathrm{i}$ forskjellige dybder fra 150 til henimod 400 favnes dyb. I sommerens løb kommer der saaledes betydelige mængder lange, blaalange, storuer, kveite samt lidt stor torsk og hyse paa land, som dels blir solgt til russernes kjobefartøier, dels til stedets handelsmænd. Den 20de august saa vi slige baade fiske i "Andenæsdjufta", som den bugt i eggen kaldes, der gaar ind mod Andenæs. De satte to sætninger, hver paa 2000 kroge, som stod i 4 timer.

En baad havde sin boje paa 246 favnes dyb (vort lodskud), den fik ca. 150 blaalanger

- 20 almindelige langer (norske langer)

- 80 uer

- 14-15 hyse (meget store)

- 10 torsk $(89,90,76,85,75,84,83,64 \mathrm{~cm}$.)

- 10 sei

- 15 brosmer

- 10 svartkveite 
En anden baad (vort lodskud 224 favne) fik i 2 sætninger à 4 timer tilsammen 3800 kroge:

$$
\begin{aligned}
& \text { ca. } 200 \text { blaalanger } \\
& \text { - } 50 \text { storuer } \\
& \text { - } 100 \text { smaauer } \\
& \text { - } 50 \text { norsklange } \\
& \text { - } \quad 30 \text { svartkveite } \\
& \text { - } \quad 9-10 \text { torsk } \\
& \text { - } \quad 9-10 \text { hyse } \\
& \text { - } \quad 30 \text { langstjert (Macrurus fabricii) } \\
& \text { - } \quad 3-4 \text { stavsild (Argentina silus) } \\
& \text { endel blaastenbit. }
\end{aligned}
$$

En tredie baad, som angav dybden til $400-500$ favne fik paa 100 store kveitekroger 8 kveiter og endel storuer.

Disse 3 eksempler giver et billede af fangsten, dybden og driften. De fortalte alle, at naar der var noget over 400 favne, var der kun blød mudderbund og ingen madnyttig fisk.

Et forsøg paa linesætning paa ca. 500 favnes dyb 300 kroge gav følgende fangst:

\section{4 haakjærring}

13 svartkveite

16 langstjert, en dybhavsfisk

2 rokker (Raia batis, $R$. hyperborea)

Et forsøg paa 1000 favne mislykkedes, da linen brast. Man ser saaledes, at der ikke er ubetydelige mængder af store fisk selv paa meget store dyb. Meget instruktivt herfor er nogle fors $\emptyset \mathrm{g}$ med engelsk trawl, som jeg gjorde i Skageraks største dyb i september ifjor.

Midtveis mellem Arendal og Skagen i over 300 favnes dyb gjordes 1 times træk med en 60 fods trawl med følgende fangst:

281 langstjert (Coryphonoides rupestris)

28 isfisk (Chimcera monstrosa)

14 stavsild (Argentina silus)

2 svarttorsk (Spinax niger)

2 rokker (Raia batis)

56 hundetunge (Pleuronectes cynoglossus)

2 gabeflyndre (Drepanopsetta platessoides)

Store eksemplarer af ræger (Pandalus borealis, Pasiphae tarda) etc.

Andenæsfisket er, saavidt mig bekjendt, det eneste større fiskeri, som drives langs eggen paa hele den vældige strækning fra Kristianssund til Spitsbergen. Aalesundsfiskerne har vistnok trukket sig nordover med sit dampskibsfiske paa eggen til nordenfor Kristianssund til det saakaldte Storenæsset, men herfra nordover er eggen særdeles lide 
prøvet, end sige brugt. Udenfor hele Vesteraalen gaar den jo temmelig nær kysten, men her siges strømforholdene særdeles vanskelige, hvorimod der i læ af Andenæs skal være langt gunstigere i den henseende. Det kan dog vistnok med rette siges, at der er gjort altfor faa forsøg paa dette vældige felt, $\mathrm{og}$ her ligger en af de største fiskeriopgaver for os. Rygtevis meddeles, at engelske fiskedampere med stort held har prøvet bankerne vest om Senjen, særlig Svendsgrundens skraaningnr mod dybet.

Norske dampere har ogsaa gjort enkelte særdeles fortjenstfulde forsøg særlig paa havet Trænen-Røst altsaa banken fra Vestfjordens munding mod eggen. Af disse dampere har jeg erholdt endel meddelelser, særlig har hr. kaptein KJæzRTAD, fører af dampskibet „Expres“, meddelt mig følgende resultater af hans fiskeforsøg.

1 ste tur gik fartøiet ud fra Trænen 22de april 1901 ca. 7 mil n.v. af Trænens fyr. Fiskede her i 3 døgn nord og syd, vest og øst lige ind under land, men fik lidet fisk. Fangsten var $415 \mathrm{~kg}$. lange, $368 \mathrm{~kg}$. torsk, $1282 \mathrm{~kg}$. brosme og $389 \mathrm{~kg}$. kveite. En masse haakjærring plyndrede linen, og ødelagde en masse brug.

2 den tur styrede op under Skomvær, styrede derfra 29de april 6 mil v.n.v. udover. Satte „stubberne“. Der var godt om fisk, lange og kveite. Bunden bestod af fin sand med lidt rød koral iblandt. Strøm-

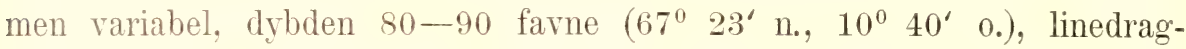
ningen foregik noksaa let. Vi kunde bruge 6 stubber i døgnet, hver paa 1000 kroge. Kom 3 die mai ind med $3230 \mathrm{~kg}$. lange, $2050 \mathrm{~kg}$. brosme, $1940 \mathrm{~kg}$. torsk og $2709 \mathrm{~kg}$. kveite.

3 die tur brugte omtrent paa samme strøg som forrige tur med nogenlunde samme resultat. Strøm og veirforhold ogsaa omtrent de samme. Turen varede fra 6 te til 11 te mai.

tde tur fra 12te til 16de mai. Denne gang gik man lige ud i "bratten" eller eggen. Mandag den 13de mai observeredes $67^{\circ} 20^{\prime}$. Dybden var 175 farne. Sterk nordgaaende strøm, bunden var noksaa jevn uden særlig meget af koral. Der var en masse haakjærring, hvilket omtrent umuliggjorde fisket, ligesom man ogsaa af den grund mistede en stor del af bruget. Der var godt om fisk, men af ovennævite grund blev ikke fangsten stor. Man kom ind med $1125 \mathrm{~kg}$. lange, $1460 \mathrm{~kg}$. brosme og $1682 \mathrm{~kg}$. kveite.

5 te tur 20de-24de mai. Komne klar af land styredes n.v. ${ }^{1 / 2}$ v. indtil eggen. Begyndte paa en dybde af 140 favne $o g$ fortsatte udover til 270 farne. Stormfuldt veir med svær sjø, hvilket hindrede bedriften. Der var godt om fisk, særskilt kveite. Orkanagtige byger tvang skibet iland. Udbyttet kr. 1000 . 
6 te tur 27 de mai til 1ste juni. Denne gang styredes nordligere kurs. „Efter lang undersøgelse fandt vi den nordre kant af et lidet koralrev, der strækker sig ud mod egkanten samt i længere strækning i n.o.-s.v. Vi satte vore stubber i en dybde af 200 favne. Sterk nordgaaende strøm. Dette i forbindelse med storm af s.v. og svær sjø hindrede bedriften. Der var rigt med fisk, særlig kveite. Under gunstigere veirforhold vilde fangsten denne gang blit glimrende. Vi kom ind med en fangst for kr. 1200." Antagelig bredde $67^{\circ} 44^{\prime} \mathrm{n}$.

7 de tur 3die-8de juni. Samme sted. Storm, sterk strøm, masser af haakjærring. Fangstudbytte kr. 1200.

8 de tur 10de--14de juni. Styrede denne gang sydligere og ikke saa langt ud. „Det viste sig, at ogsaa her var godt om fisk. Da det tidligere havde været smaat om fisk saalangt indenfor eggen" $\left(\begin{array}{ll}67^{0} & 34^{\prime}\end{array}\right)$, „drog vi heraf den slutning, at fisken frempaa sommeren siger op og indover bunden fra eggen. Bunden bestod her af sand $0 \mathrm{~g}$ ler. Dybde omkring 100 favne. Strømmen sagte nordgaaende. Vi kom dengang ind med en fangst af $3945 \mathrm{~kg}$. kveite, $1951 \mathrm{~kg}$. længe og $585 \mathrm{~kg}$. brosme. Fangsudbyttet udgjorde kr. 1115.57."

9 de tur. Denne gang styredes 36 mil n.v. Dybden var 300 favne. „Efter længere undersøgelse opdagedes et næs, der stak noksaa langt udover. Udmerket fiskebund. Den bestod nemlig af sand, sterkt blandet med rødkoral. Der var rigt med fisk - baade kveite og rundfisk. Ligeledes var baade veir og strømforhold dennegang gunstige. Fangsten blev derfor dennegang den største under hele dette fiskeforsøg. Efter 3 døgns fiske kom vi nemlig ind med en fangst for kr. 1244.95. Priserne paa fisken var dennegang lave." Bredden $67^{\circ} 46^{\prime}$.

10 de tur 24de-29de juni. Samme sted, men paa grund af storm mislykket.

Om fiskeforsøgene udtaler hr. KJæRstad og rhederen hr. Dув: „Vi har temmelig grundig undersøgt denne strækning mellem Træna og Røst, og, som det vil sees af opgaverne over fangsten for hver tur, har vi omtrent overalt fundet fisk. Angaaende veir- og strømforhold fandt vi ingen væsentlig forskjel mellem kyststrækningerne deroppe og bankerne udenfor Søndmøre. Hvad angaar den hindring, som den masse haakjærring forvoldte os, saa tror vi, at efter den erfaring, man har gjort ude paa Søndmørsbankerne, vil den hindring svinde bort, efterhvert som bankfisket øges og udvides deroppe. Det er derfor vor overbevisning, efter de erfaringer, som vi har gjort, at paa strækningen Træna-Røst vil bli et fangstfelt for en stor del af vor fiskerflaade."

„Det var yderst vanskeligt at faa fat i agn. Ligeledes var det vanskeligt at faa solgt fisken til nogenlunde rimelige priser - med sikker udsigt til, at fiskepriserne yderligere vilde falde. Den saakaldte 
"makketid“ var nu kommet med sterk varme, og da nordlændingerne hænger rundfisken, vilde de $\mathrm{i}$ denne tid nødig kjøbe fisk af frygt for at faa den ødelagt af mak. Priserne paa kveiten var nu ogsaa yderst lave. Det var vor bestemmelse at fortsætte dette fiskeforsøg endnu en tid fremover, og ri forsøgte gjennem flere henvendelser til forskjellige handelsmænd rundtom at faa solgt fisken til nogenlunde rimelige priser, men forgjæves. Af disse grunde saa vi os derfor nødte til at afslutte forsøget og gaa hjem."

Jeg har refereret denne beretning saa udførligt, fordi den er det eneste materiale baseret paa tal og journalhold, som staar til min raadighed over denne havstrækning, hvor planen for mine togter desværre endnu ikke har tilladt mig at arbeide. Endvidere fordi de meddelte kjends. jerninger synes at give et interessant og klart billede af forholdene ved disse forste tilsprang til bankfiske, som med det nævnte og andre lignende forsøg er gjort. Forsøget viser lovende felter, men store vanskeligheder i bedriften. Vi skal senere komme tilbage til disse ting.

\section{Skreifisket.}

Af det foregaaende kapitel har vi seet, at saavel studiet af de flydende egs udbredelse i torskens gydetid februar-marts, som kjendskabet til fiskerierne fastslaar den kjendsgjerning, at skreien kun forekommer i masser paa kystbankerne vestenfor eller søndenfor Sørøen. Medens vinterfisket i Finmarkens amt derfor er begrænset til mindre, lokale fiskerier, foregaar der som bekjendt i Nordlands $0 g$ Troms $\emptyset$ amter store skreifiskerier. Vi skal her forbigaa det store, almindelig bekjendte Lofotenfiske, der er knyttet til Vestfjordens kystbanker, men derimod i korthed omtale de skreifiskerier, som foregaar paa yttersidens (Vesteraalens) og Tromsø amts banker.

Ifølge den beretning over skreifisket i Tromsø amt, som aarlig paa grundlag af lensmændenes opgaver udarbeides af hr. fiskeridirektør DAHL, foregaar der paa mange spredte lokaliteter skreifiskerier. Alt i alt var der i aaret 19006417 mand i Tromsø amt med 1682 baade, 150 skøiter og 7 dampskibe. Tilsammen fiskede disse ca. 3000000 skrei til en omtrentlig værdi af 1000000 kroner. Fisket falder i to bestemte grupper - baadfisket og bankfisket. Baadfisket drives fra mange forskjellige harne, og dette fiske repræsenterer bedriften $\mathrm{i}$ sin oprindeligste form. Det drives i regelen paa saadanne steder, hvor der findes mindre fladere grunder af 30-70 favnes dybde lige i nærheden af kysten, og 
saadanne mindre flak findes særlig rundt de mange store øer udenfor denne kyststrækning, saasom red Sørøen, Loppen, Silden, Fuglø, Arnø (Løksund), Vandø, Helgø, Karlsø o. s. v.

Hvorsomhelst der findes en brugbar havn i nærheden af saadanne steder, samles der en større eller mindre mængde saadanne baade, mest otringer, som paa grund af faldveiret fra de høie fjeldsider i regelen kun ror uden engang at have seil ombord. Som saadanne steder kan eksempelvis nævnes Løksund, hvor der i 1900 laa 325 mand, der tilsammen havde en fangst af 62000 skrei; fisket foregik her i januar og februar. Helgø, hvor der fiskede 110 mand paa 40 baade med en fangst af 50000 skrei. Hilles $\emptyset$ med 240 mand paa 118 baade med 275000 skrei til en værdi af $76710 \mathrm{kr}$. Foruden disse eksempler findes ogsaa mange andre steder helt fra de yderste øer ind i skjærgaarden $0 \mathrm{~g}$ fjordene, saaledes dreves i Tromsøsundet fisket af 504 fiskere paa 172 baade med en fangst laf 79150 torsk til en værdi af $19681 \mathrm{kr}$., og i Lyngen af 36 mand paa 18 baade med en fangst af 6500 torsk til en værdi af $1740 \mathrm{kr}$. Disse sidste eksempler fra fjordene kaldes mest „hjemmefiske“ og drives kun leilighedsvis og i kortere tidsrum. Gjennemsnitslotten var da i Lyngen ogsaa kun $48 \mathrm{kr}$.

Saadanne eksempler som disse viser fisket i sin oprindelige skikkelse, som det er drevet gjennem aarhundreder. I de sidste aar har der imidlertid vist sig en særdeles rask udvikling af fisket; medens der saaledes i 1891 fiskedes 1209200 skrei i Tromsø amt,

$$
\begin{aligned}
& \text { var udbyttet i } 19003027150 \quad \text { - - - } \\
& \text { i } 19015642050 \text { - - - }
\end{aligned}
$$

Denne raske vekst skyldes væsentlig bankfiskets udvikling.

Medens fisket tidligere udenfor Senjens kyst kun dreves som baadfiske paa den landbakke, der findes lige udenfor kysten, fandt de dækkede fartøier i 90 -aarene paa i slutten af skreitiden ogsaa at seile over den (dybrende, som skiller landbakken fra den vestenfor liggende banke Svendsgrunden (se kartet fig. 21). Her fandt de meget fisk, og foretagsomme damperrhedere fandt da $\mathrm{i}$ slutten af 90 -aarene paa at prøve fiske der, ligesom det i stor maalestok drives paa Søndmørs bankerne. Ifølge hr. DAHLS statistiske oversigt, var der

$$
\begin{aligned}
& \text { i } 18985 \text { dampskibe og } 4 \text { skøiter, } \\
& \begin{array}{lllll}
\text { i } 1900 & 7 & - & -150 & \text { - } \\
\text { i } 1901 & 14 & - & -130 & \text { - * }
\end{array}
\end{aligned}
$$

*) For iaar (1902) foreligger ingen fuldstændig oversigt, men et telegram fra lensmanden i Torsken af 19de april melder, at der var tilstede 22 dampskibe, 155 skøiter, 120 smaabaade, 1700 fiskere med en samlet fangst, bare fra dette strøg, af 3000000 skrei. 
Denne raske udvikling har spillet en stor rolle for fiskerierne i det nordlige Norge, særlig fordi den har muliggjort anskaffelse af bedre farkoster for bedriften, hvilket kun var muligt, hvor bankfiske kunde drives i den bedste fisketid.

Dels for at udrede spørgsmaalet om torskestammens gydepladser i det hele, dels for at søge efter nye felter for saadant bankfiske, anvendte jeg meget af "Michael Sars"s drift paa studiet af disse banker i Tromsø og den nordligste del af Nordlands amter. Allerede de første erfaringer fra de i foregaaende kapitel skildrede studier af de drivende torskeegs udbredelse fremkaldte hos mig en sikker følelse af rigtigheden af min tidligere formodning om, at skreiens samlede gydepladser bedst lod sig finde red et studium af eggene i forbindelse med talrige fiskeforsøg udførte med et mindre antal redskaber, istedetfor ved anvendelse af store redskabsmasser paa mindre arealer. Havbunden viser jo nemlig langs den norske kyst, ligesom landet selv, særdeles store niveauforskjelle i meget korte afstande. Lige ud for bankerne har man bratte egger med dybe render eller flader. Da torskens eg erfaringsmæssig kun gydes, medens fisken staar paa de grundere partier, var det at forudsætte, at man $0 \mathrm{~g}$ saa kort tid efter eggenes gydning vilde finde fisken staaende under eggene.

Ved at forfølge denne tanke viste der sig mange steder masser af gydende eg i sjøen ogsaa udenfor de strækninger, hvor fisket nu drives, saaledes særlig paa banken søndenom Sørøen, den fra gammel tid bekjendte "Malangsbanke", der ligger nordenfor Svendsgrunden (se herom kart, fig. 21, teksten nedenfor og foregaaende kapitel). Paa bankerne rundt den vestligste del af Lofoten (Værø) fandtes mængder af flydende eg, ligesaa i Vestfjorden, medens der udenfor Andenæs fandtes mindre. Udenfor Sørøen og paa Malangsbanken fandtes ogsaa straks fisk paa juks og liner. Udstrakte fiskefors $ø g$ tillod ikke den hovedopgave for togtet, som krævede vor nærværelse i Finmarken, og jeg besluttede mig derfor til at forfølge disse fund videre ved at søge igangsat prøvedrifter med det i teknisk henseende bedste fiskeapparat, som fortiden kjendes, nemlig vore smaa linedampere. Tanken vakte overalt tilslutning. Fiskeristyrelsen optog straks forslaget paa sit budgetforslag, og ved velvilje fra alle instantser, fiskeriraad, regjering og storthing lykkedes det at erholde de fornødne statsbidrag paa den maade, at kr. 10000 bevilgedes til prøvedrift paa bankerne udenfor kyststrækningen AndenæsRøst, medens det fornødne beløb til prøvedriften fra Sørøen til Malangen tillades taget af de til "Michael Sars"s drift bevilgede midler. Ved anbudene meldte der sig flere udmerkede fiskedampere, af hvilke "Alken“, tilhørende hr. Fredriksen, Melbo, blev antaget til forsøget Røst-Ande- 
næs, medens „Havellen“, tilhørende hr. BRandtzæG, Abelvær, overtog forsøget paa strækningen Sørøen-Malangen.

Af hensyn til den mængde ny viden, som disse forsøg har bragt os om disse nordlige banker, skal jeg^i det følgende skildre forsøgenes gang og tilslut give enkelte oplysninger om vinterfisket paa disse banker i det hele. Herunder støtter jeg mig dels til de gode indberetninger, som de med forsøgsdamperne sendte observatører har afgivet, dels til andre erfaringer.

\section{„Alken"s forsøg fra Andenæs til Røst.}

Allerede i lange tider har der i Nordland været næret ønske om, at bankerne udenfor Vesteraalen skulde undersøges. Som saa mange andre steder af kysten, er de grundere partier af bankerne (af $40-50$ favne dyb) skilt fra landbakken ved en ca. 1 mil bred rende. Fiskeriet foregaar mest langs land. Det har her for befolkningen længe staaet som desto mere ønskeligt at faa disse banker undersøgt, som skreiens forekomst paa landbakken frembyder adskillige eiendommeligheder. I regelen afsluttes nemlig fisket her i marts, uden at man i nævneværdig grad ser spor af gydning eller til, at fisken opholder sig der længere. Ifølge hr. fiskeridirektør J. O. DAHLs mangeaarige erfaringer fra dette distrikt har dette været regelmæssig i lange tider, og det langs store dele af den nordenfjeldske kyststrækning. Derimod hænder det i regelen paa steder som B $\emptyset$ (ved Hadselfjordens munding), at der indtræder et saakaldet efterfiske i slutningen af april og mai. Der fiskes da udgydt fisk (skraapfisk.)

Disse forhold har hos befolkningen naturlig opkastet den tanke: Hvor gyder Yttersidens fisk? Et spørgsmaal, som hr. DAHL ogsaa gjentagende har gjort opmerksom paa. Det har ligget nær for mange at antage, at fisken seg ud til de ovennævnte banker for at gyde der, et spørgsmaal, til hvis løsning „Alken“s togt skulde søge at give sit bidrag.

I tiden fra 1ste til 14 de februar gjordes ud for Langenæs, henholdsvis $12,13^{1 / 2}, 14^{1} / 2$ kvartmil af Langenæsfyrlygten, 4 smaa forsøg. Tilsammen blev der trukket 3200 angler line, med en fangst af 1000 skrei. Storm og snekave samt strøm hindrede i høi grad bedriften og foraarsagede tildels betydelige redskabstab i denne tid.

Den sidste halvdel af februar gav heller ikke bedre resultater, idet veiret var haardt, og ingen tyngde af fisk kunde merkes. I tiden fra 30te februar til 2 den marts, blev der trukket ialt paa 11 stationer 78600 angler line med en fangst af kun 1400 skrei, 2200 brosme og hyse, 
ca. 200 kg. kveite og 6 stkr. „Haabrand“. Linetabet udgjorde 20400 angler. Fra 5te marts toges station i Stene, Bø. Fra denne station fiskedes mest ud for Stensfjorden $0 \mathrm{~g}$ Skolmen indtil den 21de marts, uden at fangsten blev nævneværdig.

Det eneste sted, hvor der fandtes lidt fisk, var klos i land, hvor garnbaadene, saaledes under Hovden, kunde faa op til 300 paa en lænke. Længere ude aftog fisken meget hurtig, idet linebaade $5 / 4$ mil af land kun fik ca. 40 skrei paa 2500 angler, $0 g^{*}$ „Alken“ $16 \mathrm{kv}$. mil ud i samme retning fik paa 11400 angler, agnet med sild og saltede sprutbællinger, 40 torsk, 250 brosme, ca. $100 \mathrm{~kg}$. kveite.

Forsøg tvers af Skolmsnæs, 5 kvartmil af land paa 50-60 favne vand, gav f. eks. kun 118 skrei og 150 brosme paa 12000 angler line.

De forsøg, der gjordes, dels under stormende veir og mange hindringer, godtgjorde til evidens, at Lofotens yderside var yderst fattig paa skrei, ligesom heller ingen betydelig egmængde kunde konstateres i sjøens overflade paa de undersøgte lokaliteter.

Fra begyndelsen af april toges station ved Røst, hvor den 2 den og 3 die april paa 12000,11000 angler line blev fisket henholdsvis 500 og 1200 skrei, 3 kvartmil søndenfor Skomvær.

Indtil den 2 den mai, da fartøiets forpligtelser ligeoverfor forsøget bortfaldt og forsaavidt afsluttedes, bibeholdtes denne station, og fangsten faldt tildels meget heldig.

Der fiskedes den hele tid hovedsagelig paa grundt vand ca. $3-5$ kvartmil af Skomvær. Paa 16 fangstdage var der saaledes indtil den 24 de april fisket paa tilsammen 239000 angler line 34719 skrei og 4650 brosme og hyse. Den 27 de april meldte observatøren, at der var fisket yderligere 10200 skrei. Den 28de og 29de april fiskedes endnu henholdsvis 2870 og 1200 skrei, og der meldtes om godt fiske vest og nord af Røst. Yderligere telegraferer observatøren efter forsøgenes afslutning, at Alken alt ialt paa 22 fangstdage fra Skomvær $3-7$ kvartmil af land fik 50650 skrei, et resultat, der i betragtning af den korte fangsttid maa kaldes udmerket godt.

Af "Alken"s togt har vi altsaa høstet den erfaring, at bankerne udenfor Vesteraalen iaar (1902) praktisk talt var tomme for fisk, først saa langt vest som ved mundingen af Vestfjorden (rundt Røst og Skomvær) fandtes i april mængder af torsk, hvilket stemmer med de ovenfor skildrede forsøg, udførte af „Expres“. Her synes der at være paavist et udmerket fiskefelt for havfiskefartøier. Med hensyn til den paaviste fattigdom udenfor Vesteraalen gjør jeg opmerksom paa, at det vilde være forhastet at trække den slutning, at forholdene altid vil være som iaar. Til en saadan slutning kræves langt flere erfaringer, som kun fremtiden kan give. 


\section{„Havellen“s fiskeforsøg fra Sørøen til Malangen.}

Forsøget begyndte den 21de januar med station i Bergsfjord (Loppehavet). I tiden 22de januar til 15de februar gjordes ialt 10 forsøg, hvorunder ialt sattes 115500 kroge med en fangst af ialt 6137 skrei, 1500 hyse og brosme. Linetabet var 24000 kroge. Storm og snetykke hindrede i denne tid forsøgene i høi grad.

Saa meget fremgik iallefald dog af forsøgene, at der paa banken rundt øen Loppen kun var meget lidet fisk, mens der paa banken udenfor Sørøen (Brevig) især i begyndelsen af forsøget var særdeles meget fisk. Nogle eksempler kan vise dette:

22 de januar, 10500 kroge sattes paa 70-120 farnes dyb n.o. af Loppen. Fik kun 2000 kroge igjen, fangst 106 skrei.

25 de januar, sammesteds 10500 kroge, 225 torsk, 360 brosme, 20 hyse, 6 kveiter.

28 de januar sattes 10500 kroge paa Brevigsbanken (paa $70^{\circ} 32^{\prime} \mathrm{n}$. $21^{0} 47^{\prime}$ 0) 50 favne med fangst af 1480 torsk, 150 brosmer, 20 hyse.

Fra den 21de februar toges station i Sommerø og fra denne station blev alle forsøg paa Malangsgrunden 1ste dag fik man paa 7200 kroge 1700 torsk foruden endel brosme, hyse og stenbit. (Linerne sattes paa $69^{\circ}\left[\begin{array}{llllll}53^{\prime-1} \mathrm{n} & \mathrm{og} & 17^{0} & 44^{\prime} & 0 .\end{array}\right)$. En anden sætning samme dag (3 600 kroge) med kun $1 / 4$ times henstaaen gav 600 torsk. Paa juks toges 600 torsk. Fra denne dag af faldt fiskeriet stadigt heldigt. I den tid observatøren var ombord, 22de bebruar til 26de marts, gjordes følgende fangster (se tabellen).

Fiskens forekomst syntes at være begrænset til en bestemt lokalitet syd for banken omkring den rende, som stikker sig nordover fra Vengsødybet og omtrent midt ind fi banken. Et par dage tilbragtes saaledes med at forsøge rundt omkring paa hele banken med juks og liner, men intetsteds kunde man merke fisketyngde uden i den skjæve firkant, som ligger mellem folgende 4 punkter: N. br. $69^{0} 53^{1} \mathrm{z}^{\prime}$, l. 0. $17^{0} 53^{\prime}$. N. br. $69^{0} 49^{1} / 2^{\prime}$, l. o. $17^{0} 42^{\prime}$. N. br. $69^{0} 55^{3} / 4^{\prime}$, l. o. $17^{0} 35^{\prime}$. N. br. $69^{0} 53^{\prime}$, 1. ø. $17^{0} 21^{\prime}$.

Som eksempel paa dette forhold kan det forsøg "tjene, der gjordes den ${ }^{17} / 3$. Man dampede da rundt omkring paa hele banken $0 \mathrm{~g}$ forsøgte hvert 5te minut med juks. Paa bankens ydre del sattes ogsaa '4 800 liner, paa hvilke der kun fangedes 8 skrei. Hele dagens fangst blev kun 240 skrei, foruden nogle faa andre fiske.

„Havellen"s forsøg gav allerede iaar stødet til et stort fiskeri paa Malangsgrunden. 


\section{Havellens fangst paa Malangsgrunden}

22 de febr. - 26 de marts 1902 .

\begin{tabular}{|c|c|c|c|c|c|c|}
\hline Datum & 1902 & Antal linekroge & Fanget skrei & \multicolumn{3}{|c|}{ Anmerkninger } \\
\hline Febr. & 22 & 18200 & 2400 & Deraf & aa juks & 100 \\
\hline & $2 t$ & 18200 & 5300 & - & - & 200 \\
\hline & 25 & 17800 & 5800 & - & - & 300 \\
\hline & 26 & 10600 & 1278 & - & - & 28 \\
\hline & 27 & 17800 & 4750 & - & - & 250 \\
\hline & 28 & 17800 & 3500 & - & - & 200 \\
\hline \multirow[t]{18}{*}{ Marts } & 3 & 11200 & 3000 & - & - & 341 \\
\hline & $t$ & 18000 & 4720 & - & - & 220 \\
\hline & 5 & 18000 & 2951 & - & - & 251 \\
\hline & 6 & 21600 & 2553 & - & - & 53 \\
\hline & 7 & 8600 & 2590 & - & - & 70 \\
\hline & i & 28400 & 7540 & & & \\
\hline & 11 & 18000 & 3170 & - & - & 170 \\
\hline & 13 & 7200 & 1170 & & & \\
\hline & 15 & 32400 & 7170 & - & - & 150 \\
\hline & 17 & \pm 800 & 248 & - & - & 240 \\
\hline & 18 & 10800 & 710 & & & \\
\hline & 19 & 25200 & 2505 & & & \\
\hline & 20 & $1 \pm 400$ & 2510 & & & \\
\hline & 21 & $1 \pm 400$ & 3350 & & & \\
\hline & 22 & 32400 & 3500 & - & - & 39 \\
\hline & 24 & 10800 & 800 & & & \\
\hline & 25 & 7200 & 1340 & & & \\
\hline & 26 & 18000 & 3000 & & & \\
\hline $\begin{array}{c}\text { Tils. } \\
\text { fangsto }\end{array}$ & $\begin{array}{c}24 \\
\text { tdage }\end{array}$ & 401200 & 75847 & Deraf & a juks 2 & 612 \\
\hline
\end{tabular}


Allerede den 3die marts, da efterretningen om „Havellen"s gode fangst $\mathrm{i}$ den første uge gjennem telegrafen og gjennem rygtet blev bekjendt, indfandt damperne "Sigerfjord" $0 \mathrm{~g}$ "Rener" sig paa feltet. Disse efterfulgtes snart af andre, saaledes at ved ugens udløb ialt 21 dampere fiskede paa feltet sammen med „Havellen".

Efter de af kaptein Iversen indhentede opgaver hidsættes følgende tabellariske oversigt over den første uges fangst, som disse dampere gjorde paa Malangsgrunden. I en særskilt rubrik ved siden findes tilført de totalfangster, som disse dampere opgav at have gjort tidligere paa Svendsgrunden.

Ugen fra $10 / 3{ }^{15} / 3$ var fra 23 dampere, hvoraf 2 hvis fangst ikke kom til observatørens kundskab, den samlede fangst $15 \pm 000$ skrei. Ugefangsten for skøiter og baade beløb sig til ca. 30000 skrei. Totalsummen for ugen blir altsaa over 180000 skrei.

Den derpaa følgende uge, ${ }^{17} / 3{ }^{22} / 3$, var der 24 dampere tilstede. Deres fangst med undtagelse af 2, fra hvem opgaver ikke kunde erholdes, var 234000 skrei, medens skøiter og baade opfiskede ca. 45000 skrei. Alt i alt altsaa for denne uge ea. 279000 skrei.

Totalsummerne af disse opgaver for Malangsgrunden indtil $22 / 3$ bliver saaledes:

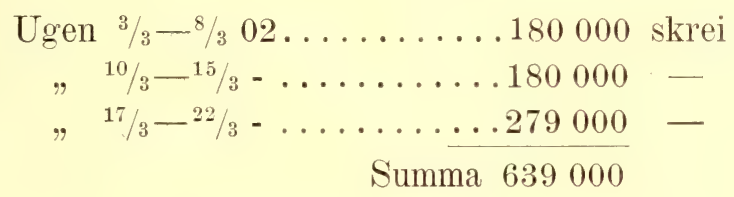

Kommer hertil „Havellen“s fangst indtil $26 / 3$ af 75847 skrei, faar man altsaa et totalkvantum af over 700000 skrei, som vi ved er opfisket.

Fisket fortsattes videre hele april maaned. Om dette tidsrum har jeg ikke saadanne paalidelige opgaver for marts maaneds vedkommende.

Om forsøget meddeler observatøren - _ „Michael Sars"s kaptein IverSEN — i sin indberetning følgende: „Veirforholdene viste sig iaar at være gunstigere paa Malangsgrunden end paa Svendsgrunden, dette bevistes derved, at vi havde adskillig flere sjøveir end de, der var stationeret $\mathrm{i}$ Gryllefjord. Grunden herfor var, at den mest mulige vind var landvind, det vil sige s.o. til nordlig. Dog er det sandsynligt, at Svendsgrunden ligger heldigere til for vind fra syd til v.s.v., men dette blev ikke bevist i den tid, jeg opholdt mig ombord. Haakjærringer voldte os en del bryderi den første tid ved at rane fisk og afbide linerne, men senere var vi den ganske kvit. 


\begin{tabular}{|c|c|c|c|}
\hline Skibets navn & Hjemsted & $\begin{array}{c}\text { Fangst paa } \\
\text { Malangsgrunden } \\
3 / 3 \_8 / 3 \quad 1902\end{array}$ & $\begin{array}{l}\text { Tidligere total- } \\
\text { fangst paa } \\
\text { Svendsgrunden }\end{array}$ \\
\hline Otteren ......... & Harstad & 5500 & 29000 \\
\hline Vulkan........... & 一 & 10000 & 18000 \\
\hline Skolpen ......... & Sigerfjord & 22000 & 36000 \\
\hline Rener... . . . . . . . . & - & 22000 & 36000 \\
\hline Sigerfjord . . . . . . & - & 19000 & 9000 \\
\hline Braken ......... & $\mathrm{B} \emptyset$ & 14000 & 17000 \\
\hline Olaf ............ & Tromsø & 10000 & 14000 \\
\hline Slogen .......... & Aalesund & 5000 & 9000 \\
\hline Skarven... . . . . . . & Tromsø & 21000 & 14000 \\
\hline Fiskeren ........ & Vesteraalen & 9000 & 20000 \\
\hline Greip .......... & Trondhjem & 4000 & 16000 \\
\hline Trio ............ & Strømsøen & 8000 & 10000 \\
\hline Falken ........... & Namdalen & 5000 & 3000 \\
\hline Rolf ........... & Harstad & 4500 & intet \\
\hline Lurvik ........... & Chr.sund (N.) & 5000 & - \\
\hline Koral .......... & Aalesund & 8600 & 400 \\
\hline Uræd ............ & Chr.sund (N.) & 5000 & 2000 \\
\hline Hans Egede ...... & Harstad & 2500 & 5000 \\
\hline Reform......... & Aalesund & $?$ & $?$ \\
\hline Forsøget ........ & Harstad & $?$ & $?$ \\
\hline Kvædfjord........ & Kvædfjord & $?$ & $?$ \\
\hline 21 dampere & ialt & 180000 skrei & 238400 skrei \\
\hline
\end{tabular}

Anm. Af disse dampbaade brugte kun "Sigerfjord" og "Rener" Malangsgrunden hele ugen, resten fra $1-5$ dage af ugen. 
Af andre fiskesorter forekom ikke saa lidet og ofte meget stenbit, smaabrosmer, hyse og tildels lidt smaakveite samt store rødspætter, men alle disse sorter blev som regel bortkastet under linetrækningen, da det ikke lønnede umagen at gjemme paa dem. Dog blev kveite, naar den ikke var altfor liden, som oftest hjemsendt af fiskerne til husholdningen.

Kyststrækningen fra Malangen og nordover er, som man kan se ved et blik paa kartet, overstrøet med øer, holmer og skjær og baaer, der tildels ligger adskillig tilhavs, men dog er den del, der hovedsagelig vedkommer fiskerne, ikke paa langt nær saa farlig, som den ser ud til og har ordet for. Uden belysning og daarlig opmerket vil den $\mathrm{i}$ den mørke vintertid og i snetykke være meget styg, derom er jo ingen tvivl, men ved opsætning af $3-4$ lygter vil man kunne drive denne grund meget greit. Naar man først blir vant og kjendt med kysten, synes man alt er greit og klart, bare ikke snetykken blir for slem, men den er lei at have med at gjøre andre steder ogsaa. Man har tildels gode og rummelige havne, kun ca. 2 timers stiming fra fangstpladsen."

Indseilings- og havneforholdene var gjenstand for særlig opmerksomhed fra kaptein Iversens side (se herom fiskeristyrelsens videnskabelige afdelings aarsberetning, hvor detaljerede opgaver herom).

„Eftersom skreien iaar stod meget begrænset," siger kaptein IversEN, „og det paa samtlige banker, var der blandt fiskerne paa Svendsgrunden, hvor ca. 500 skøiter deltog i fisket, et voldsomt stort linetab. Disse linetab blev i de færreste tilfælder forvoldt ved uheldigt veirforhold, men mest foraarsaget ved kollision mellem fiskerne selv. Mange afholdt sig fra at sætte linerne, hvor fisken stod tykkest; thi for at kunne konkurrere med held, som forholdene nu er, blir man nødt til at kappe anden mands line og pilke ind anden mands fisk, eftersom man saa udmerket godt ved, at omtrent alle andre gjør det samme. Iaar var forholdene vistnok værre end nogensinde, hvorfor ogsaa fiskerne selv har skreget efter opsyn, men hvordan skal et opsyn blive effektivt blandt en saadan mængde?"

Dette fortjener vistnok den mest indgaaende $o g$ energiske overveielse.

Som vi ovenfor saa, var det væsentlig kun det sydlige og sydostlige afheld af banken, hvor fisken stod, ganske som tilfældet er paa Svendsgrunden. Afheldet gaar her over i en tragtformig rende, som samler op fisken, som kaptein Iversen udtrykker det "som radgarnet paa en ruse". Grunden til at "Havellen" fandt fisken saa hurtigt, var utvivlsomt det heldige forslag fra hr. Iversen straks at prøve der, hvor forholdene mest lignede det sted, hvor der fiskes paa Svendsgrunden. Her fandtes i 1901 ogsaa de største masser flýdende eg. 
Foruden de mindre partier af Svendsgrunden og Malangsgrunden, hror disse skreifiskerier foregaar, findes der utvivlsomt ogsaa andre partier, hvor der vil kunne drives andet lønnende bankfiske paa disse banker. Et engelsk-norsk kompagni satte for nogle aar siden igang forsøg her ude og siges tildels at have fundet meget fisk, særlig kveite. Hjemmeboende fiskere kjender jo ogsaa begge banker meget godt og driver dem om sommeren, men med meget faa og smaa farkoster, hvad der jo ikke kan undre nogen, naar man erindrer, hvad der ovenfor er anført om dampskibet „Expres"s fiskeforsøg. Kaptein Iversen meddeler, at man nu tænker paa at drive bankerne efter lange og kveite som paa Storeggen, og naar folk først blir kjendt, finder de nok de rette fiskepladse.

For til slutning at omtale dette fiske med nogle ord, skal vi betragte de fartøier, skikkede for havfiske, som forefindes der nord. Kaptein Iversen beskriver fartøierne deroppe saaledes:

„Bankskøiterne er af de mest forskjellige typer og størrelser, mest dækkede, men ogsaa udækkede; de fører 2-3 doryer med 6-8 mands besætning. Disse fører stadig med sig agn, og fiskerne agner selv sine liner. Naturligris kan disse farkoster ikke konkurrere med dampskibene i kvantum, men de har dog vist sig tildels meget lønnende, eftersom udgifterne blir saa smaa i alle henseender i forhold til dampernes.

Idealet af en bankskøite kræver, at den er billig, sterk, med stor bæreerne, velseilende i storm og i løi vind, let at manøvrere, bjergelig i storm, let at ro i stille veir, sterk og letvindt rigget og kravelbygget. Alle disse egenskaber maa vel næsten ansees for en umulighed at forene, og dette er da ogsaa grunden til, at typerne er saa forskjellige, den ene med nogle gode egenskaber, den anden med andre, og ingen fuldkommen til alslags fiskeri."

De fiskedampere, der deltager i skreifisket er hjemmehørende paa strækningen Aalesund-Tromsø og er af de forskjelligste typer, størrelse $o g$ hensigtsmæssighed, og for en dels vedkommende er de indrettet som fiskebaade kun i skreitiden, og naar denne er slut, blir de, som oftest, sat $\mathrm{i}$ agnsildfart eller lignende.

Til et veludrustet fiskedampskib i skreitiden hører en besætning af 12 fiskere, 1 dæksmand, 1 fyrbøder, kok, maskinist og fører - ialt 17 mand med 6 doryer. Enten har man en brygge med hus iland paa det sted, der ønskes som station, eller man har en lægter eller jægt foranankret der. Disse blir brugt for agningen af linerne, som besørges af 6 leiede mænd, samt for opbevaringen af agnet og redskaberne. Nogle fører ogsaa egne kulprammer, og atter andre bruger en stor pram baade til kul og. agnoplag, hvilket sidste synes mest hensigtsmæssigt.

Som agn bruges hovedsagelig "sprutgor" (lever af blæksprutten „ak- 
keren" (Ommatostrephes todarus) nedsaltet i gjennemhullede tønder, men - især længere paa vaaren bruges ogsaa saltet skjæl. Begge disse sorter agn har vist sig mest hensigtsmæssig udfor Senjen; dog bruges og saa tør og saltet „belling“" (kappen af blæksprutten) og sild.

Som et eksempel paa hvorledes man indretter sig med delingen af udbyttet meddeler kaptein Iversex, at "Havellens, rhederi fik $60 \%$ af fangsten, og de resterende $40 \%$ deles i 16 lotter. De 12 fiskere faar 1 lot hver, dæksmanden 40 kroner pr. maaned $+1 / 2$ lot, fyrbøderen $0 \mathrm{~g}$ kokken $60 \mathrm{kr}$. pr. maaned uden lot. Maskinisten $150 \mathrm{kr}$. pr. maaned + $1 / 2$ lot. Føreren $125 \mathrm{kr}$. pr. maaned +- 1 lot. De resterende 2 lotter tilfalder rhederiet. Rhederiet $0 \mathrm{~g}$ alle lotsfolk er delagtige i agn og agneudgifter efter samme forhold $(60 \%$ og $40 \%$ ). Alle mand holder egen kost.

Hver dory bemandes med 2 mand, og alle 6 doryer sætter og trækker sine liner samtidig. Linerne sættes altid parallele. Eftersom de alle i regelen har lige meget at trække, hersker herunder stor kappestrid.

„Skreien blir ikke altid saa pent behandlet, at den blir forste kvalitet i varen. Fiskerne tænker navnlig paa at faa mest mulig fisk, og for at faa udføre dette, maa de bruge mest mulig line og ligge længst mulig ude. Hermed har fiskerne nok at gjøre den tid, de er paa sjøen, og de har ingen anledning til at tænke paa at sløie, slagte eller vaske fisken, heller ikke har de nogen fordel deraf, eftersom ingen høiere pris opnaaes. Følgen heraf er, at fisken, ved at ligge i dynge paa 4-8 fods høide nede $\mathrm{i}$ et ildelugtende fiskerum ofte $\mathrm{i}$ stadig bevægelse $\mathrm{i}$ slingringen, allerede før udlosningen til kjøberen har tabt endel i salgsværdi. Kjøberne, specielt fartøierne, lader 2-5000 fisk henligge i en stor dynge sløiet eller usløiet paa dæk, ofte i sterk frost, og med knapt mandskab tager flekningen en lang tid, især naar endel er frossen og maa udhænges i not i sjøen for at tines op, før de kan tilberedes for nedsaltning. Vaskning af fisken før saltningen blir der sjelden tale om, men nytten af dette er der jo delte meninger om. Dog maa vel en del af den behandling, den faar af kjøberen, ogsaa ansees for mindre heldig for at frembringe god vare." 
Efter denne korte fremstilling af skreifisket paa bankerne i det nordligste Norge skal vi foreløbig afslutte vor skildring af fiskerierne i det hele for at komme tilbage til overveielser over disse i sidste kapitel. Forst skal ri dog betragte en anden bedrift, der knytter sig til landets nordligste egne, nemlig hvalfangsten og de dyrs levevis og vandringer, som er gjenstand for denne bedrift. 


\section{Fjerde kapitel.}

\section{Hvalerne.}

Hvalerne er den eneste gruppe blandt pattedyrenes mangfoldige og indbyrdes saa forskjellige former, som gjennem hele sit liv tilhører det aabne hav. Selv de glimrende srømmere, sælerne, maa i den tid, de skal føde sine unger, søge kysterne eller isen, medens hvalerne, fra de fødes, $o g$ til de selv sætter en ny generation i livet er fuldt uafhængige af det faste land. Den mest fremtrædende forskjel i deres levevis fra fiskenes er derfor den, at de paa grund af sin luftaanding med bestemte mellemrum maa søge havoverfladen for at fylde sine lunger med luft. Det er i dette ‘qieblik, de blir synlige for fiskeren og den sjøfarende, medens fiskemasserne under hans fødder ofte blir ham ganske ubekjendte.

I overensstemmelse med denne hvalernes levevis i det aabne hav har hele deres legemsbygning stor lighed med fiskenes. Ligesom hos fiskene er deres hale bygget som et kraftigt svømmeredskab med en stor halefinne, der dog skiller sig fra fiskenes derved, at hvalernes er vandret, medens fiskenes er lodret. Hvalernes forlemmer er luffer, der sidder tæt bag hovedet og anvendes til at styre retningen for deres bevægelse. Baglemmerne mangler. Huden er glat og nøgen. De for pattedyrene saa karakteristiske haar forekommer kun $i$ form af enkelte børster især rundt !munden. !Huden er forsynet med et tykt lag spæk, der dels isolerer den høie kropsvarme fra det ofte iskolde vand, i hvilket de færdes, dels tjener som reservenæring under de lange vandringer, de foretager uden at optage næring, dels bidrager til at formindske deres vægt og holde dem svævende i vandet. Munden er enten forsynet med flere eller færre tænder, der i regelen har form af stumpe kegler, men ogsaa kan være spidse, eller ogsaa mangler tænder ganske, og i saafald er munden forsynet med store parallele hornplader (barder), som 
hænger ned fra overmunden, ganen, $\mathrm{og}$ tilsammen danner et mægtigt sileapparat til opsamling af harets drivende liv (planktonet), som udgjør disse hvalers føde. Øinene er meget smaa, de ligger lige nede i mundvigen. Ørene mangler den ydre ørebrusk og har alene en meget fin øregang ind til ørets indre dele. Meget karakteristisk er det, at næseborene, ligger oven paa hovedet, hvorved hvalen kan aande i samme øieblik, den naar overfladen. Den støder da ud sin aande, som vistnok i regelen river med sig endel af overfladens vand, og desuden i den kolde luft fortætter sin vanddamp til en straale, der i regelen forsvinder som en fin liden støvsky, der hos de forskjellige arter har saavidt forskjellig form, at den ovede fangstmand allerede paa langt hold ved, hvilken art han har for sig.

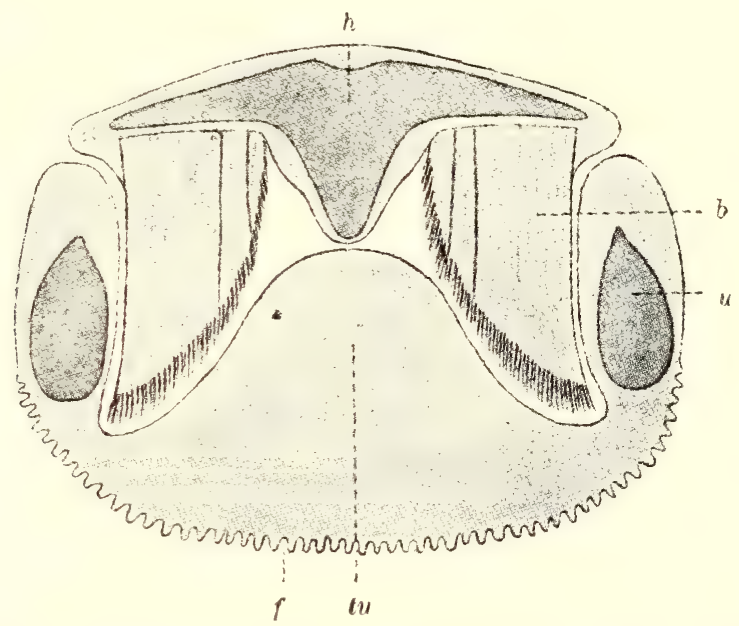

Fig. 35. Skematisk tversnit af hovedet af en finhval efter Boas lærebog i zoologien. $\mathrm{h}=$ hovedet, $\mathrm{b}=$ barderne, $\mathrm{u}=$ underkjæven, tu $=$ tungen, $\mathrm{f}=$ furer paa bugsiden.

Hvalerne deles $\mathrm{i}$ to fra hinanden meget forskjellige grupper tandhvalerne og bardehvalerne, som indbyrdes skilles fra hinanden ved en række meget udprægede karakterer.

Tandhvalerne har flere eller færre tænder, aldrig barder, næseborene munder sammen ud i et rendeformet „tverstillet blæsehul“. (I sin benbygning udmerker de sig ved, at issebenene (pxrietalia) adskilles ved et mellemisseben (interparietale), overkjævebenene er særdeles sterkt udviklede og bagud støder helt til nakkebenene (occipitalia), underkjævebenene er sammensmeltede, saa underkjæven danner en hel bue, brystbenet er sammensat af flere stykker til en stavformet plade med flere egte ribben. Ribbenenes forening med brystbenet ofte forbenet, de forreste ribben med sit hoved fæstede til hvirvlernes corpus, med tuberositas til processus transversus). Tandhvalerne er rovdyr, de lever af blæk- 
sprut, fisk, ja enkelte angriber - dog kun undtagelsesvis, sæler og andre hvaler.

Bardehvalerne har kun i fosterlivet tænder, som igjen forsvinder, før barderne udvikler sig. Barderne er trekantede tynde hornplader, som i sin indre rand er flosset op til tynde trevler. De hænger i to rækker ned fra ganen og danner derved tilsammen et filter (se fig. 35), der holder tilbage smaadyr (smaa fisk, krebs, bløddyr), som med vandmasserne strømmer ind i det svære gab, medens vandet selv presses ud gjennem filtret af den store kjødfulde tunge, der virker som et stempel. Næseborene er adskilte.

(I benbygningen kan merkes: Issebenene støder sammen, overkjævebenene grænser kun mod pandebenene, underkjævebenene er ikke sammenvoksede, men danner hver en stor bue. Brystbenet har kun et forbeningspunkt $\mathrm{og}$ staar i forbindelse kun med 1 par ribben. Ribbenene fæstes dorsalt kun med tuberculum).

Bardehvalerne er, som deres maade at ernære sig paa antyder, fredelige og store dyr. Fordi munden er omdannet til det store sileapparat, er hovedet af overordentlig størrelse, hvilket gir deres hele kropsform et fra tandhvalerne afvigende udseende.

I det følgende skal vi give en kort beskrivelse af de vigtigste hvalarter, som forekommer i det hav, som omgiver det nordligste Norges kyster, og i senere give en skildring af, hvad der er bekjendt om deres levevis.

\section{Tandhvalerne.}

Denne store dyregruppe omfatter særdeles mange arter, hvoraf de fleste lever i sydligere farvand. De, som forekommer hos os, kan deles i flere grupper, som iallefald bidrager til at lette oversigten, om grupperne end ikke omfatter særdeles ensartet byggede (beslegtede) former.

I. Delfinerne har i begge kjæver flere eller færre, oftest smaa kegledannede tænder. Der findes en mængde former især af de mindre arter, som mest lever i nærheden af kysterne og der forfølger stimfisk som f. eks. sild, makrel o. l. Man deler dem i regelen i de spidshovede og buthovede arter.

A. De spidshovede delfiner udmerker sig ved en mere eller mindre skarp fure, som skiller panden fra snuden eller, som den kaldes, nebbet. De har af alle hvaler de fleste tænder ialt 80-200 (20 til 50 i hver kjævehalvdel). Her tillands bærer de alle navnet "springer", 
som er en fællesbetegnelse paa samtlige former. Der har hersket tvivl om, hrilken art de f. eks. i Finmarken almindeligst forekommende springere tilhører. Collett saa saaledes i 1872 og 1880 i Porsangerfjorden i Finmarken „en stor delfinart med en længde af omkring 12 fod $^{1}$ ), der altid var kjendelig ved sine voldsomme bevægelser, idet den gjentagne gange efter hinanden sprang helt op over sjøen og lod sig falde paa ryggen; herunder var allerede i lang afstand synlig dens skinnende hvide underside." Han antager, at denne art er Delphimus tursio. SparreSchneider $^{2}$ ) har seet det samme fænomen, og antager ligeledes, at den tilhører samme art. Jeg har ogsaa seet dette mange gange og seet disse springere tumle sig rundt bougen af fartøiet. Derved var det mig muligt at iagttage dem saa nøiagtig, at de for mig med sikkerhed synes at maatte henføres til arten Delphimus acutus, hvorimod jeg ingen holdepunkter kan finde for, at $D$. tursio er konstateret at forekomme i det nordligste Norge. Derimod er Delphinus albirostris iagttaget af Schneider, og det synes ikke udelukket, at $D$. delphis kan forekomme. Jeg vil derfor nævne

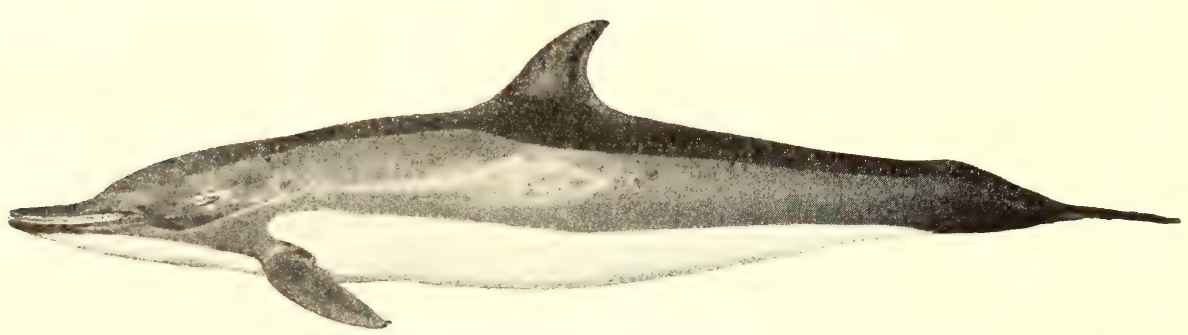

Fig. 36. Spidssnudet delfin, Delphinus delphis. Fotograferet i Bergens museum.

disse tre arter springere, idet jeg personlig altsaa antager, at den art, fiskerne fortrinsvis kjender, er $D$. acutus, men at de ogsaa vilde kalde de andre arter med samme narn.

1) Delphinus delphis (kaldes i England „almindelig delfin“) har af alle arter længst snude (se fig. 36), som er tydelig skilt fra panden ved en skarp fure, snuden er sort. Tændernes antal kan variere fra 94 til $\left.100^{3}\right)$ i hver kjæve. (73 hvirvler, 12-13 par ribben). Kroppen langstrakt og slank, rygfinnen midt paa ryggens medianlinie, ikke meget bagoverbøiet. Farven varierer meget. Ryggen, overkjæven, halen og fin-

1) Robert Coldett: Meddelelser om Norges Pattedyr i aarene 1876-1881. Nyt Mag. f. Naturv. 27 bd. 1883.

2) Sparre-Schneider: Delphinus albirostris etc. Tromsø museums aarshefter 1 . 1878

3) F. W. True. A. Review of the Family Delphinidae. Bull. Smiths inst. no. 361889. 
nerne sorte eller mørke, graa, undersiden hvid eller lys grøngraa. Siderne indtagne af to elliptiske lysere felter, der fortil snart er gulagtige, snart graa. Øiet omgivet af en sort ring, der fortsætter forover i en sort streg. Gjennemsnitlig længde $6-7$ fod. Findes ved Danmarks, Englands, Amerikas kyster, har i det hele stor udbredelse, lever af fisk og blæksprutter. CoLLETT ${ }^{1}$ ) omtaler nogle kranier, sandsynligvis fra vor vestkyst. J. A. GRIEG ${ }^{2}$ ) omtaler et skelet fra Bergen.

2) Delphinus (Lagenorhyncus) albirostris, hvidsnudet springer. Snuden kort, gulagtig hvid. 52 tænder i hver kjæve. (88-92 hvirvler) (se fig. 37). Kroppen mere kort og tyk end foregaaende, rygfinnen høi og bagoverbøiet. Ryggen $0 \mathrm{~g}$ finnerne sorte med lysere schatteringer paa kropssiderne. Undersiden $\mathrm{og}$ snuden hvide. Længde ca. 5 fod.

To eksemplarer i 70 aarene fangede i Lyngenfjorden (beskrerne af

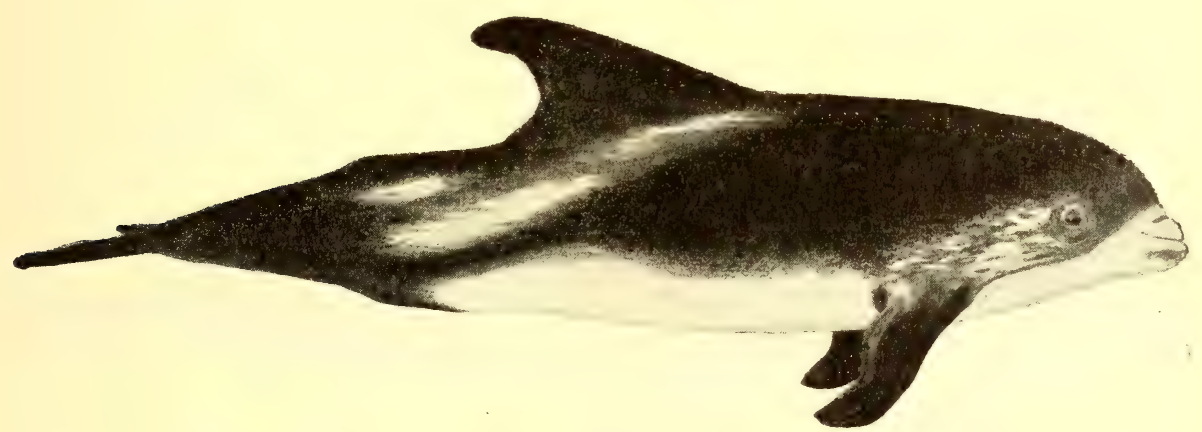

Fig. 37. Hvidsnudet delfin, Delphinus albirostris. Fotograferet i Bergens museum.

Sparre-Schneider loco cit.) 2 inde i Trondhjemsfjorden (Storm). Paa vestlandet (Bildøen) stængtes mai 18877 stykker, 15de april 1889 en flok paa $60-70$ stykker (meddelt af J. A. GrIEG loc. cit.)

3) Delphinus (Lagenorhyncus) acutus, almindelig springer eller ,hvidskjævingen" (se fig. 38). Spids, men kort snude, vel markeret fra panden. I overkjæven 70, i underkjæven 74 tænder (ca. 80 hvirvler). Kropsformen ligner meget den foregaaende, dog slankere og kanske med noget større rygfinne. Skjelnes let fra foregaaende derved, at snuden er sort, og ved en hvid flek paa hver side bagenom rygfinnen. Længde ca. 12 fod. Lever af fisk.

1) Bemerkninger til Norges Pattedyrfauna. Nyt Mag. f. Naturvidensk. Bd. XXII.

2) Cetologiske notitser. Bergens Mus. aarsberetn. 1889. 
Første gang beskrevet som forekommende hertillands af $\mathrm{RASCH}^{1}$ ) fra et stæng af 22 eks. i nærheden af Drøbak 1845.

Under „Michael Sars"s togter saaes de stadig i havet mellem Bjørnøen og Norge og langs eggen udenfor Tromsø. Under loddeindsigene nærmede de sig meget Finmarkens kyst (ud for Vardø). J. A. Grieg (loc. cit.) meddeler, at de vel næst nisen er den hyppigste tandhval paa vestlandet og fanges hvert eneste aar om vinteren under fisket. 1885 stængtes 200-300 individer, som var sprængt ud af en større flok, „der af bønderne ansloges til at bestaa af ea. 1000 dyr."

B. De buthovede delfiner har en mere eller mindre steil pande $\mathrm{og}$ mangler den fure, som hos de spidshovede delfiner skiller snuden fra panden. Ligeledes er kjæverne kortere, og tændernes antal i regelen mindre. I vore farvand hører hid 3 indbyrdes meget forskjellige arter, nemlig:

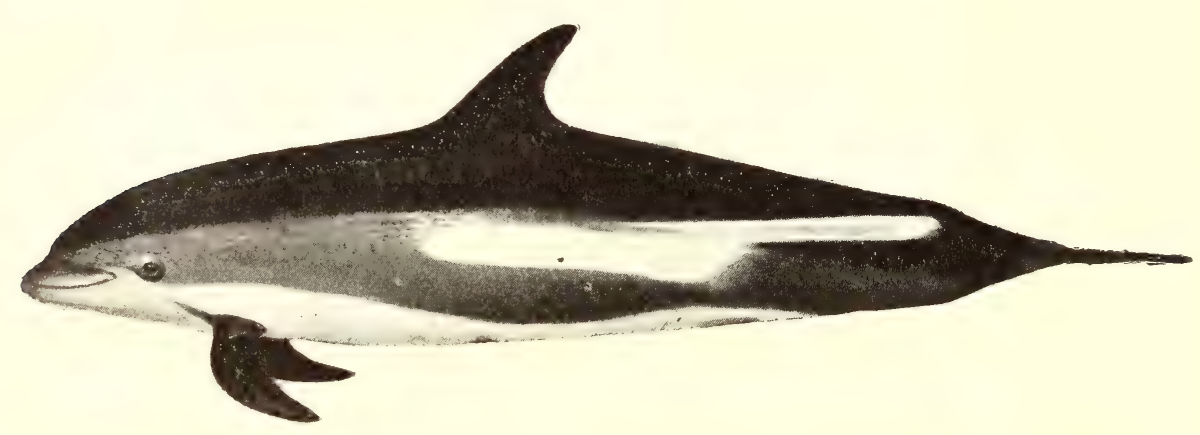

Fig. 38. Hvidskjævingen, Delphinus acutus. Fotograferet i Bergens museum.

1) Phocaena communis, nisen (dansk: marsvinet). (Se figur 39). Snuden stump, hovedet lidet. I overkjæven 50-56 tænder, i underkjæven 44-52 (65-67 hvirvler). Klumpet, tyk kropsform. Ryggen blaasort, bugen hvid. Længden ca. 6 fod. Har en særdeles vidstrakt geografisk udbredelse fra Hvidehavet og Grønlands kyster til Frankrige og Østersøen. Den vandrer om vaaren ind i Østersøen (naar varmen kommer i vandet) og tvinges om høsten ud igjen, fanges da i Lillebelt.

Sparre-Schneider meddeler (loc. cit.), at den er almindelig overalt i Tromsø amt, særdeles talrig under loddefisket ved Skjærvø april 1878. Collett (meddelelser 1883) meddeler, at den er lige talrig langs hele kysten. GRIEG anfører det samme for vestlandet.

1) RASCH: Beskrivelse over en i Christianiafjorden fanget ny delphinart. Nyt Mag. f. Naturv. 4 bd. 1845. 
2) Globiocephalus melas, grindehvalen (se fig. 40). Den har en stor fedtpude paa hovedet, som derved faar et kuglerundt udseende. 16-24 tænder i over- og ligesaa i underkjæven. Særlig kjendelig ved de lange spidse luffer. Kroppen sort med en hvid stribe under bugen. Størrelsen ca. 26 fod. Lever vel især af blæksprutter.

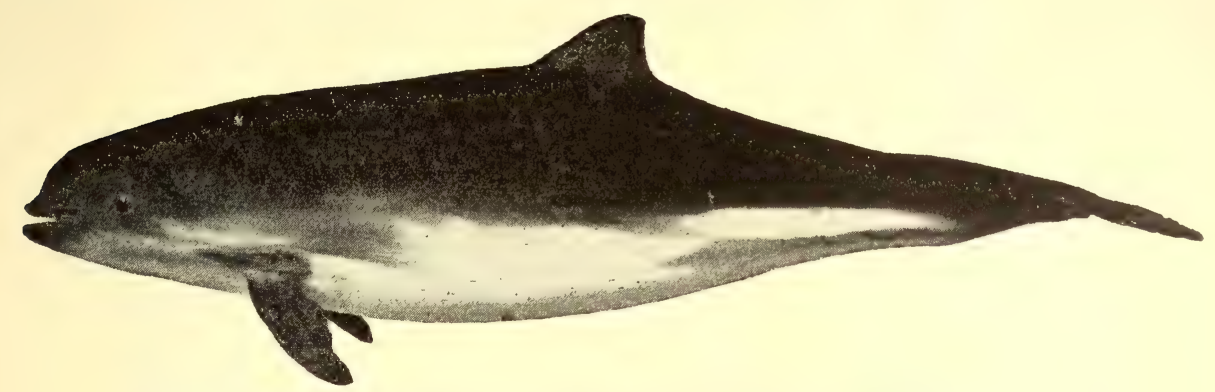

Fig. 39. Nisen, Phocaena comnunis. Fotograferet i Bergens museum.

De er kjendt fra Spitsbergen og fra Baffinsbugten ned til Danmark, Belgien, ja undertiden i Middelhavet. Træffes i mængder ved Færøerne, hvor de sees i store flokke.

Schneider meddeler (l. c.), at man i 1877 i august saa en stim paa tusinder ved Grøtavær paa Grytø, og at i 1889 en flok paa 189 dyr stængtes samme sted. Ved Aalesund saaes ifølge CoLletet store

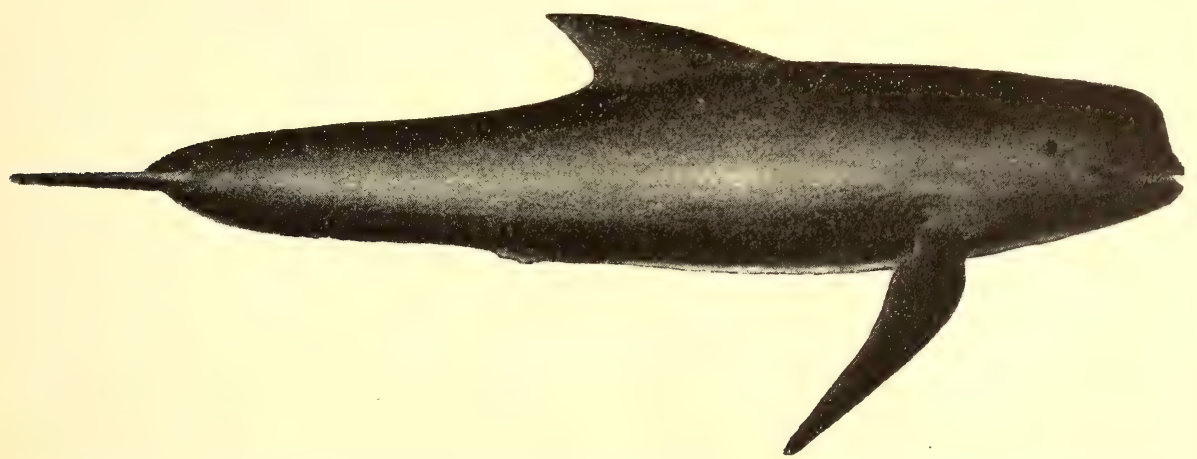

Fig. 40. Grindehvalen, Globiocephalus melas. Fotograferet i Bergens museum.

flokke i december 1876, og ifølge Grieg skal der i 1847 ved Søndfjord være stængt $2-3000$ individer.

3) Orca gladiator, spækhuggeren, vagnhund, Staurhynning (se fig. 41). Den har et lidet hoved med tykke, sterke tænder, 24-26 i antal i overkjæven og ligesaa i underkjæven ( 64 hvirvler). Kroppen er kraftig og muskuløs med brede luffer og en høi, skarp rygfinne. Farven 
er paa ryggen sort med hvid bug og karakteristiske hvide flekker bag øiet og paa siderne, de sidste danner en elliptisk fortsættelse af bugens hvide farve (se figuren). Den opnaar en størrelse af indtil 30 fod, er et glubsk og graadigt dyr, der væsentlig lever af fisk, sees især paa sildefisket (vaarsildfisket). Den angriber ofte større dyr, sæler, bardehvaler, - dette har ledet til den feilagtige forestilling, at den regelmæssig skulde ernære sig af disse dyr.

Er ifølge CoLlext en af de hyppigste $0 \mathrm{~g}$ talrigste langs vor kyst optrædende delfiner. Dens udbredelse forøvig vanskelig at fastsætte, da man er i tvivl, om der findes flere arter af den.

II. Som en egen gruppe opføres her to hvaler, der staar delfinerne nær og ofte henregnes til disse, men dog skiller sig fra dem i væsentlige punkter, blandt andet derved, at de mangler eller har en yderst lidet udviklet rygfinne. Disse hvaler er hvidfisken og narhvalen, der begge særlig er knyttede til de arktiske have.

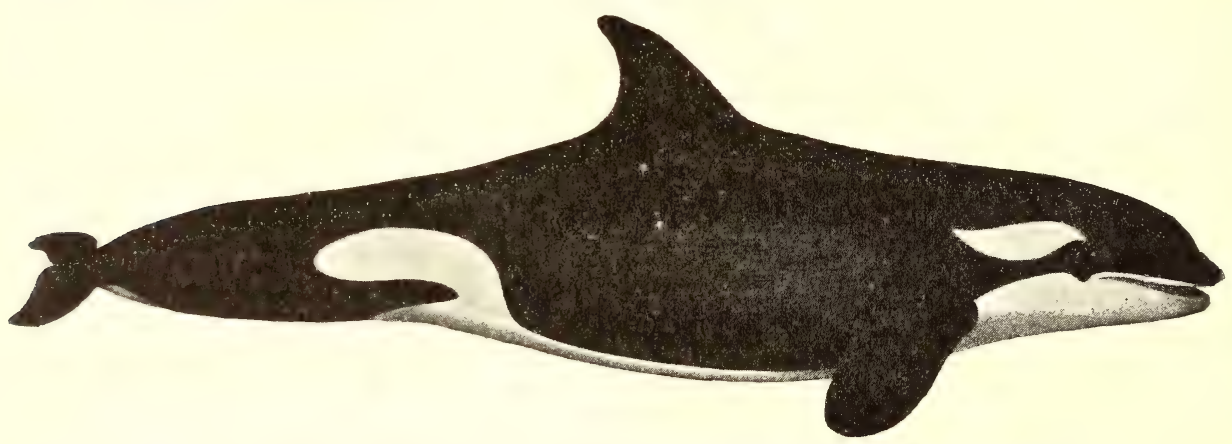

Fig. 41. Spækhuggeren, Orca gladiator. Efter Guldberg og Nansen.

1) Delphinapterus leucas, hvidfisken (se figur 42). Har et but hoved med 14-20 tænder i over- og ligesaa i underkjæven (ca. 50 hvirvler). Kroppen tenformet, mangler ganske rygfinne, smaa luffer. Farven ganske hvid overalt. Længden er indtil 20 fod. Den lever af fisk, krebsdyr og blæksprut. Er en arktisk hval, som specielt er gjenstand for fangst ved Spitsbergen, ved Sibiriens og Grønlands kyster, hvor den forekommer i flokke. SparRe-Schneider oplyser, at et individ blev observeret ved Tromsø sommeren 1877. CoLlet 'meddeler, at i „vinteren $1880-81$, da drivisen under de ekstraordinære veirforholde dette aar nærmede sig landets nordlige kyster, hvor enkelte isbjerge faktisk stødte under land, viste sig flere gange enkelte individer af denne art i Tromsø amts eller Finmarkens fjorde, og enkelte observerede slige indtil ud paa vaaren. Saaledes blev et par individer (ifølge konservator ScHnerDER) observerede i Balsfjorden i mai 1881, ligesom samtidigt et individ drev dødt iland ved Makkur i Østfinmarken." 

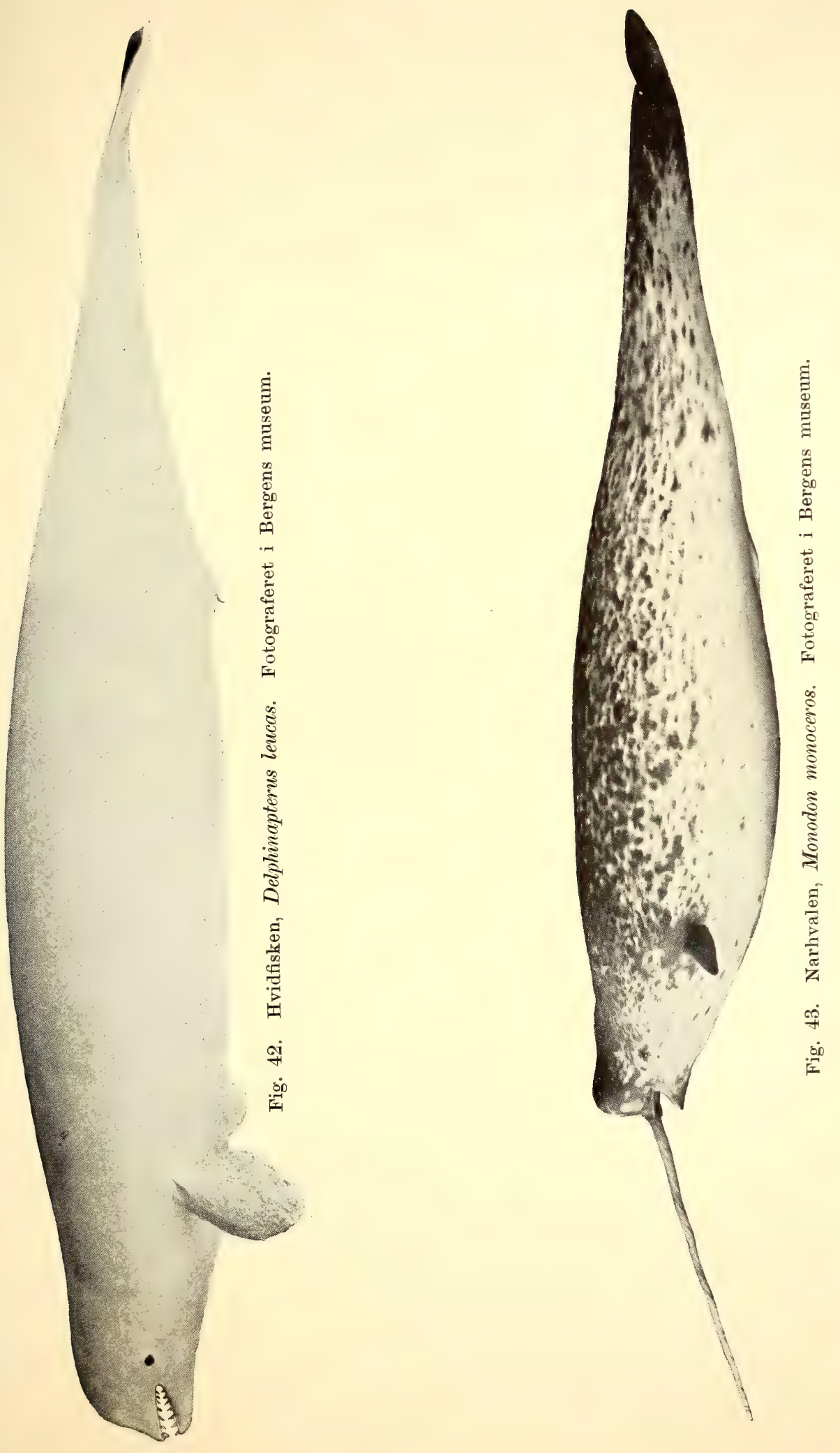

2) Monodon monoceros, narhvalen (se fig. 43). Hovedet but som hos hvidfisken. I overkjæven findes et tandpar, som kun vokser ud hos hannen, hos hvilken i regelen venstre, sjelden begge rokser ud til en "lige, fremadrettet, spiralfuret stødtand“, soni kan naa mere end kroppens halve længde. Kropsformen ligner særdeles hvidfiskens; hunnerne, som mangler stødtænderne, faar derfor især lighed med hvidfisken, men skjelnes dog fra denne ved de mørke farvepletter. Længden naar optil 20 fod. De lever som hvidfisken af fisk, blæksprutter, men formodentlig mest af krebsdyr. De skal kunne forekomme i store flokke mellem isflakene i de arktiske egne og gaar endnu længer nord end hvidfisken.

Kjendt fra Sibirien, Novaja Zemblja, Spitsbergen, Grønland til $65^{\circ} \mathrm{n}$.

III. Nebhvalerne frembyder enkelte lighedspunkter med delfinerne, men dog mere med følgende, kaskelotten. De har et rundt hoved med hvælvet pande, der skarpt aforænses fra den "flaskeformede", nebagtige snude.

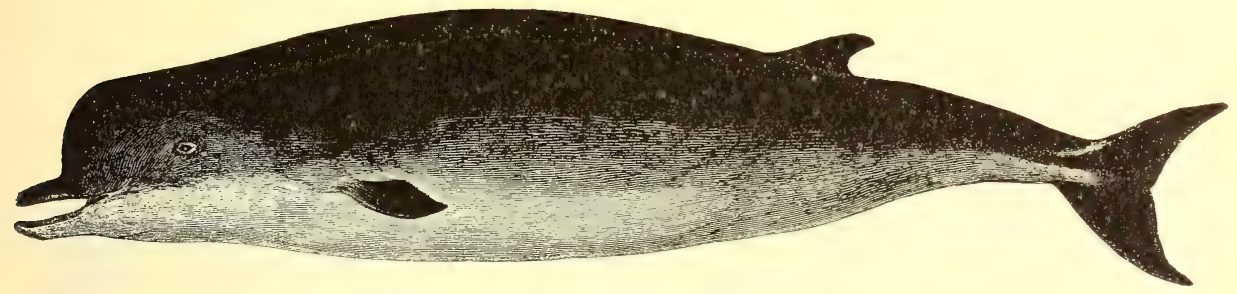

Fig. 44. Bottlenosen, Hyperoodon diodon. Efter GuldberG.

Tænderne er meget svagt udviklede, der findes ganske smaa skjult baade i over- og underkjæve, men udviklede er kun hos hannen 2 eller 4 i underkjævens forreste spids. De udmerker sig ved en tydelig rygfinne, som kaskelotten mangler eller har yderst lidet udviklet, smaa luffer. De lever pelagisk i regelen over svære havdybder, og dykker til store dyb efter blæksprut, som udgjør deres vigtigste føde. Hos os findes kun en repræsentant af denne gruppe, nemlig

Hyperoodon diodon, „bottlenosen"1) som den almindeligst kaldes over hele landet, andre navne er nebhvalen, andehvalen. (Se fig. 44). Den har de ovenfor nævnte karakterer, kjendes lettest paa den skarpt afskaarne pande, som især hos de store hanner seet forfra har en tydelig cirkelform; disse kaldes derfor af fangstmændene "tøndebund". Farven varierer fra sort hos de unge til brunt eller lysebrunt hos de gamle. Længden gaar op til ca. 30 fod, dog er den almindelige længde 20-25 fod.

1) Angaaende den nærstaaende form Mesoploon bidens, der nogle gange er strandet ved vestkysten, henvises til J. A. GRIEG. Bergens Museums aarbog 1897. 
"Bottlenosen" vandrer ind i Nordhavet tidlig paa vaaren, den fanges da mangfoldige mil fra land n. af færøerne, o. af Island og ud for Tromsø (se kartet, fig. $56 \mathrm{og}$ senere beskrivelse). Om høsten, ja allerede i juli-august forlader de Nordhavet og drager sydover i Atlanterhavet. De søger sin føde fra store dyb, lever væsentlig af blæksprutter. De strander af $0 \mathrm{~g}$ til ved Europas kyster (Storbritannien, Belgien, Danmark, marts 1878 i Borgevær, Lofoten, september 1881 Bundefjorden, Kristiania (Collett). I ottiaarene strandede ifølge Grieg 5 eksemplarer mellem Kristianssund og Stordøen.

IV. Som en fjerde gruppe kan nævnes p othvalerne, hvis eneste repræsentant i vore farvand er:

Physeter macrocephalus, kaskelotten eller pothvalen. (Se fig.45).

Dens hoved er overordentlig stort, fortil ret afskaaret. Over hjerneskallen ligger en stor bindevævsmasse, mellem hvis fibre indeholdes en olieagrtig rædske, som efter døden (afkjølingen) størkner til det saakaldte

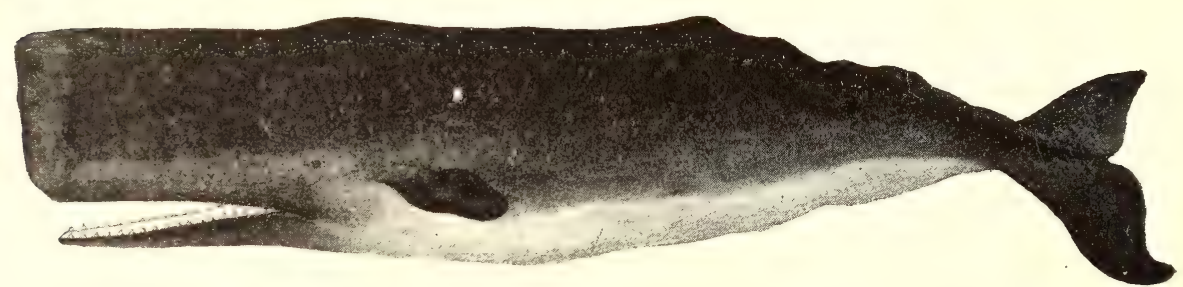

Fig. 45. Kaskelotten, Physeter macrocephalus. Efter tegning i Bergens museum.

"hvalrav" eller spermacet. Næseborene ligger langt fortil paa hovedet, og i overensstemmelse hermed er ogsaa pusten rettet forover, hvorved den paa lang afstand kjendes fra andre hvaler.

Tænderne findes kun fuldt udviklede i underkjæven (40-50 stk.), i overkjæven sidder nogle ufuldkomment udviklede smaa tænder. Rygfinnen er ufuldkomment udviklet, lufferne smaa. Ryggen med pukler sortfarvet, graa under bugen.

Længden $50-60$, ja opimod 80 fod.

Er en tropisk art, som er talrigst paa begge sider af ækvator. Dog strander der af $o g$ til nogle ved Europas kyster, ligesom hvalfangerne i Finmarken af og til har skudt et enkelt eksemplar. Herom mere nedenfor. 


\section{Bardehvalerne.}

De deles i to grupper, nemlig:

Glathvalerne med plump krop uden rygfinne eller furer paa bugsiden, og

Finhvalerne (i videste betydning af ordet) med rygfinne $0 \mathrm{~g}$ længdefurer paa bugsiden. (Luffen uden tommel med lang smal haand).

I. Glathvalerne, Sletbagene, Rethvalerne, har som næunt en plump krop med store hoveder $\left(1 /{ }_{3}-1 / 4\right.$ af kroppens længde). Barderne mødes ikke fortil som hos Finhvalerne, men er langt større og værdifuldere end hos disse. Særdeles tykt spæklag. Dorske og langsomme dyr. Fra det norske Nordhav kjendes kun to arter.

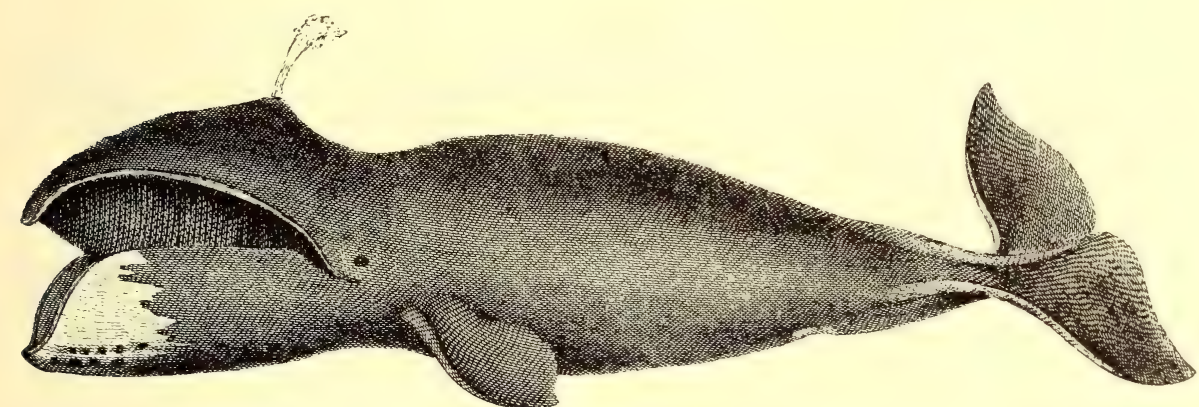

Fig. 46. Grønlandshvalen, Balana mysticetus. Efter SconesBr.

1) Balcena mysticetus, grønlandshvalen (rethvalen, bowhead), (se fig. 46). Særdeles stort hoved ( $1 / 3$ af kropslængden, medens hos den følgende ${ }^{1 / 4}$, GuldberG ${ }^{1}$ ). Mere klumpet $0 g$ dorsk end følgende. Oversiden mørk eller sort, bugen lys, eller hvid. Barderne 300-400 paa hver side og indtil 15 fod lange. Kropslængden indtil 60 fod.

Udpræget arktisk, lever fortrinsvis mellem isflagene af smaa planktondyr.

2) Balana biscayensis. Nordkaperen eller Biskayerhvalen. (Se figur 47.)

Hovedet noget kortere, men høiere end grønlandshvalens, kroppen slankere. Mundranden danner en S-form. De sorte barder ligner grønlandshvalens, men mindre, i regelen kun 5-7 fod lange.

1) GuldberG, G. A. Nordkaperen eller biscayerhvalen naturen 1889. 
Farven ganske sort over hele kroppen. Noget mindre end Grønlandshvalen, indtil 50 fod lang. „Da den er vildere og livligere end grønlandshvalen, er den ogsaa vanskeligere at fange . . . . Nordkaperens udbredningsfelt er den tempererede del af Atlanterhavet, fra Syd-Carolina og Bermudasøerne i vest og Middelhavet i øst op til Ishavet" (GuldberG).

Grønlandshvalen er „polarisens rethval“, biskayerhvalen „Golfstrømmens rethval". (Van Beneden.)

Guldberg har fundet knokler af nordkaperen paa Sørøen og ved Vardø og samlet oplysninger om, at den i aaret 1889 og i 90 -aarene er skudt ved Islands kyst samt i Nordhavet.

\section{Finhvalerne (i videste betydning).}

Til disse hører i norsk farvand to slegter, hvis ydre udseende er meget forskjellig. Til den første hører:

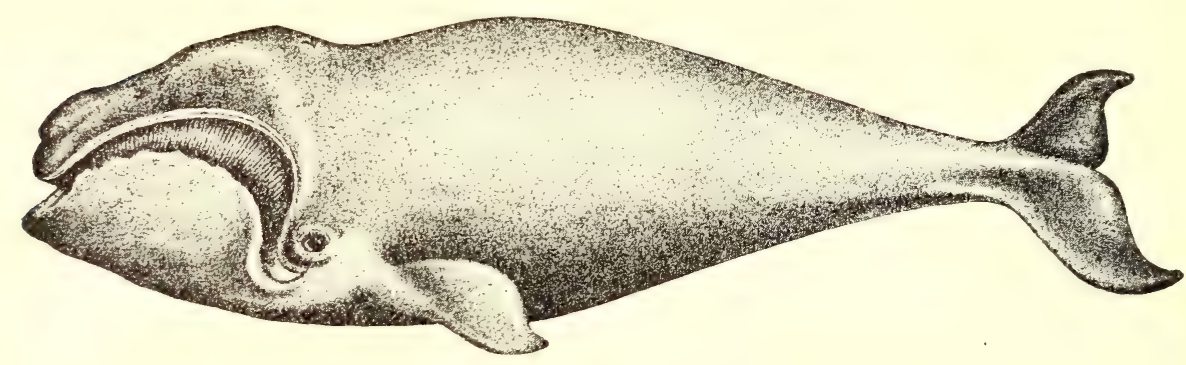

Fig. 47. Nordkaperen, Balana biscayensis. Efter Guldberg.

A. Megaptera boops, knølhvalen (pukkelhvalen, Нuмрваск). (Se figur 48). Adskiller sig overordentlig meget fra de øvrige, de „e ge n tlige finhvaler". Hovedet er meget stort med flad pande, forsynet med store knuder med børster i, især paa snuden. Kroppen er særdeles kort og tyk, især struben $0 \mathrm{~g}^{\circ}$ bugen. Lufferne meget lange, $1 / 3$ af kropslængden, langt storre end hos de andre. Rygfinnen liden, pukkellignende. Furerne langs bugen færre og større end hos de følgende. Farven paa rygsiden sort, paa bugsiden fortil hvid.

Barderne graa, de flossede kanter gulagtige, deres længde $2^{1} / 2$ fod, der findes ca. 350 paa hver side.

Knølhvalen blir henimod 50 fod lang.

Den lever af kril, lodde. Findes i Finmarken i aarets første maaneder (januar-marts), forsvinder $\mathrm{i}$ april $\mathrm{og}$ mai for at komme igjen $\mathrm{i}$ juni $\mathrm{og}$ forblive sommeren $\mathrm{og}$ antagelig udover høsten. Den er ogsaa bekjendt fra Grønland, Amerikas kyster og Sydeuropa. (Se det følgende). 
B. De egentlige finhvaler ${ }^{1}$, slegten Balaenoptera.

Langstrakte, med slank legemsbygning, smaa luffer. Rygfinnen ikke. pukkellignende, men undertiden (blaahvalen) meget liden. Talrige bugfurer. Af denne slegt har vi 4 arter:

a) Balaenoptera Sibbaldii. Blaahvalen (Blue Whale). (Se figur 49). Mere robust end „finhvalen“, kropshøiden i forhold til længden

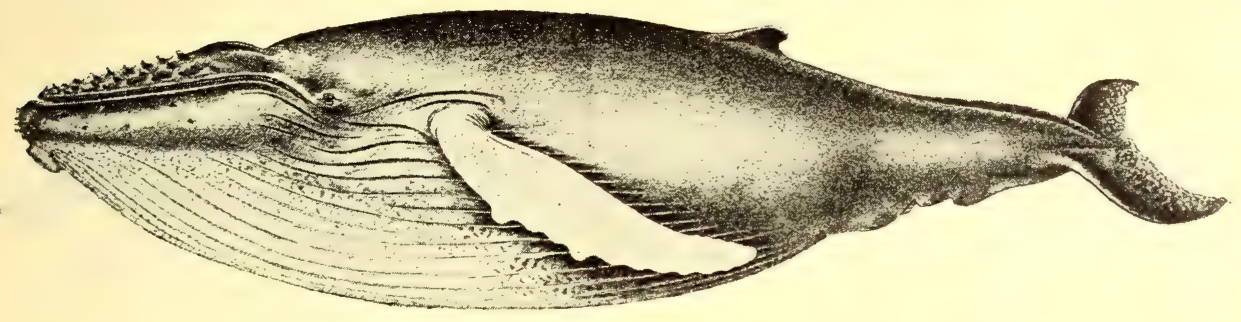

Fig. 48. Knølhvalen, Megaptera boops. Efter G. O. SARS.

som 1 til $5^{1 / 2}$. Rygfinnen specielt liden og lav med rette kanter, den er situeret langt bag paa grænsen af de forreste $3 / 4$ og sidste $1 / 4$ af krops længden. Lufferne forholdsvis store, omtrent ${ }^{1 / \tau}$ af kropslængden. Barderne har sorte kanter, der findes 400 paa hver side af 3 fods længde (930 mm. Nansen). Farven er mørk, blaagraa, med smaa hvide flekker paa brystet. Nedersiden $o g$ indersiden af lufferne hvide. Længde indtil 85 fod. Forekommer fra Murmankysten, Bjørnøen til Island, Amerika. Ved Island fra marts til juli, ved Finmarken fra begyndelsen af juni til slutten af august. (Se følgende).

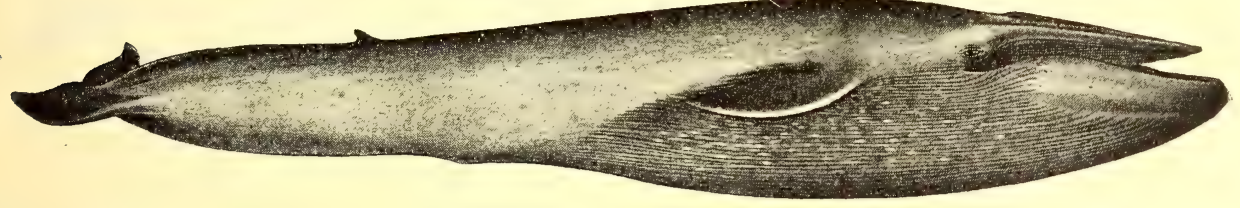

Fig. 49. Blaahvalen, Balcenoptera sibbaldii. Efter G. O. SARS.

b) Balaenoptera musculus. "Finhval", sildehval. (Se figur 50.)

Kropsformen meget slank. (Største høide i forhold til længden som 1 til $6^{1 / 2}$ eller $6^{3} / 4$ ). Rygfinnen større med næsten ret kant, siddende lidt længer fortil end hos blaahvalen. Lufferne smaa, maalende $1 / 9$ af hele kropslængden. Barderne $350-370$ i antal paa hver side, de er

1) Se Collett: On the external Characters of Rudolphis Rorqual. Proceedings: of Zool. Soc. London 1886. Her Synopsis over Finhvalerne. 
mørkeblaa eller sorte af farve, med undtagelse af de forreste paa høire side, som er hvide. Deres største længde er $950 \mathrm{~mm}$.

Rygsiden og venstre underkjæve brunsorte, undersiden, høire underkjæve $0 g$ indersiden af lufferne hvid.

Kropslængden $60-65$ fod, sjelden over 70 fod.

Følger silde- og loddestimerne $0 g$ optræder langs kysten derfor særlig under silde- og loddefiskerierne. Fanges dog ogsaa af og til med

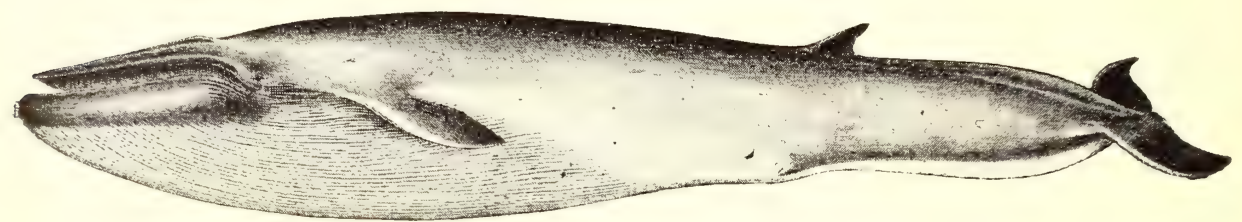

Fig. 50. Finhvalen, Balcenoptera musculus. Efter G. O. SARs.

kril i maven. I Finmarken optræder den fra loddens første ankomst, i regelen i marts, udover til høsten (se nedenfor). Har været iagttaget fra Noraja Zemblja, Spitsbergen, Grønland til Middelhavet og til Æquator.

c) Balaenoptera borealis. Seihval. (Se figur 51).

Kroppen temmelig slank. (Høiden i forhold til længden som 1 til $5^{1 / 2}$ ). Lufferne usedvanlig smaa, maalende $1 / 11$ af kropslængden. Rygfinnen høi, jevnt krummet med dyb indskjæring bagtil, siddende langt foran ved overgangen til sidste trediedel af kroppen. Barderne sorte

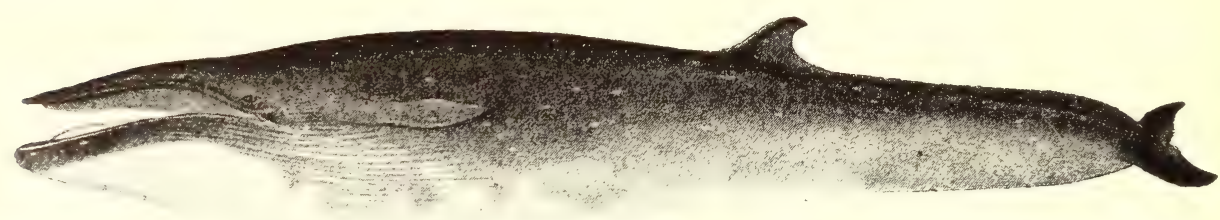

Fig. 51. Seihvalen, Balonoptera borealis. Efter R. CoLLetr.

med hvide børster, der er krøllede og meget fine. Omtrent 330 paa hver side, af en største længde af $630 \mathrm{~mm}$.

Hele oversiden, hele halen og lufferne blaasorte med aflange, lysfarvede flekker, undersiden saa langt som til genitalia hvid.

Kropslængden $40-50$ fod.

Optræder i Finmarken til samme tid som blaahvalen (juni-september), da den ligesom denne lever af plankton (kril, Calanus). Udbredelse fra Frankriges vestkyst til Nordkap. 
d) Balaenoptera rostrata. Vaagehval. (Se figur 52).

Kropsformen lidt mere robust end de foregaaende. (Høiden i forhold til længden som 1 til 5). Rygfinnen høi, jevnt krummet og dybt indskaaren i bagre rand, ligesom hos seihvalen siddende ved overgang til sidste trediedel af kroppen. Lufferne middels lange, 1/s af kropslængden. Barderne med gulhvide børster, 325 barder paa hver side af indtil $200 \mathrm{~mm}$. længde.

Farven oventil graasort, hele undersiden til og med halen hvid. Et hvidt baand over lufferne, hvis inderside ogsaa hvid.

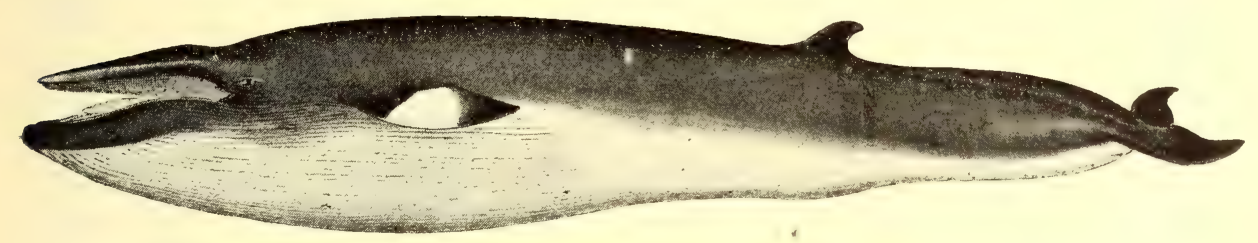

Fig. 52. Vaagehvalen, Balcenoptera rostrata. Efter G. O. SARs.

Kropslængden 25 til 30 fod, sjelden over 33 fod. Forekommer hertillands især ved vestkysten. Sydover udbredt til Biskayerbugten.

I den foregaaende oversigt har vi behandlet hvalerne fra et systematisk synspunkt, det vil sige, vi har beskrevet dem efter deres bygning og indbyrdes slegtskabsforhold. I det følgende skal vi omtale dem fra andre synspunkter, nemlig først med det maal for øie at skildre deres liv og vandringer, og dernæst i det følgende kapitel at skildre den fangst, som de i tidens løb har været gjenstand for.

Ligesom bunddyrene og planktonorganismerne, hvis udbredelse vi har skildret i første kapitel, kan hvalerne i biologisk henseende (med hensyn paa deres levevis) deles i forskjellige grupper, nemlig i arktiske, tropiske, syd-og nordatlantiske hvaler samt kysthvaler.

\section{De arktiske hvaler.}

Til denne gruppe hører tre arter nemlig, grønlandshvalen, hvidfisken og narhvalen.

1) Grønlandshvalen tilhører udelukkende den nordlige hemisfæres polaregne, og her er dens liv paa det nøieste knyttet til isen, især 
da iskanten. I forste kapitel saa vi nu, hvorledes denne iskant ikke var en fast, men en berægelig linie, som om sommeren flyttede sig nordover, om vinteren rykkede langt nærmere Europas og Amerikas kyster. Vest om Spitsbergen finder man om sommeren i gunstige isaar havet frit langt nordenom øen (f. eks. 1898), i andre aar kan isen her ligge fast i øen omtrent midt paa denne. I havet fra Spitsbergen mod Island saa vi, at isgrænsen om vinteren flytter sig øst, om sommeren vest, saaledes at norske fangstfartøier da i heldige aar kan naa ind i østkystens fjorde paa Grønland. I ældre tider, da der endnu fandtes mængder af grønlandshval, foregik paa disse strækninger store fangster. Som vi siden skal se, vrimlede Spitsbergens fjorde om sommeren af fangstfartøier især i mai-juni. I juli-august-september sværmede hvalerne i isfrie aar ifølge Sconesby ${ }^{1}$ ) i havet nordover mod Nordpolen (nordenom Spitsbergen), i mindre isfrie aar fangedes de ved Spitsbergen hele sommeren. Om vinteren $0 g$ især om vaaren færdedes de da langs iskanten mod JanMayen (Martens²), senere paa vaaren ,trak de mod øst mod Spitsbergen".

Ved Grønlands vestkyst , viser rethvalerne sig til ingen tid af aaret sydligere end $65^{\circ}$ (Sukkertoppen)“ Еsснвіснт. ${ }^{3}$ ) „Kun et par gange har en enkelt ung hval forekommet noget mere sønder paa, navnlig paa $64^{\circ}$ (Godthaab). Ved $66^{\circ}-69^{\circ}$ sees rethvalerne derimod hvert aar, men ved $66^{\circ}$ $67^{\circ}$ (Holsteinsborg) kun fra december til marts, ved $68^{\circ}-69^{\circ}$ (Diskobugten) fra december til enden af juni." Senere trækker de nordefter. Ved den nordligste del af de danske besiddelser paa Grønlands vestkyst, $71^{0}-75^{\circ}$. (Upernarik distrikt), vides rethvaler kun at være seet om sommeren indtil juli maaned $o g$ om efteraaret i oktober og november. I denne maaned har man selv i de senere aar undertiden truffet den der i stor mængde. Fra juli til oktober har rethvalen aldeles forladt hele den beboede del af det danske Grønlands vestkyst. Efter grønlændernes beretning, skal man derimod hver sommer se rethvalen i fjordene indenfor kystlandet mellem $71^{\circ}$ og $75^{\circ}$, saasnart isen tillader deres ophold der." Denne udmerkede fremstilling af den ved sin klare, logiske fremstilling saa tiltalende forfatter Eschricht giver et godt billede af forholdene saa sent som 1844. I følgende kapitel skal vi redegjøre for forholdene baade før og senere. Her skal vi kun tilføie nogle ord om hralens levevis. De gamle hvalfangere fra begyndelsen af det forløbne aarhundrede talte blandt sin midte en række yderst begavede mænd fremfor alle andre skotlænderen W. Sconesby, junior, hvis verk om

1) W. Scoresby, jr.: An account of the arctic regions. Edinburgh 1820.

2) Martens: Spitzbergische oder Grönlandische Reise Beschreibung Hamburg 1675.

3) Eschricht : Undersøgelser over hvaldyrene. Første afhandling. Kjøbenhavn 1844. 
de arktiske farvand staar over saa mangen en videnskabelig af handling. De stillede sig store problemer og søgte at løse dem, saaledes Nordostpassagen, hvalernes vandringer fra Behringshavet til Spitsbergen. ScoRESBY meddeler at have beviser for saadanne vandringer i harpuner fra Behringshavet fundne ved Spitsbergen, men andre forfattere, saaledes Pechuel-Løsche ${ }^{1}$ ) har benegtet dette. Iallefald er ved deres bestræbelser saameget fastslaaet, at rethvalerne fandtes og vandrede med isgrænserne efter bestemte lovmæssigheder. Pechuel-Løsche skildrer dem saaledes: "Nordhvalen er en meget frygtsom og slu fyr og holder sig almindelig mellem isen, hvor baadene aldeles ikke kan naa den, eller vandrer omkring ved iskanten; ser man den i det aabne hav, da er den paa vandring og da har den sterkt hastværk. Da den hører temmelig skarpt, undgaar man ombord i fartøiet og i baadene omhyggelig enhver støi. Af alle hvaler er den lettest at fange, godmodig og snil, og blir kun sjelden ubehagelig med sin hale; undertiden berøver dødsangsten den ganske dens forstand." "Ofte ligger den ogsaa i ro og mag i en beskyttet raak mellem isen, skyver da oversiden af sit vældige hoved op og lader et drønende hu-ff-ff! Blu-w-w-w høre langt bortover." „Jeg havde kun engang anledning til fra mastetoppen at iagttage paa nært hold en nordhval, mens den tog næring til sig og følte sig sikker mellem isen. Jeg saa, hvorledes den langsomt skjøv sig frem langs den speilglatte havoverflade og ligesom skuffede ind med sin aabne mund den i store mængder i havet svømmende næring".

Scoresby fortæller, at deres føde bestaar af det i kap. 1 skildrede arktiske plankton. I de maver af grønlandshvalen, som han har undersøgt, fandt han udelukkende ræger, men han antager, at ogsaa de bløddyr (clio, limacina), som vi tidligere har skildret, ogsaa udgjorde deres næring.

2) Narhvalen er den hval, som kommer grønlandshvalen nærmest i levevis. Ligesom denne, holder den sig nær polarlandenes kyster eller isen særlig ved Grønlands vest- og østkyst, Spitsbergen, Novaja Zemblja og den sibiriske kyst. Scoresbr (loc. cit. II) fortæller, at den er et „hurtigt, livligt og godsligt dyr, som svømmer med adskillig fart. Naar den kommer op til overfladen for at aande, ligger de sedvanlig ubevægelig $\mathrm{i}$ flere minutter med hoved og ryg saavidt synlige over vandfladen. De har tilbøielighed til at leve i flokke, ofte viser de sig i talrige smaa "hjorde" paa et halvt dusin eller mere. Hver "hjord" bestaar af dyr af samme kjøn. Naar den træffes af harpunen dukker den paa samme maade og med samme fart som grønlandshvalen, men ikke saa dybt. Almindelig gaar den ned 200 favne, saa vender den op til overfladen,

1) M. E. Pechuel-Løsche: Wale u. Walfang. Das Ausland 1871. 
og landsen gjør det af med den paa nogle faa minutter." Scoresby fandt blæksprutter i dens mave, men man har ogsaa langs land fundet bundfisk $\mathrm{i}$ den. Eskimoerne fanger den ligesom hvidfisken fra sine kajaker.

Nogle faa eksemplarer har i tidernes løb forvildet sig til sydligere farvand $0 \mathrm{~g}$ strandet der.

3) Hvidfisken er ogsaa en udpræget arktisk hval dog ikke i den grad som de to foregaaende. Dens udbredelse strækker sig fra Sibirien i øst over Spitsbergen, langs Grønlands kyster ned langs Labradorkysten. Se desuden den systematiske oversigt. Inden dette omraade foretager den dog betydelige vandringer, hvilket alene kan indsees deraf, at den ikke kan leve under isen uden at komme op til overfladen for at aande. Naar isen lægger sig i de Spitsbergske fjorde og havet udenfor, maa de derfor flygte. De vandrer da syd og vest mod Amerikas kyster, hvor de særlig træffes ud for Labradors kyster om vinteren i masser. Det samme er tilfældet med Sibiriens talrige hvidfiskehjorde. Beviser for vandringerne findes ifølge mundtlige meddelelser til mig fra den erfarne hvalfanger INGebrigtsen fra Tromsø deri, at han ofte fandt kugler fra Nordamerika i hvidfisken paa Spitsbergen.

De kommer til Spitsbergen henimod mai og kaster da sin ene unge. De lever af blæksprut $\mathrm{og}$ fisk, formodentlig væsentlig polartorsken $\mathrm{og}$ laks eller sjørøje, hvoraf der findes mængder ved Grønlands og Spitsbergens kyster.

Da fangsten af hridfisk ligesom fangsten af delfinerne er noget for sig og væsentlig skiller sig fra den store hvalfangst, som er gjenstand for følgende kapitel, skal jeg med nogle ord omtale den her.

Ved Grønlands ${ }^{1}$ ) kyster fanges hvidfisken enten fra kajaker med harpuner og landser paa samme maade som sælen, eller med nøter i isfrie fjorde. Eller ogsaa paa en eiendommelig maade under isen. Naar der nemlig pludselig danner sig nyis, og hvidfisken blir overrasket af denne nær land, danner den sig et aandehul, som den stadig maa opsøge for ikke at drukne. Disse huller opspores med hunde, da de er vanskelige at finde, skjønt man langveis kan høre dyrenes pust. Ved saadanne aandehuller kan der gjøres god fangst. Rink meddeler at i vinteren 1849 dræbtes i fem dage ved Claushavn 400 hvidfisk, og i 1850 ligesaa mange ved Nugsuak.

VANHÖFFEN meddeler efter RyBerg, at der i aarene 1874-91 aarlig fangedes 638 hvidfisk i Sydgrønland $0 \mathrm{~g}$ i aarene $1863-77543$ hvidfisk i Nordgrønland.

1) H. Rink: Grønland geografisk og statistisk beskrevet I og II. Kjøbenhavn 1855 og 1857.

E. VANHÖFFEN : Grønland-Expedition 1891-1893 II. Berlin 1897. 
Ved Spitsbergen fanges den, som bekjendt, med store ca. 600 favne lange nøter med 6 tommer store masker og garn af lillefingers tykkelse (A. W. i „Norsk fiskeritidende“). Med disse store nøter stænges stimerne inde mod land, og med mindre nøter tages hvidfiskene enkeltvis op mod land og dræbes der. Fangsten er meget underkastet tilfældigheder, og fangstmændene kan vente forgjæves i uger.

Nordmændene begyndte fangsten paa Spitsbergen i 1866. Hr. Ingebrigtsen, der drev fangsten med særligt held, har fortalt mig følgende:

I 1867 saa han for første gang hvidfisk paa Spitsbergen. I 1868 dræbtes der hundreder med daarlige redskaber. I aarene 1869-1878 var der god fangst først langs vestkysten saa i Hinlopenstrædet. I 1877

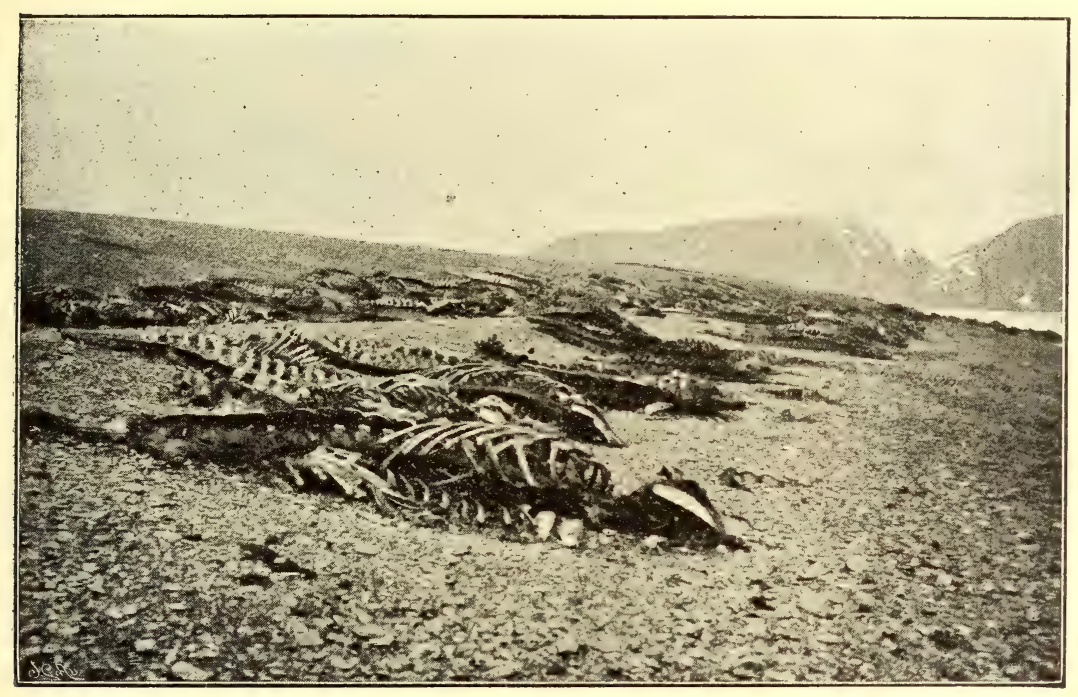

Fig. 53. Hvidfiskskeletter paa stranden i en af Spitsbergens fjorde. Fra NAтHoRst.

var Ingebrigtsen alene om fangsten. I aarene 1878-1881 store laster ved Amsterdamøen (Magdalena Bay), hvor hvidfisken søgte op, naar farvandet nordenfor var stængt. Senere godt fiske 1 Belsund, hvor hvidfisken var kommen igjen. Ved n.o.-vinde var der fiske i Storfjorden, ved sydlige derimod i læ i Belsund. Der fangedes i det hele i disse aar ikke faa dyr. Nondenskiöld fortalte saaledes i "Vegas reiser", at der i 1871 fra Tromsø i det hele fangedes 2167 stykker i not.

I aaret 1891 mener Ingebrigtsen, at der derfor ved Spitsbergen kun var 400-500 igjen, og nu findes der næsten ingen deroppe, mener han. Han forklarer sig deres forsvinden paa den made at hvidfisken aar efter andet opsøgte de samme pladser. 
Naar de derfor udryddedes paa en plads, kom der ingen igjen. Under fangsten dræbtes nemlig baade unger og voksne.

Nord om Sibirien antager Ingebrigtsen derimod, at der fremdeles findes store masser.

NordenskiöLd saa her store stim. Hvidfisken vandrer nord for Sibirien op i floderne (Jenisej) og blir her og ved Novaja-Zemblja jaget af Russer og Samojeder.

I meddelelse, som velvillig er mig meddelt fra Troms $\emptyset$, fangedes derfra i aaret 1901 kun 26 hvidfisk, som betaltes med kr. 60 pr. stykke.

\section{Nordatlantiske hvaler.}

Denne gruppe omfatter de hvaler, hvis vandringer, som regel betragtet, er begrænset til den nordlige del af Atlanterhavet. Hermed forstaaes det norske Nordhav, - det er havet nordenom Shetland - Færø Islandsryggen samt de tilstødende dele af Atlanterhavet mellem Europas og Nordamerikas kyster. Blandt disse hvaler har imidlertid de forskjellige arter en meget forskjellig levevis, saaledes at man vistnok faar det klareste begreb over deres vandringer ved at dele dem i forskjellige mindre grupper.

Efter arten af den føde, de søger, kan man dele de nordatlantiske hvaler i tre grupper, som ogsaa i andre henseender (vandringerne) frembyder visse eiendommeligheder, nemlig

1) Planktonhvaler (Nordkaperen, Blaahvalen, Seihvalen, Knølhvalen).

2) De blæksprutjagende hvaler (Bottlenosen, Grindehvalen).

3) De fiskejagende hvaler (Finhvalen, Vaagehvalen, Delfinerne, Spækhuggeren).

\section{Planktonhvalerne.}

De herhen hørende hvaler er bardehvaler, som lever af at sile havets smaa drivende organismer fra vandet, særlig er det de laverestaaende krebsdyr, som rødaaten, krilen og tildels om sommeren det arktiske plankton, som udgjør deres føde. De foretager særdeles store vandringer, idet de om høsten forlader de nordlige egne af Nordhavet for at søge sydligere farvand $0 g$ om vaaren eller forsommeren igjen drager nordover for at udnytte det da opblomstrende nordlige drivende dyreliv. 
1) Nordkaperen tilhører, som man af den systematiske oversigt vil have seet, rethvalerne. Først i 50-aarene af det forløbne aarhundrede blev det især ved Eschrichts bestræbelser erkjendt, at den var en fra grønlandshvalen forskjellig art, og derved blev det gaadefulde ved denne sidstes geografiske udbredelse først fuldstændig opklaret. Tidligere havde det nemlig været uforklarligt, at den saa rent arktiske grønlandshval af $\mathrm{og}$ til ogsaa fandtes paa langt sydligere bredder. $\mathrm{Nu}$ forstod man, at disse dyr var en egen art Biskayerhvalen eller Nordkaperen. Denne art maa i tidligere tider i store mængder have sværmet langs Frankriges, Storbritanniens, Islands kyster og derfra ved sommertid have vandret nordover i det norske Nordhav, saaledes at den østenom den lange iskant fra Island til Spitsbergen i havet mellem Spitsbergen og Bjørnøen og mellem denne sidste og Norge var gjenstand for fangst. G. A. Guldberg ${ }^{1}$ ) har fortjenesten af at have paavist, at gamle hvalben fundne paa Sørøen og ved Vardø tilhørte nordkaperen, levninger fra fortidens hvalfangst. Medens den i tidligere tider maa have forekommet i store mængder, er den nu særdeles sparsom og kan betragtes som et meget sjeldent dyr, men af, hvad der foreligger, faar man indtrykket af, at dens vandringer har havt stor lighed med de, som i vor tid blaahvalen foretager, og som nedenfor skal skildres nærmere.

GULDBERG ${ }^{2}$ ) har givet en samlet fremstilling af de sikre meddelelser, som foreligger, om dens forekomst i vor tid, og efter disse skal jeg meddele følgende. Til forskjellige tider viste der sig eller strandede der i sidste halvdel af forrige aarhundrede nordkapere i den Biskaiske bugt (St. Sebastian), ved Galicien, ved Skotlands kyster, ved Azorerne, ja i bugten ved Taranto (Italien), ligesaa viste den sig ved nordostkysten af de forenede stater (Charlestown i Syd-Carolina) og ved New-Jerseykysten. I 1888 fik GuLdBerg meddelelse om, at den norske sælfanger $J_{A S O N}$ søndenom Grønland paatraf en amerikansk hvalfanger, der var paa jagt efter nordkaper, og i 1889 fangede kaptein C. A. LARSEN af Sandefjord en nordkaper paa bottlenosefeltet $\left(67^{\circ} .7^{\prime}\right.$ n. og $66^{0} .20^{\prime}$ v. $)$. I aaret 1890 skjød saa hr. hvalfanger L. BERgs dampere fra Island 5 nordkapere, samme aar 'kaptein Aмuie ogsaa 1, og i 1891 fangede hr. Berg 7, kaptein Eluefsen 2 og kaptein Amure 1, tilsammen i disse 3 aar er dette altsaa 17-nordkapere.

Desuden meddeler Guldberc, at skibskapteiner har fortalt ham, at de i 1883 saa hvaler uden rygfinne (sletbager) omkring Bjørnøen, dog kan dette antagelig have været knølhval.

1) G. A. Guldberg: Sur la présence aux temps anciens et modernes de la Baleine de Biscaye. Bull. d. l'Acad. roy. de Belgique 1884.

9) Bidrag til kundsk. om Atlanterhavets rethval. Chr. videnskabsselsk. forh. 1891. 
Alt $\mathrm{i}$ alt tyder disse meddelelser paa, at nordkaperen, som P. I. Van Beneden anfører, tilhører Atlanterhavets varme strøm, medens grønlandshvalen tilhører polarvandet, og at nordkaperens vandringer ligner blaahvalens. De hvalfangere, som har fanget den ved Island, driver fortrinsvis blaahvalfangst, og de har vel da fundet den paa de samme felter, hvor ogsaa blaahvalen færdes.

2) Blaahvalen forekommer efter alle de oplysninger, der foreligger, i Finmarkshavet kun i tiden juni-august. Ved hvalfangernes velvillige imødekommenhed har jeg havt anledning til at gjennemgaa 40 journaler, hver omfattende et fangstaar, og som angiver, naar hver enkelt hval er skudt. Af disse journaler fremgaar det, at kun i det hele 3 blaahval i disse 40 fangstaar er skudt før 1ste juni, og af disse 3 er de 2 skudt i sidste halvdel af mai. Kun en eneste er skudt før og det saameget før som i marts (1893 af hvalfanger Ingebrigtsen). Denne staar derfor som et enestaaende tilfælde, der afviger fra den af alle hralfangere almindelig erkjendte regel, at blaahvalen hverken sees eller fanges før i de sidste dage af mai. Den ovennævnte hval blev skudt $2^{1 / 2}$ mil n. af Hekkingen. Ligesaa angives blaahvalen at forsvinde i september, da desuden det oftest stormfulde veir hindrer observationerne og fangsten tilsøs. Som eksempel paa, naar og hvor blaahvalen i et heldigt aar skydes, skal fra hr. Ingebrigtsens journaler, nemlig fangstaaret 1897 anføres.

Den 1ste blaahval fangedes da 19 de mai 10 mil s. v. af Bjørnøen.

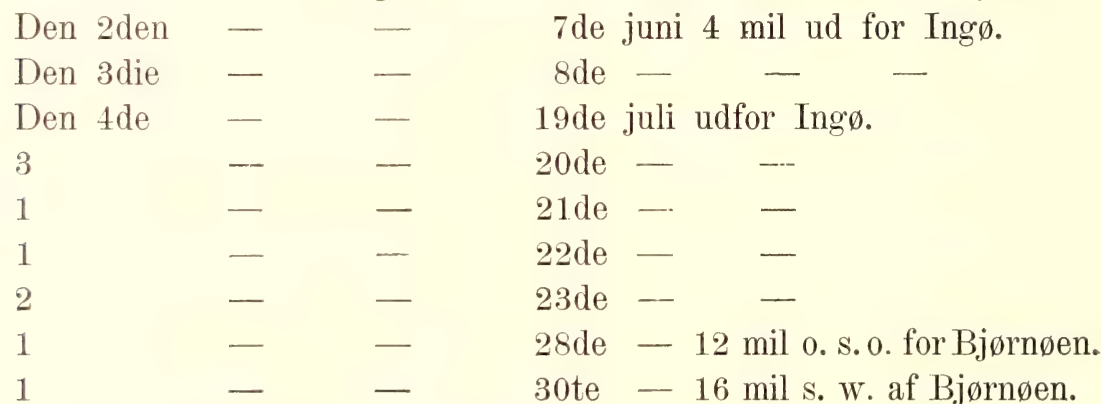

Senere fangedes ingen, ialt altsaa 13 blaahval. I andre aar har hr. INGEBRIGTSEN imidlertid aldeles ikke faaet nogen blaahval, f. eks. 1892, 1894, i andre aar kun en enkelt (1896).

Under Island og ved Færøerne, hvor blaahvalen ogsaa fanges i vore dage, giver blaahvalfangsten væsentlig andre resultater. Som eksempel herpaa skal anføres nogle data, som er mig meddelte af hr. hvalfanger Lauritz BerG, der i det hele har understøttet „Michael Sars" ekspedition paa den mest forekommende maade.

I aaret 1890, da hr. BERGs fangst begyndte paa Island, fangedes 29 blaahval. 
I 1891 fangedes 28 blaahval.

$\begin{array}{lllrl}\text { I } & 1892 & - & 42 & - \\ \text { I } & 1893 & - & 39 & - \\ \text { I } & 1894 & - & 69 & - \\ \text { I } & 1895 & -- & 90 & - \\ \text { I } & 1896 & - & 108 & - \\ \text { I } & 1897 & - & 74 & - \\ \text { I } & 1898 & & ? & \\ \text { I } & 1899 & - & 71 & - \\ \text { I } & 1900 & - & 94 & - \\ \text { I } & 1901 & - & 86 & -\end{array}$

Herved er dog at bemerke, at hr. BERG anvendte 4 baade, medens hr. Ingebrigtsen kun har 1. Alligevel fremgaar dog den store forskjel i antal. Ogsaa i tidsrummet for fangsten er der forskjel, hvilket følgende eksempel kan vise.

I marts og april 1901 fangedes 6 blaahval udenfor Isafjord (nordvestkysten).

I mai 11 blaahval i havet nord om Island mellem Kap Langenes og Kap Nord, vest om øen Grimsey.

I juni 26 blaahval. Sammested fanget

I juli $27 \quad-$

I august 14 - fanget n.v. af Dyrafjord.

I septbr. 1 - - - - -

Fangsten begynder, som man ser, ud for de store fjorde i Islands nordvestlige hjørne, foregaar senere i den østlige del af havet nord om Island, for udover sommeren at trække vestover mod Kap Nord og senere i n.v. retning af fjorden, (Dyrafjord). Afstanden fra land retter sig meget efter isen, idet fangsten mest finder sted i grænselagene mellem isen og det varme vand. Skiønt blaahvalen her viser sig meget tidligere, saaledes at der allerede $\mathrm{i}$ april og mai finder sted en rig fangst, er dog ogsaa her juli maaned den rigeste fangstmaaned.

Nøglen til forklaringen af blaahvalens vandringer ligger i det af G. O. SARS i 1874 konstaterede og stadig senere bekræftede forhold, at blaahvalen udelukkende lever af plankton, særlig af smaa krebsdyr, krilen. SARS meddeler dengang følgende: „Den hvalart, som Forn saagodtsom udelukkende fanger, den saakaldte blaahval, har nemlig efter al rimelighed intetsomhelst at bestille med lodden. Dens føde bestaar efter gjentagne af mig anstillede undersøgelser af mavens indhold næsten udelukkende af en liden, gjennemsigtig ræke (Thysanopoda inermis) eller som den heroppe kaldes: „Kril“. Skjønt der i Varangerfjorden den tid, jeg opholdt mig her, slet ikke manglede paa sild af forskjellig størrelse, har jeg dog aldrig fundet spor af sild i blaahvalens mave, og Foyn har forsikret mig, at 
han heller ikke nogensinde har kunnet opdage spor af hverken lodde eller sild hos den." I første kapitel har vi nu seet, at denne kril „gror" op om vaaren $\mathrm{og}$ forsommeren, $\mathrm{og}$ at der saaledes kun midtsommers er de næringsforhold tilstede, som kan gjøre blaahvalens ophold i Finmarkshavet muligt. Heri ligger altsaa forklaringen til denne hvals vandringer, som vi senere skal se, gjælder det samme seihvalen, ligesom det antagelig har været tilfældet med nordkaperen. I tilsyneladende strid hermed staar den omstændighed, at den arktiske planktonhval, grønlandshralen, jo aldrig forlader de arktiske egne selv midtvinters, og det skjønt den lever af plankton ligesom de andre her nævnte hvaler. At opklare denne modsigelse er særdeles vanskelig med de kundskaber, vi nu har om dyrelivet i de rent arktiske egne om vinteren. De allerfleste observationer deroppefra skriver sig jo fra sommeren. Paa den ene side synes det ikke umuligt, at der blandt det rent arktiske plankton oppe blandt isflakene, findes enkelte former, som overvintrer uden at dø bort, f. eks. de arktiske ræger (Hymenodora, polartorsken), men paa den anden side maa vel grønlandshvalens næring i allefald være særdeles sparsom om vinteren. Der er jo mange dyr, selv blandt pattedyrene, som i længere tidsrum kan leve med særdeles ringe næring. Herom vides nu særdeles lidet. De forskjellige forfattere, som omtaler grønlandshvalens liv om vinteren, er i stor tvivl om dens vinteropholdssted, og det er jo naturlig nok, naar man betænker, at hvalfangerne, hvorfra saagodtsom al viden om den sag skriver sig, forlader de arktiske egne om vinteren. For tiden er der derfor lidet at meddele om alle disse ting, vi kan kun konstatere den store forskjel mellem de arktiske hvalers og de her nævnte nordatlantiske planktonhvalers vandringer.

Hvor langt nu disse vandringer strækker sig, er det ikke godt at konstatere. Takket være hr. fiskeriinspektør SøREnsens opmerksomhed paa vigtigheden af dette problem, har man erholdt nogle sikre data, som fortæller særdeles meget mere, end man ellers med sikkerhed kunde vide. Hr. Sørexsen har nemlig af hvalfangerne erholdt og offentliggjort ${ }^{1}$ ) meddelelse om, at der af og til i disse vandrende hvaler findes harpuner, saadanne, som aldrig anvendes under fangsten i Finmarken, men som bruges ved Nordamerikas østkyst. Ved hr. Sønensens velvillige assistance erholdt jeg disse tillaans, de afbildes i hosstaaende figurer (fig. 54, fig. 55). Af disse fremstiller fig. 54 en harpun, som i aaret 1888 blev fundet $\mathrm{i}$ en blaahval. Harpunen bærer indskriften E. Pierce's Pat. June. 1. C 0, hrilket noksom viser dens amerikanske oprindelse, lignende harpuner er afbildede bl. a. i den amerikanske fiskerikommissions beskrivelse af de amerikanske fiskerier (N. S. C. of fish \& fisheries: The fisheries of U.

1) Beretning til departementet for det indre for 1899 . 


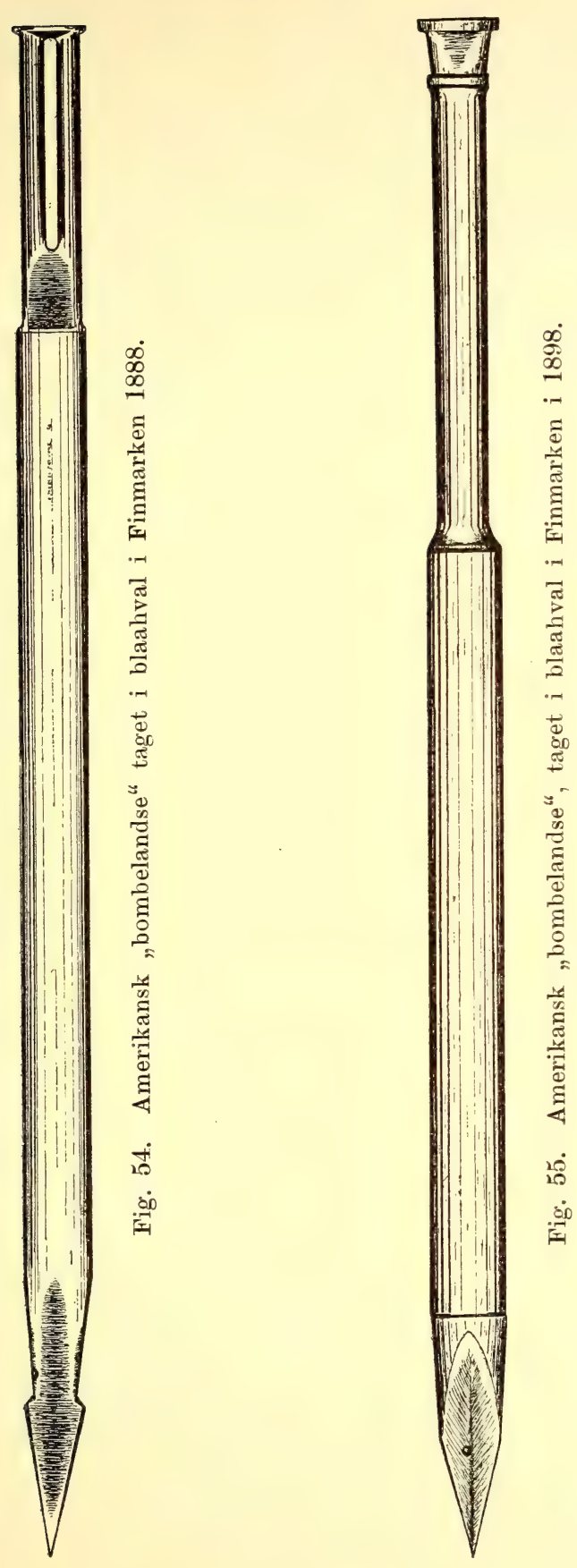


S. Sect V. Pl. 198), harpunen kaldes der the Pierce bomb-lance, og der beskrives, hvorledes den udskydes fra et gevær, og saadant anvendes ligesaalidt som disse smaa harpuner i Finmarken (se følgende kapitel.) Den anden afbildede harpun (fig. 55) blev 1898 fundet i en blaahval. Denne harpun afbildes ligeledes i det ovennævnte verk (planche 197) og kaldes der „Brand muzzle-loading bomb-lance“, den udskydes ligeledes fra gevær. Ifølge Sørensen fik 1899 en hvalfanger ogsaa en knølhval, hvori dele af amerikansk harpun, og han trækker med rette den slutning heraf, at „dette viser jo, at hvalerne gjør store vandringer, før de kommer til Finmarkskysten."

Ifølge Van Beneden og Gervais er blaahvalen ogsaa funden ved Skotlands, Hollands, Bohuslæns og Frankrigs (Biskayerbugtens) kyster; ifølge ovenomtalte amerikanske verk forekommer den ved den nordøstlige kyst af de forenede stater saaledes, at omraadet for dens vandringer, som man ser, falder sammen med det havomraade, inden hvilket vi ovenfor omtaite, at disse nordatlantiske hvaler vandrer.

$\mathrm{Vi}$ saa ovenfor, at den aarlige fangst af blaahval ved Finmarken var langt mindre pr. fartøi end ved Island. Af det følgende kapitel skal vi se, at dette forhold ikke var det samme, da hvalfangsten begyndte i Finmarken, og vi skal i tilslutning dertil drøfte spørgsmaalet om aarsagerne til den saaledes indtraadte forandring.

Blaahvalen viser sig efter de forliggende oplysninger aldrig ved Finmarken med smaa unger, derimod el den ofte seet at parre sig deroppe. Ingebrigtsen mener ogsaa at have seet større unger. Blaahvalen antages at gaa mere end et aar drægtig, og at den ikke har nogen bestemt tid, da den kaster unger.

3. Seihvalens forekomst i Finmarken ligner mest blaahvalens, hvilket maa forklares derved, at de begge er typiske planktonhvaler. Af de ovennævnte journaler, der meddeler fangst af hval i 40 fangstaar, fremgaar der, at der $\mathrm{i}$ disse blev skudt 357 seihval, men af disse kun 7 før 1ste juni samtlige $7 \mathrm{i}$ mai. Den kommer altsaa ogsaa først, naar planktonet er groet op, den holder sig særlig til Vestfinmarken, hvor ogsaa flest skydes.

Deres forekomst synes ogsaa at variere særdeles meget i antal fra det ene aar til det andet, saaledes meddeler den departementale kommité af $1890 \mathrm{i}$ sin beretning, at der i 1884 kun blev skudt 6 stykker, i 1885 659 stykker. I dette aar fangedes den helt fra Sørøen til Murmankysten.

Collett meddeler, at dens maveindhold bestod af rødaate (Calanus) og at den sidste dato, den til 1885 var observeret i Finmarken var 8de september.

VAN Beneden og Gervais angiver flere lokaliteter for dens fore- 
komst rundt Nordsøens kyster, saaledes udfor Holsten, Holland, Skotland og Norges vestkyst. Den skal aldrig være seet ved Grønland.

GuLDBERg har undersøgt dens fostre og fundet, at den i juni har fostre af en længde af mellem $3 \mathrm{og} 4$ fod, hvoraf han antager at kunne slutte, at de føder sent paa aaret altsaa ikke i den tid, de opholder sig indenfor norske farvand.

4. Knølhvalen opføres her blandt planktonhvalerne, skjønt den ikke udelukkende lever af de smaa planktonorganismer; den er nemlig ofte funden med lodde i maven, men efter alt hvad der foreligger, er man berettiget til at slutte, at den i overveiende grad i allefald lever af kril.

Betragter man nu den ovennævnte fangststatistik (de 40 journaler), der, som vi saa, for blaahvalens og seihvalens vedkommende viste en omtrent udelukkende forekomst i Finmarken i tiden juni-august, saa finder vi tvertimod for knølhvalens vedkommende, at det største antal individer skydes før første juni. Af 175 knølhval, fangne i disse aar, faldt nemlig 104 før første juni, 71 efter, hvilket jo tyder paa en væsentlig forskjel i deres levevis. Betragter vi en saadan typisk fangstjournals fangst af knølhval aaret rundt, vil den vise os omtrent følgende:

Hr. Ingebrigtsen, Tromsø, skjød med sin fangstbaad „Skytten" i aaret 1896 19, 189818 knølhval paa følgende dage og steder:

\section{6}

Nr. 1 28. febr. 2 mil n.v. af Ing $\emptyset$

- 2 2. marts.

- 33 . -

- 44 . -

- 56 . -

- 67 .

- 712 -

- 814 . -

- 916.

- 1017.

- 1120 . -

- 12 23. - 3 mil n.v. af Ingø

- 13 24. - $1 \frac{1 / 2}{2}$ - -

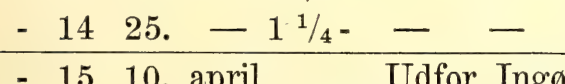

$\begin{array}{llr}-15 & 10 . \text { april } & \text { Udfor Ing } \emptyset \\ \text { - } 16 & \text { 4. juli } 5 \text { mil udfor n. Fugl }\end{array}$

- 17 4. aug. 9 - n.v. af Ingø

- 18 20. - 10 - s. af Bjørnøen

- 19 2. sept.
1898

Nr. 1 12. februar. Udfor Ing $\emptyset$

$$
\begin{array}{lrrrr}
- & 2 & 15 . & - & - \\
- & 3 & 15 . & - & - \\
- & 4 & 16 . & - & - \\
- & 5 & 21 . & - & - \\
- & 6 & 24 . & - & - \\
- & 7 & 25 . & - & { }^{1} / 2 \text { mil udfor Ing } \emptyset \\
- & 8 & 28 . & - & \text { Udfor Ing } \emptyset \\
- & 9 & 2 . & \text { marts } & - \\
- & 10 & 4 . & - & - \\
- & 11 & 9 . & - & - \\
- & 12 & 10 . & - & - \\
- & 13 & 11 . & - & - \\
- & 14 & 12 . & - & - \\
\hline & 15 & 29 . & \text { juni } & \text { Syd for Bjørnøen } \\
- & 16 & 29 . & - & - \\
- & 17 & 9 . & \text { august. } & \text { Udfor Ing } \emptyset \\
- & 18 & 13 . & - & -
\end{array}
$$


Af disse eksempler vil man se, at knølhvalen forekommer til to ganske forskjellige og fra hinanden skarpt adskilte tidsrum, det første omfattende aarets første maneder (februarmarts), det andet tiden midtsommer. Det sidste falder saaledes sammen med blaahvalens $0 \mathrm{~g}$ seihvalens forekomst, medens det første staar i væsentlig strid med de vandringer, disse to hvaler foretager. Hr. IngEBRIGTSEN, der har særlig erfaring i denne vinterfangst, har meddelt mig, at knølhvalen $\mathrm{i}$ disse aarets første maaneder viser høist eiendommelige forhold. Medens den om sommeren vandrer særdeles rolig og med forholdsvis langsomme bevægelser, er den om vinteren øiensynlig paa træk, "den stimer med dampskibsfart vestover" og gaar herunder saa nær land som muligt. Mange hvalfangere paastaar, den skal ind paa stenene for at skubbe sig ren for de mange store parasiter, som den er befængt med, og som hvalfangerne saa godt kjender. Dens mave er ganske tom, derimod har de fleste store fostre, der næsten er fuldbaarne. Kun de enkelte, der fanges saa sent som f. eks. no. 15 (10de april 1896), har af $\mathrm{og}$ til lodde; thi denne er da paa indsig, men alle de tidligere har tomme maver. Med slutten af marts eller begyndelsen af april forsvinder de, som saavel ovenstaaende fangsteksempler, hele journalmaterialet $O g$ samstemmige meddelelser bekræfter, fuldstændig fra Finmarkens hav, og trods at de til sine tider af aaret lever af lodde, er de ikke tilstede under loddeindsigene i april-mai maaned, og de viser sig forst igjen, naar lodden har forladt Finmarkens kyster, og det saakaldte loddefiske er forbi.

Efter de her meddelte observationer og talrige lignende data maa knølhvalens vandringer være at forstaa saadan, at den i januar viser sig ved Østfinmarken for langs land at stryge vestover langs Norges kyst for at føde sine unger "langt vest i havet". Hermed stemmer meddelelser af Eschricht, „at der i begyndelsen af april 1846 strandede en knølhval paa en ø vest for Fæøen og Karmøen i Stavanger amt; det 45 fod lange dyr var i begreb med at føde, men fosteret laa, som man vel tør antage, forkjert, idet halen kom først ud af genitalaabningen; da foetus var født saa langt frem som til forekstremiteterne, der buttede imod, kunde ei fødselen fuldbyrdes. Fosteret blev udskaaret og maalte 14 fod." (GuLDBerG. Bidrag til Cetacéernes biologi Chr. Vidensk. Forh. 1886). Heraf fremgaar, at knølhvalen føder $\mathrm{i}$ april under langt sydligere bredder, og at den foretager lange vandringer, fremgaar af en meddelelse i den ovenomtalte beretning af Søkensen, at dele af amerikansk harpun er funden i en knølhval som i blaahvaler.

Om sommeren vandrer saa knølhvalen nordover igjen. Man finder dem da i juli maaned oppe ved Bjørnøen, hvor de "vaser i lodde og kril" (Ingebrigtsen). De har nu smaa fostre ifølge meddelelse fra 
INGEBRIGTSEN og maalinger af GULDberg (loc. cit.), som i juni fandt $1 / 4$ meter lange fostre, $i$ juli over $1 / 2$ meter, ud paa høsten henimod 2 meter (Еsснгіснт), hvilket viser, at de parrer sig, lige efter at ungerne er født i april. Om sommeren finder man endvidere undertiden ved Bjørnøen hunner med diende unger (ca. 20 fod lange) ifølge observation af Ingebrigtsen, og disse unger følger endnu de store, naar disse i det følgende aars første maaneder forlader Finmarken meddeler hr. IngEBRIGTSEN.

Observationer over knølhvalens liv i Østhavet i tiden september-januar foreligger, mig bekjendt, ikke; thi i denne del af aaret drives jo. ingen hvalfangst, og der færdes ingen fartøier over havet nordenom Finmarken. Men man maa da antage, at de i modsætning til blaahvalen og seihvalen, som allerede i september drager vestover, forbliver hele høsten ud til juletid og i denne tid forlader loddestimerne, naar samtidig temperaturen begynder at synke $\mathrm{i}$ vandet, for at foretage sin store vandring vestover.

Knølhvalen har en vidstrakt udbredelse. Den forekommer ved Grønland, efter hvad der meddeles, særlig i tiden slutten af april--november langs sydkysten. I maanederne marts til mai ser man ved Bermudasøerne hunner med unger. (Van Beneden et Gervais).

Ifølge det amerikanske verk skydes der ikke faa knølhvaler fra de forenede Staters nordostkyst (Provincetown).

Ogsaa i det sydlige Atlanterhav, i det sydlige Stillehav, den Persiske bugt og ud for Californiens kyst forekommer der knølhvaler; hvorvidt disse er samme art som den, der forekommer ved Norges kyst, synes der for tiden ikke at foreligge noget brugbart materiale til at afgjøre. De californiske knølhvaler trækker i bestemte periodiske vandringer nord om. sommeren og syd om vinteren som Finmarkens knølhval.

\section{De blæksprutjagende hvaler.}

Disse tilhører i fremtrædende grad det aabne hav. Der har inden den zoologiske litteratur været talt om, at hvalerne i regelen var kystformer, men selv om man regner for "kystfarvand" alt ud til kystbankernes egger, saa vil ikke de hvaler, som her skal omtales, kunne, kaldes kysthvaler. De findes nemlig saagodtsom udelukkende udenfor kystbankerne, og de enkelte individer, som er fangede indenfor disse, er vistnok undtagelser, og disse forekommer særlig ved Færøerne, der geografisk jo er beliggende midt mellem to store have og ikke egentlig danner noget 
kystfarvand. I overensstemmelse med livet i det aabne hav og den føde, de søger, nemlig blæksprutterne, formaar de at gaa ned til store dyb,

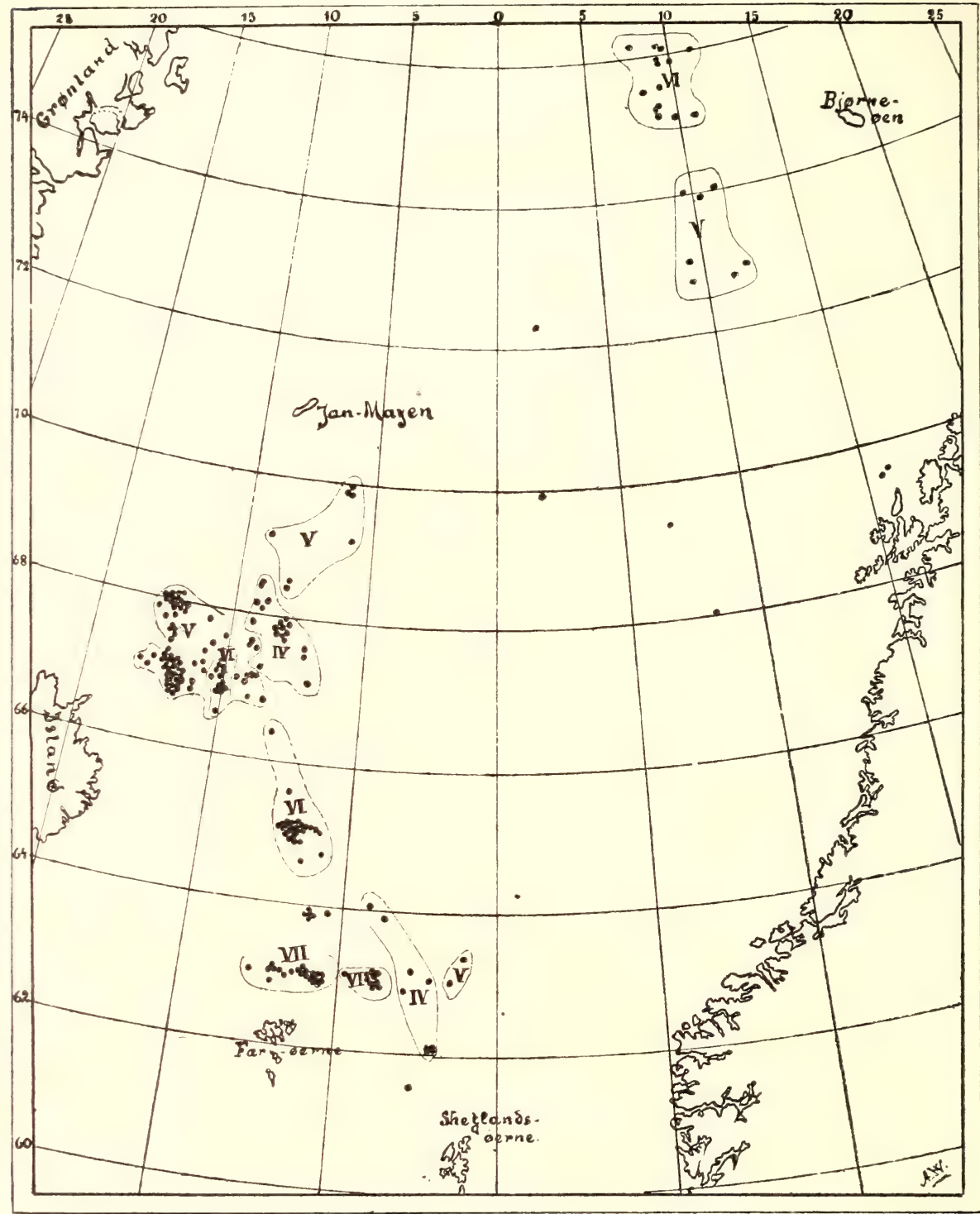

Fig. 56. Kart over Nordhavet, visende hvor bottlenosen skydes til forskjellige aarstider. Hvert punkt angiver et sted, hvor der har været skudt eller iagttaget en eller flere bottlenoser. Romertallene angiver maanederne.

hvor formodentlig ofte deres iøde er at finde. Deres levevis er saaledes i store træk den samme i de nordatlantiske have som kaskelottens i de tropiske (se tropiske hvaler). 
1) Bottlenosens liv og vandringer er kun kjendt fra den del af aaret, da den færdes i det norske Nordhav. For at faa paalidelige oplysninger, hvor den opholder sig mest inden dette til forskjellige tider, har jeg henvendt mig til de norske bottlenosfangere, som med særdeles stor imødekommenhed har (meddelt mig, hvor de ifjor skjød sine bottlenoser, og paa grundlag af disse oplysninger er kartet, (fig. 56), tegnet, hvor hver prik angiver nøiagtig bestemte lokaliteter, hvor en eller flere bottlenoser er skudt. Af de tilføiede romerske tal, der angiver maaneden (V = mai), vil man endvidere se, hvor bottlenosen fandtes og derfor fangsten foregik i maanederne marts-juli 1901.

I marts og april ser man bottlenoser fangede nordost om Færøerne 20-30 mil af. I april og mai er de spredt over store dele af Nordhavet. Enkeltvis ser man dem 50-60 mil vest for Lofoten, nordvest for Tromsø, men i store mængder paa det store felt mellem Island og Jan Mayen, hvor flaaden er samlet slutten af april, mai og begyndelsen af juni. Ikke faa skydes i dette tidsrum ogsaa vest til nordvest om Bjørnøen ca. 40 mil af. I slutten af juni begynder de ligesom allerede at blive urolige, og i første halvdel af juli begynder de at trække sydover for $\mathrm{i}$ slutten af juli $\mathrm{g}$ august at forsvinde. I juli finder da den sidste fangst sted ca. 15 mil n. af Færøerne, og helt ud i september faar indbyggerne af Færøerne af og til fangster af bottlenose. Hvor der saa bliver af dem, har jeg ikke kunnet faa oplysninger om. Fra Nordhavet er de øiensynlig borte, og de færdes antagelig i den nordligere del af det egentlige Atlanterhav. Med hensyn til deres forekomst i Nordhavet kan det i sin almindelighed siges, at de holder sig udenfor de store egge, et forhold, som ogsaa fangstmændene er opmerksomme paa.

Ingebrigtsen, som i mange raar drev bottlenosefangst fra Troms $\emptyset$ ligesom de fangstmænd, hvem kartets nordligste observationer skyldes, og som senere hvert aar har færdedes saa meget i havet mellem Norge og Bjørnøen, meddelte mig, at bottlenosen følger 800 -favne-kurven og saaledes aldrig trænger ind i Østhavet, hvor dybderne er mindre, derimod fandtes den nordover vestenfor 800-favne-kurven helt op til $76^{\circ}$. Helt fra 1868 til 1901 havde han aldrig seet bottlenosen østenom den 18-19 længdegrad. Derimod sees den udfor Tromsø helt henimod eggen, og der saa jeg selv i juli flere bottelenoser.

Af bottlenosefangerne har jeg ogsaa faaet oplysninger om maveindholdet af en hel del skudte dyr. Hos de allerfleste fandtes udelukkende blæksprut, som paastaaes at være den bekjendte akker (Ommatostrephes todarus), dog maa jeg meget beklage ikke at have faaet beviser herfor ved præparater. Mange forfattere anfører, at det er en art onychoteuthys.

Saafremt det virkelig er akkeren, bottlenosen forfølger, staar dens 
forsvinden fra Nordhavet maaske i forbindelse med akkerens endnu ikke opklarede maassevandring mod kysten om høsten. Denne fiskes da i store masser i norske fjorde (Romsdal, Nordland). I mange andre bottlenoser fandtes dog ogsaa sild og det særlig paa feltet $65^{\circ}$ n. $0 \mathrm{~g} 5^{0}-$ $6^{0}$ v. samt langs eggen n. om Færøerne i juni. Ingebrigtsen meddeler, at han i mai 1888 paa $71^{\circ}$ n. og $10^{\circ}$ o. (ca. 45 mil n.v. af Lofoten) fik bottlenose med sild i maven, men ellers er den her fuld af "akker".

INGEBRIGTSEN har den forestilling, at bottlenosen stikker meget dybt efter sin føde, akkeren. Under fangsten stak bottlenosen altid ret ned, saa linen stod altid ganske verttikalt, og den løb da ud indtil 500 favne line for at komme op igjen ganske paa samme sted.

Under almindelige forhold stikker den nok ikke saa dybt, hvor dybt ved man ikke. At udrede dette spørgsmaal vilde have den allerstørste interesse; thi intet tyder formentlig mere paa, hvilken rigdom af store organismer der forekommer i havets midtre vandlag, end erfaringer over disse hvalers vandringer saadan, som vort kart (se fig. 56) viser det.

Her betegner jo hver prik et felt, hvor bottlenose er skudt fuldproppet af blæksprut, hentede fra forholdsvis dybt vand. Men naar vi ved, at havet paa disse steder er $800-2000$ favne dybt, forstaar vi, hvilket overordentlig rigt liv af organismer midt i vandmasserne der maa findes.

Denne overordentlige vigtige erfaring stiller os en lang række af uløste spørgsmaal. Vi maa vide, i hvilke dybder disse masser af blæksprut lever, hrad de lever af, og fremfor alt om de selv forfølges af fisk, om der med andre ord vandrer fisk der ude paa bottlenosefeltet over de svære havdybder. Ovenfor nævntes, at jeg i aaret 1900 fandt sild derude, $o g$ at flere af de skudte bottlenose havde sild i maven. I min første beretning fra „Michael Sars"s ekspeditionen i aaret 1900 (se denne aarsberetning for 1900 de hefte) har jeg omtalt nærmere, at vi under de øverste 100 favne fandt svævende et dyreliv af større planktonorganismer (krebsdyr, orme etc.), der kan antages at udgjøre disse blæksprutters næring, og at vi ogsaa der ude fiskede stor torsk, sei og hyse, som altsaa vandrede midt $\mathrm{i}$ vandlagene over de store dybder. At nu blækspurtterne forekommer i vældige masser derude, fremgaar af vort kart; i hvilken udstrækning torsken forekommer, kan mine faa forsøg fra 1900 ikke bevise, og løsningen af dette spørgsmaal er fremtiden forbeholdt.

Som vi senere skal se, møder vi i de tropiske have de samme spørgsmaal, idet vi der finder en bottlenosen nærstaaende hval, kaskelotten, levende af blæksprut over de større havdyb.

Kükenthal anfører (Wale der Arktis), at ungerne antagelig fødes tidlig paa vaaren, da man i mai og juni hyppig kan se hunner med ny- 
lig fødte unger, som ved fødselen er 11 fod lange. Dette stemmer ogsaa dermed, at bottlenosen i juni igjen har smaa fostre (30-45 $\mathrm{cm}$. Henkiva).

Bottlenosen vandrer mest i flokke paa nogle faa stykker, de er fredelige, nysgjerrige dyr, som ofte søger hen til skibene, og da fortrinsvis blir gjenstand for fangst.

Af og til strander de paa Norges kyst som i Nordland, langs vestkysten, og enkelte forvilder sig helt ind i Kristianiafjorden (se den systematiske oversigt).

2) Grindehvalen. I den systematiske oversigt er der nævnt, at den af og til forekommer ved Norges kyst, men hyppigst iagttages i farvandet om Færøerne, hvor den af og til stænges. Efter hvad der foreligger, skal den dog færdes tilhavs og ligeledes ernære sig af blæksprut.

\section{De fiskejagende hvaler.}

Til de nordatlantiske fiskejagende hvaler henregner vi følgende arter: Finhvalen, Vaagehvalen, Delfinerne og Spækhuggeren. Disse er i mange henseender meget forskjellige, de to første er jo saaledes bardehvaler og er derfor henvist til at ernære sig af væsentlig smaa fiske (lodde, sild), medens de sidste ogsaa kan søge sig større bytte og er graadige rovdyr. Fælles for alle disse hvaler er foruden den omstændighed, at de alle ernærer sig af fisk, ogsaa det, at de fortrinsvis holder sig nær kysterne og ikke antages at foretage saa store vandringer som de foregaaende. Naar jeg siger, at de holder sig nær kysterne, maa dog dette ikke opfattes altfor snevert, idet de dels gjennem store, ja de største dele af aaret færdes over hele kystbankernes hav (og dermed hele Østhavet) men ogsaa er at finde udenfor dette. Saaledes saa jeg i 1900 finhval paa bottlenosefeltet, hvor vi ogsaa fiskede sild (ca. $64^{0}$ n. og $6{ }^{0}$ v.). Men i sammenligning med de vandringer, som saadanne hvaler, som blaahval og seihval foretager, maa man antage, at deres omraade er adskillig mere begrænset.

1. Finhvalen. Undersøger vi paa grundlag af de tidligere nævnte journaler denne hvals forekomst i Finmarken til forskjellige tider af aaret, saa vil vi faa følgende resultat: 
I marts fangedes 41 finhval $5.6 \%$ af journalernes fangst affinhval

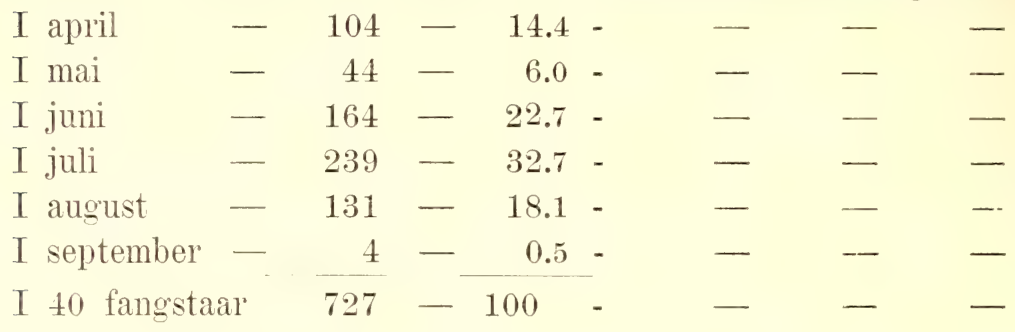

Ved nærmere studium af disse tal og endmere journalerne selv vil man se, at finhvalens forekomst afviger adskillig baade fra blaahvalen og seihvalen paa den ene side og' knølhvalen paa den anden.

Medens blaa- og seihvalen ikke forekom for 1ste juni, fanges af finhral $26 \%$ før første juni, men disse fanges dog hovedsagelig til en anden tid end knølhvalen, der ogsaa forekommer i aarets første halvdel, men inden denne udelukkende $\mathrm{i}$ aarets forste maaneder, januar-marts. I dette tidsium fanges meget faa finhval, som ovenstaaende eksempel viser, i 40 fangstaar kun 41 finhval, det vil sige 1 pr. fartøi i et aar, det samme el tilfældet i mai maaned, da der findes 44 finhval, derimod ser man, at a pril maned viser en fangst af 104 .

Med andre ord, finhralen støder under kysten sammen med lodden under dennes indsig, der, som vi af kap. 3 saa, i regeIen finder sted i april maned, senere fjerner den sig igjen fra kysten og skydes senere paa a aret, sommeren, i regelen flere mil paa sjoen eller helt oppe mod Bjørnøen eller isgrænsen.

I april maaned er den da fuldproppet af lod̉de; den 24 de april saaes f. eks. i Troldfjorden nogle finhvaler, som var saa fulde af lodde, at det randt ud af dem, da de droges paa land. Om sommeren er de, som f. eks. af Ingebrigtsen skydes ved Bjørnøen, fulde af lodde, de, som skydes nærmere Norge i juni maaned, fandtes at have stor og liden Kristianiasild i maverne.

Hrad der her er anført, tyder ikke paa saa udstrakte vandringer, som vi for de tidligere nævnte hvalers vedkommende saa var tilfældet. Til samme resultat kommer vi ved betragtningen af de erfaringer, som er gjort angaaende finhvalens forplantningsforhold. G. A. GuLdBERG har anstillet en stor række undersøgelser over hvalernes fostre, hvis størrelse han har maalt til forskjellige aarstider. Maalingerne viste ristnok nogen individuel variation, men tyder dog i det store og hele paa, at finhralen har en bestemt parringstid nemlig aarets første maaneder, hvilket ogsaa bekræftes af andre iagttagelser. 
I marts fandtes foster af 0.125 meters længde

\begin{tabular}{|c|c|c|c|}
\hline april & $-\quad-$ & $0.3-0.8$ & \\
\hline (som en enkelt & undtagelse & 2.5 & \\
\hline [ mai fandtes & foster af & $0.3-1$ & \\
\hline juni - & - $\quad-$ & $1.1-2$ & \\
\hline [ juli - & - & $1.7-3.1$ & \\
\hline
\end{tabular}

Efter dette skulde man slutte, at den parrer sig i februar, og at den fuldbaarne unges størrelse, $6 \mathrm{~m}$., vil kunne naaes til næste aars første maaneder, med andre ord, at finhvalen gaar drægtig i 1 aar. Hermed stemmer mange andre iagttagelser. GuLdBERG anfører saaledes: "I et par dage i slutningen af mai 1883 blev der af flere af hvalfangerne paa Østfinmarken iagttaget en masse „ung hral" sammen med en del voksne finhval, der viste sig orer hele Varangerfjorden, idet de gik $\mathrm{og}$ fraadsede i loddestimerne. De mindste af disse finhvalunger harde en længde af knap 20 fod, altsaa omkring 6 meter. Mange) af ungerne havde ikke engang rede paa at lægge sig paa siden for at fylde munden med lodde, men gik blot og "nafsede“, medens de større unger havde lært grebet. Denne mængde hval forsvandt dog snart igjen."

"Ogsaa i juni maaned saa man af $o g$ til en del ung finhval sammen med nogle faa voksne. De ældre og erfarne skyttere . . . beretter, at de aldrig har seet en enkelt finhval ledsaget af sin unge, derimod altid i flok og følge, dels lidt større unghral sammen, dels i større flokke sammen med de ældre. Kapt. GrøxN (skib „Skjold“) har berettet mig, at han den 24de juli 1883 fangede en finhvalhun, som ledsagedes af en liden unge. - Størrelsen er mig desværre ikke bleven opgivet -; af moderens yver udtappedes flere potter melk."

INGEBRIGTSEN har meddelt mig, at man om sommeren hvert aar ser unger af finhvalen, dog aldrig i saa stort antal, som de voksne, ja endog væsentlig færre end de fostre, som findes i de voksne hval. Fostre forekommer slet ikke i hver hunhval, hvilket ogsaa stemmer dermed, at ungen i flere maaneder følger moderen, saaledes at det ikke er sandsynligt, at finhvalens hun gaar drægtig hvert aar.

IngEBRIGTSEN antager, at om der et aar fanges 50-60 finhval, er det antal fostre, der forefindes, ca. 10-15, medens i forhold endnu færre unger er at se. Det sidste forklarer han 'sig saaledes, at en stor del af finhvalhunnerne, ligesom knølhvalerne, vandrer "vest i havet" og kaster der, medens kun endel gjør dette i Finmarkshavet.

Finhvalen forekommer foruden i Finmarkshavet, ved Europas kyster, ved Grønland, Nordamerika og er den eneste finhval, der er funden i Middelhavet.

Langs det sydlige Norges kyster viser den sig især under sildefiskerierne specielt ved storsildfisket udenfor Romsdal, vaarsildfisket og 
østlandsfisket. Da storsildfisket fandt sted udfor Vesteraalen, optraadte de ogsaa der i mængde. Enkeltvis er de iagttagne i de danske farvand søndenom Skagen, ja helt ind i Ostersøen, langs Hollands, Belgiens, Skotlands, Englands kyster, i Kanalen, den Biskayiske bugt, ved Spaniens, Frankrigs og Italiens middelhavskyster.

Deres forekomst synes meget variabel og er utvivlsomt afhængig af de fiskestimers optræden, som de følger. Deres antal paa en kyststrækning vil derfor være afhængig af asstiderne $o g$ vekslinger i fiskestimernes indsig i de forskjellige aar. (Dette forhold vil senere blive omhandlet).

Den fanges ogsaa paa den vestlige side af Atlanterhavet særlig ved Island. Ifolge meddelelse fra hr. L. BERG, Island, fangede han i aaret 190190 finhral $\mathrm{i}$ følgende maaneder ( $\$$ fangstbaade):

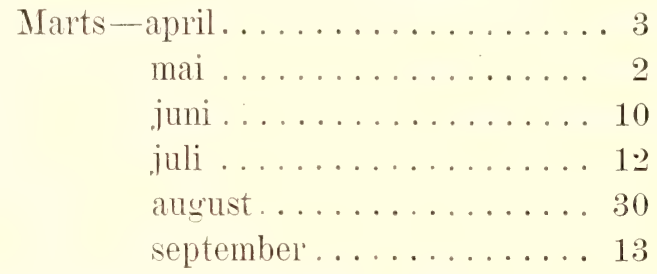

Som man ser, falder hovedfangsten her sent paa sommeren, hvilket formentlig staar i forbindelse med, at silden da nærmer sig Island. Tidlig paa sommeren har finhralen ifolge hr. Bergs meddelelse kril i maven, og den færdes da meget sammen med blaahvalen nord om Island.

Man har endnu ingen saadanne sikre beviser for, at finhvalen foretager saa lange vandringer, som vi ovenfor saa, at man har for blaahvalens og knolhralens vedkommende, dog maa det iallefald - efter deres vekslende forekomst at domme - med sikkerhed kunne sluttes, at de vandrer f. eks. langs hele den norske kyst.

2. Vaagehvalen er ifølge Collett maaske den hyppigst forekommende finhvalart ved vore kyster.

Den fanges hvert aar paa Vestlandet i skjærgaarden paa den maade, at de stænges inde med not og senere dræbes med forgiftede pile. Til denne fangst knytter der sig den interesse, at befolkningen gjennem lange tider har været opmerksomme paa, at visse pile frembringer en fra saaret hurtig fremadskridende blodforgiftning, som i løbet af 24-36 timer dræber dyret, og at pile, som er stukne i slige saar, fortrinsvis fremkalder lignende blodforgiftning paa et nyt dyr. De kaldes derfor for "dødspile“. Mest berømt som „kvalvaag“ er Skogsvaag paa Sartorøen ud for Bergen, hvor der ifølge Grieg aarlig fanges ca. 6 stykker, merkelig nok i regelen hunner, hvoraf Grieg slutter, at hanner og hunner gaar hver for sig. Nogen synderlig stor fangst foregaar altsaa ikke af disse dyr, men de er leilighedsvis fangede helt ned i Christianiafjorden. 
Eschricht, Guldberg og Grieg har studeret deres forplantning, og deraf fremgaar, at vaagehvalen „parrer sig tidlig om vaaren og føder sent paa høsten eller midtvinters" (GRIEG).

Van Beneden og Gervais nævner eksempler paa deres forekomst fra de mest forskjellige steder af Nordsøens kyster, ligeledes fra Kanalen og Biskayiske bugt, enkeltvis er de ogsaa iagttaget i Østersøen.

Henking har beskrevet fangsten af et ved Bjørnøen skudt dyr.

VAnHöffen omtaler, at de forekom ved Grønlands vestkyst. Han meddeler, at han i Umanakfjorden saa tre stykker, som holdt sig flere dage der mellem isflagene, $\mathrm{og}$ han meddeler, at den findes langs vestkysten baade $\mathrm{i}$ den nordlige og sydlige del.

Vaagehvalen forfølger ligesom finhvalen sildestimerne og synes i det hele at have samme levevis som finhvalen. Paa grund af sin ringe størrelse er den dog ikke gjenstand for hvalfangernes jagt.

3) Delfinerne. Idet jeg angaaende disse henviser til, hvad der under den systematiske oversigt er sagt, skal jeg her kun nævne endel iagttagelser over den i det nordligste Norge mest betydningsfuide delfin (Delphinus acutus) „springeren“, hvidskjævingen.

Disse iagttoges paa begge de sommertogter, vi i 1900 og 1901 foretog fra Norge til Bjørnøen omtrent midtveis. Her samlede de sig i mængder rundt bougen af fartøiet og fulgte os lange strækninger, idet de tumlede sig snart foran, snart ud til siden, snart rundt fartøiet. Som jeg ovenfor har nævnt, blir der ogsaa herude om sommeren skudt finhval, der til den tid og fra dette sted jevnlig har middelstor sild (,Kristianiasild") i maven. Delfinerne færdes derfor sandsynligvis herude forfølgende de yngre aarsklasser af silden.

Under loddeindsigene i midten af marts 1901 saaes de i mængder langs Østfinmarken og Murmankysten en mil eller to af. Vi saa dem her lege og utrættelig springe "sjøløst" den ene gang efter den anden.

Midtsommers saa vi dem ogsaa ude paa bankerne vestenom Tromsø og det netop over eggen, ogsaa her fulgte de fartøiet paa samme maade som ellers.

4) Spækhuggeren. Denne hval er særlig kjendt i vort land fra Vaarsildfisket, hvor den forekommer i store mængder især paa de saakaldte „aater", det vil sige de tætpakkede samlinger af silden, som pludselig viser sig i havoverfladen, og som ofte giver anledning til rige fangster. Jeg har selv her ofte havt anledning til at se flokke paa 7-8 spækhuggere, „staurgris" eller „grisen“, som fiskerne kalder den, gaa rundt baaden saa nær, at de kunde naaes med en aare.

De lever utvivlsomt saagodtsom udelukkende af fisk, væsentlig af sild. Men leilighedsvis angriber de ogsaa større dyr, selv hvalerne. 
Eschricht ${ }^{1}$ ) meddeler et interessant eksempel paa, hvor graadige disse spækhuggere kan være. I juli 1861 undersøgte han nemlig i nærheden af Grenaa, Danmark, en spækhugger af $21^{1 / 3}$ fods længde. Maven viste sig, da dyret aabnedes, at være ca. 6 fod lang $0 g^{1} \frac{1}{2}$ fod bred. I denne fandtes der levninger af ikke mindre end 13 "marsvin" (niser) og 14 sæler, og disse levninger var saavidt friske, at de ikke kan antages at have været mange dage gamle. Interessant er det, at der ikke fandtes skind i maven, derimod et afllaaet skind i dyrets mund, saaledes at Eschricht mener at kunne slutte, at sælerne, „efterat være slugte under fordøielsen blir flaaede“, og „at de afflaaede skind endog temmelig hurtig kastes op ". Denne spækhuggernes rovdyrnatur er gammel kjendt. Esсниicht meddeler saaledes, at allerede oldtidens forfatter PLinius fortæller, at hralerne blev forfulgt af disse dyr. Eschricht meddeler efter ham, at ..hralfiskene søge deres frelse i flugten ud i det aabne hav, men orcaene stille sig imod dem og myrde dem i de snevre farvande eller jage dem ind paa land." „Kongespeilets forfatter giver endog st aldeles naturtro billede af deres characteer i sin beskrivelse af vognhvalerne: "I deres grumhed mod andre hvaler", siger han, "ere de lige med hunde mod andre dyr, idet de 'samles i flokke og anfalde store hvaler, og hvor der er en stor hral alene, bide og udmatte de den, indtil den faar sin død deraf."

Den danske kaptein HoLbøLL, som i mange aar var paa Grønland, har samlet yderst værdifulde oplysninger om hvalernes livshistorie. Eschricht meddeler efter ham folgende: „Spækhuggeren angriber ogsaa gronlandshralen. Et saadant tilfælde blev i 1823 iagttaget ved Holsteinsborg fra de slupper, som der holdt strandvagt. En flok spækhuggere $\mathrm{kom}$ under deres forfølgelse af en stor grønlandshval sydfra ganske tret forbi slupperne. Nogle af dem havde bidt sig fast til dens stjert og laller, medens andre sprang over den ved blæsegattet og sogte at forhindre den fra at drage aande, atter andre puffede den fra siderne. For at se, hrorledes kampen vilde ende, fulgte slupperne efter. Hvalen styrede ind $i$ en bugt ved Pivertshavn, rev sig her løs og gav een af angriberne et saadant slag lige paa hovedet med kanten af sin stjert, at han ganske langsomt sank tilbunds, høist sandsynlig slaaet ihjel. Derpaa gik hvalen ind $\mathrm{i}$ det inderste af bugten, dens hoved løb paa grund, og i denne stilling blev den et let bytte for grønlænderne."

.Kapt. Houbøuls egen beretning om spækhuggernes levemaade lyder paa følgende maade: 1827 var jeg øienvidne til et af disse rovdyr anstillet slagteri. En flok hvidfisk var af disse blodtørstige dyr bleven jaget ind $\mathrm{i}$ en bugt $\mathrm{i}$ omegnen af Godhavn, og de bleve der $\mathrm{i}$ ordets

1) Foredrag af etatsraad EsRichт on spækhuggeren (Delphinus orca). Oversigt orer det kgl. danske Vidensk. Selsk. Forh. 9de Mai 1862. 
egentligste forstand sønderrevne af dem. Der blev dræbt langt flere end ædt, hvorved grønlænderne, foruden deres eget bytte, endnu fik en god andel i spækhuggernes. - 1830 blev i nærheden af Narparsok ifølge grønlændernes angivelse, en stor krepokak“ (knølhval) „overvældet og. efterat have opgivet aanden, sønderrevet af en orca. Af det paa valpladsen svømmende spæk kom endnu henimod 15 tønder gronlænderne tilgode."

Eschricht slutter heraf, at meddelelserne om, at spækhuggerne, „skjønt unegtelig tildeels nærende sig af store fisk, er glubende dyr, er fuldkommen rigtige. De kunne sluge saavel marsvin (,niser") som sælhunde, endog meget store individer, hele $0 \mathrm{~g}$ holdne, idetmindste 4 lige efter hinanden (den Nilsonske iagttagelse) $0 \mathrm{~g}$ i løbet af faa dage indtil 27 individer, ei heller skye at anfalde og sønderrive selv de allerstørste bardehvaler, for at mætte sig af deres spæk."

Jeg har anført dette saa udførlig, fordi det, som her er omtalt, har spillet en vis rolle i folks tankegang i Finmarken, med hensyn paa de store periodiske indvandringer af kobbe (grønlandssæel) under fisket. Man har nemlig hørt om netop den ovenfor meddelte Eschrichт'ske meddelelse om hin spækhugger, der havde slugt saa mange sæl. Heraf sluttede man, at kobben utvivlsomt vilde sky de steder, hvor spækhuggeren fandtes. Jo flere spækhuggere, des mindre sæl. Men spækhuggernes forekomst, mente man igjen, var afhængig af bardehvalernes forekomst, fordi, mente man, spækhuggerne levede af bardehvalerne. Naar nu bardehralerne bler skudt bort af hvalfangerne, vilde ogsaa spækhuggeren forsvinde, og dermed vilde kobben holde sit indtog. $\mathrm{Og}$ aarsagen til, at kobben nu antages at være talrigere end før, var ifølge ovenstaaende derfor den, at hvalfangsten havde bortskudt bardehvalerne.

Denne noksaa udspekulerede bevisførsel, som af aviserne sees at have spillet en vis rolle i folks tanker om alle disse ting, er dog hverken sandsynlig eller stemmende med en flerhed af sikre kjendsgjerninger. Der er nemlig en stor forskjel paa den ting, at spækhuggerne virkelig vides at angribe visse bardehvaler, og paa den ting at paastaa, at spækhuggerne normalt lever af disse hvaler og derfor opholder sig der, hvor disse findes, saaledes at de vilde forsvinde fra et sted, hvor bardehvalerne ikke mere fandtes.

Det er ganske usandsynligt, at bardehvalerne skulde være en normal føde for disse dyr bl. a., fordi det da maatte være et langt hyppigere syn at se spækhuggerne forfølge og dræbe dem. Trertimod dette vil enhver, som har færdedes paa vaarsildfisket, hvor spækhuggerne findes i slige mængder, have seet finhval og spækhugger noksaa fredelig sammen $0 \mathrm{~g}$ fremfor alt have seet spækhuggeren forfølge silden, ikke 
hvalen. Dette har jeg for min del mange gange seet, og det er enhver fisker paa Vestlandet bekjendt.

Nansen fortæller i sin bog „Paa ski over Grønland“ om, at han under Grønlands østkyst et par gange saa spækhuggeren. Han skildrer, hvorledes den ofte angriber de store hvaler, og fortæller, at eskimoerne har fortalt ham, ., hrorledes de har seet „ardluken“ — saa kalder de den, tage sælen i en eneste bid." Men han fortsætter videre:

„Paa rore kyster synes spækhuggeren delvis at fore et mere fredeligt liv; den sees stadig paa vore sildefiske og synes der kun at leve af sild og sei; den viser ingen tilbøielighed til at angribe de store hraler, som den daglig har anledning til at komme sammen med, og disse synes heller ikke at være rædde for den. Grunden hertil er muligens, at der er nok af fiskefode, saa den ikke bryder sig om hvalspæk; mere sandsynligt er det dog; at de bardehvaler, som kommer paa sildefiskene, nemlig sildehvalen (Bulcenoptera musculus) og vaagehvalen (Balcenoptera rostrata) ikke er de, den pleier at angribe; dette er sandsynligvis den ikke saa hurtige og sterke blaahval og muligvis ogsaa troldhvalen (knølhvalen, Megaptera boops)."

Selv om man indrømmer, at blaahvalen og knølhvalen er aftaget som følge af hralfangsten i Finmarken, antager jeg dog for min del, at der ingen grund er til at antage, at dette vilde kunne forklare forekomsten af spækhuggeren, hvis hovednæring, jeg efter den erfaring, som foreligger, maa antag'e, el fisk. Har nemlig hvalfangsten formindsket antallet af blaahval i Finmarken - hrad man ikke kan betegne som usandsynligt -- vil det maatte ansees som høist sandsynligt, at spækhuggerne forlængst vilde have udryddet blaahvalen, om denne virkelig udgjorde deres hovedsagelige føde. Paa den anden side tror jeg ikke, at noksaa mange spækhuggere vilde væle istand til at øve indflydelse paa det vældige kobbeindsig, hvis bevægelser efter min tro skyldes naturforhold langt større og mægtigere end sely særdeles store flokke af spækhuggere, hvor rovlystne disse end maatte være.

At paa den anden side hval (bardehvalerne) og sælerne forekommer paa de samme steder, og at saaledes den ene ikke maa forsvinde, hror den anden færdes, er der ogsaa en mængde beviser for. Saaledes fortæller NANsEx i sin nævnte bog om, at han langs isen, hvor han skildrer, sælerne opholdt sig, ofte saa bardehvaler, mest blaahval, og enkelte spækhuggere. Jeg har herom desuden indhentet erklæringer fra sælfangere ved Grønlandsisen og førerne af sælfangerne "Capella“, „Hekla“, „Vega“, "Viking“, "Morgenen" bekræfter alle at have seet hval nær isen, hvor sælen laa, og undertiden sælen og hvalen i vandet sammen.

Det er idethele en stor feiltagelse, som man saa ofte møder i fiskerispørgsmaal, at tro, at, fordi en dyreart af og til lever af en anden, 
de altid følges ad, og at den ene derfor er udelukkende afhængig af den anden. Man ved altsaa, at spækhuggeren af $\mathrm{og}$ til angriber hvalen, men man ved jo ogsaa, at den af $0 \mathrm{~g}$ til angriber sælen. Men man klager jo i Finmarken netop over, at der ingen spækhugger er til at jage sælen, skjønt denne ofte er et kjært bytte for den. Kan der være klarere bevis for, at der ikke behøver at være denslags sammenhæng mellem to saadanne dyrearters forekomster, selv om den ene leilighedsvis lever af den anden? Levede spækhuggeren bare af sæl, maatte der vrimle af spækhuggere langs iskanten, i Hvidehavet o.s.v. Levede den bare af hval, maatte vi se den daglig angribe hvalen. Men det er et sjeldent syn, som beskrives som en stor og interessant begivenhed.

Jeg formaar derfor ikke at tillægge hvalerne den betydning for sælens vandringer, som man har villet tilskrive dem, og anser denne side af de diskuterede spørgsmaal om forholdet mellem fiskeri og hralfangst for at have liden eller rettere ingen betydning. Hertil vil jeg dog senere komme tilbage i kap. 7 .

\section{De tropiske hvaler.}

Blandt de hvaler, som lever hele sit liv i de varme egne, paa begge sider af Ekvator, besøger en art "kaskelotten" af og til ogsaa det nordligste Norge. Den kaldes af engelskmændene „Sperm-whale“, der antages være en forkortelse af „Spermacet-whale"; dens opholdssteder sees bedst ved at kaste et blik paa kartet fig. 61, hvor der med bogstav $\mathrm{S}$ er angivet de dele af havet, hvor den fortrinsvis færdes og er gjenstand for fangst.

Man vil deraf se, at den har en særdeles vidstrakt udbredelse saavel i Atlanterhavet som i Det stille hav iallefald indenfor de varmeste dele af disse (indenfor "vendekredsene").

I Atlanterhavet lever de ved de Azoriske øer og streifer derfra undertiden op mod Kanalen, Frankriges, Englands og Skotlands kyster. GULDBERG $^{1}$ ) har sammenstillet de kjendte tilfælde, da den har været observeret inden Nordhavet. CoLLETT ${ }^{2}$ ) meddeler saaledes, at i aarhundredet $1777-1877$ strandede to gange kaskelotter paa Norges kyst, GRIEG ${ }^{3}$ )

1) Guldbeng: Cetologische Mittheilungen. Nyt Mag. f. Naturv. 1901.

9) Collett: Bemerkninger til Norges pattedyrfauna. Nyt Mag. 1877 og 1883.

3) Grieg loc. cit. 
meddeler, at Bergens Museum har en kaskelottand fundet i Jæderens sand, SARS ${ }^{1}$ ) omtaler forekomsten af en kaskelot ved Lofoten. GuLdBERG meddeler, at i 1895 blev en kaskelot skudt af et af hr. L. BERGs skibe ved Islands nordkyst ca. 20 mil af i juli maaned. Et andet eksemplar blev skudt ca. 4 mil af Færøerne af hr. A. GRønn fra Sandefjord.

I 1896 blev to kaskelotter skudt i nærheden af Østfinmarken, begge tidlig paa sommeren. Man saa en flok paa 7 stykker, af hvilke altsaa to blev skudt.

Den ene af disse forekommer $i$ en af de 40 fangstjournaler, som jeg tidligere har omtalt, og er den eneste, som der forekommer, hrilket jo riser, hvor sjeldne de er.

I 1899 saa hr. GRøNN en flok kaskelotter nær Færøerne, men fik ing'en.

I 1901 blev et dyr skudt n.o. for Færøerne af en bottlenosefanger, og hr. GRøNn saa ligeledes i august en flok - omtrent 10 stykker nær Færøerne.

De forekommer saaledes af $0 g$ til - om sommeren $i$ de nordlige farrand, og er allerede fra gammel tid kjendt i Norge. GuLdBeng meddeler, at Kongespeilet omtaler dem og beskriver dem saa nøiagtig, at ingen trivl kan næres om, at beskrivelsen gjælder kaskelotten.

Kaskelotterne lever væsentlig af blæksprutter, af og til af fisk. Fyrsten af Monaco har beskrevet flere arter store blæksprut fra deres maver. Deres forekomst over de store gjennemsnitlig 3000 favne dybe verdenshave faar derfor den samme store interesse som bottlenosens i Nordharet, den riser nemlig, at blæksprut vandrer i de midtre vandlag orer alle verdenshave.

De holder sig mest i flokke optil 100 stykker. De hører godt og flygter alle $i$ en mils afstand. (Se følgende kapitel).

1) G. O. Sars: Forh. Vid. Selsk. Christiania 1865 p. 289. 


\section{Femte kapitel.}

\section{Hvalfangsten,}

I det foregaaende kapitel gaves en oversigt over det norske Nordhavs hvaler, der, som vi saa, danner en lang række indbyrdes meget forskjellige former fra de smaa hurtige delfiner til de graadige store tandhvaler og dyreverdenens største kolosser, bardehvalerne.

Forskjellig, som de forskjellige hvalers legemsbygning og udseende er, saaledes viste sig ogsaa deres levevis at være. De arktiske egne har sine typiske beboere (grønlandshvalen, hvidfisken, narhvalen), som yderst sjelden forvilder sig bort fra de vandlag, hvor den evige is giver alt sin karakter. De varme tropiske have sender af og til, men yderst sjelden, sine store kaskelotter op i Nordhavet, og som store rariteter skydes de af Finmarkens hvalfangere og vækker da samme forundring, som de sydfrugter, Nordlandsbeboerne finder paa sin strand. Men ogsaa Nordhavet har sine egne hvaler, de hvis vandringer lovmæssig er bundne inden Nordhavet og det nordligste Atlanterhav. Vi saa, at der sent paa vaaren og forsommeren indfandt sig en mængde hvaler over hele Nordhavet, af hvilke nogle (bottlenosen) lángt fra alle kyster forfulgte de store blæksprutstimer, medens andre (blaahvalen, seihvalen, knølhvalen $o g$ vel fordums nordkaperen) vandrede nordover mod de rige planktonmarker, som den arktiske sommer frembringer, for allesammen at forsvinde, naar høsten $0 \mathrm{~g}$ begyndelsen af vinteren med sit mørke og "goldhed dræber sommerens kortvarige liv.

En egen gruppe forlader dog kun undtagelsesvis Nordhavet, det er de former, som oftest sees ved vore kyster, som lever af kysthavets fisk $o g$ derfor følger disse paa deres vandringer. Disse hvaler kan derfor fremfor de andre kaldes det norske kysthavs hvaler.

Som alle disse dyrs levevis er forskjellig, saaledes har ogsaa menneskets bestræbelser efter at fange og tilgodegjøre sig dem maattet antage forskjellige former. 
Af mere tilfældig art saa vi i det foregaaende kapitel, at den fangst var, som kom istand derved, at man i kysthavet (skjærgaarden, fjordene) med nøter stængte inde større eller mindre mængder af slige hral, som til visse aarstider regelmæssig søgte ind i disse farvand. Ved omtalen af grindehvalen nærntes, hvorledes denne af og til paa Færøerne og ogsaa hertillands i større mængder fangedes paa denue maade, det samme saa vi, ved Bergenskysten var tilfældet med vaagehvalen, i Danmark med "marsvinene" (niserne), paa Spitsbergen og den sibiriske kyst med hridfisken.

Den egentlige hralfangst adskiller sig dog fra disse mere leilighedsrise fangster derved, at den opsøger hvalen i sit element paa det aabne hav og binder an med ham der i en kamp, der saa mangen gang har ræret ført paa „liv og død" fra begge sider.

Scoresbr ${ }^{1}$ ) skildrer i sit berømte værk, hvorledes han tænker sig oprindelsen til, at fiskerne ved den Biskaiske bugt først vovede at binde an med de store hvaler. Han antager, at hvalerne leilighedsvis har kommet til at ødelægge fiskernes garn, og at fiskerne for at beskytte disse, .som antagelig udgjorde det væsentlige af, hvad de eiede", brugte sine pile og spyd for at jage hvalerne. "Ved nu at skyde paa disse hraler, vil de utvivlsomt være blevne overrasket ved at finde, at istedetfor at være vilde, forfærdelige $o g$ farlige dyr, som de havde troet, var de rædde og uskyldige. Denne iagttagelse vil da lettelig have indgydt dem saa meget mere selvtillid og mod, at de mest forvovne af dem enten for kappelystens skyld eller i haab om det rige bytte eller ogsaa bare af dumdristighed er blevne bevægede til at nærme sig nogle af disse dyr og endog til at vore at bore sine spyd i deres krop. Naar de da merkede, at dyret ikke viste nogen tanke paa at gjøre modstand, men at det trertimod øieblikkelig med største hast flygtede ned mod havets bund, og at det, naar det igjen kom op til overfladen, var ganske afkræftet og øiensynlig i en døende tilstand - da maa de have undfanget tanken om muligheden af at binde an med nogle af disse dyr ved hjælp af en line forsynet med en spids pil eller spyd. Hvis de nu til enden af denne line bandt en af de bojer, som de almindelig brugte i sit fiskeri, saa vilde denne vise dem det sted, hvor det saarede dyr udmattet af sine bevægelser kom op, og denne boje vilde desuden drive dyret til en saadan grad af udmattelse, at det vilde falde som et let bytte for de forvovne fiskere. Naar forst et saadant dyr var fanget paa denne maade, og man havde lært dettes værdi at kjende, da vilde udsigten til fordel rære nok til at faa hvalfangsten igang."

1) Naar der her og i det følgende henvises til Sconesby, gjælder det hans: An account of the arctic regions. 1820 . 
Der har væeret meget tvivl om, hvilket folkeslag som først har drevet denne den egentlige hvalfangst. Nogle har ment at beboerne af den Biskaiske bugt, andre at eskimoerne, atter andre at nordmændene var de første.

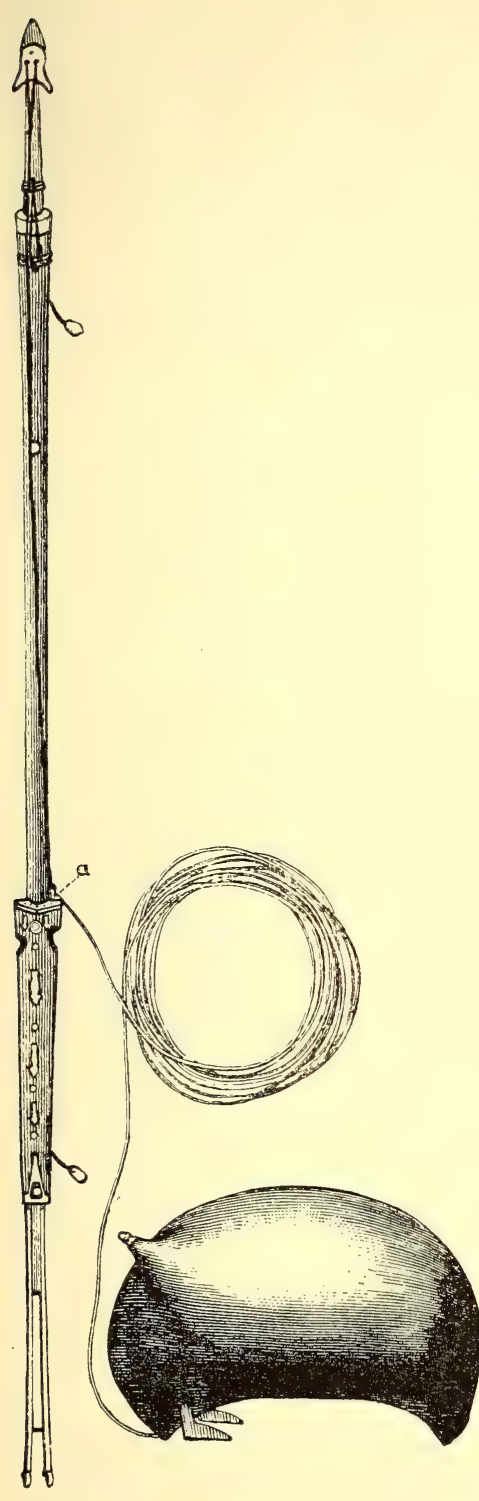

Fig. 57. Eskimoernes harpun med line og skindbøie. Efter Nansens "Eskimoliv".

EsCHRICHT fortæller, at eskimoerne til fangst af grønlandshval bruger en line med kastespyd i den ene og boje $\mathrm{i}$ den anden ende, en fangst som altsaa i vore dage repræsenterer det allerførste stadium Scoresby tænkte sig for al hvalfangst.

En anden fangstmaade, som kræver stort mod, skildrer Eschricht saaledes: „Denne fangemaade, der maaske fordrer mere dristighed og større færdighed end alle europæiske hvalfangere i regelen have leilighed at udvise, er allerede $\mathrm{i}$ lang. aarrække anvendt af grølænderne ved colonien Fredrikshaab paa "keporkaken" (knølhvalen). - „Flere mænd er samlede i en af grønlændernes største baade (de saakaldte konebaade). Man søger at komme den ganske tæt paa livet, medens den ligger stille i overfladen. Til den ende ror man med løse kajakaarer, som ellers kun bruges til kajakker. Med dem staar mændene opreiste til begge sider, og ved at støde det ene endeblad af dem næsten lodret $i$ vandet $o g$ føre det kraftigen agterud (en roningsmaade, der kaldes "at pagaye“, HoLBøLL) bringe de baaden meget hurtigt og næsten lydløst frem. Tvende af de bedste harpunerere stille sig i forenden, hver med sin landse. Det gjælder at stikke hvalen tæet bag en af brystfinnerne og derved træffe hjertet, og dette udfører de med en saadan færdighed, at det ikke ganske sjelden lykkes, at se den trufne hval øieblikkeligen opgive aanden."

NANSEN siger $i$ sin bog „Eskimoliv", at eskimoerne fra sin lille kajak ogsaa angriber „hvalerne, af hvilke der særlig er en, som kan være farligere end nogen anden, det er spækhuggeren eller, som han 
kalder den, ardluk. Med sin styrke, sin hurtighed og sine uhyggelige tænder kan denne, naar den en enkelt gang angriber, i et øieblik gjøre det af med en kajak, og for den har selv eskimoerne frygt; men det afholder ham dog ikke fra at angribe den, naar leilighed byr sig.

Ogsaa de store hvaler drev de før i tiden fangst paa. Dette skede dog fra de store konebaade, hvori der da var mange mennesker, mænd og kvinder. Til denne fangst „udruste de sig“, siger Hans Egede, „i deres største stads ligesom til bryllup, ellers skal hvalen skye for dem; thi han fordrager ikke urenlighed. Hvalen blev harpuneret fra forstavnen, men det hændte jo undertiden, at den da ved et slag med halen kunde knuse baaden eller kantre den. Ofte var mændene saa dristige, at de, naar hvalen begyndte at udmattes, sprang op paa dens ryg for at stikke den ihjel. Denne fangst forekommer nu sjelden."

Guld berg har givet en udmerket oversigt over, hvad man ved om nordmændenes første hvalfangst. Det er almindelig bekjendt, at kong Alfred den store af England fra nordmanden Ottar fra Helgeland fik en meddelelse, hvoraf det fremgaar, at han i aaret 890, tre dagsreiser nord for sit hjem (i den nordlige del af Tromsø amt eller Finmarken), drev hvalfangst. Disse hval var nok delvis hvalros, som dengang fandtes i mængde i Norge; thi Ottar dræbte selv sjette 60 paa 2 dage og han brugte huden til skibstauge. Der tales ogsaa om mange andre hvaler, men som Guldberg anfører, er det vel sandsynligt, at fangsten har „indskrænket sig til at dræbe de paa sine steder ilanddrevne dyr eller til at jage hvaler, der gik i trange fjorde eller havbugter, der stængtes inde, for derpaa red mange folks forenede anstrengelser at dræbes. Under alle omstændigheder synes nordmændene saaledes kun leilighedsvis at have drevet hvalfangst, og ikke at have deltaget i den større bedrift paa dette omraade."

Den egentlige store hvalfangst viser sig nu ved nærmere betragtning ikke at kunne skildres overet, den har nemlig havt særdeles forskjellige former efter de forskjellige nationers maade at arbeide paa og efter de arter af hvalerne, som har været fangstens gjenstand eller rettere sagt dens hovedsagelige gjenstand.

Det bedste overblik faar man vistnok ved i al korthed at skildre hvalfangsten $\mathrm{og}$ dens historte i 4 afsnit, nemlig:

1. Den ældste hvalfangst. Fangsten af Grønlandshval og Nordkaper.

2. Kaskelotfangsten.

3. Bottlenosefangsten.

4. Vor tids finhvalfangst. 


\section{Fangsten af grønlandshval og nordkaper.}

Denne fangst skriver sig utvivlsomt fra de biskaiske fiskere, hvis første forsøg Sconesbr saa anskueligt skildrer. Allerede i det 11te aarhundrede var der saadan fangst paa Frankriges kyster. „I aaret 1202 bar normanniske krigere paa sine hjelme dusker af bardehaar istedetfor fjædre; og 1315 var hvalbarder en handelsvare saarel i England som i Frankrig." Den hval, som fangedes, var ifølge GuldBerG utvivlsomt nordkaperen, denne „golfstrømmens sletbag“, som den har været kaldt i modsætning til Grønlandshvalen, der tilhører polarrandet. ScoresBr antager, at det var vaagehvalen man først begyndte at fiske, maaske har det været flere. Utvivlsomt er det i allefald, at fangsten snart gik over til at drives langt tilsøs og utvivlsomt da til ræsentlig at gjælde nordkaperen. Scokesby skildrer denne overgang saaledes: „Først viste disse dyr sig i den Biskaiske bugt hvert aar til en bestemt aarstid, da de blev angrebne af biskaierne. Da imidlertid fangsten af dem blev formaal for en egen bedrift, og hvalerne blev forstyrrede og mindre talrige, samtidig med at biskaierne ønskede at drive en mere uafbrudt fangst, saa blev de i længden lidt efter lidt mere modige, og da de var gode sjøfolk, saa ventede de ikke paa hvalernes tilbagekomst, men forfulgte dem, naar de forlod bugten, indtil de tilsidst nærmede sig Islands, Gronlands og Newfoundlands kyster. Islænderne rustede nu ogsaa ved synet af denne nye bedrift ud sine skibe $0 \mathrm{~g}$ idet de forenede sine kræfter med biskaierne, drev de hvalfangst i saa stor maalestok, at antallet af de skibe, der ved slutten af det 16de aarhundrede anvendtes af disse nationer, gik op til en flaade af 50 til 60 seilere."

Længere og længere bort maatte disse fartøier seile og saa opdagede de, som Scoresby siger, „paa grund af eventyrlystens foretagsomme aand" den saakaldte Grønlandshvalfangst, hvormed forstaaes fangsten af grønlandshval og nordkaper paa strækningen GrønlandSpitsbergen (den sidste regnedes først til Grønland). Denne fangst viste sig at være den allermest indbringende og den allermest betydningsfulde nationaløkonomiske bedrift, som nogensinde har aabnet sig for den menneskelige flid" siger Scoresbr i sin begeistrede skildring af den. Kjøbmændene i Hull havde allerede fra 1590 sendt fartøier til Island og Nordkap og i aaret 1610 sendte det i London i 1583 stiftede ,selskab for opdagelsen af ukjendte lande" kaptein Jovas PooL paa en opdagelsesreise til Spitsbergen. Han meldte om de rige forekomster af hval, og i 1611 sendtes hvalfangere derop, og allerede 1612 viste ogsaa Hollænderne sig deroppe. Fra nu af udviklede forholdene sig deronpe med kjæmpeskridt. Allerede i 1616 havde et engelsk kompagni 14 skibe 
med fangst af 150 hval. Danske, Hamburgere, Franskmænd og Spaniere viste sig ogsaa, de delte bugterne og havnepladsene mellem sig, byggede paa land store etablissementer som Hollændernes Smeerenburg, „en liden by af respektabel størrelse." I aarene 1660 til 1670 var der fra Holland og Hamburg mellem 400 og 500 seilere. „Inspektøren for den hollandske fangst paa denne tid (1697) fortæller at da han engang laa $\mathrm{i}$ en af Spitsbergens bugter med sit skib „De fire brødre“, der havde en last af 7 hvalfiske ombord, samlede der sig en rigt lastet flaade paa denne plads, bestaaende af 121 hollændere, hvis last bestod af 1252 hval, $5 \pm$ hamburgere med 515 hval, 15 bremere med 119 hval og 2 emdenere med hval." Hele flaaden bestod derfor af en flaade paa 192 skibe, der bragte hjem produkterne af 1888 hval" og det paa en havn alene. -

Jeg har i de sidste linier saa kort skildret denne det 17 de aarhundredes raske udvikling af Grønlands- eller Spitsbergsfangstens statistik uden at omtale alle de interessante enkeltheder ved de forskjellige aars udbytte $0 \mathrm{~g}$ de forskjellige nationers deltagelse $o g$ indbyrdes stridigheder, fordi vi for rort horedformaal neppe har noget at lære af disse - i og for sig meget interessante ting.

Her skal vi kun se lidt paa selve hvalernes forekomst i dette tidsi'um.

I begyndelsen af det 17 de aarhundrede blev hvalfangsten paa Spitsbergen drevet som det saakaldte ,bajfiskeri" eller fjordfangst. Scoresby skildrer, at tranen! blev kogt iland i kobberkjedler, barderne blev renset, og mens en del af mandskabet drev paa hermed, gik resten paa fangst. Allerede i 1630 til 1640 blev fjordfangsten daarligere, hralerne blev mere og mere sky, de forlod fjordene og fangsten gik over til den saakaldte, isfangst" langs iskanten.

Man kunde da kun leilighedsvis søge ind for anker i Spitsbergens fjorde og iallefald ikke koge paa land. Man maatte følge iskanten fra Spitsbergen nedover mod Island, som vore sælfangere nu gjør det. I denne tid opstaar da ogsaa Jan Mayen fangsten, som, saavidt jeg kan se, omkring $16 \pm 0$ naaede sit maksimum og gav glimrende fangster, saaledes at et skib i et aar gjorde 2 reiser hver med fuld last af 1000 tønder tran. Og denne Jan Mayen fangst holdt sig til ud i 80 -aarene af det 17 de aarhundrede.

Imidlertid aftog fangsten $0 g$ i begyndelsen af det 18de aarhundrede (1716) begyndte man fangsten i Davisstrædet og, ,allerede 1721 udrustedes en storartet flaade fra forskjellige nationer for hvalfangst paa Baffinsbugten. Flaaden bestod af 355 seilere, hvoraf 251 hollandske, 55 hamburgske, 24 fra Bremen, 20 biskaiske og 5 fra Norge." Udover størstedelen af det 18de aarhundrede fortsatte da denne fangst. At den 
imidlertid ikke alene gjaldt Baffinsbugten og, at Spitsbergsfisket fremdeles fortsattes kan man slutte bare deraf, at i maaneden mai 1747 blev ikke mindre end 30 hollandske og 3 engelske skibe vrag under en storm ved Spitsbergen. Om størrelsen af hvalfangsten faar man et begreb derved, at der i tidsrummet 1669 til 1769 udrustedes alene fra hollandske havne 14167 fartøier. I det 18de aarhundredes sidste halvdel stillede forholdet sig saaledes, at der da blev udrustet følgende antal skibe:

$\begin{array}{cccc} & \text { Stor-Britannien } & \text { Holland } & \text { Tyskland } \\ 1750-1759 & 556 & 1679 & 215 \\ 1760-1769 & 459 & 1620 & 250 \\ 1770-1779 & 741 & 1337 & 459\end{array}$

Man har ogsaa talrige beviser paa, at denne fangst ogsaa maa have foregaaet saa nær Norge, at det har lonnet sig at drive den fra Norge. Der skal være fundet brudstykker af gamle trankjedler, og GULdBerg har paavist, at gamle hvalben fundne paa Sørøen og ved Vardø var Nordkaperben. Nordkaperen har der formodentlig havt en udbredelse i Østhavet som blaahvalen nu tildags eller i 70-aarene. Denne hvalfangst omtales af amtmand LiLienskjold i Speculum boreale, forfattet $1698 \mathrm{og}$ angives der at være dreven rundt Nordkap som centrum, men at have strukket sig helt fra Hasvig paa Sørøen til Vardø.

I slutten af det 18 de aarhundrede begyndte dog hvalfangsten og det over hele fangstfeltet at aftage, og det faar man tydeligt indtrykket deraf, at de engelske hvalfangere ikke alene søger de arktiske hvalfelter, der oprindelig kaldtes ,de nordiske guldminer", for hvalernes skyld men for at tjene præmier opsatte af den engelske regjering. For at opmuntre sin søfart og faa dygtige matroser udbetalte England i tidsrummet $1733-1785$ ca. $19000000 \mathrm{kr}$. og Scotland ea. $4000000 \mathrm{kr}$. i præmier (SCORESBY).

Ved overgangen til det 19de aarhundrede indtraadte paa grund af de store politiske begivenheder store forandringer i hvalfangsten. Napoleons „fastlandsafspærring“ (1807) bragte den tyske og hollandske hvalfangst til at gaa tilgrunde, idet England, som bekjendt, kaprede disse nationers skibe. Derimod fik Englands hvalfangst et stort opsving.

I tiden fra 1810 til 1818 seilede ifølge Lindeman ${ }^{1}$ ) 824 skibe fra England til Grønland og Davisstrædet og 361 fra Skotland. Fangsten var udmerket. I 1814 bragte hvert af de i fangsten deltagende skibe

1) Moritz Lindeman: Die arktische Fischerei der Deutschen Seestädte 16201868. Petermanns Mittheilungen 1869. 
ca. 19 hval. Et skib fra Peterhead bragte 44, og dette skibs indtægter siges at have været 198000 kroner.

Efter Napoleons fald blomstrede den tyske og hollandske hvalfangst op igjen, men dette varede kun meget kort, og en almindelig stadig nedgang gjør sig gjældende gjennem hele det 19de aarhundrede. Mens saaledes f. eks. det a arlige gjennemsnitlige tal af skibe, som forlod brittiske havne i aarene 1815-1834 er beregnet til 116, var det samme tal i 185760 og i 186830 .

Fra Grønland kom der ifølge Lindeman:

til Hamburg til Weserflodens havne

$\begin{array}{rrrrr}1821-1830 & 25 & \text { skibe } & 51 & \text { skibe } \\ 1831-1840 & 29 & - & 23 & - \\ 1841-1850 & 32 & - & 126 & - \\ 1851-1860 & 16 & - & 114 & - \\ 1861-1863 & 4 & -- & 43-\end{array}$

"Nutildags" siger J. IsAAC ${ }^{1}$ ) i aaret 1897, „sendes der idethele omtrent 10 hvalfangere til Davisstrædet og Grønland. Omtrent midt i marts forlader disse skibe havnene Dundee, Peterhead eller Aberdeen, de drager først til Davisstrædets østside, hvor de i april og mai søger efter hval. Undertiden begunstiges de der af lykken, idet de kan finde flokke paa 2 eller 4. Oftest finder de dog ingen. De drager derfor længer mod nord til vestkysten af Davisstrædet, Lancastersund, hvor de blir i juni-juli. I august hviler fangsten, fordi da ingen hvaler er at se, i september faar de af $o g$ til nogen. De hvalfangere, som drager til Grønlands østkyst, undersøger i mai-juni Spitsbergenshavet, juli 0 o august gaar de sydligere. Faar de til og med den første uge ingen hval, gaar de hjem.

Efter Lindeman ${ }^{2}$ ) og IsaAC skal jeg meddele, hvorledes disse skibes fangst stillede sig i et udvalgt aar, 1896, i vor tid. Fra Skotland sendtes da følgende fartøier:

1) IsAaC: Ueber die Fangergebnisse der Walfischjagd. Mitth. Deutsch. Seef. 1897. IV. 1899.

2) M. Lindeman: Die gegenwärtige Eismeerfischerei. Abh. Deutsch. Seef. Bd. 


\begin{tabular}{|c|c|c|c|c|c|}
\hline Skibsnavn & Fangstfelt & Hvalros & Sæl & $\begin{array}{c}\text { Grøn- } \\
\text { landshval }\end{array}$ & $\begin{array}{l}\text { Hvidfisk } \\
\text { Narhval }\end{array}$ \\
\hline $\mathrm{D} / \mathrm{S}$ Active .... & Grønlandshavet & Ingen & & 4 & \\
\hline - Balæna.... & - & \multirow{2}{*}{\multicolumn{4}{|c|}{ Uden fangst }} \\
\hline S/S Diana ..... & - & & & & \\
\hline D/S Eclipse.... & Davisstrædet & 21 & & 1 & \\
\hline - Esquimaux. & - & 21 & 8457 & & 5 \\
\hline - NovaZembla & - & & & 2 & \\
\hline - Polar Star. & Grønlandshavet & & & 1 & \\
\hline - Terra Nova & Davisstrædet & 1 & 5339 & & 4 \\
\hline S/S Alert...... & Cumberlandbugten & & 3890 & 3 & \\
\hline
\end{tabular}

Som man ser, fik disse 9 fartøier kun. 11 hval. Af disse fangedes 5 i Grønlandshavet, det vil sige langs iskanten fra Spitsbergen mod Grønlands østkyst, nærmere oplysninger, om hvor kan man ikke finde i de nævnte beretninger.

Som man ser er dette et yderlig slet resultat. Den ovennævnte forfatter J. IsAac antyder derfor, at alt taler for at denne fangst snart vil blive indstillet.

Som aarsager til den enorme tilbagegang i hvalfangsten angiver LiNDEMAN „det ringe fangstudbytte, tranens ringere værdi, den vældige konkurrence i gas, planteolier og mineralske olier samt den stadig voksende og mangesidige udvikling af søhandelen, som skaffer fartøier anden lønnende beskjæftigelse." Men naar man studerer alle disse aarsager nærmere, kan der nok ikke være tvivl om, at den første aarsag, ,,det ringe fangstudbytte", eller med andre ord den store aftagen af bestanden af grønlandshval, er den udelukkende aarsag.

Ifølge IsaAc har nemlig grønlandshvalẹn endnu en enorm værdi. Han anfører nemlig, at en middelstor grønlandshval gjennemsnitlig giver fra 700 til 1000 kilo barder og det 20-dobbelte i tran, altsaa indtil 1 ton barder og 20 ton tran. $\mathrm{Nu}$ koster barderne (i 1897) ca. 40000 kroner pr. ton og tranen ca. $350 \mathrm{kr}$. pr. ton. En grønlandshval skulde efter dette kunne have en værdi af indtil 47000 kroner. Alene dette kan naturligvis forklare, at de ovennævnte fartøier med saa ringe antal hval i fangst kan vove sig ud paa nyt togt. Men det forklarer jo ogsaa til fuldkommenhed, at det kun er den omstændighed, at der nu findes meget faa hval i de farvand, hvor der før vrimlede af dem, som er aarsagen til hvalfangstens aftagen. 
Hvad er nu aarsagen til denne hvalbestandens aftagen? Efter min mening kan der ingen tvivl være om, at det er hvalfangsten, som udelukkende er skyld heri.

Ifølge Sconesby, blev der alene fra Holland i aarene 1669-1778 skudt 57590 hval, og hele forløbet i denne hvalfangsts historie taler for, at hvalbestanden stadig har aftaget. Vi saa saaledes ovenfor, at fangsten i det 17 de aarhundrede blev drevet hovedsagelig ved Spitsbergen og langs isen mod Jan Mayen for saa her at bli mindre og mindre, til man i begyndelsen af det 18de aarhundrede begyndte med Davisstrædet, hvor ogsaa hvalbestanden efterhaanden blev yderst formindsket, saaledes at

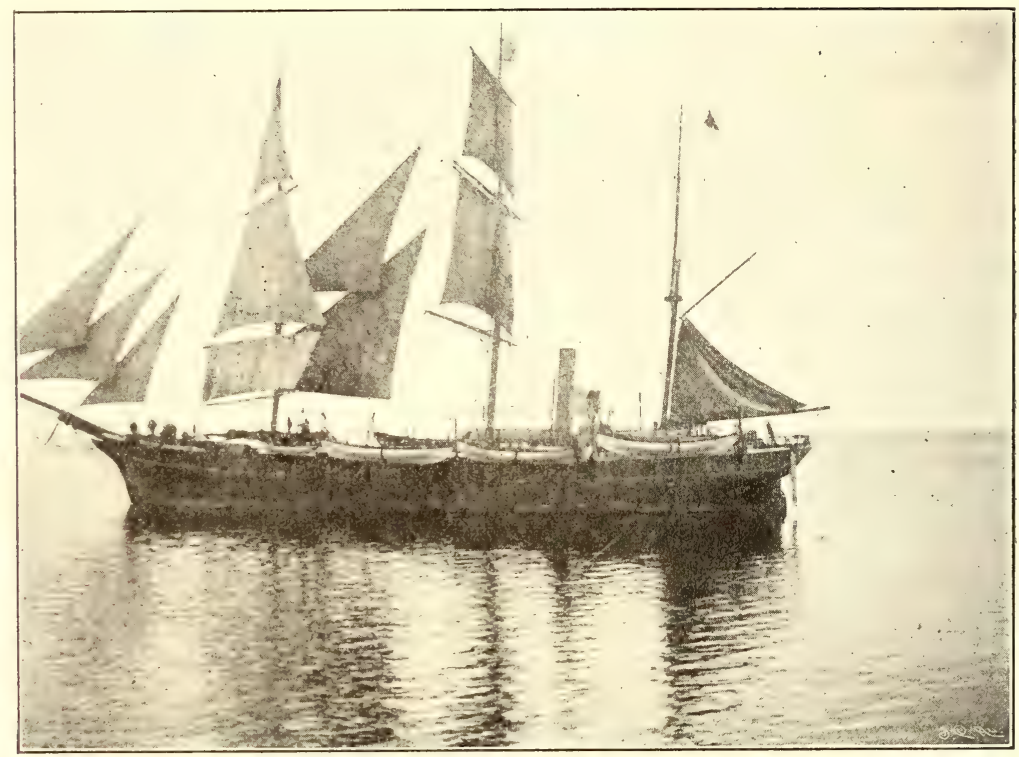

Fig. 59. Hvalfangeren "Balæna“ fra Dundee, et af de faa fartøier, som endnu seiler efter grøndlanshval. Fra Nathonst.

nu $\mathrm{i}$ vore dage et stort fartøi, skjønt det er udrustet kun til fangst af disse dyr baade ved Spitsbergen-Grønland distrikt og i Davisstrædet kan krydse forgjæves en hel sommer uden at fange en eneste hval, hvor tidligere flaader paa hundreder af skibe saa sent som i 1814 gjennemsnitlig havde 19 hval hver.

Karakteristisk i denne hvalfangstens historie er ogsaa den omstændighed, at hvalbestanden viste sig at aftage temmelig lokalt som f. eks. ved Spitsbergen uden at der skede indvandring andetstedsfra, da de hvaler, som vrimlede i Spitsbergens fjorde, først var skudt bort. Og at der var hvaler nok andetsteds, viste dengang den senere opdagelse af masseforekomsten i Davisstrædet. 


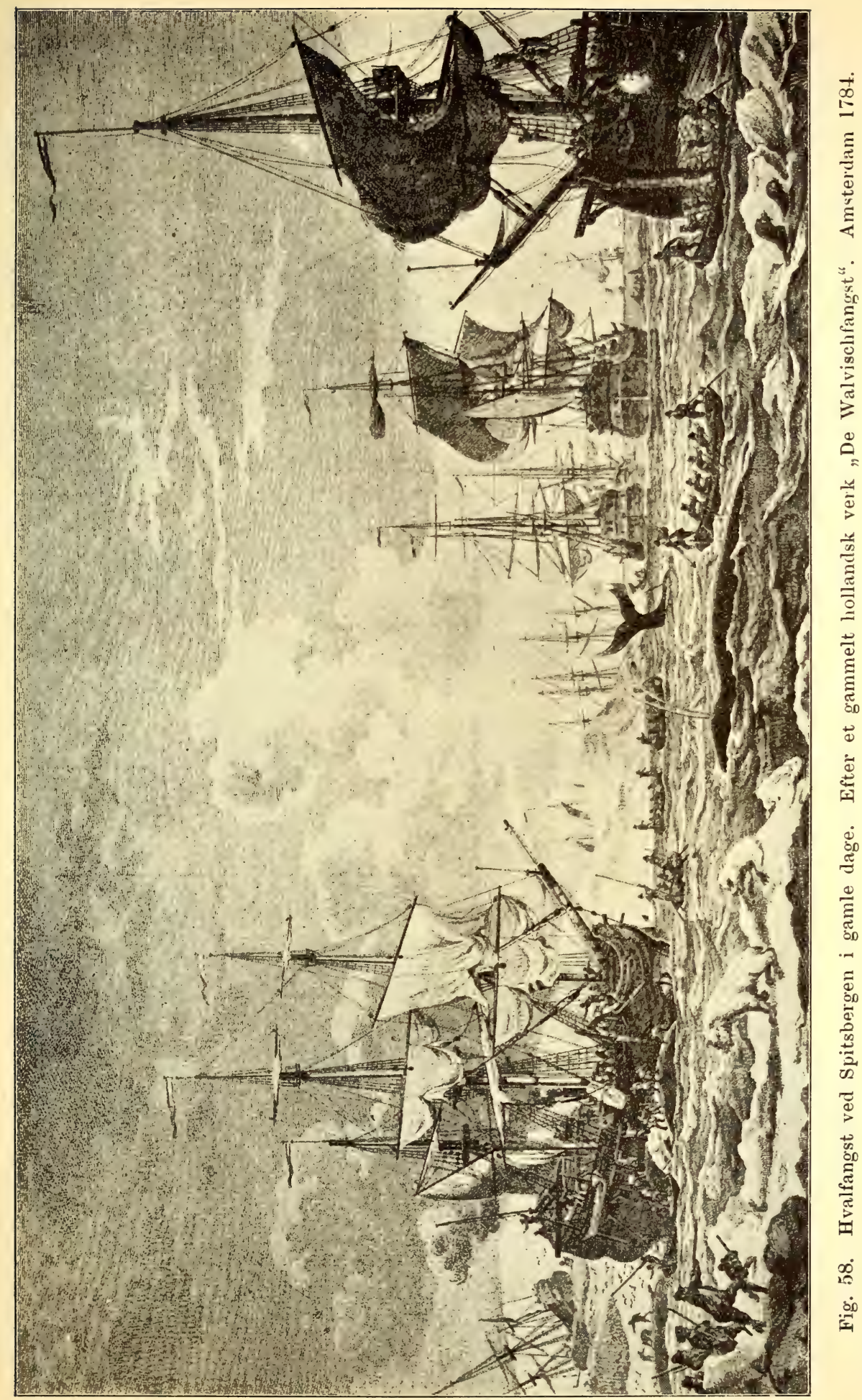


Indenfor hvert enkelt distrikt igjen viste der sig ogsaa denne samme ting, at hvalerne ikke kom igjen, naar de først var skudt bort, men her maa man vel mere tænke paa, at de blev skræmt bort af fangsten.

Sconesby skildrer, hvorledes i begyndelsen af det 17 de aarhundrede (1607) hvalrosfangerne, som da drev en udstrakt og lønnende fangst ved Bjørnøen, fandt at disse dyr, som følge af fangsten blev sky og mindre talrige, og at fangerne derfor drog nordover til de fandt Spitsbergen. Bjørnøen blev da forladt, thi ved Spitsbergen var der masse af hval og hvalros, og denne $\emptyset$ blev derfor skuepladsen for deres foretagsomhed.

"Ved denne tid“, siger han, „fandtes grønlandshvalen i umaadelige mængde langs hele den udstrakte kyst $0 \mathrm{~g}$ i de forskjellige større fjorde, som den har saa mange af. Aldrig havde disse dyr været forstyrrede, de var uvidende om, hvad farer var, og de lod de modige fiskere komme sig lige ind paa livet $0 \mathrm{~g}$ faldt da som et let bytte. Der var ingen nødvendighed dengang for at skibene skulde krydse over alle de vældige havstrækninger i Polarhavet, som de maa gjøre nutildags“ (1820), „for hvalerne var der i masser, i disse fjorde, og derfor kunde skibene ligge for anker paa en eller anden bekvem plads, og ialmindelighed blev de liggende i sine fortøininger, til lasten var fuld."

Men som vi ovenfor har seet, varede dette fjordfiskeri ikke længe; hralfangerne maatte gaa tilhavs, søge isgrænsen nedover mod Jan-Mayen, saa ind i Davisstrædet saa langt mod nord som isen tillod; og nu vandrer der kun nogle ganske faa, sjeldne grønlandshvaler langs disse fordums saa rige felter.

Saa meget man end maa beklage at denne, den ældste, store hvalfangst har formindsket i saa voldsom maalestok en rigdomskilde paa vor jordklode, som det maaske er et spørgsmaal om, ja mest usandsynligt at man nogensinde vil kunne erholde paany, saa maa det indrømmes, at denne hvalfangst har spillet en stor rolle i Europas historie. Den har udviklet Nordeuropas sømandsstand i et tidsrum, da næsten ingen bedrift paa sjøen kunde sammenlignes med hvalfangsten, den har udviklet kundskaben om ror jordklode, den har skaffet mennesket produkter, som man paa den tid ikke kunde skaffe sig paa anden maade, specielt da fedtstofferne. Den senere middelalder havde ingen andre belysningsmidler, som kunde sammenlignes med hvaloljen. Selv i 1820 siger Scoresbr. Oljen 
"bruges i stor maalestok til at oplyse byernes gader, det indre af verksteder, huse, butikker, fabriker; den bruges i stor maalestok i fabrikationen af blød sæbe saavelsom til tilberedning af læder . . . . til maskinolje etc." Barderne blev anvendt i klæde og møbelindustrien og i mange andre industrier.

Det er ogsaa denne grønlandshvalfangst som har givet tekniken i hvalfangsten sin udvikling. Ved Spitsbergenfangstens begyndelse brugte man en harpun, der lignede en pil, $2-3$ fod i længde med et træhaandtaag til at kasfe den med mod hvalen. Til harpunen var fæstet en line af 300 favnes længde, hvilket "var mere end nok til at naa bunden i fjordene, hvor dybden sjelden gik over 80-100 favne; saa at linen, naar fisken gik tilbunds efter at være truffen, altid kunde holdes ombord i baaden. Baadens bevægelser fulgte da naturligvis hvalens og viste nøiagłig, hvor denne var, saa de andre hjælpebaade kunde være paa pladsen, naar hvalen kom op til overfladen igjen. Den blev da forfulgt med kraft - et tilstrækkelig antal harpuner boret i den - og tilsidst angrebet den ene gang efter den anden med 10-12 fod lange landser til den døde." Saa bugserede da baadene den som et langt spand heste til skibets agterende, hvor den blev flenset.

I 1730 opfandtes en slags kanon til at skyde harpunen ud med men denne synes først at komme i brug i aaret 1772. Selv i 1820 synes dog mange at have foretrukket den ældre, ovenfor beskrevne methode.

Sconesby siger nemlig: „Harpun-kanonen har undergaaet store forandringer, og den kan med virkning skyde harpunen ud i 40 alen; men paa grund af vanskeligheden og den store øvelse den fordrer ete. har den ikke blit saa almindelig brugt, som man kunde ventet." Bedriften holdt sig derfor som man ser i flere hundrede aar inden den gamle oprindelige teknik. Dette har, som man af det følgende vil se, ikke kunnet være muligt med den fangst, som har havt andre hvaler til gjenstand.

\section{Kaskelotfangsten.}

Kaskelotfangsten begyndte paa et historisk meget senere tidspunkt end rethvalfangsten, som vi ovenfor har skildret. „Den første kaskelot eller spermacethval, som blev bekjendt for folkene i Nantucket", en by paa 
Nordamerikas nordøstkyst, ,.fremkaldte stort opstyr. Den blev fundet død paa kysten, $\mathrm{og}$ en hel strid om, hvem der eiede den, opstod; thi spermacetoljen som man fik af dens hoved, antoges at være af stor værdi som lægemiddel."1)

I aaret 1712 skal saa den første kaskelot være bleven dræbt i aabent hav og i 1715 var der allerede 6 skibe paa jagt efter dem. Fra dette tidspunkt af $0 \mathrm{~g}$ udover i det attende aarhundrede udvikledes nu den amerikanske hvalfangst stadig, og det ikke alene ved antallet af skibe, men ogsaa red disses størrelse og dristighed $\mathrm{i}$ at opdage nye felter.

I 1770 var der saaledes 125 skibe, der havee en aarlig indtægt af ca. $1200000 \mathrm{kr}$. Om disse skibe siger Scammon. ${ }^{1}$ ) „Omkring 1774 var flaaden øget til endnu større skibe, af hvilke nogle krydsede ekvator og fik fuld last paa det velkjendte felt, som kaldes "Brazilbankerne", medens andre krydsede rundt de Kap Verdiske øer eller Vestindien, i den Meksikanske Golf, det Karibiske hav eller paa sydamerikas østkyst Kort tid senere udstrakte de sine togter til den sydlige del af Atlanterhavet rundt Falklandsøerne $\mathrm{og}$ til kysten af Patagonien, hvor undertiden „pelssælen"s skind og søelefantens spæk ogsaa erholdtes. I saadanne tilfælde kaldtes disse hralfanger- og sælfangerekspeditioner „blandede turer:" Som man ser er dette allerede store foretagender, og fartøierne var i overensstemmelse hermed ogsaa store brigger eller barker (se fig. 60).

I 1788 udsendte Enderby i London et stort skib, "Amelia“, som seilede rundt Kap Horn og ind i Stillehavet, det kom hjem i 1790 efter en tur paa 19 maaneder, men bragte hjem den enorme last af 139 tons kaskelottran. Dette gav et sterkt stød til Stillehavsfangsten, hvor der ogsaa vrimlede af kaskelotter. Og allerede ti aar senere i aaret 1800 pløiede amerikanske hvalfangere hele Stillehavet baade nord og syd om Akvator. Fra denne tid af kan man sige, at de amerikanske hvalfangere seilede jorden rundt. I 1802 og 1803 seilede saaledes ifølge BEale „mange skibe i det Chinesiske hav rundt Moluccaøerne efter kaskelotten". "I 1828", siger Scammon, sendtes 4 skibe fra Nantucket paa hvalfangst udenfor Zanzibars kyst, rundt Seychelleøerne ${ }^{2} \mathrm{og}$ rundt indløbet af det Røde hav". Fra 1819 opsøgte de Japans hav.

Saaledes naaede denne de store verdenshaves hralfangst i 1837 sit høidepunkt med en indtægt af 16 millioner kroner. „De fleste

1) Hovard Clark: The Whale Fishery. The fisheries and fishery industries of the U. S. section V. vol II. Washington 1887. De fleste data angaaende den amerikanske hvalfangst er hentet fra dette verk.

1) The marine mammals etc. San Francisco 1874. 



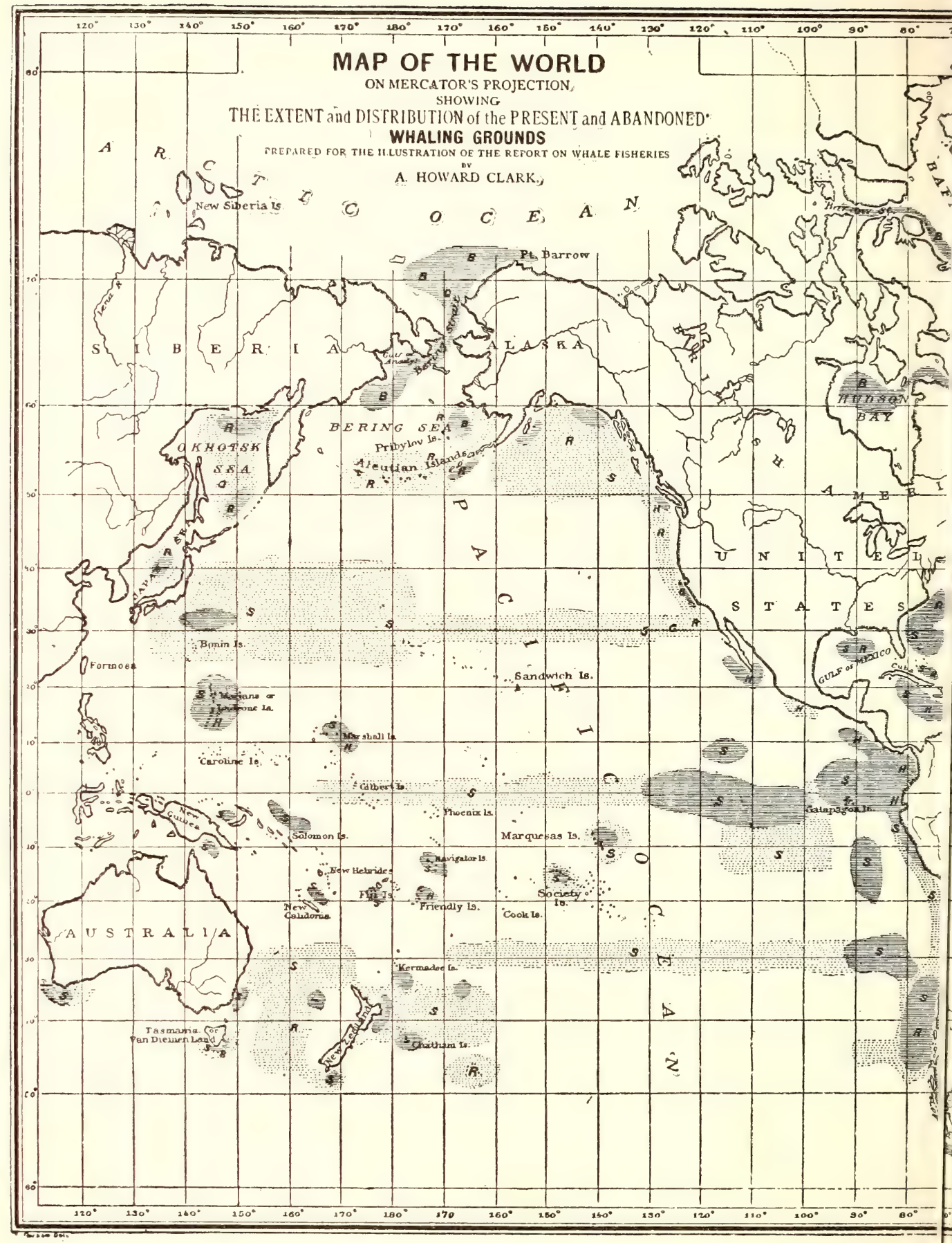

Fig. 61. Verdenskart over hvalfangsten før og nu af A. HowaRd CLAR $\mathrm{S}=$ steder, hvor kaskelotfangst har været eller blir drevet. $\mathrm{B}=$ steder, hvor grønlandshval $\mathrm{H}=$ steder, hvor knølhvalfangst har været eller blir drevet. $\mathbf{F}=$ steder, hvor fangst ar finhval pe hvalfangst har været drt 


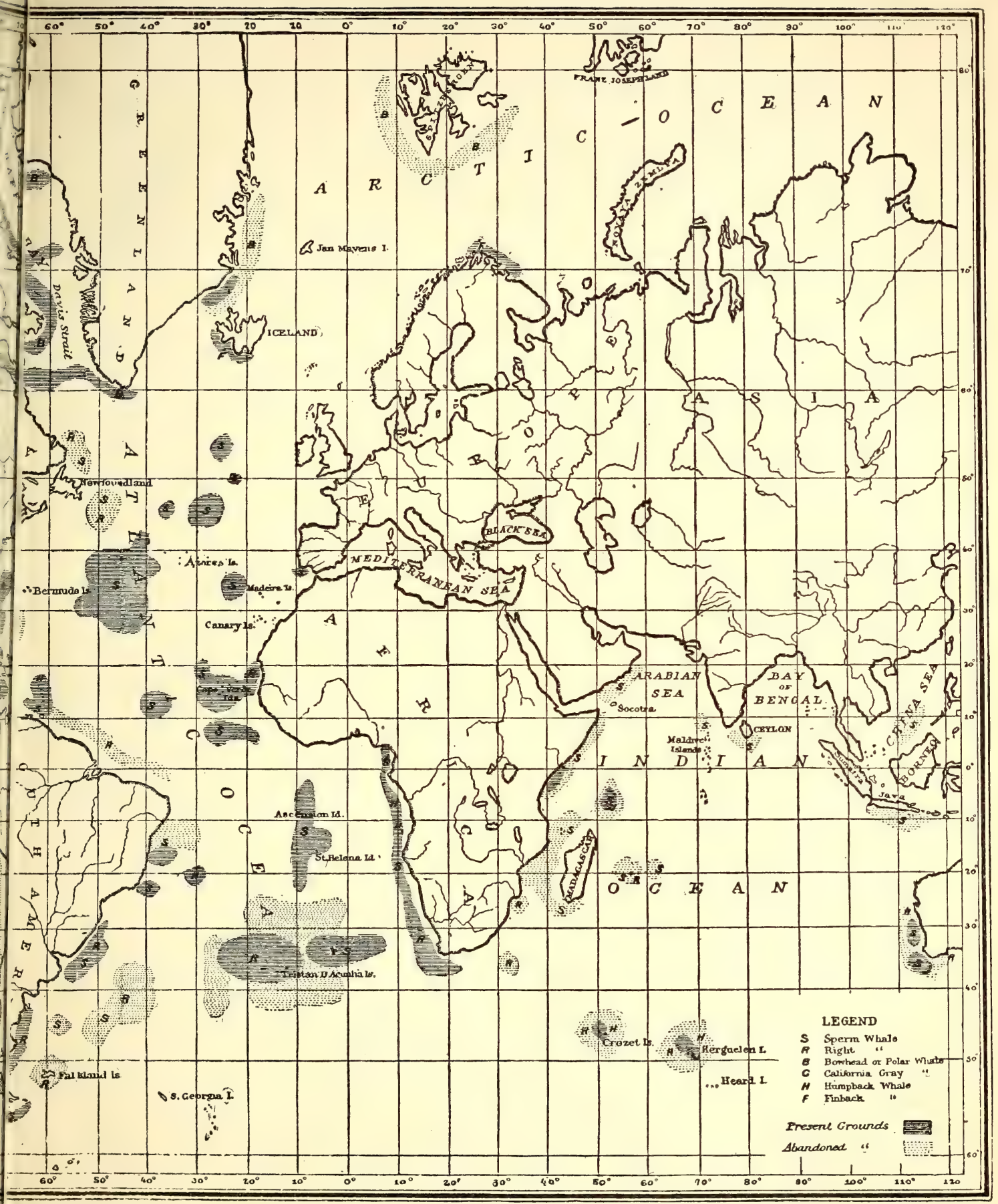

den amerikanske beretning (udgivet 1887 saaledes ikke ganske svarende til vor tid).

været eller blir drevet. $\quad \mathrm{C}=$ steder, hvor fangst af en amerikansk hvalart har været eller blir drevet. e har været eller blir drevet. $\bar{\equiv}=$ steder, hvor der dreves fangst i 1887 . $\quad . \ldots \ldots$ m................. steder, hvor t, men som i 1887 var forladte. 



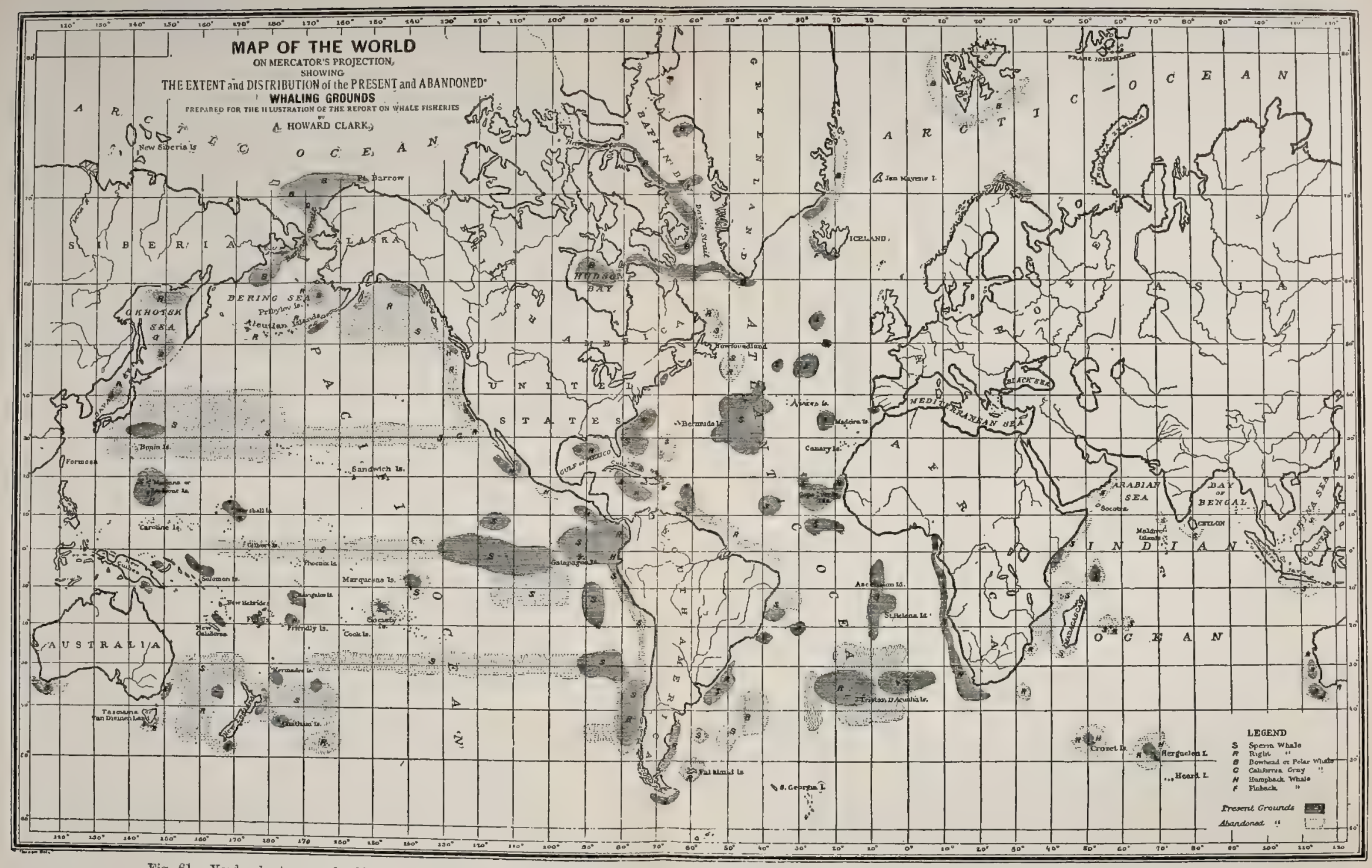

Tig. 61. Verdenskart over hvalfangsten for og nu af A. HowsRD CLARK $\mathrm{i}$ den amerikanske beretning (udgivet 1887 saaledes ikke ganske svarende til vor tid).

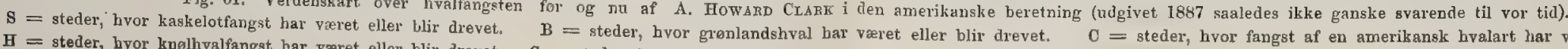

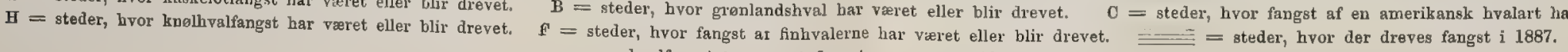

hvalfangst har været drevet, men som i 1887 var forlacte.

eller blir drevet. = steder, hror 

af hvalfangerne er spredte over de forskjellige felter i den nordlige og sydlige del af det Stille hav, i det Japanske hav, og laster paa over 3000 tønder er ikke ualmindeligt paa et tre aars togt."

I 1842 var antallet af amerikanske skibe $594 \mathrm{og}$ andre landes 230, saa at hele verdensflaaden dengang havde 824 hvalfangstskibe.

Fra 40 -aarene begyndte denne hvalfangst at gaa tilbage. I 1860 var fangstudbyttet kun det halve af i 1837 , skjønt tranpriserne var høiere. Hele hvalfangerflaaden gik da op til 560 skibe. I 1870 sank antallet til 316 skibe, der var saaledes fordelt: 125 i den nordlige og sydlige del af Atlanterhavet, 41 i det Indiske hav og 65 i Stillehavet.

I 1875 talte hele flaaden 163 skibe, hvoraf 134 drev kaskelotfangst. Mange af de store og berømte felter var nu forladte, og laster kunde nu kun faaes ved de mest energiske anstrengelser og de største seiladser. I den vestlige del af Stillehavet, det Indiske og Japanske hav, hvor tidligere store flaader seilede, var der nu kun faa skibe. 1880 forlod amerikanerne ganske det Indiske hav. Samtidig blev reiserne længere og længere.

„Før 1830 kunde et skib, som lastede 2000 tønder krydse i Stillehavet og komme hjem med kaskelotolie, fuld last efter 2 aars tid. Det samme skib kunde seile til Delagoabugten eller Woolwichbugten og tage last med olie i 15 maaneder eller til Braziliens kyst og vende hjem efter 9 maaneder, fuldlastet med olie af de hvaler, som findes i disse farvand; men alt dette er forandret, og reisens langvarighed staar nu ikke i forhold til den mængde olie, som man faar med hjem."

Vi har i det foregaaende talt om denne hvalfangst som udelukkende kaskelotfangst, idet vi hovedsagelig har havt til hensigt at vise den samlede bedrifts historiske vækst $\mathrm{og}$ senere tilbagegang. Hovedfangsten har i hele dette tidsrum ogsaa været kaskelotten, saaledes drev i 1875 af 162 skibe 134 kaskelotfangst. Men disse hvalfangere opdagede under sine verdensseiladser ogsaa en hel del andre hvaler, hvis geografiske udbredelse har den allerstørste interesse, om det end maa beklages, at deres legemsbygning synes saa ufuldstændig undersøgt, at der endnu raader adskilig uklarhed over, hvor mange arter der findes inden de forskjellige grupper.

Paa østsiden af Sydafrika, rundt Crozettøerne, St. Pauls ø, Kerguelen, ligeledes i nærheden af Ny-Zealand og udenfor Sydamerika (Chili) fandt man rethvaler. Saadanne fandtes ogsaa i det Behringske hav, det Okhotske hav og helt ned til Japans kyster. Van Beneden og Gervais $^{1}$ ) antager, at alle rethvaler maa indordnes under 5 former.

1) Osteographie des Cétacés. Paris 1880. 
Grønlandshvalen (Balcena mysticetus), hvis forekomst i Atlanterhavets arktiske del vi tidligere gjentagende har omtalt, og som ogsaa er fundet af hvalfangere i Behringshavet. Mange forfattere paastaar endog, at harpuner fra Behringshavet er fundne i Atlanterhavet, hvilket benægtes af andre.

Nordkaper (Baloena biscayensis), dens forekomst gjentagende gange tidligere omtalt.

Japans rethval (Balona japonica), der meget skal ligne nordkaperen, ja af enkelte endog siges være den samme art. Dens udbredelse svarer i Stillehavet til nordkaperens i Atlanterhavet, den lever nemlig $\mathrm{i}$ de tempererede havstrømme mellem polarstrøm og de tropiske have.

A ustraler rethvalen (Balcena australis) er den hval, som kaskelotfangerne fandt ved Kap, Chili og de sydlige øer St. Paul og Kerguelen.

Nyzealands rethvalen (Balcena antipodarum) paastaaes at være forskjellig fra australerhvalen, men dette er kanske tvivlsomt. Som navnet antyder blev den især fanget ved Ny-Zealand.

Disse rethvaler spillede en vis rolle i den store amerikanske hvalfangst, man tog anledningen til ogsaa at fange disse hvaler med og drev snart rethvalfangst, snart udelukkende kaskelotfangst. Ogsaa disse rethvaler gik sterkt tilbage i antal. Saaledes var der i sin tid ved NyZealand en stor fangst, som nu er meget indskrænket. I 1895 fandtes kun meget faa steder, som hvalfangsten kunde drives fra, og i aaret forud var hele exporten 70 tons barder; lignende forhold finder man ogsaa paa de andre kjendte, gamle hvalfangerpladser. (Se herom Lindeman.)

I hvilken grad den hele hvalfangst fra Amerika er gaaet tilbage viser sig af følgende tal fra den sidste tid ${ }^{1}$ ).

\begin{tabular}{|c|c|c|c|c|c|c|}
\hline \multirow[b]{2}{*}{ Aar } & \multicolumn{2}{|c|}{ Kaskelottran } & \multicolumn{2}{|c|}{ Anden hvaltran } & \multicolumn{2}{|c|}{ Hvalbarder } \\
\hline & Tønder & Værdi i kroner & Tonder & Værdi i kroner & Kilo & Værdi ikroner \\
\hline 1888 & 16.265 & ca. & 17.185 & ca. 700.000 & 165.000 & $3,500.000$ \\
\hline 1898 & 9,780 & " 450.000 & 6.905 & $" 160.000$ & 130.000 & $2,850.000$ \\
\hline
\end{tabular}

1) Lindemax: Die Gegenwärtige Eismeer Fischerei loc. cit. 
Af disse tal ser man, at denne hvalfangst, som i 1837 gav 16 millioner kroner, baade er gaaet sterkt tilbage og fremdeles er i tilbagegang. Endvidere ser man, at særlig kaskelotfangsten, der oprindelig udgjorde hovedfangsten, er svunden ind til under $1 / 2$ millions værdi, og at det største udbytte kun faaes ved de enorme priser paa rethvalernes barder,

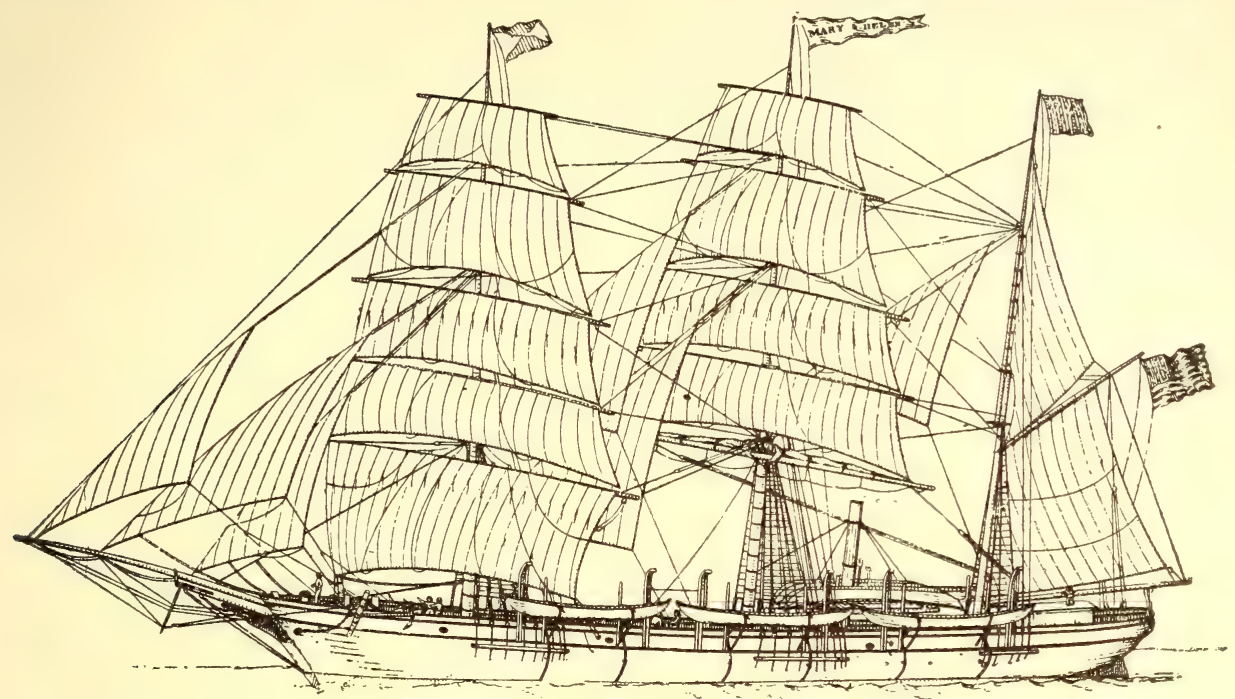

Fig. 60. Amerikansk hvalfanger. Efter den amerikanske beretning af HowarRd Clark.

væsentlig fra Stillehavets arktiske fangst, der naturlig begyndte først langt senere end den tilsvarende fangst i Atlanterhavet, over hvis historie vi ovenfor gav et overblik.

Kaskelotten er vel den hval, hvis levevis er bedst kjendt. De gaar oftest i flokke (Schools) fra 15-20 op til flere hundreder. De ældste og største hanner gaar dog største delen af aaret alene, til enkelte |tider er dog disse ogsaa bleven fundet i flokke; men da er der i regelen nogle faa gamle hanner og resten hunner med unger. Hunnen skal være meget omsorgsfuld for sin unge og hjælpe den til at flygte ved at støtte den med luffen.

Naar de angribes og blir truffet af skuddet, ligger de ofte stille som lammede og kan da ofte naaes af landsen. Man har derfor troet, at de var meget frygtsomme, men der skal dog være eksempler paa, at de har gjort voldsom modstand, ja angrebet sine forfølgere paa det voldsomste. 
Saaledes fortæller Scammon om en rasende kaskelot, som i Stillehavet $i$ aaret 1820 angreb et fartøi „Essex“. Dyret blev seet foran bougen, nærmende sig skibet med en hastighed af 3 kvartmil i timen. Skibet løb samme fart, da det vældige dyr gav skibet sligt et stød, at det øieblikkelig gik læk. Hvalen gik ned og viste sig igjen en skibslængde eller to af, piskende vandet til skum. Efter at have løbet en kvartmils vei og kommet sig af rystelsen, vendte den om med stor fart, traf bougen og slog denne ind, saa fartøiet sank 10 minutter efter. - Ofte skal den angribe baadene $\mathrm{og}$ herunder ogsaa bide med kjæverne. Om alt dette gaar der blandt de amerikanske hvalfangere mange historier, og man antager der, at mangt et skib, som aldrig kom hjem, blev sendt tilbunds af kaskelotterne.

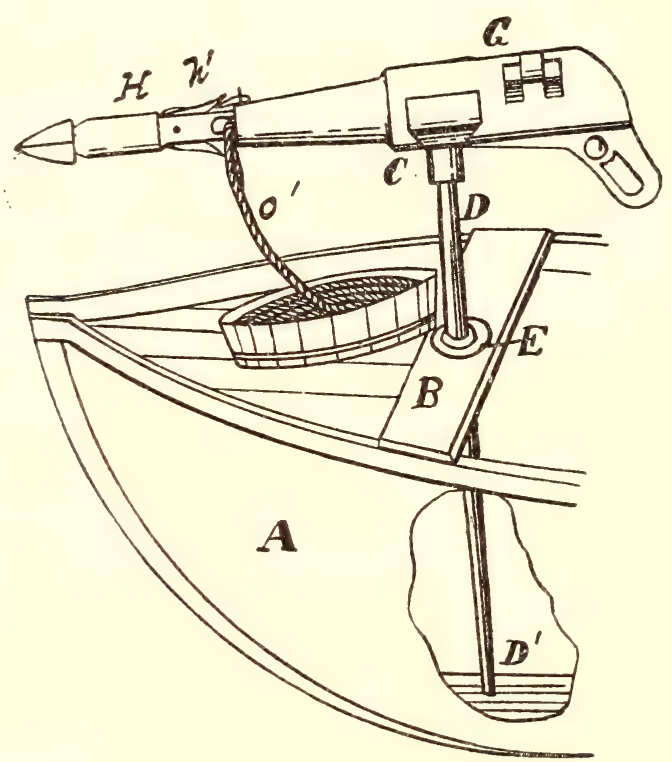

Fig. 62. Bougen af hvalfangstbaad med harpun - svivelkanon. Fra den amerikanske beretning.

Naar kaskelotten blir skudt, kaster den op blæksprutter af forskjellig størrelse, af og til ogsaa fisk; Scammon siger, torsk og boniter er seet som dens føde, hovedsagelig bestaar dog denne af blæksprutter.

Dette kaster et overordentlig interessant lys over dyrelivet i havet og fremkalder tanker, som langtfra har været overveiet, som de burde. Thi det fortæller os om de vældige masser af dyr, som der i alle verdenshave maa findes svævende i vandmasserne; overalt i disse har der jo været skudt kaskelotter, og det over de vældigste havdybder (se kartet fig. 61). Herom er tidligere talt ved talrige anledninger. 
Hvad selve fangstmaaden angaar, har de amerikanske hvalfangere udviklet en noget anden methode end den ovenfor under grønlandshvalfangsten skildrede svivelkanonfangst (se fig. 62), skjønt de ogsaa har anvendt denne især til finhvaler, knølhval og rethvalerne. De foretrak lette "geværkanoner", som dog ofte "fyrede agterover med større virkning end forover", nogle skyttere skal have brukket kravebenet, andre være kastet overbord ved de første forsøg med saadanne. De nu anvendte skyder ud eksploderende pilformede bomber (se fig. 63) af forskjellige konstruktioner, og det er disse som er fundne i forskjellige hvaler i Finmarken (se fig. 55).

Man søger dog først at faa "fast fisk" med harpuner, der enten udskydes fra svivelkanonen eller fra en dertil indrettet geværkanon, og saa dræber man hvalen med den saakaldte "bombelandse“, der er fyldt med eksplosivstoffe. For bedre at styres i luften har disse pilformige

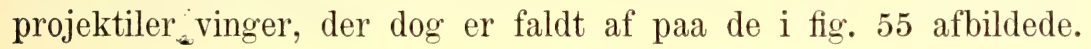

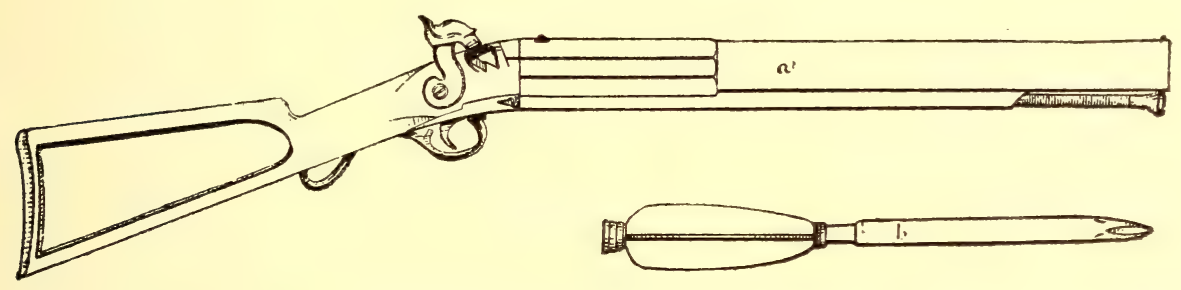

Fig. 63. Gevær med "bombelandsen" (som den i Finmarken fundne og paa fig. 55 afbildede). Efter den amerikanske beretning.

Behandlingen af hvaler efter fangsten skildrer EschRicht paa følgende maade:

Saasnart hvalen er dræbt, bugseres den til skibet og fastgjøres til siden af det. To "stillinger" af brede planker anbringes udvendig paa samme side og tjene |til stade for to af baadstyrerne, der ved hjælp af smaa spader med meget lange skafter udføre afspækningen. Om livet have de et bælte, hvori et sikkerhedstoug er fastgjort. - Om den ene af hvalens finner anbringes en kjætting; den heises i veiret og sættes af i leddet. I sammenhæng med denne finne afskjæres nu spækket i form af en strimmel $1^{1 / 2}-2$ alen bred; strimlen skjæres i skruegang omkring hvalens krop helt ned til halen, og under dens afløsning maa man altsaa dreie dette colossale i vandskorpen hængende legeme lige saa mange gange, som strimlen gaar skrueformig omkring det (omtrent 9-10 gange). Naar finnen er kommen ombord, stikkes et rundt hul i den medfølgende strimmel, og deri indbringes et øie af et tykt stærkt taug, som fæstes ved en bred tverpind. Derpaa afskjæres finnen, der bruges ituhugget som brændsel under trangryderne. Strimlen opheises til under 
mærset; $;$ man stikker da atter hul i den nederste ende af strimlen, indbringer slyngen af tverpinden, og gjennemskjærer strimlen ovenover. Det opheisende stykke fires ned i storlugen, og man begynder nu paa det næste stykkes opheisning. Til opheisningen bruges altid to tailler, den ene bærer det stykke, der er opheiset og derpaa nedfires, den anden er fæstet i det næstfølgende stykke, saa at ingen forsinkning finder sted. Fra storemærs gaar tailleløberne hen til fokkemærs og derfra ned til spillet.

Her ere alle de folk anbragte, som kunne undværes; thi der maa en betydelig kraft dels til at løfte det store stykke spæk, der fra hvalen naar op til tæt under mærset, og dels til at afrive det fra hvalkroppen. I uroligt veir er afspækningen et farefuldt arbeide for de dermed nærmest beskjæftigede; ja selv det øvrige mandskab er ofte udsat for beskadigelse derved. Skibet slingrer og krænger i regelen meget

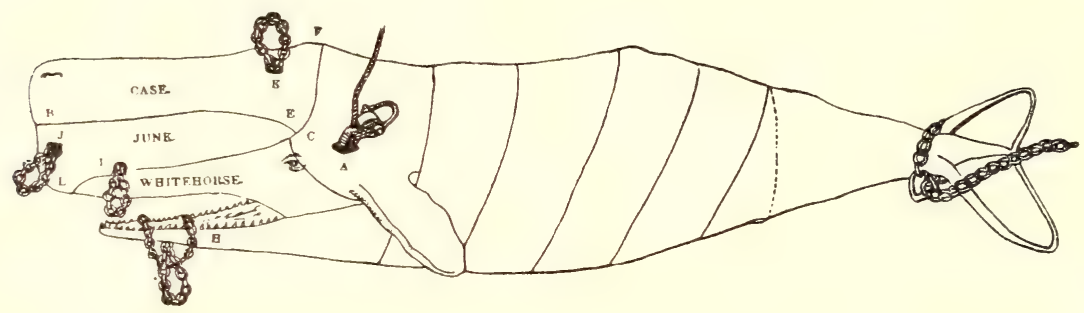

Fig. 64. Kaskelot færdig til flensning (den spiralformige linie viser, hvorledes skrotten rulles ud af hud-og spæklaget). Efter den amerikanske beretning.

stærkt, medens masten sukker og knager under den svære vægt; mange skarpe instrumenter haves i brug, og naar, som undertiden sker, strimlen slipper, idet den løsskjæres, kan den, ved at slingre frem og tilbage, knuse hvad den træffer paa.

Saasnart det sidste spæk er aftaget, overgives skroget til bølgerne og disses graadige beboere, thi hundreder af haier samle sig ofte omkring byttet. Hovedet skjæres (Beale Sperm-Wahle pag. 186) af i begyndelsen af denne „Flensning“", og man lader det flyde til skibets agterende, indtil den er fuldendt og skroget gjort løs. Da hales hovedet frem og aabnes, for at den flydende spermacet kan øses ud. Den hele masse af bløde dele øverst og fortil paa hovedet, skjæres af og heises, medens det øvrige af hovedet gaar tilbunds, ombord for atskjæres i lange firkantede stykker. Kun af smaa spermhvaler tages ofte hele hovedet ombord. 


\section{Bottlenosefangsten.}

Ligesom bottlenosen i sin bygning og levevis i mange henseender minder om kaskelotten, saaledes har ogsaa bottlenosefangsten mange lighedspunkter med den fangst, vi i det foregaaende har skildret.

Fremfor alt foregaar begge langt fra alle kyster i det aabne hav, og hvalen flenses ved fartøiets side. Medens kaskelotfangerne anvender „bombelandsen“, bruger dog de norske bottlenosefangere smaa „svivelkanoner", 30-36 tommer lange af $1 \frac{1}{2}-2$ toms diameter, hvortil svarer harpuner af forskjellig størrelse. Kanonerne er dels fiestede i fartøiets ræling, dels $\mathrm{i}$ bougen af baadene, $\mathrm{og}$ da bottlenosen har den vane ,af nysgjerrighed" at komme lige ind paa fartøiets boug, skydes de ofte fra

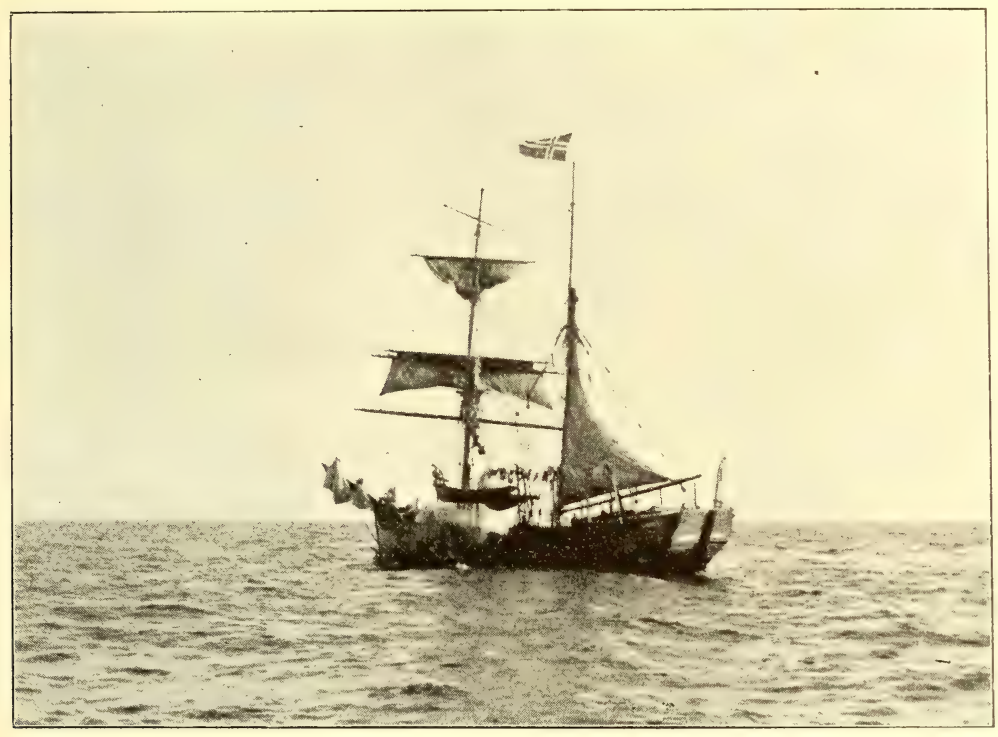

Fig. 65. Norsk bottlenosefanger i begreb med flensning af bottlenose. Efter fotografi af A. Wolleв

selve fartøiet. Af den grund kan man ogsaa anvende fartøier; thi man behøver ikke i den grad jage bottlenosen som f. eks. finhvalerne. Karakteristisk for bottlenosen er det, at den stikker ret ned mod bunden „som et lod", naar den træffes, ofte, ifølge meddelelse fra kaptein Ingebrigtsen, 400 favne, $0 \mathrm{~g}$ at den kommer op paa samme sted igjen. Dette giver interessante oplysninger om disse hvalers store evne til at udholde havdybenes vældige tryk.

I forrige kapitel saa vi (se kartet, fig. 56), at bottlenosen tidlig paa vaaren indfandt sig i Nordhavet, og at den i tiden april-juli fandtes paa de saakaldte "felter", fra aar til aar bestemte omraader af havet, hvor den fortrinsvis ynder at færdes, og hvor antagelig dens føde, sild og blæksprut, fortrinsvis har sit opholdssted paa denne aarstid. 
Disse felter er dels nord af Færøerne, øst om Island og vest om Spitsbergen-Bjørnøeggen. I overensstemmelse hermed udruster Norge bottlenosefangere baade fra Tromsø og fra det sydlige Norge (Østlandet, Aalesund).

Bottlenosefangsten begyndte først i Skotland (hvalfangeren David Gray fra Peterhead), som i følge JueL ${ }^{1}$ ) i 1881 skjød 39 bottlenoser,

i 1882 - 202 -
i $1883-157 \quad-$

I Norge var konsul Auf Monsen i Tønsberg den første, som udrustede fartøi paa bottlenosefangst. Hans fartøi Eskimo fik

$$
\begin{array}{llll}
\text { i } & 1883 & 33 & \text { hval } \\
\text { i } & 1884 & 31 & - \\
\text { i } & 1885 & 58 & -
\end{array}
$$

Snart opstod der en hel liden flaade for denne bedrift. Juec anfører, at der i 1884 var 8 fartøier med 211 hval,

$$
\text { i } 1885-22-\quad-\text { ca. } 800 \text { - }
$$

I slutten af 90-aarene har der nu været skudt mellem $2000 \mathrm{og}$ 3000 bottlenoser $0 \mathrm{~m}$ a aret af norske fangstfartøier. Disse har dels været udrustede udelukkende for bottlenosefangst $\mathrm{og}$ da flest fra østlandsbyerne (Tønsberg, Sandefjord, Larvik, Arendal), dels fra Aalesund, dels fra Tromsø. Desuden har imidlertid ogsaa sælfangerflaaden paa turen nordurer gjort fangst og Finmarkens hvalfangere har leilighedsvis udenfor Malangen (udenfor eggen) skudt flere bottlenoser.

Jeg skal indskrænke min omtale af denne i saa mange henseender interessante fangst til disse faa bemerkninger, da bedriften og dens historie kun frembyder meget faa forhold af betydning for de spørgsmaal, som er denne fremstillings maal.

\section{Finmarkens finhvalfangst.}

Om finhvalerne skriver A. Howard Clark i sin beretning om den amerikanske hralfangst, at de væsentlig kun fanges af kysthvalfangere, .,da større fartøier foretrækker mere fordelagtigt vildt, eftersom finhvalerne kun har lidet tran, ingen værdifulde barder og alt $\mathrm{i}$ alt er meget vanskelig at fange."

Samme forfatter giver følgende skildring af kystfangsten ifølge meddelelse af kaptein ATWOOD: "Tidlig i marts 1880 kom der ind i bugten red Provincetown (Amerikas nordkyst) umaadelige mængder af sild og "ræger". Disse fulgtes af et stort antal finhvaler, som blev gaaende i bugten meste tiden til midt i mai, da de alle forlod kysten. I dette.

1) Kaptein JueL: nebhvalen. Norsk fiskeritid. 1886. 
tidsrum blev mange af dem dræbt med bombelandsen. De sank, saasnart de var dræbt, og blev liggende paa bunden 2 til 3 dage, da de flød op igjen til overfladen. Men da mange flød op om natten eller i styggeveir, da hvalfangerne ikke var tilstede for at passe paa dem, drev mange ud tilsøs og gik derved enten tabt, eller ogsaa blev de samlet op af fiskefartøierne fra Gloucester og slæbt ind til den havn."

Paa denne særdeles lidet rationelle og ødsle maade skydes der af og til finhvaler langs Amerikas nordostkyst. Enkelte bruger vistnok at forsøge at sikre sig hvalen ved foruden bombelandsen at skyde eller kaste en harpun i hvalen, men da hvalen isaafald, om bomben i den ikke straks dræber den, slæber de smaa baade afsted med voldsom fart, er dette ingen synderlig afholdt bedrift.

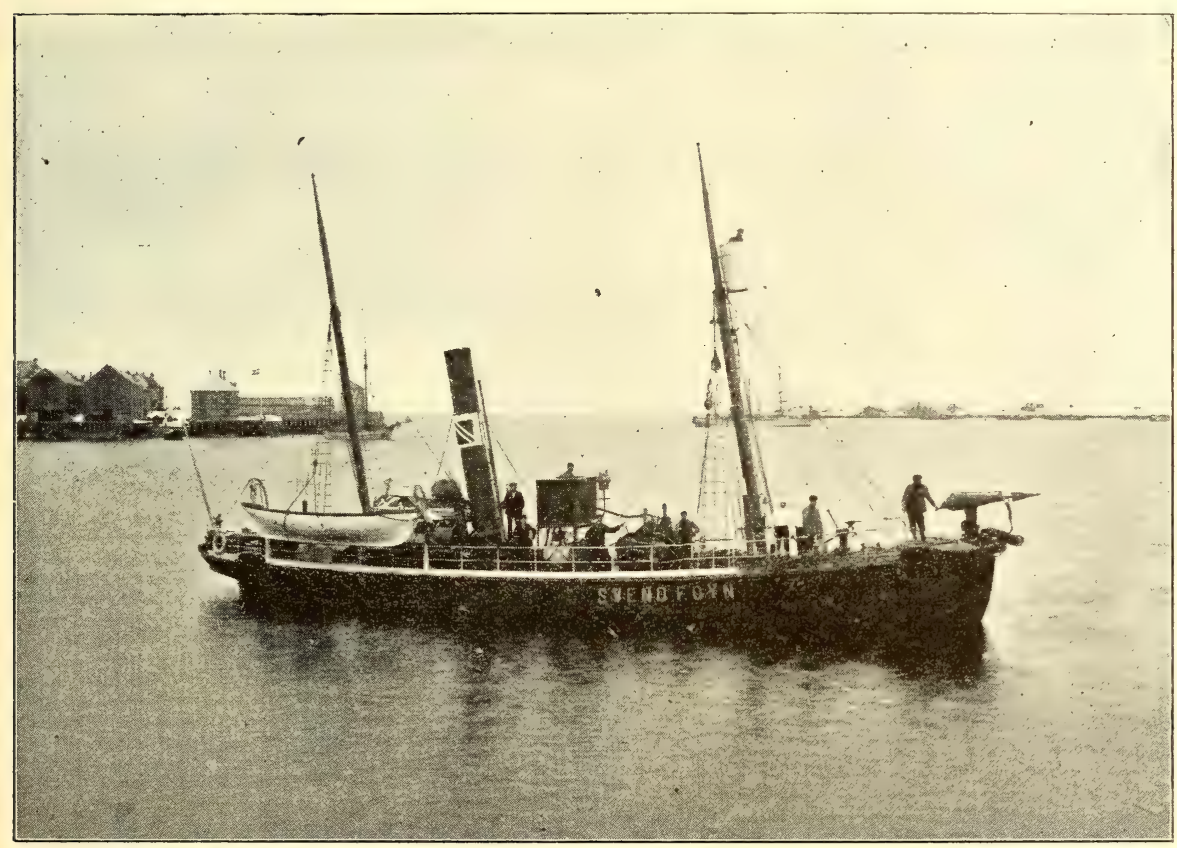

Fig. 66. Norsk hvalfanger paa Hammerfest havn. Efter fotografi af hr. fotograf Kalland, Hammerfest.

Finhvalfangsten kunde først drives som en regelmæssig og organiseret bedrift ved det system og de opfindelser af redskaber for bedriften, som i 60-aarene af det forløbne aarhundrede blev indført af nordmanden Svend Foys. Den maade, han organiserede finhvalfangsten paa, afviger i mange henseender fra al anden hvalfangst.

Som vi ovenfor har seet, var der i tidligere hvalfangster enten anvendt store fartøier, mest seilskonnere eller brigger, eller store kombi- 
nerede seil- $0 \mathrm{~g}$ dampskibe mest lignende de norske sælfangere. Disse drev selve fangsten fra et større eller mindre antal baade, der enten anvendte svivel-harpun-kanonen, haandharpuner og bombelandser eller lignende, medens opspækningen blev foretagen langs skibssiden og spækket kom lige i de store lasterum.

Istedetfor anvendte Svend Foyn smaa dampskibe, der selv drev fangst $o g$ saaledes nærmest svarede til de store hvalfangerskibes baade, men som, fordi de var dækkede og meget sjødygtige, selvfølgelig havde en ganske anden erne til at forfølge de hurtige finhvaler og til at klare sig, naar de fik "fast fisk" og blev slæbt afsted med 8-10 mils fart af den saarede hval. Istedetfor at anvende en liden harpun med tynd line

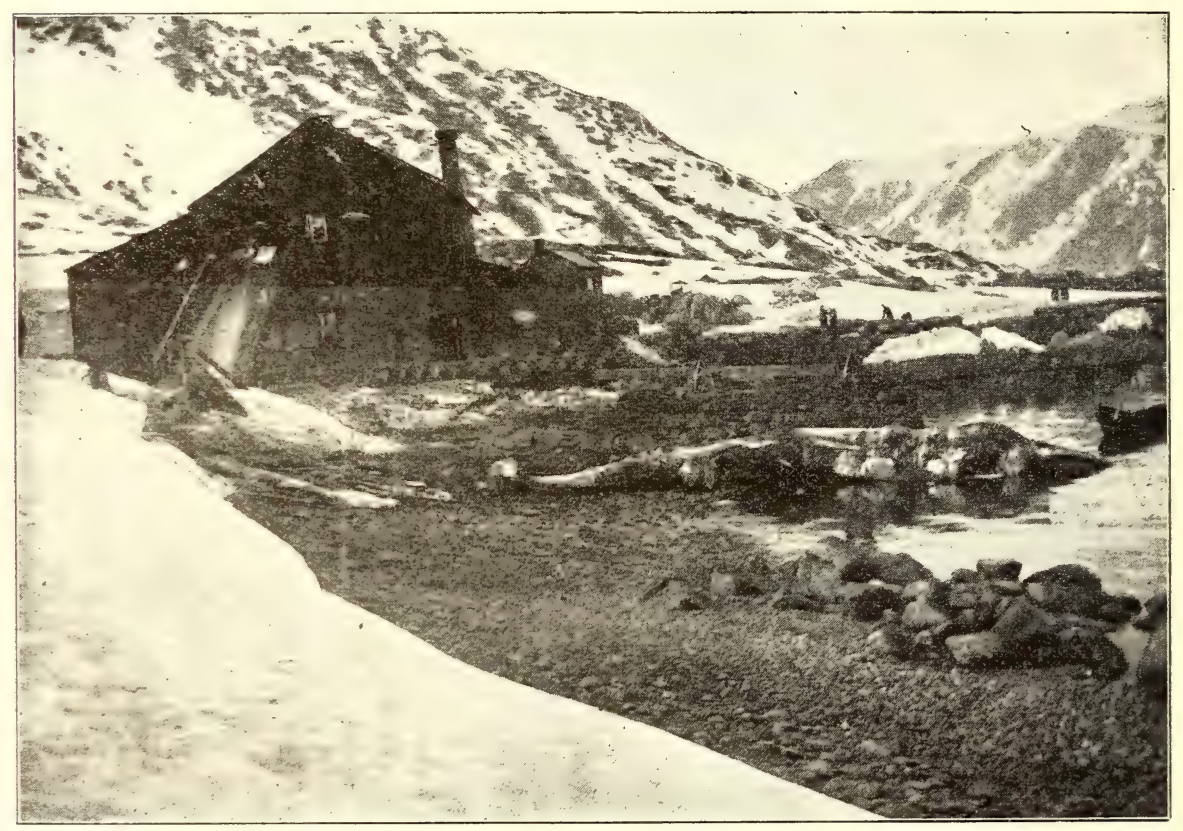

Fig. 67. Hr. Ingebrigtsens hvalfangstetablissement i Troldfjorden (Rolfs $\varnothing$ ) med flenset hval i stranden.

$o g$ et gevær til udskydning af bombelandsen, kunde han i fartøiets boug opstille en kraftig kanon, som udskjød en kombineret harpun-bombe, den saakaldte spidsgranatharpun, der dels havde til hensigt ved granatens sprængning i det anskudte dyr at dræbe dette, dels at fæste hvalen gjennem harpunen og den kraftige line til dampskibet, som saa med sin kraftige winch kunde hale dyret ind til fartøiet.

Da dampskibet imidlertid, om det skulde være tilstrækkelig letvindt at manøvrere og vende og desuden kunne drives med rimelige omkostninger, 
ikke kunde gjøres af den størrelse, at flensning kunde foregaa ved skibssiden og spækket bringes i lasterummet, maatte hele denne proces foregaa i land ved de saakaldte hvaletablissementer, beliggende $i$ en eller anden bekvem havn nær det felt, hvor tilstrækkelig fangst kunde paaregnes for de smaa dampskibe. Dette er i hovedtrækkene det karakteristiske ved fangstmaaden af finhval i Finmarken.

Den ovenfor nævnte spidsgranatharpun er det redskab, som gjorde hele denne bedrift mulig. I regelen bestaar den i en granat, der skrues fast paa harpunen, saaledes at dens ladning antændes, naar et med syre fyldt glasrør knuses af harpunens klør, som springer ud og borer sig ind

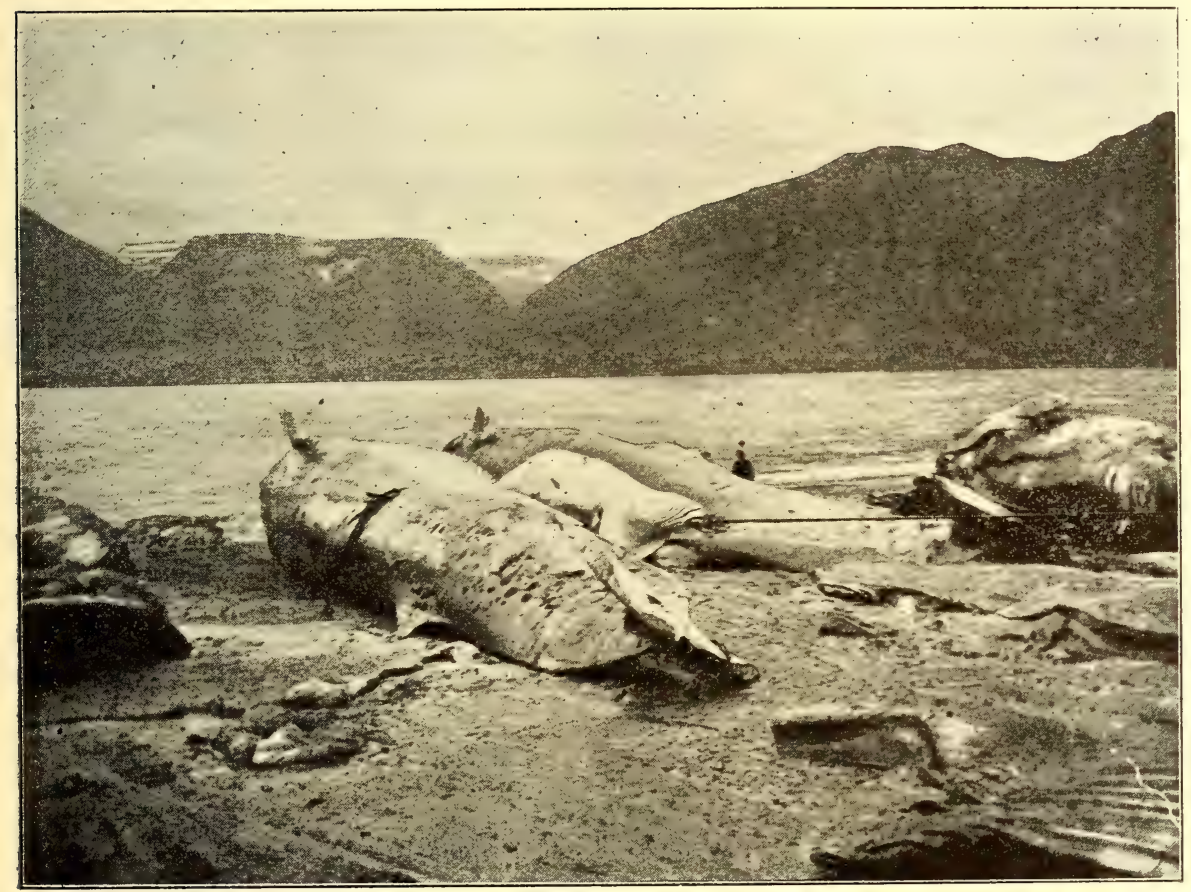

Fig. 68. Flensning af hval paa stranden. De store spækstykker winches af med kraftige staaltauge.

i hvalkjødet, saasnart harpunen træffer. Hele redskabet er 1,35 meter langt og kanonen af 3 toms kaliber. Alligevel maa man paa en 15 favnes afstand selv med de bedste greier for at være sikker paa at kunne træffe. Der bruges i regelen en 300 favne lang, 51/4-53/4 toms (omkreds) line, af hvilken forløberen ligger skudt op foran kanonen og resten i lasterummet bag winchen. Det er denne svære tunge line, som gjør, at skuddet maa affyres paa saa nært hold.

Naar hvalen ikke dør straks, efterat granaten er sprunget, stikker den først ned mod bunden, siden med stor fart forover, og fortæller hval- 
fangerne mange historier om, hvorledes de har ladet dampskibet arbeide med fuld fart agterover $0 g$ alligevel er blevet slæbt forover med dampbaadsfart i mangfoldige timer. "Naar hvalen begynder at blive udmattet," siger JuEL, ,kortes ind paa linen, indtil man har den 50-60 favne fra fartoiet, da baaden fires af, hvorpaa man søger at give den fra denne den sidste rest med landserne. Er søen $0 \mathrm{~g}$ hvalen urolig, kan dette ofte være et vanskeligt arbeide. Er veiret rimeligt, kan man faa lændset den temmelig hurtigt."

Hvalen slæbes nu tillands, og her blir den paa stranden afspækket, idet spækket blir winchet af den (se fig. 68) og direkte op i „fabrikken“, hror det blir dampsmeltet i jernkjedler. Efter at være klaret paa forskjellig vis haves da tranen paa tønder eller fustager, mest paraffinfade.

Det vilde her fore os altfor langt at skildre, hvorledes denne tranberedning foregaar, hvorledes ogsaa fedtet i tunge, indvolde etc. udnyttes, og hrorledes de guanofabrikker er indredede, som ofte er knyttede til hraletablissementerne, $0 \mathrm{~g}$ hvor ben, kjød etc. torres $0 \mathrm{~g}$ pulveriseres til gjodningsstoffe. Man har ogsaa med mere eller mindre held søgt at fabrikere kraftfoder af hvalkjødet. Barderne renses for alt kjød, vaskes med soda $0 \mathrm{~g}^{\circ}$ torres.

Det var i 1865, at Svend Fors begyndte sine forsøg paa hvalfangst i Tarangerfjorden. I aarene 1865, 1866 og 1867 skal han kun have havt lidet held med sig og vresentlig arbeidet med at forsøge sig frem; men i aaret 1868 skjød han 30. hval, og dermed begyndte den regelmæssige fangst, for i lobet af meget faa aar at vokse op til en for norske forhold betydelig bedrift. Paa hosstaaende tabel gives der nu en oversigt, udarbeidet af hr. fiskeriinspektør Sørensen, over de forskjellige hraletablissementers oprettelse $o g$ antallet af de fartøier, som i aarene 186t-1901 har været i virksomhed i hvalfangsten i Finmarken, og denne tabel vil vistnok være til adskillig veiledning ved den følgende korte orersigt over bedriftens historie. Som man ser, er der til tabellen føiet et orersigtskart, der med sorte punkter angiver etablissementernes beliggenhed; i tabellen er i overensstemmelse hermed stationerne ordnede saaledes, at de vestligste er længst til venstre, de østligste til høire; det har dog naturligvis ikke været muligt i tabellen at sætte hvert etablissement ret under dets beliggenhed i kartet.

Af denne tabel vil man ligesom af de historiske fremstillinger, der i tidens løb har været givet af hvalfangsten, se, at denne begyndte i den aller østligste del af Finmarken. I aarene 1864-1868 arbeidede Forn alene og kun med et skib fra sit etablissement i Vadsø, i aarene $1869 \ldots$

Se angaaende nærmere enkeltheder herom: JukL: Hvalfangsten i Finmarken. Norsk Fiskeritidende 1888. 
Antal fangstfartøier i aarene 1864-1901 med kart ove Fi

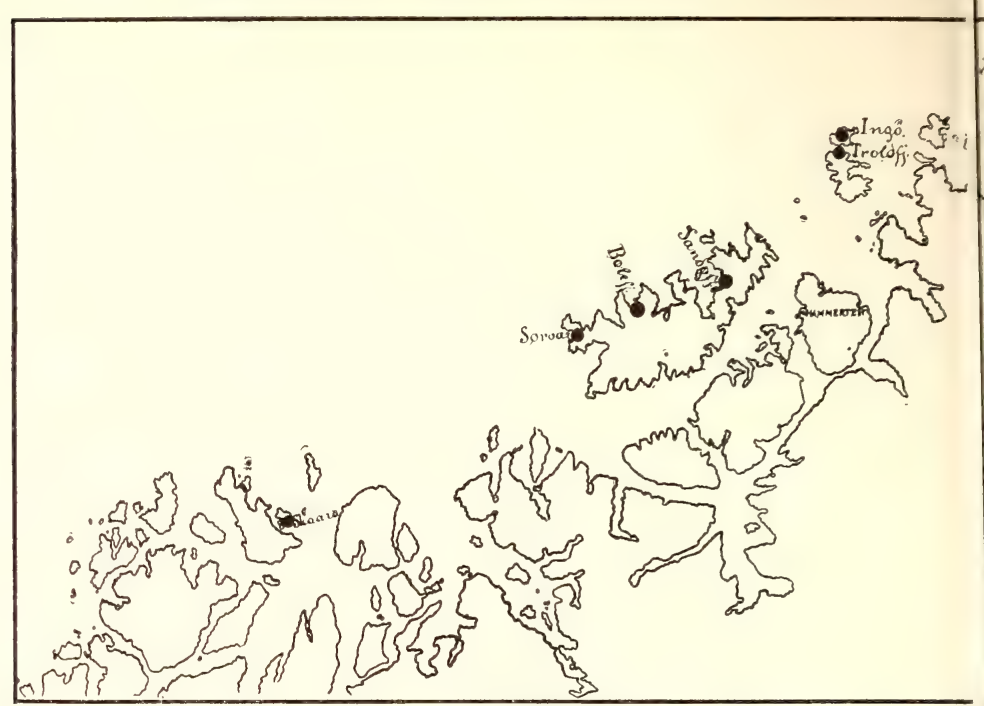

\begin{tabular}{|c|c|c|c|c|c|c|c|c|c|c|c|c|c|c|c|}
\hline & \multirow[b]{2}{*}{ A ar } & \multirow[b]{2}{*}{ 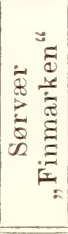 } & \multicolumn{2}{|c|}{ Bole } & \multirow[b]{2}{*}{ 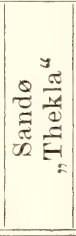 } & \multirow[b]{2}{*}{ 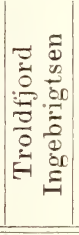 } & \multirow[b]{2}{*}{ 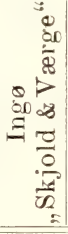 } & \multirow[b]{2}{*}{ 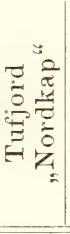 } & \multirow[b]{2}{*}{ 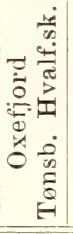 } & \multirow[b]{2}{*}{ 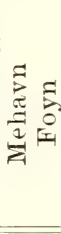 } & \multirow[b]{2}{*}{ 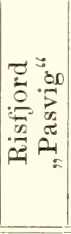 } & \multicolumn{4}{|c|}{ Baadsfjord } \\
\hline & & & 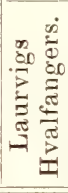 & है & & & & & & & & 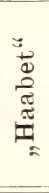 & 节 & 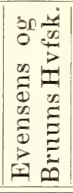 & 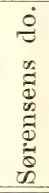 \\
\hline 1864 & $\ldots \ldots \ldots$ & - & - & - & - & $\ldots$ & - & - & - & - & - & - & - & - & 一 \\
\hline 1865 & $\ldots \ldots$ & - & - & - & - & - & - & - & - & - & - & - & - & - & - \\
\hline 1866 & $\ldots \ldots \ldots$ & - & - & - & - & - & - & - & - & - & - & - & - & - & - \\
\hline 1867 & $\ldots \ldots \ldots$ & - & - & - & - & - & - & - & - & - & - & - & - & - & - \\
\hline 1868 & $\ldots \ldots \ldots$ & - & - & - & - & - & - & - & - & - & - & - & - & - & - \\
\hline 1869 & $\ldots \ldots \ldots$ & - & - & - & - & - & - & - & - & - & - & - & - & - & - \\
\hline 1870 & $\ldots \ldots \ldots$ & - & - & - & - & - & - & - & - & - & - & 一 & - & - & - \\
\hline 1871 & $\ldots \ldots \ldots$ & - & 一 & - & - & - & - & - & - & - & - & - & - & - & - \\
\hline 1872 & $\ldots \ldots \ldots$ & - & - & -- & - & - & - & - & - & - & - & - & - & - & - \\
\hline 1873 & $\ldots \ldots \ldots$ & - & - & - & - & - & - & - & - & - & - & - & - & - & - \\
\hline 1874 & $\ldots \ldots \ldots$ & - & - & - & - & - & - & - & - & - & - & - & - & - & - \\
\hline 1875 & $\ldots \ldots \ldots$ & - & - & - & 一 & - & - & - & - & - & - & 一 & - & - & - \\
\hline 1876 & $\ldots \ldots \ldots$ & - & - & - & - & - & - & - & - & - & - & - & - & - & - \\
\hline 1877 & $\ldots \ldots \ldots$ & - & - & - & - & - & - & - & - & - & - & - & - & - & - \\
\hline 1878 & $\ldots \ldots$ & - & - & - & - & - & - & - & - & - & - & - & 一 & - & 一 \\
\hline 1879 & $\ldots \ldots \ldots$ & - & - & - & - & - & - & - & - & - & - & - & - & - & - \\
\hline 1880 & $\ldots \ldots \ldots$ & - & - & - & - & - & - & - & - & - & - & - & - & - & - \\
\hline 1881 & $\ldots \ldots \ldots$ & 2 & - & - & - & - & - & 1 & - & - & - & - & - & - & - \\
\hline 1882 & $\ldots \ldots \ldots$ & 2 & - & - & - & - & - & 2 & - & - & - & - & - & - & - \\
\hline 1883 & $\ldots \ldots \ldots$ & 2 & - & - & - & - & - & 2 & - & - & - & 一 & - & - & - \\
\hline 1884 & $\ldots \ldots \ldots$ & 2 & - & - & - & - & - & 2 & - & - & - & - & - & - & 1 \\
\hline 1885 & $\ldots \ldots \ldots$ & $\overline{2}$ & - & 2 & - & - & - & 2 & - & 2 & - & - & - & - & 1 \\
\hline 1886 & & $\overline{2}$ & - & 2 & - & - & - & 2 & - & 2 & - & - & - & $\ldots$ & 2 \\
\hline 1887 & & $\overrightarrow{2}$ & - & 2 & - & - & - & 2 & - & 2 & - & - & - & - & 2 \\
\hline 1888 & $\ldots \ldots \ldots$ & 2 & - & 2 & - & - & - & 2 & - & 2 & - & - & - & - & 2 \\
\hline 1889 & $\ldots \ldots \ldots$ & 2 & - & 2 & - & - & 2 & 2 & - & 2 & - & - & - & 1 & 2 \\
\hline 1890 & $\ldots \ldots \ldots$ & 2 & - & 2 & 1 & 1 & 2 & 2 & - & 2 & - & - & - & 1 & 2 \\
\hline 1891 & & 2 & - & 2 & 1 & 1 & 2 & 2 & - & 2 & 2 & - & - & 1 & 2 \\
\hline 1892 & & 2 & - & 2 & 1 & 1 & 2 & 2 & - & 3 & 2 & - & - & 1 & 2 \\
\hline 1893 & & 2 & - & 2 & 1 & 1 & 2 & 2 & - & 3 & 2 & - & - & 1 & 2 \\
\hline 1894 & & 2 & - & 2 & 1 & 1 & 2 & 2 & - & 3 & 2 & - & 2 & 1 & - \\
\hline 189.5 & & 2 & - & 2 & 1 & 1 & 2 & 2 & - & 3 & 2 & - & 2 & 1 & - \\
\hline 1896 & & 2 & - & 2 & 1 & 1 & 2 & 2 & - & 3 & $\overline{2}$ & - & 2 & 1 & - \\
\hline 1897 & $\ldots \ldots$ & 2 & - & - & 1 & 1 & 2 & 2 & - & 3 & 2 & - & 2 & 1 & - \\
\hline 1898 & & 2 & - & - & 1 & 1 & 2 & 2 & 2 & 3 & 2 & 1 & 2 & 1 & - \\
\hline 1899 & & 2 & - & - & 1 & 1 & 2 & 2 & 2 & 3 & 2 & 1 & 2 & 1 & - \\
\hline 1900 & & - & 2 & - & 1 & 1 & 2 & 2 & 2 & 3 & 2 & 1 & 2 & 1 & - \\
\hline 1901 & $\ldots \ldots$ & - & 2 & - & 2 & 1 & 2 & 2 & 2 & 3 & - & 1 & 2 & -- & - \\
\hline
\end{tabular}



Antal fangstfartøier i aarene 1864-1901 med kart over Finmarken. De sorte prikker angiver hvaletablissement.

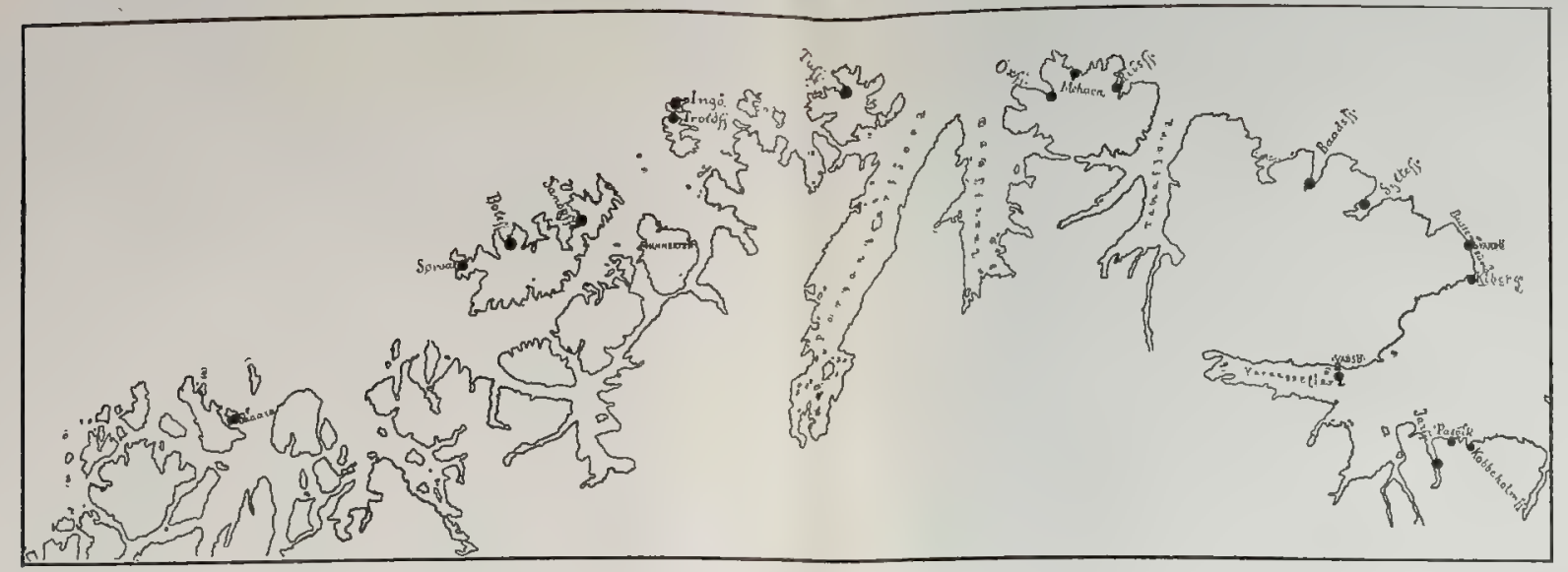

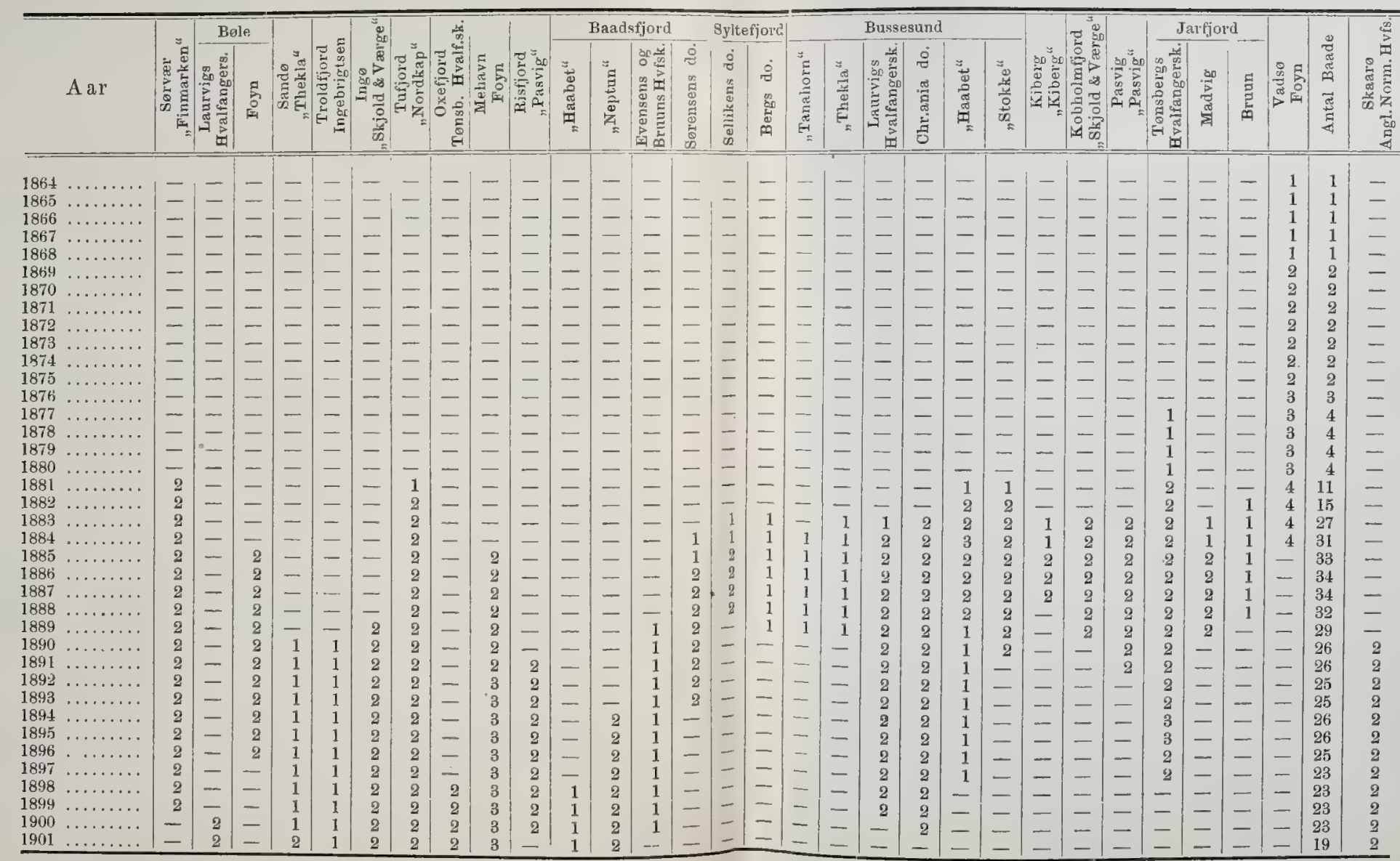



1875 havde han to skibe, fik i 1876 sit tredie skib, og i 1877 begyndte det første konkurrerende selskab (Tønsberg Hvalfangerselskab); men først fra 1882 blev der dog fart i udviklingen. Der var da, som man ser, 15 skibe, som allerede i 1883 forøgedes til 27. I aarene $1886 \mathrm{og}$ 1887 naar antallet af skibe sit høidepunkt med 34 skibe, og fra nu af begynder der en langsom, men stadig nedadgaaende bevægelse i skibenes antal, saaledes at disse ifjor, 1901 , kun var 19, et tal, som jo nærmer sig halvdelen af antallet paa dets høidepunkt.

Af tabellen læser man videre, at der har skeet en stor forandring i etablissementernes geografiske beliggenhed. Alle de østligste, som

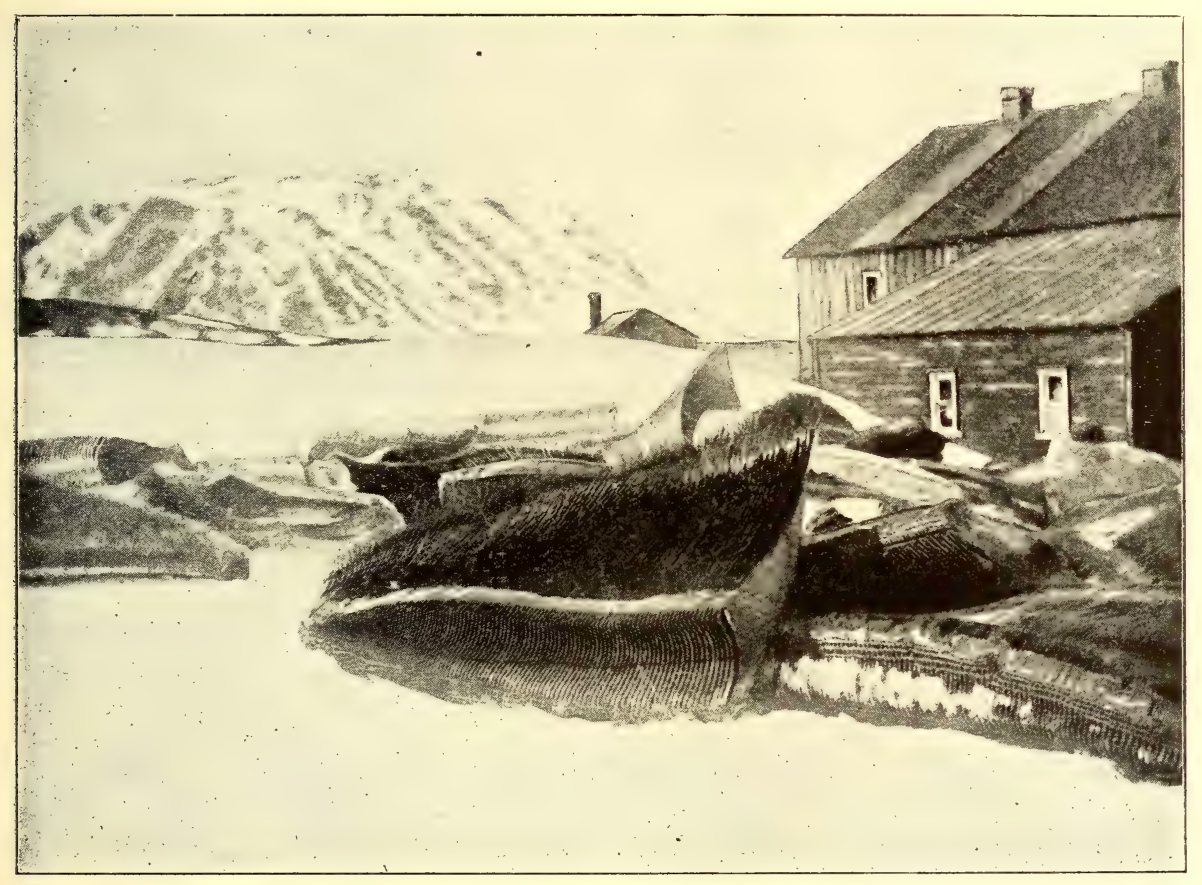

Fig. 69. Knøl- og finhvalbarder ved Ingebrigtsens hvaletablissement.

var de først anlagte, er nedlagte, og bedriften har stadig flyttet vestover. Saaledes var der i sin tid rundt den store Varangerfjord fra Kobholmfjord til Vardø paa en gang ikke mindre end 13 etablissementer, hvoraf nu ingen er i drift. Længer vest ligger Syltefjord, her var engang to etablissementer, af hvilke det sidste blev nedlagt $\mathrm{i}$ aaret 1899 . Baadsfjord er derfor det østligste punkt, hvor der endnu findes hvalfangstetablissement i drift, men her er der ogsaa to nedlagte stationer. Af de vestligere etablissementer er flere tilhørende de samme gamle selskaber, som tidligere drev længer øst, saaledes ser man, at Foyss baade, 
der før drev i Varangerfjorden, nu dels driver fra Mehavn, dels ogsaa drev fra Bøle paa Sørøen. Med andre ord selskaberne har mattet flytte vestover og forlade de store felter, hvor hvalfangsten begyndte.

Før vi gaar til drøftelsen af det særdeles vigtige spørgsmaal om aarsagerne til denne eiendommelige først særdeles sterkt opadgaaende saa igjen nedadgaaende bevægelse i hvalfangstens historie, skal vi først nærmere søge at udrede, hvilke hvaler (arter), der i tidens løb har været fangstens maal, hvilken betydning de enkelte arter har havt for bedriften, samt til hvilke aarstider, paa hvilke steder og under hvilke forhold de forskjellige arter fanges.

De hvaler, som er gjenstand for hvalfangsten i Finmarken, er blaahvalen, seihvalen, knølhvalen og finhvalen. I det foregaaende kapitel har vi udførlig skildret, hvad der er bekjendt om disse dyrs liv og vandringer, og deraf vil man have seet, at de tre første arter kun opholder sig til begrænsede tider i Finmarkshavet, at de foretager særdeles store vandringer (helt til Amerika), og at der kun yderst sjelden sees unger af dem i Finmarkshavet. Finhvalen derimod iagttages i de norske farvand aaret rundt og i Finmarkshavet til store dele af aaret, om den end til enkelte tider er væsentlig sjeldnere end til andre. Desuden sees dens unger, saaledes at den $\mathrm{i}$ hele sit liv kan siges at tilhøre norske farvand.

I overensstemmelse med disse hvalernes forekomst er da selvfølgelig ogrsaa fangsten. Om denne faar man det bedste indtryk ved at betragte en af de journaler over et aars hvalfangst, som velvillig er stillet til min raadighed.

Af tabel nr. 2 over hr. Ingebrigtsens fangst med dampskibet „Skytten“ af Tromsø i aaret 1898 vil man se, at fangsten har faldt $\mathrm{i}$ følgende karakteristiske afsnit:

1) Knølhvalfangst i tiden 12 te februar til 12 te marts. I denne tid blev der skudt 14 knølhval udenfor Ingø indtil $3^{1 / 2}$ mil af land. Knølhvalen er, som man vil erindre af foregaaende kapitel, paa vandring vestover, og den holder sig mest mulig nær land. I slutten af marts forsvinder knølhvalen ganske for først midtsommers (juli) at vise sig igjen.

2) Det andet afsnit kan sættes fra 12 te marts til 12 te mai. Karakteristisk for dette tidsrum er, som man vil se, en overordentlig ujevn fangst med lange tidsmellemrum. Den eneste hval, som skydes, er finhvalen og nogle bottlenose vest for Malangen. I tiden fra 12 te marts til før 12 te mai altsaa 2 maaneder skydes 7 finhval. I disse to maaneder er der meget lange tidsrum, da intet skydes, saaledes fra 
12te-24de marts, fra 2 den-12te mai, gjennemsnitlig mindre end 1 hval pr. uge.

3) Fra 12 te mai til $18 \mathrm{de}$ juni begynder en mere regelmæssig finhvalfangst. I denne tid af lidt over en maaned skydes 14 finhval. Den bedste tid er dog først efter 1ste juni, tidligere er der ogsaa lange, døde tidsrum som f. eks. fra 16de til 27 de mai. I de første 18 dage af juni skydes 10 finhval, hvilket er mere end en hveranden dag.

4) Fra 18 de juni til 22 de august falder den bedste fangsttid. Der skydes da:

\author{
11 blaahval, \\ 24 finhval, \\ 8 seihval, \\ 4 knølhval, alt ialt
}

47 hval.

Fangsten er da, som man ser, udstrakt over særdeles store havstrækninger, fra Sørøens vestlige del (Sørvær) til Bjørnøen. Ved Bjørnøen er det fortrinsvis, at blaahvalen skydes, mens finhvalen skydes udenfor Norges kyst.

I de her skildrede forhold fra aaret 1898 findes der fra aar til aar adskillige variationer, saaledes varer knølhvalfangsten det ene aar lidt længer, det andet aar kortere, finhval- og senere blaahvalfangsten begynder det ene aar tidligere, det andet aar senere. Vi skal derfor betragte nogle andre eksempler paa andre fangstaar, før vi søger at udlede en almindelig regel for fangstens gang.

I aaret 1896 skjød hr. Ingebrigtsen, som det sees af journaludtoget (tabel nr. 1) følgende hval:

1) Fra $28 \mathrm{de}$ februar til $10 \mathrm{de}$ april blev der skudt $15 \mathrm{kn} \emptyset \mathrm{l}-$ hival, men dette aar var finhvalen kommen tidligere, og samtidig skjødes 4 finhval.

2) Fra $10 \mathrm{de}$ april til 1 ste juni indtraadte igjen et lignende langt ujevnt tidsrum, da der dels paa grund af stormende veir, dels paa grund af lidet hval kun blev skudt 7 finhval. Af disse blev de 6 første skudt meget nær kysten, saa indtraadte der fra 23de april helt til 19de mai, altsaa næsten en hel maaned, et tidsrum uden at en eneste hval fangedes, og den sidste finhval, som fangedes i tidsrummet (19de mai) blev skudt ikke mindre end 32 mil nord for Nordkyn.

3) Først fra 1ste juni af begyndte der en regelmæssig fangst, og i maanederne juni og juli blev der skudt

40 finhval,

1 blaahval,

2 seihval,

1 knølhval. 
4) Som man ser, er her finhvalen aldeles overveiende, og dette aar faldt fangsten af de andre hvaler først i a ugust og september. I disse maaneder blev der skudt

$$
\begin{aligned}
& 6 \text { blaahval, } \\
& 6 \text { finhral. } \\
& 9 \text { seihval, } \\
& 3 \text { knølhval. }
\end{aligned}
$$

I hele tidsrummet juli-september færdedes", fartøiet tildels meget langt fra land, op imod Bjørnøen.

Sammenligner man de to aar 1896 og 1898 ser man adskillige forskjelle; saaledes blev der i 1896 kun skudt 1 blaahval før 1ste august, i 1898 blev alle 11 blaahval skudt før første august. I 1898 blev den første finhval først skudt 24 de marts, og i tiden før første juni blev der ialt skudt 11 finhval. I 1896 blev den første finhval skudt 16de marts og ligeledes 11 finhval skudt før første juni.

Flere eksempler vilde her virke trættende. Istedetfor at anføre dem skal jeg meddele nogle sammenstillinger af, hvad samtlige de 40

\begin{tabular}{|c|c|c|c|c|}
\hline & & & pr. fangstaar & antal hval \\
\hline & januar-1ste juni ... & 199 & 5 & 14.6 \\
\hline Finhval & 1ste juni-september & 538 & 13.5 & 39.3 \\
\hline & hele aaret ........ & 737 & 18.5 & 53.9 \\
\hline & januar-1ste juni ... & 104 & 2.5 & 7.6 \\
\hline Knølhval & 1ste juni-september & 71 & 1.8 & 5.2 \\
\hline & hele aaret ........ & 175 & 4.3 & 12.8 \\
\hline & januar-1ste juni ... & 3 & 0.07 & 0.2 \\
\hline Blaahval & 1ste juni-september & 93 & 2.3 & 6.9 \\
\hline & hele aaret........ & 96 & 2.4 & 7.1 \\
\hline & januar-1ste juni ... & 7 & 0.17 & 0.5 \\
\hline Seihval & 1ste juni-september & 350 & 8.7 & 25.6 \\
\hline & hele aaret ........ & 357 & 8.9 & 26.1 \\
\hline & januar-1ste juni ... & 313 & 9.0 & 22.9 \\
\hline Totalfangst & 1ste juni-september & 1052 & 26.3 & 77.1 \\
\hline & hele aaret ......... & 1395 & 33.3 & 100.0 \\
\hline
\end{tabular}
fangstjournaler, som jeg indgaaende har gjennemseet, lærer om fangsten i de forskjellige tider af aaret.

Af tabel nr. 3 for de 40 fangstaar kan man se følgende resultat.

Antal hval Gjennemsnit Pct. af samlede 
ca. $54 \%$ af de skudte hvaler var finhval

$\begin{array}{rrl}-13 \% & -,- & \text { knølhval } \\ -\quad 7 \% & -,- & \text { blaahval } \\ \text { - } 26 \% & -,- & \text { seihval }\end{array}$

samt at blaahval og seihval saagodtsom udelukkende skydes efter 1ste juni, knølhvalen derimod mest før 1ste juni - ja efter hvad eksemplerne viste før 1ste april, medens hovedtyngden af finhvalen skydes efter 1 ste juni, skjønt der især $\mathrm{i}$ april maaned i regelen optræder adskillig finhval udenfor kysten.

Med denne oversigt over de senere aars hvalfangst for øie skal vi paany nærmere betragte Finmarkhvalfangstens historie og da specielt med det maal at udrede, hvilken rolle de forskjellige hvaler i tidens løb har spillet for fangsten.

Ifølge hvalfangstkommissionen af 1890 blev der i de første aar, da Fors drev hvalfangst alene i Varangerfjorden, udelukkende skudt blaahval.

Der anførtes at i 1868 erholdtes 30 stykker

$\begin{array}{lllll}\text { i } & 1869 & \text { - } & 17 & \text { - } \\ \text { i } & 1870 & \text { - } & 36 & \text { - } \\ \text { i } 1871 & \text { - } & 20 & \text { - } \\ \text { i } 1872 & \text { - } & 40 & \text { - } \\ \text { i } & 1873 & - & 36 & \text { - }\end{array}$

„I 1877 begyndte derhos et andet selskab at drive hvalfangst i Varangerfjorden ved siden af hr. Fors“, ,jagten dreves fra nu af heller ikke udelukkende efter blaahval. Af de skudte hvaler var der

$$
\begin{array}{lllllll}
\text { i } & 1877 & 28 & \text { blaahval og } & 8 & \text { finhval } \\
\text { i } & 1878 & 76 & -- & - & 40 & - \\
\text { i } & 1879 & 90 & - & - & 40 & -
\end{array}
$$

I 1878 toges saagodtsom den hele fangst ud for Holmengraa samt indover mod Næsseby, altsaa inde i selve Varangerfjorden."

Til og med 1879 -var der (se tabellen) kun 4 fartøier.

I 1880 steg fartøiernes antal til 11
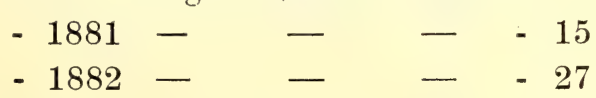

og naaede som ovenfor nævnt i 1886 og $1887 \quad-34$

Ifølge Juel var i disse aar fangsten følgende: 


$\begin{array}{rrccccr} & \text { Blaahval } & \text { Finhval } & \text { Knølhval } & \text { Seihval } & \text { Ubekjendt } & \text { Ialt } \\ 1880 & 113 & 50 & & & & 163 \\ 1881 & 221 & 52 & 9 & & 1 & 483 \\ 1882 & 101 & 250 & & & & 351 \\ 1885 & 34 & 337 & 92 & 724 & 11 & 1298 \\ 1886 & 114 & 609 & 88 & 61 & 60 & 932 \\ 1887 & 66 & 268 & 22 & 302 & 239 & 797 \\ 1888 & 76 & 388 & 75 & 171 & & 710 \\ 1889 & 22 & 368 & 12 & 131 & & 533 \\ 1890 & 22 & 368 & 24 & 213 & & 617\end{array}$

Som man heraf vil se, skiftede hvalfangsten meget hurtig karakter. I de første 5 aar, da fangsten blev drevet med held (1868-1873), blev der kun skudt blaahval (179 stykker ialt), saa drev man under voksende antal af fartøierne $\mathrm{i}$ aarene $1874-1881$ baade blaahval- $0 \mathrm{~g}$ finhvalfangst. Blaahvalen var dog i denne periode endnu langt overveiende $\mathrm{i}$ antal saaledes i 1891, da der var 15 skibe, 251 blaahval mod 52 finhval med en fangst af 14.5 blaahval paa hver af de 15 skibe. Men fra 1882 af, da skibenes antal pludselig steg til 27 og til 1887 forøgedes til 34, blev forholdet helt omvendt. Finhvalen udgjør mere og mere hovedfangsten saaledes f. eks. i 1885437 finhval mod 34 blaahval, hvilket kun er 1 blaahval pr. skib, og dette trods at blaahvalen har den dobbelte værdi af finhvalen. Samtidig begynder man nu ogsaa at skyde knølhval og seihval, og den hele fangst nærmer sig mere den karakter, vi ovenfor skildrede som gjældende $\mathrm{i}$ de seneste aar.

„Fordelt paa de 27 fartøier" siger JuEL om fangsten i aaret 1890 , „bliver udbyttet for hvert med hele tal

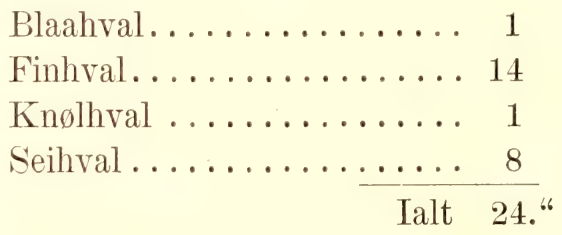

Af de nævnte 22 blaahval er 9 skudt af et fartøi, som gik til Bellsund paa Spitsbergen, saaledes at der det aar kun blev skudt 13 blaahval udfor Finmarken, hvilket gjennemsnitlig kun blir $1 / 2$ pr. fartøi.

Den indtraadte forandring i fangsten af blaahvalen sees bedst af følgende af hvalfangstkommissionen af 1890 udarbeidede statistik:

Fangsten var af blaahval i

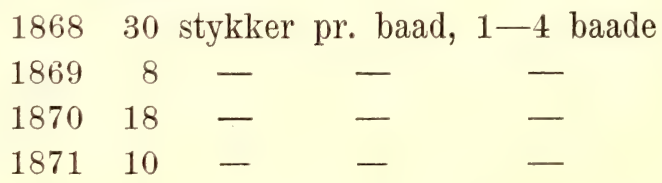




\begin{tabular}{|c|c|c|c|c|c|}
\hline 1872 & 20 & tykke & r. b & & $-4 b$ \\
\hline 1873 & 18 & - & - & & - \\
\hline 1874 & 25 & - & - & & - \\
\hline 1875 & 18 & - & - & & - \\
\hline 1876 & 21 & - & - & & - \\
\hline 1877 & 7 & - & - & & - \\
\hline 1878 & 19 & - & - & & - \\
\hline 1880 & 22 & - & - & 4 & baade \\
\hline 1881 & 20 & - & - & 11 & - \\
\hline 1882 & $\dot{6}$ & - & - & 15 & - \\
\hline 1883 & 4 & - & - & 27 & - \\
\hline 1884 & 3 & - & - & 31 & - \\
\hline 1885 & 1 & - & - & 33 & - \\
\hline 1886 & 3 & - & - & 34 & - \\
\hline 1887 & 3 & - & - & 34 & - \\
\hline 1888 & 2 & - & - & 32 & - \\
\hline 1889 & 1 & - & - & 29 & - \\
\hline 1890 & 1 & - & - & 26 & - \\
\hline
\end{tabular}

Denne store nedgang i baadenes fangst af blaahval kan ikke forklares derved, at der var saa mange baade om at fange det antal blaahval, som forefandtes; thi af tabellen vil man se, at fartøierne nu var spredt over hele Finmarkens og Tromsø amts kyster, mens de faa, som var i de første aar, kun fiskede i Varangerfjorden.

I 90-aarene har dette forhold ikke forandret sig. For aarene 1891-1895 har jeg ikke fundet nogen opgaver over, hvor meget der er fanget af hver art, men for aarene 1896-1901 viser statistiken følgende for Finmarkens amt:

$\begin{array}{lccrcr} & \text { Blaahval } & \text { Finhval } & \text { Knølhval } & \text { Seihval } & \text { Ialt } \\ 1896 & 58 & 733 & 174 & 106 & 1071 \\ 1897 & 94 & 400 & 56 & 513 & 1063 \\ 1898 & 24 & 448 & 55 & 54 & 581 \\ 1899 & 47 & 256 & 54 & 117 & 474 \\ 1900 & 12 & 263 & 68 & 39 & 382 \\ 1901 & 11 & 348 & 118 & 22 & 498\end{array}$

Blaahvalen fanges der, som man ser, kun meget faa af trods dens store værdi. Finhvalen er langt talrigere end nogen af de andre, dog synes ogsaa den i de senere aar at have været noget sparsommere, om end ikke sparsommere end i slutten af 80-aarene, skjønt baadenes tal da var paa sit høieste. Knølhvalen har der i de seneste aar været skudt flere af, fordi man har opdaget dens træk langs land tidlig paa aaret $\mathrm{og}$ derfor begyndt fangsten før. De, der særlig har lagt sig efter 


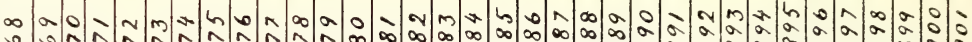

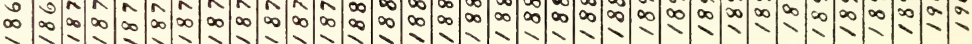

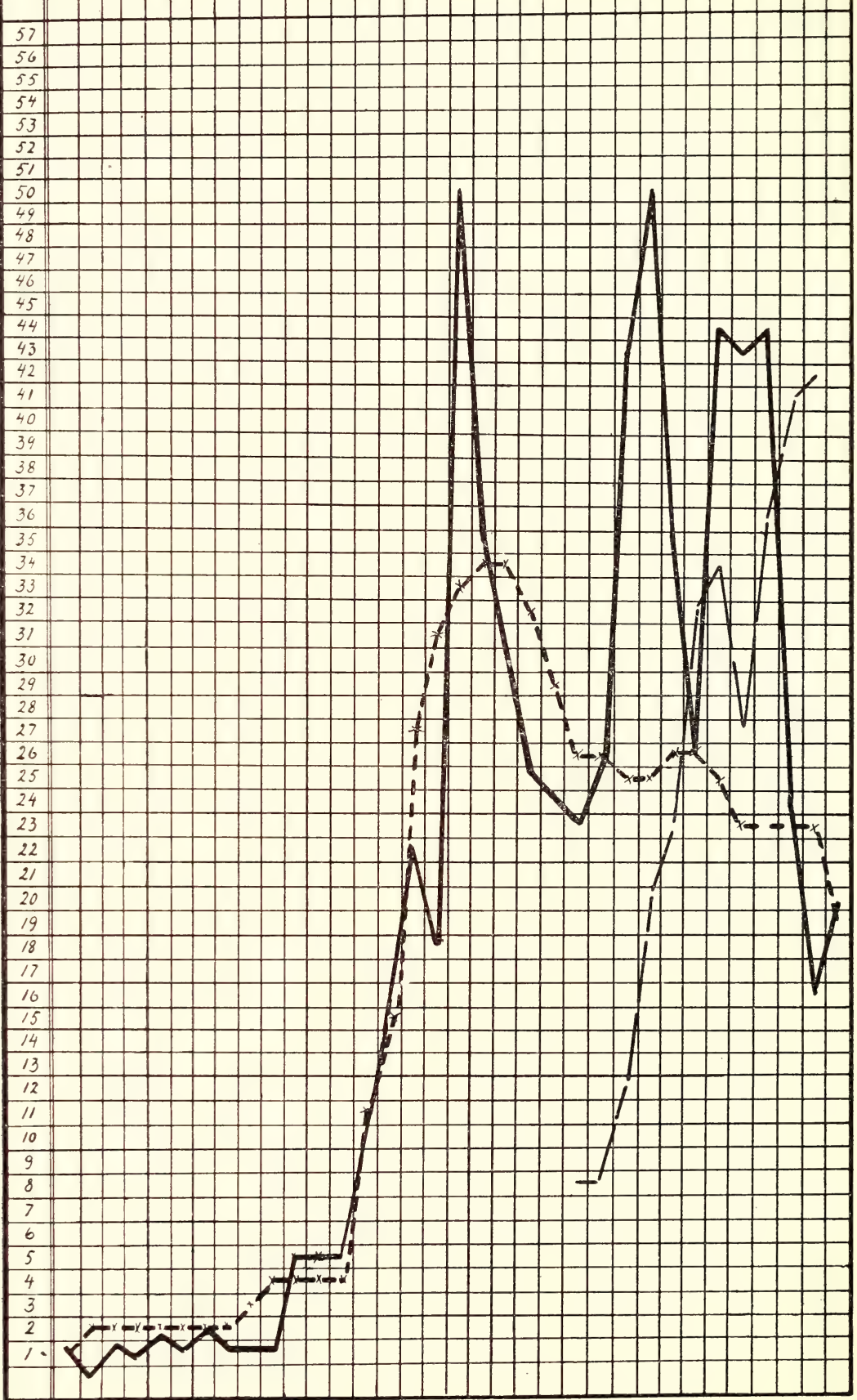

$-\infty$

Fig. 70. Fangst af finhval i aarene 1868-1901. —— Antal hval skudt i Finmarkshavet $1=25$ hval. $\quad x-->$ Antal hvalfangerdampskibe i Finmarken. - - Antal hval skudt fra Island $1=25$ hval. 
denne fangst, har i marts skudt mange. Seihvalens forekomst viser i det hele særdeles store variationer saaledes fra 513 det ene aar til 54 det følgende. Saadanne sprang kan vistnok kun forklares ved variationer i artens vandringer.

Naar vi nu overveier, hvad den foregaaende fremstilling har vist, nemlig at hvalfangeretablissementerne har flyttet sig fra øst mod vest til at omfatte hele Finmarken $o g$ endel af Tromsø, endvidere at fangsten fra oprindelig at omfatte bare blaahval efterhaanden har udviklet sig til ogsaa at omfatte 3 andre arter, $\mathrm{og}$ at den er bleven udstrakt fra aarets første maaneder til september - saa vil vi bedre paany kunne betragte spørgsmaalet om bedriftens nuværende stilling.

Paa figur 70 ser vi fremstillet udviklingen af hvalfangerflaaden (antal baade i de forskjellige aar), udbyttet af fangsten i Finmarken (antal hval pr. aar) og paa Island og Færøerne. At den kurve, som gjengiver antal hval pr. aar, kan der ikke trækkes nogen bestemt slutning om, at der i fremtiden vil fanges mindre hval end før. I de seneste aar, særlig i aaret 1900, har der vistnok været fanget meget faa (ca. 400) mod ca. 1100 i 1896-97, men for disse aar 96 og 97 var der ogsaa aar med lave tal. En stigning i kommende aar kan derfor ikke siges at være udelukket.

Derimod betyder de lave tal i de senere aar iallefald saa meget, at der i denne tid trods, at hvalfangerne nu undersøger hele Finmarkshavet, og trods, at de begynder tidligere paa aaret, har været forholdsvis mindre hval at fange end i tidligere aar, $0 \mathrm{~g}$ særlig er forskjellen paafaldende for blaahvalens vedkommende. At et eneste fartøi skulde kunnet skyde 30 blaahval i de senere aar i Varangerfjorden, som Foxn gjorde det i slutten af 60-aarene, synes ganske utænkelig, naar den hele flaade spredt over hele Finmarken ikke tilsammen har kunnet fange det halve af dette antal af den aller værdifuldeste hvalart.

Det er ikke alene statistiken, som fortæller om det ringe antal hval, som i de senere aar har været at se og fange ud for Finmarkens kyster. Finmarkens befolkning, særlig dens fiskere, hævder paa det bestemteste, at der nu er langt færre hvaler at se imod i tidligere tid. Dette blev saaledes i de sterkeste ord fremholdt paa de møder, som jeg holdt i Finmarken med fiskerne for at høre deres opfatninger af forholdene. Ogsaa blandt hvalfangerne er flere enige heri. Nedgangen i antallet af hvalfangerbaade viser det. $O g$ en mand af den erfaring $0 g$. det klartskuende blik paa forholdene som hvalfanger INGEBRIGTSEN fra Troms $\emptyset$ fremholder det samme. Han har saaledes udtalt sig overfor mig som hævet over tvivl, at der i 1864, da Forn begyndte, var masser af hval i hele Finmarken og havet Bjørnøen-Finmarken. Foyss fangster viser jo dette ogsaa tilstrækkelig for blaahvalens vedkommende. 
Gaar man ud fra denne forudsætning, som vi senere skal behandle nærmere, og spørger vi om aarsagen til dette forhold, saa møder vi to meget forskjellige opfatninger.

Den ene opfatning kommer tilsyne i hvalfangstkommissionens indstilling af $1890 \mathrm{og}$ har ofte senere været oppe. Den fremholder, at det er naturforholdene $\mathrm{i}$ havet, som $\mathrm{i}$ de sidste aar har været saa forskjellige fra de forhold, som fandtes i de gode aar, saaledes at hvalernes livsbetingelser, særlig deres næring, i den sidste tid har været ugunstig, og at de derfor ikke har søgt ind under Finmarkens kyst.

Den anden opfatning derimod mener, at hvalfangsten har formindsket antallet af hval i den grad, at der nu overhovedet ikke findes saa mange hval, at forekomster som i tidligere aar er mulige.

I første kapitel saa vi, at naturforholdene i Finmarkshavet undergaar store vekslinger fra aarstid til aarstid og fra aar til aar. Man erindre kun, hrad der anførtes om de vekslende isgrænser, der antages at fortælle mere om havets vekslinger end mange andre ting. Vi saa ogsaa, at grænserne for udbredelsen af de drivende organismer, af hvilken hvalen lever (se f. eks. Clio borealis, fig. 16), var forskjellige i de forskjellige aar, og det synes mere end rimeligt at antage, at disse forhold har indflydelse paa hvalernes vandringer.

Direkte iagttagelser over variationerne i udbredelsen af de smaa næringsdyr, som blaahvalen og seihvalen lever af, foreligger der, som sagt, meget faa af, derimod ved man mere om vekslingerne for de hvalarters vedkommende, som lever af fisk f. eks. sild. Man ved saaledes, at der i 60-aarene $\mathrm{og}$ begyndelsen af 70-aarene $\mathrm{i}$ det forløbne aarhundrede fandt store sildefiskerier sted udenfor Vesteraalen (det saakaldte storsildfiske), $\mathrm{og}$ at disse fiskerier siden den tid har været helt borte. Hr. fiskeridirektør DAHL har af sine erindringer fra disse gode fiskeaar fortalt mig, at der f. eks. den 2 den december 1866 udfor Langenæs i Vesteraalen var saa mange storhval og springere, at seilleden var aldeles forhindret. Ligeledes beretter hr. DAHL, at i slutten af 40 -aarene brugte nordlændingerne fra Stegen, naar de reiste til sommerfiske i Finmarken, at tage med sig storsildegarn til fangst af sild til agn. Disse garn brugtes ogsaa til fangst af storsild ved at ringe storsildknuder paa aabent hav (aatefiske). For den, der har seet de senere aars mangel paa sild i de nordlige landsdele, viser dette noksom, hvilke store forandringer i sildens optræden der kan finde sted. Nu ser man storsilden kun ud for Romsdal, og der kan man ogsaa ofte se store "hvalgrinder" af finhval. Enhver vil vide, hvor vekslende vaarsildfisket har været og dermed de hvalforekomster, som altid følger med fisket. Paa østlandet opstod der i de gode sildeaar i begyndelsen af 90-aarene ogsaa hvalfangst, som igjen ophørte, da fisket var forbi. Fangsten var finhval, og for denne arts 
vedkommende synes altsaa dens afhængighed af de vekslende sildevandringer til overflødighed fastslaaet.

Af det foregaaende kapitel saa vi endvidere, at hvalerne foretager særdeles store vandringer, at der i Finmarken er fanget hvaler med amerikanske harpuner i sig, og det har i overensstemmelse hermed været anseet for urimeligt at antage, at hvaler, der om sommeren var i Finmarkshavet og om vinteren under Amerikas kyster, som blaahvalen, skulle kunne blive udryddet eller formindsket i antal, al den stund der fandtes mængder af samme art hvaler andetsteds.

Paa den anden side har vi i dette kapitel under vor skildring af hvalfangstens historie seet, hvorledes det gjentagende har hændt, at en opblomstrende hvalfangstbedrift har maattet standse, fordi hvalerne er blevet færre og færre, og at der f. eks. for Spitsbergenfangstens og kaskelotfangstens vedkommende foreligger de sikreste beviser for, at hvallestandens aftagen skyldtes hvalfangsten. Man erindre, hvorledes i begyndelsen af det syttende aarhundrede hvalfangerne fangede grønlandshval i masser i Spitsbergens fjorde, hvorledes de saa maatte søge langs iskanten fra Spitsbergen til Jan Mayen og Island, saa derpaa ind i Davisstrædet, medens der nu næsten ikke kan findes nogen af disse enormt værdifulde dyr. Man erindre fremdeles, at de amerikanske kaskelotfangere har seilet alle verdenshavene rundt for stadig at maatte flytte fra sted til sted, eftersom bestanden aftog.

Naar hvalfangstkommissionen af 1890 siger, at en henvisning til sammenligning med fangsten af grønlandshval i anledning af spørgsmaalet, om hvalbestanden kan aftage, "maa bero paa mindre kjendskab til forholdene", $\mathrm{og}$ at "grunden til den aftagende spekulation $\mathrm{i}$ hvalfangst ligger mindre $i$ en aftagen af hvalen end i de nedadgaaende tranpriser", saa kan jeg iallefald ikke finde nogen tanke i denne udtalelse for grønlandshvalens vedkommende. Thi et dyr, som kan koste op til $47000 \mathrm{kr}$., kunde det vel altid lønne sig at gaa paa jagt efter, om de bare fandtes i slige mængder, at man kunde ha udsigt til at fange et eneste et. Det forekommer mig hævet over tvivl, at disse dyr i en voldsom grad er bleven formindskede i antal, og hvad der synes mest eiendommeligt ved fangstens historie, er den omstændighed, at trods at grønlandshvalen forekommer om sommeren, og kun om sommeren, helt fra Spitsbergen til Grønland, saa blev den først udryddet eller iallefald meget mere sjelden ved Spitsbergen, medens den endnu var i mængde ved Jan Mayen. Det synes af grønlandshvalfangstens historie at fremgaa, at et vandrende dyr har kunnet fordrives fra steder, hvor det kun opholdt sig en del af aaret.

$\mathrm{Og}$ dette er ikke enestaaende forhold inden de erfaringer, man har om de store vandrende pattedyr. 
Hr. hvalfanger INGEBRIGTSEN har meddelt mig følgende erfaringer fra den tid, da han drev hvidfiskefangst paa Spitsbergen.

I 1867 saa han for første gang hvidfisk deroppe, i 1868 blev der dræbt hundreder af hvidfisk med meget daarlige resultater. I 18691878 var der udmerket fangst først langs vestkysten saa i Hinlopenstrædet. I 1877 var Ingebrigtsen alene om hvidfiskefangsten. I aarene 1878-81 fik han store laster ved Amsterdamøen og i Magdalenabay, hror hvidfisken søgte op, naar farvandet udenfor var stængt. Senere igjen godt fiske i Bellsund, hvorfra hvidfisken var forsvunden, men nu var kommen igjen. I 1891 antager INGEBRIGTSEN, at der var 4-500 stykker igjen, og at der nu er yderst faa tilbage. Ingebrigtsen har den opfatning, at hvalerne om vinteren vandrer til Nordamerika, saaledes fandtes kugler af fremmed kaliber i dem, og at hvalerne, naar de kom tilbage til Spitsbergen om sommeren, opsøgte ganske de samme bugter og pladser, som de havde været paa aaret forud. Naar man derfor et aar paa en plads udryddede alle unger og voksne, kom der næste aar ingen igjen.

Medens Spitsbergens hvidfiskbestand nu er yderst liden, er der masser nord om Sibirien, og det skjønt ogsaa disse vandrer særdeles langt udenfor Sibiriens ja Osthavets farvand om vinteren. De vender dog tilbage til Sibirien næste sommer og ikke til Spitzbergen.

Det samme antager Hr. Ingebrigtsen ogsaa er tilfældet med blaahralen, der fandtes i mængde i Finmarkshavet i 60-aarene, og efterhaanden er forstundet, eftersom hvalfangsten har udviklet sig.

Eschricht siger om grønlandshvalens forsvinden, at den „maa vel altsaa snarere forklares omtrent paa samme maade som den forandring, der er foregaaet i spermhvalernes (kaskelottens) udbredelse. Det er bekjendt, at ikke alene blandt standdyrene, men ogsaa blandt trækdyrene, hvert individ med sit afkom eller sin familie holder sig til et vist indskrænket strøg af den hele region, hvori arten er udbredt. At dette ogsaa gjæider for hvalerne overhovedet, læser man blandt andet af et eksempel, som er fortalt i Sibbalds phalænologia nova (pag. 83). En "rørhval" (finhval), som fangedes i en bugt af Skotland, havde i 20 aar været kjendt af fiskerne paa et hul i rygfinnen og deraf faaet navnet "Hollie-Pyke". - Rethvalens forsvinden ved Spitsbergen og St. Lorenzbugten kan saaledes vel forklares ene $0 \mathrm{~g}$ alene derved, at fortrinsvis de individer er udryddede, der paa en vis tid af aaret søgte tilflugt til dette sted."

Ogsaa kaskelotfangerne fortæller om enkelte gamle kaskelotter, som de "personlig" kjendte godt og gjentagne gange forgjæves forsøgte at faa livet af. 
Vi ser saaledes, at begge disse to forklaringer for variationerne i hvalernes forekomst indeholder store sandhedsmomenter. Man har baade erfaringer for vekslinger i næringsdyrenes udbredelse, hvilken igjen er afhængig af havstrømmene, og for at hvalfangsten formaar at bestemme antallet af en arts optræden udenfor en bestemt kyst. Hvor der indtræder bestemte forandringer af lang varighed, vil der i mange tilfælde ikke være nogensomhelst tvivl om, hvilken af de to maader at forklare forandringen paa der er den rigtige. Saaledes er der ingen tvivl om, at finhvalen forsvandt fra Langenæs, fordi silden blev borte og paa den anden side, at grønlandshvalen forsvandt fra Spitsbergen paa grund af hvalfangsten.

Hvad er nu tilfældet i Finmarken? Enhver, som uhildet stiller sig overfor dette spørgsmaal, vil forstaa vanskelighederne ved dets besvarelse. For det første blev der i de gode hvalaar ikke gjort saadanne undersøgelser af havet, at man har noget at sammenligne med forholdene nu. Den eneste vei til med sikre haandgribelige kjendsgjerninger her at konstatere havets indflydelse kan derfor kun være den at studere forholdene fremover i tiden og se, hvorledes det arter sig med naturforholdene $i$ havet paa den ene side $o g$ hvalforekomsten paa den anden side. Men det ligger i sagens natur, at et saadant program maatte tage tid, iallefald en række aar. Under alle omstændigheder er det ønskeligt for vor videns skyld, at dette blir gjort.

Til forsigtighed i bedømmelsen af disse spørgsmaal maner ogsaa den kjendsgjerning, at statistiken allerede tidligere viser en nedgang med paafølgende stigning.

Der kan for tiden derfor kun udtales en skjønsmæssig dom over disse ting.

Denne dom vil ogsaa maatte baseres paa den opfatning, man kan danne sig af størrelsen af Nordhavets hvalbestand i det hele, idet det jo har vist sig af den vekslende forekomst af hval i Finmarkshavet i de forskjellige aar, at der maa finde et tilsig af hval sted.

Hvalkommissionen af 1890 udtalte sig meget forhaabningsfuldt om størrelsen af Nordhavets hvalbestand saaledes: „Hvis alle Ishavets hvale skulde gjøre sig om end en kort tur ind i Finmarkens fjorde, er man bange for, at disse vilde blive ufremkommelige for andre skabninger. Man maa tvertimod antage, at det kun er en liden brøkdel, der kommer ind under land. Massen holder sig ude i det vide hav." Hvor mange er der nu ude i det, „vide hav"?

Intet har forbauset mig mere paa de talrige Nordhavstogter, vi har foretaget i de to forløbne aar, end det, at vi saa yderst sjelden saa hval. Hermed stemmer ogsaa alle de fangstmænds journaler, som er sendt mig, 
og som efter min anmodning velvillig har holdt regnskab over, hiver gang hval blev seet.

Den samme erfaring udtaler fyrsten af Monaco saaledes i et foredrag holdt paa geografkongressen i Berlin 1899: „Man tror almindelig at man, for at se hvaler, skal reise til de arktiske have. Indtil de sidste tider seilede hralfangerne til Grønlands og Spitsbergens kyster. Paa to togter i disse egne har jeg ikke seet en eneste hval, mens jeg hjemme i Monaco fra mit vindue ofte ser dem. For at finde hval $o g$ finde dem i stort antal maa man reise til Middelhavet. Paa en dag har jeg her skudt 3 forskjellige arter og forfulgt en fjerde, en finhvalart."

Seiler man over Nordhavet, vil man i den del af Nordhavet, som indtages af den varme Atlanterhavsstrøm, saagodtsom aldrig se en eneste hval. Det er dels i kysthavet, dels i et bælte langs iskanten, hvor hvalerne frodes. Med kysthav menes havet over kystbankerne, saaledes ogsaa Osthavet.) Paa disse steder kan man vistnok særlig paa visse bestemte felter se betydelige mængder saaledes f. eks. udfor Søndmørsbankerne, Bottlenosefeltet, langs iskanten fra Island til Jan Mayen, dels oppe i Østhavet, og den hurtig opblomstrende Islands-hvalfangst viser jo ogsaa, at der findes steder, hvor der endnu i de allersidste aar har været mange dyr at se. I mai-juni har der efter de erholdte observationer været iagttaget mange hval paa feltet $0^{0}-10^{0}$ ost og $71^{0}-73^{0}$ nord, endridere ca. 20 mil so. af Jan Mayen, 30 mil no. af Kap Langenæs (Jsland), desuden i Osthavet langt oppe i isen (se kartet figur 24.)

Af disse forekomster vil man se, at fangststederne (Færøerne, Island, Finmarken) kun er forholdsvis mindre dele af de havstrækninger, hvor hvalerne frerdes, men da hvalerne jo vandrer netop forbi disse fangstfelter, er de ristnok udsat for en skarp jagt. Hvalfangstkommissionen af 1890 regnede ud, at der til 1890 ialt var dræbt 7000 dyr, et tal, som fremkom ved til antallet af de fangede dyr at lægge $10 \%$ for de antagelig tilskadeskudte dyr. Gjør man det samme for hele fangstperioden fra 60-aarene til 1901, saa faar man det resultat, at der nu i det hele er dræbt ca. 27000 hval i disse aar.

Sammenligner man dette med de fangster af grønlandshval, som i tidernes løb er gjort, vil man erindre, at der fra Holland alene i aarene 1669-1778 blev skudt 57590 hval (grønlandshval og nordkaper). Hvorvidt der nu fra en sammenligning mellem grønlandshvalfangsten og finhvalfangsten kan trækkes direkte slutninger over finhvalbestandens stilling i øieblikket $0 \mathrm{~g}$ dens fremtid, formaar vistnok intet menneske at afgjøre.

Tager man imidlertid alle de $\mathrm{i}$ dette og det foregaaende kapitel nævnte erfaringer og kjendsgjerninger under samlet overveielse, saa er det indtryk, alle disse har gjort paa mig følgende: 
Det synes mig klart, at hvalbestanden i havet rundt det nordligste Norge er merkbart paavirket af hvalfangsten, særlig for de to arter blaahvalens og finhvalens vedkommende, endvidere tror jeg, at de forestillinger om hvalernes overordentlige talrighed, som man har havt, er meget overdrevne. Paa den anden side anser jeg det ogsaa for overdrivelse at paastaa, at bestanden holder paa at forsvinde, og mener jeg, at en ødelæggelse, der kan sammenlignes med den, som grønlandshval og nordkaper har været udsat for, endnu ikke har fundet sted eller kan være nær forestaaende. Derimod er det min tro, at en fortsat fangst som hidtil aar for aar vil formindske bestanden, idet denne ikke vil kunne formere sig saa raskt, at balancen i individantallet vedligeholdes. Hvor raskt denne formindskelse vil finde sted, kan for tiden ingen med sikkerhed angive. Jeg for min del tror, at formindskelsen mere og mere vil merkes, men at den foreløbig ikke truer bestanden med nogen krise i adskillige aar fremover. 


\section{Sjette kapitel. \\ Striden mellem fiskeri og hvalfangst.}

Oversigt orer striclens

historie.

I den tidligere ofte omtalte indstilling angaaende hvalfangsten i Finmarkens og Tromsø amter giver kommissionen af 1890 en udførlig historisk fremstilling af striden mellem fiskeri $\mathrm{og}$ hvalfangst. Af denne fremstilling fremgaar det, at „Finmarkens indvaanere lige fra begyndelsen af ikke synes at have havt noget godt øie til hvalfangsten; thi allerede i 1873, før loddefisket endnu var begyndt, omhandlede amtmanden for departementet, at den sterke aftagen af fisket i Varangerfjorden ...... tilskreves af fiskerne hvalfangsten."

Som man af femte kapitel vil have seet, bestod hvalfangsten i begyndelsen af 70-aarene udelukkende af blaahvalfangst, i 1872 blev der skudt 40, i 187336 stykker. Og fangsten dreves kun i Varangerfjorden fra Foyns etablissement red Vadsø. Professor G. O. Sars, som i $1874^{1}$ ) undersøgte fangsten, udtaler om denne følgende: „Den hvalart, som Foyn saagodtsom udelukkende fanger, den saakaldte blaahval, har efter al rimelighed intetsomhelst at bestille med lodden. Dens føde bestaar efter gjentagne af mig anstillede undersøgelser af mavens indhold næsten udelukkende af en liden gjennemsigtig ræke (Thysanopoda inermis) eller som den heroppe kaldes „kril"." SARs paaviste, at der var andre hvalarter, som fulgte lodden og optraadte under loddefisket for "ved loddefiskets slut at forlade kysten $0 \mathrm{~g}$ at følge lodden tilhavs, hvorimod blaahvalen først efter loddefisket begynder at indfinde sig i nogen mængde under kysten for at fraadse i de umaadelige masser af "kril“, som af strømmen paa denne tid bliver sat op under land navnlig i Varangerfjorden. Selv de, der endnu fremdeles holder paa den gamle forestilling, at det er hvalen, der jager lodden ind mod kysten, vilde saaledes ikke kunne have nogensomhelst rimelig grund til urolighed, da

1) Indberetning til indredepartementet for aaret 1874 . 
Foyns hvalfangst ikke gjælder loddehvalen, men hovedsagelig en fra denne forskjellig art, der først paa en senere tid besøger vor kyst."

Allerede faa aar efter denne SARs' erklæring forandrede imidlertid hvalfangsten karakter, i 1877 fangedes 28 blaahval og 8 finhval

$$
\begin{array}{lllllll}
\text { i } 1878 & - & 76 & - & - & 40 & \text { - } \\
\text { i } 1879 & - & 90 & - & - & 40 & \text { - }
\end{array}
$$

Der kom nu ogsaa flere selskaber, og der indkom da talrige andragender fra de herreder, inden hvilke fangsten dreves, om at undersøgelser maatte anstilles under loddefisket, ligesaa diskutteredes lovforslag om fredning fra 1ste januar til 1ste juni. Dette forslag begrundedes (ifølge kommissionens meddelelse) deri, at hvalen jager lodden tillands, og rammedes forsaavidt ikke af SARS' ovenfor anførte erklæring, som denne jo der kun udtalte sig om blaahvalen, der, som vi saa i femte kapitel, først indfinder sig efter 1 ste juni.

I aaaret 1879 udførte da $\mathrm{SARS}^{1}$ ) en række nye undersøgelser nu i loddefisketiden. Som ved alie de anledninger, ved hvilke Sars har udført undersøgelser, indvandtes ogsaa nu nye og værdifulde erfaringèr. Medens de forskjellige finhvaler, som optræder i Finmarkshavet, tidligere kun var lidet kjendt, gav $\mathrm{SARS}_{\mathrm{RS}}$ en række udmerkede beskrivelser og afbildninger af dem, han paaviste endvidere, at det udelukkende var de to hvaler, finhvalen og vaagehvalen, som ernærede sig af og fulgte lodden, medens blaahvalen, seihvalen og knølhvalen var henviste til at leve af de smaa krebsdyr.

Heller ikke de to første hvaler antog han at spille nogen rolle for loddens indsig. Han paaviste, at denne gjød sin rogn paa Finmarkens flade havbugters sandbund. Han udtaler herom: "Man har nemlig ingensomhelst sikre data for, at loddestimernes sig i nogen væsentlig grad influeres af de bagefter følgende hvaler ligesaalidt som af torskemasserne eller fuglesværmene. Derimod har man al grund til at antage, at hvad der væsentlig bestemmer loddens sig, naar den er under land, er rent fysisk-meterologiske forholde." Ligesaa anfører han: „Der har været aar, da stort brug har været seet i havet, uden at lodden er kommet op paa de sedvanlige gydepladse, og omvendt, man har ikke faa eksempler (f. eks. fra Varangerfjorden) paa, at lodden er gaaet klos op i land, uden at en eneste hval har været at se udenfor."

I saadanne indvendinger, som den, at affaldet fra fabrikikerne skulde forpeste havbunden etc., fandt SARs heller ingen realitet. Derimod fremholdt han det ønskelige $i$, at der af hensyn til liv og redskaber paa fiskehavet gaves bestemmelse om en "grænse fra land, indenfor hvilken hval ikke maatte anskydes under fisketiden".

1) Indberetning til indredepartementet for 1879 . 
I overensstemmelse hermed $0 \mathrm{~g}$ en af andre videnskabsmænd indhentet erklæring foreslog regjeringen 1880 en fredningstid inden milegrænsen fra 1 ste januar til 31 te mai. Dette vedtoges af stortinget samme aar (lov af 19de juni 1880).

I 80-aarene udviklede hvalfangsten sig med sterke skridt, den udbredte sig over hele Finmarkshavet, og skibenes antal voksede særdeles raskt (se femte kapitel). Befolkningens forbitrelse mod hvalfangsten voksede stadig, man samledes efter talrige diskussionsmøder, resolutioner $o g$ omvandrende cirkulærer dels om det forslag at faa al hvalfangst $0 \mathrm{~g}$ al tilgodegjørelse af hval ved fast etablissement forbudt i aarets første fem maaneder, dels om absolut forbud aaret rundt af alslags hvalfangst baade indenfor og udenfor territorialgrændsen. For stortinget fremsattes ogsaa en hel række saadanne privatforslag, der med mere eller mindre styrke udtrykte de ovenfor nævnte synspunkter. (Se herom hvalfangstkommissionens udførlige fremstilling.) Af disse skal jeg alene anføre en i 1888 af en flerhed af Finmarkens amts ordførere (12 i antal) undertegnet erklæring, og den lyder saaledes ${ }^{1}$ ):

.Som bekjendt er det en enstemmig formening hos Finmarkens fiskende befolkning, at aarsagen til de aar efter aar stedse aftagende fiskerier alene maa tilskrives hvalfangsten, hvorved hvalen fordrives fra fjorde $0 \mathrm{~g}$ kyster.

Det er ganske vist saa, at loddefisket er periodisk, at der saaledes har været tider, hvor intet loddefiske har foregaaet; men aarsagen hertil har været loddens udebliven eller ophør med at søge sine gydepladse i rore fjorde og red vore kyster.

Hvad aarsagen hertil har været, er ikke kjendt af nogen. Men saaledes er ikke forholdet nu. Lodden har hvert aar i større masser søgt sine vanlige gydepladse, men fisken er udebleven, har kun været at finde 2 à 3 mil til havs, der hvor hvalen har gaaet, hvorfor det i regelen kun har været de store baade, der har kunnet gjøre noget nævneværdigt fiske. Det er saaledes en kjendsgjerning, at, eftersom hvalerne aar efter aar har trukket sig længere og længere tilhavs, har fisken fulgt med, medens lodden som sedvanligt søger tillands. Som eksempel kan anføres, at under flere paa hinanden følgende stormdage hindredes hvalfangerne omkring Vardø for at gjøre jagt, og i disse dage søgte en mængde hval tillands og med dem fisken, saa at baadene gjorde rig fangst; men ved hvalfangernes ankomst til fiskepladsene igjen efter indtraadt roligere veir forsvandt atter hval og fisk og søgte tilhavs igjen. Hvad aarsagen kan være til disse foreteelser, er det selvfølgeligt umuligt at paavise, men fiskerne slutter deraf, at fisken muligens

1) Kommissionens indstilling. Separataftryk pag. $28 \mathrm{ff}$. 
instinktsmæssig følger hvalen for at finde føde, da den ellers af sig selv maatte finde de under land staaende loddestimer. Skulde dette muligens forholde sig saaledes, hvilket ligesaalidt kan modbevises som bevises, vil resultatet blive, at med hvalens fuldstændige fordrivelse følger Finmarksfiskets ophør. Men under enhver omstrendighed er det nu en uimodsigelig kjendsgjerning, at under de heldige og store fiskerier har altid hvalen været en medarbeider.

Skulde det imidlertid vise sig, at hvalens fordrivelse fra vore kyster virkelig skulde have en ødelæggende virkning paa de store fiskerier og derved lægge en hel landsdel øde for en uberegnelig fremtid, noget ingen videnskab hverken kan bekræfte eller benegte, - maa det formentlig indrømmes - at det er et altfor voveligt forsøg, der anstilles ved fremdeles at tilstede hvalfangsten i dens nuværende udstrækning."

Jeg har citeret denne forestilling saa udførligt, da den synes mig at være den bedste fremstilling af de anskuelser, som i slutten af 80aarene samlede befolkningens meninger om sig. Som udtryk for disse meninger forelaa der da i slutten af 80-aarene en mængde udtalelser og forslag fra Troms $\emptyset \mathrm{g}$ Finmarkens amter $\mathrm{og}$ det dels fra herredsstyrelser og kommunebestyrelser, dels fra fiskeriforeninger, dels fra fogder og amtmænd, alle udtalte sig for fredning, dels totalfredning for hele aaret, dels til 1ste juli, dels til 15de juni, dels til 1ste juni. Amtmanden „udtalte sig for totalfredning til 15de juni saavel i Finmarkens som i Tromsø amt, dog kun forsaavidt et lignende forbud vedtoges af Rusland. Indtil dette sker er han af den formening, at lov af 19 de juni 1880 bør fremdeles gjøres gjældende."

Professor SARs foretog paany i 1889 undersøgelser i Finmarken. Han udtaler i sin beretning herom til indredepartementet: „Siden“ de forrige undersøgelser „er nu hengaaet en række af aar, hvori hvalfangsten alt mere og mere har udviklet sig, saa at der nu findes, istedetfor et par, over et dusin forskjellige etablissementer, fordelte over hele Finmarkens kyst, fra Skaarøen nordenom Tromsø til den russiske grænse. Ligeledes er man nu begyndt ogsaa at fange, anden' slags hval end blaahvalen, ja $\mathrm{i}$ de senere aar har antallet af finhval (den egentlige loddehval) og seihval været det langt overveiende. I samme forhold, som hvalfangsten har udviklet sig, er ogsaa klagerne fra fiskerne blevne mere høilydte, og man har i de senere aars mindre heldige loddefiskerier troet at se et sikkert forbud paa, at dette fisker;, paa grund af hvalfangsten, tilsidst ganske og aldeles vil ophøre. Den herskende misnøie mod denne bedrift har faaet sit udtryk ved et paa sidste thing af hr. stortingsmand AкRE fremsat forslag, gaaende ud paa absolut fredning af hval ved Finmarkens kyst for et tidsrum af 10 aar." 
SARS gjennemgaar dernæst kritisk samtlige de fremførte paastande om hvalens betydning for fiskerierne og kommer paany til samme resultat som ved sine tidligere undersøgelser. Han udtaler sin opfatning saaledes, at den rolle, hvalerne spiller under loddefisket, efter hans mening er "af en ganske underordnet betydning“", da, „det som bekjendt ikke saa sjelden har hændt, at der har foregaaet et meget godt loddefiske, uden at hvalen har været at se, og omvendt, at loddefisket kan mislykkes, trods det at hvalen er tilstede i mængde." Dog gjør han opmerksom paa, at han aldrig har benægtet, "at hvalerne i enkelte tilfælde kan bidrage til at trykke en loddestim op paa en grund bugt, hvor den vil kunne stænges med en dragnot; men at det vistnok ligesaa ofte hænder, at de virker netop omvendt til at hindre loddens opsig; noget, hvorpaa der ingenlunde mangler eksempler." Efter at have gjennemgaaet samtlige fiskeres klager udtaler han endvidere: „Skjønt jeg, som det vil sees, ....... ikke kan finde, at de fremførte paastande om hvalfangstens skadelige indflydelse paa fiskerierne er begrundede, er jeg dog forsaavidt enig med fiskerne, som jeg anser det for at være paa høie tider, at der sørges for at faa hvalfangsten indskrænket inden nogenlunde rimelige grænser. Saaledes som denne bedrift nu for tiden har udviklet sig ved Finmarken, kan der være liden tvivl om, at hvalerne inden ikke ret lang tid vil blive udryddede eller fordrevne fra vor kyst, og saaledes udsigten til endyderligere at udnytte denne rigdomskilde blive forment efterslegten. At allerede blaahvalen er aftaget $\mathrm{i}$ antal, synes temmelig sikkert, trods hvalfangernes protest herimod, og ligesaa sikkert er det, at man om sommeren i tidligere aar kunde se langt flere hvaler i den sedvanlige dampskibsrute end nu for tiden. Tillige synes hvalerne nu ialmindelighed at være blevne betydelig skyere end tidligere." - „Dette hensyn til hvalfangstens bevarelse for efterslegten har for mig altid staaet som det væsentligste moment, naar der er tale om indskrænkning i hvalbedriften." "Ved siden heraf har jeg ogsaa .... fremhævet et andet hensyn, som jeg ligeledes maa fastholde, nemlig den mulige collision mellem hvalfangerne og fiskerne under begges bedrift."

Af hensyn til disse synspunkter mener SARs at maatte tage afstand fra forslaget om total fredning, hvorimod han synes at nære sympathi for en fredning til 1ste juni.

I anledning af de fra fiskernes side fremholdte anskuelser indgav hvalfangerne i 1888 følgende andragende: „I forvisning om, at en upartisk og indsigtsfuld undersøgelse og bedømmelse af de herhen hørende forholde vil lede til hvalfangstens frigivelse, andrager forsamlingen om, at der maa blive nedsat en kongelig kommission af dertil skikkede mænd med det opdrag i fangsttiden at gjøre sig bekjendt med forholdene i distrikterne for derefter at overveie og afgive indstilling i sagen." 
I henhold til herom fremsat forslag fra indredepartementet bevilgedes beløb til nedsættelse af en kommission (af 30te januar 1890), til hvis formand udnævntes kaptein i marinen Niels Juel. Denne kommission afgav 7 de august samme aar sin indstilling til ny lov.

Kommissionen har fortjenesten af at have tilveiebragt et særdeles stort materiale væsentlig af historisk og statistisk art, ligesom den ogsaa indhentede en mængde udtalelser fra forskjelligt hold.

Om grundlaget for dens egne overveielser udtaler kommissionen: „Som seet findes der i de officielle dokumenter, som omfatter fiskernes klager over hvalfangstens skadelighed, saagodtsom ingen paa bestemte fakta bygget argumentation." "Noget bevis for paastandenes rigtighed føres kun undtagelsesvis, medens der forlanges, at hvalfangerne skal levere fyldestgjørende saadant for deres bedrifts uskadelighed."

„Man har derfor for en større del været henvist til avisartikler, referater, samtaler, egen erfaring og de optagne forklaringer samt til professor SARs's erklæringer og indberetninger, til hvalfangernes imødegaaelser, og delvis til de fremsatte lovforslag for at kunne give en nogenlunde fyldig fremstilling og grundene til disse, de være virkelige eller indbidte."

Kommissionen uddeler nu fiskernes „klagemaal“ i en lang række forskjellige grupper og diskutterer dernæst punktvis hver enkelt. Disse er af meget forskjellig art. Først drøftes politisk-nationaløkonomiske spørgsmaal som „bygdeinteresser", „skattespørgsmaal“, konkurancen mellem fiskernes og hvalfangernes tranprodukter, hvalfangstspørgsmaalets anvendelse i den politiske konkurrances tjeneste.

Saa gjennemgaaes selve loddefisket i historisk-statistisk henseende.

Dernæst drøftes de naturhistoriske spørgsmaal som hvalens forhold til loddens og torskens indsig, fangstens indflydelse paa hvalbestanden, hvalaffaldets skadelighed for dyrelivet og fiskebestanden langs land.

Og tilslut betragtes betydningen af mulige kollissioner og sammenstød mellem de to bedrifters fartøier (spørgsmaal, der nærmest henhører under fiskeriopsynets administrationssfare.)

For samtlige punkters vedkommende finder kommissionen de mod hvalfangsten fremførte paastande uberettigede. Den anfører som hovedresultat af sine overveielser:

"I henhold til hvad der er anført i det foregaaende, er kommissionens samtlige medlemmer fuldt enige i de der anførte præmisser samt $i$, at der i anledning af hvalfangsten i Troms $\varnothing$ og Finmarkens amter ikke paakræves andre lovbud end politibestemmelser." Altsaa ingensomhelst fredning ansees nødvendig og dette motiveres paa den ene side 
med, at hvalen ikke er af nogen betydning for fiskerierne, paa den anden side med, at hvalbestanden er saa overordentlig stor i Nordhavet, at den heller ikke behøver at fredes ,for sin egen skyld“ (sammenlign prof. SARs's ovenfor citerede udtalelser om denne side af sagen).

I overensstemmelse med dette standpunkt foreslog kommissionen kun indført politibestemmelser. Majoriteten enedes om kun at foreslaa følgende :

"Hval maa ikke anskydes nærmere enkelt baad eller fartøi eller samling af baade og fartøier paa $4 \mathrm{og}$ under end 1/a kilometer og ikke nærmere end 1 kilometer, hvis antallet er storre. Denne bestemmelse gjælder saa langt tilhavs, som fiske drives fra land" etc.

Minoriteten derimod sluttede sig til det af loven af 1880 indtagne standpunkt og foreslog i henhold hertil:

„Det skal. være forbudt at dræbe eller jage hval i Finmarkens og Tromsø amter i tiden fra 1ste januar til 31 te mai i en afstand fra kysten af indtil 1 geografisk mil at regne fra nærmeste land, o eller holme, som ikke overskylles af havet, hvilken regel ogsaa gjæelder fjorde, bugter og indløb indtil 1 geogr. mil udenfor det sted, hvor farrandets bredde indsnrerres til 21/o mil eller under" etc.

Nugjældende Disse forslag gav anledning til megen diskussion og mange overbestemmel- veielser, og i 1896 vedtoges en ny lov (af 6te juni 1896), hvis væsentser.

lige bestemmelser - af interesse for de her omtalte spørgsmaal — er folgende :

.. 1. Det skal være forbudt paa den havstrækning ved kysterne af Finmarkens og. Tromsø amter, som kongen bestemmer, at jage, anskyde eller dræbe hval i tidsrummet fra lste januar til udgangen af mai.

\$2. Ligeledes skal det være forbudt under de større sildefiskerier paa strækninger og i tidsrum, der af kongen bestemmes, at jage, anskyde eller dræbe hval.

\$3. Paa fjord eller vaag, hvor sildefiske foregaar, skal det ogsaa udenfor de red $\$ \$ 1$ og 2 fredede strækninger og tidsrum være forbudt at jage, anskyde eller drebe hval.

\$ 4. Hval maa ikke jages, anskydes eller dræbes nærmere baad eller fartøi, der er forandret eller optaget med fiske, end 2 kilometer og ellers ikke nærmere baad eller fartøi end 1 kilometer.

§ 5. De i foranstaaende paragrafer omhandlede forbud mod hvalfangst, omfatter ikke den jagt, som drives efter mindre tandhval, eller som foregaar i forbindelse med afstængning.

$\S 6$. Det er forbudt at bruge jagtmaader, hvorved det kun afhænger af tilfældet, om hvalen bliver gjenfunden".

I overensstemmelse med denne lov er da plakat (af $17 \mathrm{de}$ dec.) indeholdende bestemmelser om fredning af hval ved kysten af Tromsø og Finmarkens kyster, der bestemmer følgende:

„Paa havstrækningen ved Trømsø amts og Finmarkens amts kyst i en afstand af indtil 1 geografisk mil fra kysten, regnet fra den yderste ø eller holme, som ikke overskylles af havet, skal det indtil videre være forbudt at jage, anskyde eller dræbe hval i tidsrummet fra 1ste januar til udgangen af mai.

For Varangerfjordens vedkommende i Finmarkens amt bliver græusen for den fredede strækning udad mod havet en ret linie trukket fra Kibergnæs til Grændse- 
Jakobselv, dog saaledes, at det ogsaa udenfor denne linie skal være forbudt $\mathrm{i}$ den ovenanførte tid at jage, anskyde eller dræbe hval i kortere afstand fra kysten ved Kíibergnæs end én geografisk mil.

Plakat indeholdende bestemmelser om fredning af hval ved Finmarkens kyst af 5te januar 1881 ophæves."

Dette er, hvad der nu er gjældende bestemmelser i Finmarkens og Tromsø amter.

Om stemningen overfor hvalfangsten i 90-aarene udtaler hr. Fortsatstrid. fiskeriinspektør Sørensen følgende ${ }^{1}$ ): „Da der i 1892, 93-94 og 96 indtraf gode Ioddefiskerier i Finmarken, hørtes i denne tid ikke synderlig klage over hvalfangsten; men da fiskerierne ifjor" (1897) „og" iaar atter har været mindre gode, er atter krav fremkommet fra en stor del af befolkningen om, at hvalfangsten skal aldeles forbydes. Den paastand, at hvalen jager lodden tillands, høres nu ikke mere, men man begrunder sine klager over hvalfangsten i følgende:

1. Hvalernes forsvinden fra kysten, der gjør, at den nødvendige "røre“ ikke kommer i sjøen under dybsagnsfisket om vaaren.

2. Skud fra hvalfangerdampskibene skræmmer fisken fra land.

3. Blod fra anskudt hval forpester sjøen, saa fisken skyr.

4. Sælen „(kobben)“ kommer i større antal, fordi der er mindre hval under land.

5. Og som følge af alt dette stadigt aftagende loddefiske."

I aaret 1898 indkom der flere klager til indredepartementet ${ }^{2}$ ) og fol stortinget i 1899 forelaa der to forslag til ny lov om hvalfangst. Det ene foreslaar forbud mod fangst og tilgodegjørelse (almindelig kaldet "total fredning“) fra 1 ste januar til 15 de juni (subsidiært: til udgangen af mai). Forbudet tænkes altsaa udstrakt til at omfatte hvalfangst ogsaa udenfor territorialgrænsen samt tilgodegjørelse af hval iland. Det andet forslag kræver saadan "total fredning " for hele aaret i et tidsrum af 20 aar fra lovens ikraftræden.

Det første forslag forslagsstillere finder, at en saadan absolut fredning aaret rundt vil være en ubillighed mod de heri interesserede, al den stund det ikke er tilstrækkelig bevist, at det er hvalfangsten, som udelukkende bærer skylden for loddefiskets aftagen.

Disse forslag blev af stortinget oversendt regjeringen. Indredepartementet udtalte dernæst i skrivelse af 17 de juni 1899 til forfatteren; „Den i 1896 emanerede lov om hvalfangst har ikke formaaet at dæmpe striden mellem de forskjellige synsmaader, der gjøres gjældende af fiskeDe udførte undersøgelsers forudribefolkningen paa den ene side og af videnskabsmændene paa den anden.

1) Hvalfangstens indflydelse paa de andre fiskerier. Foredrag holdt paa den internationale fiskerikongres i Bergen 1898.

2) Se herom ot. med. hr. 1 (1899-1900). 
Departementet antager, at der ikke paa grund af de nu fremkomne fordringer fra fiskernes side bør træffes nogen forandring i hvalloven, forinden spørgsmaalet om hvalens betydning for loddefisket er nærmere undersøgt gjennem praktisk-videnskabelige undersøgelser."

Der udtaltes videre, at departementet ansaa tidspunktet til saadanne undersøgelser at være inde, da der var bevilget et dampskib til undersøgelserne.

I anledning af departementets skrivelse udtalte jeg, at den af departementet stillede opgave bedst burde optages paa den maade, at 1 à 2 aar anvendtes til at give en oversigt over „hvorledes der ad videnskabelig vei bør arbeides med dette $0 g$ andre spørgsmaal og om udsigten til, hvad videnskabeligt arbeide her kan udrette".

I henhold hertil erholdt jeg min ordre til ,med al mulig hurtighed og kraft" at søge dette mit maal fremmet, og jeg har da, saalangt de givne bevilgninger dertil aabnede anledning søgt at skaffe mig den oversigt over spørgsmaalet, som jeg ansaa for at være det første, der fra min side burde gjøres, naar der stilledes mig en saadan opgave. Til opnaaelse heraf har "Michael Sars" i aarene 1900 og 1901 udførte de talrige togter, hvis resultater i de foregaaende kapitler er meddelt. I det følgende skal jeg give en fremstilling af min opfatning af de gamle stridsspørgsmaal mellem fiskeri $o g$ hvalfangst i lys af de erfaringer, jeg har kunnet erhverve mig, og herunder skal jeg i overensstemmelse med min orenfor citerede udtalelse til departementet lægge hovedvægten paa, hvad der efter min formening fra statens $0 \mathrm{~g}$ fra befolkningens side bør udføres af arbeide i denne sag. Thi nu som tidligere staar det for mig saa, at man allerede paa forhaand vil kunne gaa ud fra, at en saa gammel og saa dybt ind i hele befolkningens interesser $0 g$ tænkning gribende bevægelser aldrig vil kunne løses uden ved udførelse af det fremskridt, der kan hidføre større tilfredshed og lykkeligere arbeidsforhold. Paa forhaand vil man kunne sige sig selv, at et noksaa lykkelig formet lovforslag - om det end maatte indeholde en aldrig saa retfærdig og klartskuende domsafsigelse $\mathrm{i}$ en bitter strid - dog ikke vil være et tryllemiddel til at læge et onde, der giver sig saa langvarige $0 g$ sterke udtryk som det, der har fremkaldt bevægelsen i den nordligste del af landet.

Diskussion af stridssporgsmaalene.
Ser man tilbage paa den lange strid mellem fiskeri og hvalfangst, vil det være paafaldende, hvormange de spørgsmaal er, som almenheden har beskjæftiget sig med. Hvallovkommissionen behandler ikke mindre end 17 forskellige spørgsmaal. Der har saaledes i høi grad været ført en "spredt fægtning", der af og til har faaet karakteren af procedure. Herunder maa en hel række spørgsmaal siges at være uddeba- 
terede, forsaavidt som det iallefald er erkjendt, at de ikke er af indgribende betydning overfor stridens hovedspørgsmaal. Som saadanne spørgsmaal betragter jeg de følgende:

Om hvalfangernes skud jager fisken.

Om blodet af hvalen forpester havet.

Om affaldet fra fabrikkerne ødelægger fiskebestanden.

Hvad man end mener om slige spørgsmaal, erkjendes det vistnok af alle, at de ingen afgjørende betydning har. Tidligere har jeg diskuteret spørgsmaalet, om hvalen spiller nogen rolle til at holde kobben borte, og jeg har heller ikke for dette spørgsmaals vedkommende kunnet finde nogen realitet af nævneværdig rækkevidde overfor den store sag, det her gjælder.

Istedetfor punktvis at drøfte de mange spørgsmaal, man efterhaanden har formet om disse ting, skal vi her indskrænke os til at behandle et eneste spørgsmaal nemlig det: „Hvilken rolle spiller hvalerne overfor sildens og loddens og dermed ogsaa for torskens vandringer og hvilken indflydelse kan de faa paa udbyttet af fiskerierne?"

Af fjerde kapitel saa vi, at hvalerne

kan deles i de planktonædende (f. eks. blaahvalen, seihvalen, knølhvalen).

" - - i de blæksprutjagende (bottlenosen, kaskelotten).

" - - i de fiskejagende (finhvalen, vaagehvalen, spækhuggeren, springerne).

Af disse hvaler er de blæksprutjagende kun sjeldne gjæster. Hvalfangerne skyder en sjelden gang en bottlenose paa bankerne vest om Troms $\emptyset$ og aldrig længer øst. Af $\mathrm{og}$ til forvilder ogsaa en kaskelot sig op til Finmarken og blir der skudt som en merkværdighed. Disse dyr har saaledes sikkerlig ingensomhelst indflydelse paa fiskeriernes gang.

Planktonhvalerne kan heller ikke indsees at øve nogen indflydelse paa fiskenes vandringer. Som vi af fjerde kapitel har seet, indfinder de sig først i Finmarkshavet, efter at loddefisket er forbi, medens knølhvalen ogsaa viser sig i tiden, før fisket begynder, dog da uden at staa forbindelse med fiskestimernes indsig. Disse dyr foretager desuden særdeles store vandringer og er kun en mindre del af aaret i det farvand, hvor norske fiskerier drives. Der har derfor neppe nogensinde for alvor været paastaaet, at disse dyr har nogen indflydelse paa loddefiskets gang, iallefald ikke efterat man lærte at skjelne mellem de forskellige hvalarter, $o g$ at indse, at de forskjellige hvalarter havde ligesaa forskellig levevis som de bedre kjendte store pattedyrarter paa land.

Kun for sommerseifisket har man ment, at blaahvalen og seihvalen skulde kunne have en vis betydning bl. a. ved at varsle de sammen- 
stuvede krilmasser, i hvis folge ogsaa sejen i regelen færdes. Men nogen større betydning har dette ikke, og af alle hvalfangernes journaler og erfaringer fremgaar det, at disse hvaler skydes saa langt fra land, at de ingen betydning vilde kunne have for det nær land foregaaende seifiske. Den som kjender seifisket vil desuden vide, at fiskerne i selve „,sejens gang" har de bedste ,.syner" at rette sin fangst efter.

Af alt, hvad der foreliger af videnskabsmænds, fiskeres, hralfangeres og andre erfaringer, synes det derfor med fuld sikkerhed at fremgaa, at de saakaldte planktonhvaler ingensomhelst indflydelse har hverken paa fiskenes vandringer eller udbyttet af fiskerierne.

Spørgsmaalet om hralernes indflydelse paa disse ting kan og maa derfor straks begrændses til at gjælde de fiskejagende hvaler, og af disse er det da kun finhralen, som er gjenstand for hvalfangernes jagt.

Finhvalens betydning for fiskerierne.

Hrilken betydning har nu de fiskejagende hvaler og særlig finhvalen for fiskenes randringer $\mathrm{og}$ fiskets gang?

Allerede fra de ældste tider har de fiskejagende hvaler af landets fiskere været anseet for at spille en stor rolle i fiskenes vandringer.

Guldberg har gjort opmerksom paa, at der allerede i kongespeilet, "der ifølge prof. dr. G. Storms historiske granskninger blev skrevet i Norge, sandsynligvis i Nordland, omkring aar 1250" omtales en egen art, "fiskreke“, om hvilken der berettes, at "den driver til landet udenfor havene baade sild og alskens andre fiske, som han er bestemt og dertil sendt af Gud og som om det er hans skyldige embede, saalængesom fiskemænd passe paa sin fangst med forstand; og den har dog en underlig natur; thi den forstaar nok saa godt at spare baade folk og skibe; men hvis folkene blir uenige og slaas, saa blod udgydes, da er det som om denne hval ved det; thi den farer da mellem landet og fiskene og driver dem allesammen bort og ud i havet fra dem, saa som han før har drevet dem til dem."

Under drivgarnsfisket udfor Søndmør, under vaarsildens indsig mod land, under fedsildfisket og de store stængninger af sild i Nordland og under loddeindsigene i Finmarken træffer fiskerne finhvalen, som snart faar navnet „sildehvalen“, snart „loddehvalen“. For at forstaa den glæde og iver, det kan sætte i fiskerne at faa øie paa denne hval, maa man have oplevet og deltaget $\mathrm{i}$ disse eiendommelige hazardiøse og vekslende fiskerier. Som vi af tredie kapitel har seet, kan der til lange tider være "svart" for fisk langs store dele af den norske kyst. Paa steder, hvor man til sine tider kan komme ind med laster paa 10000 torsk, kan man til andre tider sætte 10-20000 kroge uden fangst af mere end nogle ganske faa fisk. Naar man nu betænker de enorme strækninger og afstande, det norske hav har, de vældige havmasser med de store dybder 
vil man forstaa fiskernes nedslagne stemninger i de ofte særdeles lange ventetider, hvor intet er at gjøre, og hvor de anstrengelser, som gjøres, ingen løn bringer for alt det store slid. En stor rolle i disse periodiske fiskerier spiller de saakaldte „syner" eller „udsigter“. Efter disse speides der, naar tiden for fisket nærmer sig, om dem sendes der telegrammer landet rundt i masser, og de vækker desto større forhaabninger, jo længere og tristere ventetiden har været. . Blandt disse syner er „hvalblaasten" vistnok den allerværdifuldeste. Mangfoldige -gange sættes der garn, bare fordi den er seet i nærheden, og mangfoldige gange opnaar man derved fangst, hvor ellers ingen vilde være opnaaet. Jeg har selv været med at opleve dette mangen en gang $0 \mathrm{~g}$ kan af mine erfaringer ogsaa udtale, at det har været af stor hjælp at se hvalen.

Der har ofte været sagt, at dette vistnok er saa, men at fiskerne godt kunde finde fisken alligevel, hvis de bare gjorde nok prøveforsøg. Den som ved, hvor vanskeligt det er at gjøre fiskeforsøg efter vore lunefulde stimfisk, han vil imidlertid være varsom med at fraskrive de faa syner, man har, værdi. Thi overfor de store vandmasser, i hvilke f. eks. silden paa et sted kan staa i vældige masser, mens havet en kort strækning derifra er ganske tomt, der føler man sig let magtesløs overfor den store vanskelighed at finde fiskestimen. Synet af en hval, som "gaar i silden", har der en stor værdi.

Der anføres ofte $\mathrm{og}$ med stor ret, at der ofte sker sildeindsig og loddeindsig, uden at de ledsages af hval. Hvalen kommer ofte flere dage bagefter. Dette synes at hænge sammen med, hvor dybt silden eller lodden gaar. Saaledes har flere store fiskerier fundet sted uden tilstedeværelse af hval. Men dette formindsker ikke betydningen af hvalen som syner, naar den er tilstede.

Hvad specielt sildefiskerierne angaar, saa viser de, som bekjendt, større vekslinger end noget andet fiske. Ikke alene veksler de fra aar til andet i tid, men de forlader pludselig hele landsdele for paa andre steder af kysten at slaa til i stor maalestok. Saaledes var der jo større storsildfiskerier i Nordland i 70-aarene med masser af finhval. $\mathrm{Nu}$ er de forsvundne baade fiskerierne $\mathrm{og}$ finhvalen, men ved Søndmør tager man storsilden med drivgarn, og der ser man store hvalgrinder. Sæt nu at storsilden forsvandt fra-Søndmørsbanken for at styre sin gang mod en anden del af havet. Det staar for mig, at det vilde være et meget værdifuldt middel til at finde den igjen det at lede efter hvalerne, og at man vilde være vanskeligere stillet, hvis man tænkte sig, at der ingen hval var.

Selvfølgelig vilde man efterhaanden komme over disse vanskeligheder, men imens vilde vistnok mangen chance være gaaet tabt.

Ogsaa for loddefisket har dette, at hvalblaasten kan sees i lang afstand sin store betydning. 
For fiskerne staar det eller stod det iallefald i tidligere tider som om det var hvalen, som drev hele fiskemasserne tillands; man mente at den var skyld i hele fiskeindsiget. At dette ikke er tilfældet er forlængst bevist og vistnok ogsaa i det store og hele erkjendt. Man ved, at silden $\mathrm{og}$ lodden under vaarsildfisket $\mathrm{og}$ loddefisket søger ind mod de flade sandige bugter $0 \mathrm{~g}$ sund for at lægge sin rogn paa sandbunden. Og for loddens vedkommende har vi af de foregaaende kapitler faaet et indtryk af, at dette loddens indsig er en ganske anden og stor begivenhed end, at den kan tænkes fremkaldt af hvalerne.

Vi har i den udførlige fremstilling af torskens liv og vandringer seet en stor lovmæssighed fra skreiindsigene paa Nordlandsbankerne, der er kjendte gjennem 1000 aar, til yngelens, ungfiskens og den voksne fisks vandringer ind $0 \mathrm{~g}$ ud af Osthavet.

Vi har seet isgrænserne og polarvandet $\mathrm{i}$ en stor bue nærme sig Finmarkens kyster, vi har seet næringsdyrene dø bort $\mathrm{og}^{\mathrm{g}}$ alle de større arktiske dyr, fisk, fugl og hval fjerne sig fra isens regioner og nærme sig den norske kyst. I marts ifjor kunde „Michael Sars" dampe nogle mil udenfor kysten $\mathrm{og}$ se det vældige brug af alker og fugl strække sig helt fra Fiskerhalvøen til Tanafjorden, som vi ovenfor har skildret det. $\mathrm{Og}$ at dette indsig ikke skyldes de i forhold til dette fænomens størrelse faa hvaler, som man kunde iagttage, er nu vistnok almindelig anerkjendt og paastaaes ikke længer med nogen styrke nogetsteds.

Derimod fremholdes af fiskerne, at skjønt hvalen saaledes ikke er aarsag i det store indsig, kan den faa stor indflydelse paa indsigets gang inde under kysten. Man siger ofte, at hvalen jager lodden eller silden nærmere land, og at derved mange stæng, som ellers ikke vilde blevne gjort, har fundet sted. Endvidere, at hvalen bringer "røre i sjøen". Under sildefisket med drivgarn er det saaledes almindelig anerkjendt og ganske sikkert, at mange gode fangster af sild er gjort, naar hvalen har sat silden i bevægelse og derved bragt de ganske stillestaaende sildemasser til at "gaa paa garnene", mens garn, som stod midt i mængder af sild, hvor ingen hval var, har staaet uden fangst. Ligesaa mener finmarksfiskerne, at fisken bedre bider under den bevægelse, som hvalen kan sætte i loddemasserne.

I alle disse ting findes der efter min mening meget sandt og mange rigtige iagttagelser. Spørgsmaalet er imidlertid ikke, om der findes sandhed eller ikke $\mathrm{i}$ disse ting, men hvilken betydning og størrelse fænomenerne har. Specielt er det af vigtighed, at udrede dette for det første spørgsmaals vedkommende, nemlig i hvilken grad hvalen bidrager til at bringe fiskemasserne $n æ r$ land.

Dette spørgsmaal har, som man vil have seet af den ovenfor givne fremstilling, spillet en stor rolle i striden mellem fiskeri og hvalfangst. 
Der har været paastaaet, at fiskemasserne i det store og hele nu blir staaende saa langt længer tilhavs end før, mens de tidligere kom langt nærmere land paa grundt vand, og at denne omstændighed er skyld i den omlægning af bedriften, som de senere aar har medført, fra juksefiske til linefiske, hvorved især de mindre, aabne baade skal være blevne langt ugunstigere stillet end før.

Af den i tredie kapitel givne fremstilling af Finmarksfisket, vil det sees, at paastanden om, at fisken nu ikke siger saa nær land, at juksefiske kan foregaa, ikke er ganske korrekt. Der baade kan fiskes og der fiskes endnu adskillig fisk med juks, dog er der ingen tvivl om, at der fiskes langt mindre end før. Dette paastaaes ofte kun at skyldes den stadig mere stedfindende omlægning af baadtyperne, som særlig for de fremmede nordlændingers vedkommende i de senere aar har været meget stor. Men hvor rigtigt dette end er, saa er det dog utvivlsomt, at fiskens sig i de senere aar neppe har naaet saa langt ind mod stranden som før. Nogle har nu sagt, at dette er de udenfor paa landbakken staaende liners skyld, som har stanset fisken, atter andre mener altsaa, at det skyldes den omstændighed, at der nu er saa faa hvaler til at jage loddemasserne og dermed fisken ind mod land.

Her, som i mange saadanne spørgsmaal, foreligger der faa sikre og nøiagtige beskrevne erfaringer at bygge sin mening paa.

Jeg for mit vedkommende formaar hverken at tillægge linerne eller hvalen den store betydning til at paavirke de store fiskemassers gang, som de to ovenfor nævnte anskuelser af sagen gjør, og jeg bygger min opfatning af sagen paa følgende erfaringer.

Under skildringen af torskens vandringer har vi i de tidligere kapitler udførlig omtalt de store vekslinger, disse undergaar. Vi har saaledes seet, at der i tidligere tider fandtes et stort Spitsbergfiske, mens nu intet saadant findes. Ligesaa at der nu findes store Murmanfiskerier, mens der tidligere næsten ikke har været fisk under Murmankysten. Idethele giver disse erfaringer indtrykket af store vekslinger, og saadanne fandt sted, længe før baade linefisket og hvalfangsten tog saadant opsving.

De samme erfaringer kjender vi ogsaa fra Søndmørskanten og her synes vi særlig at kunne lære meget. Iaar fandt der nemlig et vældigt indsig af skrei sted og det langt ind i de indre af de fjorde, hvor der for 25 aar siden fandt store fiskerier sted (Borgundfjorden). Her kunde man med synkenot og juks laste sine baade saa hurtig som man kunde komme til for pladsens skyld, og imens fik damperne ude paa bankerne paa sine titusinder af kroge kun saa knap fangst, at de sluttede hele bedriften, tog sine doryer og reiste ind i fjorden for at drive juksefiske. En saadan begivenhed har paa Søndmør ikke fundet sted paa 
25 aar, men før den tid var der store aarvisse, ja gjennem lange tidsrum historisk kjendte fiskerier i Borgundfjorden. At her hverken liner eller hvalen har spillet nogen rolle er selvfølgelig ganske sikkert, og det synes heraf at være berettiget at trække den slutning, at det heller ikke for Finmarksfiskets vedkommende er linerne og ei heller hvalen, som er den store aarsag til, hvorledes torskens indsig nu arter sig, og det saameget mere som det er historisk bekjendt, at der ogsaa i tidligere tider har været lignende vekslinger i fiskenes gang. (Se herom hvalkommissionens historiske udredning).

Selv om det imidiertld ikke er hvalen, som bestemmer de store forhold, saa udelukker erkjendelsen heraf ikke den antagelse, at hvalerne naar de er tilstede i mængder kan bidrage til at øge fisket ved i mindre grad at befordre et indsig nærmere ind mod land, og er der al grund til at antage, at fiskernes hyppige meddelelser herom er fuldt ud korrekte.

Hrad er nu aarsagerne til fiskens lunefulde vandringer snart fjernere snart nærmere land? Dette spørgsmaal kan kun besvares ved længere tids erfaringer baseret paa grundige undersøgelser, som kræver aars arbeide, og har jeg kun havt anledning til at udføre faa saadanne. Det synes mig ikke usandsynligt, at fjordenes kolde vandmasser og den i kapitel 1 skildrede vestgaaende Hvidehavsstrøm her maa spille en stor rolle. At udrede dette og da særlig, hvor stor rolle den i tilfælde spiller, er en rigtig og interessant opgave for fremtidige studier.

Ser vi nu tilbage paa den ovenfor givne fremstilling af hvalens betydning for fisket, saa kommer vi til den slutning, at hvalen (finhvalen) i mange tilfælde er af stor betydning for fiskernes bedrift, og da dels som syner, det vil sige varsler af fiskens tilstedeværelse, dels ved at lette fangsten (som paa drivgarnene og under juksefiske), dels ved i mange tilfælde at bringe sild og lodde nærmere kysten. Paa den anden side finder vi, at antagelsen af hvalen som hovedaarsagen til fiskets hele gang og udbytte i de forskjellige aar er feilagtig, ligesom denne paastand, der altid har været let at giendrive i striden mellem fiskeri og hvalfangst, har skadet fiskernes synspunkter, fordi dens uholdbarhed selv af mange fiskere blev indrømmet.

I striden mellem fiskerne og hvalfangerne har det nu været anført, at selv om finhvalen saaledes gjør en del nytte, saa opveies dette derved, at den selv jo tilintetgjør store mængder sild og lodde. Og hvalen har af den grund ligefrem ræret betegnet som et "skadedyr". Det er imidlertid min tro, at dette ikke kan tillægges nogen betydning, da disse stimfiske utvivlsomt er tilstede i slige vældige mængder, at man i en overskuelig fremtid vistnok ikke behøver at nære nogen bekymring med 
hensyn til spørgsmaalet om stammens aftagen. Fiskeriets vanskeligheder er vistnok udelukkende vanskeligheder i fangsten.

For mig staar derfor hvalens nytte som hjælp til fangst som det væsentlige, og dette berettiger efter min mening til det at betragte finhvalen som et for fiskerne og deres bedrift nyttigt dyr.

Vender vi os nu efter disse overveielser mod betragtningen af de De opstillede krav, som af fiskerne opstilles om en begrænsning respektive et absolut krav om fredforbud af al hvalfangst, blir det nødvendigt paany at minde om den ningsbedrøftelse af spørgsmaalet om hvalfangstens indflydelse paa hvalbestandens størrelse, hvormed vi afsluttede forrige kapitel. Som man vil erindre, kom vi der til det resultat, at de foreliggende erfaringer nu syntes at tyde paa, at hvalfangsten havde øvet en merkbar indflydelse paa hvalbestanden, men at denne indflydelse endnu langt fra havde naaet den størrelse, som anden hvalfangst, der var drevet gjennem længere tidsrum og efter andre hvalarter, bevislig havde naaet. Paa den anden side antager vi, at indflydelse ogsaa i fremtiden stadig vilde gjøre sig gjældende.

Paa grundlag af den i det foregaaende udviklede opfatning af finhvalens betydning for fiskerierne og hvalfangstens indflydelse paa hvalbestanden, skal jeg da i det følgende søge at udvikle, hvad der efter min opfatning bør gjøres for at bevare finhvalen for fiskerierne.

Af den i forrige kapitel givne skildring af hvalfangsten saa vi, at denne forløber i forskjellige - indbyrdes meget forskjellige afsnit.

1. I aarets første maaneder foregaar der en fangst af knølhval (februar-mars), som afsluttes, forinden loddefisket begynder og i et tidsrum, da der udenfor Finmarkskysten intet eller i høiden kun meget lidet fiske drives.

2. Efterat knølhvalfangsten er forbi eller under dens afslutning indfinder finhvalen sig sammen med loddeindsiget. I denne tid skydes kun finhval, og det helt, indtil

3. planktonhvalerne efter 1ste juni indfinder sig, og da skydes fra 1ste juni til begyndelsen af september samtlige hvaler (blaahval, seihval, knølhval og finhval).

Heraf ser man, at finhvalen fanges i hele fangsttiden med undtagelse af aarets første maaneder, da knølhvalen er fangstens eneste gjenstand. Vi har endvidere seet, at finhvalen i det tredie tidsrum udgjør den allervæsentligste del af fangstudbyttet, efterat blaahvalen er bleven saa sjelden, at den trods dens store værdi, dog kun udgjør en liden del af hele værdiudbyttet.

At forbyde fangst af finhvalen saavel $i$ andet som i tredie afsnit af fangsttiden er derfor ganske det samme som at umuliggjøre enhver hvalfangst. Er nu dette nødvendigt eller ønskeligt? Besvarelsen af dette 


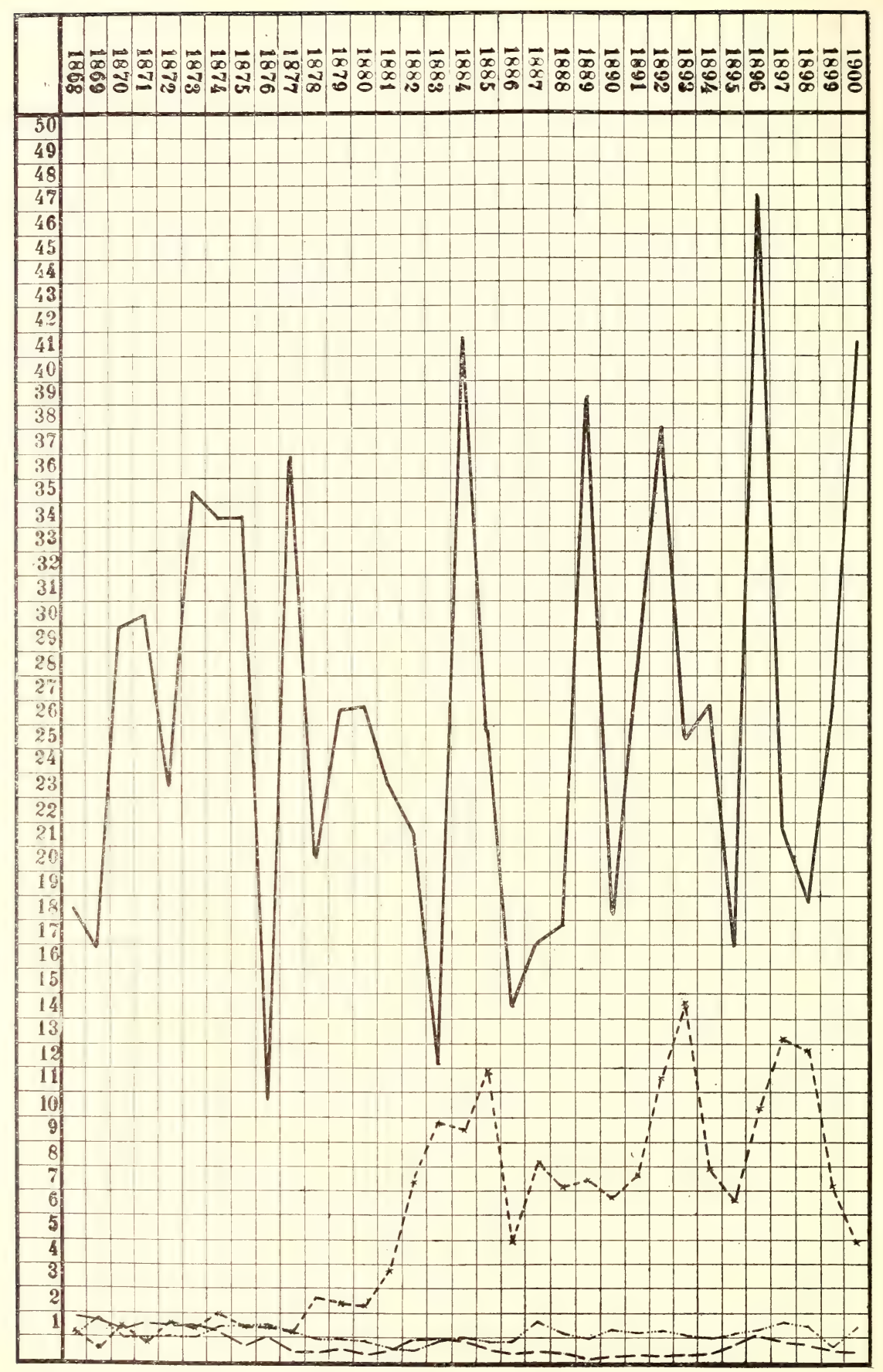

Fig. 71. Grafisk fremstilling af værdien af Finmarkens fiskerier.

$$
-\cdots-\text { hvalros og sæl. }
$$


spørgsmaal afhænger efter min mening af den værdi, man tillægger finhvalens indflydelse paa fiskerierne. Sammenligner man udbyttet af fiskerierne med udbyttet af hvalfangsten, viser det sig nemlig, at de første har en langt større værdi (se figur 72, hvor der er givet en grafisk fremstilling af udbyttet af fiskerierne, hvalfangsten, haakjærringog sælfangsten i aarene 1868--1900). Desuden har fiskerierne en langt større betydning for staten, idet de utvivlsomt er en absolut nødvendig eksistentsbetingelse for hele det nordlige Norges befolkning. Endvidere er det hævet over tvivl, at fiskerierne indeholder store fremtidsmuligheder, medens al hvalfangsts historie tyder paa, at ogsaa Finmarkshavets hvalfangst er en bedrift, hvis fremtid er begrænset.

Det er derfor min opfatning, at hensynet til fiskerierne, saafremt det maatte ansees nødvendigt, vilde retfærdiggjøre kravet paa hvalfangstens ophør, men jeg formaar alligevel ikke - med mit syn paa betydningen af finhvalens indflydelse paa liskerierne paa den ene side og bestandens størrelse i øieblikket paa den anden side - at anbefale, at man gaar til et saadant skridt.

Jeg mener, at det har sin betydning, før man tager standpunkt i Følgerne af denne sag, at overveie, hvilke følger et totalt forbud af hvalfangsten vil og betingelmedføre for landet, for staten $\mathrm{og}$ for fiskerne selv, samt hvad der kan gjøres i denne sag uden at umuliggjøre hvalfangsten.

For landets nationalindtægt betyder forbudet af hvalfangsten serne for gjennemførelsen af totalt tabet af et aarligt beløb, som i de sidste aar var følgende:

$\begin{array}{rrr}1896 & \mathrm{kr} . & 1.034 .600 \\ 1897 & - & 1.320 .600 \\ 1898 & - & 1.286 .600 \\ 1899 & - & 712.000 \\ 1900 & - & 498.000\end{array}$

Som man ser, er dette et særdeles betydeligt aarligt beløb, naar man sammenligner det med de øvrige indtægtskilder i Finmarken; i enkelte aar har indtægten endog naaet halvdelen af udbyttet af fiskerierne, i de senere aar har det sunket ned til omtrent en tiendedel. Til en rigtig bedømmelse af værdien af hvalfangsten hører selvfølgelig en rigtig bedømmelse af dens fremtid. Saafremt denne viser sig fremdeles at kunne give værdier som de ovenfor nævnte, er selvfølgelig betydningen af hvalfangsten for de kommende aar klar; viser hvalfangsten sig derimod stadig at gaa tilbage, er det klart, at en fortsættelse væsentlig har den betydning, at den i etablissementerne nedlagte kapital efterhaanden $0 \mathrm{~g}$ under varetagelse af eget tarv kan afvikle forretningen. Fra dette synspunkt maa der ogsaa reises det spørgsmaal, hvorvidt der ikke lader sig træffe en ordning med hvalfangsten, saaledes at denne paa den ene 
side varig fremover gjennem tiden under rimelig beskatning af bestanden kan lønne sig, uden at den derved skader fiskerierne. Dette synspunkt vil kunne gives desto mere vægt, om det erkjendes, at det kun er en enkelt hval (finhvalen), som har betydning for fiskerierne. Naar det gjælder de store landdyr, søger man jo, selv om man sætter aldrig saa meget pris paa dem, at høste rimeligt udbytte af dem uden at skade bestanden. Hertil skal vi senere komme tilbage, efterat vi først videre har betragtet spørgsmaalet, hvilke følger det opstillede krav - totalt forbud - vilde have.

Der reiser sig i anledning dette af sig selv det spørgsmaal: Paa hvilken maade kan en foranstaltning som totalt forbud af hvalfangsten iverksættes, i det øieblik den maa antages at ville paaføre en del af statens borgere saa store tab som det, at de anlagte etablissementer sættes ud af virksomhed $o g$ dermed gjøres værdiløse.

Fra enkelte hold har det været anfort, at hvalfangerne faar finde sig heri uden erstatning, naar deres bedrift skader de langt vigtigere fiskerier. Paa den anden side har der været fremholdt, at dette vilde være en uretfærdighed fra statens side og staa i strid med statens fremgangsmaade i lignende tilfælder, som tidligere er indtrufne. Det er ikke udelukket, at afgjørelsen af dette spørgsmaal først vilde blive at træffe af landets domstole, en afgjørelse, hvis udfald ikke kan vides paa forhaand. Da det imidlertid har staaet for mig, som at det - særlig for Den juridiske fiskerne $0 \mathrm{~g}$ deres arbeide for sin bedrifts fremtid - maatte have betydning side. Hr. Ur'- at have dette spor'smaal saavidt paa det rene, som det paa forhaand er byes udta-

lelse. muligt, har jeg sogt herom at erhverve mig en selvstændig opfatning, og jeg kan i denne henseende fuldt ud slutte mig til følgende udtalelse om sporgsmalet, som statsadrokat Urbye, Tromsø, velvillig har givet mig:

"Naar jeg skal udtale mig om, hviike indskrænkninger staten er berettiget til at gjøre i fangst og tilgodegjørelse af hval, maa paa forhaand siges, at om mange af de spørgsmaal, som her opstaar, er det vanskeligt at udtale noget sikkert. Hverken i lovgivning eller retspraksis har man, saavidt mig bekjendt, helt analoge tilfælde, og navnlig gjælder dette spørgsmaalet om totalfredning o: absolut forbud mod fangst og tilgodegjorelse. Da selve fangsten for en stor del foregaar udenfor rigets territorium, opstaar ogsaa af den grund her særspørgsmaal.

Jeg skal først behandle indskrænkninger i selve fangsten.

At staten for sjøterritoriet kan give hvilkesomhelst fredningsbestemmelser er selvsagt. Da imidlertid den udenfor dette drevne fangst maa være af samme betydning for fiskerierne som den paa sjøterritoriet drevne ialfald forsaavidt, som den medfører en formindskelse af hvalbestanden, maa undersøges, om staten kan give fredningsbestemmelser 
eller fangstforbud, som har gyldighed ogsaa udenfor sjøterritoriet. Sikkert er, at disse ikke uden traktatmæssig overenskomst kan gjøres gjældende mod andre landes undersaatter, og de vil derfor ingen indskrænkning gjøre i hvalfangst, drevet f. eks. fra Murmankysten langs den norske kyst. Derimod skjønnes intet til hinder for, at saadanne bestemmelser gives med fuld virkning for norske undersaatter, saafremt hvalfangst udenfor kysten antages at skade vigtige norske interesser. En del af |bestemmelserne i den gjældende hvallov af 6te juni 1896 maa ogsaa efter min opfatning have gyldighed udenfor territorialgrænsen ${ }^{1}$ ). Ogsaa saadanne bestemmelser maatte imidlertid gives lokal begrænsning af hensyn til norske undersaatters fangst andetsteds f. eks. under Island.

Som almindelig regel kan vistnok opstilles, at nye fredningsbestemmelser ikke medfører ret til erstatning, selv om private fiske- eller jagtberettigede derved tilføies $\left.t_{a b}{ }^{2}\right)$. Denne regel er ogsaa i almindelighed billig, idet en fredningsbestemmelse, selv om den i øieblikket medfører tab, dog i længden tilsigter at komme den tilgode, som har fiske- eller jagtretten. Undersøger man om denne regel uden videre kan anføres overfor den uværende eiere af hvalfangere $o g$ hvaletablissementer, saafremt nye fredningsbestemmelser eller et absolut forbud mod hvalfangst gjør en væsentlig indskrænkning i deres bedrift eller endog medfører dennes ophør, tror jeg, det maa indrømmes, at sagen her staar noget anderledes. Der handles nemlig her om en fredningsbestemmelse af anden art end de almindelige. Fredningen sker nemlig ikke for hvalens egen skyld, men for fiskeriernes, - fredningsbestemmelserne vil ikke komme hvalfangerne selv til gode, tvertom deres bedrift indskrænkes eller ofres til fordel for en anden bedrift. Saafremt et absolut forbud mod hvalfangst vil medføre en væsentlig forringelse i værdien af de til fangsten nyttede dampbaade, redskaber eller anlæg - eller for anlæggenes vedkommende gjøre disse næsten værdiløse, vil det i realiteten være ensbetydende med, at staten tilføier enkelte et økonomisk tab ved at forbyde dem at bruge sin eiendom paa den maade, hvortil eiendommen i overensstemmelse med den bestaaende lovgivning er indrettet og bestemt. Spørgsmaalet om erstatning for et saadant forbud synes derfor at maatte afgjøres efter de samme grundsætninger, som nedenfor skal fremstilles ved drøftelsen af

1) Smlgn. om et nogenlunde beslegtet tilfælde indredepartementets skrivelse af 30te august 1901, om at lov om stranding og vrag af 20de juli $1893 \S 11$ ogsaa gjælder gods, fundet udenfor territorialgræensen, jfr. hvallovens $\S 11$.

2) Under voteringen $\mathrm{i}$ en i Retstidenden for 1888 s. 529 refereret sag udtaler dog førstvoterende (s. 535), til hvem de øvrige voterende sluttede sig, at erstatning maaske maatte gives, naar det var vitterligt, at en fredningsbestemmelses gjennemførelse vilde være ensbetydende med fuldstændig eller delvis ødelæggelse af vedkommende eiendomsgjenstand (en faststaaende fiskeindretning). 
virkningerne af et forbud mod tilgodegjørelse af hval; jeg kan derfor henvise did.

Jeg tror nemlig, at skal man opnaa noget effektivt, kan man ikke nøie sig blot med bestemmelser, som er rettede mod fangst af hval. Disse vil som før nævnt ikke hindre udlændinger i at jage hval udenfor territorialgrænsen, og det er at befrygte, at fredningsbestemmelserne vilde blive søgt omgaaet derved, at selve fangstfartøierne eiedes og dreves af fremmede landes undersaatter. Forbudet maa derfor i tilfælde rettes ikke blot mod fangst, men ogsaa mod tilgodegjørelse af hval paa norsk grund, $o g$ det uden hensyn til, om hvalen er fanget indenfor eller udenfor territorialgrænsen. Ogsaa ved et saadant forbud maa man imidlertid have for øie, at det ikke vil hindre udlændingers fangst langs kysten, $\mathrm{og}$ selv om dette for tiden antages at være af mindre betydning, maa man formentlig regne med den mulighed, at nye stationer kan oprettes eller de gamle optages paa Murmankysten, hvis totalfredningen i Norge medførte en væsentlig øgning af hvalbestanden.

Med hensyn til statens ret overfor de bestaaende hvaletablissementer eller nye saadanne bemerkes:

Utrivlsomt er staten berettiget til at forbyde anlæg af nye etablissementer. Herved krænkes ingens ret, og der er jo ingen, som vil have noget særligt fundament for skadeserstatning.

Saafremt et anlæg nedbrænder eller ødelægges paa anden vis, er staten ogsaa berettiget at forbyde dets gjenopforelse uden erstatning. Eksempel paa lignende bestemmelse har man bl. a. i den nye bygningslov af 27 de juli $1896 \S 70$. Smlgn. ogsaa Retst. 1877 s. 673.

Videre maa staten være berettiget til at bestemme, at saaflemt driften af et anlæg efter lovens ikrafttræden nedlæg ges en bestemt tid, kan gjenoptagelse af driften forbydes uden erstatning. Smlgn. ogsaa her den citerede $\$ 70$ i den almindelige bygningslov, som gjør gjenoptagelse af driften bl. a. ved trankogerier, fabrikker for tilvirkning af lim og gjødningsstoffe afhængig af reguleringskommissionens tilladelse, naar de har været nedlagt 1 aar. En lignende bestemmelse har man i lov om ildsfarlige gjenstande af $3 / 51871 \S 22$, sidste punktum.

I de nævnte tilfælde synes neppe heller nogen billighedsgrunde at tale for erstatning.

Det vigtigste spørgsmaal er imidlertid det, om staten uden erstatning kan forbyde, at de nu bestaaende hvalfangeretablissementer for fremtiden nyttes til tilgodegjørelse af hval. Hvis det antages, at grundlovens $\$ 97$ er til hinder for uden erstatning at give et saadant forbud, har staten 
vistnok adgang til efter grundlovens $§ 105$ at ekspropriere anlæggene, men der maa da betales fuld erstatning.

$\mathrm{I}$ en afhandling $\mathrm{i}$ ugeblad for lovkyndighed X p. 387 udtaler Aschenоug: „Hvis loven forbyder eieren netop den benyttelse, som efter grundens natur er dens egentlige og væsentligste bestemmelse, og dette forbud rammer den hele eiendom, saaledes at denne bliver næsten værdiløs, kan det siges, at forbudet i den grad faar karakteren af en berøvelse af selve eiendomsretten, at man vel vilde tilkjende eieren erstatning." Denne mening har imidlertid Aschenoug selv senere fraveget i en afhandling i Retstidenden for 1879 s. $761 \mathrm{og}$ videre i sin statsret, hvor han udtaler om dette punkt (bind III, 2den udgave s. 79):

„Forbyder lovgivningen at benytte en gjenstand efter dens eneste eller endog efter dens nærmeste bestemmelse, saa berøves gjenstanden undertiden al værdi. Det kunde derfor synes, som om det i grlv.'s $\S$ 105 udtalte princip maatte medføre, at staten ogsaa i dette fald pligtede at betale eieren erstatning. En saadan lære, der saavidt vides ikke er antagen i noget andet land, maa dog erkjendes at være uholdbar. Eiendomsret er intet andet end den naturlige frihed, der er hjemlet enkelt person til at raade over de ham tilhørende legemlige gjenstande. Ligesom enhver maa finde sig i, at lovgivningen, forsavidt ikke grundloven har bestemt noget modsat, indskrænker hans naturlige frihed til at rade over sin person og sine kræiter, sa aledes maa han ogsaa taale, at lovgivningen forbyder ham at benytte sine eiendele paa hvilkensomhelst maade, der findes skadelig eller farlig for samfundet." ${ }^{1}$ )

I Nordiske Retsencyklopædi bind I, Retskilderne s. 209 slutter Ebbe Hertzberg sig til Aschenougs lære. Derimod synes MorgeNSTIERNE i sin statsforfátningsret p. 648 at antage, at hvor en indskrænkning rammer den eneste benyttelse, hvortil en ting praktisk talt er skikket, kan der gives tilfælde, hvor erstatning maa gives.

I retspraksis har spørgsmaalet været løst paa forskjellig maade. Noget rent og klart præjudikat findes neppe. I en række domme synes høiesteret, navnlig efter udtalelse under voteringen at helde til den opfatning, at erstatning skal gives i slige tilfælde. Navnlig kommer dette frem i en i Retstidenden for 1880 s. 257 refereret dom, hvor det bl. a. heder i justitiarius ThomLes votum: „Hensynet til, hvad naturlig retfærdighed og billighed mod enkelt mand tilsiger, ikke mindre end hensynet til den i grundlovens $\S 105$ udtalte almindelige grundsætning, maa medføre, at den enkelte ikke bør være pligtig til at taale saadan indskrænkning uden erstatning, naar indskrænkningen medfører

1) Udhævet her. 
væsentlig forringelse af hans eiendom eller gjør den ganske ubrugbar til sit øiemed."1) Paa den anden side blev ved en i Retstidenden for 1889 s. 601 refereret høiesteretsdom eierne af en oprindelig til parafinoljelager bestemt bygning negtet erstatning i et tilfælde, hvor en senere lov hindrede dem i at nytte eiendommen til saadant brug. Denne dom anføres baade af Aschenoug og Hertzberg som præjudikat for rigtigheden af den af dem hævdede lære, men det forekommer mig meget tvivlsomt, om der dertil er fuld grund. Meget mere synes faktiske betragtninger over værdiforringelsens art $\mathrm{og}^{\circ} \mathrm{grad}$ at have spillet en ikke liden rolle ved.afgjørelsen. Navnlig kan bemerkes, at en af de voterende, der er enig i resultatet, udtaler følgende, der staar direkte i strid med Aschenougs lære:

„Naar indskræukningen gaar saa vidt, at eiendomsgjenstanden bliver paa det nærmeste eller endog helt ud unyttig, da synes der at være grund til at indrømme erstatning, $0 \mathrm{~g}$ da synes det mest stemmende med grundlovens \& $105 \mathrm{og}^{\circ}$ med den anvendelse, der i vor private lovgivning hidtil er gjort af nævnte grundlovsbestemmelse, at der tilkjendes erstatning. Der er i virkeligheden relativt til eieren ingen forskjel mellem til brug for det offentlige at tage en eiendomsgjenstand fra en mand og i det offentliges interesse at forbyde ham at bruge gjenstanden til det, hrortil den overhovedet kan bruges, eller mellem gjenstandens fysiske og økonomiske tilintetgjørelse. Det, som er af interesse for eieren det, for hris skyld han har erhvervet gjenstanden, -- er ikke den blotte ihændehavelse, men beføielse til at raade over gjenstanden". I senere domme er, saavidt sees, spørgsmaalet ikke direkte behandlet. Under voteringen i en i Retstidenden for 1900 s. 850 omhandlet sag udtales imidlertid: "Naar indskrænkningen i en eiendoms benyttelse ikke gar videre end her er tilfældet, ${ }^{2}$ ) kan der formentlig under ingen omstændighed rære tale om analogisk anvendelse af nævnte grundlovsbestemmelse (\$ 105)." Dette synes at tyde paa, at ialfald ikke denne roterende erkjender høiesteretsdommmen af 1889 som et præjudikat for Aschenougs lære; thi efter denne er jo hver indskrænkning, selv om den gaar aldrig saa vidt, berettiget. Smlgn. ogsaa høiesteretsdom i Retst. for 1897 s. 593, hvor det i høiesterets fællesbegrundelse heder: „Efter de foreliggende oplysninger i deres helhed gaar man i hvert fald ud fra som sikkert, at nogen væsentlig værdiforringels $e^{2}$ ) ikke foreligger," hvorfor høiestelet finder, at erstatningskrav ikke har hjemmel i grundlovens \$ 105 .

Efter det oplyste om praksis, tror jeg, man intet sikkert kan sige

\footnotetext{
1) Udhævet her.

9) Udhævet her.

3) Udhævet her.
} 
om, hvorledes høiesteret vil stille sig overfor et erstatningssøgsmaal, hvis en lov forbød tilgodegjørelse af hval. Jeg tror, man maa være forberedt paa, at betydelig vegt vil lægges paa, om et saadant forbud medfører en væsentlig værdiforringelse. Under hver omstændighed kan man ikke med sikkerhed paaregne, at den af Aschenoug hævdede lære vil blive godkjendt af høiesteret.

Er det allerede vanskeligt at faa rede paa de principer, som i retspraksis er fulgt med hensyn til dette spørgsmaal, saa er det billede, lovgivningen frembyder, endnu langt mere broget. Saa meget kan ialfald siges, at denne saa langt fra konsekvent har fulgt den af Ascheнoug hævdede lære, at den meget mere i mange tilfælde har vist noksaa stor ængstelighed for at gribe ind med forbud mod at benytte eiendom paa før tilladt vis.

Jeg skal nævne nogle eksempler herpaa.

Loven om ildsfarlige gjenstande af 3die mai $1871 \S 22$ tilsiger fuld erstatning, hvis ældre anlæg skal sløifes eller forandres.

I bygningslovgivningen er der vistnok adskillige bestemmelser, som kommer til anvendelse ogsaa paa bygninger, der er ældre end vedkommende love, men deres hovedregel er dog, at nye love blot gjælder bygninger, som opføres eller underkastes hovedreparation efter lovenes ikrafttræden.

Ligeledes tilstaaes i enkelte tilfælde erstatning, hvor væsentlige indskrænkninger lægges paa benyttelse af byggegrund. Bygningsloven for Kristiania af 26 de mai $1899 \S 10,2$ indrømmer f. eks. erstatning, naar beslutning om villamæssig bebyggelse paa grund af særlige omstændigheder bevirker, at en eiendom bliver ødelagt som byggegrund. I den før omtalte almindelige bygningslovs $\S 70$ ser man ogsaa, at bestaaende anlæg af den der nævnte art ikke forbydes at fortsætte sin virksomhed, hvor generende denne end kan være for en by; alene nye, nedbrændte eller nedlagte anlæg gaar ind under loven.

Lakseloven af 30te juni $1891 \S 39$ bestemmer, at det $\mathrm{i}$ en vis tid efter lovens ikrafttræden skal være tilladt at bruge redskaber af den tidligere tilladte maskevidde, uanseet bestemmelser i lovens $\S 5$, som paabyder større maskevidde end før for bundne redskaber.

Af de mange andre love, som her kunde nævnes, skal jeg endnu blot omtale to, der frembyder nogen analogi med det tilfælde, som her omhandles. Den ene er loven om forbud mod udførelse af trævirke fra Nordlands, Tromsø og Finmarkens amter af 27 de juni 1892. Denne vilde jo i visse tilfælde kunne gjøre betydelig indskrænkning i skogeiernes nytte af sin skog; men loven giver paa den anden side kongen adgang at dispensere fra forbudet, hvor billighedshensyn i særlig grad stiller sig imod lovens anvendelse. ${ }^{1}$ ) Den anden lov er loven om

1) Udhævet her. 
værnskogenes bevarelse m. v. af 20de juli 1893. Under debatten i odelstinget om denne lov er det spørgsmaal, som her behandles, drøftet meget indgaaende (se forhandlingerne i odelstinget $1893 \mathrm{s.} 543 \mathrm{ff}$.) Der blev her fra en række talere fremholdt, at den indskrænkning, man ved denne lov vilde gjøre i private skogeieres raadighed, gik grundlovens $\$ 105$ for nær. Et forslag om i selve loven at indtage en erstatningsbestemmelse faldt vistnok, men af flere af dem, som stemte mod dette forslag, blev det fremholdt, at grundlovens $\$ 105$ var tilstrækkelig hjemmel for et erstatningssøgsmaal, ifald domstolene fandt, at privates ret var krænket. Heller ikke her er dommen af 1899 anseet som præjudikat.

De anførte eksempler kunde forfleres, men jeg antager, at de alt nævnte tilstrækkelig viser, at lovgivningen enten ikke har anseet sig berettiget til at gjøre vidtgaaende indskrænkninger i enkeltmands raadighed over sin eiendom, eller at den under hver omstændighed har ladet billighedsbetragtninger spille en stor rolle.

Hvorledes lovgivningen vil stille sig overfor spørgsmaalet om erstatning til hvaletablissementernes eiere, hvis forbud mod hvalfangst eller hvaltilgodegjørelse væsentlig forringede disses værdi, kan ikke med sikkerhed siges. Skulde man slutte fra lovgivningens stilling til lignende spørgsmaal hidtil, synes man nærmest at komme til det resultat, at erstatning vil blive indrømmet, men en saadan slutning vil dog være høist usikker.

Min opfatning er, at stricte juridisk seet, vilde eierne af de nuværende anlæg ingen ret til erstatning have overfor en forbudslov. En saadan erstatningsret kan ikke bygges paa grundlovens $\$ 97$ - forbudet mod at give love tilbagevirkende kraft - da eierne af hvalfangeretablissementerne ingensomhelst ret har erhvervet til at drive disse. Den maatte i tilfælde grundes paa en analogisk anvendelse af grundlovens $\$ 105$, men til saadan analogi savner man efter min opfatning hver beføielse. Den af domstolene forsøgte sondring, eftersom væsentlig. værdiforringelse har fundet sted eller ei, kan vistnok have gode billighedsgrunde for sig, men den er helt vilkaarlig og har heller ikke i grundlovens \$ 105 nogen støtte.

Selv om man indrommer staten en saa vidtgaaende ret, kan der imidlertid selvfølgelig være tilfælde, hvor dens haandhævelse vilde være en stor ubillighed overfor enkeltmand, og hvor derfor erstatning bør gives af billighedsgrunde. Som før paavist er dette hensyn i mange tilfælde taget i betragtning af lovgivningen. Hvorvidt saadanne billighedsgrunde foreligger overfor forbud af den slags, som det her gjælder, er et spørgsmaal af væsentlig faktisk natur; dets afgjørelse vil i første række bero paa, hvor vidtgaaende forbudet er, og hvilke følger det faar. Jo større forringelse det vil medføre $\mathrm{i}$ anlæggenes værdi, desto mere vil 
det overfor disse faa en ekspropriationsartet karakter, og desto mere synes billighed at tilsige, at erstatning gives. Ogsaa det hensyn vil sandsynligvis blive taget i betragtning, at man her indskrænker eller stanser e $n$ bedrift af hensyn til en anden.

Som resultat af den anstillede undersøgelse kan sættes:

Vil man indføre et forbud mod fangst eller tilgodegjørelse af hval, som medfører en væsentlig forringelse i de bestaaende etablissementers værdi, kan man ikke sætte ud af betragtning, at et saadant forbud muligvis eller endog sandsynligvis vil have til følge erstatning til etablissementernes eiere, og altsaa ikke kunne gives uden betydelige økonomiske ofre. Derimod vil forbud, som ikke har denne virkning, kunne gives uden erstatning, og det samme gjælder forbud mod opførelse af nye, gjenopførelse af nedbrændte eller gjenoptagelse af $i$ en vis tid nedlagte anlæg."

Af denne hr. statsadvokat URBres udtalelse vil det formentlig for enhver fremgaa, at man maa regne med den forudsætning, at domstolene eller ogsaa den lovgivende magt selv kun vil tillade den saakaldte totale fredning af hval gjennemført mod erstatning af det hvalfangerne derved paaførte tab.

Som ovenfor antydet er det min mening, at dette ikke burde af- Mit forslag til skrække fra kravets gjennemførelse, saafremt det ansaaes nødvendigt for fredning. fiskerierne. Det er imidlertid min tro, at det vilde være særdeles uheldigt for vor fiskerbefolkning selv, om den vilde sætte alle sine krav og ønsker om arbeide for fiskeriernes ophjælp ind paa det ene store kort - ekspropriation af hvalfangsten - hvilket - paa grund af kravets størrelse - selvfølgelig i lange tider vilde virke hemmende paa opnaaelsen af alle andre maal. I det følgende kapitel skal jeg nærmere søge at udvikle min opfatning af, hvad der i første række synes paakrævet for at ophjælpe det nordligste Norges fiskerier; her skal jeg gaa over til overveielsen af spørgsmaalet: Hvad kan der og bør der gjøres for at regulere forholdet mellem fiskeri $\mathrm{og}$ hvalfangst $\mathrm{og}$ for at bevare finhvalen for fiskerierne? Kan her overhovedet noget gjøres, der har værdi for fiskerierne og som ikke umuliggjør hvalfangsten?

De store pattedyr paa land fredes, som bekjendt, paa den maade, at man fortrinsvis forbyder at jage eller dræbe dem i den del af aaret, da ungen bringes til verden og følger moderen. Ifølge GuLdberas undersøgelser (se fjerde kapitel) kastes finhvalens unge i aarets første maaneder, og i mai maaned (1883) har man i Østfinmarken seet „en masse "unghval" sammen med en del voksen finhval, der viste sig over hele Varangerfjorden, idet de gik og fraadsede i loddestimerne. De 
mindste af disse finhvalunger havde en længde af knapt 20 fod, altsaa omkring 6 meter. Mange af ungerne havde ikke engang rede paa at lægge sig paa siden for at fylde munden med lodde, men gik blot og "nafsede", medens de større unger havde lært grebet. Denne mængde hval forsvandt dog snart igjen. Ogsaa i juni maaned saa man af og til endel ung finhval sammen med nogle faa voksne."

Skulde man anvende de overfor andre store dyr anvendte fredningsprinciper paa finhvalen, saa vilde dette derfor føre til at fastsætte en fredningstid af aarets første fem maaneder. Selvfølgelig vilde dette ikke medføre andet end en delvis fredning, men dels vilde det beskytte de nyfødte unger, dels formindske antallet af skudte finhval overhovedet. Af de $\mathrm{i}$ forrige kapitel anførte 40 fangstjournaler fremgik det, at der i disse "fangstaar" var skudt

199 finhval for 1ste juni, 538 efter 1ste juni, altsaa

$$
27 \% \text { - - - - } 73 \% \text { - } 7 \text { - }
$$

At sætte fredningstiden til aarets første fem maaneder vilde, foruden at derved den med almindelige fredningsprinciper overensstemmende tid valgtes, ogsaa have til følge to store fordele. For det første vilde derred al hvalfangst ophøre i det tidsrum, da loddefisket finder sted, idet der $\mathrm{i}$ denne tid kun skydes finhval. Se herom, hvad der ovenfor er anført angaaende de forskjellige afsnit, hvori hvalfangsten falder. De forstyrrelser i fiskens indsig, som fiskerne mener, at hvalfangerne fremkalder ved at forfølge finhvalen under loddeindsigene, vilde bortfalde.

Desuden vilde fredning $i$ dette tidsrum ingen indflydelse øve paa hvalfangsten forøvig og ikke paa fangsten af de hvaler, som ikke kan indsees at have betydning for fiskerierne, saaledes hverken paa fangsten af knølhvalen før loddefisket og finhvalens ankomst, eller paa fangsten af planktonhvalerne efter loddefiskets afslutning. Fredningen vilde praktisk talt være en totalfredning i loddefisketiden.

Til gjengjæld vilde det — væsentlig af hensyn til loddefisket etablerede forbud mod fangst af hval indenfor milegrænsen $i$ aarets forste fem maaneder kunne bortfalde, saaledes at fangsten af knølhvalen Kunde foregaa under samme betingelser, som den nu efter første juni stedfindende fangst-- altsaa kun med visse politibestemmelser af hensyn til forebyggelse af kollision mellem hvalfangsten $o g$ de særdeles faa fiskerbaade, som i aarets første maaneder er tilstede. For hvalfangsten vilde denne indrømmelse have betydning, fordi knølhvalen vandrer saa nær landet.

Saameget desto mindre synes det af mig stillede forslag, der tilsigter en ogsaa for hvalfangstens fremtid fordelagtig fredning af finhvalen, at ville medføre de vanskeligheder, som et totalt forbud af hvalfangsten med deraf følgende erstatningskrav vilde have til følge. 
Med hensyn til den form, hvori fredningsbestemmelsen i tilfælde blev at fastslaa, da staar det for mig, at det ofte foreslaaede forbud mod tilgodegjørelse af hval - i dette tilfælde altsaa finhval i tiden 1ste januar til 31te mai - ikke er den heldigste form. Jeg mener, at der ingen betænkeligheder kan være ved at fatte den bestemmelse, at det ligefrem forbydes norske borgere at jage, dræbe eller anskyde finhval saavel indenfor som udenfor territorialgrænsen i nævite tidsrum. For det første er der i havet udenfor det nordligste Norge ingen udenlandske konkurrenter, saaledes at norske borgere derved ikke vil blive værre stillet end andre landes borgere. Der har vistnok været talt om tysk hvalfangst drevet fra Bjørnøen, men - forudsat at der tales om hvalfangst drevet som forretning - er der vistnok ingen grund til at antage, at dette vil ske. Ved Bjørnøen skydes desuden væsentlig blaahval, og denne $\emptyset$ er i regelen utilgjængelig før 1ste juni. Ved Murmankysten er hvalfangsten ligesom i den østlige del af Østfinmarken ophørt som ikke lønsom. For det andet er jo den hele territorialgrænse et paa norske statsbeslutninger hvilende begreb og der kan ikke indsees nogen ranskelighed $i$ at give bestemmelser for norske borgere ogsaa udenfor denne grænse. Parallel hertil haves fra den engelske lovgivning, som forbyder engelske undersaatter at anvende visse fiskeredskaber udenfor det havomraade, som Storbrittanien anser for territorialomraade, $o g$ det trods at dette forbud ikke anerkjendes af andre nationers fiskere. Majoriteten i hvallovkommissionen af 1890 afgav ogsaa forslag om politibestemmelser for hvalfangsten udenfor territorialgrænsen.

Alene paa „blaasten“ kan nu hvalfangerne i lang afstand kjende de enkelte arter. Saaledes blæser knølhvalen en ganske kort og bred (tyk) dampstraale. Finhvalens og blaahvalens blaast har mest indbyrdes lighed, men bla ahvalens er mere jevn og lig en høi dampstraale, medens finhvalens først er ganske tynd og opad breder sig ud til en fontæn elignende størsky. Seihvalen og vaagehvalen kjendes allerede ved den ringere størrelse ud fra de ovennærnte tre hvalarter.

Da saaledes enhver hvalfanger allerede paa lang afstand kan kjende en finhval fra de andre hvaler, synes mig den mest praktiske maade at frede finhvalen paa at maatte være den, at det i sin almindelighed forby des at gjøre jagt paa $0 \mathrm{~g}$ dræbe den i det nævnte tidsrum.

Mit forslag gaar derfor ud paa, at lovens $\S 1$ (se ovenfor) omforandres saaledes:

„Det skal være forbudt at jage, anskyde, dræbe eller ilandbringe finhval, (Balænoptera museulus), i tidsrummet fra 1 ste januar til udgangen af mai."

Foruden at lovens nuværende $\S 1$ saaledes vilde bortfalde, vilde ogsaa den paa dette lovbud byggede plakat af 17 de december 1896 blive 
at ophæve. Ved den nye lovens $\S 1$ vilde forbudet mod fangst af andre hvalarter indenfor milegrænsen i samme tidsrum blive hævet, og $\S 4$, der ligesom lovens øvrige paragrafer skulde blive staaende, vilde da blive den bestemmelse, som baade paa og udenfor søterritoriet skulde hindre kollisionen mellem fiskere $o g$ hvalfangere.

Andre frem-

Som man har seet, vil den ovenfor foreslaaede bestemmelse bidrage tidsopgaver. til at frede finhvalbestanden, idet et ikke ubetydeligt antal, der skydes før 1ste juni, vil blive skaanet. De forslag, som har været fremsat i tidens løb, har imidlertid været væsentlig videregaaende og været saaledes formede, at de stillede os overfor den eventualitet, at hvalfangsten umuliggjordes.

Vil nu den af mig foreslaaede bestemmelse være tilstrækkelig til frem igjennem tiden at bevare hvalbestanden? Dette spørgsmaal kan lrun fyldestgjorende besvares, naar der foreligger væsentlig større erfaringer om disse ting, end man for øieblikket har.

Fra statens side bør man derfor efter min mening ogsaa i fremtiden have sin opmerksomhed henvendt paa spørgsmaalet om forholdet mellem fiskeri og hralfangst paa den ene side $o g$ spørgsmaalet, om hvalfangsten kan reguleres som en varig indtægtskilde paa den anden side.

For at løse de opgaver, som disse spørosmaal indebærer, maa man arbeide videre med studiet af hvalfangsten $0 g$ desuden efterhaanden træffe de bestemmelser, som kan give staten anledning til paa et senere tidspunkt at have mest mulig frie hænder til at træffe den ordning, som senere erfaringer viser at være den ønskelige.

Af hensyn hertil synes det mig, at oprettelsen af nye etablissementer og gjenoptagelse af drift ved nedlagte etablissementer, indtil mere erfaringer om hvalfangstens videre udvikling og hvalbestandens aftagen foreligger, ikke bør tillades, ialfald ikke uden administrationens samtykke.

Forbud mod anlæg af nye etablissementer kan selvfølgelig gives, uden at nogens ret gaaes for nær, om det ansees at være i samfundets interesse.

Forbud mod gjenoptagelse af drift af et allerede nedlagt etablissement eller et etablissement, der i fremtiden nedlægges, kan billigvis kun gives, saaledes at en bestemt frist regnes fra lovens ikrafttrædelse. Mindre frist end et aar bør der formentlig ikke være tale om, men saa kort frist kan visselig sættes, om end dette maa siges at være en sær- 
deles streng fremgangsmaade (jevnfør bygningslov af 27 de juli 1896, $\S$ 70, hvor det heder: "Gjenopførelse af afbrændt anlæg af ovennævnte slags, deriblandt trankogeri, fabrik for tilvirkning af lim, kemiske præparater og gjødningsstoffe) samt gjenoptagelse af saadant, naar det har været nedlagt 1 aar, betragtes som nyt anlæg. "

Ved bestemmelser gaaende i denne retning vilde staten faa i sin haand efterhaanden at kunne regulere denne bedrift $0 \mathrm{~g}$ søge at lede den i det rette spor, saafremt det skulde vise sig, at hvalfangstens fortsættelse yderligere skulde formindske bestanden trods den ovenfor foreslaaede fredningsbestemmelse. Bestandens aftagen vilde nemlig isaafald vistnok ligesom tidligere have tilfølge nedlæggelse af etablissementer, og der vilde herunder være anledning til at indtage en afventende holdning overfor det hele spørgsmaal i fremtiden og samtidig indvinde nye erfaringer til de store strids spørgsmaals bedømmelse.

Indtil videre bør man da efter min mening med størst mulig energi optage til overveielse det spørgsmaal, hvad der kan gjøres for direkte at ophjælpe fiskerierne. I det følgende kapitel skal jeg søge at udvikle de synspunkter for et saadant arbeide, jeg under mine undersøgelser nordpaa har kunnet erhverve mig. 


\section{Syvende kapitel. \\ Hvilke maal bør arbeidet for det nordlige Norges fiskerier stille sig?}

Dybere aarsager til antihralfangstbevæe elsen.
Det forslag til løsning af stridsspørgsmaalene mellem fiskeri og hralfangst, som jeg i det foregaaende kapitel har fremsat og motiveret, stemmer forsaavidt overens med det væsentlige i de af fiskerne oprindelig stillede $\mathrm{klav}$, som det søger at forebygge hvalfangstens indflydelse paa fisket under loddemassernes indsig og desuden tilsigter bevarelse af den hvalart, som har betydning for fiskerierne. Derimod stiller det sig i modsætning til de krav om absolut forbud af hvalfangsten, som i de senere tider er fremsat, og det fordi jeg ikke har kunnet tillægge hvalfangsten de vidtrækkende følger for fiskeribedriften, som den almindelig. af fisk erbefolkningen og dennes talsmænd paastaaes at have.

For enhrer undersøger, som paa et eller flere punkter stiller sig i modsætning til en saa sterk og energisk bevægelse som anti-hvalfangstberægelsen, vil det føles som en pligt at begrunde sit standpunkt ikke alene saaledes, at han rent saglig fremholder motiverne for sine egne forslag, men ogsaa paa den maade, at han søger at klargjøre de dybere aarsager og grunde for de forslag, om hvilke opinionen samler sig, men som han selv ikke kan tiltræde.

Hvallovkommissionen af 1890 formaaede ikke at give anden forklaring for berægelsens omfang og størrelse end den, at opinionen var kunstig lavet af en særdeles paagaaende og mere eller mindre aabent arbeidende agitation. Den siger herom: „Komiteen har fundet støtte for sin opfatning i den almindelige mening, som nævner uden forbehold de 5-6 mænds navne, der væsentlig har bidraget til at holde hvalspørgsmaalet oppe samt til, at stedse større og større fordringer er blevne opstillede. Ogsaa disse fordringer bærer i og for sig agitationens 
kjendemerke, idet de simpelthen afhugger den gordiske knude, uden engang at forsøge paa at løse den."

Uden at finde andet end rene politibestemmelser nødvendige fandt kommissionen hermed bevægelsen forklaret. Herfor er den tildels blevet meget strengt bedømt, idet man har bedømt den alene efter de udtalte meninger og ikke efter det arbeide, den har præsteret. Efter min mening bør det udtales, at kommissionen ved sin ovennævnte forklaring ikke har formaaet at naa frem til bevægelsens dybeste aarsag og realitet. Til dens forsvar bør det dog fremhæves, at bevægelsen har ytret sig i former, som har vanskeliggjort spørgsmaalenes løsning.

Bevægelsens talsmænd har jevnlig fremstillet fiskernes meninger i sprogets allersterkeste udtryk, hvorved tilsidst offentligheden - og særlig modstanderne - er bleven meget mindre modtagelige for de fremførte argumenter.

Efterhaanden har enkelte grupper af fiskerne $0 \mathrm{~g}$ deres talsmænd tilskrevet hvalen den hovedsagelige rolle $\mathrm{i}$ alt, hvad der skeede og havde betydning i fiskeribedriften, og følgen heraf har været, at den heri liggende aabenbare overdrivelse har været anvendt som et middel til at bevise, at fiskernes syn paa sagen i det hele savnede enhver berettigelse.

Under disse omstændigheder gjælder det at komme tilbage til en noget roligere tankegang, saafremt lykkeligere tilstande i det hele skal kunne opnaaes, og særlig gjælder det at enes om, hvad der maa foretages for at bedre de onder, som man paa forhaand tør antage er tilstede, hvor en befolkning viser sig at kunne samles til en saa sterk bevægelse.

Af vor fremstilling af fiskerierne fremgik det, at medens statistikken ingen nedgang i fangstudbyttet kunde paavise, viste de foreliggende meddelelser om selve bedriften i de sidste 30 aar store forandringer. Disse Omlægning af fiskeribedriften. forandringer stemmer ganske med de af fiskerne fremholdte paastande, at bedriften er gaaet over fra et juksefiske til et linefiske, fra en bedrift med forholdsvis smaa baade og billigt udstyr af redskaber, til større og større baade og fartøier med store udgifter til redskaber og agn. Dette øver den største indflydelse paa fiskernes livsvilkaar og kan utvivlsomt føles for hver eneste mands vedkommende - og det langt mere end vekslingerne fra aar til aar i de opfiskede kvanta. Ikke alene stiller det den enkelte overfor store vanskeligheder med kapital til udrustning og forberedelser til hvert eneste fiske, men det betinger en hel anden levevis. Det aarhundreder gamle otringfiske er i Finmarken beregnet paa at kunne drives inden et forholdsvis begrænset farvand det hele aar. Og maaske intetsteds langs den norske kyst har dette fiske kunnet holde sig saalænge, fordi der under Finmarkskysten i store dele af 
aaret er særdeles rigt med fisk. Hjemmebefolkningen i Finmarken driver derfor i overveiende grad fiske fra otringer.

Langs store dele af landet har der forlængst skeet forandringer i denne driftsmaade, som jo fra Søndmør til Finmarkem var den oprindelige. I Nordlands og Tromsø amt har man anskaffet sig halvdækkede, dækkede sneseilsfartøier,e skøiter, dampskibe, og de, som har slige fangstredskaber, de driver i regelen fisket mere eller mindre aaret rundt paa den maade, at de flytter fra sted til sted. Saaledes tilbringer mange

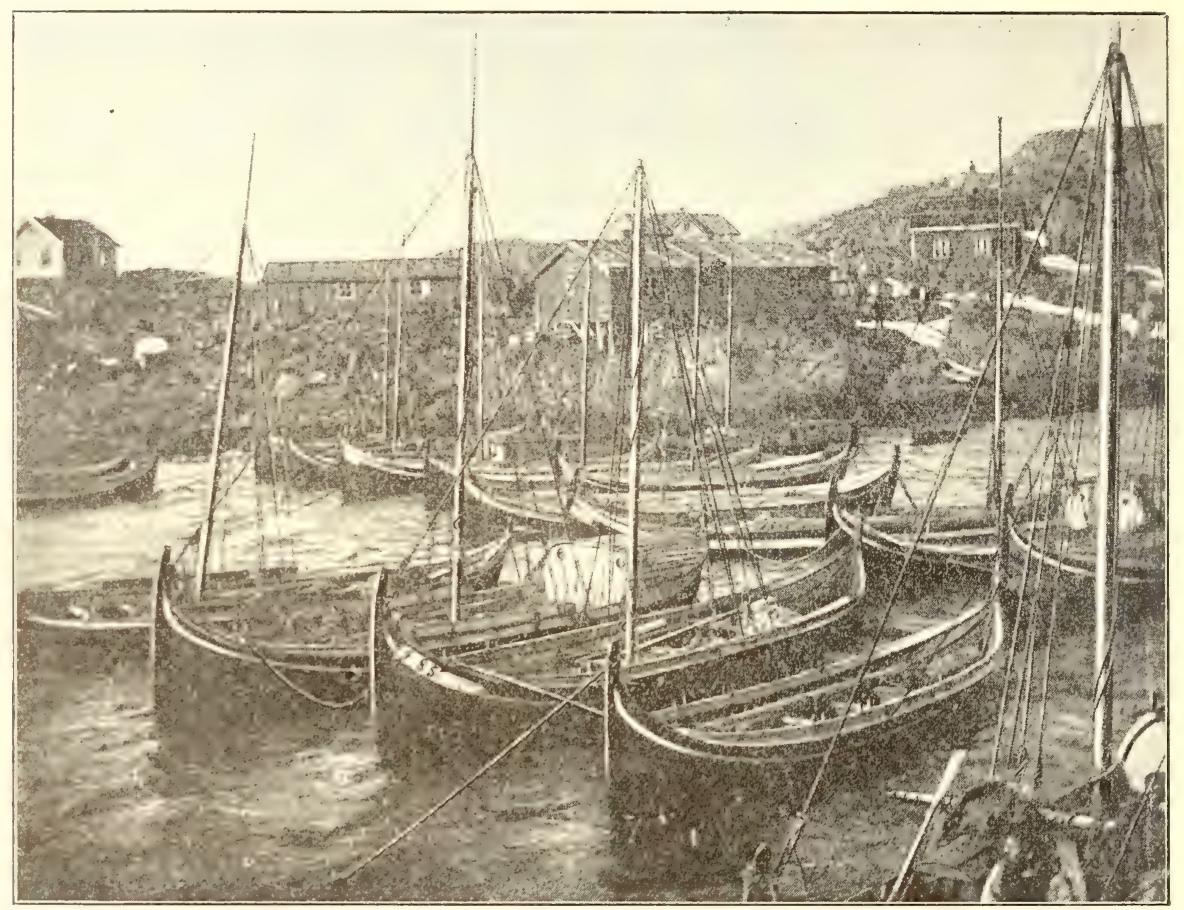

Fig. 72. viringer og rorboder pad tiskevær i Finmarken.

skreifisketiden paa bankerne udenfor Senjen, derfra drager de til Finmarksfisket, derfra til Nordland og Tromsø, hvor de enten driver bankfiske efter længe, deltager i seifisket eller driver efter sild i Vestfjorden og det langt udover høsten. Nogle reiser endog til Søndmør. Deres fiskefelt omfatter hele det nordligste Norge, og de er fiskere en stor del af aaret.

Hvad forandringer dette medfører, vil man vanskelig forstaa uden at kjende bedriften langs hele kysten helt fra Søndmør til Finmarken. Kjendskabet til denne kyststrækning vil imidlertid bringe forstaaelsen af, at man i øieblikket staar overfor en af de største omlægninger af en driftsmaade, som vort land har seet i den seneste tid, den kan forsaavidt 
sammenlignes med overgangen fra seil til damp inden vor handelsflaade, skjønt det i fiskeribedriften jo ikke dreier sig om saa store kapitaler samlet paa en mands haand som i handelsflaaden.

Ligesom nu omlægningen fra seil til damp i vor handelsflaade vakte stor modstand, misstemning ja helt kriselignende tilstande, saaledes staar vi nu i fiskeribedriften overfor lignende forhold.

Det gamle materiel passer kun delvis, det er uskikket for at udnytte de nye fangstfelter og driftsmaader, der er en særdeles følelig man- • gel paa kapital, alle de mange indretninger, som kræves til en fuld og rationel udnyttelse af de større forhold, som nye driftsmaader fører med sig, - og da fremforalt hensigtsmæssige kommunikationer - mangler. Hertil kommer, at selve den nye driftsmaade endnu kun delvis er saa gjennemarbeidet, at man helt ud ved, hvorledes man skal indrette sig og sysselsætte det nye materiel, man møisommelig har anskaffet sig. Og derfor hviler der en vis usikkerhed ogsaa over de nye methoder. Saaledes ved man saavel i Finmarken som i Nordland kun delvis, hvad man egentlig skal tage sig til om sommeren, særlig fordi man har slette kommunikationer. Paa de steder af kysten derimod, hvor man som i Aalesund har kunnet løse det vanskelige spørgsmaal, at sysselsætte sine fartøier aaret rundt ved at gaa fra den ene bedrift til den anden, har opsvinget været enestaaende $\mathrm{i}$ vore fiskeriers historie.

Følelsen af opgavernes store vanskeligheder har vakt den dybe misstemning, som altid indtræder, hvor man ikke kan arbeide sig frem, særlig har dette været føleligt paa de dele af kysten, hvor man har seet nærliggende distrikter gjøre de bedste fremskridt. Saadanne steder er det Søndenfjeldske kanske, særlig Østlandet og Finmarken. Søndenfjelds har man seet svenskerne drive bankfiske, danskerne seile med fisk til Norge, tyskerne og engelskmændene drive havfiske udenfor kysten. Til Finmarken kommer nordlændingerne og andre fiskere, hvoraf mange har de nyere $0 \mathrm{~g}$ bedre baadtyper, $\mathrm{og}$ disse sidste viser sig særlig mere fordelagtige, naar fisket forløber som i de senere aar, da fisken fra at være tilstede i de største masser f. eks. ved Østfinmarken pludselig efter indtrædende langvarige storme og efter de store kobbemassers tilstedekomst - totalt forsvinder fra store kyststrækninger. De baade, som ikke er sødygtige nok til straks at flytte med de vandrende fiskemasser, er da henvist til at ligge ledige i havn, medens telegrafen ofte kan melde om glimrende fangster andetsteds fra. Saaledes hænder det ofte, at der efter kobbeindsig længst øst, Varangerfjorden og Vardø, er svart for fisk der, medens der er udmerket fiske f. eks. fra Mehavn. At dette fremkalder triste og bitre stemninger hos den del af befolkningen, som føler sin virksomhed hæmmet i den tid af aaret, da grundlaget for hele aarsindtægten skulde lægges, er ikke vanskeligt at forstaa. 
Ja man kan endog forstaa, at det kan fremkalde bitre følelser overfor dem, hvis arbeide har mere held med sig, saameget mere, som disse i regelen ikke er hjemmehørende og trods dette høster det rigeste udbytte af de sparsomme herligheder, Finmarken byder paa.

Forestillin-

gen om

lykkeligere svundne tider.

Under disse forhold har forestillingen om lykkeligere svundne tider bragt det ønske til at vokse sig større og større, at de gamle driftsforhold maatte vende tilbage. Søndenfjelds har man tænkt tilbage paa de tider, da fjordene skal have været fulde af fisk, og man alene $i$ en liden baad kunde drive et tilstrækkeligt lønnende fiske, og man har troet at kunne faa saadanne tilstande til at vende tilbage ved at frede og formere den „fiskebestand“, som man troede saa yderlig formindsket af fiskeriet. I

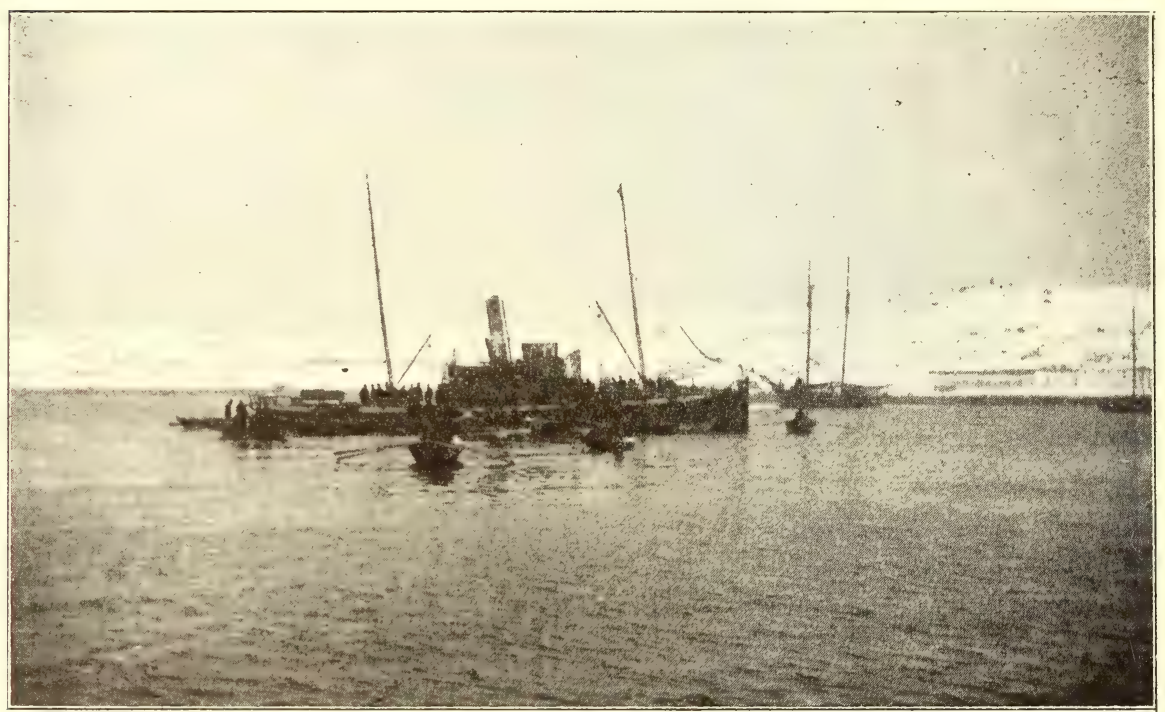

Fig. 73. Agndamper omgivet af fiskerbaade i Finmarken.

Finmarken har man ment ved forbud af hvalfangsten at kunne faa bedriften omlagt til juksefiske igjen.

Ved disse forestillinger er man imidlertid efter alt, hvad der foreligger til sagens bedømmelse, slaaet ind paa en feilagtig vei.

Søndenfjelds har der vistnok til regelmæssighed aldrig været det paradis, man tror at have tabt. Fjordene har vistnok altid med undtagelse af visse kortere dele af aaret $0 \mathrm{~g}$ enkelte særlig gunstige perioder været fattige; men de smaa fordringer til livet og de smaa markeder for varen har dengang havt meget lettere for at blive tilfredsstillede end nu. Og hvor priselig end befolkningens vilje er til at underkaste sig de strengeste forbudslove, saa er dette dog ikke den store vei til bedriftens ophjælp og udvikling. 
I Finmarken har altid loddefiskerierne været yderlig vekslende som fiskerierne i det nordlige Norge i det hele. Sammenlign de tidligere viste kurver for fangst- og værdiudbyttet. Den af hvallovkommissionen af 1890 udarbeidede historiske oversigt viser dette med afgjørende sikkerhed. Og allerede Petter Dass har kunnet synge:

Men ak! Den søhandel staar aldrig ved lav

Den har alt forkjeret og tager flux af,

Os havet sin rigdom nu nægter.

Her intet har vanket et aar eller ti,

Stor armod er landet geraaden udi

Formedelst mislingende føde.

$\mathrm{Al}^{\prime}$ hytter er raadned og gjelder nedkast,

Man ser der ei jægter, ei seile, ei mast,

Ret ligesom landet var øde.

Folkemængdens bevægelse taler ogsaa her et tydeligt sprog. I det 18de aarhundrede havde Finmarken kun en befolkning af 5000 mennesker.

I 1815 var der 7018 indbyggere

$\begin{array}{llll}-1835 & - & 10838 & -,- \\ -1865 & - & 16389 & - \\ - & - & - \\ -1875 & - & 24185 & -,- \\ -1900 & - & 32800 & -,-\end{array}$

Denne raske vekst af en befolkning, som i saa overveiende grad er henvist til at leve af fiskerierne, synes ikke at tyde paa en nedgang af selve bedriften. Der er nu flere fiskere i Finmarken, end der ved det forløbne aarhundredes begyndelse var indbyggere. Dette synes mig at bekræfte min opfatning, at det mere er det utilfredsstillende i driftsmaaden end i selve bedriften, som virker som et tryk paa befolkningens kamp for eksistentsen.

Lykkeligere tider kan derfor vistnok ikke opnaaes ved at ønske Arbeidet for de gamle tider tilbage, men ved at arbeide for kommende fremskridt.

Disse tanker har havt særdeles store vanskeligheder at kjæmpe tekniske fremskridt. med i Finmarken, dels paa grund af den her raadende mangel paa kapital til anskaffelse af mere kostbare farkoster, dels fordi farvandet i mange henseender er anderledes end havet udenfor den øvrige kyststrækning.

Jeg har ofte hørt den paastand fremsat, at fiskeforekomsternes eiendommelighed samt farvandets og veirligets beskaffenhed i Finmarken er saadan, at det der ikke vilde kunne lønne sig at optage driftsmaaden med større og kostbarere farkoster. Det har været fremholdt, at der kun kan fiskes i nærheden af land og paa den nærmest dette liggende 
del af landbakken, $o g$ at her fisket med otringer er det mest økonomiske saavel under loddefisket som i sommertiden. Man har ment, at det er disse forhold, som er aarsaagen til, at et fiske med mere sødygtige fartøier ikke har udviklet sig der. Det er dette, som det først og fremst er af størst betydning at faa bragt paa det rene som grundlag for alle overveielser over, hvad der kan og bør gjøres for Finmarkens fiskere. Thi selv om mangelen paa kapital er noksaa følelig, har befolkningen dog ved udviklingen af sin sælfangst $0 \mathrm{~g}$ sit bankfiske efter haakjærring i fuldt maal bevist, baade at den formaar at vænne sig til det ulige mere slidsomme liv som havfisker i dette veirhaarde farvand, og at den ogsaa kan erhverve sig de dertil nødvendige midler. Alene de her næunte eksempler viser det ubegrundede $\mathrm{i}$ den mistillid til befolkningen i denne henseende, som af og til er kommen til syne.

Allerede de forhold, man kjender, berettiger efter min mening til den slutning, at mere sødygtige fartøier vil vise sig mere lønnende for befolkningen $o g$ saaledes kunne hæve dennes kaar. Under loddefisket er det saaledes utvivlsomt, at det er fordelagtigt med sødygtige baade og fartøier at kunne flytte langs den aabne og veirhaarde kyst og at søge fisken længer ude paa landbakken, og særlig har dette vist sig fordelagtigt i de senere aar, da fiskens indsig dels ikke har naaet saa nær landet, dels har forladt hele dele af kysten under de indtrufne kobbeindvandringer. I de sødygtige farkoster har man derfor et middel - ja det bedste $o g$ muligens eneste middel til at overvinde de vekslinger $\mathrm{i}$ fisket, som mægtige $o g$ endnu lidet forstaaede naturforhold medfører.

Men ogsaa senere paa aaret er der al grund til at anse det som afgjort, at de sødygtigere baade vil skaffe sin eier større indtægt. Foruden at veirforhold ogsaa da spiller en stor rolle, har man udenfor kysten en række banker, som giver begrundet haab om fremtidsmulighed for et bankfiske. I det foregaaende har vi skildret, hvorledes de af fiskeriinspektør SøRENsEN udførte fiskeforsøg paa den saakaldte østbanke (øst om Vardø) gav meget gode resultater, ligesaa at det lykkedes „Michael Sars" paa flere steder i Østhavet at finde betydelige mængder af fisk, endvidere at den russiske undersøgelsesekspedition gjentagende har paavist rige forekomster af fisk $\mathrm{i}$ havet nordost om Østfinmarken. Ogsaa udenfor Vestfinmarken og Tromsø amt findes der en stor række banker, som giver de bedste forhaabninger i denne henseende.

Sødygtigere farkoster gjør det ogsaa muligt for finmarksfiskeren at deltage $i$ fisket paa andre felter end i hans hjemstavn, ligesom nordlændingen besøger Finmarken $\mathrm{i}$ den for fisket gunstigste tid af aaret. I selve driftsmaaden ligger der ogsaa for de større farkoster store fordele, idet disse ved anvendelsen af doryerne kan bruge langt større redskabs- 
masser pr. mand og derved faa større udbytte, selv om man fisker paa samme sted, som de aabne baade.

Som eksempel paa, hvad en god skøite kan udrette, kan anføres hvad hr. ЈАков Andersen, Honningsvaag, skriver i Fiskeritidende (3die hefte 1902): „Nu ihøst, da mange folk har sat livet til paa søen under fisket, bliver man saa meget mere taknemmelig, naar man er hjulpen til en farkost ${ }^{1}$ ), som er saa livssikker som „Fremad“, og medens der klages over feilslaget fiske, kan jeg berette om det modsatte.

I det aar, som gik, tjente „Fremad“ kr. 10000 brutto for hele mandskabet. Beløbet fremkommer saaledes:

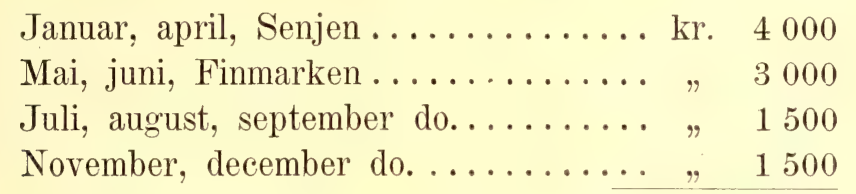

kr. 10000

Fordelingen af dette beløb har været noget forskjelligt, eftersom mandskabet har været stort til, saa "Fremad" for sin del har kun 2000 kroner og de folk, som har været med hele aaret, 1000 kroner. Aaret 1900 var resultatet om muligt endnu bedre. Dertil har vi med „Fremad" indslæbt mange baade under delvis farefulde forhold. Dette er da resultatet af den hjælp, jeg fik for at anskaffe mig en god farkosi, og jeg mener, at veien herved er vist, hvordan man bør hjælpe fiskerne heroppe til mere livssikker bedrift og bedre økonomisk udkomme."

Som man ser, har dette fartøi arbeidet saavel inden Tromsø amt som i Finmarken, og i det sidste distrikt hele tiden fra mai-december. Imidlertid bør man vistnok ikke være blind for, at ophjælpen af fiskerierne vil frembyde store vanskeligheder i Finmarken. I den tid, jeg med „Michael Sars“ undersøgte Finmarkshavet, søgte jeg mest muligt at tilveiebringe materiale til udarbeidelsen af en plan for fremtidige arbeider med det maal for at skaffe mere viden om, hvorledes havfiske med større farkoster kan drives i Finmarken. I tilslutning til mine $0 \mathrm{~g}$ tidligere erfaringer (som f. eks. hr. fiskeriinspektør SøkEnsens fra Østbanken) er der i disse dage igangsat et større anlagt forsøg paa at faa oversigt over, hvad en prøvedrift i Østfinmarken med en vel udrustet og tidsmæssig linedamper kan udrette paa de ovenfor omtalte banker ud for Østfinmarken. I sit budgetforslag for kommende termin (1903-1904) har fiskeristyrelsen endvidere foreslaaet lignende undersøgelser foretagne ud

1) Hr. Andersen erholdt hjælp til at anskaffe en skøite efter Colin Archer typen af "Selskabet for de norske Fiskeriers Fremme", Bergen. 
for Vestfinmarken ogsaa med en linedamper. Man har herved troet at kunne opnaa i det korteste tidsrum at faa mest mulig oversigt over, hvor der bedst kan arbeides med sommerfiske i det hele - ogsaa udenfor de felter nær land, som fiskerne allerede kjender.

Den forhaabning, som jeg ved min deltagelse i udarbeidelsen af disse forslag har havt, har været den, at man, naar resultaterne af forsøgene forelaa, vilde være istand til paa grundlag af et stort, sikkert materiale at optage til drøftelse det store spørgsmaal: Hvorledes skal man bedst hjælpe til, at en bedrift med bedre redskaber og fartøier kommer igang - eller paa glid i Finmarken?

Det er da min tro, at tiden vil være inde til paa bedste maade at hjælpe folk til at komme over den uvished og uklarhed over, hvorledes bedriften bedst bør lægges an, som man nu kan føle er saa fremherskende. Det vil da vistnok være klart, at det fremtidige arbeide ikke vil burde fortsætte med linedampere som de første orienterende forsøg, som nu er igangsatte af den grund, at en saadan damper kan overfare den største strækning. Dət fremtidige arbeide maa have til maal at sætte igang prøvedrifter passende for selve befolkningen.

Der har været særdeles meget talt om oprettelsen af et eget laanefond for Finmarken i den tanke, at de i mange henseender eiendommelige forhold der — blandt andet $\mathrm{og}$ særlig mangelen af kapital — var det, som fortrinsvis g.jorde fiskeriernes opkomst umulig med de midler bl. a. laanefond, som af staten er oprettet til det hele lands fiskeriers fremme. Man har fordret laan paa langt lempeligere vilkaar, end de andre laan giver, saaledes har man udtalt nødvendigheden af, at fiskerne fik et laan svarende omtrent til hele fartøiets kostende, at laanet gaves til lave renter og at staten gav laanet uden garanti af kautionister. Jeg har for min del stor sympathi for - ja jeg anser det for at være en nødvendighed, at der fra statens side gjøres, hvad der er muligt, for at ophjælpe Finmarkens befolkning, og for mig staar det usedvanlige i disse forslag i og for sig ikke som nogen hindring for, at de fremmes. Derimod staar det for mig som tvivlsomt, om disse forslag om oprettelsen af et permanent laanefond paa andre betingelser end dem, som gjælder for det øvrige land, er en foranstaltning, der er nødvendig eller et rigtigt udtryk for de vanskeligheder, med hvilke Finmarkens fiskere nu har at kjæmpe. Idet jeg paany minder om, at man i Finmarken har formaaet at skabe en bankfiskerflaade for haakjærringfiske $0 \mathrm{~g}$ sælfangst, udtaler jeg som min tro, at det fremfor alt gjælder ved eksemplets magt at faa igang den samme udvikling, som har begyndt saa mange andre steder paa vor kyst, og at vise, at dette er muligt. Saadanne fremskridt kommer kun igang ved erfaring om, at fremskridt kan gjøres, og hertil kræves forsøg og atter forsøg. Paa grund af opgavens størrelse mener jeg, at kraftige 
forsøg bør gjøres og for mig staar det saadan, at følgende plan er den mest anbefalelsesværdige:

Ved at give laan paa gunstige betingelser til et større antal fiskere Forslag til skaffer staten disse gode skøiter, mod at de aarlig afgiver beretning efter en nærmere udarbeidet plan for sin bedrift i det forløbne aar. Disse belaan til retninger offentliggjøres, og et beløb gives aarlig til bidrag for de dygtigste til forsøg paa felter udenfor de almindelige.

Ved en saadan foranstaltning vil opnaaes, at man faar gjort en stor mængde forsøg paa, hvorledes sødygtige fartøier kan klare sig i Finmarkshavet, og at disse forsøgs resultater blir bekjendt for alle. Naar det da ved de vundne erfaringer almindelig er konstateret, hvad der er at gjøre, kan sagen optages til fornyet overveielse, uden at staten er bunden, som tilfældet f. eks. er med et laanefond, der stadig giver nye laan ud. Forhaabentlig vil det vise sig, at befolkningen efter forsøgets afslutning kan fremme sin bedrifts videre udvikling ved hjælp af de almindelige laanefond. Et saadant forsøg vil ogsaa, selv om det lægges noksaa stort an, falde langt billigere og indvinde langt mere erfaring end almindelige fiskeforsøg, naar først saadanne er gjort saalangt, at en flaade af gode fartøier vover at begive sig udenfor de gamle felter. Det er at haabe, at vi i nær fremtid vil være saa langt i Finmarken.

Et forsøg som det ovenfor skitserede vil selvfølgelig maatte gjennemarbeides i alle detailler før et bestemt forslag fremsættes. Jeg vil ikke her fremsætte noget forslag, da denne bogs hensigt kun er i sin almindelighed at antyde de maal og veie, som for mig staar som de rette. Jeg vil dog ikke undlade rent eksempelvis og uden dermed netop at udtale noget bestemt vedkommende beløbenes størrelse at omtale, hvorledes et saadant forslag vilde stille sig. Jeg vil da nævne et eksempel, der synes mig at vise, hvorledes et forsøg, selv om det lagdes an i stor maalestok, vil kunne gjøres med rimelige omkostninger.

Tænker man sig, at staten satte 100 gode skøiter hver til en pris af 4000 kroner igang paa slig en prøvedrift, vilde altsaa statens udlæg hermed blive kr. 400000 ; hvis man forudsætter, at fiskerne selv f. eks. betaler $1 / 8 \mathrm{kr}$. 350000 . Lad os imidlertid eksempelvis forudsætte kr. 400000 . Efter $3 \frac{1}{2} \%$ rente vilde dette udlæg koste staten kr. 14000 aarlig; forlanger staten af fiskerne $2 \%$ rente blir det aarlige rentetab kr. 6000.00. Assurerer endvidere staten samtlige fartøier selv til fuld værdi mod at afkræve fiskerne $3 \%$, vil den antagelig herved (efter tidligere erfaringer at dømme) tabe ca. $1 \%$ af beløbet $(\mathrm{kr} .400000)=4000 \mathrm{kr}$. Statens aarlige tab skulde altsaa blive kr. 10000 i det første aar, i de følgende aar vilde dette ved afdrag af 
laanene formindskes. Tænker man sig laanet tilbagebetalt i 10 aar, vilde statens tab i de 10 aar stille sig saaledes:

\begin{tabular}{|c|c|c|c|c|}
\hline Straks & & $\begin{array}{l}\text { Rentetab } \\
6000 \mathrm{kr} .\end{array}$ & $\begin{array}{c}\text { Assurancetab } \\
4000\end{array}$ & $\begin{array}{c}\text { Tilsammen } \\
10000\end{array}$ \\
\hline Efter & 1 aar & 5400 & 4000 & 9400 \\
\hline - & $2 \%$ & 4800 & 4000 & 8800 \\
\hline - & 3 & 4200 & 4000 & 8200 \\
\hline - & 4 & 3600 & 4000 & 7600 \\
\hline 一 & 5 & 3000 & 4000 & 7000 \\
\hline - & 6 & 2400 & 4000 & 6400 \\
\hline- & 7 & 1800 & 4000 & 5800 \\
\hline - & 8 & 1200 & 4000 & 5200 \\
\hline - & 9 & 600 & 4000 & 4700 \\
\hline- & 10 & Intet & & 73000 \\
\hline
\end{tabular}

Altsaa gjennemsnitlig kr. 7300 i hvert af de $10 \mathrm{aar}^{1}$ ).

Som man ser, er dette ikke særdeles afskrækkende beløb, selv om man hertil lægger et beløb af kr. 5000 aarlig til betaling til de dygtigste fartøier for at prøve sig frem paa nye felter.

Ted et saadant forsøg vilde man opnaa:

1) at faa gjort en hel masse forsøg $0 \mathrm{~g}$ vinde erfaringer, der kom almenheden tilgode.

2) at staten havde fuld frihed til at fatte beslutning om, hvad den videre vilde gjøre efter forsøgets afslutning.

3) at skafie 5-700 mand tidsmæssige fartøier med engang, hvilke fartøier desuden, saafremt forsøget mod al formodning ikke skulde vise lovende resultater, var anvendelige andetsteds $\mathrm{i}$ landet.

Det er min tro, at denne maade at hjælpe paa forholdene er den rigtige; selve forslaget bør selvfølgelig drøftes fra mange sider, før det i tilfælde iverksættes. Saaledes vil meget afhænge af, om foretagendet administreres godt. Endvidere vil der være tvivl og meningsforskjel om, hvilken type af fartøier der bør vælges, særlig hvilken størrelse. Paa Aalesundskanten er man kommen til det resultat, at man finder kravelbyggede skøiter af ca. $4000 \mathrm{kr}$. kostende og 15-20 tons (brutto) drægtighed mest regningssvarende. Med disse baade seiles der fra Aalesund baade til Storeggen og henimod Shetland, saa det forlængst er bevist, at der med dem kan drives bankfiske i store afstande fra land.

Som et bevis paa, hvor særdeles nødvendig det er at søge at finde

1) Ved denne beregning maa merkes, at intet hensyn er taget til rentesrente af den grund, at overslaget $i$ det hele nu ikke lader sig udarbeide med nøiagtighed, hvilket alene vil indstes deraf, at det hele jo vil være afhæugigt af renten til det jaan, staten selv maa optage. 
den rette form for, hvorledes spørgsmaalet om havfiskets opkomst i Finmarken skal løses, skal jeg her - til alt det øvrige, som i denne bog er anført - kun give følgende oversigt over, i hvilken grad det gamle laanefond i februar iaar var benyttet i forskjellige amter nordenfor Stat.

Romsdal havde 28 laan, tilsammen $177,730 \mathrm{kr}$.

$\begin{array}{lrrllll}\text { Nordland } & - & 75 & - & - & 206,393 & - \\ \text { Troms } \emptyset \text { amt } & - & 106 & - & - & 125,200 & - \\ \text { Finmarken } & - & 13 & - & - & 22,750 & -\end{array}$

De sødygtige farkoster er efter min mening ogsaa det eneste mid- Kan kobbedel, med hvilket kobbeindvandringerne kan bekjæmpes. Jeg har gjen-vandringerne tagende været vidne til. $\mathrm{c} g$ ved studium af amtmandstelegrammerne kan en- bekjæmpes? hver overbevise sig om, at der kan være glimrende fiske længer vest, naar Østfinmarken herjes af kobben. Det staar da vistnok desværre ikke i menneskelig magt at gjøre andet end at flytte med fisken.

Tidligere har vi skildret kobbens liv og vandringer, endvidere har vi drøftet den fremsatte tanke, at kobbeindsigene skyldtes hvalfangsten. Vi fandt den fremsatte paastand, at kobbeindsigenes størrelse afhang af mængden af spækhugger og denne igjen af mængden af bardehval usandsynlig. Hele theorien er bygget paa den paastand, at spækhuggeren lever af hval og derfor er aftaget $i$ antal med hvalbestanden. Man kunde imidlertid da i bevisførselen lige saa godt gaa ud fra, at spækhuggeren lever af kobber (det maatte den vel gjøre, om den skulde kunne jage disse). Men hvorfor er da spækhuggeren aftaget, naar kobben er tiltaget? Disse enkle overveielser viser, at der ikke kan trækkes saadanne theoretiserende slutninger om levende væseners vandringer. For mig staar det derfor saa, at hvad man end mener om hvalfangsten, paa kobbeindsigene har den ingen indflydelse havt. Alt taler for, at isforholdene er den store vekslende faktor for kobbens vandringer. Langs isen lever kobben hele aaret rundt $o g$ af denne bringes den under sin vandring ud af Hvidehavet det ene aar nærmere Norges kyst end det andet. I mai i aar indløb fra Amtmanden til Fiskeristyrelsen følgende telegram: „Opsynsbetjenten Grænse-Jakobselv indberetter: Russiske politibaad telegraferer: Polarisen 1 mil af land ved Teriberka og lille Renø, Murmankysten. Overalt paa isen store masser af kobbe". Naar kobben saeledes føres saa nær torskemasserne under Murmankysten eller Norges kyst følger den en kortere tid torske- og loddemasserne for igjen at følge disse sidste op mod polarisen.

Kun naar kobben befinder sig langs eller paa iskanten har det lykkedes at drive systematisk jagt paa den. Saadan jagt drives, som vi har seet ovenfor, af russerne i Hvidehavet, af norske fangstfartøjer i Østisen og Vestisen (Jan Mayen feltet). Man har talt om at ødelægge de indvandrende kobbemasser langs Finmarkskysten, og der har i dette 
øiemed dels været foreslaaet at skyde paa dem med revolverkanoner, at sprøite petroleum mod stimerne etc. ete. Det eneste sted i verden, hvor sæl fanges fritsvømmende i vandet - altsaa ikke paa is eller land er saavidt mig bekjendt Behringshavet og østkysten af Stillehavet (Californiens kyst). Her drives pelagisk sælfangst (pelagic sealing) efter pelssælen i det tidsrum, da denne vandrer op mod de berømte pelssæløer i Behringshavet, hvor den kaster sine unger. Denne pelssælfangst har været underkastet særdeles indgaaende undersøgelser af en international (amerikansk-engelsk-russisk) kommission. For at overveie enhver mulighed for, at kobben kunde fanges langs Finmarkskysten har jeg henvendt mig til hr. professor d'ARCr Thomson, som fra engelsk side deltog i den

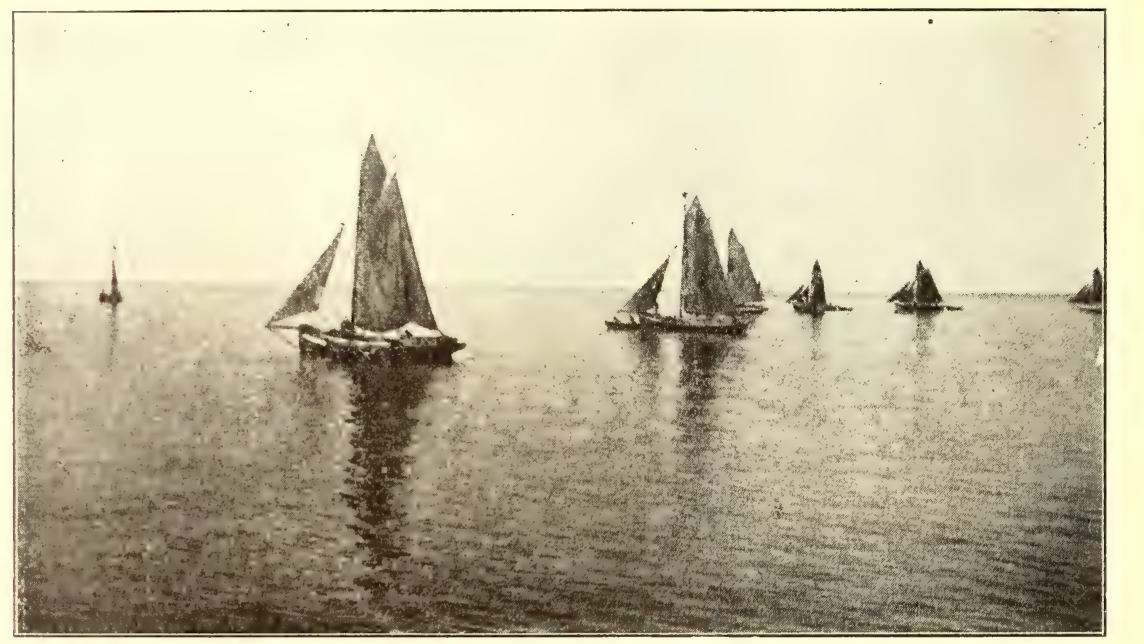

Fig. 74. Sneseilsbaade i Finmarken seiler ud fra fiskevær.

omtalte undersøgelse, $0 \mathrm{~g}$ anmodet ham om at meddele mig nærmere enkeltheder om, hvorledes den pelagiske sælfangst foregik, og at udtale sig om spørgsmaalet, om der kunde tænkes nogen mulighed for at øve indflydelse paa de store kobbestimer.

Af hr. d'ARcy Thomson's svarskrivelse skal jeg hidsætte følgende: „Fangst af sæl i aabent vand kan kun foregaa derved, at priserne paa pelssælens skind er saa høie; fangstmaaden er altfor dyr for kobben (Phoca groenlandica).

Den drives af et stort antal $(40-60)$ fartøier, af hvilke hvert har 12-20 kanoer, og disse kanoer sprede sig paa havet i et stort netverk. De bemandes mest af indianere, som bruge spyd (harpuner), og ved hjælp af disse faar de fat i næsten alle de dyr, de træffer. Et mindre antal bemandes af hvide mænd, som bruger riflen, men med dette vaaben 
mistes mange dyr; thi de, som kun saares, dukker og undslipper. Et fartøi regner, at 500 sæl i tre maaneder er udmærket fangst. Mænd.

Hver skonner har som regelen omkring 30 indianere og 10 hvide

Heraf tror jeg, at man vil se, at det at forfølge kobben (Phoca groenlandica) paa aaben havkyst vil koste mere end det er værd. Selvfølgelig kan man, hvis man kun vil dræbe dyrene uden at faa skindet, med riflen dræbe et større antal; thi jægeren i Behringshavet maa komme meget nær sælen, før han kan gaa løs paa at sikre sig dyret med sin harpun og klep, før dyret synker.

Men min personlige mening er den, at man ikke vilde kunne bevirke nogen større formindskelse af antallet af dyrene".

Mit indtryk af kobbemassernes størrelse er det, at forsøg paa at ødelægge eller skræmme dem i farvandet udenfor Finmarken vilde lede til skuffelser og ihvertfald ikke vilde faa nogen mærkbar indflydelse paa fiskeriernes udbytte. Det vilde da vistnok føre længer at støtte vor sælfangstflaade i Østisen; thi denne har allerede bevist, a t den kan drive en stor fangst langs iskanten.

Det gjælder vistnok her - som ved saa mange ting paa sjøen man maa indrette sig efter naturforholdene - man kan ikke forandre dem. Dygtigst er den, som bedst formaar at tilpasse sig forholdene og det vil i de fleste tilfælde den være, som har god nok farkost til at seile fra kobbemasserne og fiske, hvor der er fisk.

I det foregaaende har jeg fremhæret sødygtige baade som de vig- Eksport- og tigste af alle midler til at fremme en lykkeligere udvikling af forholdene $\mathrm{i}$ det nordligste Norge. I forbindelse hermed staar imidlertid en hel række omsæetningsforholdene. andre spørgsmaal af ikke mindre rækkevidde, saaledes eksportforholdene, omsætningen af varen ete. Under omtalen af det fiskeforsøg, som tidlig paa sommeren paa strækningen Trænen-Røst udførtes af dampskibet „Expres" nævntes, at fartøiet, trods at store mængder af fisk var tilstede, saa sig nødsaget til at slutte fisket paa grund af vanskelige omsætningsforhold. Ved samtaler med erfarne fiskedamperrhedere i Nordland har jeg faaet den overbevisning, at et sommerfiske som paa Aalesundskanten ikke lader sig oparbeide der, før man faar egne kommunikationer for fisken. De forbindelser, som man har, er jo vistnok $\mathrm{i}$ forhold til de store afstande gode, men passer dog ikke for udviklingen af en ferskfiskeksport, hvilket alene fremgaar af de smaa kvanta, som sendes f. eks. med vore hurtigruter. I det nordligste Norge blir derfor, som bekjendt, den meste fisk om sommeren solgt til russerne, som paa hele 
strækningen fra Tardø til Andenæs fylder havnene med sine kjøbefartøier. Torsk, hyse, lange, brosme, sei, kveite, svartkveite - alt sælges da til russerne, som salter det og indfører det frit til Archangelsk, medens norske fartøier, som maatte ønske at konkurrere i denne bedrift, maa betale indførselstold. Af det her fremsatte - mangelen paa vestgaaende skikkede ruter - det østlige markeds afstængthed for norske skibe og norsk foretagsomhed - vil man forstaa, under hvilke vanskelige forhold vareomsætningen $o g$ de, som lever af denne, har at kjæmpe, vanskeligheder, som fuldt kan sidestilles med den omlægning af fiskeribedriften, som vi ovenfor gjentagende har skildret.

Beklagelig nok har nu denne saavel for fiskere som for handelsmænd saa vanskelige stilling ført til et modsætningsforhold, som paa enkelte steder har flammet op til bitter strid med hadefulde følelser og udtalelser, - ord og stemninger, som særlig for den, som har seet lidt af sydligere landes herligheder og forskjelle i livsvilkaar, synes urimelige og beklagelige.

Det er klart, at denne misstemning ikke fremkaldes derved, at forskjellen mellem de forskjellige bedrifters mænd - f. eks. fiskere og handelsmænd - her nord er større end mange andre steder i verden, hror arbeidsforholdene er langt mere tilfredsstillende. Reiser man langs den norske kyst og lærer man fiskeribedriften og dens mænd paa vidt fra hinanden forskjellige steder at kjende, vil man faa et levende indtryk af, at der overalt, hror bedriften er i fremgang, hvor der er liv og udsigter til at komme ud af den haabløse stilstand, som har været saa kuende i lange tider, der er der ogsaa tilfredshed $0 \mathrm{~g}$ et langt bedre forhold $0 \mathrm{~g}$ samarbeide mellem de forskjellige bedrifters mænd, medens den dybe misstemning særlig er knyttet til de steder, hvor udviklingen har været mindst. Det samme kan man iagttage i andre lande. Hvor fiskeribedriften har gjennemgaaet en enestaaende rask udvikling, der finder man en kappelyst $0 g$ en iver og lyst over arbeidet, som slaar den imøde som et frisk pust, som første gang oplever det. Og at ikke dette er en forskjel paa folkene, det kan man se paa de steder af vor kyst, hvor arbeidet er i fremgang, og hvor folk kan arbeide sig op.

Disse ting kunde maaske synes saa selvindlysende, at de overhovedet ikke burde berøres, men de har dog neppe - særlig maaske inden den velmenende men ikke sagkyndige almenhed - været tilstrækkelig erkjendt og forstaaet. Derfor har ogsaa mangt et ønske, ytret under udbrud af misstemning hos fiskerbefolkningen, blevet opfattet som udtryk for dennes største arbeidsmaal. Disse er igjen af usagkyndige om end velmenende talsmænd sat i system og er siden fremkommet som befolkningens største programsager. Men herunder er det simple og enkle program at arbeide op fiskerierne ad de nærmest liggende veie blevet forsømt, dels fordi 
lidet krav er bleven fremsat om dette, dels fordi hertil fordredes en sagkundskab, som ikke var tilstede, hvor den vilde gavnet mest.

Det er ligesom, om der i dette som i saa meget andet har været organisation en vis modløshed - man har endnu ikke begyndt at haabe paa at af fiskerinterkunne tage sagen i sin egen haand og ved eget arbeide at komme fremesserne. over. Og derfor er ogsaa mange af de krav, som reises blandt fiskerne saa uorganiserede - saa lidet varetagende bedriftens allernærmeste tarv. Og. det tiltrods at det norske fiskeri i de senere aar har vokset op til en bedrift, som foregaar i fuldt saa stor maalestok og tæller ligesaa dygtige mænd inden sin midte, som nogen anden bedrift.

Det vilde være at ønske, at fiskeribedriftens mænd nordpaa vilde slutte sig sammen for gjennem den enighed som diskussion og samarbeide giver, at udforme de krav, som fiskeribedriften maa stille.

Jo hurtigere dette sker, desto mere kan man forebygge, at en skjæv udvikling lammer den evne, som baade staten og den enkelte maatte have til at paaskynde udviklingen. For de nordligste landsdele vil da vistnok disse ting staa som de vigtigste, paa hvis gjennemførelse al indflydelse maa samles: bedre fartøier, egne ruter for fisk, bedre ordning af omsætningsforholdene, organisation af de fiskeriinteresserede til under diskussion $\mathrm{og}$ samarbeide at varetage bedriftens eget tarv. 


\section{Tilføielser.}

1. Efterat de første fem kapitler allerede var trykt, har hr. HeLlandHANsen fra sit togt med chefsfartøiet „Heimdal" i aar medbragt et værdifuldt materiale af blæksprutter samlede fra bottlenosemaver paa det sydlige bottlenosefelt. Materialet er bearbeidet af hr. dr. Appestøf, der oplyser, at de fundne blæksprutter kan henføres til arten Gonatus fabricii og at de var af følgende størrelser:

2 ufuldstændige kapper paa 150-165 mm. længde, den virkelige længde sandsynligvis $200 \mathrm{~mm}$. da blandt resterne fandtes et løst skal af denne længde.

4 løse hoveder, 2 noget større, sandsynligvis tilhørende de to større kapperester $\mathrm{og}$ to mindre sandsynligvis tilhørende andre fundne kapperester af $175 \mathrm{~mm}$. længde. De største hoveder ea. $175 \mathrm{~mm}$. lange.

I forbindelse hermed kan oplyses, at jeg paa ekspedition med "Michael Sars" i marts 1901 (tde marts paa st. 25 a) i havet vest for Bjørnøen fandt en ganske liden Gonatus fabricii paa omtrent $9 \mathrm{~mm}$. kappelængde.

I august 1900 fandtes mellem Jan Mayen og Norge (st. 46 se beretn. for 1900) i en sejmave eksemplarer af Gonatus paa resp. 61 og $68 \mathrm{~mm}$. kappelængde. Denne art viser sig saaledes pelagisk i de forskjelligste størrelser og udgjør $\mathrm{i}$ alt fald en del af bottlenosens føde. Den er vel den art, som OHLin har benævnt onychotheutis.

"Akkeren" (Ommatostrephes todarus) fandtes ikke i bottlenosemaverne, men heraf vilde det være forhastet at slutte, at den ikke forekommer. Dr. Appelcøf oplyser at have fundet kjæver af akkeren i grindehvalen (globiocephalus melas).

2. Ved trykningen af tredie kapitel og de deri omtalte fiskefors $ø$ g kunde jeg kun meddele resultaterne af fangsten paa Malangsgrunden til og med marts maaned. Senere har jeg fra hr. fiskeriinspektør Sørensen erholdt meddelelse om, at der $\mathrm{i}$ april maaned alene af 10 dampskibe blev fisket 523,500 skrei. Hr. SøREnsen meddeler endvidere følgende: „Iaar var det jo væsentlig dampskibe, der drev fisket paa Malangsgrunden, og jeg antager, at man ikke regner disses fangst der for høi, naar man anslaar denne til $1^{1 / 2}$ million".

3. Efter trykningen af tredje og fjerde kapitel er jeg bleven opmerksom paa, at den her opstillede inddeling af fiskerierne og hvalerne er bleven mindre oversigtlig paa grund af lidet konsekvent gjennemførelse af det typografiske udstyr. I anledning oversigten henvises derfor til indholdsfortegnelsen. 
Uddrag af journaler for finhvalfangsten. 

Tabel nr. 1.

Opgave over fangst med dampskib „Skytten" af Tromsø aaret 1896.

\begin{tabular}{|c|c|c|c|c|c|c|}
\hline \multicolumn{2}{|c|}{ Dato } & $\frac{\overrightarrow{\widetilde{J}}}{\stackrel{\vec{J}}{\mathbb{T}}}$ & $\underset{\Xi}{\stackrel{\Xi \Xi}{E}}$ & है & 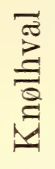 & Hvor skudt \\
\hline Februar & 28. & & & & 1 & 2 Mil NV af Ingø \\
\hline Marts & 2. & & & & 1 & Udfor \\
\hline - & 3. & & & & 1 & " \\
\hline- & 4. & & & & 1 & $"$ \\
\hline - & 6. & & & & 1 & $"$ \\
\hline - & 7. & & & & 1 & $"$ \\
\hline - & 12. & & & & 1 & ". Meget Knølhval saaes \\
\hline- & 14. & & & & 1 & $"$ Hjelmesø \\
\hline - & 16. & & 1 & & 1 & $" \quad$ Ingø \\
\hline - & 17. & & & & 1 &., \\
\hline - & 20. & & & & 1 & "Sørøen \\
\hline - & 21. & & 1 & & & $1^{1 / 2}$ mil nord for Hjelmesø \\
\hline - & 23. & & & & 1 & $3 \quad " \quad \mathrm{NV} \quad-$ Ingø \\
\hline - & 24. & & & & 1 & $1^{1} / 2 \quad "$ udfor Sørøen \\
\hline - & 25. & & & & 1 & $1^{1 / 4} \quad " \quad " \quad "$ \\
\hline - & 30. & & 2 & & & Udfor 'Torsvaag' \\
\hline April & 10. & & & & 1 & $" \quad$ Ingø \\
\hline 一 & 15. & & 2 & & & $1^{1 / 2}$ mil udfor Baadsfjord \\
\hline - & 22. & & 2 & & & $1^{1 / 4} \quad " \quad " \quad \%$ \\
\hline- & 1)23. & & 2 & & & Udfor Baadsfjord \\
\hline Mai & 19. & & 1 & & & 32 mil nord for Nordkyn \\
\hline Juni & 1. & & 1 & & & $6 \quad, \quad-\quad$ Ing $\emptyset$ \\
\hline - & 2. & 1 & - & & & Udfor Ingø \\
\hline - & 3. & & 1 & & & $"$ \\
\hline - & 9. & & 1 & & & $" \quad " \quad$, \\
\hline- & 11. & & 1 & & & 10 mil udfor $0 g$ nord for Ingø \\
\hline - & 12. & & 1 & & & $12 \% \quad-,-$ \\
\hline
\end{tabular}

1) Senere saaes ikke hval paa længere tid, endskjønt der søgtes langt tilhavs. Der var ogsaa i mai maaned meget stormende veir. 


\begin{tabular}{|c|c|c|c|c|c|c|}
\hline \multicolumn{2}{|c|}{ Dato } & 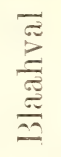 & $\begin{array}{l}\vec{\sigma} \\
\stackrel{\Xi}{\Xi} \\
\text { 孚 }\end{array}$ & 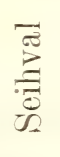 & 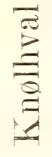 & Hvor skudt \\
\hline Juni & 13. & & 1 & & & 12 mil udfor $0 \mathrm{~g}$ nord for Ingø \\
\hline- & 15. & & 1 & & & Udfor Ingø \\
\hline - & 16. & & 1 & & & $" \quad$, \\
\hline- & 17. & & 1 & & & 10 mil NO af Ingø \\
\hline 一 & 18. & & 2 & & & Udfor Ingø \\
\hline - & 19. & & 1 & & & $" \quad "$ \\
\hline - & 20 & & $\stackrel{2}{2}$ & & & $" \quad "$ \\
\hline - & 23. & & 1 & & & $" \quad "$ \\
\hline- & 24. & & 1 & & & $" \quad "$ \\
\hline- & 25. & & 1 & & & $"$ \\
\hline 一 & 26. & & 1 & & & $"$ \\
\hline - & 27. & & 1 & & & $"$ \\
\hline - & 29. & & 2 & & & $"$ \\
\hline - & 30. & & 1 & & & $" \quad "$ \\
\hline Juli & 4. & & 1 & & 1 & 5 mil udfor Nord-Fuglø \\
\hline - & 7. & & 1 & 2 & & Udfor Ingø \\
\hline - & 8. & & 1 & & & $" \quad " \quad "$ \\
\hline- & 10. & & 3 & & & $" \quad " \quad$ \\
\hline- & 11. & & 1 & & & 6 mil nord for Ingø \\
\hline - & 13. & & 2 & & & Udfor Ingø \\
\hline - & 14. & & 1 & & & $"$ \\
\hline - & 15. & & 1 & & & $"$ \\
\hline - & 16. & & 1 & & & $"$ \\
\hline - & 17. & & 1 & & & $" \quad "$ \\
\hline - & 18. & & 2 & & & $"$ \\
\hline - & 20. & & 1 & & & $" \quad " \quad$ \\
\hline - & 21. & & 1 & & & $12 \mathrm{mil} \mathrm{NV}$ af Ingø \\
\hline - & 22. & & 1 & & & Udfor Ingø \\
\hline Aug. & 4. & & 1 & & & 9 mil NV af Ingø \\
\hline
\end{tabular}




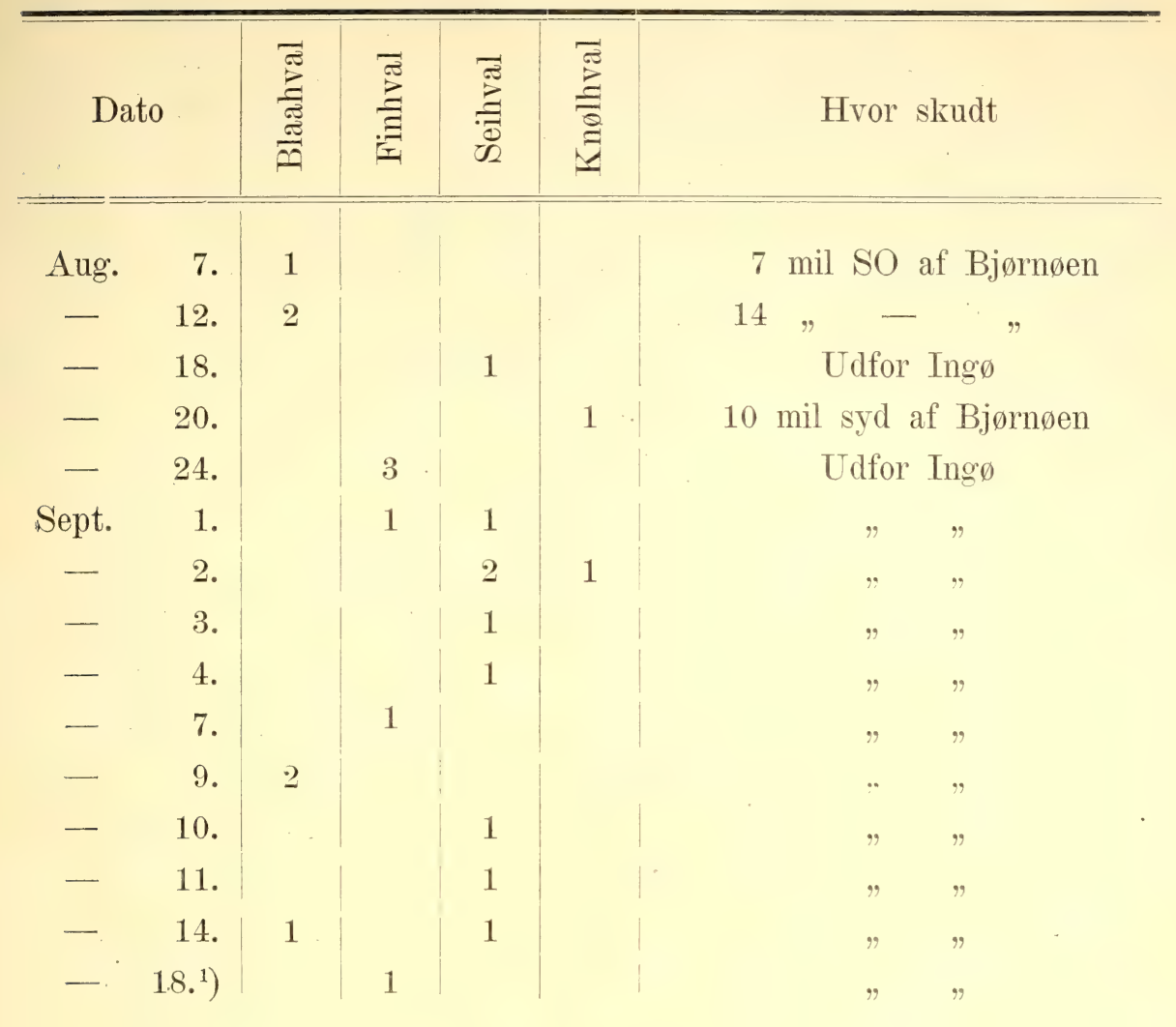

Tabel nr.2.

„Skytten“" 1898.

\begin{tabular}{|c|c|c|c|c|}
\hline Februar & 12. & & 1 & Udfor Ingø \\
\hline - & 15. & & 2 & $"$ \\
\hline - & 16. & & 1 & $"$ \\
\hline - & 21. & & 1 & " \\
\hline - & 24. & & 1 &, \\
\hline- & 25. & - & 1 & $3^{1 / 2}$ mil udfor Ing $\emptyset$ \\
\hline - & 28. & & 1 & Udfor Ingø \\
\hline
\end{tabular}

1) Den 18de september paatraf man $2^{1} / 2$ mil fra Ingø en stor fisk svømmende i vandskorpen med en stor finne over vandet. Der gjordes jagt paa den og man fik skudt paa den, men harpunen tog ikke fast. En hel del fedt kom paa vandet efterat der var skudt paa fisken, hvis længde anslaaes til 30 fod. Den var mørkebrun med hvide spetter - antagelig en sjøorm, skriver kapt. Ingebrigtsen i journalen. Efter min tro en brugde (Selache maxima). 


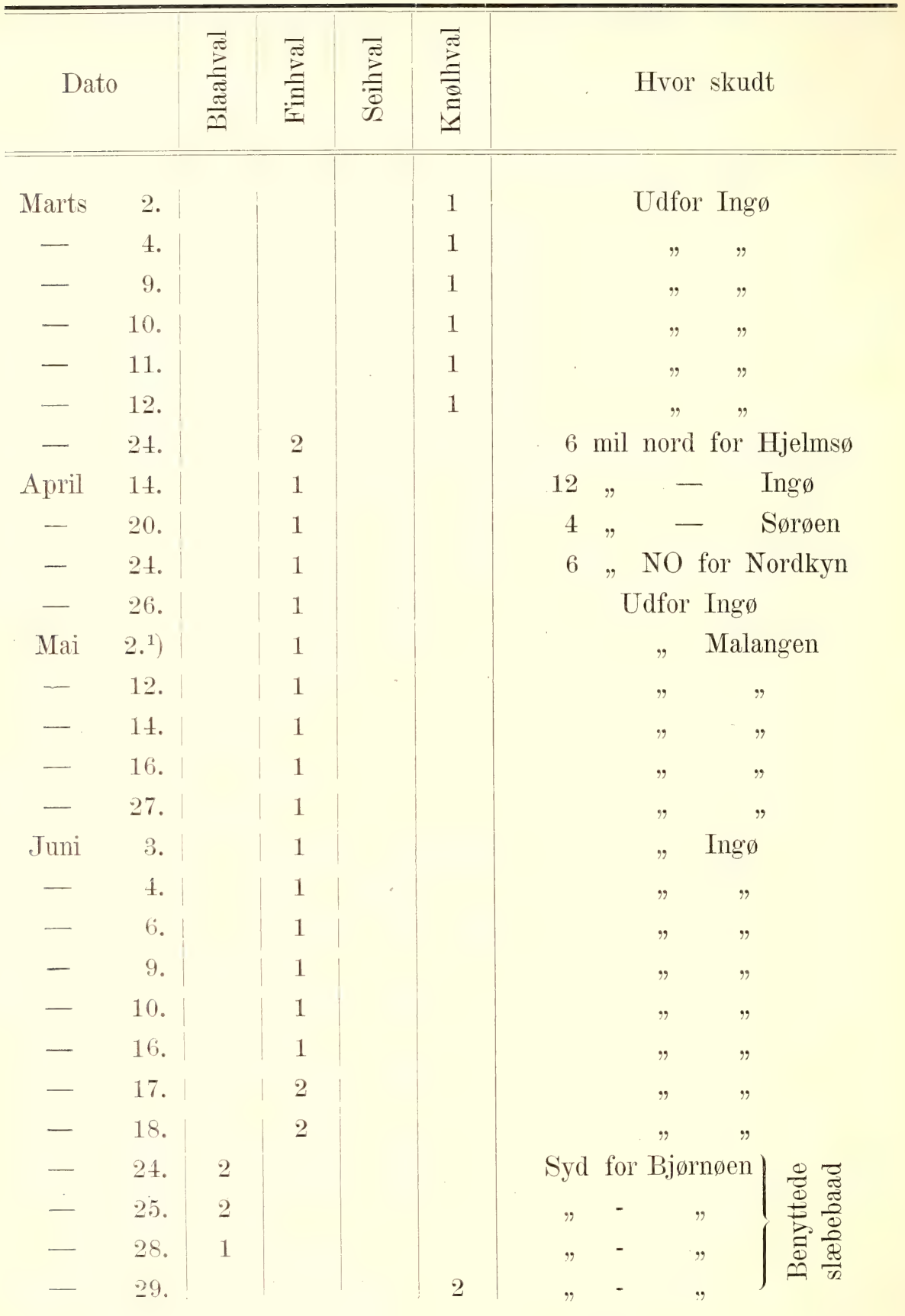

1) Fra 29 de april til slutningen af mai blev fangsten drevet udfor Malangen, hvor der fandtes nogle Finhval og saa fangedes 4 Bottlenoser. 


\begin{tabular}{|c|c|c|c|c|c|c|c|c|}
\hline \multicolumn{2}{|c|}{ Dato } & \multirow{2}{*}{ 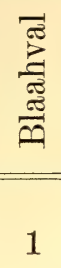 } & \multirow{2}{*}{ 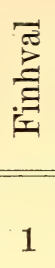 } & \multirow{2}{*}{ 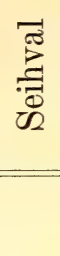 } & \multirow{2}{*}{ 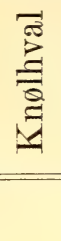 } & \multicolumn{3}{|c|}{ Hvor skudt } \\
\hline Juli & 2. & & & & & Syd for & jørnøen & \\
\hline - & 4. & 1 & & & & $\% \quad-$ & \% & \\
\hline- & 5. & 2 & & & & $"$ & $"$ & \\
\hline- & 6. & 1 & & & & $" \quad-$ & $"$ & \\
\hline - & 12. & & & 1 & & Udfo & Ingø & \\
\hline - & 14. & & & 1 & & $"$ & & \\
\hline - & 15. & & 2 & & & $"$ & & శ్ర్ల్ర \\
\hline - & 16. & & 1 & & & $"$ & & 8 \\
\hline - & 18. & & 1 & & & $"$ & $"$ & $\frac{8}{\pi / 2}$ \\
\hline 一 & 20. & & & 1 & & $"$ & $"$ & $\frac{0}{2}$ \\
\hline 一 & 21. & & 3 & & & $"$ & $"$ & $\stackrel{\Delta}{\frac{D}{2}}$ \\
\hline - & 22. & & & 2 & & $"$ & Sørøen & हैं \\
\hline- & 23. & & 3 & 1 & & $"$ & & \\
\hline - & 26. & & 1 & & & $"$ & & \\
\hline 一 & 28. & 1 & & & & 5 mil $\mathrm{SSO}$ & or Bjørnøen & \\
\hline - & 29 . & & 1 & & & Udfor & jørnøen & \\
\hline- & 30. & & 2 & & & 20 mil syd & or Bjørnøen & \\
\hline Aug. & 1. & & 2 & & & Udfol & Ingø & \\
\hline - & 4. & & 2 & & & $"$ & $"$ & \\
\hline- & 6. & & & 2 & & $"$ & Sørøen & \\
\hline - & 9. & & 2 & & 1 & 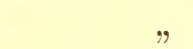 & Ingø & \\
\hline 一 & 13. & & 1 & & 1 & $"$ & $\eta$ & \\
\hline - & 16. & & 1 & & & " & " & \\
\hline- & 22. & & 1 & & & , & , & \\
\hline
\end{tabular}


Tabel

\begin{tabular}{|c|c|c|c|c|c|c|}
\hline & \multicolumn{3}{|c|}{ Finhval } & \multicolumn{3}{|c|}{ Knølhval } \\
\hline & 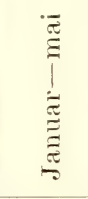 & 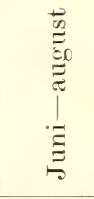 & 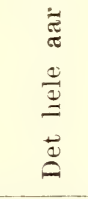 & 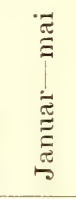 & 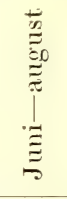 & 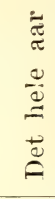 \\
\hline Skytten $1892 \ldots \ldots \ldots$ & 6 & 6 & 12 & - & 1 & 1 \\
\hline Skytten $1893 \ldots \ldots \ldots$ & 4 & 4 & 8 & 4 & 1 & 5 \\
\hline Hivalen $1893 \ldots \ldots \ldots$ & 5 & 20 & 25 & - & 2 & 2 \\
\hline Skytten $1894 \ldots \ldots \ldots \ldots$ & 2 & 12 & 14 & 4 & 3 & 7 \\
\hline Hval =n $1894 \ldots \ldots \ldots$ & 10 & 20 & 30 & 4 & 4 & 8 \\
\hline Fiskeren \& Nimrod 1894. & 7 & 40 & 47 & 2 & 3 & 5 \\
\hline Skytten $1895 \ldots \ldots \ldots$. & 3 & 25 & 28 & 9 & 1 & 10 \\
\hline Hvalen 1895 . . . . . . . & 8 & 10 & 18 & 5 & 5 & 10 \\
\hline Fiskeren \& Nimrod 1895. & 3 & 21 & 24 & 6 & 3 & 9 \\
\hline Skytten $1896 \ldots \ldots \ldots$ & 11 & 49 & 60 & 15 & 11 & 26 \\
\hline Hvalen $1896 \ldots \ldots \ldots$. & 10 & 7 & 17 & 8 & 2 & 10 \\
\hline Fiskeren \& Nimrod 1896. & 13 & 28 & 41 & 2 & 3 & 5 \\
\hline Jupiter \& Neptum 1896. . & 22 & 31 & 53 & 19 & 5 & 24 \\
\hline Skytten $1897 \ldots \ldots \ldots$ & 11 & 26 & 37 & 8 & 1 & 9 \\
\hline Hvalen $1897 \ldots \ldots \ldots$ & 1 & 7 & 8 & 一 & 3 & 3 \\
\hline Jupiter \& Neptun 1897. . & 5 & 19 & 24 & - & 3 & 3 \\
\hline Fiskeren \& Nimrod 1897. & 8 & 14 & 22 & - & - & - \\
\hline Skytten $1898 \ldots \ldots \ldots$ & 11 & 34 & 45 & 14 & 4 & 18 \\
\hline Iivalen $1898 \ldots \ldots \ldots \ldots$ & 5 & 20 & 25 & - & 1 & 1 \\
\hline Jupiter \& Neptun 1898. . & 8 & 23 & 31 & - & 3 & 3 \\
\hline Fiskeren \& Nimrod 1898. & 4 & 24 & 28 & - & 1 & 1 \\
\hline Hvalen 1899 ......... & - & 12 & 12 & - & - & - \\
\hline Jupiter \& Neptun 1899 .. & 2 & 12 & 14 & 2 & 2 & 4 \\
\hline Providentia $1899 \quad \ldots \ldots \ldots$ & 2 & 10 & 12 & - & - & - \\
\hline Spes \& Fides $1899 \ldots . .$. & 2 & 9 & 11 & - & 1 & 1 \\
\hline Hvalen $1900 \ldots \ldots \ldots \ldots$ & 1 & 5 & 6 & - & 1 & 1 \\
\hline Svend Foyn $1900 \ldots \ldots$ & 4 & 12 & 16 & - & 2 & 2 \\
\hline Providentia $1900 \ldots \ldots$. . & 2 & 5 & 7 & - & 2 & 2 \\
\hline Hvalen $1901 \ldots . . \ldots$. . & 6 & 9 & 15 & 3 & 1 & 4 \\
\hline Alfa \& Beta $1901 \ldots . .$. . & 13 & 24 & 37 & 9 & 2 & 11 \\
\hline Tilsammen & 199 & 538 & 737 & 104 & 71 & 175 \\
\hline Antal $\%$ & 14.6 & 39.3 & 53.9 & 7.6 & 5.2 & -12.8 \\
\hline
\end{tabular}

1) I marts. 9) 19. mai, 3) I Mai. 4) 28. og 29. mai. 5) I april 1 kaskelot. 
nr. 3.

\begin{tabular}{|c|c|c|c|c|c|c|c|c|}
\hline \multicolumn{3}{|c|}{ Blaahval } & \multicolumn{3}{|c|}{ Seihval } & \multicolumn{3}{|c|}{ Totalfangst } \\
\hline 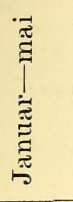 & 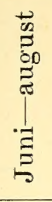 & 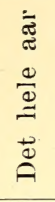 & 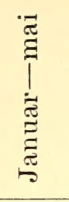 & 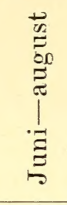 & 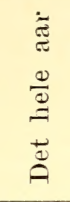 & 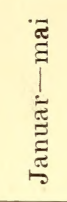 & 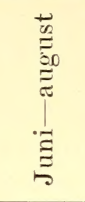 & 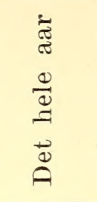 \\
\hline - & - & - & - & 18 & 18 & 6 & 25 & 31 \\
\hline $\left.1^{1}\right)$ & - & 1 & - & 38 & 38 & 9 & 43 & 52 \\
\hline- & - & - & - & 14 & 14 & 5 & 36 & 41 \\
\hline - & - & - & - & 14 & 14 & 6 & 29 & 35 \\
\hline - & 3 & 3 & - & 4 & 4 & 14 & 31 & 45 \\
\hline- & 12 & 12 & - & 5 & 5 & 9 & 60 & 69 \\
\hline- & 2 & 2 & - & 4 & 4 & 12 & 32 & 44 \\
\hline- & - & - & - & 4 & 4 & 13 & 19 & 32 \\
\hline- & 3 & 3 & - & 5 & 5 & 9 & 32 & 41 \\
\hline- & 1 & 1 & - & 6 & 6 & 26 & 67 & 93 \\
\hline - & 1 & 1 & - & 3 & 3 & 18 & 13 & 31 \\
\hline- & 4 & 4 & - & 5 & 5 & 15 & 40 & 55 \\
\hline- & 1 & 1 & - & 12 & 12 & 41 & 49 & $\left.90^{5}\right)$ \\
\hline $\left.1^{2}\right)$ & 12 & 13 & $\left.2^{4}\right)$ & 21 & 23 & 22 & 60 & 82 \\
\hline- & 4 & 4 & - & 12 & 12 & 1 & 26 & 27 \\
\hline- & 5 & 5 & $\left.4^{3}\right)$ & 45 & 49 & 9 & 72 & 81 \\
\hline- & 21 & 21 & $\left.1^{3}\right)$ & 21 & 22 & 9 & 56 & 65 \\
\hline - & 11 & 11 & - & 8 & 8 & 25 & 57 & 82 \\
\hline- & 1 & 1 & - & 23 & 23 & 5 & 45 & 50 \\
\hline- & 1 & 1 & - & 39 & 39 & 8 & 66 & 74 \\
\hline- & 2 & 2 & - & 30 & 30 & 4 & 57 & 61 \\
\hline- & - & - & - & 5 & 5 & - & 17 & 17 \\
\hline $\left.1^{3}\right)$ & 8 & 9 & - & 2 & 2 & 5 & 24 & 29 \\
\hline- & - & - & - & 2 & 2 & 2 & 12 & 14 \\
\hline- & 1 & 1 & - & 3 & 3 & 2 & 14 & 16 \\
\hline- & - & - & - & 1 & 1 & 1 & 7 & 8 \\
\hline- & - & - & - & 1 & 1 & 4 & 15 & 19 \\
\hline- & - & - & - & 1 & 1 & 2 & 8 & 10 \\
\hline- & - & - & - & 2 & 2 & 9 & 12 & 21 \\
\hline - & - & - & - & 2 & 2 & 22 & 28 & 50 \\
\hline 3 & 93 & 96 & 7 & 350 & 357 & 313 & 1052 & 1365 \\
\hline 0.2 & 6.9 & 7.1 & 0.5 & 25.6 & 26.1 & 22.9 & 77.1 & \\
\hline
\end{tabular}



SMITHSONIAN INSTITUTION LIBRARIES

39088014709752 